\title{
Pénzügyi intézményrendszer Magyarországon 2019
}

DOI 10.35511/978-963-334-336-4

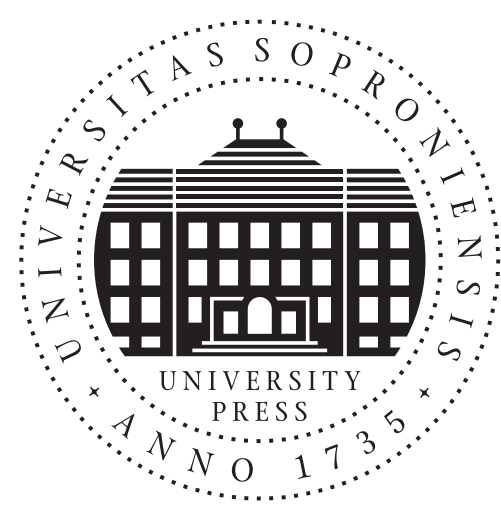

SOPRONI EGYETEM KIADÓ

Sopron, 2019 
Szerkesztők:

Kovács Tamás, Szóka Károly, Varga József

Szakmai lektor:

Parragh Bianka

\section{Szerzők:}

Baranyi Aranka

Moizs Attila

Bartók János

Fóriánné Horváth Margit

Parádi-Dolgos Anett

Pataki László

Für István

Gál Veronika Alexandra

Sipiczki Zoltán

Szarka Gábor

Gulyás Éva

Hegedűs Mihály

Kómár András

Szóka Károly

Tatay Tibor

Kovács Róbert

Tóth Gergely

Kovács Tamás

Varga József

Végh Richárd

Nyelvi lektor: Tompáné Székely Zsófia

Technikai szerkesztő: Horváthné Józsa Ágnes

\section{A könyv a Soproni Egyetem és a Magyar Nemzeti Bank közötti együttmúködés keretében, a Magyar Nemzeti Bank támogatásával készült.}

Kiadja: Soproni Egyetem Kiadó

9400 Sopron, Bajcsy-Zsilinszky u. 4.

Felelős kiadó: Dr. Alpár Tibor László kutatási és külügyi rektorhelyettes

(C) Soproni Egyetem Kiadó

Nyomdai kivitelezés: Pátria Nyomda Zrt.

Felelős vezető: Simon László vezérigazgató

ISBN 978-963-334-335-7 (nyomtatott)

ISBN 978-963-334-336-4 (elektronikus)

DOI 10.35511/978-963-334-336-4

Minden jog fenntartva. 


\section{Tartalomjegyzék}

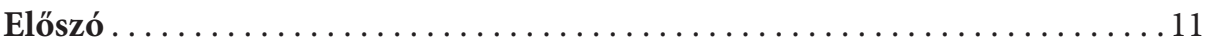

I. rész A hazai bankrendszer müködése ....................13

1. Új irány a monetáris politikában Magyarországon A modern jegybanki eszközök és intézkedések gyakorlatorientált rendszerezése (Tóth Gergely) ................. 15

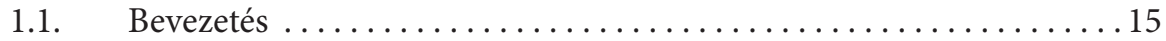

1.2. A monetáris politika fogalma, müködése, szerepe............ 15

1.2.1. Monetáris politika fogalma ....................... 15

1.2.2. A monetáris intézkedések hatásmechanizmusa .............16

1.2.3. A jegybanki eszköztár...........................25

1.2.4. A Magyar Nemzeti Bank ............................ 36

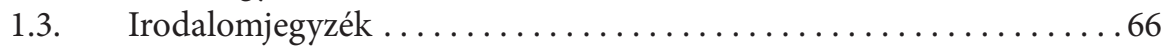

2. A belföldi fizetési forgalom (Varga József) ...................69

2.1. A belföldi fizetési forgalom kerete ......................69

2.1.1. A belföldi fizetési forgalom meghatározása ...............69

2.1.2. A fizetési számla típusai ...........................70

2.1.3. A pénzforgalmi jelzőszám ........................71

2.1.4. Fizetési szokások Magyarországon .....................72

2.2. Fizetési formák ................................ 75

2.2.1. Az átutalás................................. 75

2.2.2. Beszedési megbízás ...........................77

2.2.3. Okmányos meghitelezés (akkreditív) .................. 80

2.2.4. Bankkártya ............................... 81

2.2.5. Fizetési számlához kötődő készpénzfizetési

2.2.6. A csekk ................................... 87

2.3. Irodalomjegyzék $\ldots \ldots \ldots \ldots \ldots \ldots \ldots \ldots \ldots \ldots \ldots \ldots \ldots$

3. Bankok müködése a Hitelintézeti törvény alapján (Kovács Róbert).......91

3.1. Helyzetkép a magyar hitelintézeti szektor intézményi összetételérool .........................91

3.2. A magyar hitelintézeti szektor szabályozási háttere ...........92

3.3. A pénzügyi szolgáltatás és kiegészítő pénzügyi szolgáltatás ........94

3.4. A pénzügyi intézmények: a hitelintézet és szervezeti formái, valamint a pénzügyi vállalkozás .....................999

3.5. A hitelintézetek alapításának és müködésének, illetve egyes tevékenységeinek engedélyezése .........................101

3.6. A kiadott engedély felügyeleti visszavonása .................. 104

3.7. A szolgáltatás nyújtásának szabadsága: másik EGT-államban történő fióktelep létesítés szabályai ............. 105

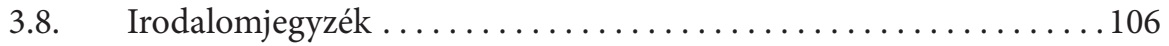


4. A banki müködés kockázatai (Sipiczki Zoltán) . . . . . . . . . . . . 109

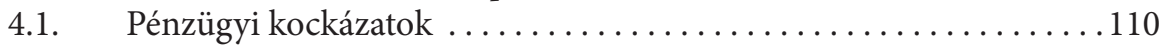

4.1.1. Hitelkockázat ........................... 110

4.1.2. Kamatlábkockázat ............................... 116

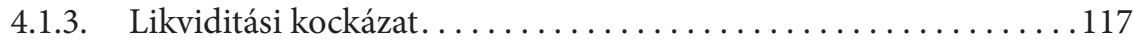

4.1.4. Mérlegen kívüli kockázat . . . . . . . . . . . . . . . . . . . . . . . . . 119

4.1.5. Befektetési kockázat ........................... 119

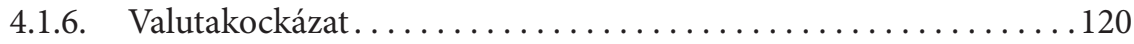

4.1.7. Nyereség és jövedelemszerkezet romlása . . . . . . . . . . . . . 120

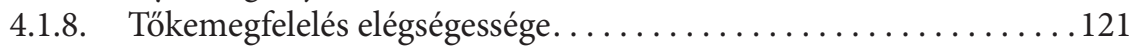

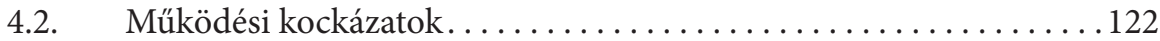

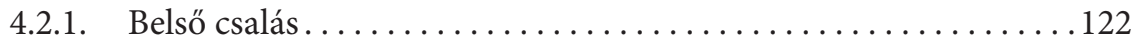

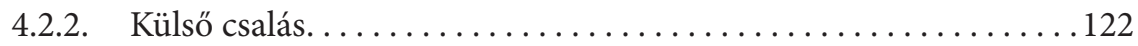

4.2.3. Foglalkoztatási gyakorlat és a munkahelyi biztonság. . . . . . . 123

4.2.4. Ügyfelek, termékek és üzleti szolgáltatások . . . . . . . . . . . . 123

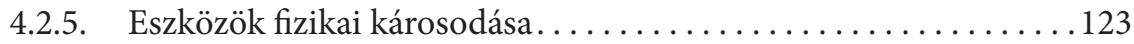

4.2.6. Üzleti zavarok és rendszerhibák (technológiai kockázatok) . . . . . 124

4.2.7. Végrehajtás és folyamatmenedzsment . . . . . . . . . . . . . 124

4.3. Szabályozási és környezeti kockázatok. . . . . . . . . . . . . . 124

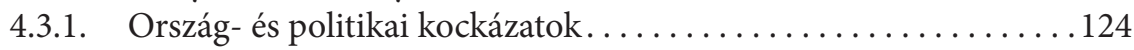

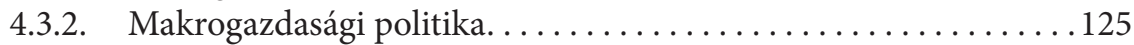

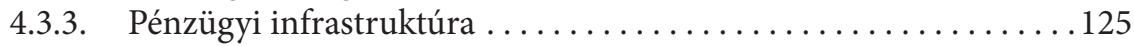

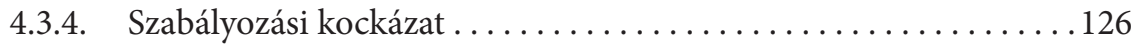

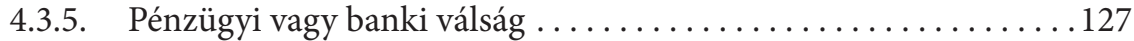

4.4. Kockázatok kezelése a treasury menedzsmenttel . . . . . . . . . 127

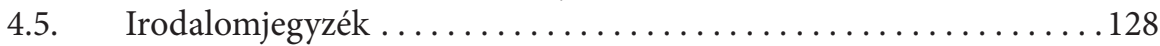

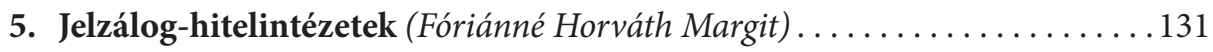

5.1. Jelzálog-hitelintézet, zálogjog, önálló zálogjog, jelzálogjog fogalma. Jelzálog-hitelintézet elhelyezése a pénzügyi intézmények között. . . 131

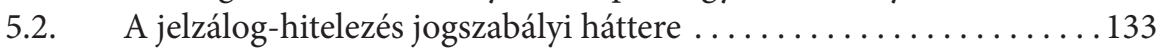

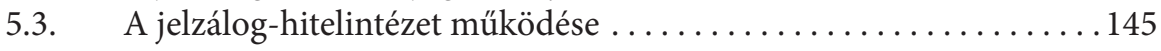

5.4. A magyar intézményi szabályozás hasonlítása más modellekhez . . 146

5.5. A magyar jelzáloghitelezés története a kezdetektől

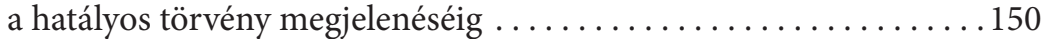

5.6. A magyar jelzálog-hitelezés intézményei................. 153

5.7. Irodalomjegyzék . . . . . . . . . . . . . . . . . . . . 159

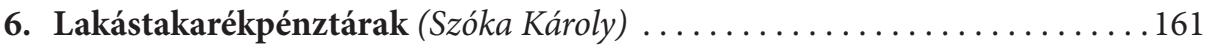

6.1. A lakástakarékpénztárak és kialakulásuk. ................. 161

6.2. A magyarországi lakáspiac. ......................... 161

6.3. A lakástakarékpénztárak kialakulása ....................... 166

6.4. A lakástakarékpénztárak magyarországi kialakulása ..... . . . . 170

6.5. A lakástakarékpénztárak tevékenysége .................. 172 


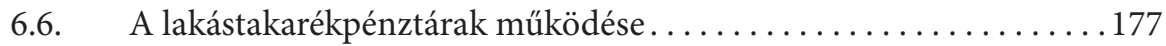

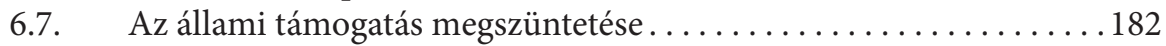

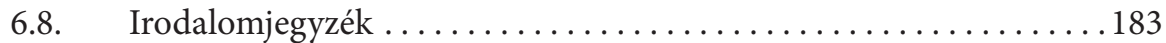

7. A szövetkezeti hitelintézetek Magyarországon (Moizs Attila) . . . . . . . . 187

7.1. A szövetkezeti hitelintézet, a hitelintézetek

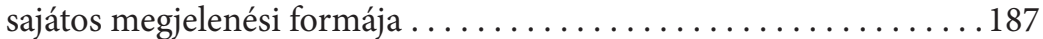

7.2. Szövetkezeti hitelintézetek Magyarországon................ 191

7.3. A szövetkezeti hitelintézetek átalakításának aktuális állapotáról . . . 199

7.4. A szövetkezeti hitelintézetek jövője a magyar pénzügyi piacon... . 203

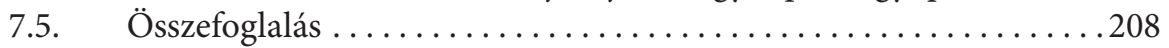

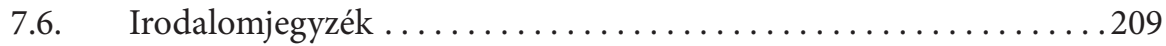

8. Egyéb banki müveletek és szereplök (Baranyi Aranka) . . . . . . . . . 213

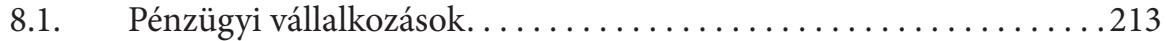

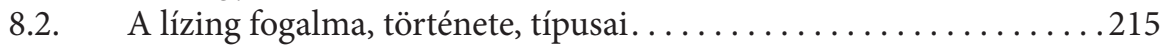

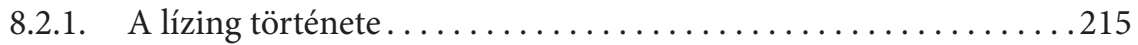

8.2.2. A lízing fogalmának meghatározása a hazai jogszabályi környezetben ......................216

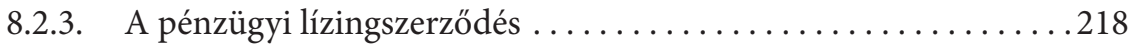

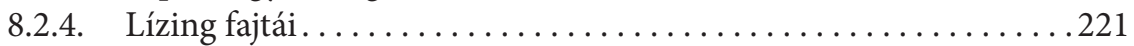

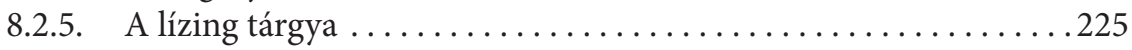

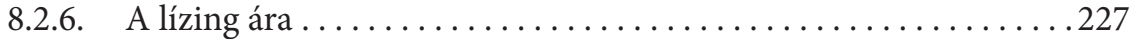

8.2.7. A lízing és a hitel, mint eszközfinanszírozás jellemzői . . . . . . . . 229

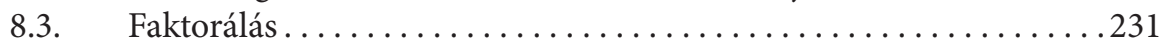

8.3.1. A faktorálás fogalma, jogi szabályozása . . . . . . . . . . . 231

8.3.2. Milyen jellemzői vannak a faktorálásnak? . . . . . . . . . . 232

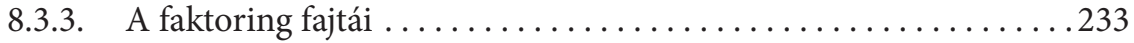

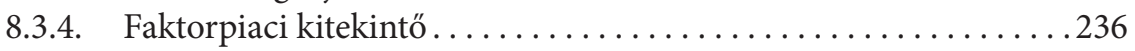

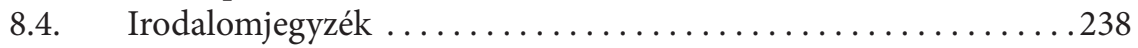

9. A bankszektor számviteli sajátosságai (Gulyás Éva) . . . . . . . . . . 241

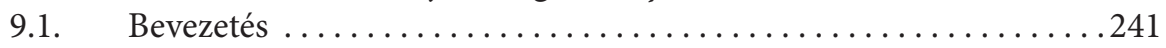

9.2. A hitelintézetek és pénzügyi vállalkozások beszámolójára és könyvvezetésére vonatkozó számviteli előírások . . . . . . . . 242

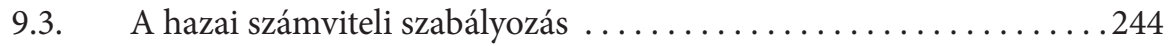

9.4. Az IFRS-ek szerinti szabályozás . . . . . . . . . . . . . . 250

9.4.1. A mérleg - pénzügyi helyzet kimutatás - felépítése . . . . . . . . 251

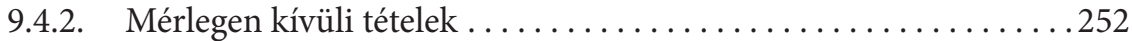

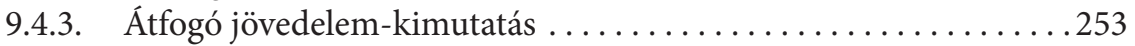

9.4.4. CF és Saját tőke-változás (SOCIE) kimutatás . . . . . . . . . . 254

9.5. Pénzügyi instrumentumok ....................... 255

9.5.1. A pénzügyi instrumentumok fogalma . . . . . . . . . . . . 255

9.5.2. A valós érték. . . . . . . . . . . . . . . . . . . . . . 261

9.5.3. A pénzügyi instrumentumok besorolására vonatkozó elöírások . . 263 
9.5.4. Fedezeti ügyletek............................265

9.5.5. Magyar sajátosságok következményei.................266

9.5.6. Közzétételi kötelezettségek........................268

9.6. Függelékek ..................................270

9.6.1. Azonos jelentéssel használt kifejezések és rövidítések . . . . . . . . 2270

9.6.2. A számviteli kormányrendelet szerinti mérlegséma...........271

9.6.3. A számviteli kormányrendelet szerinti eredménykimutatás felépítése .....................272

9.6.4. Egy lehetséges IFRS szerinti bankmérleg...............273

9.6.5. Az Átfogó jövedelemkimutatás egy lehetséges felépítése........274

9.7. Irodalomjegyzék ............................... 275

II. rész A tökepiac müködése.........................279

10.A tőkepiac és a tőzsde (Végh Richárd, Szarka Gábor) ................281

10.1. A tőkepiac szerepe a gazdaságban . ....................281

10.1.1. Finanszírozás ..................................284

10.1.2. Kereskedés és árképzés ...........................288

10.1.3. Kockázatkezelés ................................289

10.2. A tőzsde régen és ma - A tőzsde fejlődése napjainkig...........293

10.3. A Budapesti Értéktőzsde müködési környezete és sajátosságai 2019 elején ............................295

10.4. A Budapesti Értéktőzsde piacfejlesztési stratégiája 2016-2020 .....301

10.5. Irodalomjegyzék ..............................306

11. Befektetési alapok (Tatay Tibor) .............................309

11.1. A befektetési alapok rövid története a kezdetektől napjainkig . . . . . 309

11.2. A befektetési alapok, mint portfólióbefektetések ..............313

11.3. A befektetési alapok létrehozása, müködése ..................319

11.4. A befektetési alapok csoportosítása ......................321

11.5. A hozamok és kockázatok összemérésének gyakorlati kérdései. . ...325

11.6. Irodalomjegyzék ...................................... 329

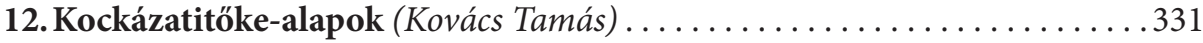

12.1. Fogalmi értelmezés ................................ 331

12.2. Jogi szabályozás ...................................... 335

12.3. A piac számokban - az elmúlt négy év rövid áttekintése..........337

12.4. Irodalomjegyzék .............................. 340

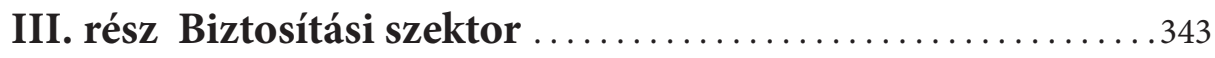

13. A biztosítási piac jellemzői és szereplöi (Parádi-Dolgos Anett) ..........345

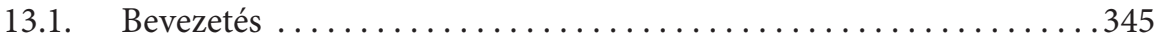

13.2. Kockázatok...................................346

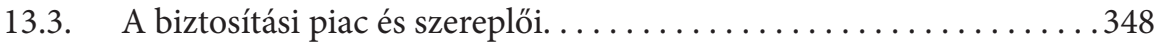

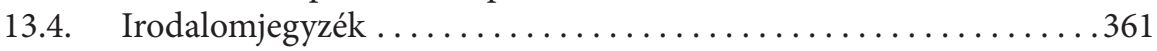


14. Élet- és nem-életbiztosítások (Bartók János) . . . . . . . . . . . . . 363

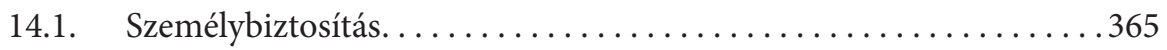

14.2. Életbiztosítás . . . . . . . . . . . . . . . . . . . . . . 366

14.2.1. Az életbiztosítások története . . . . . . . . . . . . . . . . 366

14.2.2. Az életbiztosítási piac szereplői Magyarországon . . . . . . . . . . . 367

14.2.3. Az életbiztosítások célja . . . . . . . . . . . . . . . . . 368

14.2.4. Az életbiztosítási szerződés szereplői . . . . . . . . . . . . . . . . . 369

14.2.5. Az életbiztosítások típusai . . . . . . . . . . . . . . . . . . 369

14.2.6. Kiegészítő biztosítások . . . . . . . . . . . . . . . . . . . . 372

14.2.7. Az életbiztosítások egyéb szempontú csoportosítása . . . . . . . . 373

14.2.8. Az életbiztosítások specialitása . . . . . . . . . . . . . . . . 373

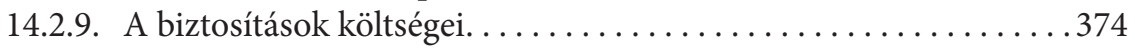

14.2.10. A díjtartalék . . . . . . . . . . . . . . . . . . . . 376

14.2.11. Az életbiztosítási piac gazdasági jelentősége . . . . . . . . . . . . . . 377

14.2.12. Az életbiztosítási piac intézményrendszere . . . . . . . . . . . 378

14.2.13. Az életbiztosítási piac szabályozása, etikus biztosítás. . . . . . . . . . 379

14.3. Nem-életbiztosítások . . . . . . . . . . . . . . . . . . . . . 385

14.3.1. A nem-életbiztosítások története. . . . . . . . . . . . . . . . 386

14.3.2. A nem-életbiztosítási piac szereplői Magyarországon . . . . . . . . . 387

14.3.3. A nem-életbiztosítások célja. . . . . . . . . . . . . . . . . 388

14.3.4. A nem-életbiztosítási szerződés szereplői . . . . . . . . . . . . 388

14.3.5. A nem-életbiztosítások típusai. . . . . . . . . . . . . . . . . . . 389

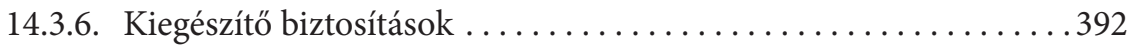

14.3.7. A nem-életbiztosítások egyéb szempontú csoportosítása . . . . . . . 393

14.3.8. A nem életbiztosítások specialitásai . . . . . . . . . . . . . . . . 393

14.4. Viszontbiztosítás . . . . . . . . . . . . . . . . . . . . . . . . . 394

14.5. A biztosítási szektor kihívásai ... . . . . . . . . . . . . . . . . . 395

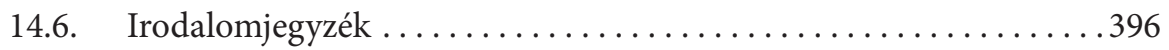

IV. rész Pénztári szektor .................................... 399

15. Önkéntes kölcsönös biztosító pénztárak (Gál Veronika Alexandra) . . . . . 401

15.1. Önkéntes pénztárak fejlődése Magyarországon . . . . . . . . . . . . 402

15.2. Az önkéntes pénztárak működési alapelvei. . . . . . . . . . . . 403

15.3. Az önkéntes pénztárak alapítása . . . . . . . . . . . . . . . . . 404

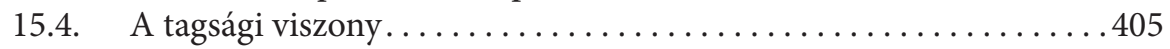

15.5. Az alapszabályra vonatkozó elöírások . . . . . . . . . . . . 407

15.6. Az önkéntes pénztárak szervezete . . . . . . . . . . . . . . . . 408

15.6.1. A közgyülés feladata és hatásköre . . . . . . . . . . . . . . . . . 409

15.6.2. Az igazgatótanács feladata és hatásköre . . . . . . . . . . . 411

15.6.3. Az ellenőrző bizottság feladata és hatásköre . . . . . . . . . . . 411

15.6.4. Az ügyvezetö feladata és hatásköre . . . . . . . . . . . . . . . . 412

15.7. A pénztárak gazdálkodása . . . . . . . . . . . . . . . . 412

15.8. Az önkéntes pénztárak átalakulása, megszünése . . . . . . . . . . 414 
15.9. Az önkéntes nyugdíjpénztárak ......................416

15.10. Az önkéntes önsegélyező pénztárak ...................418

15.11. Az önkéntes egészségpénztárak ........................419

15.12. A pénztári szektor helyzete és tendenciái $\ldots \ldots \ldots \ldots \ldots \ldots \ldots . \ldots 421$

15.13. Irodalomjegyzék ............................ 425

16. Magánnyugdíjpénztárak és foglalkoztatói

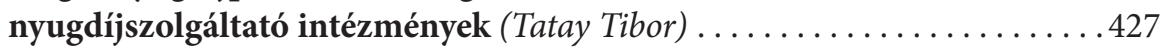

16.1. A magánnyugdíjpénztárak..........................427

16.2. A foglalkoztatói nyugdíjszolgáltató intézmények.............431

16.3. Irodalomjegyzék ............................. 434

V. rész A pénzügyi intézményrendszer müködésének egyes speciális területei $\ldots \ldots \ldots \ldots \ldots \ldots \ldots \ldots \ldots \ldots \ldots \ldots$

17.A pénzügyi szervezetek szanálása (Kómár András) .................449

17.1. A szanálási keretrendszer kialakulása és magyarországi bevezetése ...........................439

17.2. A hazai szanálási keretrendszer föbb elemei ................440

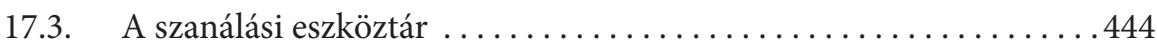

17.4. Szanálási kollégiumok ............................. 445

17.5. A szanálás finanszírozása ...........................446

17.5.1. A Szanálási Alap ..............................447

17.5.2. Az Országos Betétbiztosítási Alap szanálásfinanszírozási szerepe ........................448

17.6. Az MKB Bank Zrt. szanálása . ........................448

17.7. A szanálási keretrendszer jövője ..................... 450

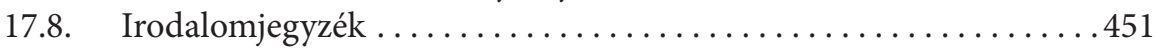

18. Az OBA, a BEVA és a Szövetkezeti Hitelintézetek Tökefedezeti

Közös Alapja müködésének jellemzői (Pataki László) ...............455

18.1. Nemzetközi kitekintés ............................. 455

18.2. A hazai betétbiztosítási rendszer jellemzői ................456

18.3. A BEVA működésének jellemzői .......................464

18.4. Szövetkezeti Hitelintézetek Tökefedezeti Közös Alapja...........467

18.5. Önkéntes Betétbiztosítási Alapok........................4469

18.6. Irodalomjegyzék .............................4 470

19. A pénzmosás és a terrorizmus finanszírozása, valamint a leküzdésükre irányuló szabályozás (Für István). . . . . . . . . 473

19.1. A pénzmosás fogalma..............................473

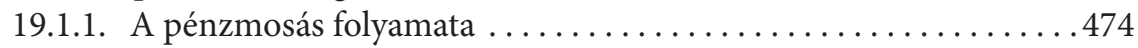

19.1.2. Pénzmosási technikák.............................474

19.2. A terrorizmus finanszírozása ...................... 483 
19.3. Nemzetközi fellépés a pénzmosás és a terrorizmus

finanszírozása ellen ...............................4484

19.3.1. ENSZ Egyezmények ............................. 484

19.3.2. A Pénzügyi Akciócsoport (FATF) . . . . . . . . . . . . . . . . 485

19.3.3. Az Egmont Csoport. ...............................486

19.3.4. Az Európa Tanács egyezményei és a Moneyval.............. 487

19.3.5. Az Európai Unió szabályozása . ..................... 487

19.3.6. Az Európai Felügyeleti Hatóságok ajánlásai és iránymutatásai. . . 490

19.3.7. A Bázeli Bankfelügyeleti Bizottság ajánlásai .............. 490

19.3.8. Wolfsberg Csoport.............................. 491

19.4. A pénzmosás és a terrorizmus finanszírozása

elleni hazai szabályozás és intézményrendszer . .............. 492

19.4.1. Előzmények ................................... 492

19.4.2. Hatályos szabályok .............................. 492

19.5. Irodalomjegyzék .............................. 498

20. A hitelintézetek könyvvizsgálata (Hegedüs Mihály).................501

20.1. Bevezetö ................................... 501

20.2. A hitelintézeti könyvvizsgálat környezete .................502

20.2.1. A könyvvizsgálat célja és a könyvvizsgálati kötelezettség . . . . . . 5052

20.2.2. A könyvvizsgálóval szemben támasztott szakmai

és függetlenségi követelmények. .....................5504

20.3. A könyvvizsgálati munka szakaszai ....................507

20.3.1. A megbízás elfogadásához szükséges alapfeltételek ............507

20.3.2. A könyvvizsgálat tervezése.........................508

20.3.3. A társaság tevékenységének megismerése ............... 509

20.3.4. A kockázatok és kezelésük ......................... 510

20.3.5. Átfogó könyvvizsgálati terv kidolgozása ................ 512

20.3.6. Az alapvető vizsgálati eljárások, tesztek jellegének, ütemezésének és terjedelmének meghatározása . . . . . . . . . 5 517

20.3.7. Az általános kontrollkörnyezet vizsgálata ............... 518

20.3.8. A csalás kockázatának vizsgálata a hitelintézeti könyvvizsgálat részeként. ........................5520

20.4. A beszámoló vizsgálata egyéb szempontjai .................523

20.5. Irodalomjegyzék . . . . . . . . . . . . . . . . . . . . . . . . 529

VI. rész A szerzőkröl röviden ...........................533 


\section{Előszó}

A pénzügyi intézményrendszer területén az információk avulása gyorsabb, mint amit a többi tudományos területen megtapasztalhatunk. Ezért fontosnak tartottuk, hogy e szakkönyv immár harmadik kiadását bocsássuk a Tisztelt Olvasók elé.

Az első kiadás 2003-ban a Nebuló 2000 Kiadó, a második 2011-ben a Soproni Felsőoktatásért Alapítvány gondozásában jelent meg. Nagy örömünkre szolgál, hogy szakkönyvünk teljesen aktualizált kiadása ez évben a Magyar Nemzeti Bank anyagi támogatásával valósulhat meg a Soproni Egyetem Kiadónál.

A könyv célja, hogy a pénzügyi intézményrendszer teljes területéről átfogó, friss képet adjon. A kiadvány e téren ritkaság, hiszen bankismeretek, banktan, banküzemtan könyvek szép számmal jelentek meg hazánkban, ám a bankrendszeren kívüli területek elemzésére sokkal ritkábban kerül sor. Éppen ezért a szerzők a monetáris politika és a bankrendszer müködésének, kockázatainak, számviteli sajátosságainak áttekintő bemutatása után a hangsúlyt a bankrendszeren kívüli területek elemzésére helyezték. Így a nyugdíj- és egészségpénztárak, a tőzsde, a biztosítás, a jelzálog-hitelintézetek, lakástakarékpénztárak, befektetési alapok, lízing- és faktoringcégek állnak a publikációk középpontjában.

A kötet elsősorban szakmai érdeklődőknek ajánlott, akik a terület egészéről szeretnének átfogó ismeretet szerezni, de reményeink szerint a felsőoktatásban tanuló diákok és a szélesebb közösség érdeklődésére is számot tarthat.

A Szerkesztőbizottság a Tisztelt Olvasóknak hasznos és kellemes időtöltést kíván!

Sopron, Budapest, 2019. május 31.

a Szerkesztök 



\section{I. rész \\ A hazai bankrendszer müködése}




\section{1. Új irány a monetáris politikában Magyarországon - A modern jegybanki eszközök és intézkedések gyakorlatorientált rendszerezése}

\subsection{Bevezetés}

A 2013. évi CXXXIX. törvény szerint a monetáris politika meghatározója és megvalósítója a Magyar Nemzeti Bank. A törvényi kiindulópont alapján, és a monetáris politikai gyakorlat nagyfokú szakmai hitelességgel történő bemutatása érdekében jelen fejezet a Magyar Nemzeti Bank által publikált könyvek, tanulmányok és a témához kapcsolódó tudományos, szakmai cikkek felhasználásával és rendszerezésével készült. A 2008-as válságot követően a jegybankok szerepe, gazdaságban betöltött funkciója nemzetközi és regionális térben egyaránt átalakult. Magyarországon a 2010 után bekövetkezett fiskális, illetve a 2013 után lehetővé vált monetáris politikai fordulat a két fö gazdaságpolitikai ág közötti együttműködést lehetővé tette, míg a 2010-től érvényes, új gazdaságpolitikai értékrend és a növekedésfókuszú gazdaságpolitika pedig szükségessé tette a gazdaságpolitikai ágak közötti összhang megteremtését.

\subsection{A monetáris politika fogalma, müködése, szerepe}

\subsubsection{Monetáris politika fogalma}

A monetáris politika elméleti hátterének bemutatása és definiálása fontos pillérét képezi a monetáris politikai célok, eszközök, intézkedések és programok rendszerszemléletű megközelítésének és megértésének.

Definícióját tekintve a monetáris politika a gazdaságpolitika azon része, amelynek viteléért a jegybank felel. A gazdaságpolitika célja, hogy a gazdasági folyamatok befolyásolásán, irányításán keresztül a társadalom jólétét növelje. A monetáris politika ehhez leginkább az árstabilitás biztosításával tud hozzájárulni. A monetáris politika főbb elemei a kamat- és az árfolyampolitika. (Matolcsy, 2015) Magyarország monetáris politikáját a Magyar Nemzeti Bank határozza meg és valósítja meg. ${ }^{1}$

1 A 2013. évi CXXXIX. törvény (Jegybanktörvény) 1. fejezet, 4. \$. 
A monetáris politika fogalmi meghatározása nem elválasztható a 2013. évi Jegybanktörvény által megfogalmazott hármas jegybanki mandátumtól':

- A Magyar Nemzeti Bank elsődleges célja az árstabilitás elérése és fenntartása.

- Az MNB elsődleges céljának veszélyeztetése nélkül támogatja a pénzügyi közvetítőrendszer stabilitásának fenntartását, ellenálló képességének növelését, a gazdasági növekedéshez való fenntartható hozzájárulásának biztosítását.

- A rendelkezésére álló eszközökkel támogatja a Kormány gazdaságpolitikáját.

Mielőtt a monetáris politika hatásmechanizmusát részletezzük, érdemes a monetáris politikai eszköztár fogalmát is áttekinteni.

A monetáris politikai eszköztár mindazon eszközök összességét jelenti, amelyek a jegybanktörvény felhatalmazása alapján a jegybank rendelkezésére állnak a monetáris politikai céljai eléréséhez. Az eszköztár elemeivel a bankközi kamatok szintjét, illetve a bankközi piacon forgó jegybankpénz mennyiségét lehet közvetlenül befolyásolni.

\subsubsection{A monetáris intézkedések hatásmechanizmusa ${ }^{3}$}

\section{A monetáris transzmisszió hagyományos csatornái}

A monetáris politika a monetáris transzmisszió többlépcsős mechanizmusán keresztül befolyásolja a makrogazdasági változók alakulását.

A monetáris transzmissziónak jellemzően öt csatornáját különböztetjük meg:

- a kamat-,

- az árfolyam-,

- az eszközár,

- a hitel-,

- és a várakozási csatorna.

Ezen csatornák mindegyike sajátos mechanizmust jelent, amelyen keresztül az árupiaci keresletet elérik a monetáris politikai lépések. A jegybank alapkamatról hozott döntései, illetve a jövőbeli döntésekre utaló kommunikációja első lépés-

2 2013. évi CXXXIX. törvény, 1. fejezet, 3. \$.

3 Felcser et al. (2017). 
ben a pénzügyi piacokon fejti ki hatását, ahogy a piaci kamatok, az eszközárak és a forintárfolyam gyorsan reagál. Ezt követi a termékpiaci reakció. Amint a vállalatok és a fogyasztók alkalmazkodnak a pénzpiaci fejleményekhez, megváltozik az aggregált kereslet. A megváltozó keresletre a vállalatok egyrészt az előállított termékek mennyiségének, másrészt áraik változtatásával reagálnak, így végül a monetáris politika a kibocsátást és az inflációt is befolyásolja.

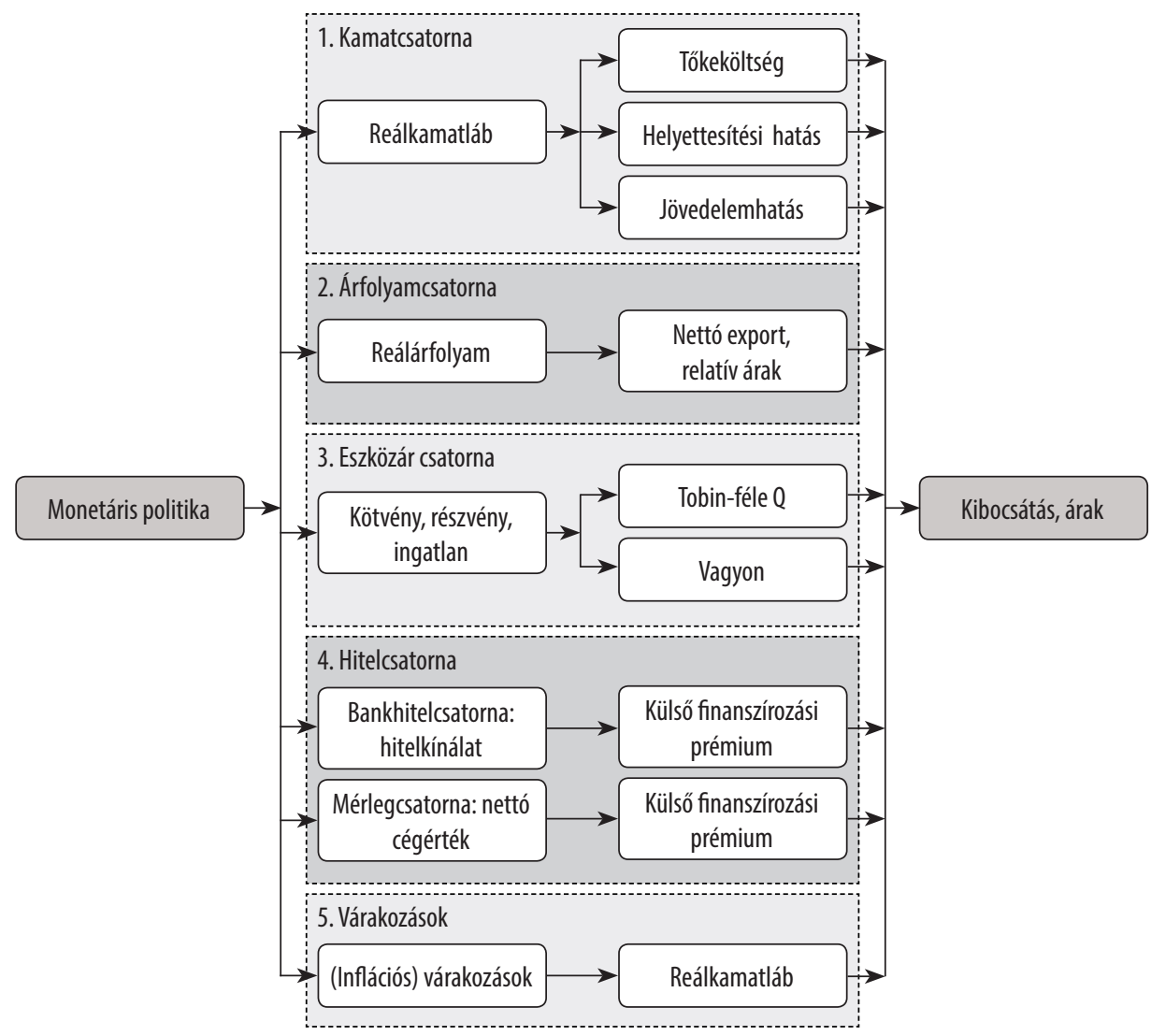

\section{1. ábra: A transzmissziós mechanizmus sematikus ábrája}

Forrás: $M N B$

A gazdaságok és a pénzügyi piacok egyes strukturális jellemzői számottevő mértékben befolyásolják, hogy a monetáris politikai lépések hogyan fejtik ki hatásukat a makrogazdasági változókra. Ezen tényezők közé tartozik többek között a pénzügyi rendszer szerkezete vagy a gazdaság nyitottsága. 
A kamatcsatornánál a jegybanki lépések a pénzügyi piaci és banki kamatokon keresztül fejtik ki makrogazdasági hatásukat, a hitelcsatornánál a banki hitelkínálatnak van kitüntetett szerepe. Az eszközár-csatorna jelentősége részben a tőkepiacok fejlettségén múlik. Mindezek miatt a pénzügyi rendszer fejlettsége és struktúrája meghatározó jelentőségű a monetáris transzmisszió hatékonyságát illetően. A pénzügyi mélyülés erősíti a monetáris politika makrogazdaságra gyakorolt hatását, emellett a pénzügyi innovációk (értékpapírosítás, új kockázatkezelő eszközök) és a szabályozás változása is érintheti a transzmissziós csatornákat. A nem banki pénzügyi szereplők (beruházási alapok, biztosítótársaságok, nyugdíjalapok stb.) növekvő jelentősége erősíti a piaci alapú finanszírozást (kereskedelmi papír, vállalati kötvény), így nő a pénzügyi piacok tőkepiaci orientáltsága. A fenti hatások emellett a banki hitelezést is befolyásolják. Ha növekszik a banki hiteleknél a piaci alapú árazás jelentősége, akkor a banki kamatok érzékenyebbé válnak a jegybank kamatlépéseire és azok piaci hatására.

A bankok hitelkínálata mellett egyéb finanszírozási formák is rendelkezésre állnak a gazdasági szereplők számára. Ezek közé tartozik az értékpapírpiac. Az Egyesült Államok pénzügyi rendszerében jóval nagyobb hangsúly jut a tőkepiacoknak a vállalatok és a háztartások finanszírozásában, mint a bankrendszernek. A feltörekvő és egyes fejlett gazdaságokban (különösen az EU-n belül) azonban elsősorban a bankok dominálnak a gazdasági szereplők finanszírozásban, ezért a bankrendszer kiemelt szerepet tölt be a monetáris politikai lépések tovagyürűzésében. A monetáris politika hatása az egyes csatornák esetében több tényezőtől, például a gazdasági szereplők eladósodottságától is függ. A nagyobb banki hitelállomány a hitelcsatornán, míg az értékpapírpiacon keresztüli eladósodás (kötvények) fokozódása az eszközár-csatornán keresztül erősítheti a monetáris politikai lépések hatását a makrogazdasági változók alakulására.

A bankok számos gazdaságban kiemelt szerepet töltenek be a pénzügyi rendszerben, a bankrendszer strukturális jellemzői nagy jelentőséggel bírnak a transzmisszió szempontjából.

\section{Makrogazdasági és gazdaságpolitikai környezet}

A makrogazdasági és gazdaságpolitikai környezet több eleme is fontos szerepet játszhat a transzmisszió hatékonysága szempontjából. A gazdaság (és a pénzügyi 
rendszer) fejlettsége mellett a gazdaság nyitottsága, az inflációs környezet jellemzői, a fiskális politika viselkedése, a monetáris politika keretrendszere, vagy a gazdaságot jellemző nominális merevségek mértéke is befolyásolja az egyes transzmissziós csatornák relatív eredményességét.

A makrogazdasági környezet változása, különösen az infláció szintjének és változékonyságának mérséklődése, fontos tényező lehetett az árfolyam-begyürűzés megfigyelt csökkenésében, és így az árfolyamcsatorna működésében.

A monetáris politika nagyobb fokú hitelessége az inflációs várakozások horgonyzásával erősítheti a monetáris transzmissziót. Ezen kívül lebegő árfolyamrendszer mellett a piaci szereplők várakozásai kevésbé kötődnek az árfolyam alakulásához, ezért gyengébb lehet az árfolyamváltozások begyürüzése a fogyasztói árakba. Speciális eseménynek tekinthető az euró bevezetése, amely során az érintett európai országokban megszűnt az árfolyamkockázati prémium, az árfolyamcsatorna pedig egységesebb lett az euróövezet országaiban.

A fiskális politikának is fontos szerepe lehet a monetáris politika hatásmechanizmusában. Az infláció fiskális elméletében az inflációt a monetáris és a fiskális hatóság viselkedésének együttese határozza meg.

\section{A nemkonvencionális eszközök transzmissziója}

A válság során számos jegybank egészítette ki korábban használt eszköztárát nemkonvencionális jegybanki eszközökkel. A nemkonvencionális eszközök alkalmazására akkor van szükség, ha a hagyományos kamateszköz alkalmazása valamilyen korlátba ütközik, vagy a jegybank a kamateszközzel nem tudja kellő hatékonysággal kezelni a monetáris politikai célokat akadályozó problémát. Korlátot jelenthet a zéró nominálisalsó-korlát elérése, mert a jegybank nem tudja tovább csökkenteni a kamatot a technikai alsó korlátnál. Emellett a monetáris politikai célok elérését akadályozhatja, ha egyes pénzügyi piacokon zavarok, vagy fundamentálisan nem igazolható felárak alakulnak ki, amelyek jelentősen rontják a monetáris politikai transzmisszió hatékonyságát. Ilyen problémákat a kamateszköztől eltérő nemhagyományos eszközök képesek kezelni. A válság alatt mindegyik kihívásra adódott példa, ezért a jegybankok a nemkonvencionális eszközök számos típusát alkalmazták. 
A nemkonvencionális eszközök alkalmazásának kiemelt célja a defláció elkerülése volt. Mivel az irányadó kamatot a jegybankok nem tudták tovább csökkenteni, miközben további monetáris lazításra volt szükség, új eszközökkel igyekeztek a cél alá csökkenő inflációt a célra emelni. A fejlett országok jegybankjai által a klasszikus likviditásbővítő (fedezetért nyújtott jegybanki hitel) eszközökön kívül a legáltalánosabban használt nemkonvencionális intézkedés a pénzügyi eszközök vásárlása volt. Az eszközvásárlások jelenthetnek elöre bejelentett összegü vagy nyílt végü állampapír-vásárlást és egyéb értékpapír-vásárlást is. Attól függően, hogy konkrétan milyen értékpapírt vásárol a központi bank, a transzmisszió némileg különbözhet, de az eszközvásárlások általános transzmissziója minden esetben hasonló csatornákon keresztül zajlik. Az eszközvásárlások hosszú hozamokra gyakorolt hatását a jegybankok kommunikációjuk előretekintő iránymutatásával erősítették, amely segítségével tartósan elköteleződtek az alacsony kamatpolitika mellett. Így több évre elöre nem számíthattak a piaci szereplők kamatemelésre, ami a hozamgörbe hosszabb lejáratú szakaszain is csökkentette a hozamokat. Számos országban a banki hitelezés hiánya jelentett nehézséget. Emiatt több jegybank alkalmazott hitelezést ösztönző, támogató eszközöket, amelyek elsősorban a vállalati hitelezés élénkülését célozták meg.

\section{A nemkonvencionális intézkedések csoportosítása}

A válság és annak pénzügyi szektorra gyakorolt hatásai a jegybanki eszköztár átalakításához vezettek. Az új kihívások kezelésére a jegybankok számos új eszközt alkalmaztak. Ezeket jellemzően eltérő céllal, saját pénzügyi rendszerük sajátosságainak megfelelően, hazai transzmissziós mechanizmusaik töredezettségét figyelembe véve alakították ki.

Csoportosításunkban az eszközök evolúcióját is figyelembe véve négy különböző eszközt különböztetünk meg:

- általános likviditásbővítő eszközök,

- eszközvásárlások, azon belül állampapír-vásárlások,

- elöretekintő iránymutatás,

- célzott hitelösztönző intézkedések.

A válságkezelés során a jegybankok szinte kivétel nélkül hajtottak végre általános likviditásbővítést. A jegybankok jellemzően a saját korábbi, hagyományos 
likviditásnyújtó eszközeiket bővítették, sok esetben korlátlan mennyiségekkel és kedvezőbb feltételekkel alkalmazva azokat. A likviditásbővítést elősegítő eszközök célja a likviditási zavarok kezelése, a pénzügyi piacok stabilizálása. Az akut válság időszakában a bankközi piaci hozamok ugrásszerü növekedése, és a bankok közötti jelentősen csökkenő tranzakciószám megnehezítette a bankok forrásszerzését, ami így a banki hitelezést veszélyeztette. A jegybanki likviditásnyújtás történhet hazai vagy külföldi devizában. Egy jól funkcionáló pénzügyi rendszerben a jegybank korlátozott likviditást nyújt a bankrendszer számára, válság esetén viszont többnyire felső korlát nélküli mennyiségben tették elérhetővé hiteleszközeiket, és esetenként devizalikviditást nyújtó eszközökkel egészítettek ki. További likviditásbővítő célt szolgált a jegybankban elfogadható fedezeti kör bővítése, a jegybanki partnerkör bővítése, a tartalékszabályok módosítása és jegybanki hiteleszközök futamidejének meghosszabbítása.

Az eszközvásárlások során a jegybankok különböző típusú értékpapírokat, pénzügyi eszközöket vásárolnak nagy volumenben a magánszektor szereplőitől. A vásárlások az esetek többségében transzparensen, előre bejelentett ütemben és mennyiségben történtek, de van példa a nyíltvégü vásárlásokra is, ahol a jegybank nem kommunikálta a vásárlások tervezett végösszegét, időhorizontját vagy egyéb részleteit. Az eszközvásárlási programok célja az adott hitelpiacon való célzott beavatkozás, a piaci zavarok, felárak mérséklése. Az eszközvásárlások jelentős része az állampapírpiacra fókuszált. Állampapír-vásárlások során a központi bank célja általában a nominális kamatok alsó korlátja melletti további lazítás a kockázatmentes hozamgörbe hosszú végének csökkentésén keresztül, így az esetleges deflációs vagy cél alatti inflációs kockázatok csökkentése. Előfordulhat, hogy más céllal, a túlzott kötvénypiaci felárak mérséklése (transzmisszió helyreállítása) miatt kezd a központi bank állampapír-vásárlásba. Az eszközvásárlások a jegybankmérleg növekedésével járnak, ezért gyakran jegybanki mérlegpolitikának is nevezik őket. Az állampapír-vásárlások jelentősen növelték a magánszektor likviditását és csökkentették a hosszú hozamokat, ezáltal mérsékelték az államadósság refinanszírozásának költségeit.

Ha az irányadó ráta eléri a nominális alsó korlátot, az inflációs várakozások lefelé eltávolodhatnak az inflációs céltól, hiszen a központi bank hagyományos eszköztárán keresztül nem tud tovább lazítani a monetáris kondíciókon. 
Ebben az esetben a jegybank kommunikációs eszközök segítségével is lazíthat a nominális alsó korlátnak megfelelő kamatszint tartós tartása melletti elköteleződéssel. Ilyenkor a jegybank nem csökkenti alacsonyabb szintre a kamatot, amit később a cél elérésével összhangban emelne, hanem jóval hosszabb ideig való tartást kommunikál, amivel szintén lazítást ér el a hozamgörbe hosszabb szakaszán.

Ez a kommunikáció az előretekintő iránymutatás (forward guidance). Az alacsony kamat fenntartására vonatkozó elköteleződéssel a jegybank a hozamgörbe hosszabb lejáratú szegmensében igyekszik csökkenteni a hozamokat, azzal az üzenettel, hogy hosszabb ideig nem fog emelni az irányadó kamatokon.

Az elöretekintő iránymutatásnak több típusa létezik. A jegybanknak lehetősége van előrejelzés jellegü és elköteleződés jellegű iránymutatást adni. Az elörejelzés jellegü iránymutatás gyengébb jelzést ad, mert az adott pillanatban rendelkezésre álló információk alapján fejezi ki a jövőre nézve a kamatszint tartását. Így, ha például egy sokk hatására emelkedik az infláció, az iránymutatás érvényét vesztheti, és a piaciszereplők arra számíthatnak, hogy ha az infláció előrejelzett értéke a cél fölé emelkedik, akkor a jegybank a korábbi - más információs bázison tett - kamattartási ígéretével szemben mégis kamatot emel. Ezzel szemben az elköteleződés jellegü iránymutatás erőteljesebb jelzést adhat, és jobban köti a jegybankot a korábbi bejelentésének betartására. Ebben az esetben, ha a jegybank súlyosnak ítéli meg a lefelé mutató inflációs kockázatokat, akkor konkrét időponthoz is kötheti az előretekintő iránymutatást. Ezt akkor tudja hitelesen kommunikálni, ha elhiteti a szereplőkkel, hogy akkor is tartani fogja az alapkamatot, amikor más esetben már kamatot emelt volna. Hasonlóan megteheti azt is, hogy egy konkrét makrogazdasági mutatószám szintjéhez, például a munkanélküliségi ráta egy értékéhez köti az első kamatemelés lehetőségét (ahogy azt a Federal Reserve és a Bank of England tette). Ekkor egy inflációs sokk esetén is fenn kellene tartania a kamatszintet a komolyabb hitelességveszteség elkerülése érdekében.

A válság kitörését követően a bankközi piacok súlyos zavarai, az emelkedő forrásköltségek, valamint a recessziós várakozásokból fakadó veszteségek és a bankrendszer mérlegleépítési folyamatának következményeként a bankok jelentősen szigorítottak hitelkondícióikon. A folyamat során a bankok magánszektor 
számára nyújtott hitelezése visszaesett. A jegybankok által alkalmazott nemkonvencionális eszközök ugyan lefelé tolták a hozamgörbét és oldották a pénzpiaci zavarokat, ennek ellenére azonban nem voltak képesek jelentősen élénkíteni a magánszektornak nyújtott banki hitelezést. Ezért a központi bankok egy része célzottan a banki hitelezés támogatása érdekében avatkozott be. A hitelösztönzést segítő jegybanki programok jellemzően kiszámítható (például többéves fix kamatozású hitel) és olcsó banki forrásszerzést tettek lehetővé (jellemzően a jegybanki hiteleszköznél alacsonyabb kamaton). A legtöbb hitelösztönzést támogató jegybank valamilyen formában olcsóbb forrást vagy egyéb transzfert biztosított a hitelintézetnek, amit célzottan hitelezésre kellett fordítaniuk a kereskedelmi bankoknak. A bankszektor számára nyújtott kedvezményes jegybanki eszközöktől a banki hitelezési hajlandóság és a hitelezési aktivitás növekedését várták.

Az első ilyen programokat a jegybankok 2010-2013 között alkalmazták (a japán jegybank hitelezésösztönző programja, az angol jegybank FLS programja, az MNB Növekedési Hitelprogramja), majd 2014-től fokozatosan hitelvállalási feltételekhez kötve, de továbbra is kedvezményes hitelt nyújtottak a kereskedelmi bankok számára (EKB TLTRO I-II programok, az angol jegybank Term Funding Scheme programja, az MNB Növekedéstámogató Programja). A két típus között a fö különbség az volt, hogy a korábbi eszközöknél a kereskedelmi bankok legfeljebb annyit vállaltak, hogy az eszközt célzottan, adott célcsoport finanszírozására fordítják, míg 2014-től a jegybankok az eszközök feltételéül szabták, hogy valamekkora mértékben növeljék az adott célcsoportnak nyújtott hitelezést egy referencia-időszak hitelállományához képest.

\section{Az eszközvásárlások transzmissziója}

Az eszközvásárlás során a jegybank pénzügyi eszközöket vásárol a másodlagos piacon, amit jegybankpénz teremtésével, így a jegybanki tartalékok megfelelő mértékủ megemelkedésével finanszíroz.

A mennyiségi lazítás közvetlen hatással van mind a szük, mind a tág értelemben vett pénz mennyiségére. A mennyiségi lazítás különböző eszközök, elsősorban államkötvények vásárlását célozza, az esetek döntő többségében nem banki pénzügyi vállalatoktól (például nyugdíjalapoktól). 


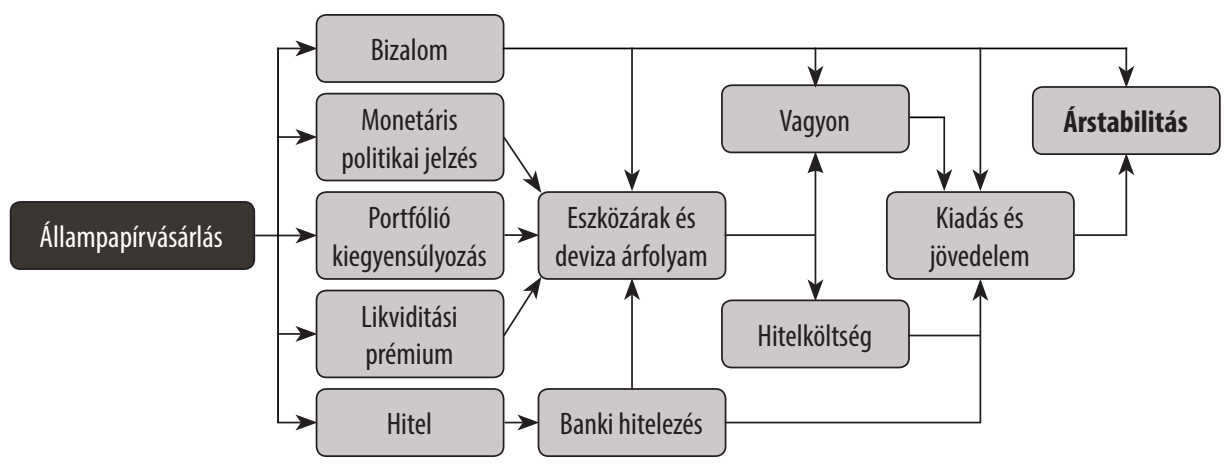

2. ábra: A mennyiségi lazítás hatása a mérlegekre

Forrás: $M N B$

A nemkonvencionális eszközök müködése és így monetáris transzmissziója is eltér a hagyományos kamateszköz transzmissziójától. A leggyakrabban használt nemkonvencionális jegybanki lépés, az eszközvásárlás (mennyiségi lazítás), számos lehetséges csatornán keresztül hat a gazdaságra. Az eszközvásárlások során a központi bank rövid idő alatt nagy mennyiségi pénzt juttat a pénzügyi rendszerbe.

A vásárlások a kereslet élénkülésével a piacok működésének javulásához és magasabb árakhoz, így alacsonyabb hozamokhoz vezetnek. A reálgazdaság élénkítéséhez szükséges feltétel volt, hogy a pénzügyi rendszer likviditási zavarait oldják a jegybankok, amire az eszközvásárlások gyors megoldást jelentettek.

A hagyományos monetáris transzmissziós mechanizmushoz hasonlóan a jegybankok által alkalmazott mennyiségi lazítás is számos csatornán képes hatni a reálgazdasági és pénzpiaci kondíciókra. Amikor a pénzügyi piacok nem müködnek megfelelően, a jegybankok mennyiségi lazítási programjai a likviditás növelésén és az adottrészpiac keresletének ösztönzésén keresztül hathatnak a piaci kondíciókra. A jegybank erőteljes elköteleződése a további lazítás mellett, általános bizalmat adhat a piacoknak, amit bizalmi csatornának nevezünk. 


\subsubsection{A jegybanki eszköztár}

\subsubsection{Devizatartalék szerepe $e^{4}$}

Egy ország devizatartaléka alatt alapvetően a monetáris hatóság számára elérhető, idegen devizában denominált, külföldiekkel szemben fennálló követeléseket, pénzügyi eszközöket értjük. Az eszköznek - legalább - három kritériumnak kell megfelelnie ahhoz, hogy beleszámítson a devizatartalékba.

A követelésnek:

- külfölddel szemben kell fennállnia, tehát például hazai kibocsátású devizakötvény vásárlása nem számít bele a devizatartalékba;

- külföldi devizában denomináltnak kell lennie, azaz egy külföldi kibocsátó esetleges hazai devizában kibocsátott kötvénye nem számít tartalékelemnek;

- a jegybank számára elérhetőnek, könnyen hozzáférhetőnek kell lennie, ami a devizatartalékból kizárja a nem konvertibilis devizában fennálló, illetve tőkekorlátozás alá eső követeléseket.

A devizatartalék mértékét bruttó módon szokás megjeleníteni és értelmezni, azaz a jegybank külföldi követeléseiből a jegybank külfölddel szembeni kötelezettségei nem kerülnek levonásra. A devizatartalék-tartás nem más tehát, mint egy - külfölddel vagy hazai bankrendszerrel szemben fennálló - adósságból finanszírozott bruttóvagyon-alap fenntartása, kezelése, gyarapítása.

\section{Célok}

A jegybankok a devizatartalék tartásának céljaiból kiindulva, és a befektetők elvárásai alapján meghatározzák, mekkora devizatartalékot tartanak szükségesnek. A tartalékszint meghatározása után a következő lépés a devizatartalék befektetési, illetve tartalékkezelési stratégia kiépítése, mely a tartalék szerkezetének, összetételének meghatározását foglalja magába. A jegybankok a kockázathozam preferenciáik alapján eldöntik milyen eszközökbe, és az egyes eszközökből mekkora arányban kívánnak befektetni.

A jegybankok különböző célok elérése érdekében tartanak devizatartalékot, a legtöbb ország egyszerre több célt is megjelöl. A modern jegybankok által kitü-

4 Csávás - Kiss (2017). 
zött tartaléktartási célok szerteágazóak. A célok egy része a monetáris politika és a pénzügyi stabilitás támogatásához kapcsolódik.

A fejlett országoktól jellemzően nem várnak el érdemi devizatartalékot, a feltörekvő országokban azonban fontos a megfelelő devizatartalékszint fenntartása. Általánosnak tekinthető az a nézet, hogy a fejlett országoknak alacsony mértékü devizatartalékra van szükségük. A legfejlettebb országok jellemzően rugalmas árfolyamrendszert alkalmaznak, így leginkább piaci zavarok esetére tartanak fenn devizatartalékot. Ezzel szemben a feltörekvő gazdaságok erősebben rá vannak utalva a külföldi forrásokra, így a tartaléktartás fő motivációja, hogy egy pénzügyi válságra való felkészülésként megfelelő mértékü puffert tartsanak. A tartaléktartási célok többsége monetáris politikai vagy pénzügyi stabilitási célokhoz kapcsolódik. Az intervenciós kapacitás biztosítása például a monetáris politika, azon belül is az árfolyam-politika része.

A devizalikviditás nyújtása pedig pénzügyi stabilitási célokkal van összefüggésben. Ugyanakkor egy konkrét cél egyszerre tölthet be monetáris politikai és pénzügyi stabilitási funkciót is.

\begin{tabular}{|c|c|c|c|}
\hline Monetáris politikai célok & Pénzügyi stabilitási célok & Tranzakciós célok & Egyéb \\
\hline & $\begin{array}{c}\text { Piaci szereplők elvárásainak } \\
\text { megfelelés }\end{array}$ & & \\
\hline \multicolumn{2}{|c|}{ Bankoknak devizalikviditás nyújtása } & \\
\hline Új-merkantilizmus & \multicolumn{2}{|c|}{ Fizetési mérleg finanszírozása } & \\
\hline & & Állami tranzakciós devizaigény & \\
\hline & & & Vagyonfelhalmozás \\
\hline
\end{tabular}

\section{3. ábra: A tartalékolási célok meghatározása}

Forrás: $M N B$

A piaci szereplők elvárásainak megfelelö tartalékszint biztosítása, a befektetői bizalom erősítése, mint tartalékolási cél, a nemzetközi tőkepiacokra ráutalt feltörekvő országok számára fontos. A befektetők, hitelminősítők, nemzetközi szervezetek 
nemcsak válsághelyzetben, de kedvező piaci környezetben is elvárják, hogy egy jegybank demonstrálja, a tartalékok elegendőek a pénzügyi sokkok kivédésére. A külföldi befektetők nyomon követik a jegybankok tartalékmegfelelését, ami a külső sebezhetőség egyik fontos indikátora, és hatással van a befektetési döntéseikre. A hitelminősítő intézmények is fontosnak tekintik a devizatartalék mértékét, ami befolyásolja, hogy egy ország milyen hitelminősítést kaphat. A devizapiaci intervenciós kapacitás biztosítása a rögzített, vagy szűk sávos árfolyamrendszert használó országok mellett a lebegő árfolyamú országokban is fontos. A rögzített, vagy szűk sávos árfolyamrendszert alkalmazó jegybankok számára a devizatartalékok tartásának fö célja, hogy válságok idején képesek legyenek az árfolyamrendszert intervenció alkalmazásával megvédeni, és hitelessé tegyék az árfolyamrendszert. Emellett számos feltörekvő ország ún. menedzselt lebegtetést folytat, ahol a jegybank szintén megpróbálja befolyásolni az árfolyamokat. Ezen országokban nem feltétlenül egy adott árfolyamszint, vagy árfolyampálya elérése a cél, hanem az árfolyam-ingadozások csökkentése, ami szerves része lehet a monetáris politikának. A tisztán lebegő árfolyamrendszert alkalmazó, fejlett országokban a jegybankoknak nem céljuk az árfolyam szintjének közvetlen befolyásolása. Ugyanakkor még a legfejlettebb devizapiacokon is szükség lehet beavatkozásra. A devizapiacokat érő rendkívüli sokkok egyes esetekben olyan mértékű kockázatot okozhatnak az árjegyzőként működő bankok számára, hogy azok visszavonulhatnak a piacról, ami a piacok működését és a pénzügyi stabilitást veszélyezteti, és szélsőséges árfolyam ingadozást idézhet elő. A devizapiaci likviditáshiány kezelése monetáris politikai és pénzügyi stabilitási szempontból is fontos.

Az állam tranzakciós devizaigényének biztosítása a jegybanknak, mint az állam bankja funkciójából ered. Jellemzően a jegybankok vezetik az állam hazai és külföldi devizában denominált számláit, és végzik a devizában felmerülő tranzakcióit.

A fizetési mérleg közvetlen finanszírozása, mint tartalékolási cél, a kevésbé fejlett, likvid devizapiaccal nem rendelkező, vagy rögzített árfolyamrendszert alkalmazó országokban releváns.

Az új merkantilizmus egy viszonylag új tartalékolási cél, ami gazdaságpolitikai célokhoz kapcsolódik. Ez azt jelenti, hogy egyes országok az egyensúlyinál leértékeltebb árfolyamot igyekeznek fenntartani, és azon keresztül az exportot ösztönözni (például Kína). 


\section{Tartalékszint meghatározása}

A devizatartalékok megfelelö, illetve optimális szintjét az akadémiai irodalom és a gyakorlati szakemberek számos kritérium alapján határozzák meg. Fontos megkülönböztetni egymástól az optimális és a megfelelö devizatartalék szintet. Az optimális szint egy adott közgazdasági modell eredményeként kapott szintet jelöl, ami számos tényező függvénye, és jellemzően az akadémiai irodalomban használatosak. A megfelelő szint a befektetők által elvárt, szükségesnek tartott szintet jelenti.

A befektetők, piaci szereplők számos, széles körben használatos, mutatót követnek nyomon a devizatartalék megfelelő szintjének meghatározására. A mutatók egy része tradicionális, régóta használt mutató, amelyek egyszerűek, így szinte bárki által könnyen kiszámolhatóak és nyomon követhetőek. Az optimális devizatartalék-szint meghatározásánál egyre inkább terjednek a modell alapú megközelítések, amelyek országok széles körét használó becslésekre építenek, illetve a gazdasági szereplők optimalizáló viselkedését is figyelembe veszik. Az egyszerübb mutatók sokasodásával az összetett, kombinált mutatók használata is kezd elterjedni, melyek az egyes komponensekhez különböző súlyokat rendelnek.

\begin{tabular}{|l|l|}
\hline Egyszerű szabályok & Összetett szabályok \\
\hline -Guidotti-mutató & · Bruttó finanszírozási igény (rövid külső adósság+ fizetési mérleg deficit) \\
· Importszabály & - Költség-haszon alapú modellek \\
· Pénzmennyiség szabály & $\cdot$-IMF-féle kombinált mutató (rövid külső adósság, külföldi tartozások, pénzmennyiség, export) \\
- Bruttó külső adósság aránya & $\cdot$ Wijnholds-Kapteyn mutató (rövid külső adósság és pénzmennyiség) \\
\hline
\end{tabular}

\section{4. ábra: Tartalékmutatók csoportosítása}

Forrás: MNB

Ezek közül az egyik legelfogadottabb és leginkább használt a Guidotti-mutató. A Guidotti-szabály szerint a devizatartalékoknak fedezniük kell az ország egy éven belül lejáró külföldi adósságát. Az 1990-es években a rövid, külső adósság jelentősen nőtt egyes latin-amerikai és délkelet-ázsiai országokban, melyet a devizaliberalizáció terjedése tett lehetővé. Az 1994-1995-ös mexikói, az 19971998-as délkelet-ázsiai és az 1998-1999-es brazil válságok kitöréséhez hozzájárult, hogy a devizatartalék lényegesen elmaradt a rövid, külső adósság szintjétől. Ezen országok jelentős tőkekivonást szenvedtek el, melynek ellensúlyozásához a devizatartalékok nem voltak elegendőek, így a rögzített árfolyamrendszer feladá- 
sára kényszerültek. E válságok tapasztalata nyomán Pablo Guidotti, az argentin jegybank korábbi alelnöke és Alan Greenspan, az amerikai Fed volt elnökének javaslatai alapján született meg a Guidotti-szabály 1999-ben (a Guidotti-Greenspan-szabály elnevezés is használatos). A Giudotti-szabály egy olyan válsághelyzetben jelent releváns mutatót, amikor a külső finanszírozás leáll, és csak a devizatartalékból biztosítható a lejáró külső adósság visszafizetése.

\subsubsection{Pénzforgalom fenntartása, mint jegybanki feladat ${ }^{5}$}

A gazdasági szereplők egymással szemben teljesített fizetéseinek összességét pénzforgalomnak nevezzük. A pénzügyi infrastruktúrák kifejezést azoknak az informatikai rendszereknek, technológiai megoldásoknak, folyamatoknak és szabályoknak összefoglaló megjelölésére használjuk, amelyek a fizetések kezdeményezését és lebonyolítását, valamint az értékpapírok és egyéb pénzügyi eszközök gazdasági szereplők közötti áramlását lehetővé teszik.

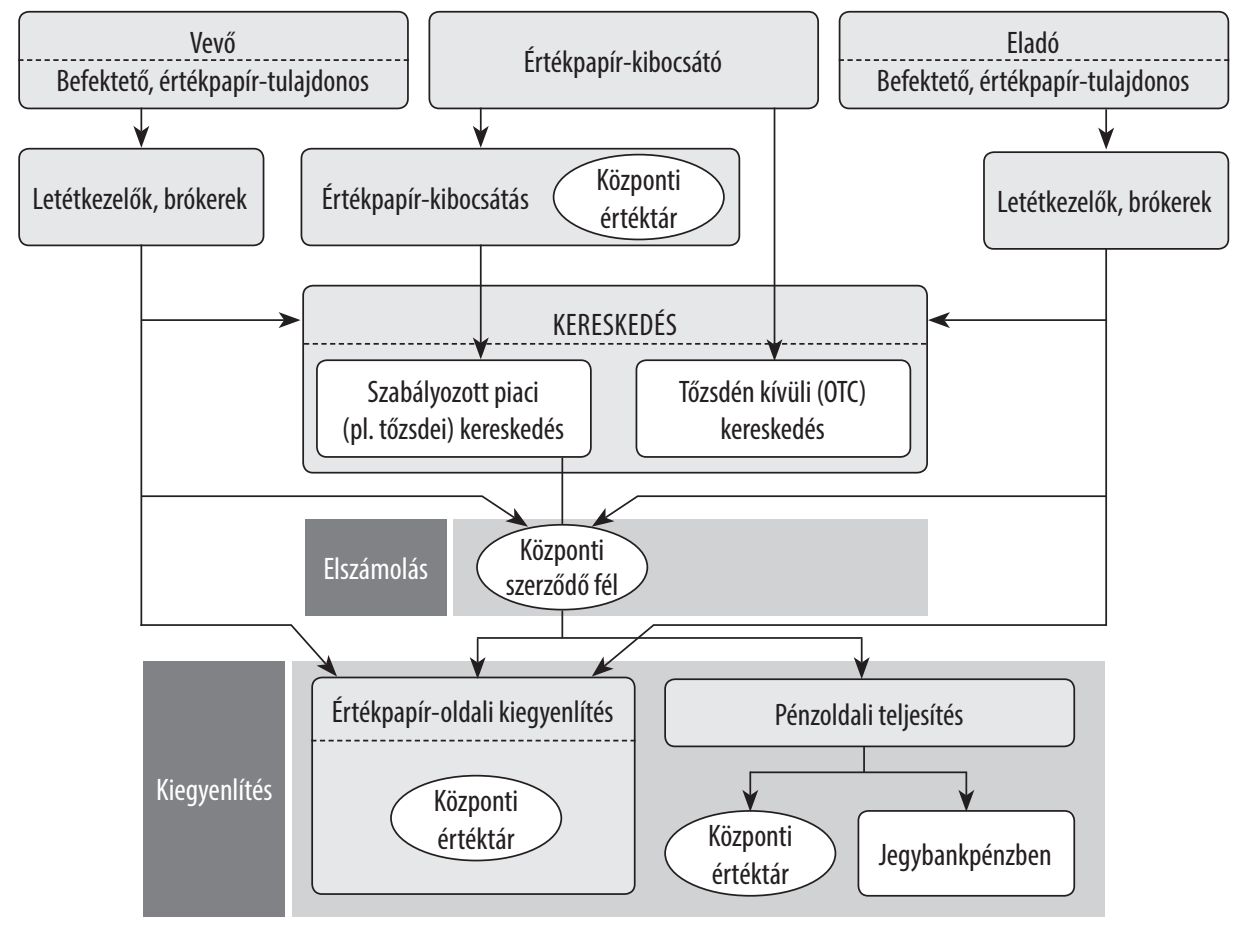

5. ábra: Értékpapír-piaci infrastruktúra

Forrás: $M N B$

5 Bartha et al. (2017). 
A jegybankok döntő többségének alapvető feladatai között explicitmódon rögzítésre kerülnek - sokszor a központi bankok müködését szabályozó törvények szintjén is - a pénzforgalommal és a pénzügyi infrastruktúrák müködésével kapcsolatos célok. Ennek oka elsődlegesen az, hogy e területek több ponton is kapcsolódnak a jegybank alapvető céljaihoz, és meghatározó módon képesek befolyásolni, hogy azok teljesülnek-e vagy sem.

A pénzforgalom és a pénzügyi infrastruktúrák müködése befolyásolhatja a központi bankok három nagy céljának, a monetáris stabilitás és a monetáris transzmisszió hatékonyságának, a pénzügyi stabilitásnak és a gazdasági növekedés támogatásának teljesülését.

\section{A monetáris stabilitás és a monetáris transzmisszió hatékonyságának növelése és fenntartása}

A monetáris stabilitás szűk értelemben az árstabilitást jelenti, ami a legtöbb jegybank elsődleges célja, és a pénz értékmérő és felhalmozási eszközfunkciójának védelmét jelenti. Tágabb értelemben azonban a fizetőeszközbe vetett bizalom általános megőrzésének követelményeként is lehet rá tekinteni. Ebben az értelemben pedig nem hanyagolható el a pénzforgalmi vagy csereeszköz funkciójába vetett bizalom növelése és fenntartása. Ez utóbbi viszont nem képzelhető el a pénzforgalom és a pénzügyi infrastruktúrák megbízható, biztonságos és hatékony müködése nélkül.

A megbízhatóan és stabilan működő pénzügyi infrastruktúrák elengedhetetlenek, ezen túlmenően egyrészt a monetáris politikai műveletek gyors és hatékony végrehajtásához, másrészt a pénzpiacok súrlódásmentes működésének támogatásán keresztül hozzájárulnak a monetáris transzmisszió hatékonyságának növeléséhez.

\section{A pénzügyi közvetítés mélyülésének biztosítása, a pénzügyi stabilitás megte- remtése és fenntartása}

A pénzügyi piacok hatékony müködése alapfeltétele mind a pénzügyi közvetítés mélyülésének, mind a pénzügyi stabilitás megteremtésének. A jól működő (biztonságos, megbízható és hatékony) pénzügyi infrastruktúrák ennek megvalósulását és fenntartását jelentős mértékben támogatják, hiszen ezek a rendsze- 
rek jelentik a gazdasági szereplők egymással szembeni megbízható pozíció nyilvántartásának, elszámolásának és teljesítésének az alapját. A nem megbízható, a felmerülő kockázatokat nem megfelelően kezelő fizetési rendszer ezzel szemben alapjaiban ingathatja meg a pénzügyi piacok müködését, sőt felerősítheti a pénzügyi piacok egy-egy szereplőjénél jelentkező problémákat, így rendszerszintű kockázatok kialakulásának kiindulópontja lehet. Ezen túlmenően a bankok és a pénzügyi piacok egyéb jelentős szereplői közötti, nagy összegü fizetési forgalom biztonságos, megbízható és hatékony lebonyolítása szintén kulcskérdés a pénzügyi stabilitás megőrzése szempontjából.

\section{A gazdaság növekedésének támogatása}

A biztonságosan, megbízhatóan és hatékonyan működő pénzügyi infrastruktúrák közvetett módon már a fenti célok támogatásán keresztül is kedvezően hatnak a gazdaság teljesítményére.

A pénzforgalom hatékony müködésének azonban jelentős közvetlen hatása is van a makrogazdaság teljesítményére. Nemzetközi kutatások egybehangzó eredménye azt mutatja, hogy a hatékonyabb pénzforgalmi rendszer több csatornán keresztül is kedvezően hat a gazdaság versenyképességére és növekedésére. A társadalmi szinten olcsóbban müködő pénzforgalom egyrészt erőforrásokat szabadít fel, amelyek más, esetleg produktívabb termelési folyamatokban használhatók fel. Másrészt, a pénzforgalmi szolgáltatások költségszintjének csökkenése általánosan javítja a vállalatok hatékonyságát. Harmadrészt, a hatékonyabb elektronikus fizetési módok terjedésével együtt általában kimutatható mértékben visszaszorul a feketegazdaság, amely az adóbeszedési hatékonyság javulásán keresztül fejti ki kedvező gazdasági hatását.

\section{Jegybanki célok}

Általánosan elfogadott az a nézet, hogy a jegybankoknak transzparens módon megfogalmazott célként kell kitüzniük maguk elé annak elérést, hogy az adott gazdaság pénzforgalma és pénzügyi infrastruktúrái biztonságosan, megbízhatóan és hatékonyan müködjenek. A különböző országok más és más modelleket alkalmaznak a pénzügyi infrastruktúrák felügyeletére, szabályozására és felvigyázásra. Egyes országokban a jegybankok egyedül, máshol más állami hatósá- 
gokkal közösen gyakorolják ezeket a funkciókat. Az alkalmazott modelltől függetlenül egyértelmüen megállapítható, hogy minden jelentős központi bank - a rájuk vonatkozó jegybanktörvények alapján - az elsődleges céljának való megfelelés keretein belül biztosítja a fizetési és elszámolási rendszerek stabilitását, és biztonságos, kiszámítható müködését.

\section{Kockázatok a pénzügyi infrastruktúrában}

A jegybankok világszerte a pénzügyi infrastruktúrák jelentőségét és központi szerepét felismerve arra törekednek, hogy feltárják, beazonosítsák és csökkentsék azokat a kockázatokat, amelyek a rendszer működését veszélyeztetik, funkcionális és hatékony müködését ellehetetleníthetik. A jól megtervezett és robosztusan müködő pénzügyi infrastruktúra piaci stressz esetén is képes arra, hogy költséghatékonyan, fennakadás nélkül lássa el alapvető funkcióját, a gazdasági szereplök tranzakcióinak teljesülését. A pénz- és tőkepiac az az elsődleges hely, amely a bankok likviditási helyzetének hatékony kezelésére szolgál, azaz ahol a likviditási felesleggel rendelkező bankok ki tudják azt helyezni, illetve ahonnan a likviditáshiánnyal küzdő bankok forrást tudnak bevonni. A bankok számára a gyors és olcsó likviditásszerzés alapvető fontosságú, csakúgy, mint a többletlikviditással rendelkező bankok számára, hogy rövid időn belül és a lehető legkedvezőbb feltételek mellett tudják kihelyezni a többletüket. A jól működő pénzpiacok éppen ebben a gyorsan változó helyzetben segítik a piaci szereplőket. A pénzpiacokon azonban nemcsak a kereskedelmi bankok aktívak, hanem sok esetben a jegybank is, hiszen a pénzpiacokon keresztül interveniál, illetve számos esetben a jegybanki monetáris politika is közvetlenül a pénzpiacokra gyakorol hatást.

A pénzügyi stabilitás szempontjából kiemelkedő jelentősége van annak, hogy stresszidőszakban is normálisan tudjanak működni a pénz- és tőkepiacok, mert ha ez nem így történik, akkor a piac szereplöi nem tudnak forrást szerezni és kihelyezni, ezáltal pedig megrendülhet az alapvető bizalom a teljes rendszerben. Piaci stressz esetén a pénzügyi és tőkepiacokat kiszolgáló pénzügyi infrastruktúrának stabilitási okból is kezelni kell tudnia azt a helyzetet, ha egy rendszertag fizetésképtelenné válik, és nem tudja teljesíteni a fizetési kötelezettségeit. Sok esetben egy fizetési kötelezettség nemteljesítése az első jele annak, hogy egy intézmény fizetésképtelen helyzetbe került, ezért óriási jelentőségü, hogy a fizetési 
rendszerek milyen eszközökkel és módon képesek csökkenteni a likviditási és hitelkockázatot, és milyen módon tudják meggátolni, hogy egyes rendszertagok fizetési nehézségei átgyürüzzenek másokra. A kockázatkezelési eszközök kialakítása jellemzően jelentős anyagi ráfordítást igényel, de még mindig összehasonlíthatatlanul kisebb költséggel jár egy jól megtervezett és megfelelő kockázatkezelési protokollokat alkalmazó pénzügyi infrastruktúra üzemeltetése, mint egy rendszertag nemteljesítéséből fakadó pénzügyi krízis kezelése.

A jegybankoknak a következő kockázattípusokat kell kezelni:

- rendszer és résztvevőinek likviditásával összefüggő kockázatok,

- működési kockázat, szolgáltatás ellátásnak kockázata,

- jogi kockázat,

- üzleti, működési modellek kockázata,

- pénzforgalmi szabályok be nem tartásának kockázata.

\section{A felvigyázás, mint a jegybankok rendszerkockázatot csökkentő tevékenysége}

A pénzügyi infrastruktúrák komplexitása, hálózati felépítése miatt rendkívül sokféle fertőzési csatorna jelenik meg a rendszerekben, amik így végső soron az egész pénzügyi rendszer stabilitását is veszélyeztethetik, és amiket ráadásul az egyes szereplök a döntéseik meghozatalakor nem is feltétlenül mérlegelnek. Éppen a pénzügyi infrastruktúrák ezen jelentős negatív externáliái miatt, jellemzően szükséges a jegybankok beavatkozása, hogy a felvigyázási tevékenységen túl szabályozással, fejlesztéssel olyan irányba tereljék a rendszerek müködését, mely a rendszerkockázatokat minimalizálja.

Felvigyázásnak nevezzük azt az alapvető jegybanki funkciót, aminek során a jegybank biztosítja a pénzügyi infrastruktúra megbízható és hatékony müködését, valamint folyamatosan nyomon követi és elemzi a már létező és jövőben kialakítandó rendszereket. A jegybankok felvigyázási tevékenységük során elsősorban azokat a pontokat, azokat a kockázatokat keresik, ahol a rendszer egésze nem kellően biztonságos, ahol a kockázatok realizálásának következtében a teljes rendszer működése veszélybe kerülhet. A felvigyázási tevékenység rendszerszemléletben, a pénzügyi közvetítőrendszer egészének hatékonyságát és stabilitását hivatott előmozdítani, más megfogalmazásban a rendszerkockázat csökkentését hivatott szolgálni. 
A pénzforgalom és a pénzügyi infrastruktúrák hatékony müködése érdekében a jegybankoknak a következő eszközrendszer áll rendelkezésükre:

- készpénz és jegybanki számlapénz kibocsátás,

- a pénzforgalommal és a pénzügyi infrastruktúrákkal kapcsolatos elemzés és kutatás,

- pénzügyi infrastruktúrák működtetése és tulajdonlása,

- a pénzforgalmat és a pénzügyi infrastruktúrákat érintő piaci fejlesztés kezdeményezése és koordinálása (katalizátor funkció),

- a pénzforgalmat és a pénzügyi infrastruktúrákat érintő szabályozás kezdeményezése vagy alkotása.

\subsubsection{A jegybank, mint végsö hitelezö}

\section{A végső hitelezői szerep meghatározása}

A jegybank a végső hitelezői funkció (Lender of Last Resort) ellátása során a stresszhelyzetbe került hitelintézeteknek likviditási segítséget nyújthat. Ennek segítségével az illikvid pénzügyi intézmények számára lehetővé válik, hogy rövid távon eleget tegyenek pénzügyi kötelezettségeiknek. A likviditási segítségnyújtás tipikus kivitelezési módjának tekinthető, amikor a jegybank megfelelő fedezet, vagy állami garanciavállalás mellett nyújt hitelt, vagy egyéb ügyletével jegybanki számlapénzhez, vagy a piacokon fedezetképes likvid eszközhöz segít hozzá olyan szolvens (hosszú távon fizetőképes) bankot, vagy a bankrendszer több intézményét, melyek átmenetileg nem képesek a piacokról elegendő pénzbeáramlást elöteremteni az azonnal (vagy rövidtávon) felmerülő kötelezettségeik teljesítéséhez.

A végső hitelezői szerepkör elősegítheti a monetáris politika transzmiszsziós csatornáinak működését rendszerszintű likviditási krízisek időszakában. A jegybank monetáris politikai eszközeinek tényleges végrehajtói a kereskedelmi bankok, akiken keresztül egy-egy döntés meghatározza az adott ország pénzügyi stabilitását. A monetáris politika és a végső hitelezői funkció kapcsolata elsősorban nem egyedi banki, hanem rendszerszintü likviditási sokk esetében markáns. Ebben az esetben ugyanis egy illikvid bankrendszer nem képes közvetíteni azon monetáris politikai eszközök hatását, amelyet a jegybank monetáris politikai célja teljesítésére felhasznál. Rendszerszintű likviditási krízis időszakában a kamattranszmisszió egyik első közvetítőjének a működése válhat bizonytalanná.

6 Rédei-Zsigó (2017). 
A prudenciális szabályozási és felügyeleti tevékenység preventív módon mérsékelheti a likviditási krízisek bekövetkeztének valószínűségét.

\section{A likviditási segítségnyújtás célja és indokai}

A likviditási segítségnyújtás indoka, hogy a pénzügyi rendszer a likviditási krízisek időszakaiban piaci tranzakciókon keresztül képtelenné válhat a likvid eszközök és a likviditási kockázat hatékony rendelkezésre bocsátására és elosztására. A likviditási krízisek jellemzően többféle piaci súrlódás és piaci kudarc egymást erősítő hatásainak következtében a bankrendszer egészének szintjén okoznak pénzügyi stresszt. A jegybank gyakorlati céljai a végső hitelezői funkció ellátásával a bank- és pénzügyi rendszer válságát előidéző piaci tökéletlenségek hatásának mérséklése, mivel ezek jelentősen ronthatják a hatékony gazdasági erőforrás-elosztást, a pénzügyi stabilitást, a monetáris transzmisszió hatékonyságát és a reálgazdasági teljesítményt.

A jegybank ideális szereplő a végső hitelezői szerepkör betöltéséhez, miután:

- rövidtávon képes nagy mennyiségü likvid forrást gyorsan az érintettek rendelkezésére bocsátani,

- többletinformációval rendelkezik, miután a pénzügyi stabilitási feladatainak ellátása során szerzett információi miatt széles rálátással rendelkezik a pénzügyi közvetítőrendszerre,

- a kormányzattól monetáris és stabilitási feladatainak ellátásában független jegybank hitelessége az inszolvens bankok megsegítésével szemben gyakorolt szigorral könnyebben biztosítható, mint a fiskális hatóságé.

\section{A végső hitelezői funkcióval szemben támasztott követelmények}

1. A likviditási krízisek gyakran rendszerszinten jelentkeznek. A bankrendszer szintjén jelentkező likviditási krízisek a pénzügyi fertőzési hatások, a bankközi piacok általános befagyása, valamint a bizalmatlan ság és pánik gyors terjedése a rendszer egymástól távoli intézményeinél is problémát okozhatnak. A bankok széles körének (vagy akár bizonyos eszköztípusok teljes piacainak) szüksége lehet tehát a végső hitelező segítség igénybevételére. Továbbá a pánik indulhat olyan intézmény(ek)től, amelyeknek a jegybank nem akar segítséget nyújtani. 
2. Az inszolvens intézmények likviditási segítségnyújtásban való részesítése több kedvezőtlen következménnyel járhat, ezért azok az intézmények, melyekről ezt a jegybank megállapítja, kizárása kerülnek a likviditási segítségből.

3. A jegybank jó minőségü fedezet megkövetelésével védheti magát a partner nemteljesítésének kockázatával szemben, a szigorú fedezeti követelmények azonban likviditási krízisben korlátozhatják a segítségnyújtásban részesíthető bankok körét, illetve a segítségnyújtás mértékét.

4. A likviditási segítségnyújtásra vonatkozó hatékony jegybanki kommunikáció jelentős hatást gyakorolhat a likviditási krízisek kockázataira. Az előzetesen folytatott egyértelmű, nyilvános kommunikáció hozzájárulhat ahhoz, hogy a bankok, a betéteseik és hitelezőik várakozásaiba beépüljön, hogy a fenti követelményeket teljesítő intézmények számára a végső hitelezői segítségnyújtás elérhetö lesz likviditási krízis esetén. Ez hatásosan mérsékelheti, vagy megelözheti mindazon kedvezőtlen piaci folyamatokat, melyek kialakulását az illikviditás realizálódására vonatkozó piaci várakozások magyarázzák (bankpánikok, bankközi piacok befagyása és továbbiak).

\subsubsection{A Magyar Nemzeti Bank}

\subsubsection{Az MNB története}

A XIX. század elején Magyarország a Habsburg uralkodóház fennhatósága alatt állt. A birodalomban a jegybanki feladatokat előbb az 1816. július 1-jétől müködő Osztrák Nemzeti Bank, majd az 1878. szeptember 30-án létrejött és paritásos alapon dolgozó Osztrák-Magyar Bank látta el.

Az 1848-49-es forradalom és szabadságharc idején a megalakuló első független magyar kormány a jegybanki feladatok ellátását a Pesti Magyar Kereskedelmi Bankra bízta. Az első világháború következményeként 1918. október végén az Osztrák-Magyar Monarchia felbomlott, az Osztrák-Magyar Bankot felszámolták. A központi banki feladatkört az 1921. július 11-én megalakult Magyar Királyi Állami Jegyintézet vette át.

Az önálló magyar jegybank, a Magyar Nemzeti Bank részvénytársasági formában 1924. június 24-én kezdte meg munkáját. Első elnöke Popovics Sándor

7 www.mnb.hu/a-jegybank/informaciok-a-jegybankrol/az-mnb-tortenete, letöltve: 2019. május 30. 
volt. A központi bank teremtette meg az első világháborút követően inflálódott korona stabilizációját, majd kibocsátotta az új valutát, a pengőt. Átvette az állami számlák vezetését, az államadósság kezelését. Kamat- és hitelpolitikájával, váltóleszámítolási elveivel és gyakorlatával irányította az ország hiteléletét, befolyásolta a bankrendszer működését. Hatáskörébe került a devizagazdálkodás felügyelete is. Megalakulásától - 1930 - részvényese és aktív tagja a Nemzetközi Fizetések Bankjának (BIS).

Az 1929 őszén kirobbant világgazdasági válság előidézte pénzügyi krízis 1931 júliusában elérte Magyarországot is. A Magyar Nemzeti Bank ez időtől kezdve az 1990-es évek elejéig a kötött devizagazdálkodás megvalósítója, e téren a hatósági feladatok ellátója, gazdaságpolitikai felelősséggel és hatáskörrel rendelkező központi bank. A második világháború időszakában a jegybank erőfeszítései dacára a nemzeti valuta, a pengő inflációja bontakozott ki. A háború befejezését követően a pengő értékvesztése a világtörténelem eddigi legnagyobb méretű pénzromlását produkálta.

A Magyar Nemzeti Bank közremüködésével valósult meg 1946. augusztus 1-jén a stabilizáció, jelent meg az új fizetőeszköz, a forint. A nagybankok - köztük a jegybank - magyar tulajdonú részvényeinek 1947 végén lezajlott államosítását követően a bankrendszert rövid idő alatt átalakították. A kereskedelmi bankokat és a takarékpénztárakat felszámolták, a bankrendszert egyszintűvé tették. A Magyar Nemzeti Bank 1948 második felétől a jegybanki hatáskörök mellett kereskedelmi banki feladatokat is ellátott. Mint államosított központi bank, irányítása kormányzati fennhatóság alá került.

1987. január 1-jével Magyarországon visszaállt a kétszintü bankrendszer. A létrejövő új kereskedelmi bankok apparátusa, fiókhálózata, ügyfélköre kevés kivételtől eltekintve a Magyar Nemzeti Banktól került át a megalakuló pénzintézetekhez. A Magyar Nemzeti Bankról 1991 októberében elfogadott - majd többször módosított - törvény helyreállította a jegybank függetlenségét, újraszabályozta feladatkörét.

A Magyar Nemzeti Bankról szóló 2001. évi LVIII. törvény alapján az árfolyamrendszer megválasztása tekintetében a kormány az MNB-vel egyetértésben dönt. A forint árfolyama az euróval, mint referenciavalutával szemben 2008. február 26tól kezdődően szabadon lebeg, a forint mozgását a piaci erők határozzák meg. 


\subsubsection{MNB feladatköre, ${ }^{8,9}$}

A Magyar Nemzeti Bank Magyarország központi bankja. Az MNB a Központi Bankok Európai Rendszerének tagja.

Az MNB, valamint döntéshozó szerveinek tagjai a Magyar Nemzeti Bankról szóló törvényben foglalt feladataik végrehajtása és kötelességeik teljesítése során függetlenek, nem kérhetnek és nem fogadhatnak el utasításokat az Európai Központi Bank kivételével a Kormánytól, az Európai Unió intézményeitől és szerveitől, tagállamainak kormányaitól vagy bármilyen más szervtől.

A Magyar Nemzeti Bank elsődleges célja az árstabilitás elérése és fenntartása. A Magyar Nemzeti Bank elsődleges céljának veszélyeztetése nélkül, a rendelkezésére álló monetáris politikai eszközökkel, támogatja a Kormány gazdaságpolitikáját.

Az MNB alapvető feladatai:

- Az MNB meghatározza és megvalósítja a monetáris politikát.

- Az MNB jogosult Magyarország hivatalos pénznemében bankjegy- és érmekibocsátásra. Az MNB által Magyarország hivatalos pénznemében kibocsátott bankjegy és érme - ideértve az emlékbankjegyet és emlékérmét is - Magyarország törvényes fizetőeszköze.

- Az MNB a magyar gazdaság külső stabilitásának megőrzése érdekében hivatalos deviza- és aranytartalékot képez, és kezeli azt.

- Az MNB a devizatartalék kezelésével és az árfolyampolitika végrehajtásával kapcsolatban devizamüveleteket végez.

- Az MNB felvigyázza a fizetési és elszámolási, valamint az értékpapír-elszámolási rendszereket, ennek keretében felvigyázza a rendszer, valamint a központi szerződő fél tevékenységét végző szervezet tevékenységét e rendszerek biztonságos és hatékony müködése, továbbá a pénzforgalom zavartalan lebonyolítása érdekében. Ezen jogkörében, valamint a 171. \$ (2) bekezdésében meghatározott jogalkotási jogkörében részt vesz a fizetési és elszámolási, valamint az értékpapír-elszámolási rendszerek kialakításában.

- Az MNB feladatai ellátásához és az Európai Unió működéséről szóló szerződéshez füzött, a Központi Bankok Európai Rendszere és az Európai Központi Bank Alapokmányáról szóló (4.) Jegyzőkönyv 5. cikkében

8 2013. évi CXXXIX. törvény, Jegybanktörvény.

9 Lentner (2017a). 
meghatározott az EKB-val szemben fennálló statisztikai adatszolgáltatási kötelezettség teljesítéséhez statisztikai információkat gyüjt és hoz nyilvánosságra.

- Az MNB alakítja ki a pénzügyi közvetítőrendszer egészének stabilitására vonatkozó makroprudenciális politikát, amelynek célja a pénzügyi közvetítőrendszer ellenállóképességének növelése, valamint a pénzügyi közvetítőrendszernek a gazdasági növekedéshez való fenntartható hozzájárulásának biztosítása. Az MNB ennek érdekében az e törvényben meghatározott keretek között feltárja a pénzügyi közvetítőrendszer egészét fenyegető üzleti és gazdasági kockázatokat, elősegíti a rendszerszintű kockázatok kialakulásának megelőzését, valamint a már kialakult rendszerszintű kockázatok csökkentését vagy megszüntetését, továbbá hitelpiaci zavar esetén a hitelezés ösztönzésével, a túlzott hitelkiáramlás esetén annak visszafogásával, járul hozzá a közvetítőrendszer gazdaságfinanszírozó funkciójának kiegyensúlyozott megvalósulásához.

A jegybank végső, távlati célja, hogy a monetáris politika kialakításakor minél kisebb és moderálható infláció elérésére törekedjen. Az MNB e cél veszélyeztetése nélkül - a rendelkezésére álló monetáris politikai eszközökkel - támogatja a kormány gazdaságpolitikáját. A monetáris politikát az MNB határozza és valósítja meg. A jegybank eszközrendszerében az árstabilitás biztosítása mellett megjelennek a pénzügyi stabilitás és a gazdaságpolitika támogatásának céljai és eszközei is.

A jegybank megfelelő monetáris kondíciókkal, vagyis alacsony jegybanki alapkamatokkal, és a fenntartható növekedést támogató politikával segíti a gazdasági növekedést.

Az MNB által kibocsátott bankjegy és érme Magyarország törvényes fizetőeszköze. Az MNB vezeti a kincstári egységes számlát és az Államadósság Kezelő Központ pénzforgalmi számláját. Az MNB a kincstári egységes számla egyenlege után kamatot fizet a központi költségvetés javára. Az MNB számlavezetési tevékenységével összefüggésben betétet fogad el, és megfelelő biztosíték ellenében hitelt nyújt. Nem nyújthat azonban folyószámlahitelt vagy bármely más hitelt a kormánynak, az államháztartás központi alrendszerébe vagy helyi alrendszerébe tartozó közigazgatási szervnek, közjogi testületnek, közintézménynek vagy 
közvállalkozásnak, továbbá ezektöl közvetlenül nem vásárolhat adósságinstrumentumokat.

Az MNB ellátja a pénzügyi közvetítőrendszer felügyeletét. A pénzügyi szervezeteket fenyegető, nemkívánatos üzleti és gazdasági kockázatok feltárása, a már kialakult egyedi vagy ágazati kockázatok csökkentése vagy megszüntetése, illetve az egyes pénzügyi szervezetek prudens müködésének biztosítása érdekében megelőző intézkedéseket alkalmaz. Az MNB - a Pénzügyi Békéltető Testület útján - ellátja a fogyasztók és a pénzügyi törvények hatálya alá tartozó szervezetek vagy személyek közötti vitás ügyek bírósági eljáráson kívüli rendezését. A Pénzügyi Békéltető Testület az MNB által működtetett, szakmailag független testület, amely a Pénzügyi Békéltető Testület elnökéből és a békéltetőtestületi tagokból áll. Az MNB statisztikai információkat gyüjt és hoz nyilvánosságra. A Magyar Nemzeti Bank nemcsak mint klasszikus jegybank működik, hanem tudományos műhelyként is funkcionál. Társadalmi felelősségvállalási programja keretében támogatja a közgazdasági képzés megújítását, a pénzügyi kultúra terjesztését. Az MNB számára törvény állapíthat meg feladatot. Egyéb tevékenységet csak elsődleges célja és alapvető feladatai teljesítésének veszélyeztetése nélkül folytathat.

\subsubsection{Az MNB szervei - Monetáris Tanács, Pénzügyi Stabilitási Tanács, az igazgatóság és a felügyelöbizottság ${ }^{10}$}

A Monetáris Tanács az MNB legfőbb döntéshozó szerve, amelynek hatáskörébe az MNB alapvető feladataival, a kötelező jegybanki tartalék és az azután fizetendő kamat mértékével, az árfolyamrendszerrel és a pénzügyi közvetítőrendszer egészét fenyegető kockázatokkal kapcsolatos döntések tartoznak. Továbbá az ezekkel összefüggő kommunikáció módjának meghatározása, az olyan döntések végrehajtása, amelyeket a Monetáris Tanács saját hatáskörében megtart, és minden olyan kérdés, amelyet törvény, alapító okirat vagy belső eljárási szabály a Monetáris Tanács hatáskörébe utal.

A Monetáris Tanács szükség esetén bármikor összehívható, de havonta legalább egy alkalommal ülésezik. A Monetáris Tanács legalább öt-, legfeljebb kilenctagú testület. A Monetáris Tanács elnöke az MNB elnöke, tagjai továbbá az MNB alelnökei és azok a személyek, akiket hat évre az Országgyűlés a Monetáris Tanács tagjává választ. A Monetáris Tanács tagjai megbízatásuk időtartama

10 Lentner (2017b, 181-183.o.) 
alatt az MNB-vel munkaviszonyban állnak. A Pénzügyi Stabilitási Tanács hatáskörébe tartozik az MNB mikro- és makroprudenciális feladataival kapcsolatos monetáris tanácsi döntés végrehajtásának irányítása, és a Monetáris Tanács által meghatározott stratégiai keretek között az MNB mikro- és makroprudenciális feladataival kapcsolatos döntéshozatal.

A Pénzügyi Stabilitási Tanács hatáskörében a többi között

- a pénzügyi közvetítőrendszer egészének stabilitása érdekében folyamatosan figyelemmel kíséri a pénzügyi közvetítőrendszer egészének, illetve a pénzügyi piacok stabilitását;

- számba veszi a pénzügyi közvetítőrendszer egészét veszélyeztető kockázati tényezőket;

- elemzi azokat az intézmény- vagy terméktípushoz, ezek gyors elterjedéséhez kapcsolódó kockázatokat, amelyek veszélyt jelenthetnek a pénzügyi közvetítőrendszer egészére nézve;

- nyomon követi a nemzetközi és az európai piacokon zajló fejleményeket, illetve a pénzügyi közvetítőrendszer egészének stabilitását veszélyeztető kockázatokat, és a Monetáris Tanács által meghatározott stratégiai keretek között dönt a szükséges intézkedésekről;

- megtárgyalja a pénzügyi közvetítőrendszer egészét érintő stratégiai, szabályozási, kockázati kérdéseket, és szükség esetén állást foglal;

- a pénzügyi közvetítőrendszer egészének stabilitását fenyegető helyzetben értékeli a rendszerkockázatokat, dönt az azok csökkentése vagy megszüntetése érdekében szükséges intézkedésekről;

- szükség szerint napirendre tüzi az Európai Rendszerkockázati Testületnek a pénzügyi közvetítőrendszer egészének szempontjából releváns ajánlásait, állásfoglalásait, kockázati figyelmeztetéseit;

- szükség szerint megtárgyalja az Európai Felügyeleti Hatóságok által kiadott ajánlásokat, határozatokat, ideértve az európai pénzügyi rendszer stabilitásának komoly veszélyeztetettsége esetén a nemzeti felügyeleti hatóságoknak címzett, egyedi intézkedések megtételére felszólító határozatokat is, valamint állást foglal az azokból származó feladatokról;

- évente meghatározza az MNB ellenőrzési tevékenységének kiemelt célterületeit és döntést hoz meghatározott hatósági eljárásokban. 
A Pénzügyi Stabilitási Tanács döntéseiről rendszeresen beszámol a Monetáris Tanácsnak. A Pénzügyi Stabilitási Tanács legalább három, legfeljebb tíz taggal müködő testület.

Tagjai: az MNB elnöke, a pénzügyi felügyeleti feladatot felügyelő alelnökök, valamint az MNB elnöke által kijelölt vezetők. A Pénzügyi Stabilitási Tanács ülésén a pénz-, tőke- és biztosítási piac szabályozásáért felelős miniszter képviselője, valamint az MNB elnöke által felkért külső meghívottak tárgyalási joggal vesznek részt. A Pénzügyi Stabilitási Tanács szükség szerint, de legalább kéthavonta ülésezik.

Az igazgatóság felelős a Monetáris Tanács döntéseinek végrehajtásáért és az MNB működésének irányításáért. Az igazgatóság hatáskörébe tartozik a Monetáris Tanács által hozott döntések végrehajtásának irányítása, az MNB számviteli beszámolójának megállapítása, az osztalék fizetéséről való döntés, az MNB szervezetével és belső irányításával összefüggő kérdések jóváhagyása, szakmai tervek és programok jóváhagyása stb. A Monetáris Tanács bármely, a hatáskörébe tartozó kérdés eldöntésére - beszámolási kötelezettség mellett - felhatalmazhatja az igazgatóságot. Az igazgatóság elnöke az MNB elnöke, tagjai az MNB alelnökei. A felügyelőbizottság az MNB folyamatos tulajdonosi ellenőrzésének szerve. A felügyelőbizottság hatáskörébe nem tartozó feladatok tekintetében az MNB belső ellenőrzési szervezetét az igazgatóság irányítja. A felügyelőbizottság hatásköre nem terjed ki az MNB alapvető feladataira, és azoknak az MNB eredményére gyakorolt hatására. A felügyelőbizottság tagjai az Országgyülés által választott elnök és további három tag, az államháztartásért felelős miniszter képviselője és az államháztartásért felelős miniszter által megbízott szakértő.

\subsubsection{Innovációk a magyar monetáris politikában}

\section{A monetáris politikai fordulat elötti évek ${ }^{11}$}

A Magyar Nemzeti Bank monetáris politikája 2001-ben áttért az inflációs célkövető rendszerre és a 2008-ig fenntartott sávos árfolyamrendszerre, tartósan azonban nem sikerült a 3\%-os cél közelébe mérsékelni az inflációt. A válság előtt a jegybanki politika alapvetően az egy cél egy eszköz mandátummal müködött. Ez azonban nem bizonyult kellően hatékonynak.

11 Parragh (2017). 


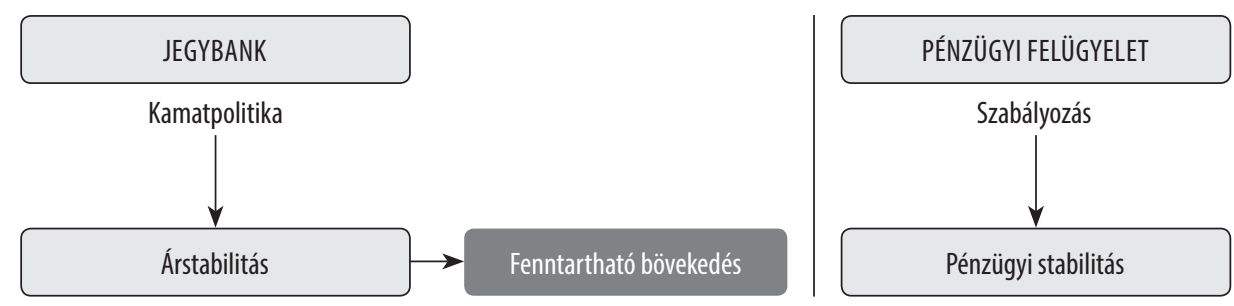

6. ábra: Válság előtt: egy cél - egy eszköz

Forrás: $M N B$

A devizahitelfelvételi-kedvet erősítette a drámai magasságú forintkamat. 2002 és 2010 között az államháztartás lokális alrendszerében és a családok szintjén is egy gyors, de 2008-ra már kezelhetetlenné vált adósságállomány halmozódott fel. Az adósságcsapdává fejlödött túlhitelezési folyamat jelentős károkat okozott, s beigazolódott, hogy a piaci szereplők tevékenységének ellenőrizetlenül hagyása nem vezet tartós piaci egyensúly kialakulásához, sőt válságba torkollott. A 2008as válság alapvetően adósságválság volt, amely ráadásul szinkronizáltan, több gazdasági régiót egy időben sújtott.

A pénzügyi-gazdasági válság következményeként kialakult egyensúlytalanság, gazdasági recesszió, vállalati szférában tapasztalt súlyos likviditási problémák bizalomhiánnyal, csökkenő vállalkozási kedvvel, romló és borúlátó piaci várakozásokkal párosultak. Az akkori gazdaságpolitikai döntéshozókkal szembeni bizalmatlanság a fennmaradni és versenyképességüket megőrizni képes vállalkozások esetében a gyors kiút keresésének igényét hozta magával. Létkérdéssé vált a hazai mikro-, kis- és közepes vállalkozói kör számára gyors és hatékony állami, kormányzati, akár jegybanki segítségnyújtás. A semleges kamatszint felett tartott alapkamat-politika csak akkor járt volna eredménnyel, ha közben a jegybank arra is képes, hogy megakadályozza a forinthitelektől a devizahitelek felé fordulást mindhárom gazdasági szereplőnél.

Az önkormányzatok eladósodási folyamata a 2010-es évre nehezen kezelhető méreteket öltött, amely a velük üzleti kapcsolatban lévő, beruházásban, fejlesztésben érintett vállalkozói körre nézve számos negatív következménnyel járt, súlyos versenyképességi és fennmaradási kihívásokat teremtve. 


\section{A monetáris politika újraértelmezése ${ }^{12}$}

2013 márciusában az új jegybanki vezetés hivatalba lépésével új korszak vette kezdetét a monetáris politikában, ami egyben új korszakot jelentett Magyarországon a fiskális és a monetáris politika közötti kölcsönhatásban is. Ettől kezdve a Magyar Nemzeti Bank irányadó eszköze mellett innovatív, újszerű instrumentumok és programok alkalmazásával igyekezett eleget tenni elsődleges céljának (árstabilitás elérése és fenntartása), továbbá a törvényben kitűzött feladatának megfelelően az elsődleges cél veszélyeztetése nélkül törekedett arra is, hogy támogassa „a pénzügyi közvetítőrendszer stabilitásának fenntartását” és „a rendelkezésére álló eszközökkel a Kormány gazdaságpolitikáját” (2013. évi CXXXIX. törvény 3. $\$(2))$. 2013 óta a jegybank tevékenységének több aspektusa is kedvezően hatott a költségvetési politikára.

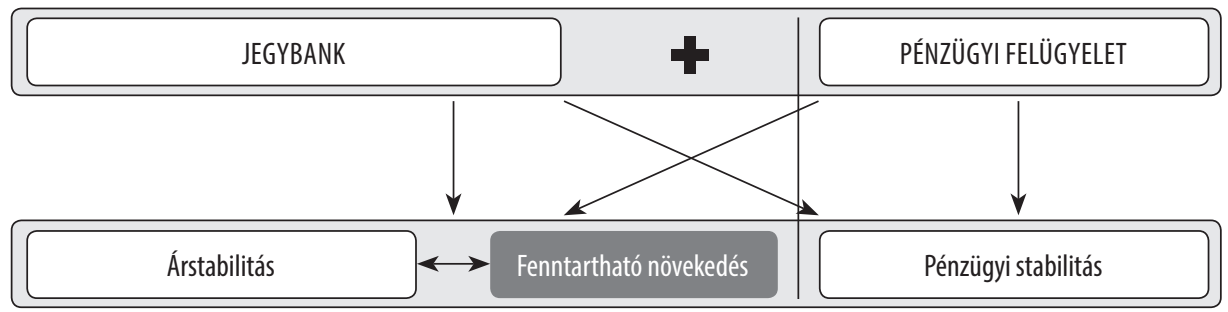

7. ábra: Válság után: több cél - több eszköz

Forrás: $M N B$

A 2013-as monetáris politikai reformok szükségesek voltak ahhoz, hogy az árstabilitás, pénzügyi stabilitás és a fenntartható költségvetési politika célkitűzései rendszerében független, mégis kölcsönös támogatás valósuljon meg, megalapozva a hosszútávon fenntartható gazdasági növekedést. A jegybanktörvényben meghatározott elsődleges jegybanki célon túlmenően új bizonyosságot is hozott a válság. A fentiek értelmében a jegybankoknak nem elegendő csak az alacsony inflációt monitorozni, mivel a gazdaságban alacsony inflációs időszakban is épülhetnek fel súlyos egyensúlytalanságok, hitelpiaci túlfutások, amelyek a buborékok kipukkanását követően tartósan visszavetik a gazdaság növekedését.

A növekedésfókuszú jegybanki eszköztár új elemeként jelent meg a jegybanki döntéshozatalban a makroprudenciális szabályozás. Az alapkamat változását

12 Matolcsy-Palotai (2016), valamint Parragh (2017). 
eredményező eszközök kiegészültek a pénzügyi rendszer aktivitását, kockázatvállalását közvetlenül is befolyásoló, a pénzügyi stabilitást, gazdasági növekedést, illetve a monetáris transzmissziót javító eszközökkel. A transzmissziós mechanizmusból kiindulva a jegybanki alapkamat alakítása jelzés értékü, mely meghatározó a piaci szereplők várakozásainak alakulásában. Az alacsony kamatkörnyezet - kiemelve a monetáris politika előretekintő jellegét - pozitív hatásai (kiszámíthatóság, átláthatóság, biztonságosabb jövőtervezés) a gazdasági szereplők széles körében érvényesülnek, és az árstabilitáshoz való hozzájáruláson túl a magán- és versenyszféra szereplői jelenben hozott, ám jövőre irányuló döntéseikkel segíteni tudják a monetáris politika eredményességét.

A magyar monetáris politikai fordulat és jegybanki szemléletváltás fontos pillérét képezik a magyar modellnek, amelyek a gazdaságpolitikai ágak közötti összhangot a gazdasági szereplőkkel kooperatív állami dimenzióban is képesek megvalósítani. ${ }^{13}$ Erre jó példa fiskális politikai értelemben az adózás és adóigazgatás területe.

\subsubsection{Az MNB kamatpolitikája a 2008-as válság kitörésétöl napjainkig}

A 2007-2008-as globális pénzügyi válság világméretűvé válásától napjainkig tartó időszakban nem csak a jegybanki eszköztár radikális és innovatív átalakítására került sor, hanem a jegybank kamatpolitikája is jelentős változáson esett keresztül. A Lehman Brothers csődjétől kezdődően az európai jegybankok többsége összehangolt kamatcsökkentésbe kezdett. Ezzel ellentétben külső sérülékenységünkre való hivatkozással (magas államadósság, magas devizahitel-állomány) az MNB 2008 szeptemberében a jegybanki alapkamat 11,5\%-ra emeléséről döntött. A válság első éveiben Magyarországon a még magas inflációs környezet és a forintra helyeződő leértékelődési nyomás magas kamatszint fenntartását tette indokolttá.

2012 nyarán kezdődött meg a folyamatos kamatcsökkentés periódusa, amikor a Monetáris Tanács külső tagjainak szavazata révén sor került az első jelentős kamatvágásra. A kamatfordulatot részben a globális jelentőségű jegybankok tartósan laza monetáris politikai irányultsága, részben az országkockázat javuló megítélése, és a fiskális politika terén meghozott, az államadósság csökkentését

13 Lásd részletesen az állami megújulásról és a kooperatív állammodellröl:

Kolozsi - Lentner - Parragh (2017). 
lehetővé tevő intézkedések támogatták. 2012 végétől ráadásul megtört a magas inflációs várakozásokkal jellemezhető periódus, és jelentős dezinfláció ment végbe a gazdaságban, ami tovább indokolta a monetáris lazítás folytatását. 2012 augusztusa és 2013 júliusa között az MNB Monetáris Tanácsa a kezdeti 7 százalékról - 25 bázispontos lépésekkel - 4 százalékra csökkentette a jegybanki alapkamatot. Ezt követően újabb kamatcsökkentési ciklusok következtek, amit 2014től az egy-egy hónapban negatívba forduló éves infláció is indokolttá tett. Végül a jelenlegi kamatszint úgy alakult ki, hogy az alacsony költségoldali inflációs nyomásra, és a korábban nem tapasztalt visszafogott inflációs várakozásokra válaszul, a Monetáris Tanács 2016 márciusa és májusa között 3 lépésben további 45 bázisponttal történelmi mélypontra, 0,9 százalékra szállította le az alapkamatot.

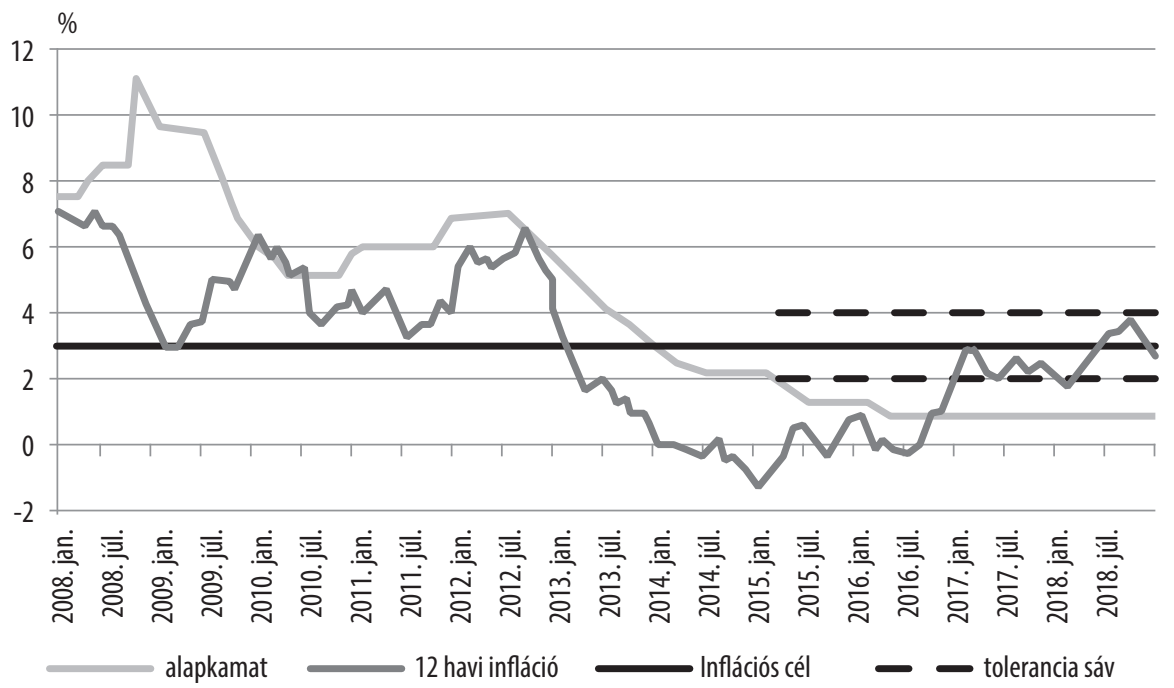

8. ábra: Az alapkamat és a fogyasztóiár-index alakulása, 2008-2018 Forrás: $M N B$

A kamatcsökkentések során alkalmazott elöretekintő iránymutatás megfelelő mederbe terelte a kamatvárakozásokat, és elősegítette, hogy a monetáris lazítás hatása hatékonyan érvényesüljön. A hagyományos és nemhagyományos eszközök aktív alkalmazásával is megtámogatott kamatcsökkentés nemcsak az árstabilitási cél megvalósítását tette lehetővé, de a kiszámítható és mérsékelt ka- 
matkörnyezet a pénzügyi stabilitás fenntartásának is kedvezett. A rövid kamatszintekhez alkalmazkodó állampapírhozamok és banki hitelhozamok jelentős megtakarítást jelentenek az államháztartás és a magánszektor hiteladósai számára, ami segíti a fogyasztási és beruházási kereslet bővülését és ezzel a reálgazdasági növekedésre is ösztönzőleg hatott.

\subsubsection{A Magyar Nemzeti Bank monetáris, mikro-}

és makroprudenciális tevékenysége ${ }^{14}$

A rendszerváltozást megelőzően a Magyar Nemzeti Bank központi bankként fontos szerepet töltött be a nemzetközi pénzügyi kapcsolatok, a pénzkibocsátás, az árfolyam- és kamatpolitika, a refinanszírozás alakításában. Ráhárultak a devizaszabályok alakításának és ellenőrzésének feladatai is. A rendszerváltozás folyamatában a jegybanktól független felügyeleti intézmény jött létre. A 2008ban kezdődő válságot megelőző időszakban Magyarország az állam és a háztartások túlzott eladósodása következtében rendkívül sérülékennyé vált. A háztartások túlzott eladósodottságában és a devizahitelek általános elterjedésében, a pénzügyi rendszer szabályozásában és felügyeletében meglévő hiányosságok is szerepet játszottak. A súlyos nemzetgazdasági és társadalmi hatássokkal járó következmények hívták fel a figyelmet arra, hogy Magyarországon meg kell erősíteni a makroprudenciális keretrendszert, illetve meg kell valósítani a felügyelet és a jegybank integrációját. Ki kellett alakítani egy átlátható, megfelelö felhatalmazással és eszköztárral felruházott makroprudenciális intézményt, illetve biztosítani kellett, hogy a makroprudenciális szempontok megfelelöen tudjanak érvényesülni az egyedi intézményi felügyeleti (mikroprudenciális) munkában. Az intézményi motivációk, felhatalmazások, eszközök és a korábbi koordinációs tapasztalatok alapján indokolt volt, hogy az MNB legyen a makroprudenciális politika elsődleges felelőse. Az MNB, mint makroprudenciális hatóság kapjon jól elhatárolt szabályozóeszközöket, amelyeket megfelelő előkészítés és konzultáció után önállóan alkalmazhat. Ugyancsak indokolt, hogy a tágabb értelemben vett pénzügyi stabilitási felelősségeket és eszközöket is vonják össze az MNB alatt, vagyis a korábbi Pénzügyi Szervezetek Állami Felügyelete által gyakorolt egyedi intézményi felügyeleti tevékenység is kerüljön a jegybankhoz. Ennek előnye, hogy mind a makro- és mikroprudenciális felügyelet, mind pedig a monetáris

14 Lentner (2017a, 180-181.o.) 
politika tágabb információs bázishoz juthat, javulhatnak az egyes döntések elökészítésének feltételei. Ezáltal konzisztensebbé válhat a pénzügyi közvetítőrendszer felé történő hatósági fellépés és tágabb eszköztár állhat a jegybank közvetlen befolyása alatt az egyedi vagy rendszerszintű pénzügyi válságok megelőzésére, illetve a már bekövetkezett válsághelyzetek gyors és eredményes megoldására. A PSZÁF fogyasztóvédelmi, piacfelügyeleti, valamint tőke- és biztosításfelügyeleti funkciói is integrálódtak a jegybankba. Az egységes makro- és mikroprudenciális intézményi rendszer létrejötte 2013-ban történt. Az árstabilitás fenntartása továbbra is elsődleges cél a jegybank müködésében, de a korábbi időszakhoz képest - és ennek veszélyeztetése nélkül - nagyobb figyelmet kap a gazdasági növekedés és a pénzügyi stabilitás. A pénzügyi stabilitás olyan állapot, amelyben a pénzügyi rendszer ellenálló a gazdasági sokkokkal szemben, és képes zökkenőmentesen ellátni alapvető funkcióit, vagyis a pénzügyi források közvetítését, a kockázatok kezelését és a fizetési forgalom lebonyolítását. Az integráció után szükségessé vált egy új felügyeleti stratégia kialakítása. Jövőkép tekintetében a stabil, versenyző, közbizalmat élvező pénzügyi szektor, és az azt felügyelő, formáló erős MNB a cél. Küldetése tehát a jegybank mikroprudenciális tevékenységének, a pénzügyi rendszer stabilitásának fenntartása és támogatása, valamint a rendszer szereplőinek a rendszerbe és egymásba vetett bizalmának megerősítése az integrált felügyeleti eszköztár segítségével. Elérendő, komplex központi értéknek pedig a stabilitás és a bizalom nevezhető a pénzügyi rendszer egészében.

A jegybank új típusú monetáris politikája keretében alkalmazott növekedést támogató hitelprogramok, továbbá a Kormány bérvezérelt gazdaságpolitikája következtében előálló fizetőképes keresletgyarapodás által megvalósuló megtakarítási hajlandóság növekedése, illetve a lakossági hitelezési igény újra emelkedése, és mindezt megelözően a vállalatok és a lakosság devizahitel terheinek konszolidálása, a bankszektor tevékenységének gyors felfutását vetítette előre. ${ }^{15}$ Mindezek következtében is szükséges volt a mikro- és makroszintű szabályozási és felügyeleti tevékenység integrációja, egy intézményi körben koncentrálása.

15 Lentner (2018, 22-25.o.) 
Jegybanki felügyeleti stratégiai célok:

- rendszer szereplőinek rendszerbe és egymásba vetett bizalmának növelése;

- a pénzügyi rendszer hitelezési, finanszírozási készségének és képességének növelése;

- egészséges, fenntartható verseny biztosítása;

- integrált működés;

- kockázatalapú felügyelet;

- eredményes fogyasztó- és piacfelügyelet;

- aktív szabályozó szerep;

- meghatározott időben történő jogérvényesítés;

- erősebb nemzetközi szerepvállalás;

- naprakész, integrált tudásbázis működtetése.

\subsubsection{Fiskális politikát támogató monetáris politika ${ }^{16}$}

A gazdaságpolitika két meghatározó szereplöjének, a fiskális és a monetáris politikának egymáshoz való viszonya meghatározó a gazdaságpolitika sikeressége szempontjából. Magyarországon gazdasági szempontból az minősíthető a legsikeresebb időszaknak, amikor a fiskális és a monetáris politika kihasználta a lehetséges szinergiákat, illetve az volt a legkevésbé sikeres időszak, amikor az egyik úgy müködött, hogy a másikat kényszerhelyzetbe hozva, utóbbi csak rossz és még rosszabb válaszokat tudott adni.

A fiskális és a monetáris politika egymáshoz való viszonyulása, továbbá a két ágközti kapcsolódási pontok, egymásra hatások nem csak elméleti szinten, hanem a gazdaságpolitika hatékony vitele és a makrogazdasági folyamatok aktív alakítása szempontjából is érdemi szereppel bírnak. A túlzó fiskális dominancia miatt 2002 és 2010 között a magyar gazdaságban a fiskális egyensúly és a reálgazdasági növekedés egyszerre nem tudott érvényre jutni, sőt a 2007 és 2010 közti időszakban sem egyensúly, sem növekedés nem jellemezte hazánkat. 2010 után azonban két lépésben fiskális, majd monetáris fordulat következett be. Előbbi megteremtette a fiskális egyensúlyt, utóbbi pedig, építve a költségvetési stabilitásra, megtette a szükséges lépéseket az árstabilitás és a pénzügyi stabilitás eléréséhez. A két gazdaságpolitika között 2013 után megvalósult független,

16 Matolcsy-Palotai (2016). 
de konstruktív összhang hazánk makrogazdasági folyamatainak (reálnövekedés, infláció, foglalkoztatottság, államháztartási hiány, külső és belső eladósodottság, sérülékenység, kockázati megítélés) tartós javulásában is tetten érhető.

Összességében megállapítható, hogy a gazdaságpolitika két fó ága közti harmonikus és sikeres együttmüködés nélkülözhetetlen alapja a makropénzügyi egyensúly és a dinamikus növekedés együttes megteremtésének.

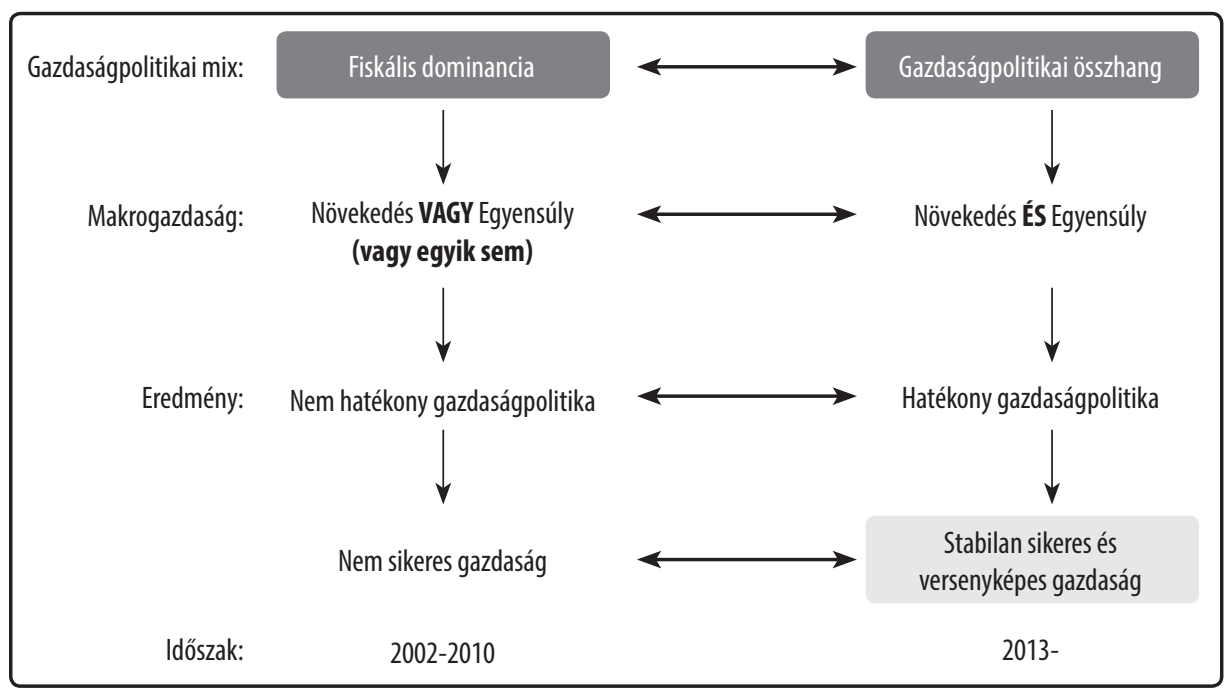

\section{9. ábra: A gazdaságpolitika dominanciája, illetve annak eredménye Magyarországon}

Forrás: $M N B$

\subsubsection{Jegybanki hitelösztönzö programok}

\section{Növekedési hitelprogram ${ }^{17}$}

A pénzügyi és gazdasági válság kitörését követően Magyarországon a vállalati hitelállomány nemzetközi összehasonlításban is kiemelkedő mértékű csökkenésen ment keresztül. 2013 elejére a hitelállomány a közel 5 éven át tartó, évi 5 százalék körüli visszaesés következtében, a válság előtti szint 75 százalékára zsugorodott, jelentős részben a banki hitelkínálati korlátoknak köszönhetően.

17 Magyar Nemzeti Bank (2018). 
A jegybanki alapkamat-csökkentéseket a bankok csak a kis- és középvállalkozások korlátozott körénél érvényesítették, a kkv-k jelentős része túlzottan magas kamatokkal szembesült, ezzel a monetáris transzmisszió sérült. A gazdaság az ún. „hitelösszeomlás” (credit crunch) jelenségével állt szemben, ami mélyítette a gazdasági visszaesést és hátráltatta a válságból való kilábalást. A kkv-hitelpiac - mint a monetáris politikai transzmisszió egyik meghatározó csatornája - működésének helyreállítása, a gazdasági növekedés elősegítése és a pénzügyi stabilitás megerősítése érdekében, az MNB 2013 júniusában elindította a Növekedési Hitelprogramot (NHP).

Az NHP 2013. június és 2017. március közötti müködése során sikeresen teljesítette az elindításakor kitűzött célokat: a kkv-hitelpiac helyreállítását és a gazdasági növekedés elősegítését. A program nemcsak a kkv-hitelállomány mennyiségére gyakorolt jelentős hatást, de kedvező irányban befolyásolta a hitelállomány szerkezetét is, köszönhetően a hosszú, akár 10 éves futamidőre elérhető fix, alacsony kamatozású hiteleknek. A program keretében közel 40 ezer vállalkozás jutott finanszírozáshoz több mint 2800 milliárd forint összegben. A program hozzájárult a hitelezési fordulat bekövetkezéséhez: a korábban tapasztalt csökkenő trend megállását követően a kkv-hitelállomány 2015-től növekedést mutat, amelynek dinamikája 2018 egészében már elérte az évi 12 százalékot. Az MNB becslései alapján a program gazdasági növekedésre gyakorolt hatása 2013-2017 között 2-2,5 százalék között lehetett, egy olyan alternatív pályához képest, amelyben az NHP hiányában csak lassabban állt volna helyre a hitelezés (a hitelösszeomláshoz, mint alternatív pályához viszonyítva pedig akár a 6 százalékot is elérhette).

Az NHP harmadik szakaszával párhuzamosan az MNB 2016-ban elindította a Piaci Hitelprogramot (PHP), a piacialapú - azaz jegybanki refinanszírozás nélkül megvalósuló - hitelezésre való gördülékeny visszaállás elősegítése, valamint a fenntartható gazdasági növekedés kkv-hitelezésen keresztüli biztosítása érdekében. A bankok 2016-ban és 2017-ben is jelentősen túlteljesítették a program keretében tett hitelezési vállalásaikat, így az sikeresen hozzájárult a hitelállomány növekedéséhez, annak szerkezetére azonban nem gyakorolt érdemben hatást, a hosszú, fix kamatozású hitelek aránya visszaszorult. A PHP 2018-ban még támogatja a kkv-hitelezés bővülését, de év végén lezárult. 


\section{A Növekedési Hitelprogram Fix ${ }^{18}$}

A vállalati hitelezés volumene 2018-2019-re megfelelő szintet ért el, de szerkezete még nem elég egészséges. A hosszú lejáratú hitelek aránya nemzetközi összehasonlításban alacsony, és a fix kamatozású hitelek aránya is alulmúlja a fejlettebb országokban jellemző arányt. Az NHP idejében teret nyertek a hoszszú futamidejü, fix kamatozású hitelek, a program kivezetését követően azonban ezek aránya visszaesett, amin a PHP sem tudott változtatni. Mivel piaci alapon nem jöttek létre széles körben hosszú lejáratú, fix és kedvező kamatozású hitelek, a vállalkozások érdemi része nem tudta kihasználni hosszútávra a kedvező kamatszintet, ezért a monetáris transzmisszió sérült, így ismét jegybanki beavatkozás volt indokolt. Az MNB ezért 2019 elején elindítja a Növekedési Hitelprogram Fix (NHP fix) elnevezésű konstrukciót, 1000 milliárd forintos keretösszeggel. Az új konstrukció a legfontosabb paraméterei és a lebonyolítás módja tekintetében meg fog egyezni az NHP korábbi szakaszaival. Így az MNB 0 százalékos kamat mellett biztosít majd a hitelintézeteknek refinanszírozási forrást, amelyet azok maximum 2,5 százalékos kamatmarzs mellett hitelezhetnek tovább kkvnak, új beruházások forint alapú finanszírozására.

Az NHP fix az NHP korábbi szakaszainál célzottabbnak tekinthető, ami alapvetően az alábbi három fö jellemzőben mutatkozik meg:

- csak 3 évnél hosszabb futamidejü hitelek nyújthatók,

- csak beruházási célra nyújthatók hitelek, és ezen belül is szűkül a felhasználás köre a harmadik szakaszhoz képest,

- a program likviditási szempontból semleges, mert az NHP fix keretében folyósított hitelvolumenből fakadó többletlikviditás alapkamaton sterilizálásra kerül.

Az MNB ezzel a programsorozattal támogatta, támogatja a pénzügyi közvetítörendszer gazdasági növekedéshez való fenntartható hozzájárulását.

\section{Néhány részlet visszatekintve ${ }^{19}$}

A 2013-2016 között elérhető Növekedési Hitelprogram első szakaszában a hitelkiváltás volt az elsődleges hitelfelvételi ok, de emellett jelentős volt az új hitelek volumene is. A Növekedési Hitelprogram keretében hitelt felvevő vállalkozá-

18 Magyar Nemzeti Bank (2018).

19 Parragh (2017). 
sok hitelállomány-szerkezete egészségesebbé vált nemcsak az árfolyamkockázat kiiktatásával, hanem a fix kamatozás és a hosszú lejárat miatt is. A közép- és hosszútávon tervezhető törlesztés biztonságát adta a fix, maximum 2,5 százalékos hitelkamatláb, amely tartósan járult hozzá a pénzügyi helyzet javításához. Az NHP első szakaszában (2013. június-augusztus) 750 milliárd forintos keretösszeg állt rendelkezésre, amelyből 93,5 százalékos kihasználtsággal kötöttek hitelszerződést a hitelintézetek; ez az arány 701 milliárd forintot, s mintegy 10 ezer szerződést jelentett. Az első szakasz a számítások szerint közel 0,5 százalékos hazai GDP-növekedést eredményezett, és új munkahelyek teremtésén túl segítette a régi munkahelyek megörzését is.

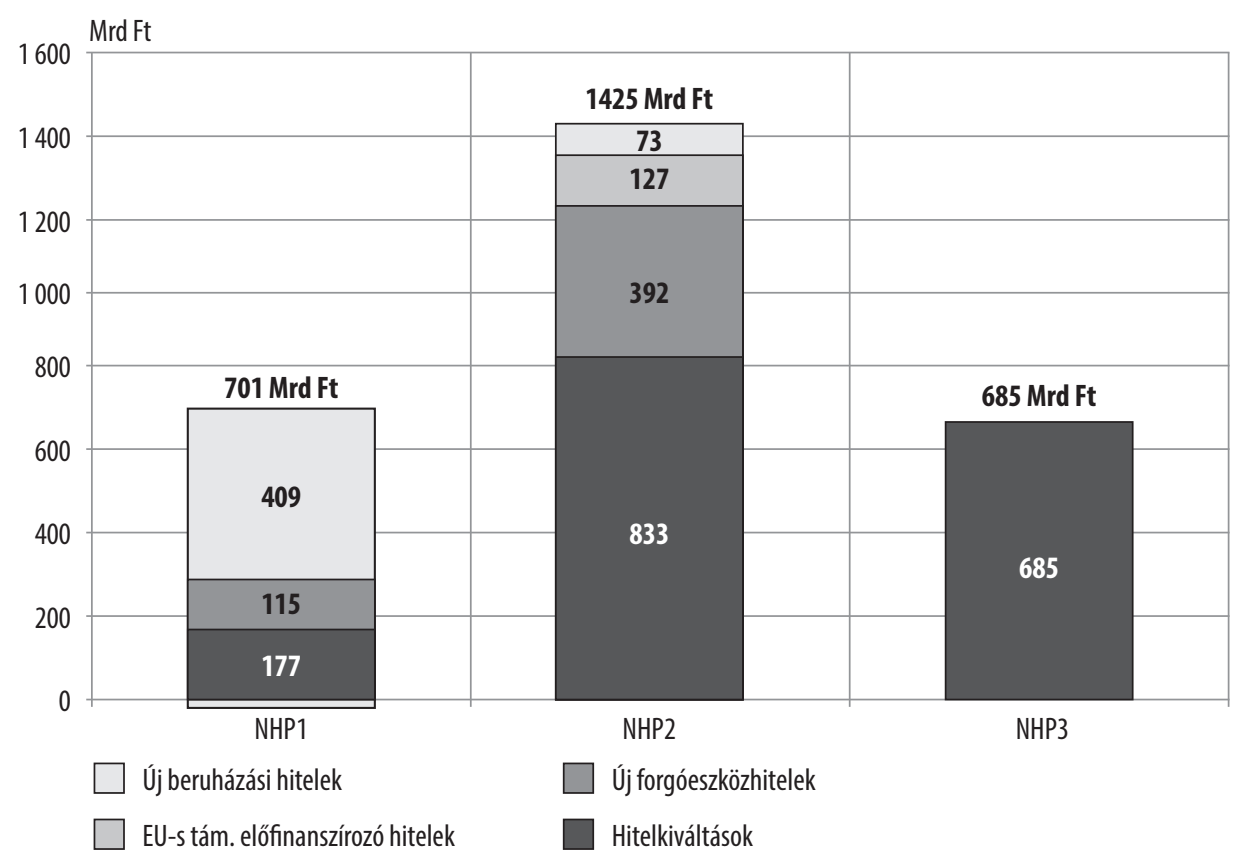

10. ábra: Hitelcélok megoszlása az NHP egyes szakaszaiban Forrás: $M N B$

Miközben jelentősen mérsékelte az NHP a kis- és közepes vállalati kör kamatterheit, versenyfokozó hatását is kifejtette a bankszektor szereplöire nézve, különösen a bankváltás lehetőségének szabadsága miatt (ezzel a hitelszerződések mintegy 20 százalékában éltek is a vállalkozások). Az NHP második szakaszában 
(2013. október és 2015. december 31. között) a kis- és közepes vállalati kör számára 1 402,1 milliárd forintösszegben nyújtottak hitelt. A második szakasz föleg új hitelkihelyezés formájában jutott el a vállalkozásokhoz, melyek esetében 97 százalékban új hitel, 61 százalékban beruházási hitel. A hosszabb szerződéskötési időszak és az élénkebb verseny a mikrovállalatok nagyobb arányú részvételét eredményezte, e szakaszban már a hitelek fele 10 millió forint alatti volt.

$\mathrm{Az}$ átmeneti eszközként elindított NHP fokozatos kivezetése jegyében került elindításra (a Növekedéstámogató Program részeként) 2016 elején az NHP harmadik szakasza, amely a korábbinál célzottabb finanszírozást tett lehetővé. A 2017. március végén zárult kivezető szakasz 700 milliárd forintos keretöszszege közel teljes mértékben felhasználásra került. Az NHP három szakaszában és az NHP+ konstrukció keretében a bankok összesen mintegy 2800 milliárd forintnyi hitelszerződést kötöttek, közel 40 ezer vállalkozás jutott kedvező finanszírozáshoz.

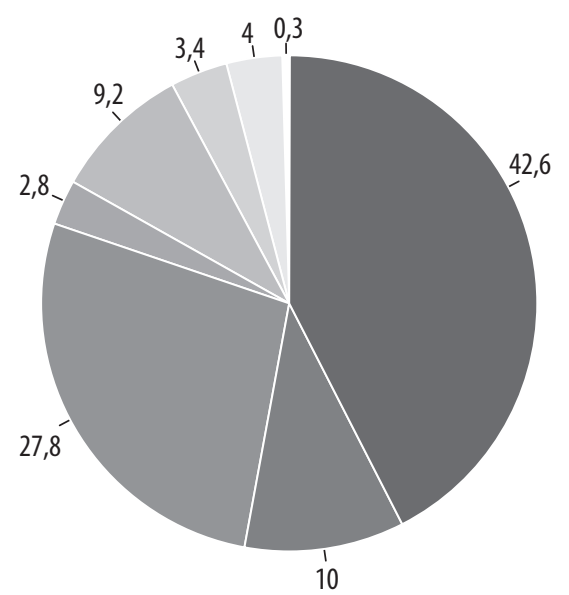

Piaci alapon nyújtott hitelállomány

$\mathrm{NPH}$

Eximbank refinanszírozási hitelek

GOP, KMOP (JEREMIE) hitelprogramjai
Garantiqa

MFB kedvezményes vállalkozói hitel Széchenyi Kártya Program

Országos és Regionális Mikrohitel Programok

11. ábra: KKV hitelállomány megoszlása (\%) 2016-ban

Forrás: Parragh (2017) 
Az NHP hatására nemcsak megállt a kkv-hitelezés évek óta tartó visszaesésének folyamata, de a hitelezési dinamika növekedésbe fordult, és 2016-ra elérte a gazdasági növekedés támogatásához szükséges bővülés mértékét. Az NHP-ra volt szükség ahhoz, hogy a vállalati hitelállomány évek óta tartó csökkenő trendje megszünjön.

\section{A hitelösztönző programok rendszerezése és főbb jellemzői ${ }^{20}$}

A monetáris politikai eszközök és így a hitelösztönző eszközök is lehetnek általánosak és célzottak. Célzottság alatt egyfelöl érthetjük azt, hogy az adott eszköz egy meghatározott, jól körülhatárolt probléma (tágabb értelemben egy kedvezőtlen makrogazdasági tendencia, pénzügyi stabilitási kockázat vagy piaci kudarc) kezelését szolgálja-e. A legkevésbé célzott eszköznek az alapkamat csökkentése tekinthető, és hasonló hatással bírnak a szintén hozamleszorító hatást elérni kívánó nagyösszegü eszközvásárlási programok, valamint az általános likviditásbővítő eszközök is. Ezzel szemben vannak olyan dedikáltan hitelösztönzési céllal bevezetett programok, amelyek célzottabb módon hatnak a hitelezésre, a bankok hitelezési aktivitására.

A hitelösztönző eszközök vonatkozásában kétféle módon beszélhetünk célzottságról:

- akkor, ha az eszköz egy körülhatárolt szektor (legtöbbször kkv-k) hitelhez jutási nehézségeit próbálja kezelni,

- valamint akkor, ha konkrétabb célt tüz ki a hitelezés élénkítésén túl (illetve azon belül), amely lehet akár az adott hitelállomány növelése, a hitelezési feltételek javítása, a beruházási hitelek növelése, nem-teljesítő állomány csökkentése.

Egy adott eszközhöz való hozzáférést, az igénybevétel mennyiségét és/vagy árát a jegybank feltétel teljesítéséhez is kötheti, a nemteljesítéshez pedig legtöbbször szankció (legalább a meg nem szolgált kedvezmények visszaszolgáltatása) kapcsolódik.

A programok megbonthatók abban a tekintetben is, hogy milyen módon ösztönzik a bank hitelezési tevékenységét. Egy hitelösztönző program hatékonysága abban az esetben a maximális, amennyiben abban a hitelezési tényezőben

20 Kolozsi-Parragh - Pulai (2017). 
„segít” a hitelintézeteknek, amely a legszűkebb keresztmetszetet jelenti a hitelezési képesség vagy hajlandóság tekintetében. Az is releváns lehet, hogy az adott program milyen széles fedezeti kör mellett érhető el, hiszen minél szélesebb az elfogadható banki fedezetek köre, annál hozzáférhetőbb banki oldalról a hitelösztönző program. Az egyes programok természetesen elérhetőségük alapján is eltérhetnek. Itt két dimenziót érdemes megemlíteni: a rendelkezésre állás hosszát és a keretösszegük GDP-hez mért arányát. A nagyobb volumenű és hosszabb rendelkezésre állású programok nagyobb valószínűséggel bírnak nagyobb hatással, mint a kisebb és rövidebb programok; bár a hatékonyságuk nem feltétlenül jobb, ebből a szempontból sok múlik a célzottság mértékén. Végül nem egységesek a hitelösztönző programok abban a tekintetben sem, hogy a hitelpiac melyik oldalára kívánnak elsődlegesen hatni, jóllehet általában valamilyen mértékben és hosszabb távon mind a keresleti, mind a kínálati oldalra hatnak az egyes intézkedések. Az elsősorban közvetlenül a hitelkínálatra ható programok jellemzően kedvező árazású forrást vagy más ösztönző - például hitelezést olcsóbbá/ könnyebbé tevő, kockázatot csökkentő - eszközöket biztosítanak a hitelintézetek számára, a hitelezés bővülése pedig jellemzően az ennek hatására megváltozó banki viselkedés, jellemzően a banki hitelkamatok csökkentése által indul el. Ezzel szemben vannak olyan monetáris politikai intézkedések is (például az általános kamatcsökkentés), amelyek a hitelezést hitelkereslet élénkülésén keresztül is támogatják. A hitelkamatok keresleti oldali élénkítés céljából, illetve annak eredményeképp bekövetkezett csökken(t)ése ugyanakkor visszahat a kínálati oldalra, mivel élénkíti a bankok közötti versenyt, valamint a javuló vállalati megtérülés és az emelkedő eszközárak hatására hosszabb távon javul a vállalatok hitelképessége is.

\subsubsection{9. Önfinanszírozási program ${ }^{21,22}$}

Kiemelt jelentőségű elem a monetáris politikai eszköztárban a Magyarország sérülékenységének csökkentése érdekében bevezetett Önfinanszírozási program. A 2008-2009-es pénzügyi-gazdasági válságot követően fő célkitűzésként fogalmazódott meg Magyarország külső sérülékenységének, valamint a külső és devizaforrásokra való ráutaltságának csökkentése. A jegybank Önfinanszírozási

21 Parragh (2017).

22 Magyar Nemzeti Bank (2019a). 
programját az államadósság belső forrásokból történő finanszírozásának segítése és a külső forrásokra való ráutaltság csökkentése érdekében hirdette meg. A programnak köszönhetően lehetővé vált a jegybanki mérleg egyszerűsödése, más néven szükülése, amely javuló monetáris transzmisszióval párosult. A külső sérülékenység csökken, ha az Államadósság Kezelő Központ a lejáró devizaadósságát forintból tudja megújítani, mindeközben törekszik a belföldi szereplőknek a folyamatba történő bevonására. Ebben az összefüggésrendszerben alapvető fontosságú, hogy a növekvő forintállampapír-kínálatra legyen elégséges szintű kereslet. Az MNB módosította az irányadóeszköz formáját és 2014 nyarán az addigi jegybanki kötvényről jegybanki betétre álltát. Az MNB 2016 augusztusától a korábbi heti gyakoriság helyett havonta egy tenderen fogad be banki betéteket a három hónapos irányadó eszközben, 2016 októberétől pedig korlátozza a tenderen elfogadott banki ajánlatok mennyiségét.

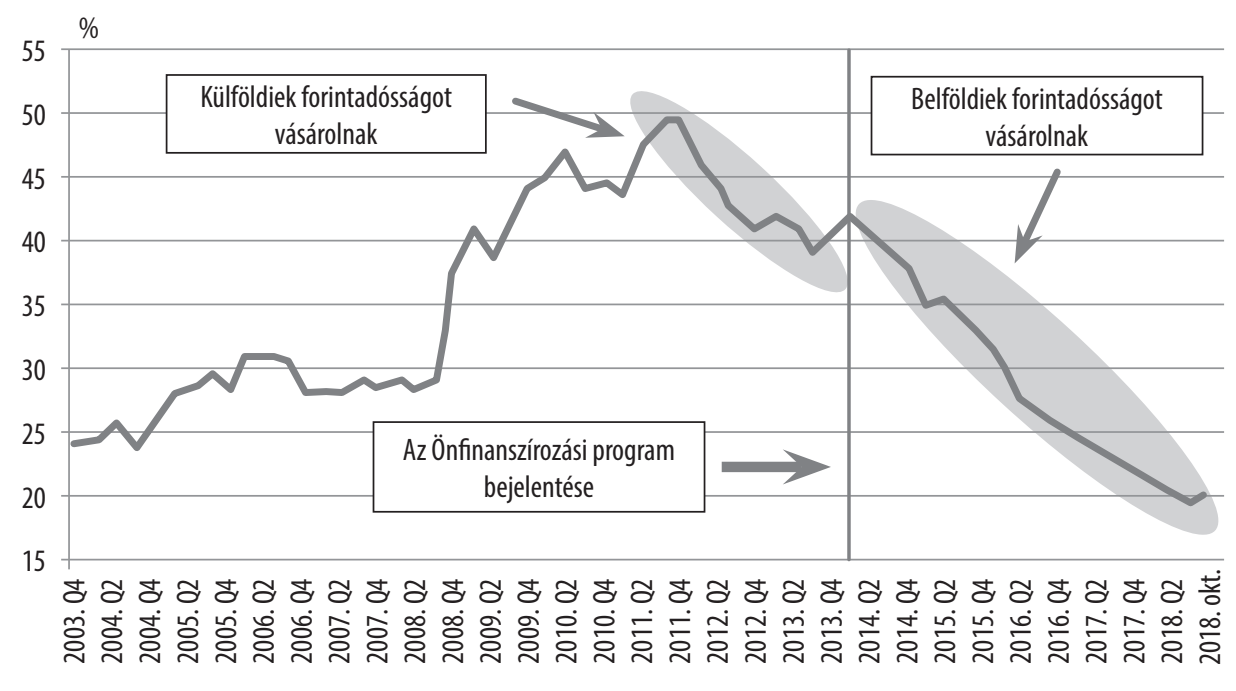

\section{2. ábra: Devizaarány alakulása a központi költségvetés bruttó adósságán belül}

Forrás: $M N B$

A 2014-2016 közötti időszakban a forint állampapírok tulajdonosi struktúrája jelentős mértékben átrendeződött, a hazai szektorok aránya érdemben emelkedett. A program során meghozott intézkedések következtében a bankrendszer 
likvid értékpapír- és kiemelten állampapír-portfóliója jelentősen bővült, így a forint állampapírok piacán a hitelintézetek váltak a legfontosabb szereplővé: arányuk 30-ról 38 százalékig emelkedett. A hazai szektorok közül a bankok mellett a háztartások tulajdonosi részaránya is kiemelkedő mértékben nőtt: a 2012-es 10 százalék alatti szintről 2014 elejére 15, 2016 végére 23, 2018 októberére pedig 25 százalékra. Az ÁKK lakossági állampapír programjainak hatására a háztartások aktívabb szerepvállalása az adósságfinanszírozásban szintén hozzájárult a külső sérülékenység csökkentéséhez.

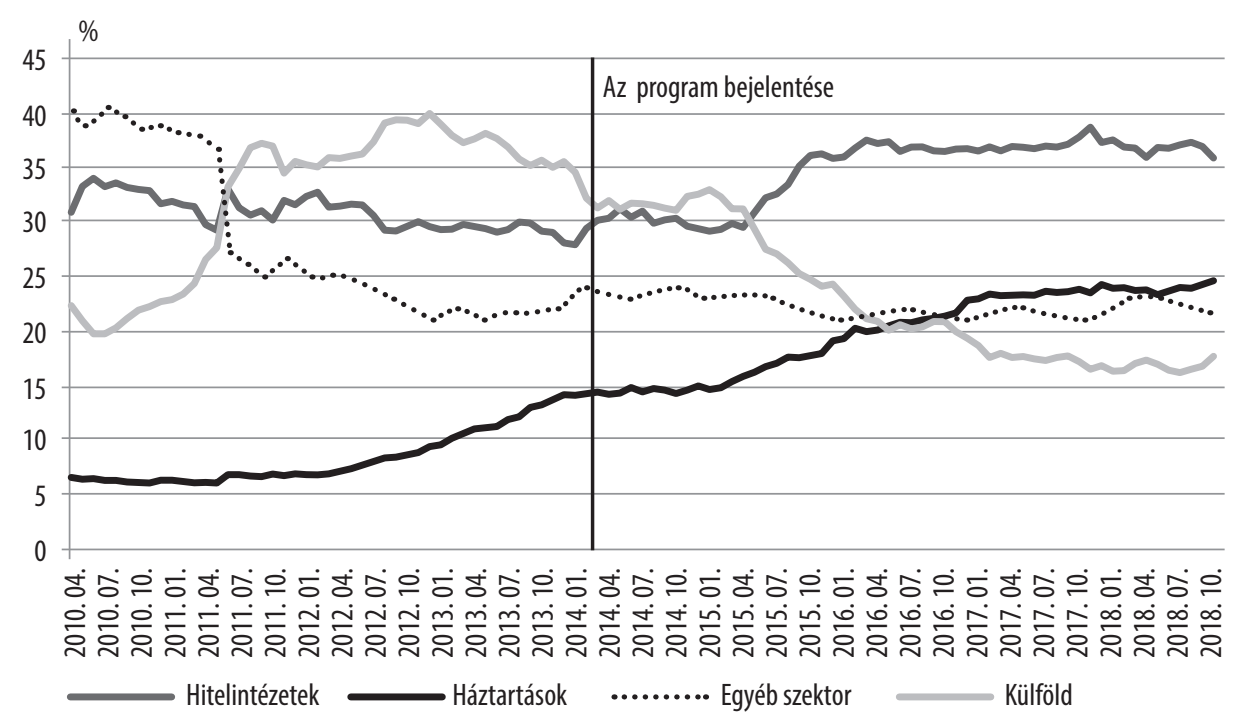

\section{3. ábra: Tulajdonosi szektorok aránya a forint állampapírok piacán Forrás: $M N B$}

A jegybanki alapkamat-csökkentések és az Önfinanszírozási program intézkedései az állampapírpiaci hozamcsökkenésen keresztül segítették elő az államháztartás kamatterheinek jelentős enyhülését, ami költségvetési megtakarítást eredményezett az állam számára.

Az Önfinanszírozási program teljesítette a meghirdetésekor kitűzött célokat, csökkent az ország külső sérülékenysége, erősödött a pénzügyi stabilitás, javult Magyarország nemzetközi megítélése. A lejáró devizaadósság megemelt forint-állampapír kibocsátásból történt megújításának köszönhetően megválto- 
zott az államadósság finanszírozási szerkezete, javult a deviza összetétele, valamint csökkent a devizaárfolyamok változására való érzékenysége. 2014 közepétől kezdődően a magyar államnak a nemzetközi hitelek törlesztéséhez, valamint a devizakötvény-lejáratok refinanszírozásához nem volt szüksége nettó értelemben devizaforrás bevonására, ennek köszönhetően az ÁKK 2014 és 2016 között összesen mintegy 11 milliárd eurónyi devizaadósságot törlesztett forintforrásokból anélkül, hogy jelentősebb összegű devizakötvény-kibocsátásra került volna sor a nemzetközi piacokon.

A banki alkalmazkodás nagyban hozzájárult ahhoz, hogy az államadósság finanszírozásán belül 2016 végére 25 százalék, 2018. október végére 20 százalék körüli mértékre csökkent a központi költségvetés devizában fennálló adósságállománya a 2013 végi 42 százalékos szintről. A nemzetgazdaság bruttó külső adóssága 2016 végére 70 százalék, 2018. szeptember végére 58 százalék, míg az állam bruttó külső adóssága 2016 végére 40 százalék, 2018 őszére pedig 30 százalék alatti GDP-arányos szintre csökkent, emellett pedig folytatódott a bankszektor alkalmazkodása is. A program a hazai makrogazdasági környezet javulásában és a külső sérülékenység jelentős csökkenésében elért eredményeit a nemzetközi pénzügyi intézmények is elismerték, illetve egyértelmüen hozzájárult ahhoz, hogy 2016-ban a három fő nemzetközi hitelminősítő Magyarország adósbesorolását a befektetésre ajánlott kategóriába emelte vissza.

\section{Devizahitelek forintosítása ${ }^{23}$}

A külföldi és devizakitettség csökkentése az Önfinanszírozási program által érintett állami szektorokon túl a háztartási szektorban is megtörtént, amelyet mindenekelőtt a lakosság jelzálog- és egyéb devizahitelek kivezetése segített elö, amiben kiemelkedő szerepet töltöttbe a jegybank is. A forintosításhoz szükséges csaknem 10 milliárd eurónyi devizalikviditást az MNB bocsátotta a bankok rendelkezésére 2014 őszétől kezdődően, mégpedig úgy, hogy az ország stabilitása szempontjából fontos tartalékmegfelelés nem sérült. A forintosítás eredményeként Magyarországon kikerültek a banki mérlegekből a fedezetlen lakossági devizahitelek, azaz sikerült visszafordulni az utóbbi másfél évtized strukturális problémáinak kialakulásához vezető téves útról.

23 Parragh (2017). 


\subsubsection{Növekedési kötvényprogram ${ }^{24}$}

A vállalatok számára a kötvénypiacon történő forrásbevonás a bankhitel felvétele melletti alternatív finanszírozási lehetőség. A vállalatok többféle forrást használnak hosszútávú beruházásaik és mindennapi üzleti tevékenységük finanszírozására: a finanszírozás saját tőke mellett történhet idegen forrás igénybevételével, azaz bankhitelből vagy kötvény-, illetve részvénypiacról való forrásbevonással is.

Az elmúlt években megvalósult hitelezési fordulat eredményeképpen a hitelezés volumene megfelelő szintre került Magyarországon. A finanszírozás diverzifikációja azonban egyelőre nem valósul meg: míg a nem pénzügyi vállalatok bankhiteleinek GDP-arányos értéke meghaladja 17 százalékot, addig a kötvényállományuk mindössze 1,5 százalék körül alakult 2018 végén. Ez az érték mind az európai uniós országok, mind a kelet-közép-európai országok átlagától messze elmarad.

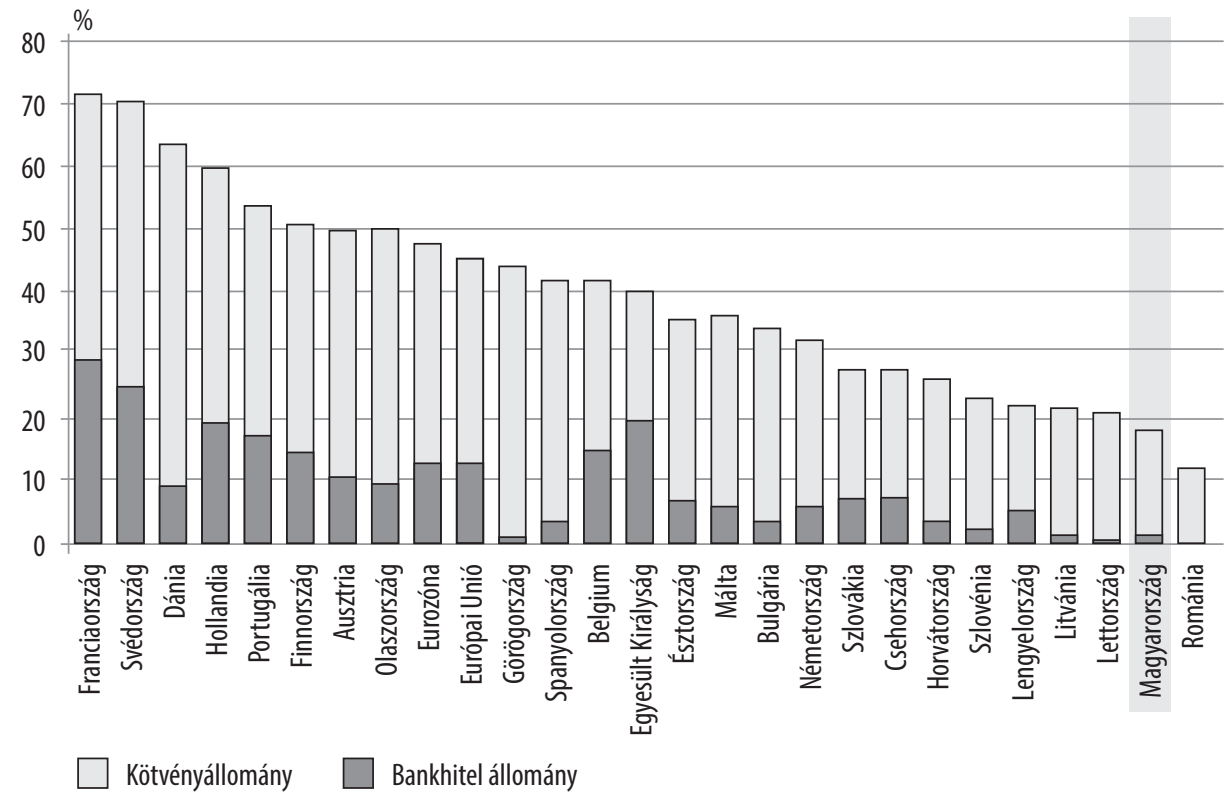
14. ábra: A nem pénzügyi vállalatok kötvény- és bankhitel állománya a GDP arányában, (2018. II. negyedév)

Forrás: $M N B$

24 Magyar Nemzeti Bank (2019b). 
A vállalatok forrásbevonásának több pillérre helyezése számos előnyt hordoz magában. Egy fejlett vállalati kötvénypiaci versenyt támaszthat a bankhitelekkel szemben, aminek eredményeképp a vállalatok forrásköltsége mérséklődhet. Ezen felül egy likvid kötvénypiac hozzájárul a monetáris politikai transzmisszió hatékonyságának javulásához, valamint a vállalatok forrásellátottságát biztosító piacok közötti egészséges verseny a jegybanki kamatdöntések hatékonyabb érvényesülését biztosíthatja. Emellett egy megfelelően likvid és fejlett kötvénypiac a pénzügyi stabilitást növelheti, és egy esetleges gazdasági válság hatásait is tompíthatja.

A vállalatikötvény-piac likviditásának növelése érdekében az MNB 2019. július 1-jétől meghirdette a Növekedési Kötvényprogramot (NKP). A program keretében a jegybank 300 milliárd forint keretösszegben nem pénzügyi vállalatok által kibocsátott, jó minősítéssel rendelkező kötvényeket, valamint vállalatokkal szemben fennálló hitelkövetelések fedezete mellett kibocsátott értékpapírokat vásárol.

\subsubsection{Aranytartalék szerepének felértékelödése $e^{25}$}

$\mathrm{Az}$ arany a megváltozott pénzügyi-gazdasági környezetben is speciális szerepet töltött be a pénzügyi eszközök között. Az elmúlt években a változó jegybanki, gazdasági és geopolitikai folyamatok hatására az arany szerepe számos országban felértékelődött, különösen likviditása, hitelkockázat-mentessége és sokk-ellenállóképessége miatt. A 2008-as világgazdasági válságot követően a világ jegybankjainak aranytartaléka jelentősen emelkedett.

\section{Az aranytartalék tartásának előnyei}

- Az aranytartalék továbbra is használt tradicionális tartalékeszköz, súlyos válságok elleni védvonal szerepét betöltő instrumentum, vagyonelem.

- Az arany a nemzetközi tartalék részeként diverzifikációs szerepet tölt be, csökkenti a tartalék koncentrációját, támogatva a tartalék pénzügyi kockázatainak szétterítését, megosztását.

- A fizikai arany, mint befektetési forma, esetében a jegybank válsághelyzetben sem szembesül hitelkockázattal.

25 Magyar Nemzeti Bank (2019a). 
- Az aranynak minden gazdasági környezetben van gazdaságstratégiai szerepe. Az aranytartalék tartásával, felhalmozásával a jegybank alkalmas az országgal szembeni bizalom erősítésére belföldön és külföldön egyaránt.

- A globális pénzügyi rendszer érdemi átalakulása, rendszerszintű válsága esetén az arany jelentősége újra megnőhet, az országok közötti kapcsolatokban ismét szerephez juthat, és nemzetstratégiai szempontból is kiemelten fontos lehet. Más jegybankoknak a válságot követő időszakban megfigyelt aranyvásárlásai jól mutatják a nemzetközi trendek és a jegybanki stratégiai hozzáállás változását.

- Válsághelyzetben az arany árfolyama potenciális menedékeszközként emelkedhet, ami növeli a devizatartalékok értékét, így javíthatja a tartalékmegfelelést, valamint az ország ellenállóképességét a válságokkal és piaci turbulenciákkal szemben.

$\mathrm{Az}$ arany Magyarország történelmében különösen fontos szerepet töltött be. Magyarország aranytartaléka a rendszerváltás környékén jelentős mértékben csökkent, miután az MNB akkori vezetése azt a stratégiai döntést hozta, hogy aranykészleteit a minimális szintre csökkenti.

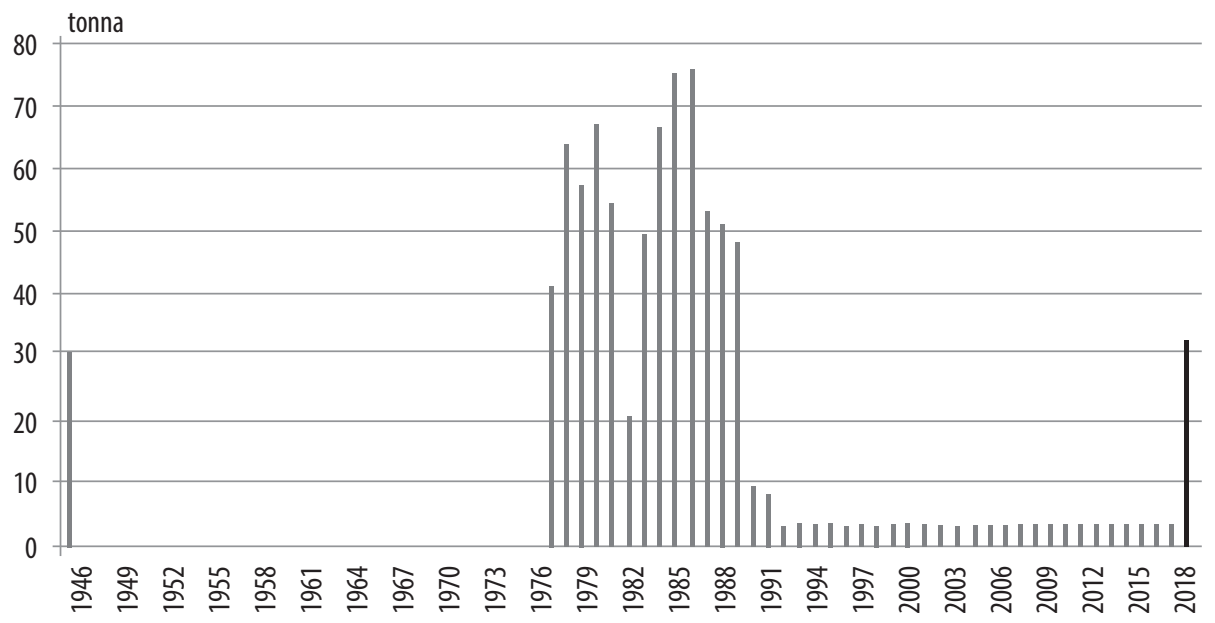

15. ábra: Az MNB aranytartalékainak alakulása

Forrás: $M N B$

2018-ban az MNB az aranytartalék helyreállítása és hazaszállítása mellett döntött. A jegybank első lépésben a már birtokában lévő 3 tonnás aranytartalékot szállította haza 2018 elején. Ezt követően a Monetáris Tanács azaranytartalék megtízsze- 
rezéséről döntött, amely 2018 őszén meg is valósult. Utolsó lépésben az MNB az újonnan megvásárolt teljes aranykészletet hazaszállíttatta. Ezzel lezárult az aranytartalék helyreállításának folyamata, Magyarország 31,5 tonnás aranytartaléka újra itthon található. A magyar aranytartalék mértéke a megtízszerezést követően mind arányát tekintve, mind abszolút értelemben a nemzetközi rangsor középmezőnyébe került, megfelel a nem-eurozónás régiós országok átlagának.

\subsubsection{Tökepiaci szerepvállalás, Budapest Értéktözsde ${ }^{26}$}

A 2008-as válság következtében a Budapesti Értéktőzsdén a nemzetközi folyamatokkal összhangban a részvények árfolyama jelentősen csökkent, a tőzsdei befektetések megítélése jelentősen romlott. A regenerálódás a mai napig tart, a részvénypiaci forgalom azóta sem érte el a válság előtti szintet, az új kibocsátások száma alacsony szinten maradt. Így a tőzsde gazdaságban betöltött szerepe a válság következtében erőteljesen csökkent.

A tőzsdefejlesztés legújabb szakasza a Magyar Nemzeti Bank 2015. év végi tulajdonossá válásával vette kezdetét. A tulajdonszerzését követően ez megváltozott, a nyers profitelvárásokkal szemben előtérbe került a hazai tőkepiac fejlesztésének szándéka, mely szükségszerüen aktív szerepvállalást igényel. A Magyar Nemzeti Bank többségi tulajdonossá válását ezen túlmenően nemzetközi kitekintésben is jellemző gazdaságstratégiai szempontok indokolják. A hosszú távú tulajdonosi szemlélet a tőzsdei müködésben és kereskedésben bizalomteremtő hatással jár.

A jegybankok monetáris politikáért, pénzügyi stabilitásért felelős intézményekként müködésük egyik kiemelt területének tekintik a tőkepiacok hatékonyságát. A tőkepiac fontos szerepet tölt be a monetáris politikai döntések transzmissziójának minél teljesebb érvényesülésében, melynek keretében a Magyar Nemzeti Bank a hazai tőkepiac fejlesztése, a befektetői bázis szélesítése és az eszközár-csatorna transzmissziójának javítása céljával növelte befolyását a Budapest Értéktőzsde Zrt.-ben.

A tőzsde valós forrásszerzési csatornaként funkcionálhat a hazai vállalatok számára, hozzájárulva a gazdasági növekedéshez, munkahelyek teremtéséhez és az innovatív vállalatok hazai központú fejlődéséhez.

26 Parragh - Végh (2018). 


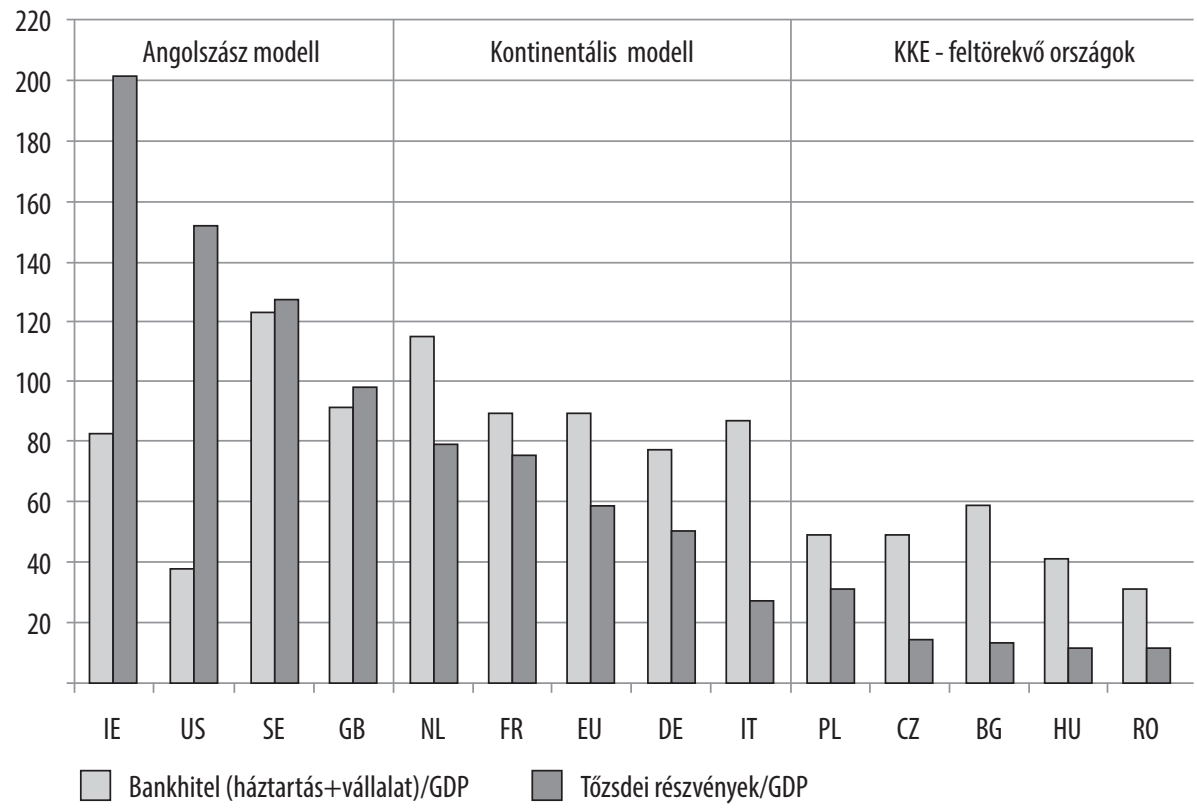

16. ábra: Banki és tôzsdei finanszírozás

Forrás: Világbank

A Magyar Nemzeti Bank aktív szerepvállalását az eddig említetteken túl további szempontok is indokolják, melyek nem választhatók el a hazai tőkepiacra hatással lévő legfontosabb trendektöl. A föbb trendek a következőképpen foglalhatók össze:

- versenyképességi fordulat, fenntartható felzárkózási célok megvalósítása (többek között demográfiai folyamatok és ezek kezelésére adott megoldások, hazai tőkés réteg megerösítése, nemzeti jólét növelése);

- EU-támogatások és források csökkenése;

- a banki finanszírozás gazdaságra gyakorolt hatása, összefüggései;

- a tőkepiaci unió törekvései a tőkepiac fejlesztése érdekében;

- banki és tőzsdei finanszírozás egészséges, gazdasági növekedést támogató aránya tekintetében, nemzetközi kitekintésben tapasztalható jelentős eltérések.

Fő célkitűzésként fogalmazódott meg, hogy a magyar tőzsde fejlesztésével olyan tőkepiac jöjjön létre, amely a vállalatok jelenleginél sokkal szélesebb körének teremt reális és elérhető finanszírozási alternatívát, így kiegészítheti a banki hi- 
telezés növekedéstámogató hatását. A magyar tőkepiac 2016 elött nem tudott a diverzifikált pénzügyi közvetítőrendszer részeként a versenyképes gazdaság és fenntartható növekedés motorjává válni, továbbá nem vált a vállalatok banki finanszírozás melletti alternatívájává sem.

A gazdasági fejlődésben rövid- és hosszútávon is meghatározó a pénzügyi közvetítés és pénzügyi rendszer működése. A banki hitelezés és a tőkepiaci finanszírozás egyaránt fontos szerepet töltenek be a gazdasági növekedés és a nemzetgazdasági teljesítőképesség alakulásában. Az egészséges szerkezetben megvalósuló hitelezés ösztönzése és a tőkepiac fejlesztése egységben járulhat hozzá a fenntartható gazdasági növekedés megvalósításához, mely téren nem hagyható figyelmen kívül a jogszabályi környezet támogató szerepe.

\subsubsection{Társadalmi felelösségvállalás ${ }^{27}$}

A Magyar Nemzeti Bank küldetésének tekinti, hogy elsődleges céljának és alapvető feladatainak veszélyeztetése nélkül fenntartható pozitív eredménye terhére a közjót szolgálja, és lehetőségeihez mérten olyan szakmai és össztársadalmi célok megvalósításához nyújtson támogatást, amelyek tükrözik a hitelességet, értéket teremtenek és erősítik a társadalmi kohéziót. Ezen elveket tükrözik az MNB Társadalmi Felelősségvállalás Programjának legfőbb pillérei, vagyis a pénzügyi ismeretterjesztés, a gazdasági oktatási-kutatási infrastruktúra fejlesztése, a nemzeti kultúra támogatása és karitatív tevékenységekhez való hozzájárulás. A jegybank társadalmi felelősségvállalási stratégiája a meghatározó külföldi jegybankok gyakorlatának figyelembevételével került kialakításra.

Az MNB lehetőségeihez mérten közvetlenül, illetve alapítványai útján, stratégiai együttmüködési megállapodások keretében, illetve eseti támogatások nyújtásával vállal szerepet az értékteremtésben, a nemzeti értékek, a szellemi és kulturális örökség megőrzésében, valamint a szakemberképzés, tudományos tevékenység támogatásában. Karitatív célú adományozással hozzájárul a hátrányos helyzetű csoportok életminőségének, esélyegyenlőségének javításához, a rendkívüli élethelyzetek okozta nehézségek enyhítéséhez.

27 Magyar Nemzeti Bank (2019): MNB jelentés: 2013-2019, Magyar Nemzeti Bank 


\section{Programok}

A Magyar Nemzeti Bank középtávú társadalmi felelösségvállalási stratégiájának részeként 2014-ben elindította az Értéktár Programot, amellyel nagyszabású kulturális missziót vállalt fel. A program célja visszahozni Magyarországra a külföldre, illetve a külföldi tulajdonba került mükincsek legjavát, a hazai hagyatékokban fellehető jelentős alkotásokat pedig megvásárlásuk révén itthon tartani.

A Pénziránytü Alapítvány a Magyar Nemzeti Bank kezdeményezésére jött létre azzal a céllal, hogy pénzügyi tudatosságot fejlesztő programokat dolgozzon ki és valósítson meg.

\subsection{Irodalomjegyzék}

2013. évi CXXXIX. törvény (Jegybanktörvény)

Bartha Lajos - Luspay Miklós - Varga Lóránt (2017): Pénzforgalom és pénzügyi infrastruktúrák, In: Magyar Nemzeti Bank: Modern jegybanki gyakorlat, Magyar Nemzeti Bank; 287-360. o.

Csávás Csaba - Kiss M. Norbert (2017): A devizatartalék szerepe a jegybankok müködésében, In: Magyar Nemzeti Bank: Modern jegybanki gyakorlat, Magyar Nemzeti Bank; 189-238. o.

Felcser Dániel - Lehmann Kristóf - Vonnák Balázs (2017): A monetáris politika működése - transzmisszió a válság előtt és után, In: Magyar Nemzeti Bank: Modern jegybanki gyakorlat, Magyar Nemzeti Bank; 9-55.o.

Kolozsi Pál Péter - Parragh Bianka - Pulai György (2017): Jegybanki hitelösztönző programok rendszerezése - célzottság és intenzitás. Pénzügyi Szemle, 2017/4, 498-519. o.

Kolozsi Pál Péter (2017): Konstruktív összhang a gazdaságpolitikában - jegybanki programok és a jól irányított állam. Új Magyar Közigazgatás, 10. évf., Különszám, 19-28. o.

Kolozsi Pál Péter - Lentner Csaba - Parragh Bianka (2017): Közpénzügyi megújulás és állami modellváltás. Polgári Szemle, 13. évf., 4-6. szám, 2017, 28-51. o., DOI: 10.24307/psz.2017.1204 https://polgariszemle.hu/ aktualis-szam/146-allampenzugyi-muhely-nemzetgazdasagtan/917-kozpenzugyi-megujulas-es-allami-modellvaltas-magyarorszagon

Lentner Csaba (2017a): Közpénzügyi menedzsment. Dialóg Campus Kiadó, Pécs, 266. o.

Lentner Csaba (2017b): Az MNB szervei - Monetáris Tanács, Pénzügyi Stabilitási Tanács, az igazgatóság és a felügyelőbizottság, Közpénzügyi menedzsment, Dialóg Campus Kiadó, Pécs, 181-183. o. 
Lentner Csaba (2018): A pénzügyi stabilitás követelményének egyes szabályozási és felügyeleti vetületei a magyar kereskedelmi bankszektorra. Controller Info Tudományos Szakfolyóirat, Jubileumi különszám, IX. osztály kategóriás lapja, 22-25.o. DOI: 10.24387/CI.2018.K.6.

Matolcsy György (2015): Egyensúly és Növekedés. Kairosz Kiadó.

Matolcsy György - Palotai Dániel (2016): A fiskális és a monetáris politika kölcsönhatása Magyarországon az elmúlt másfél évtizedben. Hitelintézeti Szemle, 15. évf. 2. szám, 2016. június, 5-32. o.

Matolcsy György - Palotai Dániel (2018): A magyar modell: A válságkezelés magyarreceptje a mediterrán út tükrében. Hitelintézeti Szemle, 17. évf. 2. szám, 2018. június, 5-42. 0 .

MNB (2015): Nemzetközi kitekintés - Az amerikai bankrendszer sajátosságai. Magyar Nemzeti Bank, 2015. augusztus 14. https://www.mnb.hu/letoltes/ nemzetkozi-kitekintes-az-amerikai-bankrendszer-sajatossagai.pdf

MNB (2017a): Magyar út: célzott jegybanki politika. Magyar Nemzeti Bank.

MNB (2017b): Modern jegybanki gyakorlat. Magyar Nemzeti Bank.

MNB (2018): A Növekedési Hitelprogram Fix elindításának jegybanki szempontjai és a konstrukció fontosabb jellemzői, Magyar Nemzeti Bank.

MNB (2019a): Jelentés 2013-2019. Magyar Nemzeti Bank.

MNB (2019b): Növekedési kötvényprogram elindításának jegybanki szempontjai és a konstrukció főbb jellemzői. Magyar Nemzeti Bank

MNB (2019c): Az inflációs célkövetéses rendszer. Magyar Nemzeti Bank. https://www.mnb.hu/monetaris-politika/a-monetaris-politika-keretrendszere/ az-inflacios-celkoveteses-rendszer. Letöltés: 2019. május 23.

Parragh Bianka (2017): Monetáris hitviták. Pénzügyi szemle, 2017/2, 234-250.o Parragh Bianka - Végh Richárd (2018): Megújuló állam - megújuló tőkepiac. Polgári Szemle, 14. évf. 4-6. szám, 48-78.o. DOI: 10.24307/psz.2018.1205 https://polgariszemle.hu/aktualis-szam/157-gazdasagpolitika/985-megujulo-allam-megujulo-tokepiac

Rédei Attila - Zsigó Márton (2017): A jegybank végső hitelezői szerepköre. In: Magyar Nemzeti Bank: Modern jegybanki gyakorlat, Magyar Nemzeti Bank; 469-492. o. 


\section{A belföldi fizetési forgalom}

\subsection{A belföldi fizetési forgalom kerete}

\subsubsection{A belföldi fizetési forgalom meghatározása}

Bevezetésül szükséges meghatároznunk a fejezet tárgyát. Könyvünk e pontjában a fizetési forgalommal, ezen belül is a belföldi fizetési forgalommal foglalkozunk. „A gazdasági szereplők egymással szemben teljesített fizetéseinek összességét pénzforgalomnak nevezzük.” (Bartha et al., 2017, 289). Közgazdaságilag tekintve, a gazdasági alanyok egymásnak fizetéseket teljesítenek, azaz pénzbevételeik és pénzkiadásaik keletkeznek. A pénznek ezt a szakadatlan áramlását, mozgását nevezzük pénzforgalomnak.

A belföldi fizetési forgalom definícióján azon fizetési műveletek összességét értjük, amelynek keretében mind a fizető fél pénzforgalmi szolgáltatója, mind a kedvezményezett pénzforgalmi szolgáltatója a Magyar Köztársaság határain belül nyúitja pénzforgalmi szolgáltatását (35/2017. (XII. 14.) MNB rendelet).

A fizetési formákat tekintve a korábbi terminológia szerint beszélhettünk:

- készpénzfizetésröl,

- készpénz nélküli fizetésről és

- a készpénzkímélő fizetési formákról.

2009. november 1-től hazánkban több ponton lényegesen megváltozott a fizetési forgalom működési módja. A pénzforgalmi szolgáltatások új logikai működési módja az erről szóló törvényi szabályozás alapján (a pénzforgalom nyújtásáról 2009. évi LXXXV. törvény) alapján az alábbi fizetési módokat különböztethetjük meg:

a) fizetési számlák közötti fizetés,

b) fizetési számlához kötődő készpénzfizetés,

c) fizetési számla nélküli fizetés.

Fontos hangsúlyoznunk, hogy a készpénzes fizetés választható fizetési mód ugyan, de a törvény értelmében nem minősül pénzforgalmi szolgáltatásnak. 
A fizetési számlák közötti fizetés esetében két számla közötti pénzmozgásról, a fizetési számlához kötődő készpénzfizetés esetében egy fizetési számlához kötődő pénzmozgásról, míg a fizetési számla nélküli fizetés esetében olyan pénzforgalmi szolgáltatásról beszélünk, amely során nem használunk fizetési számlát.

A pénzforgalom szabályozására szolgáló előírások meghatározzák nemcsak a lehetséges fizetési módokat, hanem elöírják a gazdálkodó szervek számára kötelező bankszámla-nyitást, valamint szabályozzák a szabad pénzeszközök bankszámlán tartásának feltételeit is. Már itt is fontos hangsúlyozni, hogy természetes személyek esetében is létezik számlahasználati kötelezettség: az általános forgalmi adó (áfa) alanyai kötelesek bankszámlán lebonyolítani áfa befizetéseiket, illetve visszaigényléseiket.

\subsubsection{A fizetési számla típusai}

A fizetési számla a pénzforgalmi szolgáltató és az ügyfél írásbeli megállapodása alapján megkötött, a fizetési műveletek teljesítésére szolgáló számla, amelynek egyik legfontosabb típusa a bankszámla. A fizetési művelet fogalma nemcsak a fizető fél (kötelezett) és a kedvezményezett körére vonatkozik, hanem az új elöírások alapján fizetési műveleten a fizető fél, a kedvezményezett, a hatósági átutalási megbízás adására jogosult és az átutalási végzést kibocsátó által kezdeményezett megbízás valamely fizetési mód szerinti lebonyolítását értjük.

A számlák esetében rendeltetésük szerint beszélhetünk pénzforgalmi jellegü számlákról, megtakarítási célú számlákról (betétszámla), valamint elkülönített célú pénzeszköz őrzésére szolgáló számlákról (értékpapírletéti számla, fedezeti számla).

Pénzforgalmi számla a számlatulajdonos rendszeres gazdasági tevékenység végzését szolgálja, alkalmas valamennyi fizetési mód lebonyolítására, de nem szolgál meghatározott célt (azaz nem hitelszámla, lekötött betétszámla stb.).

A folyószámla a fizetési forgalom lebonyolítására, a számlatulajdonos hitelfelvételére szolgál. A folyószámla lényeges tulajdonsága a Ptk. szerint, hogy a felek között kölcsönös tartozás vagy követelést tartalmazhat, vagyis a számla egyenlege negatív is lehet. Ekkor a számlatulajdonos egy összeghatár alatt automatikusan, külön eseti hitelkérelem benyújtása nélkül részesülhet kölcsönben.

A betétszámla a megtakarítások kezelésére alkalmas. Egyenlege csak pozitív lehet. 
A fedezeti számla azoknak az összegeknek elhelyezésére szolgál, amelyek feletti rendelkezési jogáról a számlatulajdonos lemondott. A lemondás oka általában valamilyen cél megvalósítása, mint például importfedezet, akkreditív fedezete stb.

$\mathrm{Az}$ értékpapír letéti számla az ügyfél értékpapírjainak nyilvántartására szolgáló számlatípus. Számlakivonatot általában sokkal ritkábban küldenek e számláról, mint a pénzforgalmi számlák esetében. Az értékpapír letéti számlák jelentősége egyre nő, mivel emelkedik azon értékpapírok köre, melyeket nem nyomtatnak ki, csak számítógépes nyilvántartásban szerepeltetnek.

\subsubsection{A pénzforgalmi jelzőszám}

A pénzforgalmi kapcsolatok technikai alapja a pénzintézetek és ügyfelek azonosítására szolgáló kódok, az ún. pénzforgalmi jelzőszámok. A belföldi pénzforgalmi jelzőszámok 16 vagy 24 karakter hosszúságúak és az alábbiak szerint épülnek fel:

a) az 1-8. pozíció a hitelintézet azonosító száma, az ún. irányító kód (ezen belül az 1-3. pozíció a hitelintézetet, a 4-7. pozíció a fiókot jelöli, a 8. pozíció ellenőrző szám),

b) I. forma: 9-16. pozíció: számlaszám, a fizetési számla azonosító száma (ebből a 9-15. pozíció a tényleges szám, a 16. helyen ellenőrző szám áll) vagy II. forma 9-24. pozíció (9-23. pozíció a számlaszám, 24. pozíció ellenőrző szám, ekkor a 24 karakter hosszúságú pénzforgalmi jelzőszám 16. számjegye értelemszerüen szabadon kialakítható).

Az ellenőrző számok az előttük álló számjegyek ellenőrzésére szolgálnak, melyeket a következő algoritmus szerint kell képezni: külön az 1-7., valamint külön a 9-15. vagy 9-23. számjegyeket helyi értékük csökkenő sorrendjében meg kell szorozni a 9, 7, 3, $1 \ldots 9$ 9 7, 3, 1 számokkal, a szorzatokat össze kell adni, és az eredmény egyes helyi értékén lévő számot ki kell vonni 10-ből. A különbség az ellenőrző szám. (Ha a különbség „10”, az ellenőrző szám értéke „0”.)

A nemzetközi pénzforgalmi jelzőszámot (IBAN International Bank Account Number) az alábbi szabályoknak megfelelően kell kialakítani:

a) az első két karakter Magyarország ISO 3166 szabvány szerinti országkódja: $\mathrm{HU}$; 
b) a 3-4. karakter az ellenőrzőszám, amelynek algoritmusát az Európai Banki Szabványügyi Bizottság (European Committee for Banking Standards (ECBS) IBAN képzésére vonatkozó szabványa tartalmazza;

c) az 5-28. karakter a belföldi pénzforgalmi jelzőszám (16 karakter hoszszúságú pénzforgalmi jelzőszám esetében az IBAN képzésekor az utolsó 8 karaktert nulla számjeggyel kell feltölteni).

\subsubsection{Fizetési szokások Magyarországon}

A pénzforgalmi szolgáltatások díjtételeiről az MNB Fizetési rendszer jelentés 2018 kiadványa 7. oldalán megállapítja, hogy azok magasak. „A pénzforgalmi szolgáltatások árai Magyarországon más országokkal összehasonlítva, a pénzügyi tranzakciós illeték árnövelő hatását kiszürve is relatíve magasak. Jelentős a tranzakciószámtól és a fizetési megbízás értékétől függő díjak alkalmazásának az aránya különös tekintettel az átutalásokra, amely az elektronikus pénzforgalom költségeit az azt igénybe vevők számára nagymértékben növeli.” A tranzakciók mögött különböző emberi tényezők és általuk hozott döntések állnak, amelyeket a különböző értékek és az eltérő gondolkodásmód jelentősen befolyásol (Szabó-Szentgróti et al., 2019).

Mindez nem kedvez a pénzforgalmi szolgáltatások bővülésének, bár ennek ellenére, Európához képesti pozíciónk nem rossz. „Többek között a jegybank aktív fejlesztői szerepének eredményeként az átutalási forgalom GDP-hez viszonyított arányában már csak kis mértékủ az elmaradás az európai átlaghoz képest.” (MNB Fizetési rendszer jelentés 2018, 7.) A hazai pénzforgalmat különösen a tranzakciót terhelő adótételek terhelik súlyosan.

A gazdasági alanyokat a fizetési mód megválasztásában legtöbbször a múltban kialakult fizetési szokások irányítják. A természetes személyeket ezen felül nem terhelik lényegesebb jogi előírások, a gazdálkodó szektorban azonban hol szigorúbb, hol megengedőbb jogi szabályozás érvényesül a pénzforgalmi rendet, különösen a készpénzforgalom nagyságát illetően.

A közgazdasági irodalomban széleskörüen elemzett a fizetési szokások kérdésköre, különösen a készpénzfizetés és a készpénz nélküli fizetés közötti választás területe. A szakirodalom alapján a készpénzfizetést ösztönző tényezők közé a tranzakció azonnaliságát (könnyen megállapítható, hogyan állunk pénzügyi- 
leg, nincs probléma későbbi ellenőrzésekkel vagy az egyenleg túllépésével), az elfogadás egyetemlegessége (készpénzzel bárhol lehet fizetni), a készpénzfizetés egyszerűsége (nem szükséges nyomtatványokat kitölteni, nincsenek formális elöírások) és anonimitása (nem tudja meg más, mit vásároltunk).

A készpénzkímélő fizetési formákat a biztonság (számlapénzes fizetés esetén nem lép fel a készpénz elvesztésének vagy ellopásának kockázata), a szabad rendelkezés lehetősége, kényelmessége indokolja. Mindkét fizetési módnak megvan a maga előnye, a döntés attól függ, milyen helyzetben kerül sor a fizetésre, függ a fizetési feltételektől, a pénz felvevője által nyújtott szolgáltatásoktól és a fizetőt jellemző személyes tulajdonságoktól.

A 2017 decemberében a Kormány által elfogadott Pénzügyi Tudatosság Fejlesztési Stratégia több, az elektronikus fizetési megoldások használatát elösegitö célt fogalmazott meg. Az elemzés alapján (39. oldal) „A fokozatosságot szem előtt tartva érdemes elöírni az elektronikus fizetés - jellemzően a kártyahasználat, vagy más megoldások (2019-től pl. az azonnali fizetés) - lehetőségének széleskörü biztosítását a nagyobb forgalmat bonyolító, vagy jellemzően nagyobb értékű termékek és szolgáltatások értékesítését végző kereskedelmi és szolgáltató egységekben. A kereskedők/szolgáltatók készpénzes bevételei ugyanis további készpénzhasználatot generálnak, ami a gazdaság más területein is támogathatja a rejtett gazdaságot.”

A Stratégia fóbb elemei:

- 2016 decemberében az NGM indított országos szintű POS-telepítési programot, amelynek eredményeképpen 30 ezer új terminál kerülhetett kihelyezésre a kereskedőkhöz. A kereskedők mentesültek a telepítési költség alól és a felszámítható jutalék nem lehet több mint 1\%. A vállalkozások közötti készpénzhasználat csökkentésére vonatkozó szabályozás a vállalatok közötti készpénzes fizetésekre vonatkozó limitet a jövőben csökkenteni szeretné.

- A Stratégia további célja a munkabérek és egyéb pénzbeli juttatások számlára utalásának széles körben történő elterjesztése. Az alap-számla, valamint a jövőben létrehozandó szociális fizetési számla konstrukció bevezetésével a munkavállalók döntő többségének már rövidtávon sem okozhat hátrányt ez az intézkedés. 
- Az állami kifizetések elektronizálásának ösztönzése Az állami támogatások és segélyek jelentős része még ma is készpénzben kerül kifizetésre. Számos nemzetközi példához hasonlóan célszerü bevezetni azt a gyakorlatot, hogy az állami támogatások minél nagyobb arányban fizetési számlára kerüljenek. Az elöző pontban említettekhez hasonlóan ezt a bevezetni tervezett új szociális alapszámla konstrukció elvileg mindenki számára lehetővé tenné. Az állami kifizetések fokozatos elektronikus útra terelése jelentős megtakarítást is eredményezhet, mivel az átutalás a postai kifizetésnél jelentősen olcsóbb.

- Az állami intézmények felé irányuló befizetések elektronizálása (pl. okmánybélyeg) esetén minden esetben meg kell teremteni az elektronikus fizetés lehetőségét. A NAV esetében ez már megtörtént, de a helyi adók tekintetében ez a lehetőség még nem általános gyakorlat.

A jövőbeni fejlesztés érdekes és talán leginkább döntő változást generáló kérdésköre a digitális jegybankpénz kibocsátása. A jelen időszakra a technológiai innováció elért arra a szintre, hogy a jegybankok digitális formában is teremthetnek olyan jegybankpénzt, mely a lakossági és a vállalkozói szektor rendelkezésére is állna. „A digitális jegybankpénz bevezetése alapvetően változtatná meg a pénzügyi közvetítő szektor működését és több szempontból érinti a központi bankok feladatkörét. Az érintett jegybanki területek közé tartozik a pénzforgalom, amelynek hatékonysága nőhet az új típusú jegybankpénz forgalomba hozatalával, mert a készpénz költséges elóállítása és kezelése helyett a digitális formátum társadalmi szinten megtakarítást eredményezhet." (MNB Fizetési rendszer jelentés 2018, 10.)

A digitális jegybankpénz bevezetése kockázatos tevékenység, alapvetően nem is a pénzforgalom, hanem a monetáris politika és pénzügyi stabilitás szempontjából is. Személy szerint is döntő jelentőségünek tartom, hogy az MNB az angol, a dán, a svéd jegybank és az Európai Központi Bank munkájával párhuzamosan „szakmai szempontból fontosnak tartja a kérdés megalapozott vizsgálatát” (MNB Fizetési rendszer jelentés 2018, 10.).

A főbb fizetési formák változásának hatását tanulmányozva (1. ábra) megállapíthatjuk, hogy a 2012 óta eltelt időszak során a kártyás fizetési forgalom számottevő bővülése a legfontosabb tendencia. Ez a forgalom 2017 végére több mint kétszeresére nőtt, megközelítette a 700 millió darabos forgalmat. 


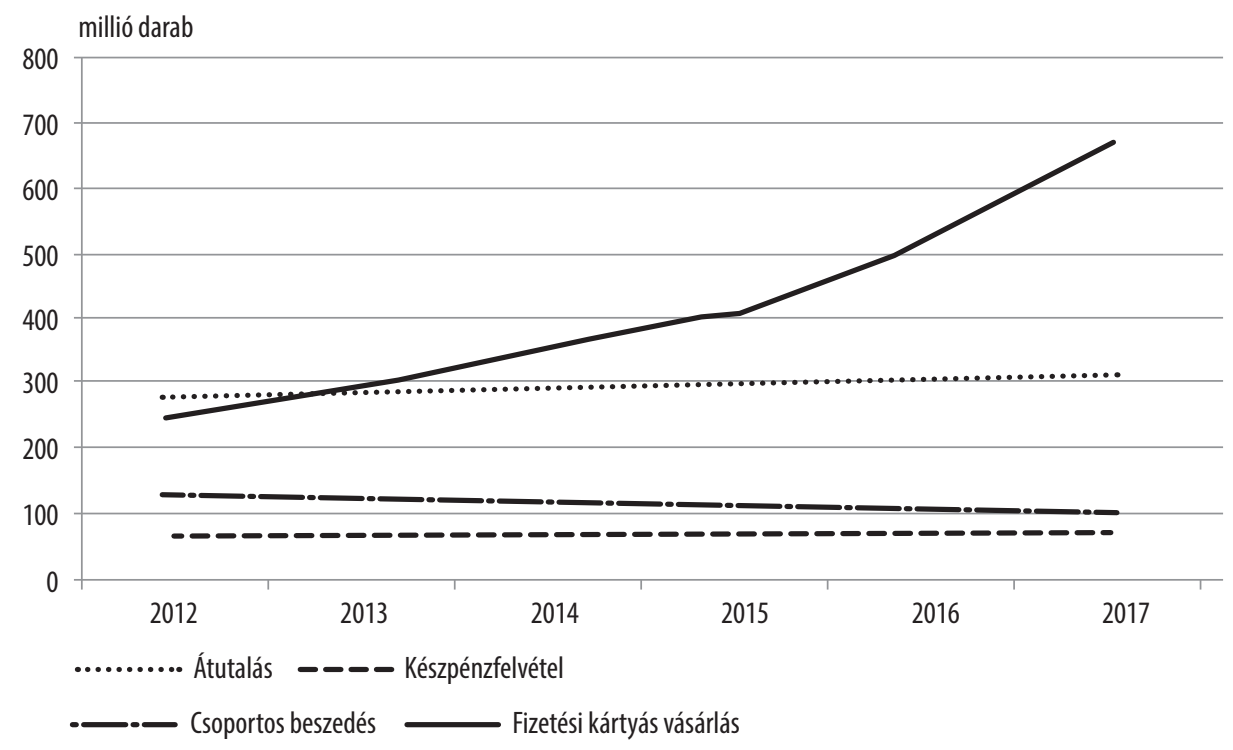

1. ábra: A fizetési számlához kapcsolódó főbb fizetési müveletek forgalma (2012-2017)

Forrás: MNB Fizetési rendszer jelentés $(2018,16)$

\subsection{Fizetési formák}

A jelenleg belföldön használatos, e fejezetben tárgyalt fizetési módok közé három típus tartozik:

a) fizetési számlák közötti fizetés,

b) fizetési számlához kötődő készpénzfizetés,

c) fizetési számla nélküli fizetés.

\subsubsection{Az átutalás}

Az átutalás megbízással a számlatulajdonos a számláját vezető pénzforgalmi szolgáltató számára megbízást ad, hogy a megbízásban megjelölt összeget számolja el bankszámlája terhére a feltüntetett számlatulajdonos bankszámlája javára. Az átutalási megbízás értékhatárra tekintet nélkül benyújtható. Az átutalás jogi definíciója a pénzforgalmi szolgáltatások nyújtásáról a 2009. évi LXXXV. törvény szerint: „a fizető fél rendelkezése alapján végzett olyan pénzforgalmi szolgáltatás, amelynek során a fizető fél számláját a kedvezményezett javára megterhelik, valamint a hatósági átutalás és az átutalási végzés alapján történő átutalás”. 
E fizetési forma feltételezi a partnerek közötti bizalmat, hiszen az áru (szolgáltatás) átvétele elötti fizetés esetén a vevő vállal kockázatot, míg utólagos fizetés esetén az eladó kockázata áll fenn. Belföldi és nemzetközi fizetési forgalomban egyaránt használatos, a két forgalmi viszonylatban lényege megegyezik.

Átutalási megbízás benyújtható későbbi időpontra vonatkozóan is. Amennyiben a számlatulajdonos nem a benyújtási, illetve az azt követő napon kívánja az átutalást végrehajtatni, az értéknap rovatba be kell írnia a kívánt teljesítési dátumot.

A pénzforgalmi szabályozás csak a különös eseteket nevesíti, eszerint az átutalás, különösen a csoportos átutalás, a rendszeres átutalás és a hatósági átutalás és átutalási végzés.

\section{Csoportos átutalás}

Csoportos átutalás esetén a fizető fél a pénzforgalmi szolgáltatójával történt megállapodás alapján az azonos jogcímü, különböző kedvezményezettek javára szóló átutalási megbízásokat kötegelve, csoportos formában is nyúitja be. Legjellemzőbb felhasználási területe a gazdálkodók és állami szervezetek által indított havi bérfizetés. Ekkor a megbízó az átutalást kötegelve nyújtja be, ezzel jelentősen automatizálhatja a munkafolyamatot.

\section{Rendszeres átutalás}

Rendszeres átutalási megbízással a fizető fél meghatározott összegnek meghatározott időpontokban (ezek az ún. terhelési napok) ismétlődően történő átutalására ad megbízást a pénzforgalmi szolgáltatójának. Jellemző azokban az esetekben, amikor ismétlődően azonos kedvezményezettnek, azonos összeget kívánunk átutalni.

\section{Hatósági átutalási megbízás és átutalási végzés}

A hatósági átutalási megbízás és átutalási végzés folyamatának lépései:

1. A kedvezményezett saját pénzforgalmi szolgáltatója útján kezdeményezi a hatósági átutalási megbízást.

2. A kedvezményezett fizetési számláját vezető pénzforgalmi szolgáltató a hatósági átutalási megbízás befogadása előtt ellenőrzi a kedvezményezettre vonatkozó adatokat: a hatósági átutalási megbízásban megjelölt kedvezményezett számlatulajdonos és a pénzforgalmi jelzőszám összetartozását és a rendelkezésre jogosultnak a pénzforgalmi szolgáltatónál bejelentett aláíását. 
3. Ezután a kedvezményezett fizetési számláját vezető pénzforgalmi szolgáltató továbbítja az adatokat a fizető fél fizetési számláját vezető pénzforgalmi szolgáltatóhoz.

Fontos eleme e fizetési altípusnak, hogy a fizető fél fizetési számláját vezető pénzforgalmi szolgáltató a hatósági átutalási megbízásról és az átutalási végzésről annak teljesítése, részteljesítése, vagy sorbaállítása előtt nem értesítheti a fizetö felet. Ezután viszont értesítési kötelezettsége keletkezik, vagyis a pénzforgalmi szolgáltató a hatósági átutalási megbízás és az átutalási végzés (rész)teljesítéséről, illetve sorbaállításáról a teljesítéssel, illetve a sorbaállítással egyidejűleg a hatósági átutalási megbízás és az átutalási végzés adattartalmának közlésével haladéktalanul, írásban értesíti a fizető fél számlatulajdonost.

$\mathrm{Az}$ átutalási forma népszerü Magyarországon. E népszerüség mutatószáma az átutalás összegének GDP-hez mért aránya, mely hazánkban 2012 és 2016 között rendre 13,6; 13,6; 14,2; 14,5 és 16,0\%-ot tett ki. Összehasonlításul az Európai Unió 2016. évi értéke 17,7\%. Az átutalás aránya hazánkban 2017-ben 16,2\%-ra nőtt. (MNB Fizetési rendszer jelentés 2018.)

Fontos jövőbeni újdonság, hogy a tervek szerint 2019 júliusától életbe lép az azonnali fizetési rendszer. A 2017 decemberében megjelent új pénzforgalmi MNB rendelet már tartalmazza az azonnali átutalás, valamint az azt kiegészítő szolgáltatások 2019. július 1-jétől hatályos részletes lebonyolítási szabályait. Ezek közül legfontosabb a határidő: az azonnali átutalási megbízás teljesítésére a fizető fél pénzforgalmi szolgáltatójának a rendelkezésre álló idő a fizetési megbízás átvételétől számítva, legfeljebb 5 másodperc. „A már bevezetett európai rendszerek például Angliában, Dániában vagy Svédországban kedvező képet mutatnak a pénzforgalom átalakulásáról. Elmondható, hogy jellemzően nem a kártyás fizetési forgalom csatornázódott át az új fizetési módba, hanem a társadalmilag drágább és kevésbé hatékony készpénzes fizetések száma csökkent." (MNB Fizetési rendszer jelentés 2018, 47.)

\subsubsection{Beszedési megbízás}

Az átutalás mellett e fizetési mód másik lényeges altípusa a beszedési megbízás. A beszedési megbízással a kedvezményezett megbízza a fizetési számláját vezető pénzforgalmi szolgáltatót, hogy fizetési számlája javára, a fizető fél fizetési számlája terhére meghatározott összeget szedjen be. A kedvezményezett a beszedési megbízást a fizetési számláját vezető pénzforgalmi szolgáltatóhoz nyúitja be. 
A pénzforgalom jogi szabályozása szerint beszedés különösen:
a) a felhatalmazó levélen alapuló beszedés,
b) a váltóbeszedés,
c) a csekkbeszedés,
d) a csoportos beszedés,
e) a határidős beszedés,
f) az okmányos beszedés.

\section{Felhatalmazó levélen alapuló beszedés}

A felhatalmazáson alapuló beszedés során a fizető fél számlatulajdonos a pénzforgalmi szolgáltatójánál bejelentett módon felhatalmazó levélben engedélyezi a kedvezményezett számára beszedési megbízás benyújtását.

\section{Váltóbeszedésen alapuló beszedés}

Ha a beszedési megbízás váltón alapuló követelés beszedésére irányul, a váltó egyenes adósának a felhatalmazását a váltó testesíti meg. Ennek a típusnak elengedhetetlen feltétele, hogy a váltón alapuló beszedési megbízáshoz a váltó eredeti példányát csatolja a benyújtó. Lehetőség van a váltókezesekkel, illetve a megtérítési váltóadósokkal szemben a váltón alapuló követelésre irányuló beszedési megbízás benyújtására is, ez külön felhatalmazó levél alapján nyújtható be.

\section{Csekkbeszedés}

Ha a beszedési megbízás csekk összegének beszedésére irányul, a csekk kibocsátójának a felhatalmazását a csekk testesíti meg. A csekkbeszedési megbízáshoz a benyújtó a csekk eredeti példányát csatolja.

\section{Csoportos beszedés}

Csoportos beszedésről beszélünk akkor, ha az érintett fizető felek felhatalmazása alapján a kedvezményezett a számlavezető pénzforgalmi szolgáltatójával történt megállapodás szerint az azonos jogcímü, különböző fizető felek fizetési számlái terhére szóló, terhelési nappal ellátott beszedési megbízásokat kötegelve, csoportos formában nyújtja be.

A pénzforgalmi szolgáltató a csoportos beszedési megbízásról annak teljesítése elött értesítheti a fizető felet. A fizető fél a terhelési napot megelöző munkanap végéig a csoportos beszedési megbízás teljesítését letilthatja a fizetési számláját vezető pénzforgalmi szolgáltatónál. A letiltás csak a beszedési megbízás teljes 
összege ellen tehető. Letiltás esetén a pénzforgalmi szolgáltató a letiltásban foglaltak szerint jár el, a letiltás indokoltságát és jogosságát nem vizsgálja. A letiltás a felhatalmazás érvényességét és feltételeit nem érinti.

A csoportos beszedési megbízás teljesítéséről, valamint a nemteljesítésről és annak okáról a fizető fél fizetési számláját vezető pénzforgalmi szolgáltató a kedvezményezett fizetési számláját vezető pénzforgalmi szolgáltatót értesíti.

\section{Határidős beszedés}

A határidős beszedési megbízás használati köre korlátozott, mert csak a kincstárnál számlát vezető ügyfél terhére alkalmazható fizetési altípus. A határidős beszedési megbízással a kedvezményezett megbízza a fizetési számláját vezető pénzforgalmi szolgáltatót, hogy pénzforgalmi számlája javára, a kincstárnál számlával rendelkező fizető fél terhére meghatározott összeget szedjen be megállapodás alapján.

A kedvezményezett a fizető fél számára a fizetés teljesítése elleni kifogás - mely lehet részbeni vagy teljes - megtételére határidőt szabhat, ez az ún. kifogásolási határidő. A kifogásolási határidő időpontja maximum a megbízás benyújtását követő tizedik munkanap lehet. A határidős beszedési megbízás benyújtásáról annak teljesítése előtt a kincstár a fizető felet előzetesen értesíti, és a megbízást a fizető fél rendelkezése szerint a fizetést elindítja, ha a fizető fél a kifogásolási határidőn belül nem él kifogásolási jogával, vagy leállítja, ha az ügyfél él kifogá-

solási jogával. Kifogásolás esetén a kincstár a kifogásolásban foglaltak szerint jár el, a kifogásolás indokoltságát, illetve jogosságát nem vizsgálja.

\section{Okmányos beszedés}

Okmányos beszedés esetében a kedvezményezett fizetési feltételhez köti az okmányok átadását. Az okmányos beszedésre vonatkozó megbízással az alapügylet kedvezményezettje a követelés alapjául szolgáló okmányokat azzal a megbízással adja át a fizetési számláját vezető pénzforgalmi szolgáltatónak, hogy azokat csak fizetés, váltóelfogadás vagy más feltételek teljesítése esetén szolgáltassa ki a fizető félnek.

A hatályos szabályozás szerint tehát a korábban alkalmazott beszedés típusok közül az azonnali inkasszó e néven megszűnt. Szintén megszűntek a határozaton, illetve jogszabályon alapuló inkasszók, de azonos tartalommal, csak hatósági átutalásra átnevezve (az átutalás fizetési módban) él tovább a korábbi végrehajtói inkasszó. 


\subsubsection{Okmányos meghitelezés (akkreditív)}

Az okmányos meghitelezés (documentary credit) alapvetően nemzetközi viszonylatban jellemző, Magyarországon belföldi viszonylatban ritka, de létező fizetési forma. Az akkreditív tulajdonképpen egy fizetési ígéret: a pénzforgalmi szolgáltató (az ún. nyitó pénzforgalmi szolgáltató) - az alapügyletben kötelezett megbízása alapján - saját nevében arra vállal kötelezettséget, hogy ha a kedvezményezett meghatározott határidőn belül a meghatározott okmányokat - rendszerint az áru feladását igazoló, és az áru feletti rendelkezési jogot biztosító okiratot - hozzá benyújtja, akkor az okmányos meghitelezésben meghatározott összeget a vevő számlája terhére részére megfizeti.

Az akkreditívügylet létrejöttéhez legalább három fél szükséges:

- a vevő (importőr), aki akkreditívnyitási megbízást ad bankjának;

- a pénzforgalmi szolgáltató (rendszerint a vevő hitelintézete), amely a feltételek teljesülése esetén fizetését ígéri, és

- az eladó (exportőr), aki az akkreditív kedvezményezettje.

Az akkreditív időrendben első jogviszonya a vevő és a nyitó pénzforgalmi szolgáltató között jön létre a vevő akkreditív nyitási megbízása alapján. Ettől független az akkreditív alapvető jogviszonya, amely a nyitó pénzforgalmi szolgáltató és az eladó között jön létre, amikor a kedvezményezett kézhez kapja az akkreditívet. Ez az eladó számára nem kötelezettség, hanem annak lehetősége, hogy a feltételek teljesítése után biztosan hozzájusson az akkreditív összegéhez. Az eladónak általában nincs kapcsolata a nyitó pénzforgalmi szolgáltatóval, ezért az akkreditívügyletbe bekapcsolódik egy (vagy több) az eladóval kapcsolatban álló másik pénzforgalmi szolgáltató is. A közbeiktatott pénzforgalmi szolgáltató(k) nak mindig a nyitó pénzforgalmi szolgáltató ad megbízást vagy felhatalmazást.

Akkreditív nyitásakor a bekapcsolódó pénzforgalmi szolgáltató lehet:

- avizáló (értesítő) pénzforgalmi szolgáltató, amely csak a „postás” szerepét tölti be a nyitó bank és az eladó között. Feladata mindössze a pontos, késedelemmentes okmánytovábbítás mindkét irányban.

- igazoló (megerősítő, konfirmáló) pénzforgalmi szolgáltató: a nyitó pénzforgalmi szolgáltató kötelezettségvállalását erősíti meg azzal, hogy emellé a saját kötelezettségvállalását is mellékeli. 
Akkreditív igénybevétele során a bekapcsolódó pénzforgalmi szolgáltató lehet:

- fizető pénzforgalmi szolgáltató, amely a nyitó bank kifejezett felkérésére teljesít kifizetést az eladó számára;

- negociáló pénzforgalmi szolgáltató, amely a saját költségére és kockázatára megveszi az eladótól az okmányokat (kamatlevonással), ezzel átvállalja az eladónak az akkreditívből eredő kötelezettségeit és jogait, az adott okmányok értékéig.

\subsubsection{Bankkártya}

A bankkártya üzletág szereplöit négy fö csoportba soroljuk:

1. Kibocsátó: A bankkártya tulajdonképpeni feltalálói éttermek, áruházak, benzinkutak, akik a náluk vásárló, szórakozó ügyfeleknek akartak ezáltal kényelmet és kedvezményt biztosítani. Idővel a pénzintézetek bankszámla tulajdonosainak meghatározott szabvány szerint kártyát bocsátott ki. A kibocsátó korlátozhatja a felhasználók körét, pl. letilthatja számláját a limithatárt gyakran átlépő ügyfeleitől, vagy hitelt vissza nem fizető ügyfeleitől megtagadja a kártyakiváltást.

2. Kártyabirtokos: Az a személy, aki elfogadva a bankkártya szerződés feltételeit, használja azt.

3. Elfogadóhely: Akivel a pénzintézet szerződést köt, hogy az általa kibocsátott bankkártyát fizetőeszközként elfogadja.

4. Elfogadó bank: az elfogadóhely hitelintézete.

A tranzakció terhelése szempontjából a kártya lehet:

\section{1. használatkor terhelt kártya}

E kártya típus a tranzakciókor, vagy röviddel azután terhelt. Ide tartozik az elektronikus leolvasható kártyák nagy része.

\section{2. halasztott fizetést lehetővé tévő kártya}

- Halasztott terheléses (charge card) kártya, melynek birtokosa egy adott időszak alatt bármekkora összeget költhet, tartozását egy bizonyos periódus letelte után egy összegben kell rendeznie. Ez azt jelenti, hogy általában 30-45 napig kamatmentes hitelnyújtás történik (a készpénzfelvételt kivéve). 
- Klasszikus hitelkártya (credit card). Az ilyen típusú kártyák esetén a bank és ügyfele a bankkártya szerződés megkötésekor egy hitelszerződést is köt, melyben rögzítik a fél hitel visszafizetési, hitelnagyság és kamatfeltételeit.

- Budget card, melynek birtokosa rulírozó hitelkeretet vehet igénybe, a klasszikus hitelkártyához képest saját ütemezésében.

\section{3. elöre fizetett kártya}

A kártyabirtokos az összeget előre kifizeti (ilyen a telefonkártya, parkolási kártya, üzemanyag-kártya).

A tapasztalatok azt mutatják, hogy a bankkártyák elterjedtségét nagymértékben növelte a kártyához tartozó hitellehetőség biztosítása. A hitelkártyák jelentős előnyöket biztosítanak tulajdonosaik számára. A kártya sokszor kényelmesebb fizetési mód, mint a csekk vagy a készpénz. A hitelfelvétel a kártya segítségével rendkívül kényelmes, hiszen nem kell a hitelcélt megindokolni, nincsenek a hitel előterjesztésnek költségei stb. A költségek tervezését segíti, hogy a tulajdonos határozhatja meg a havi törlesztőrészletek nagyságát. Mindezek az előnyök megsokszorozódnak azáltal, hogy a kártyákat nemcsak belföldön, hanem nemzetközileg széles körben is elfogadják.

A hitel igénybevételének lehetősége a hitelintézetek oldaláról is előnyös. A kártya jövedelmezőségének alapja ugyanis az elfogadóhelyek által fizetett jutalék és az ügyfél által az igénybe vett kártyahitel után fizetett viszonylag magas kamat.

\section{A kártyarendszerek technikai csoportosítása}

A kártyák technikai csoportosítása során történetileg első a dombornyomású kártya. Olyan plasztikkártya, amelyen a fontosabb, a kártya birtokosát azonosító adat karakterei a kártya szintjéből kidomborodnak. Egy egyszerü mechanikus szerkezetbe (ezt a szakzsargonban „vasaló”-nak nevezik) helyezve, önindigós papír és egy gumihenger segítségével a kártya lenyomata megjelenik a formanyomtatványon, melynek mezői viszont az elfogadó hely adatait tartalmazzák.

A rendszer előnye, hogy kis beruházással megvalósítható. Hátrányai közé tartozik, hogy a kártya elvesztése esetén a jogosulatlan felhasználás igen könynyü, hiszen csupán az aláíás utánzását kell megtanulni. Másik nagy hátránya e kártyarendszernek, hogy a bizonylatokat postai úton kell továbbítani, és ez - az 
online rendszerekkel ellentétben - nagymértékben megnyújtja a lebonyolítás fázisának időszükségletét.

A mágnescsíkos kártya nevét onnan kapta, hogy a kártya hátlapján mágnescsík található. A mágnescsíkon levő adatok az országot, a bankot, az ügyfelet, magát a kártyát és a kártya felhasználását azonosítják. Minimálisan ezek az adatok szükségesek bármely művelet elvégzéséhez.

Egy művelet teljes lebonyolításához szükség van a kártyán a PIN-kódra (Personal Identification Number - személyi azonosító szám), amely bizonyos értelemben elektronikus aláíás. Ez a kód csak a megbízót azonosítja. A biztonság elsősorban diszkréciót kíván: csak az ügyfél ismerheti a belépési kódját. A PINkód általában egy négyjegyű szám. Jelentősége különösen akkor lép előtérbe, ha az ügyfél elveszti a kártyát, hiszen ekkor a PIN-kód ismerete nélkül igen megnehezül a kártyával való visszaélés.

A kártyák harmadik típusa a chipes kártya. Ez egy olyan memóriát tartalmaz, melynek segítségével a kártya tartalma írható és olvasható. A felhasználáskor maga a kártya rögzíti a tranzakció adatait.

A negyedik típusnak, az optikailag leolvasható kártyáknak két típusa a hologramos és a lézerkártya. Tárolókapacitásuk óriási, áruk ehhez viszonyítva alacsony. Elterjedését viszont hátráltatja, hogy leolvasásához viszonylag költséges leolvasókészülék szükséges.

Új típus a biometrikus kártya is, mely ujjlenyomattal vagy a szem fizikai jellemzőivel azonosítja tulajdonosát. A leolvasó rendszer élő, emberi szövetet azonosít.

Az érintés nélküli bankkártyás fizetés Magyarországon 2009-ben indított technológia. Ennek fizetési sebessége a leggyorsabb készpénzfizetéssel azonos, tehát azzal, amikor a már pontosan előre elkészített készpénzt adjuk át a pénztárosnak. Az érintés nélküli (contactless) technológiával a kártyát elegendő az elfogadó terminálhoz néhány centiméterre közelíteni, mely kiküszöböli a kártyák véletlen leolvasását és egy csipogás, valamint a terminál felirata bizonyítja a tranzakció elfogadását. Ez a fizetési mód Magyarországon 5000 forint alatti összeg alatt használható. 
Az MNB Fizetési rendszer jelentés 2018 kiadványa szerint hazánkban a fizetési kártyák több mint 70, a POS terminálok 80 százaléka támogatja az új technológia használatát. Az érintéses technológia elterjedésében pedig Magyarország Európa élmezőnyében van. 2017 végére az érintéses kártyás vásárlások az összes vásárlás több mint kétharmadát tette ki. Ez 412 millió darab vásárlást jelentett, mely a teljes forgalom felét, 2326 milliárd forintot tett ki (lásd 2. ábra).

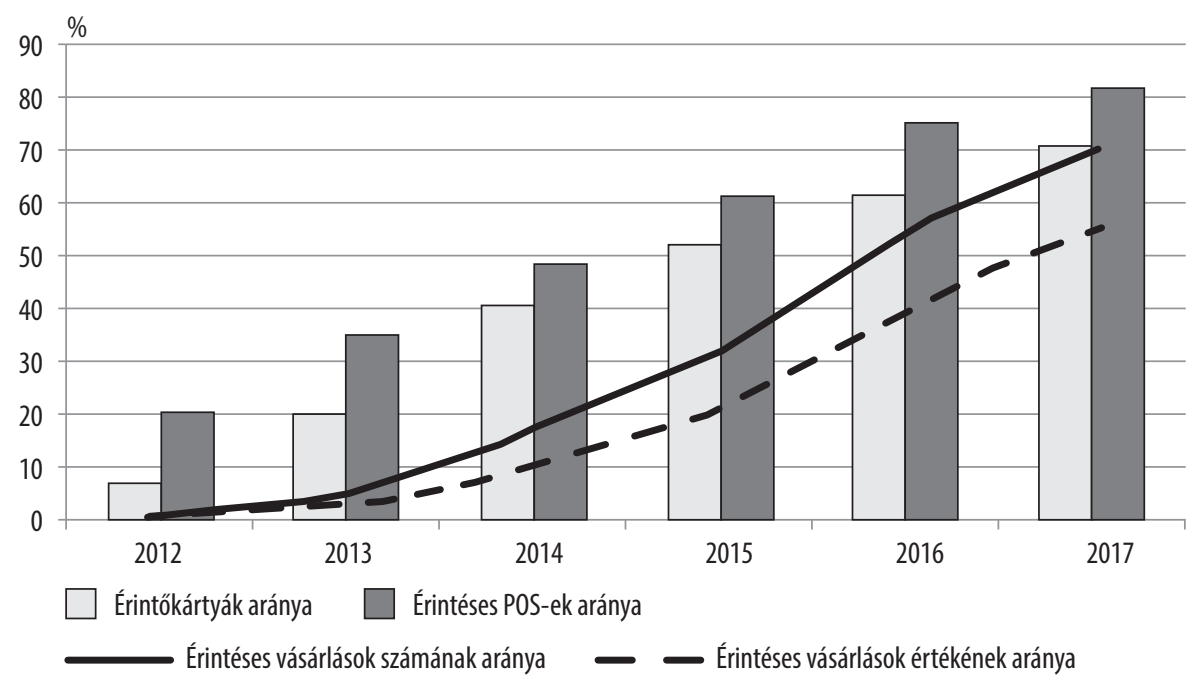

2. ábra: Az érintőkártyás technológia terjedése a magyarországi fizetési kártyás rendszerben (2012-2017)

Forrás: MNB Fizetési rendszer jelentés $(2018,18)$

Végül megemlítendők még az előbbi típusok együttes alkalmazásával létrejött hibridkártyák is. Igen elterjedt a mágnescsíkos és a chipes kártyák együttes alkalmazása. Ez egyrészt a kölcsönös előnyök kiaknázására szolgál, másrészt növeli az adott kártya elfogadottságát, hiszen a kártya mindkét típusú leolvasóegységgel rendelkező felhasználási helyen alkalmazható.

A bankkártyával lebonyolított fizetés fontos törvényi szabálya, hogy a terhelés összegének - mely lehet fizetési számlára terhelt vagy hitelkeret terhére elszámolt összeg - meg kell egyeznie a bizonylaton szereplő összeggel, vagyis az semmilyen kezelési stb. költséggel nem csökkenthető. 


\subsubsection{Fizetési számlához kötődő készpénzfizetési és fizetési számla nélküli fizetési mód}

A pénzforgalmi szolgáltatások második fő csoportját azok a szolgáltatások képezik, melyek egy fizetési számlához kötődnek. Ezek az alábbi altípusokba sorolhatók:

- készpénzfizetésre szóló csekk kibocsátása és beváltása,

- készpénzbefizetés fizetési számlára,

- készpénzkifizetés fizetési számláról.

\section{Készpénzfizetésre szóló csekk kibocsátása és beváltása}

A számlatulajdonos készpénzfizetésre szóló csekket abban az esetben bocsáthat ki, ha a számlavezető pénzforgalmi szolgáltatójával csekkszerződést kötött.

A csekk lehet névre szóló és bemutatóra szóló. A megnevezett személyre szóló csekk esetén a csekk beváltójának jogosultságát (legitimáció) a pénzforgalmi szolgáltató köteles ellenőrizni. A bemutatóra szóló csekk esetében a csekken nem szerepel a kedvezményezett neve, így a pénzforgalmi szolgáltató részéről nincs szükség legitimitás-vizsgálatra. A csekk átruházásának egyszerüsége miatt kedvelt csekktípus.

A pénzforgalmi szolgáltatóhoz eljuttatott készpénzfizetésre szolgáló csekk terhére a pénzforgalmi szolgáltató a fizetési számla egyenlege erejéig teljesít kifizetést. A csekket bemutató személlyel, vagy a csekken megnevezett kedvezményezettel (csekkbirtokos) a pénzforgalmi szolgáltató a csekk hátlapját az összeg átvételének elismeréseként aláíratja.

\section{Készpénzbefizetés fizetési számlára}

E fizetési forma esetén készpénzbefizetés a számlavezető pénzforgalmi szolgáltató bármely pénztáránál és egyes, befizetési funkciót ellátó bankjegykiadó automatánál teljesíthető. A számlavezető pénzforgalmi szolgáltatón kívül más pénzforgalmi szolgáltató is elfogadhat készpénzbefizetést, feltéve, hogy a két pénzforgalmi szolgáltató között létezzen érvényes megállapodás. Ilyen megállapodáson alapuló kölcsönös szolgáltatás megvalósítását régóta tervezik Magyarországon bevezetni a szövetkezeti hitelintézetek (Moizs - Szabó, 2016; Moizs, 2010).

A pénztáraknál készpénzbefizetési célra szolgáló nyomtatvánnyal (pl. befizetési lappal, készpénzátutalási megbízással) vagy a pénztárbizonylat aláírásával fizethető be készpénz a fizetési számlára. 


\section{Készpénzkifizetés fizetési számláról}

Fizetési számláról készpénz a számlavezető pénzforgalmi szolgáltatónál, valamint a vele erre szerződött más pénzforgalmi szolgáltatónál vehető fel. A számlavezető pénzforgalmi szolgáltató, valamint más pénzforgalmi szolgáltató pénztáránál az alábbi módokon történhet készpénz kifizetés:

- készpénzkifizetési célra szolgáló nyomtatvánnyal (pl. kifizetési lappal, kivételi bizonylattal),

- a pénztárbizonylat aláírásával,

- csekk felhasználásával,

- készpénzfelvételi utalvánnyal.

A számlatulajdonos a bankszámlája terhére kiállított készpénzfelvételi utalvány segítségével készpénzt vehet fel a számlavezető pénzforgalmi szolgáltató, illetve - külön megállapodás esetén - más pénzforgalmi szolgáltató pénztáránál. A készpénzfelvételi utalványt a kiállítás napját követő nyolc naptári napon belül kell bemutatni a hitelintézet pénztárában, ezután a kifizetés nem teljesíthető.

A kifizetés során a bankszerv kétféle módon járhat el:

- ha a készpénzfelvételi utalványon a számlatulajdonos nem határozza meg a konkrét személyt a készpénzfelvétellel, akkor az utalvány bemutatóra szóló típusú, vagyis a bank az utalvány bemutatójának fizeti ki a készpénzt.

- ha a megbízó (a számlatulajdonos) megnevezi a készpénzfelvételre jogosult személyt, akkor a bank csak neki szolgáltathatja ki a megfelelö összeget.

A pénzforgalmi szolgáltató a készpénzfelvételi utalvány hátlapján az összeg átvételének elismeréseként aláiratja. Ennél a fizetési módnál lehetőség van készpénzfelvételiutalvány-füzet használatára is. Ez az utalvány két részből áll: tőszelvény (a füzetben marad) és utalvány.

\section{Kifizetési utalvány}

A kifizetési utalvány kiállításával a számlatulajdonos megbízza a hitelintézetet, hogy a bankszámlája terhére meghatározott összeget postai úton fizesse ki a címzettnek. A számlatulajdonos a kifizetési utalványokat feladójegyzékbe foglalva nyújtja be a hitelintézethez, amely azok postai költséggel növelt összegével megterheli a bankszámlát, és az utalványokat átadja a székhelyén müködő postahelynek, postai érvényesítés és a címzettek lakhelye szerint illetékes postahelyhez való továbbítás céljából. 


\section{Fizetési számla nélküli fizetés}

A fizetési számla nélküli fizetés vizsgálatakor a készpénzátutalás folyamatát vizsgáljuk. A készpénzátutalás olyan fizetési számla használata nélküli pénzátutalás, amelynek során a készpénzátutalás tárgyát képező összeget a pénzforgalmi szolgáltató a pénztáránál való kifizetéssel vagy postai úton (kézbesítéssel) bocsátja a kedvezményezett (címzett) rendelkezésére.

\subsubsection{A csekk}

A csekk alapviszonya szerint a csekk kibocsátója utasítja bankját, hogy a csekkben megjelölt összeget számlaköveteléséből fizesse ki a csekk bemutatójának.

A csekkel történő fizetési forgalomnak négy szereplője lehet:

- A csekk kibocsátója, aki a számlája terhére fizetésre szólítja fel a saját bankját.

- A címzett vagy a csekk kifizetője, aki a fizetést teljesíti. Általában a csekk kibocsátójának a bankja.

- A csekk birtokosa, akinek részére a csekket kiállították, tehát a kedvezményezett a csekken feltüntetett összegig.

- A csekk-kezes, aki kezességet vállal a kiállított összegre.

A csekk szigorú törvényi előírásoknak megfelelő formában kiállított értékpapír. A formai követelmények (ún. alaki kellékek) közül bármelyik is hiányzik, a csekkjogi szabályok az okiratot már nem tekintik csekknek.

\section{A csekk alaki kellékei:}

1. a csekk megjelölés az okiraton a kiállítás nyelvén,

2. meghatározott pénzösszeg kifizetésére szóló feltétlen meghagyás,

3. a fizetésre kötelezett (címzett) megnevezése, telephelye, a fizetési hely megjelölése,

4. a csekk kiállításának helye és napja,

5. a kibocsátó aláírása.

Vannak még nem kötelező, ún. kereskedelmi alaki kellékek is: előre gyártott formanyomtatványokon szereplö kiegészítő adatok (számlaszám, számlatulajdonos neve stb.), amelyek annak érdekében készülnek, hogy a banki ügyfelek által kiállított csekkek minél pontosabbak legyenek. A csekket megtekintéskor fizetik ki, a fizetésért a kibocsátó felelős. 
A csekkel történő fizetés kedvező a kibocsátó részéről, mert a tényleges fizetés csak akkor történik meg, ha a kedvezményezett a címzettnél bemutatja. A kedvezményezett számára azonban az átutalás kedvezőbb, ezért inkább ezt részesítik elönyben. Fennállhat annak a veszélye, hogy a csekknek nem lesz fedezete, ezért csak megbízható partnertől szabad elfogadni (Széles, 2013).

A csekket névre szólóan vagy bemutatóra szólóan lehet kiállítani. Ha a csekken a kedvezményezett nevét nem tüntetik fel, akkor bemutatóra szóló. Ilyen csekket a címzett annak fizeti ki, aki ezt bemutatja. Lényegében ilyenkor fizetési eszközként funkcionál.

A csekk lehet továbbá:

- fizetési csekk, amely a megnevezett összeg készpénzben történő felvételére szolgál,

- elszámoló csekk, amelynek kibocsátója felszólítja a bankot, hogy a megjelölt összeget a bank egy másik ügyfelének bankszámláján írja jóvá. Előlapján szerepel a „csak elszámolásra” megjelölés.

A csekkek speciális típusa az utazási csekk. Az utazási csekk bevezetését az idegenforgalom és az üzleti élet tette szükségessé. Fontossága abban jelenik meg, hogy ne kelljen sok készpénzzel utazni. Lényegét tekintve azonos egy bemutatóra szóló csekkel, amit egy bank vagy utazási iroda állít ki. A kibocsátó neve ad olyan biztonságot, hogy bárhol a világon megvásárolják. A csekk biztonságát az is jelenti, hogy a tulajdonos mind a vásárlása, mind pedig a beváltása alkalmával adott bankügyintéző előtt írja alá.

\subsection{Irodalomjegyzék}

Baka Istvánné, Dancsó József, Ligeti Sándor, Vágyi Ferenc, Szarvas Ferenc, Varga József, Kürthy Gábor. Baka Istvánné, Kürthy Gábor (szerk.) (2012): Bankismeretek: Egyetemi tankönyv. Budapest: Tanszék Kft., 2012. 105 p. ISBN 978963-88777-4-1

Bartha Lajos - Luspay Miklós - Varga Lóránt (2017): Pénzforgalom és pénzügyi infrastruktúrák. In: Modern jegybanki gyakorlat. Magyar Nemzeti Bank 2017. https://www.mnb.hu/letoltes/mnb-modern-jegybanki-gyakorlat.pdf Letöltés időpontja: 2019. január 5. 
MNB (2018): Fizetési rendszer jelentés 2018. https://www.mnb.hu/letoltes/ mnb-fizetesi-rendszer-jelentes-2018-hun.pdf Letöltés: 2019. március 2.

Moizs, Attila - Szabó, Gábor G. (2015): The history, the current system and the special features of savings cooperatives in Hungary. In: Karafolas, Simeon (szerk.) Credit Cooperative Institutions in European Countries. SPRINGER, pp. 291-307. ISBN 978-3-319-28783-6 DOI 10.1007/978-3-319-28784-3_16

Moizs Attila: Heterogenesis PhD Tanulmányok 9. PTE Állam- és Jogtudományi Karának Doktori Iskolája, Pécs 2010. 491. o.

Széles Zsuzsanna (2013): Pénzügytan. Szent István Egyetemi Kiadó. p. 100.

Szabó-Szentgróti Gábor, Gelencsér Martin, Szabó-Szentgróti Eszter, Berke Szilárd (2019): Generációs hatás a munkahelyi konfliktusokban. Vezetéstudomány 50 : 4 pp. 77-88.

Pénzügyi tudatosság fejlesztésének stratégiája 2017. https://www.kormany.hu/download/5/39/21000/P\%C3\%A9nz\%C3\%BCgyi\%20tudatoss\%C3\%A1g\%20fejleszt\%C3\%A9s\%C3\%A 9nek\%20strat\%C3\%A9gi\%C3\%A1ja.pdf Letöltés: 2019. 04. 23.

Varga József (2011): A belföldi fizetési forgalom. In: Tatay Tibor, Vágyi Ferenc Róbert, Varga József (szerk.) A pénzügyi intézményrendszer Magyarországon 2011.418 p. Sopron: Soproni Felsőoktatásért Alapítvány, 2011.pp. 34-59. ISBN 978-963-89173-1-7

2009. évi LXXXV. törvény a pénzforgalmi szolgáltatás nyújtásáról 35/2017. (XII. 14.) MNB rendelet a pénzforgalom lebonyolításáról 


\section{Bankok müködése a Hitelintézeti törvény alapján}

Egy nemzetgazdaság bankrendszerének szabályozása összetett folyamat, ráadásul egy országban a bankok alapvetően nemcsak „nemzeti” keretek között tevékenykednek, hanem határon átnyúló tevékenységeket is folytatnak. Emellett a szabályozási tevékenységet intézményi, jogi és kulturális tényezők, nemzetközi szerződésekből származó kötelezettségek is meghatározzák. Annak ellenére, hogy léteznek nemzeti és regionális sajátosságok a bankszabályozásban, megfigyelhető egy világszintű tendencia és a szabályozásban meghatározó a nemzetközi együttműködés. A bankok szabályozása - tértől, időtől függően - mindig egyfajta megállapodás az állam és a bankok között. Tapasztalati úton megállapítható, hogy a bankszabályozási reguláció (majd a dereguláció...) előírásait alapvetően a pénzügyi és gazdasági válságok írták, a bankpánikok voltak ezen szabályozások fő mozgatórugói. (Barna et al., 2019)

\subsection{Helyzetkép a magyar hitelintézeti szektor intézményi összetételéről (2018. IV. negyedév)}

Az MNB által felügyelt 13 bankcsoportból, 13 egyedi hitelintézetből és prudenciális szempontból hitelintézetnek minősülö 2 pénzügyi vállalkozásból, valamint 9 fióktelepből álló hitelintézeti szektor 42111 milliárd forintot kitevő konszolidált eszközállománya az elmúlt három év alatt átlagosan évi 7,3\%-kal bővült. A bővülésben jelentős szerepe volt a legnagyobb részarányt képviselő bankcsoport regionális terjeszkedésének is. A belföldi irányítású hitelintézetek eszközállomány alapján számított részesedése ezen időszak alatt lényegében nem változott, 55,4\%. A külföldi irányítású bankokon belül az euróövezeti (EKB SSM felügyelet alatt álló) anyabankok által irányított intézmények részaránya meghatározó, $82 \%$-os. Kis mértékben, de tovább folytatódott a bankszektor koncentrációja, az 5 legnagyobb bank eszközállományon belüli részesedése az elmúlt egy év alatt 60,8\%-ról 61,6\%-ra nő. (2014 végén ez az érték még 58,0\% volt.) A bankcsoportok, egyedi hitelintézetek, illetve fióktelepek száma 2018 során nem változott (MNB, 2019a). 


\begin{tabular}{|c|c|c|c|c|c|c|c|}
\hline & \multirow[b]{2}{*}{ Hitelintézet } & \multicolumn{2}{|c|}{ 2016.12.31. Auditált } & \multicolumn{2}{|c|}{ 2017.12.31. Auditált } & \multicolumn{2}{|c|}{ 2018.12.31. Előzetes } \\
\hline & & $\begin{array}{l}\text { Hitelintézetek } \\
\text { száma (db) }\end{array}$ & $\begin{array}{c}\text { Eszköz } \\
\text { arány } \\
(\%)\end{array}$ & $\begin{array}{l}\text { Hitelintézetek } \\
\text { száma (db) }\end{array}$ & $\begin{array}{c}\text { Eszköz } \\
\text { arány } \\
(\%)\end{array}$ & $\begin{array}{l}\text { Hitelintézetek } \\
\text { száma (db) }\end{array}$ & $\begin{array}{c}\text { Eszköz } \\
\text { arány } \\
(\%)\end{array}$ \\
\hline 1. & Összesen & 40 & 100,0 & 37 & 100,0 & 37 & 100,0 \\
\hline 1.1 & Nagy méretűek & 8 & 75,3 & 8 & 75,9 & 9 & 80,9 \\
\hline 1.2 & Közepes méretüek & 9 & 19,8 & 9 & 18,9 & 7 & 13,1 \\
\hline 1.3 & Kis méretűek & 23 & 4,9 & 20 & 5,1 & 21 & 6,0 \\
\hline 2.1 & Bankcsoportok & 12 & 78,7 & 12 & 79,2 & 13 & 81,3 \\
\hline 2.2 & Egyedi hitelintézetek & 18 & 12,1 & 16 & 11,3 & 15 & 9,8 \\
\hline 2.3 & Fióktelepek & 10 & 9,2 & 9 & 9,5 & 9 & 8,9 \\
\hline 3.1 & Belföldi irányítású & 15 & 54,8 & 14 & 55,7 & 14 & 55,4 \\
\hline 3.2 & Külföldi irányítású & 25 & 45,2 & 23 & 44,3 & 23 & 44,6 \\
\hline
\end{tabular}

\section{1. táblázat: A Magyar Nemzeti Bank által felügyelt hitelintézetek száma, 2016-2018}

Forrás: MNB (2019a)

\subsection{A magyar hitelintézeti szektor szabályozási háttere ${ }^{1}$}

A 1996. évi CXII. törvény (régi Hpt.) 1996-os elfogadása óta számos alkalommal módosításra került, amely töredezetté és helyenként kevésbé átláthatóvá tette a jogszabályt. Emellett a 2013/36/EU tőkekövetelmény irányelv és az 575/2013/EU tőkekövetelmény rendeletnek való megfelelés a hazai hitelintézeti szabályozási keretek teljes újragondolását igényelte (Ligeti-Pesuth-Varga, 2019). Mindezek következtében indokolt volt egy új banktörvény, a 2013. évi CCXXXVII. törvény (Hpt.) megalkotása és elfogadása. Az új Hpt. a korábbi szabályok alapjaira épül, és ennek keretében kerül kiegészítésre az uniós jogszabályok által leginkább érintett prudenciális követelményekkel, különösen a tőkepufferek bevezetése, a vállalatirányítási és kockázatkezelési szabályok előírása, valamint a felügyeleti szabályok változása terén. Az új Hpt. számos rendelkezése azonban - úgy, mint az általános rendelkezések, az engedélyezésre, tevékenységre és működésre vonatkozó szabályok, titoktartásra, összevont alapú felügyeletre, tulajdonjog gyakorlására, irányításra és ellenőrzésre vonatkozó rendelkezések, a felügyeleti kérdések, az Országos Betétbiztosítási Alapra, az önkéntes betét- és intézménybiztosításra, számvitelre és könyvvizsgálatra, valamint fogyasztóvédelemre

1 A jelen fejezet összeállitása a 2013. évi CCXXXVII. törvény (Hpt.) szövegének és indoklásának felhasználásával történt. 
vonatkozó elöírások - a korábbi szabályokon alapulnak, amelyek esetén csak kisebb módosításokra volt szükség.

A Hpt. 1. \$-ban a törvény tárgyi hatálya alá vonja a Magyarország területén végzett pénzügyi szolgáltatási, kiegészítő pénzügyi szolgáltatási és bankképviseleti tevékenységet, valamint a Magyarország területén székhellyel rendelkező hitelintézet külföldön végzett pénzügyi szolgáltatási, illetőleg kiegészítő pénzügyi szolgáltatási és bankképviseleti tevékenységét, függetlenül attól, hogy azt milyen formában működő gazdasági társaság végzi. E törvény rendelkezései alkalmazandóak továbbá a magyar hatóság által ellátott, e törvényben meghatározott felügyeleti tevékenységre is. A törvény hatálya viszont nem terjed ki a külföldi bankfelügyeleti hatóság Magyarországon végzett felügyeleti tevékenységére, így biztosítja az Európai Unióban kialakult felügyeleti felelősség megosztásának érvényesülését, és a székhely szerinti ország felügyeleti szerve elsődleges felelősségének meghatározását.

A nemzetközi banktevékenység felügyeletéhez szükséges, hogy a Felügyeletnek meglegyen a megfelelő felhatalmazása arra, hogy a törvény elöírásainak betartását ellenőrizze abban az esetben is, ha a tevékenységet a hitelintézet külföldön folytatja. A törvény ezzel a kiterjesztéssel egyben a lehetőséget is megadja arra, hogy a Magyarországon bejegyzett hitelintézetek tevékenységüket külföldön is folytathassák, amennyiben arra vonatkozóan külön engedéllyel rendelkeznek, illetve ehhez kapcsolódóan kiterjeszti a felügyeleti jogkört és arra is megadja a lehetőséget, hogy a Felügyelet az ilyen tevékenységet az e törvényben meghatározott felügyeleti tevékenység körében ellenőrizze. Az EU-n belüli szabad tőkeáramlás és a szolgáltatásnyújtás szabadságának biztosítása lehetővé teszi, hogy az Unión belül a székhely szerinti ország felügyeleti felelőssége alapján történjen a hitelintézetek tevékenységének szabályozása és felügyelete, vagyis a magyar hatóságnak egyben kötelessége is a Magyarországon bejegyzett székhelyü hitelintézetnek a más EU országokban végzett tevékenységét felügyelni, míg az EU országbeli hitelintézetek magyarországi tevékenységét az EU országbeli felügyeleti hatóság felügyeli.

A Hpt. $2 . \S$ részletesen megállapítja azt a személyi és tárgyi kört, amelyekre a törvény rendelkezéseit nem kell alkalmazni. A személyi körbe tartozik a törvény 1. számú mellékletében felsorolt pénzügyi intézményeknek a Magyarország 
területén folytatott tevékenysége, az elkülönített állami pénzalapok, a Magyar Nemzeti Vagyonkezelő Zrt., a jogszabály alapján létrehozott Diákhitel Központ, továbbá a Magyar Vállalkozásfejlesztési Alapítvány Országos Mikrohitel Alapból történő pénzkölcsön nyújtási tevékenysége, valamint a megyei és fővárosi vállalkozásfejlesztési alapítványok mikrohitelezési tevékenysége. A törvény tárgyi hatálya alóli mentességet az államháztartás müködéséhez szükséges forrásgyüjtési tevékenység, illetve a müködéshez kapcsolódó pénzforgalom szabályai külön törvényben való meghatározottsága indokolja, ezért arra a törvény rendelkezései nem terjednek ki, hiszen ezekre a tevékenységekre egyébként sem alkalmazhatók a hitelintézet müködésére vonatkozó szabályok. Az MNB az állam bankja és a bankok bankja szerepköréből adódóan végez olyan tevékenységeket, amelyek ugyan tartalmilag megfelelnek az e törvényben definiált pénzügyi szolgáltatási tevékenységnek, például vezeti a hitelintézetek számláit, hitelt nyújt, váltót viszontleszámítol, de ezen tevékenységére a Magyar Nemzeti Bankról szóló törvény előírásait kell alkalmazni.

\subsection{A pénzügyi szolgáltatás és kiegészítő pénzüigyi szolgáltatás}

A Hpt. a pénzügyi szolgáltatások két típusát különbözteti meg. Az elhatárolás ismérve az, hogy a 3. $\$(1)$ bekezdésben meghatározott tevékenységeket, az ún. pénzügyi szolgáltatásokat, - a pénzügyi szolgáltatások közvetítése (ügynöki tevékenység) kivételével - kizárólag pénzügyi intézménynek minősülő jogi személyek végezhetik. Ezek a tevékenységek a jellegükből és a kockázatukból adódóan megkövetelik, hogy azokat csak olyan személyek végezhessék, akiknek tevékenységére részletes prudenciális és felügyeleti előírások vonatkoznak. Pénzügyi szolgáltatás a következő tevékenységek üzletszerű végzése forintban, devizában vagy valutában:

a) betét gyüjtése és más visszafizetendő pénzeszköz nyilvánosságtól történő elfogadása: pénzeszközök egyedileg előre meg nem határozott személyektől történő gyüjtése oly módon, hogy azzal a betétgyüjtő tulajdonosként rendelkezhet, de köteles azt - kamattal, más előny biztosításával vagy anélkül - visszafizetni. 
b) hitel és pénzkölcsön nyújtása:

ba) hitelnyújtás: a hitelező és az adós között írásban létesített hitelszerződés alapján meghatározott hitelkeret rendelkezésre tartása az adós részére, jutalék ellenében és a hitelező kötelezettségvállalása meghatározott szerződési feltételek megléte esetén a kölcsönszerződés megkötésére vagy egyéb hitelművelet végzésére,

bb) pénzkölcsönnyújtás: pl. a hitelező és az adós között létesített hitelvagy kölcsönszerződés alapján a pénzösszeg rendelkezésre bocsátása, amelyet az adós a szerződésben megállapított időpontban - kamat ellenében vagy anélkül - köteles visszafizetni,

bc) a hitel és pénzkölcsön nyújtására irányuló pénzügyi szolgáltatási tevékenység a hitelképesség vizsgálatával, a hitel és kölcsönszerződések előkészítésével, a folyósított kölcsönök nyilvántartásával, figyelemmel kísérésével, ellenőrzésével, a behajtással kapcsolatos intézkedéseket is magában foglalja;

c) pénzügyi lízing: az a tevékenység, amelynek során a lízingbeadó a tulajdonában lévő ingatlant vagy ingó dolgot, illetve vagyoni értékü jogot a lízingbevevő határozott idejü használatába adja oly módon, hogy a használatba adással a lízingbevevő

- viseli a kárveszély átszállásából származó kockázatot,

- a hasznok szedésére jogosulttá válik,

- viseli a közvetlen terheket (ideértve a fenntartási és amortizációs költségeket is),

- jogosultságot szerez arra, hogy a szerződésben kikötött időtartam lejártával a lízingdíj teljes tőketörlesztő és kamattörlesztő részének, valamint a szerződésben kikötött maradványérték megfizetésével a dolgon ő vagy az általa megjelölt személy tulajdonjogot szerezzen. Ha a lízingbevevő nem él e jogával, a lízing tárgya visszakerül a lízingbeadó birtokába. A felek a szerződésben kötik ki a lízingdíj tőkerészét, - amely a lízingbe adott vagyontárgy, vagyoni értékü jog szerződés szerinti árával azonos -, valamint kamatrészét és a törlesztésének ütemezését;

d) pénzforgalmi szolgáltatás nyújtása:

da) a fizetési számlára történő készpénzbefizetést lehetővé tevő szolgáltatás, valamint a fizetési számla vezetéséhez szükséges összes tevékenység, 
db) a fizetési számláról történő készpénzkifizetést lehetővé tevő szolgáltatás, valamint a fizetési számla vezetéséhez szükséges összes tevékenység,

dc) a fizetési műveletek fizetési számlák közötti teljesítése ${ }^{2}$,

dd) a dc) pontban meghatározott szolgáltatás, ha a fizetési művelet teljesítése a pénzforgalmi szolgáltatást igénybe vevő ügyfél rendelkezésére álló hitelkeretéből történik,

de) a készpénz-helyettesítő fizetési eszköz - ide nem értve a csekket és az elektronikus pénzt - kibocsátása, valamint fizetési mủveletek elfogadása,

df) a készpénzátutalás,

dg) a fizetés-kezdeményezési szolgáltatás,

dh) a számlainformációs szolgáltatás;

e) elektronikus pénz kibocsátása: az elektronikus pénz kibocsátójával szembeni követelés által megtestesített, elektronikusan tárolt - ideértve a mágneses tárolást is - összeg, amelyet pénzeszköz átvétele ellenében bocsátanak ki a pénzforgalmi szolgáltatás nyújtásáról szóló törvényben meghatározott fizetési müveletek teljesítése céljából és amelyet az elektronikus pénz kibocsátóján kívül más természetes és jogi személy, jogi személyiség nélküli gazdasági társaság és egyéni vállalkozó is elfogad;

f) olyan papír alapú készpénz-helyettesítő fizetési eszköz (például papír alapú utazási csekk, váltó) kibocsátása, illetve az ezzel kapcsolatos szolgáltatás nyújtása, amely nem minősül pénzforgalmi szolgáltatásnak;

g) kezesség és garancia vállalása, valamint egyéb bankári kötelezettség vállalása;

h) valutával, devizával - ide nem értve a pénzváltási tevékenységet -, váltóval, illetve csekkel saját számlára vagy bizományosként történő kereskedelmi tevékenység;

i) pénzügyi szolgáltatás közvetítése:

ia) kiemelt közvetítői tevékenység: pénzügyi intézménnyel kötött megbízási szerződés alapján, a pénzügyi intézmény nevében, javára és kockázatára, pénzügyi szolgáltatás, kiegészítő pénzügyi szolgáltatás nyújtásának, szolgáltatásra irányuló szerződés megkötésének elősegítésére irányuló tevékenység, ideértve a pénzügyi intézmény nevé-

2 A fizetési forgalomról bővebben ld. Varga (2011). 
ben, javára és kockázatára történő kötelezettségvállalást vagy a szerződés megkötését is;

ib) ügynöki tevékenység: pénzügyi intézménnyel kötött megbízási szerződés alapján pénzügyi szolgáltatás, kiegészítő pénzügyi szolgáltatás nyújtásának, ilyen szolgáltatásra irányuló szerződés megkötésének elősegítésére irányuló tevékenység, amelynek során a pénzügyi intézmény kockázatára önállóan kötelezettséget nem vállalnak, szerződést nem kötnek;

ic) pénzforgalmi közvetítői tevékenység: az egyes fizetési szolgáltatókról szóló törvényben meghatározott tevékenység;

id) alkuszi tevékenység: pénzügyi szolgáltatást igénybe venni szándékozó ügyféllel kötött megbízási szerződés alapján és nevében pénzügyi intézménnyel történő pénzügyi szolgáltatási szerződés kiválasztására, megkötésének elősegítésére irányuló tevékenység, amely nem terjed ki az ügyfél nevében, javára történő kockázatvállalásra;

ie) elzáloghitel közvetítői tevékenység: az a), b) vagy d) pontban foglalt tevékenységnek a jelzáloghitelhez vagy a fogyasztónak nyújtott ingatlanra vonatkozó pénzügyi lízinghez kapcsolódó végzése;

j) letéti szolgáltatás (pénzösszegek az ügyfél megbízásából, elkülönített letéti számlán kamatra vagy kamat nélkül történő elhelyezése és kezelése, jogszabályban rögzített feltételek szerint) ill. széfszolgáltatás (az ügyféllel kötött megállapodás alapján állandóan őrzött helyiségben széf rendelkezésre bocsátása, melybe értékeit az ügyfél maga helyezi el és veszi ki);

k) hitelreferencia szolgáltatás:

ka) banktitkot nem sértő bankinformáció díjazás ellenében történő nyújtása vagy

kb) a központi hitelinformációs rendszerről szóló törvényben meghatározott központi hitelinformációs rendszert kezelő pénzügyi vállalkozás által történő adatkezelés;

1) követelésvásárlási tevékenység: követelésnek - a kötelezett kockázatának átvállalásával vagy anélkül történő - megszerzése, megelőlegezése (ideértve a faktoringot és a forfetírozást is), valamint leszámítolása, függetlenül attól, hogy a követelés esedékességének nyilvántartását és a kintlévőségek beszedését ki végzi. 
A pénzügyi szolgáltatási tevékenységek másik típusába az ún. kiegészítő pénzügyi szolgáltatások tartoznak. Ezek a tevékenységek ugyanis jelentősen kötődnek az egyéb, engedélyhez kötött pénzügyi szolgáltatási tevékenységekhez, de ugyanígy szorosan kapcsolódhatnak más tevékenységhez is. Ezeket a tevékenységeket nem pénzügyi intézmények is végezhetik, és amennyiben kizárólag kiegészítő pénzügyi szolgáltatói tevékenységet végeznek, a szigorú bankbiztonsági elóírások alkalmazása nem indokolt. Kiegészítő pénzügyi szolgáltatás a következő tevékenységek üzletszerü végzése forintban, valutában, illetve devizában:

a) pénzváltási tevékenység: külföldi fizetőeszközök adásvétele a törvényes fizetési eszköz ellenében, valamint külföldi fizetési eszközök adásvétele külföldi fizetési eszközök ellenében. Nem minősül pénzváltási tevékenységnek a pénzforgalmi szolgáltatáshoz kapcsolódó pénznemek pénzforgalmi szolgáltató által történő átváltása, a külföldi pénznemre szóló, forgalomban lévő vagy forgalomban lévőre még átcserélhető pénzérmék és bankjegyek numizmatikai célú forgalmazása, valamint belkereskedelemben az áruval vagy szolgáltatással kapcsolatos ügyletekre vonatkozó fizetések teljesítése;

b) fizetési rendszer működtetése: elszámolási, illetve kiegyenlítési rendszer, amely a fizetési műveletek feldolgozására, elszámolására vagy teljesítésére megállapodásban vagy szabványban rögzített eljárásokat, valamint egységes szabályokat alkalmaz;

c) pénzfeldolgozási tevékenység: bankjegyek és pénzérmék tételes megszámlálása, valódiság és forgalomképesség szempontjából történő ellenőrzése, továbbá az újra forgalomba hozható bankjegykötegek és pénzérmetételek kialakítása;

d) pénzügyi ügynöki tevékenység a bankközi piacon: bankközi piaci résztvevők közötti forint-, illetve devizahitel és betétügylet, deviza-adásvétel közvetítése annak érdekében, hogy a hitelintézetek, továbbá más bankközi piaci résztvevők az erre irányuló jogügyleteket egymással közvetlenül megkössék;

e) forgatható utalvány kibocsátására irányuló tevékenység: pénzeszköz ellenében a forgatható utalványnak ${ }^{3}$ az utalványkibocsátó által közvetlenül vagy

3 Forgatható utalvány: minden olyan, az utalványkibocsátóval szembeni pénzkövetelést megtestesitő bankjegynek, készpénz-helyettesitö fizetési eszköznek és értékpapírnak nem minősülö, átruházható és többször felhasználható, papír alapú fizetési eszköz, amely áruk vagy szolgáltatások ellenértékének a kiegyenlitésére szolgál. A forgatható utalványokról ld. Varga (2016) és Varga (2018). 
utalványforgalmazó útján az utalványbirtokos rendelkezésére bocsátása;

f) hitel-tanácsadási tevékenység: új kiegészítő pénzügyi szolgáltatás, amely jelzáloghitelhez vagy fogyasztónak nyújtott ingatlanra vonatkozó pénzügyi lízinghez kapcsolódó személyre szabott ajánlások nyújtását jelenti.

A törvény ezen paragrafusa egyértelmüen rögzíti, hogy pénzügyi és kiegészítő pénzügyi szolgáltatás kizárólag engedéllyel végezhető. Viszont a Hpt. 5. \$ kimondja, hogy az engedélyhez kötöttségi általános elvtől eltérően a szolgáltatások szabad áramlása keretében az engedély kérése nem szükséges, ha más EGT-állam felügyeleti hatósága a vonatkozó engedélyeztetési eljárást már lefolytatta. Ugyanakkor a pénzügyi intézménynek nem minősülő vállalkozás csoportfinanszírozást a Felügyelet engedélye nélkül is végezhet.

\subsection{A pénzügyi intézmények: a hitelintézet és szervezeti formái, valamint a pénzügyi vállalkozás}

A Hpt. alapján pénzügyi szolgáltatást alapvetően pénzügyi intézmény végezhet, amely intézmény két formája a hitelintézet és pénzügyi vállalkozás. Egyes szolgáltatásokat azonban nem pénzügyi intézmény is nyújthat, így a pénzügyi szolgáltatás közvetítését végzö ügynök, valamint a váltóval bizományosi, illetve kereskedelmi tevékenységet, az önkéntes kölcsönös biztosító pénztár részére pedig vagyonkezelést végzö befektetési vállalkozás. A törvény meghatározza azt is, hogy pénzügyi intézmény milyen szolgáltatásokat végezhet üzletszerủen a pénzügyi szolgáltatási tevékenységén kívül. Ez azért szükséges, mert a törvény alapvető koncepciója, hogy pénzügyi intézmény szorosan pénzügyi szolgáltatási tevékenységeken kívül más tevékenységet ne folytathasson (szektoriális zártság elve alapján), ezért felsorolja azokat a tevékenységeket, amelyek kivételt képeznek az általános tilalom alól. A törvény továbbá a fizetési rendszert müködtetö vállalkozás esetében enyhébb szabályt ír elő, így egyéb tevékenységek végzését is lehetővé teszi, amennyiben ezen tevékenysége a fötevékenység végzését nem befolyásolja hátrányosan.

A Hpt. 8. $\$$ alapján betétgyüjtési és pénzváltási tevékenységet Magyarországon kizárólag hitelintézet végezhet, és - bank vagy állam által a visszafizetésre vállalt kezesség vagy garancia nélkül - kizárólag hitelintézet jogosult a saját tőkéjét meghaladó mértékben visszafizetendő pénzeszköznek a nyilvánosság- 
tól való gyűjtésére. Pénzeszköznek a nyilvánosságtól való gyüjtésére nemcsak betétgyűjtés formájában van lehetőség, hanem más módon, például kötvénykibocsátás útján is. A törvény ezáltal nemcsak a betétesek, hanem más pénzeszköz tulajdonosok részére is biztonságot kíván nyújtani azzal, hogy csak olyan intézmények számára teszi lehetővé a saját tőkét meghaladó mértékű pénzeszközgyüjtést, amelyek az e törvényben meghatározottak szerinti felügyelet alá tartoznak, rendszeres ellenőrzés alatt állnak, illetve olyan prudenciális szabályok vonatkoznak rájuk, amelyek jelentősen csökkentik a náluk elhelyezett pénzeszközök kockázatát.

A törvény a hitelintézetek típusai között az általuk végezhető tevékenységek szerint tesz különbséget. Eszerint hitelintézet lehet bank, szakosított hitelintézet vagy szövetkezeti hitelintézet (takarék-, illetőleg hitelszövetkezet):

- A bank az a hitelintézet, amely üzletszerüen betétet gyüjt, hitel és pénzkölcsönt, valamint pénzforgalmi szolgáltatást üzletszerüen nyújt, továbbá csak bank kaphat engedélyt arra, hogy az összes pénzügyi szolgáltatási tevékenységet együttesen végezhesse.

- A szakosított hitelintézet külön törvényi szabályozásnak megfelelően jogosult a pénzügyi szolgáltatási, illetőleg kiegészítő pénzügyi szolgáltatási tevékenységek meghatározott körének végzésére, azonban nem jogosult a pénzügyi szolgáltatási tevékenységek teljes körét együttesen végezni.

- A szövetkezeti hitelintézet széles körben folytathat pénzügyi szolgáltatási tevékenységet, azonban nem kaphat engedélyt hitelreferencia szolgáltatás folytatására, fizetési rendszer müködtetésére, pénzfeldolgozási tevékenységre és forgatható utalvány kibocsátására. A szövetkezeti hitelintézet sajátos formáját képező hitelszövetkezet a felsorolt pénzügyi szolgáltatásokat csak saját tagjai körében végezheti, ide nem értve a pénzváltási tevékenységet, amelyet tagjain kívül is folytathat.

A Hpt. szerint azon pénzügyi intézmények tekintendők pénzügyi vállalkozásnak, amelyek a pénzügyi szolgáltatások meghatározott körét végezhetik, mivel betétgyüjtésre és más visszafizetendő pénzeszközöknek nyilvánosságtól való gyüjtésére (saját tőkét meghaladó mértékben) nincs jogi felhatalmazásuk. További kategóriájuk a pénzügyi holding társaság. Sajátos pénzügyi vállalkozás-

4 Az 575/2013/EU rendeletben ekként meghatározott fogalom: olyan pénzügyi vállalkozás, amelynek leányvállalatai kizárólag vagy nagy részben intézmények vagy pénzügyi vállalkozások, és a leányvállalatok közül legalább egy intézmény, és amely nem minősül vegyes pénzügyi holding társaságnak. 
ként jelenik meg a pénzügyi ügynöki tevékenységet végző vállalkozás, mivel e tevékenység csak kizárólagosan folytatható, tehát emellett más tevékenység végzésére a törvény nem ad lehetőséget.

\subsection{A hitelintézetek alapításának és müködésének, illetve egyes tevékenységeinek engedélyezése}

A szabályozás versenysemlegességet biztosít, hiszen a pénzügyi szolgáltatói tevékenység végzését engedélyhez köti, függetlenül attól, hogy azt milyen vállalkozási formában végzik. ${ }^{5}$

A Hpt. 11. \$ (1) bekezdése elrendeli, hogy bank és szakosított hitelintézet részvénytársaságként vagy fióktelepként, szövetkezeti hitelintézet szövetkezetként, illetőleg - banknak vagy szakosított hitelintézetnek minősülő - részvénytársaságként, pénzügyi vállalkozás részvénytársaságként, szövetkezetként, alapítványként vagy fióktelepként müködhet.

A pénzügyi szolgáltatási tevékenységek kiemelt kockázata megköveteli, hogy az adott intézmény működéséhez megfelelő minimális induló tőkével rendelkezzen. Ez azzal jár, hogy az alapításkori minimális jegyzett tőke követelmény jóval meghaladja a részvénytársaságtól vagy szövetkezettől megkövetelt általános minimumot. A pénzügyi szolgáltatások teljes körének végzésére jogosult bank legalább kettő milliárd forint induló tőkével alapítható. Szövetkezeti hitelintézet - kizárólag szövetkezeti formában - legalább háromszázmillió forint induló tőkével alapítható, és a pénzügyi vállalkozások esetében ötvenmillió forintos minimális jegyzett tőke követelmény az előírás. Pénzügyi intézmény alapításához az induló tőkét kizárólag pénzbeni hozzájárulással lehet teljesíteni, ami kizárja a tárgyi eszközök nem pénzbeli hozzájárulásként történő bevitelét, illetve az immateriális javakkal történő jegyzett tőke befizetést vagy emelést. Az alapításhoz hasonlóan a tőkeemelésre is ezek az előírások vonatkoznak. Ezek a szabályok, elősegítik, hogy a hitelintézetek tőkéje csak olyan elemeket tartalmazzon, amelyek egy esetleges válság esetén a betétesek és hitelezők kielégítését lehetővé teszik. A jegyzett tőkét kizárólag olyan hitelintézetnél lehet befizetni, amely nem vesz részt az ala-

5 Az engedélyezési eljárásokban a kérelmeket, bejelentéseket az MNB honlapján, az ERA felületen az E-ügyintézés Engedélyezés szolgáltatáson belül található elektronikus ürlapokon kell benyújtani, a mellékletek hiteles elektronikus másolatának csatolásával. Az MNB döntései, hiánypótlási felhivásai, tájékoztatásai és egyéb közlései a kézbesitési tárhelyen való elhelyezéssel kerülnek kézbesitésre a pénzügyi szervezetek, illetve jogi képviselőik részére. 
pításban, ezáltal jobban ellenőrizhető a tőkeemeléshez szükséges pénz megléte és forrása. Igazolni kell azt is, hogy a jegyzett tőke befizetéséhez szükséges összeg az alapításban résztvevő személy törvényes jövedelméből származik.

A Hpt. tételesen felsorolja azokat a tevékenységeket, amelyek végzéséhez a Felügyelet engedélye szükséges a hitelintézetek számára. Eszerint a jogszabály elöírása alapján elkülönül egymástól a hitelintézet alapításához és működési tevékenységének megkezdéséhez kiadott engedély.

A törvény 18. \$-ban kifejtésre kerül az alapítási engedély részletszabályozása. $\mathrm{Az}$ alapítási engedélykérelemben a hitelintézetnek vagy a pénzügyi vállalkozásnak fel kell tüntetnie mindazokat az információkat, amelyek a piacra lépés lehetőségének elbírálásához szükségesek. Annak érdekében, hogy ezeknek az információknak a köre egyértelműen behatárolva legyen, a törvény részletesen felsorolja az alapítási engedély iránti kérelem kötelező kellékeit és tartalmát. Ezek között szerepel az alapító okirat, a tervezett müködési terület pontos meghatározása, a jegyzett tőke befizetésére vonatkozó információk, valamint a szervezeti felépítésre, irányításra és döntésre vonatkozó adatok, illetve az ellenőrzés rendjének a bemutatása.

A törvény az engedély megadásánál mérlegelési jogkört biztosít a Felügyelet számára, teret adva ezzel a piacra lépés szigorú kontrolljának. Az engedélykérelem elutasításának szabályait tartalmazza a $30 . \$$. Az alapítás iránti kérelmet a törvény alapján kell elutasítania a Felügyeletnek érdemi vizsgálat nélkül, ha a kérelmező az engedélyezési eljárásban félrevezette azzal, hogy megtévesztő vagy valótlan adatot közölt, az alapítani kívánt pénzügyi intézmény nem felel meg a törvényben foglalt követelményeknek (pl. nincs meg a jegyzett tőkéhez szükséges összeg, más társasági formában alapították stb.), devizakülföldi kérelmező esetén pedig, ha nem rendelkezik kézbesítési megbízottal stb.

Az alapítási engedély alapján a hitelintézet a banküzem létesítésével kapcsolatos tevékenységet végezhet (MNB 2019b). Hitelintézet működésének megkezdéséhez az alapítási engedély megadása nem elegendő, hanem a tevékenységi engedélyt is meg kell szereznie. A hitelintézet alapítását engedélyező határozat érvényét veszti, ha a tevékenységi engedély iránti kérelmet a határozat kézhezvételétől számított hat hónapon belül a hitelintézet nem nyújtja be az MNB-hez. A határidő elmulasztása miatt igazolásnak helye nincs (MNB 2019c). Ahhoz, 
hogy a hitelintézet a működését megkezdhesse, be kell mutatnia a jegyzett tőke 100\%-os befizetésére vonatkozó igazolást azzal, hogy a belöle történt felhasználás az alapítás, illetőleg a működés megkezdését szolgálta, a fontosabb tulajdonosai azonosítására alkalmas adatokat, az első három évre vonatkozó üzleti tervét, a személyi és tárgyi feltételek biztosítására vonatkozó tervét, általános szerződési feltételeinek és üzletszabályzatának tervezetét, tevékenysége megkezdésének időpontjára vonatkozó nyilatkozatát. A Felügyelet a betét gyüjtésére vonatkozó engedélyt csak az esetben adja meg, ha az adott hitelintézet csatlakozik az Országos Betétbiztosítási Alaphoz, ezért a működési engedély iránti kérelem benyújtásakor az Országos Betétbiztosítási Alaphoz való belépési nyilatkozatot is mellékelni kell. Információkat kell szolgáltatnia a kérelmezőnek arról is, hogy az adott hitelintézet közvetlenül vagy közvetve csatlakozik a hitelintézetek közötti országos fizetési rendszerhez, és az ehhez szükséges informatikai hátteret biztosítani tudja. A hitelintézetnek nyilatkoznia kell továbbá, hogy a Felügyelet által elöírt adatszolgáltatások teljesítésére felkészült, és be kell nyújtania a számviteli rendjére vonatkozó szabályainak részletes tervezetét is. Fontos - a megbízható működést elősegítő - a központi hitelinformációs rendszer kialakítása, amelyhez a hitelintézeteknek csatlakozniuk kell. Az erről szóló nyilatkozatot szintén a kérelemmel együtt kell benyújtani.

A már működő pénzügyi intézmények tevékenységi körük módosítása során mindazon igazolásokat kötelesek a Felügyelethez az engedély iránti kérelemmel egyidejűleg benyújtani, amelyekkel igazolni lehet, hogy a kérelmező megfelel azoknak a további személyi és tárgyi feltételeknek, amelyek az új tevékenység végzéséhez szükségesek.

A hitelintézetek egyesülésére és szétválására külön szabályok vonatkoznak, amelyek teljesülését a Felügyelet ellenőrzi, és az egyesüléshez, illetve szétváláshoz szükséges engedélyt csak abban az esetben adja meg, ha ezek a feltételek teljesülnek. Ugyanis a hitelintézetek egyesülésével, illetve szétválásával új hitelintézet, illetve hitelintézetek jönnek létre, amelyek esetében szintén biztosítani kell, hogy azok azonos feltételek alapján alakulhassanak meg.

A törvény a Felügyelet engedélyéhez köti többek között a hitelintézet alapszabályának módosításának kiemelt eseteit, a befolyásoló részesedés megszerzését, illetőleg növelését is. Részletes információszolgáltatási kötelezettség vonatkozik 
azokra a személyekre, akik az alapítás alatt lévő pénzügyi intézményben befolyásoló részesedést kívánnak szerezni. Ezek az információk annak elbírálásához szükségesek, hogy a leendő tulajdonos mennyiben képes a hitelintézetben a szükséges tulajdonosi ellenőrzést elvégezni, illetve annak megállapításához, hogy a tulajdonos hogyan képes menedzselni eddigi befektetéseit, és fennáll-e annak a veszélye, hogy a tulajdonos a hitelintézetet az egyéb vállalkozásai finanszírozására kívánja felhasználni.

A hitelintézet igazgatóságának, felügyelőbizottságának elnökévé, vagy tagjává történő megválasztáshoz illetőleg ügyvezetőjének történő kinevezéséhez szintén a Felügyelet engedélye szükséges.

A hitelintézetek válságkezelése során biztonsági okokból sor kerülhet a hitelintézetnél elhelyezett betétállomány teljes egészének vagy egy részének átruházására egy másik hitelintézet számára. A külföldi gyakorlat szerint a betéteseknek a betétbiztosítás által garantált betéteit bankválság esetén gyakran azonnal egy másik bankhoz irányíthatják, és ekkor a betétbiztosítási összegek nagy része a gyakorlatban kifizetésre sem kerül, hanem változatlan feltételekkel betétként a másik bankhoz kerül át. Az ilyen lépések megtételéhez szintén a Felügyelet engedélye szükséges. A törvény a fióktelep formájában működő hitelintézetekre is engedélyezési kötelezettséget ír elö, azonban korlátozottabb esetkörben, lévén, hogy egyes esetek bejelentési kötelezettséggel járnak csak.

\subsection{A kiadott engedély felügyeleti visszavonása}

A Felügyeletnek lehetőséget biztosít a törvény arra, hogy a pénzügyi intézménynek már kiadott engedélyt visszavonhassa. Ez rendkívül súlyos szankciós lehetőség a Felügyelet számára, ezért a törvény taxatíve rögzíti azokat a feltételeket, amikor erre sor kerülhet. Így elsősorban akkor vonhatja vissza a pénzügyi intézmény engedélyét, ha azt a Felügyelet megtévesztésével vagy más jogszabálysértő eszközzel szerezték meg, a pénzügyi intézmény törvény által tiltott tevékenységet folytat, a pénzügyi intézmény súlyosan veszélyezteti ügyfelei érdekeit, illetve a pénz- és tőkepiac megfelelő működését stb. A Felügyelet a fióktelep engedélyét továbbá akkor is visszavonja, ha a székhely szerinti illetékes felügyeleti hatóság a külföldi pénzügyi intézmény engedélyét visszavonta. A hitelintézetek esetében a fentebb említetteken kívül a Felügyelet akkor is visszavonhatja a hitelintézet 
tevékenységi engedélyét, ha fennáll a veszélye - vagy bekövetkezett az a lehetőség -, hogy nem tud eleget tenni kötelezettségeinek. Szintén ilyen indok lehet, ha nem vitatott tartozását az esedékességét követő öt napon belül nem egyenlítette ki, vagy vagyona az ismert hitelezők követelésének kielégítésére sem nyújtana fedezetet. A hitelintézet működési engedélyének visszavonásához szükséges a pénz-, tőke- és biztosítási piac szabályozásáért felelős miniszter jóváhagyása is. E rendelkezésre azért van szükség, mert a hitelintézet piacról való kivezetése mélyrehatóan érintheti a gazdasági folyamatokat, különösen a költségvetést, ezért az e területért felelős személy jóváhagyása feltétlenül indokolt.

\subsection{A szolgáltatás nyújtásának szabadsága: másik EGT-államban történő fióktelep létesítés szabályai}

A szolgáltatások nyújtásának és a letelepedés szabadsága értelmében a pénzügyi intézmények is több lehetőségből választhatnak, ha más EGT-államban is kívánnak tevékenységet folytatni. Ennek megfelelően a Hpt.-ben rögzítésre került az is, hogy a másik EGT-államban történő fióktelep létesítése milyen követelmények, feltételek és eljárás mentén történhet, valamint milyen elvárások jelennek meg a működés során. Alapvetően másik EGT-államban való fióktelep létesítése nem engedélyköteles, hanem csak bejelenteni kell. A bejelentéskor a létesítés tényén kívül rögzíteni kell a szervezeti felépítést, a végezni kívánt tevékenységeket, ismertetni kell az üzleti tervet, meg kell nevezni a fióktelepet irányító személyt és meg kell adni a fióktelep címét. Mindezt a bejelentést a hazai felügyeleti hatóság felé kell teljesíteni, amely a jogszabályi feltételeknek való megfelelés ellenőrzését követően a letelepedési szándék tényéről tájékoztatja a fogadó EGT-állam illetékes felügyeleti hatóságát, amely tájékoztatás tartalmazza a hazai betétgyüjtési szabályozási ismertetést és az anyavállalat tőkehelyzetének áttekintését. Ezt követően a fogadó állam a tevékenység végzésének feltételeiről tájékoztatja a letelepedni szándékozó intézményt. A tájékoztatási folyamat lezárultát követően az intézmény letelepedhet a fogadó államban. 


\subsection{Irodalomjegyzék}

Barna Piroska, Becsei András, Bógyi Attila, Csányi Péter, Csordás Katalin, Győr Tamás, Hermann Dávid, Marsi Erika, Móra Mária, Pesuth Tamás, Schenk Tamás (2018): A bankok müködéséről. In: Kovács Levente - Marsi Erika (2019): Bankmenedzsment - Banküzemtan. Alapítvány a Pénzügyi Kultúra Fejlesztéséért, Budapest. (ISBN:978-963-89653-2-5)

Indoklás a hitelintézetekről és a pénzügyi vállalkozásokról szóló 2013. évi CCXXXVII. törvényhez (egységes szerkezetbe foglalta Wolters Kluwer Jogtár adatbázisa, 2019.)

Ligeti, S.; Pesuth, T.; Varga, J. (2019): Kereskedelmi bankok. In: Kürthy, Gábor (szerk.) Pénzügytan. BUDAPEST: Budapesti Corvinus Egyetem, (2019) pp. 30-53., 24 p.

MNB (2019a): Sajtóközlemény a hitelintézetek prudenciális adatairól 2018. IV. negyedév Budapest, 2019. március 12.

MNB (2019b): Hitelintézetek alapításának engedélyezése; elektronikus dokumentum, https://www.mnb.hu/letoltes/hitelintezet-alapitasanakengedelyezese.pdf

MNB (2019c): Hitelintézetek működésének engedélyezése; elektronikus dokumentum, https://www.mnb.hu/letoltes/hitelintezet-mukodesenekengedelyezese-1.pdf

Varga József (2011): A belföldi fizetési forgalom. In: Tatay Tibor, Vágyi Ferenc Róbert, Varga József (szerk.) A pénzügyi intézményrendszer Magyarországon 2011. 418 p. Sopron: Soproni Felsőoktatásért Alapítvány, 2011. pp. 34-59. (ISBN:978-963-89173-1-7)

Varga József (2016): A helyi pénz megjelenése és szerepe a gazdaságban. In: Kerekes Sándor (szerk.) Pénzügyekről másképpen: Fenntarthatóság és közösségi pénzügyek. 249 p. Budapest: CompLex Wolters Kluwer, 2016. pp. 161-208. (ISBN:978-963-29558-5-8)

Varga József (2018): A helyi pénzrendszerek közgazdasági és társadalmi elfogadottsága. KÖZÉP-EURÓPAI KÖZLEMÉNYEK 11:(2 / No. 41) pp. 133141. 


\section{A banki müködés kockázatai}

A kockázatok a bank átfogó teljesítményére gyakorolt várt vagy nem várt kedvezőtlen hatásokat jelentik. Ellentétben a reálgazdasági vállalati tevékenységgel, a pénzügyi intézmények üzletszerüen aktívan generálják, másrészről kezelik a kockázatokat. A kockázatkezelésnek ezért be kell épülnie a hitelintézeti folyamatok teljes spektrumába.

A kereskedelmi bankok tevékenységének vizsgálata során a kockázatokra nagyobb figyelmet kell fordítani, mint más szektorokban, mivel a kereskedelmi bankok legfőbb tevékenysége „mások pénzének kezelése”, ezért fokozottan fennáll a megbízó-ügynök probléma. Vagyis az információs aszimmetria jelentős ebben a szektorban, valamint a bank-menedzsment kockázati attitüdje eltérhet a bank tulajdonosaiétól és a betétesekétöl. Egy bank csődje pedig a lakosság, a vállalati szféra, valamint más bankok, esetleg a bankszektor egy részének vagy egészének összeomlásához vezethet. A banki müködés kockázatai fejezet ezért a hitelintézetek szempontjából vizsgálja meg, milyen veszélynek vannak kitéve a tevékenységük során ezek a gazdaságilag fontos intézmények.

A bankok számos kockázatnak vannak kitéve, melyeket három fó csoportba oszthatunk: pénzügyi, müködési és környezeti kockázatokra. Részletesen lásd az 1. táblázatban.

A banki kockázatok egyrészt az intézmény müködéséből erednek (pl. technológia, működési hatékonyság, szabályozási környezet), másrészt pedig a bank portfóliójához kapcsolódóan merülnek fel (pl. hitelkockázat, valuta kockázat).

A törvényi szabályozás meghatározza, hogy milyen kockázatokra a hitelintézeteknek milyen tartalékot kell képezniük. Általános kockázati céltartalék képzendő az előre nem látható, illetőleg nem meghatározható veszteségek fedezetére. Kockázati céltartalékot kell képezni a kamat-, árfolyam- és mérlegen kívüli kötelezettség kockázataira. Végül értékvesztés képzendő a hitelezési, befektetési és országkockázati tényezők esetében. 


\begin{tabular}{|c|c|c|}
\hline Pénzügyi kockázatok & Müködési kockázatok & $\begin{array}{c}\text { Szabályozási és környezeti } \\
\text { kockázatok }\end{array}$ \\
\hline Hitelkockázat & Belső csalás & Ország- és politikai kockázatok \\
\hline Kamatlábkockázat & Külső csalás & Makrogazdasági politika \\
\hline Likviditási kockázat & $\begin{array}{l}\text { Foglalkoztatási gyakorlat és a munkahelyi } \\
\text { biztonság }\end{array}$ & Pénzügyi infrastruktúra \\
\hline Mérlegen kívüli kockázat & Ügyfelek, termékek és üzleti szolgáltatások & Szabályozási kockázat \\
\hline Befektetési kockázat & Eszközök fizikai károsodása & Pénzügyi vagy banki válság \\
\hline Valutakockázat & $\begin{array}{l}\text { Üzleti zavarok és rendszerhibák } \\
\text { (technológiai kockázatok) }\end{array}$ & \\
\hline $\begin{array}{l}\text { Nyereség és jövedelemszerkezet } \\
\text { romlása }\end{array}$ & Végrehajtás és folyamatmenedzsment & \\
\hline Tőkemegfelelés elégségessége & & \\
\hline
\end{tabular}

1. táblázat: A banki kockázatok áttekintése

Forrás: Greuning, Bratanovic (2009)

A hitelintézet a tevékenységével együtt járó hitelezési-, kamat-, árfolyam-, befektetési-, ország- és egyéb kockázatok fedezetére ráfordításként történő elszámolással kockázati céltartalékot köteles képezni, és a behajthatatlan követelés leírására először a kockázati céltartalékot köteles felhasználni. A kockázati céltartalékot a hitelintézetek ráfordításként számolják el, ami azt jelenti, hogy így a céltartalék képzett összege adóalapcsökkentő tétel (Gálfalvi et al., 2016).

A befektetési és hitelezési portfólió diverzifikálása jelentősen csökkentheti egy pénzintézet kockázatait, ezzel növelve annak ellenálló képességét a válságokkal szemben. A kockázat gondos mérlegelésének hiánya is szerepet játszik a pénzügyi válságok kialakulásában.

\subsection{Pénzügyi kockázatok}

\subsubsection{Hitelkockázat}

A hitelkockázat a bankoknak az az alapvető kockázata, hogy a hiteladósok részben vagy egészében nem fogják visszafizetni a kihelyezett hitelt. Ezt a kockázatot hitelkockázatnak vagy a visszafizetés kockázatának hívjuk. 
A hitelkockázat pontos meghatározását a Magyar Nemzeti Bank 11/2017. (XI.06.) számú ajánlása adja: „A hitelkockázat a szerződéses partnerek nem(vagy nem a szerződési feltételek szerinti) teljesítéséből fakadó, azaz a pénzügyi szervezettel szemben fennálló (mérlegben lévő vagy mérlegen kívüli) kötelezettségek teljesítésének részleges vagy teljes mulasztásából eredő, jövedelmezőséget és tőkehelyzetet érintő veszteségek veszélye." (MNB 11/2017. (XI.06.) számú ajánlás). A kockázatvállalás a pénzügyi közvetítőrendszer intézményeinek sajátossága. Ebből kiindulva a pénzintézetek célja nem a hitelkockázat megszüntetése, hanem megfelelő keretek között tartása, a pénzügyi szervezet hitelkockázati kitettségének megfelelő azonosítása, mérése és kezelése.

A bankok megpróbálják felmérni a hiteligénylők hitelképességét, és a túl nagy kockázatú ügyfeleknek nem fognak hitelt folyósítani, hogy az így keletkező veszteségeket megelőzzék. A hitelkockázat pontos mérése törvényileg is elvárt: a hitelminősítés során kockázat alapján megadott sávokba kell rendelniük a kintlevőségeiket, és ez alapján végzik el a várható veszteségekre a tartalékképzést. A kintlevőségek öt értékelési csoportba (problémamentes, külön figyelendő, átlag alatti, kétes, rossz) kerülnek besorolásra. Az egyes értékelési csoportokhoz a fizetési késedelmek alapján egy konkrét tartalék mérték van hozzárendelve és e százalékos mérték alapján kerül az adott értékelési csoportba sorolt valamennyi követelés után értékvesztés elszámolásra.

1. Problémamentes hitel esetén a megtérülés valószínűsíthető és az adósságszolgálat visszafizetésében 15 napnál nagyobb elmaradás nem történt ( $0 \%$ a várható veszteség mértéke).

2. Külön figyelendő kinnlevőség, ahol veszteség nem valószínűsíthető, de olyan információk vannak a hitelintézet birtokában, amely alapján az adós vagy a hitel az általánostól eltérő kezelést igényel (1-10\% a várható veszteség mértéke).

3. Átlag alatti besorolású hitelek a rendelkezésre álló információk alapján szokásosnál magasabb kockázatúnak minősülnek, illetve bizonyos mértékủ veszteség várható (11-30\% a várható veszteség mértéke).

4. Kétesnek minősülnek azok a kinnlevőségek, ahol veszteség várható, de mértéke még nem ismert, illetve az adósságszolgálati késedelem 90 napnál nagyobb vagy rendszeres. Ide soroljuk a peresített követeléseket is (31-70\% a várható veszteség mértéke). 
5. Rossznak minősülnek azok a követelések, ahol a várható veszteség 70\%-nál magasabb mértékű, illetve az adós ellen felszámolási eljárás indul (71-100\% a várható veszteség mértéke).

Azonban az adósminősítés múltbéli adatokkal dolgozik, így nem zárható ki ez a kockázat teljesen, csak csökkenteni lehet. Ezt támasztja alá az 1. ábra, vagyis a legalább 3 hónapja nem törlesztett hitelek aránya az összes hitelhez még a fejlett országokban is $1-3 \%$ között alakul egy nem recessziós időszakban is.

A hitelkockázat csökkentésével ellentétesen hat, hogyha a bank növelni akarja profitját és piaci részesedését, akkor a bank bővíti azoknak a körét, akiknek hitelt nyújt. Óhatatlanul elmozdul a jó hitelfelvevők körétől a kockázatosabb adósok felé. A 2008-as nemzetközi gazdasági válság alapvetően változtatta meg a banki kockázatkezelésről alkotott képet. A bankok a válságot megelőző időszak során a rövid távú jövedelmezőségre fókuszálva erős kockázati versenyt folytattak, miközben kevésbé törődtek a csak hosszabb távon potenciálisan felmerülő kockázatokkal, így például a devizahitelezés esetén az árfolyamkockázattal. A válság fájó tanulsága, hogy a bankok önmagukban nem képesek a pénzügyi rendszer stabilitását fenntartani. Ehhez a rendszerszintű pénzügyi kockázatok mérséklésére, és így megfelelően kalibrált makroprudenciális elöírásokra is szükség van. Magyarországon az MNB a Magyar Nemzeti Bankról szóló 2013. évi CXXXIX. számú törvényben felhatalmazást és eszközöket kapott arra, hogy makroprudenciális hatóságként a nemzeti szinten megjelenő pénzügyi rendszerkockázatokat hatékonyan kezelje. 


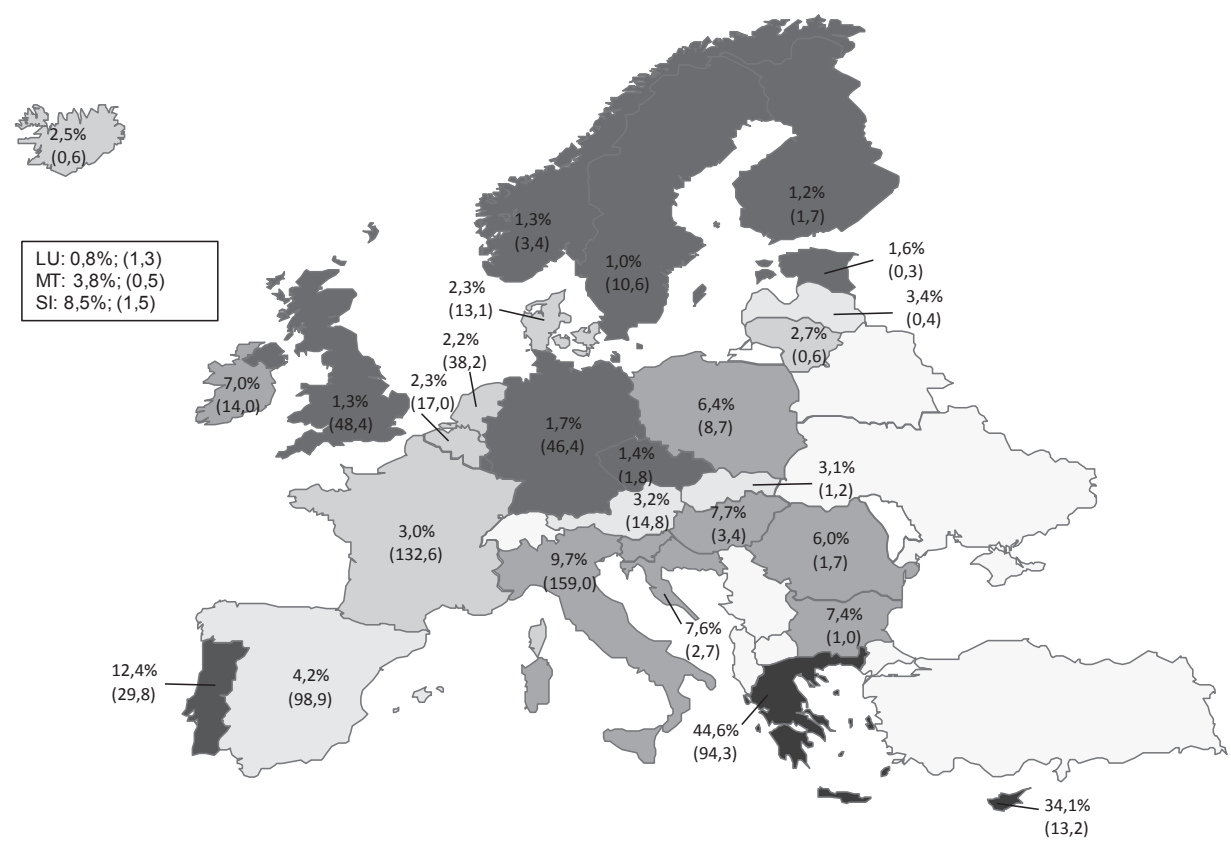

1. ábra: A nem-teljesítő hitelek aránya és volumene Európában (2018 II. negyedévi adatok; NPL ráta (3 hónapja nem törlesztett hitelek) százalékban, zárójelben pedig a nemteljesítő hitelállomány nagysága milliárd euróban. alacsony, közepes, magas NPL aránnyal bíró tagállamok.)

Forrás: MNB (2018a)

A jegybank egyik feladata tehát, hogy prudens mederbe terelje a bankok hitelpolitikáját. Nem kívánatos tehát olyan hitelkockázati politika meghatározása, melynek keretében piaci versenyelőny megszerzése érdekében a pénzügyi szervezet tudatosan vállalja a hitelezési feltételek (például egyes dokumentumok bekérésétől való eltekintés, alacsonyabb fedezettségi követelmények meghatározása) enyhítését, lazítását. Szükséges tehát, hogy a bank olyan hitelezési stratégiát alakítson ki, amellyel eredményesen tud lavírozni az észszerüen behatárolt kockázat, a jövedelmező müködés és a fizetőképesség megörzésének követelményei között. Ez elérhetö, ha sikerül a bankot érintő veszteségek bekövetkezésének valószínűségeit minél pontosabban kiszámítani, ezáltal meghatározhatóvá válik a veszteségmennyiség, amit a hitelintézet még elfogadottnak tekint, beleértve az ügyletek jövedelmezőségét és a kockázati szint optimális arányát. 
A megfelelő hitelkockázat kezelés azért is fontos tényező, mert a kereskedelmi bankok hitelképessége elsősorban nem a források és a kihelyezett hitelek terjedelmétöl, hanem szerkezetétől, összetételétől függ. A rendben megtérülő hitelek ugyanis újabb kihelyezéseket tesznek lehetővé, míg a gyakori prolongálások és késedelmes törlesztések kikezdhetik a bank hírnevét, hitelképességét.

Az elözőekből azonban az is következik, hogy a hitelképesség kétarcú jelenség: a bank hitelképessége nagyban függ azon vállalatok és szervezetek hitelképességétől, amelyekkel hitelkapcsolatban áll. Ily módon bár a bizalom a hitelkapcsolatok kezdeményezésének fontos tényezője, de létrejöttében már meghatározó szerepe a hiteladós vagyoni helyzetének, a hitelcél jellegének, a fizetőképességnek, a fedezetnek vagy biztosítéknak és a biztonságos megtérülésnek van.

A hitelkockázatot tovább súlyosbíthatja az egy hiteladós vagy egy ágazat számára kihelyezett túl nagy összegű hitel (például az eszközök és mérlegen kívüli tételek jelentős hányada összpontosul egy ágazatra vagy földrajzi régióra). Ezt a kockázatot a Magyar Nemzeti Bank a hitelezési kockázat gyüitőfogalmába teszi „koncentrációs kockázat” néven. A túlzottan koncentrált hitelezésből eredő kockázat megelőzésére, csökkentésére a bankoknak diverzifikálniuk kell kihelyezéseiket (hitelportfóliójukat) különböző hiteladósok és különböző tevékenységek között.

A hitelkockázat felismerése, kezelési módja: a legfontosabb a kitettség mértékének, ezáltal a hitelkockázat nagyságának a mérése. A várható veszteség becslésére a bankok adósminősítési rendszereket dolgoztak ki, amely már a hitelkihelyezés előtt képes az adóst, illetve az ügyletet értékelni és kockázati osztályba sorolni. A hitelek egy úgynevezett rating kategóriába kerülnek besorolásra, mely a nemfizetés valószínűségét $(\mathrm{PD})$ hivatott kifejezni.

A bankok hitelezési kockázatának csökkentésére szolgáló másik módszer a fedezet megkövetelése, amelynek értékesítéséből a bankhitel visszafizethető, ha a hiteladós normál tevékenységéből nem tudná a hitelt visszafizetni.

A hitelkockázat kezelése hitelkockázati limitek meghatározásával is megvalósul. A jövedelemarányos és fedezet arányos limiteket a bankok a belső szabályzatukban is rögzítik, de jogszabályi kötelezettség is az adósságfékek alkalmazása, főleg a lakossági hitelezés területén. 
A korábban megjegyzettek szerinti makroprudenciális politikából fakadóan, a hosszú távon fenntartható hitelezés biztosítását, valamint a válságtanulságokat szem előtt tartva, az MNB Pénzügyi Stabilitási Tanácsa 2015. január 1-jétől bevezette az adósságfék-szabályozást, amely alapvetően két fö pillérből áll. A jövedelemarányos törlesztőrészlet mutató (JTM) az ügyfelek rendszeres, legális jövedelmének meghatározott arányában korlátozza az új hitel felvételekor maximálisan vállalható törlesztési terheket és ezáltal mérsékli az ügyfelek eladósodását. A második pillér a hitelfedezeti mutató (HFM) a fedezett hiteleknél (pl. jelzáloghitelek) a fedezetek (lakásérték) arányában korlátozza a felvehető hitelek nagyságát.

A hitelezés egészséges szerkezetének fenntartásához a 2018. október 1-jétől kamatrögzítési periódusok szerint differenciált jövedelemarányos törlesztőrészlet mutató előírás is hozzájárul. A jövedelemarányos törlesztőrészlet mutató (JTM) alapján az 5 évnél rövidebb kamatperiódusú forint jelzáloghitelek felvétele esetén az adós havi törlesztőrészleteinek összege nem haladhatja meg a rendszeres havi nettó jövedelem 25, illetve magasabb jövedelem esetén 30 százalékát. Öt évnél hosszabb, de 10 évnél rövidebb kamatperiódusú új forint jelzáloghitelek esetében az arány a rendszeres havi nettó jövedelem 35, illetve 40 százaléka lehet. A legalább 10 évre vagy a futamidő végéig fixált kamatozású forint jelzáloghiteleknél - a kisebb kamatkockázat miatt - nem módosult a 2015-ös 50, illetve 60 százalékos JTM-limit. A nem forintban felvett hitelek esetében alacsonyabb limiteket kell alkalmazni (MNB 2018b).

A jövedelemarányos törlesztőrészlet mutató (JTM) és a hitelfedezeti mutató (HFM) föbb vonásait a 2. és a 3. táblázat tartalmazza. 


\begin{tabular}{|l|c|c|c|}
\hline & \multicolumn{3}{|c|}{ Kamatperiódus } \\
\cline { 2 - 4 } & Kevesebb, mint 5 év & $\begin{array}{c}\text { Legalább 5 év, } \\
\text { de kevesebb, mint 10 év }\end{array}$ & $\begin{array}{c}\text { Legalább 10 év } \\
\text { vagy végig fix }\end{array}$ \\
\hline $\begin{array}{l}400 \text { ezer forint alatti } \\
\text { havi nettó jövedelem }\end{array}$ & $25 \%$ & $35 \%$ & $50 \%$ \\
\hline $\begin{array}{l}400 \text { ezer forint vagy feletti } \\
\text { havi nettó jövedelem }\end{array}$ & $30 \%$ & $40 \%$ & $60 \%$ \\
\hline
\end{tabular}

2. táblázat: Jövedelemarányos törlesztőrészlet mutató (JTM) korlátok (százalékos értékek: A jövedelem legfeljebb mekkora \%-a fordítható hiteltörlesztésre?)

Forrás: MNB (2018b)

\begin{tabular}{|l|c|c|}
\hline & Jelzáloghitel & Gépjármúhitel \\
\hline Forinthitel esetén & $80 \%$ & $75 \%$ \\
\hline Euróalapú és euróhitel esetén & $50 \%$ & $45 \%$ \\
\hline Egyéb devizahitel esetén & $35 \%$ & $30 \%$ \\
\hline
\end{tabular}

3. táblázat: Hitelfedezeti mutató (HFM) korlátok

(értékek: Mekkora a hitel maximális elbíráláskori értéke a fedezet forgalmi értékének arányában?)

Forrás: MNB (2018b)

Az adósságfék-szabályozások célja, hogy az alacsonyabb jövedelemmel rendelkező, valamint kamatkockázatnak kitett ügyfelek is megfelelö jövedelmi tartalékkal rendelkezzenek, felkészülve ezzel a törlesztőrészletek kedvezőtlen megváltozására.

\subsubsection{Kamatlábkockázat}

Kamatlábkockázat az eszközök és források eltérő kamatláb változása miatt romló pénzáramlásának kockázata (cash flow). Ez abból ered, hogy eltérő az eszközök és források kamatérzékenysége. Az eszközöket és forrásokat akkor tekintjük kamatérzékenynek, ha az eltérő lejárat miatt jelentősen megváltozik a forrásköltség (pl. betétek után fizetett kamatok) és a kihelyezett eszközök kamatbevétele. Legjellemzőbb példája, amikor alacsony kamatkörnyezetben kihelyezett hoszszúlejáratú hiteleket évekre fixált kamatlábbal helyezi ki a bank. Azonban egy esetleges kamatkörnyezet növekedés hatására a forrásköltsége megnő a banknak 
(pl. megnő a betétek elvárt kamata), eszközeinek kamata viszont nem változik így veszteséges lesz a banki müködés.

Kamatlábkockázat felismerése, kezelésének módja: a bank szabályozni tudja a kamatkockázatot az eszközök és források lejáratainak összehangolásával, azaz, ha a kamatérzékeny eszközöket kamatérzékeny forrásokkal finanszírozza.

Minél nagyobb a kamatláb változása és minél hosszabb az eszközök, illetve források lejárata, annál nagyobb a kamatlábkockázat. A bankok az eszközök és források lejárata (kamatérzékenysége) összehangolása mellett viszonylag új módszereket, határidős kamatmüveleteket (interest rate futures) és opciókat is alkalmazhatnak a kamatkockázat csökkentésére.

\subsubsection{Likviditási kockázat}

A likviditás azt jelenti, hogy a bank folyamatosan eleget tud tenni fizetési kötelezettségeinek, azonnal teljesíteni tudja ügyfelei követelését, ha pénzt akarnak felvenni számlájukról, vagy hitelt akarnak igénybe venni. Normál körülmények között a betétek felvétele nem okozhat problémát a banknak, ha elegendő likvid eszközzel, azaz készpénzzel, jegybanki betéttel és más pénzintézeteknél elhelyezett betétekkel rendelkezik. A likviditás további forrása lehet a más bankoktól, illetve a központi banktól felvett hitel, valamint a bank eszközei között lévő értékpapírok mobilizálása.

A likviditáskezelés kulcsfontosságú banki tevékenység. A bankok különösen érzékenyek a likviditási problémákra, hiszen forrásoldalon sok likvid forrást (pl. rövid lejáratú betéteket) tartanak, de eszköz oldalon föként hosszú lejáratú illikvid hiteleket.

Számos további ok van, ami miatt a banki működéstől függetlenül is romolhat a bankok likviditási pozíciója, azonban ezeket kezelniük kell:

- Egyrészt azt, hogy fizetési kötelezettségeit milyen arányban teljesíti bankszámlapénzzel, készpénzzel vagy készpénzkímélő és -helyettesítő módozatokkal, nem a bank, hanem az ügyfél dönti el. Ennek befolyásolására azonban a kereskedelmi bankoknak kevés lehetőségük van;

- A készpénzkészlet a kereskedelmi bankoknál nem forrás, hanem eszköz. Ennek megfelelően, ha túl magas készpénzkészlettel rendelkeznek, akkor ennek arányában kevesebb hitelkihelyezésre van módjuk. Ha viszont túl 
alacsony készpénzkészletet tartanak, kifizetési nehézségei keletkezhetnek, ezért közvetlen jegybankpénzért kell fordulniuk a jegybankhoz, ami ugyancsak a hitelkihelyezési lehetőségeket korlátozza. Az indokoltnál kisebb készpénzkészlet miatt gyakori és költséges pénzszállítások merülhetnek fel;

- A készpénzkészlet mértékének meghatározásánál nem lehet eltekinteni az ügyfelek üzleti tevékenységének természetétől, a jegybanki pénzhez való jutás rendszerétől, a helyi adottságoktól, a kereskedelmi bankok hálózatának területi elrendeződésétől stb. sem.

- A bankszámlapénz formájában rendelkezésre álló likviditás biztosítása részben az ügyfelek általános pénzügyi helyzetétől, részben a bank saját üzletpolitikájától függ: a nem kielégítő fizetési morál, az ügyfelek fizetésképtelensége sok nehézséget okozhat a belső és a külső pénzforgalomban egyaránt.

A kereskedelmi bankoknak tehát - több szempontból is - elemi érdeke a likviditási problémák felismerése és készpénzkészletük optimalizálása.

A banknak a nagy likvid tartalékok fenntartása sem lehetőség, mert jellemzően a likvid eszközök alacsony jövedelmezőséget generálnak, míg a források magas költségeit fizetnie kell. Tehát magas likviditással rendelkező bankok alternatív hozamtól esnek el. A mobilizálható, likvid értékpapírok is kevesebb jövedelmet hoznak, mint a folyósított hitelek. Ha pedig a banknak kölcsönforrásokat kell igénybe vennie likviditása fenntartásához, akkor az emelkedő kamatlábak csökkenthetik eredményét.

Ezzel szemben az illikviditás kockázata, a bank csődbejutásának veszélye áll.

A likviditás kockázat veszélye különösen nagy a válsághelyzetekben. Ha megrendül az adott bankban a bizalom, vagy jelentősebb a gazdasági visszaesés, az esetleges pánik tömeges pénzfelvételt okozhat, amelyet a „bank megrohanásának" is szoktak nevezni.

A finanszírozási források és a lejáratok diverzifikálása lehetővé teszi, hogy a bank elkerülje a likviditási zavarokat, ehhez azonban fejlett likviditáskezelési menedzsment és finanszírozási stratégia szükséges. 
Ha a kereskedelmi bankok nem rendelkeznek a napi forgalom lebonyolításához elegendő egyenleggel a likviditási tartalékok mozgósítására kerül sor, amelynek keretében:

- intézkedni kell a követelések behajtásáról;

- hitelt kell felvenni a bankközi kapcsolatokban;

- jegybanki pénzért kell folyamodni.

A likviditás forrása lehet a forgalomképes, azonnal értékesíthető értékpapírok birtoklása. Azonban az értékpapír csak úgy testesítheti a likviditási funkciót, ha kereslet is van iránta. Ezért egy rendszerszintü likviditási válságban csak korlátozottan tudja betölteni likviditási funkcióját.

\subsubsection{Mérlegen kívüli kockázat}

Az utóbbi években megnőtt a száma azoknak az új pénzügyi eszközöknek, amelyeket a mérlegen kívüli tételek között tartanak nyilván. A bankok kockázati ellenőrzésének ezeket az eszközöket is figyelembe kell vennie. Az ellenőrzést meglehetősen bonyolulttá teszi, hogy e fogalomba sokféle, különböző természetü művelet tartozik (banki kezességvállalások, banki garanciák, határidős ügyletek, egyéb szerződéses kötelezettségek).

\subsubsection{Befektetési kockázat}

Az MNB 11/2017. (XI.06.) számú ajánlás szerint a befektetési kockázat: bizonyos (tipikusan hitelviszonyt vagy tulajdoni viszonyt megtestesítő értékpapírokba való) befektetések kockázata (a kifizetések nem a szerződésnek megfelelően történnek); A hitelek mellett a bankok jelentős értékpapír állományt is tartanak, egy részét befektetési szempontok miatt, másrészt likvid tartalékként. A banki üzletág ezért összefonódik a tőkepiacok üzletével. A befektetési kockázat a bank befektetéseinek esetleges értékvesztéséből következik. A befektetési kockázat különösen jelentős a befektetési bankok körében. A leggyakoribb fajtái a részvénykockázat ami a részvényárfolyam-ingadozásokból eredő potenciális veszteségeket jelenti, valamint az árucikk-kockázat (a mezőgazdasági, ipari és energiatermékek, például a búza, a réz és a földgáz árának ingadozásából eredő potenciális veszteségek). 
Befektetési kockázat felismerése, kezelésének módja: az ilyen kockázatok mérséklése érdekében a bankok fedezeti szerződéseket használnak. Például a kockázatnak kitett pozícióval ellentétes irányú pénzügyi derivatívákat használnak, amelyek bármely pénzügyi piacon szabadon értékesíthetők. Az olyan szerződések, mint a határidős, opciós és swap ügyletek a bankok mérlegéből szinte teljesen megszüntethetik a befektetési kockázatokat. Azonban a nem meglévő kockázat lefedezésére szolgáló (spekulációs) swap ügyletek, opciók, a tőzsdei és a tőzsdén kívüli határidős szerződések használata növeli a bankok befektetési kockázatát.

\subsubsection{Valutakockázat}

A valutakockázat, amelyet árfolyamkockázatnak is neveznek, az egyik valuta árának a másikhoz viszonyított változásából ered. A nem csak hazai pénzeszközöket tartó hitelintézetek vagy nemzeti határokon átnyúló üzleti tevékenységet folytató bankok olyan valutakockázatnak vannak kitéve, amely kiszámíthatatlan nyereséget és veszteséget okozhat.

A valutakockázat csökkentése érdekében az bankoknak fontolóra kell venniük az olyan valutáknak a tartását és olyan országokba történő befektetését, amelyek erősen gyengülő valutákkal rendelkeznek.

A valutakockázat csökkenthető a fedezeti ügyletekkel (swap, határidős devizaműveletek és opciók), ami ellensúlyozza a devizaárfolyam-ingadozásokat.

\subsubsection{Nyereség és jövedelemszerkezet romlása}

A nyereségességi adatokban, marginokban bekövetkezett jelentős változás kockázata. Adódhat a hitelfelvevők számának jelentős változásából (csökkenéséből), rossz költségszerkezetből, de akár a rosszul meghatározott kamatokból is.

Minél nagyobb a hitel visszafizetési kockázata, annál magasabb kamatot számolnak fel a bankok, hogy fedezni tudják az esetleges veszteséget. Azonban, ha a hitelportfólió romlik, és ezt nem követi a kockázati kamatrés emelése, az rontja a nyereséget és jövedelemszerkezetet. Hasonló végeredményt okoz, ha a versenytársaknál lényegesen magasabb személyi és dologi kiadásokat enged meg a bank, ha ezt nem követi hatékonyságjavulás, akkor hosszútávon piaci hátrányba kerül.

A nyereséget és jövedelemszerkezetet folyamatosan kontrollálnia és nyomon kell követnie a banknak. A működés ellenőrzése során a bank érintett területei- 
nek időszakos vizsgálatával meggyőződnek arról, hogy a kiadások és bevételek, hitelkihelyezési folyamatok és a kamatrések összhangja megfelelö.

\subsubsection{Tökemegfelelés elégségessége}

Minden hitelintézetnek a müködőképesség fenntartása és a kötelezettségek teljesíthetősége érdekében megfelelő nagyságú szavatoló tőkével kell rendelkeznie a végzett tevékenység kockázatának megfelelően.

A bankoknak más szektoroktól eltérően nem csak bizonyos minimális jegyzett tőkével kell rendelkezniük, hanem a folyamatos müködés során a szavatoló tőkének meghatározott minimális arányt kell képviselnie a (korrigált) mérlegföösszeghez viszonyítva. A banki forrásoldal nagy része idegen forrás (pl. betétek, bankközi és jegybanki hitel), ezért a szavatoló tőkének a kockázatok bekövetkezése esetén kell fedezetet biztosítania.

Tőkemegfelelés elégtelenségének felismerése, kezelésük módja: az egységes és prudens kockázatkezelés feltételeként az intézmény megfogalmazza kockázatkezelési alapelveit, melyet az egész szervezeten belül egységesen elvár. Az intézménynek meg kell határoznia, hogy a kockázat és a hozam milyen mértékủ átváltását fogadja el stratégiai szinten, illetve, hogy a tényleges kockázatoknak mekkora a tőkeszükséglete.

A tőkemegfelelést a fizetőképességi mutatóval (szolvencia rátával) kell kifejezni. A megállapítása az alábbi képlettel történik:

Szavatoló töke

[Kockázattal súlyozott eszközök + (Piaci kockázat tökekövetelménye $\times 12,5)$

+ (Mükködési kockázat tökekövetelménye x 12,5)]

A szavatoló tőke számítását a 2013. évi CCXXXVII. törvény. a hitelintézetekről és a pénzügyi vállalkozásokról tartalmazza. A mérlegföösszeg a számviteli szabályok által meghatározott összeg. A korrigált mérlegfőösszeg (kockázattal súlyozott kitettség) külön jogszabályban meghatározott, kockázati tényezők figyelembevételével súlyozott szorzószámok alapján kiszámított eszközök és mérlegen kívüli tételek összege. 
Tőkemegfelelés 8\%-os szint alá csökkenés a szolvencia kritikus pontját jelöli. A szavatoló tőke (pl. jegyzett tőke) növelésével, illetve a kockázatos eszközök csökkentésével kezelhető.

\subsection{Müködési kockázatok}

A müködési kockázat összefügg a bank költségstruktúrájával és az alkalmazottak hatékony munkájával. Bázel II ajánlását figyelembe véve a működési kockázatokra a következő definíciót használjuk: Müködési kockázat az emberek szándékosságából vagy hanyagságából, a munkafolyamatok hibás lebonyolítási eljárásából, lényeges erőforrások, rendszerek hibájából, kieséséből, vagy fizikai károsodást okozó kisebb-nagyobb külső eseményekből fakadó károk veszélye (beleértve a jogszabálysértésből adódó, de ide nem értve a stratégiai, illetve reputációs kárveszélyt). A működési kockázatok főbb csoportjai a következők:

\subsubsection{Belső csalás}

A bank dolgozóinak jogosulatlan tevékenysége, szélsőséges esetben a lopás és csalás (pl. tranzakciók jogosulatlan végrehajtása, szándékos téves jelentés, alkalmazotti lopás, bennfentes kereskedés). Ide tartoznak a végrehajtott tranzakciók eltitkolása (jelentés, dokumentáció elmulasztása), adat szándékos megváltoztatása, hütlen, illetve hanyag kezelés is.

A bankok jól kialakított belső ellenőrzési és számviteli rendszere megfelelő eszköz lehet mind a hagyományos, mind az elektronikus belső csalások megelőzésére.

Jellemzően csalás miatt a bankok sokkal nagyobb veszteségeket szenvednek el, mint amennyi napvilágra kerül. Ennek az a magyarázata, hogy a bankok hírnevét csorbítaná, hogy a bank belső vagy külső csalók áldozatává vált, akár „bankroham”-hoz is vezethetne, ami még nagyobb veszteséget okozna a hitelintézetnek.

\subsubsection{Külső csalás}

A bankon kívüli személyek csalása és lopása, rendszerbiztonság áthágásából fakadó problémák. Például: betörés, aláírás hamisítás, számítógépes csalás, hivatali zsarolás, számla feletti ellenőrzés megszerzése hamis személyazonossággal vagy más jelszavával, jogosulatlan számlahozzáférés. 
Súlyos rendszerbiztonsági hiányosság például még a banki ügyféladatok lopása és azzal való visszaélés.

A külső csalások visszaszoríthatóak az elektronikus bankbiztonság erősítésével: papíralapú feldolgozás és manuális aláirás-ellenőrzés csökkentése, feladatok digitalizálása (pl.: a pénzmosásra utaló jelek felfedezése), jogosultsági körök kialakítása és a többfokozatú személyazonosítás mind ennek a kockázatnak a csökkentésére irányul.

\subsubsection{Foglalkoztatási gyakorlat és a munkahelyi biztonság}

Ebbe a kockázati fajtába tartoznak az alkalmazotti kapcsolatokból eredő veszteségek, biztonságos munkahelyi környezet hiánya, diszkriminációs cselekmények (pl. munkahelyi biztonsági szabályok megsértése). Ezek a hírnévben való romlás mellett egyéni és csoportos bírósági térítésigényeket is előidézhetnek, amik jelentős költséggel járnak.

Ezért a bankok kiemelt figyelmet fordítanak a munkakörnyezet fizikai biztonságának hiányosságából adódó és az általános felelősségi körbe tartozó kárigényt eredményező események (diszkrimináció, munkahelyi zaklatási esetek, munkaegészségügyi és munkavédelmi szolgáltatások hiányosságából adódó sérülések) elkerülésére.

\subsection{4. Ügyfelek, termékek és üzleti szolgáltatások}

Ez a kockázat a hibás, rossz banki termékkonstrukciók alkalmazásából eredő lehetséges veszteségeket tartalmazza. A hirdetmények, szabályzatok rossz, félreérthető vagy hiányos megfogalmazásából és aktualizálás elmulasztásából fakadó veszteségeket foglalja magában. Ide tartozik még a titoktartási kötelezettség megszegése, bizalmas információval történő visszaélés, illetve egyéb bizalmi viszony megsértése (pl. bizalmas ügyféladatok kiadása, pénzmosás, engedélyezetlen termékek eladása, szabálytalan kereskedés, illetve piaci tevékenység).

\subsubsection{Eszközök fizikai károsodása}

A munkaeszközök, és banki értékek nem várt romlásával és megsemmisülésével kapcsolatos kockázat. Szélsőséges esetben a bank eszközeiben katasztrófák és egyéb események (pl. természeti katasztrófák, külső forrásból származó emberi veszteségek, terrorizmus, szándékos károkozás) miatt bekövetkezett rendkívüli értékcsökkenést jelenti ez a kockázat. 


\subsection{6. Üzleti zavarok és rendszerhibák (technológiai kockázatok)}

Számítógépes rendszerek hibájából fakadó veszteségnek a kockázata. Anyagi veszteségek mellett jelentős költséggel jár egy banknak az üzletmenet leállása hardver, telekommunikációs eszközök vagy szoftver meghibásodása miatti üzemszünetben.

Az informatikai javítási költségeken túl a banki működés leállítása, esetleges adatveszteségek is jelentős veszteséget okozhatnak a bankoknak.

Vészhelyzeti és üzletmenet-folytonossági terveket kell ezért készíteni a hitelintézetek folyamatos müködésének, valamint a súlyos üzletviteli fennakadások esetén bekövetkező veszteségek mérséklésére.

\subsubsection{Végrehajtás és folyamatmenedzsment}

Téves vagy fölösleges tranzakciók végrehajtásából, hiányos dokumentáció- és ügyfélnyilvántartásból származó esetleges veszteségek (pl. adatrögzítési hibák, nem teljes jogi dokumentáció, kereskedelmi partnerrel felmerülő problémák).

Jelentős károkat okozhat a hibás adatbevitel, a rossz folyamatmenedzsment (határidő vagy feladat végrehajtásának elmulasztása), hibás könyvelés, elszámolás, nyilvántartás illetve törzsadatok, referenciaadatok hibás karbantartása.

A konkrét pénzbeli veszteségen túl jelentkezhet veszteségként a nyílvánosság bizalmának elvesztése.

\subsection{Szabályozási és környezeti kockázatok}

\subsubsection{Ország- és politikai kockázatok}

Az országkockázat a hitelkockázat egy különleges fajtája. Olyan veszteség felmerülésének veszélyét jelenti, melyet az országban bekövetkező valamilyen, az adott ország (kormányzat) által kontrollálható, de a hitelező, illetve befektető által nem kontrollálható esemény generál (gazdasági, politikai, stb.). Ha egy országban anynyira romlik a gazdasági helyzet, hogy az ország nem tud, vagy nem akar külföldi valutában fennálló fizetési kötelezettségeinek eleget tenni, akkor a teljes pénzügyi szektor fizetési nehézségekkel fog szembesülni. Azonban a helyzet fokozódásával, ha az állam, mint hiteladós nincs abban a helyzetben, hogy teljesítse adósi kötelezettségeit, ott jellemzően politikai vagy társadalmi nyugtalanságok, államosítások 
és kisajátítások vannak. Az országkockázatba tehát azokat a kockázati elemeket kell belefoglalni, melyek nem speciálisan egy adott hitelfelvevőhöz kötődnek, hanem általában annak az országnak a politikai-gazdasági helyzetéből adódnak, amelyben a hitelfelvevő székhelye van. A szuverén kockázat az országkockázat altípusa, és annak az országnak a fizetésképtelenségéből adódó kockázatot jelenti, amellyel szemben a pénzügyi szervezetnek kitettsége van.

\subsubsection{Makrogazdasági politika}

Az elmúlt évtizedek bizonyították, hogy a pénzügyi válságok kialakulását és következményeit nehéz előre jelezni, mert nehéz vizsgálni egy még nem létező válság nem tudott okait, vagy egy ma még nem ismert pénzpiaci terméket, piaci mechanizmust. A válságok megelözésére azonban a makrogazdasági politika próbál szabályokat hozni.

A makroprudenciális politika egyik fó célja, hogy a túlzott kockázatvállalást megfékezze és korlátozza. Azonban előfordul, hogy a monetáris politika ellentétes hatást vált ki: a hosszú távú viszonylag alacsony kamatlábak hozzájárulnak a banki kockázat növekedéséhez. A túlzott eladósodottságnak és tőkeáttételek kialakulásának kedvez az alacsony kamatpolitika, tehát a monetáris politika a pénzügyi stabilitás szempontjából nem semleges.

\subsubsection{Pénzügyi infrastruktúra}

A pénzügyi infrastruktúra fejlettsége nagyban hozzájárul a bankok várható jövedelemtermelő képességéhez, kockázat tehát, ha a hitelintézetek nem szilárd jogi, szabályozási és pénzügyi infrastruktúrával rendelkező környezetben müködnek, akkor jelentős veszteséget szenvedhetnek el.

A pénzügyi szektor fejlesztése több lépést foglal magában, amelyek biztosítják, hogy az intézmények stabil és életképes infrastruktúrával tudjanak pénzügyi szolgáltatásokat nyújtani.

Ennek egyik alapfeltétele például a fejlett átutalások és beszedések bankközi elszámolását végző fizetési rendszer (Magyarországon GIRO Zrt. által működtetett Bankközi Klíring Rendszer (BKR)), tőzsderendszer, illetve egyéb, a különböző pénzügyi, illetve befektetési szolgáltatók közötti saját és közvetített fizetési és értékpapír forgalom elszámolását, az ügyletek pénzben, illetőleg értékpapírban történő teljesítését lehetővé tévő mechanizmusok. 


\subsubsection{Szabályozási kockázat}

A bankfelügyeletek elsődleges szerepe az, hogy a kockázatkezelési folyamatban segítő szerepet töltsön be és figyelemmel kísérje a kockázatkezelés alapjául szolgáló törvényi kereteket.

Azonban a szabályozó hatóságok amellett, hogy megfelelő környezetet teremtenek a bankműködéshez, szabályaikkal döntő szerepet játszanak a bankok jövedelemtermelő képességének javításában vagy épp rontásában.

A szabályozási kockázat annak a kockázata, hogy a törvények és rendeletek megváltoztatása jelentősen befolyásolja a biztonságot, az üzletet, az ágazatot vagy a piacot. A kormány vagy a szabályozó szerv törvényi/rendeleti változásai növelhetik a vállalkozás múködtetésének költségeit, csökkenthetik a befektetés vonzerejét, vagy megváltoztathatják a versenyképességet. A pénzügyi intézmények szabályozási kockázattal szembesülnek a tőkekövetelményekkel, a szolgáltatásokkal és termékekkel kapcsolatban.

Egyik legnagyobb hatású nemzetközi példa a Glass-Steagall törvény - amely megtiltotta a kereskedelmi bankoknak, hogy vállalati értékpapírokat vásároljanak, illetve garantáljanak (underwriting) -, ami valóban megakadályozza, hogy a bank bizonytalan teljesítményü vállalatok értékpapírjait vegye meg, de egyúttal csökkenti annak lehetőségét, hogy diverzifikálja hitelportfólióját.

A kamatláb szabályozás is befolyásolja a bankok nyereségét, ezáltal kockázatot jelent. Magyarországon (2018-ban) pénzügyi intézmény nem nyújthat olyan kölcsönt, amelynek teljes hiteldíjmutatója 24 százalékponttal több, mint a jegybanki alapkamat. Hitelkártya szerződéshez vagy fizetési számlához kapcsolódó, valamint - a gépjárművek kivételével - a tartós fogyasztási cikkek megvásárlásához és szolgáltatások igénybevételéhez nyújtott kölcsön THM-je legfeljebb 39 százalékponttal haladhatja meg az alapkamatot.

Ebből kifolyólag a pénzügyi intézmények szabályozási kockázattal szembesülnek, amelyek olyan eseményekből eredhetnek, mint például a díjszabás központi megváltozása, ami megnehezítheti az üzleti tevékenységet. 


\subsubsection{Pénzügyi vagy banki válság}

Pénzügyi válságok vagy más gazdasági ciklusok kockázata, amelyek hátrányosan befolyásolják a bank nyereségét.

Az üzleti vagy gazdasági ciklus csúcsa és mélypontja között a hitelfelvevők visszafizetési hajlandósága csökkenhet, ami alacsonyabb nyereséget és a jövőbeni hozamokkal kapcsolatos bizonytalanságot okoz.

Általánosságban a ciklikus kockázatok rendszerszintű kockázatok, amelyek nagymértékben befolyásolják a piacgazdaságot, védekezni ellenük rendkívül nehéz.

A banki válság ellenállóságát azonban javítja, ha az országok között diverzifikálja a hitel és betét portfólióját, valamint olyan ágazatokat részesít előnyben, amik kevésbé korrelálnak a gazdasági volatilitással. Ezek például a gyógyszeripari, élelmiszeripari, az erőforrásokra, a vízre és a gázra összpontosító iparágak. Ezzel ellentétben növeli a bank a pénzügyi válság kitettségét, ha luxuscikkekre, szórakoztatásra és szabadidőre összpontosító, azaz a gazdasági növekedésnek kitett ágazatokra koncentrál csak.

\subsection{Kockázatok kezelése a treasury menedzsmenttel}

A treasury menedzsment egy rendkívül specializált banki terület, amely a banknak, illetve a private ügyfeleknek, az intézményi és vállalati ügyfeleknek kezeli a likviditását, és kontrollálják azok müködési, pénzügyi kockázatát. A treasury menedzsment végzi a főbb befektetési és finanszírozási tevékenységeket: kötvényekkel, valutákkal, pénzügyi derivatívákkal kereskedhet és a kapcsolódó pénzügyi kockázatokat kezeli is.

A legtöbb banknak teljes szervezeti egysége van a treasury menedzsmentre. Egészen a közelmúltig a nagyméretü bankok voltak az elöljárók a treasury szolgáltatások biztosításában. Ugyanakkor a kisebb bankok egyre inkább elindítják és/vagy bővítik treasury funkcióikat és kínálatukat, mivel a jelenlegi alacsony kamatkörnyezetben a megtakarítók egyre inkább igénylik a hagyományos betétek helyett a magasabb hozamú (és kockázatú) pénzügyi termékeket. 


\subsection{Irodalomjegyzék}

Gálfalvi Géza, Kovács Erika, Palasikné Kirschner Dóra, Seregdi, László (2016):

Kommentár a hitelintézeti törvényhez. Kiadó Wolters Kluwer Hungary. ISBN: 978-963-2956-01-5

MNB (2018a): Magyar Nemzeti Bank Pénzügyi és stabilitási jelentés 2018. 11.29. https://www.mnb.hu/letoltes/penzugyi-stabilitasi-jelentes-prez-20181129. pptx

MNB (2018b): Magyar Nemzeti Bank Adósságfék szabályok https://www. mnb.hu/sajtoszoba/sajtokozlemenyek/2018-evi-sajtokozlemenyek/ az-mnb-az-adossagfek-szabalyok-modositasaval-is-osztonzi-a-fix-kamatozasu-lakashitelek-ternyereset

Varga József, Parádi-Dolgos Anett (2014): Bankok, pénzintézetek. In: Parádi-Dolgos Anett (szerk.) Gazdasági és vállalkozási ismeretek. 230 p. Kaposvár: Kaposvári Egyetem Gazdaságtudományi Kar, 2014. pp. 174-227. ISBN: 978-963-9821-69-9

Van Greuning, Hennie; Brajovic Bratanovic, Sonja (2009): Analyzing Banking Risk. ISBN: 978-0-8213-7728-4 , https://doi.org/10.1596/978-0-8213-7728-4 MNB 11/2017. (XI.06.) számú ajánlás: A Magyar Nemzeti Bank 11/2017. (XI.06.) számú ajánlása a hitelkockázat méréséről, kezeléséről és kontrolljáról https://www.mnb.hu/letoltes/11-2017-hitelkockazati-ajanlas.pdf 


\section{Jelzálog-hitelintézetek}

\subsection{Jelzálog-hitelintézet, zálogjog, önálló zálogjog, jelzálogjog fogalma. Jelzálog-hitelintézet elhelyezése a pénzügyi intézmények között}

A jelzálog-hitelintézet pénzügyi intézmény, ezen belül szakosított hitelintézet. E fogalmakat a 2013. évi CCXXXVII. törvény a hitelintézetekről és a pénzügyi vállalkozásokról (a továbbiakban: Hpt.) ekként definiálja:

„A hitelintézet bank, szakosított hitelintézet vagy - részvénytársasági vagy szövetkezeti formában müködő - szövetkezeti hitelintézet lehet."

Hpt. 3. §. (1) definiálja a pénzügyi szolgáltatások teljes körét is.

„A szakosított hitelintézet a rá vonatkozó külön törvényi szabályozásnak megfelelöen jogosult tevékenységének végzésére, azzal, hogy nem kaphat engedélyt a $3 . \$(1)$ bekezdésében foglalt tevékenységek teljes körének végzésére."

A pénzügyi szolgáltatások teljes körének végzésére a hitelintézetek közül a bank kaphat engedélyt, tehát a szakosított hitelintézet tevékenységi köre, ahogy neve is mutatja, ehhez képest mindig korlátozott.

Ahogy a Hpt. kimondja, minden szakosított hitelintézetnek megvan a saját, külön törvényi szabályozása. Ez a törvény a jelzálog-hitelintézet esetében a többször módosított 1997. évi XXX. törvény a jelzálog-hitelintézetről és a jelzáloglevélről (Jht.).

\section{Zálogjog, jelzálogjog, önálló zálogjog fogalma}

A zálogjog a dologi biztosítékok egyik formája. A zálogjog által biztosított követelés nem teljesítése esetén nyílik meg a lehetősége a zálogjogosultnak, hogy követelését az adott zálogtárgyból elégítse ki.

A zálogtárgy birtoklási jogosultsága szempontjából két változat létezik: kézizálogjog és a jelzálogjog.

Utóbbi esetében a zálogtárgy továbbra is, változatlanul a zálogkötelezett birtokában marad, aki jogosult annak korábbi használatára, hasznosítására. 
Az elzálogosítás tehát „jel”, vagyis jelzés jellegű, fizikai birtoklás nincs a zálogjogosultnál. Az elzálogosítás írásba foglalt zálogszerződéssel és a zálogjognak a nyilvántartásba való bejegyzésével valósul meg. Zálogtárgy szempontjából több forma létezik. Alapvető az ingatlanra alapított jelzálogjog, mert az ingatlan, mint bankári biztosíték értékálló, tartós, így alkalmas a hosszú futamidejű finanszírozásra. A jelzálogjog történelmi kialakulása is ezt bizonyítja, hiszen a földalapú finanszírozás szükségessége hívta életre.

A zálogjog járulékos természetü szerződéses biztosíték. A járulékos jellegből egyrészt az következik, hogy a követelés (főkötelem) megszűnése esetén a zálogjog is megszünik, másrészt, hogy a követelés csak a zálogjoggal együtt ruházható át.

Az önálló zálogjog - ahogy neve is jelzi - elveszíti a járulékos jellegét és egy különálló, forgalomképes dologi jogot jelent.

Az önálló zálogjog alkalmazása a gyakorlatban a kereskedelmi bankok kölcsön ügyleteinél jelenik meg.

Amennyiben egy kereskedelmi bank kölcsönt nyújt egy magánszemély részére, zálogjogot alapítanak a magánszemély ingatlanán a kereskedelmi bank, mint zálogjogosult javára, a kölcsön biztosítása érdekében. Ezt követően van lehetősége a kereskedelmi banknak, hogy a zálogjogot átengedje, jellemzően egy jelzálogbanknak. Ekkortól a jelzálogbank lesz jogosult az eredeti követelés meghiúsulása esetén a zálogtárgyból, mint jogi biztosítékból történő kielégítésre.

2014 előtt a pénzügyi intézmények saját maguk dönthették el, hogy milyen típusú zálogjogot alapítanak hiteleik biztosítékaként.

2014. március 15., azaz az új Polgári Törvénykönyv hatályba lépését követően a törvény nem biztosított lehetőséget önálló zálogjog alapítására (különvált zálogjog). Ez idő alatt erősen mérséklődött a piacon a jelzáloglevél kibocsátás.

A 2016. október 1-jével hatályba lépett Polgári Törvénykönyv módosítás ismét lehetővé teszi az önálló zálogjog létrehozását.

Az önálló zálogjog visszaállítására a jogalkotók szerint azért volt szükség, mert megnőtt a hitelezők kockázata azáltal, hogy a jelzálogbank követelésének érvényesítésére a gyakorlatban a hitelek tényleges lefutási idejénél lényegesen kevesebb idő állt rendelkezésre. A jelzálogbank nem tudta a kereskedelmi bank- 
kal szemben fennálló követelésétől függetlenül átruházni a zálogjogát, ezáltal a megtérülési esélyek romlottak a számára, ezt a kamatok emelésével tudta kompenzálni.

Az önálló zálogjog visszaállítása - több vitatott hatása mellett - összességében kedvez a hitelezési volumen növekedésének, szerves részét képezi a jelzáloghitelezés jogszabályi hátterében történt további élénkítő változtatásoknak és összhangba került az európai pénzügyi szabályozással.

\subsection{A jelzálog-hitelezés jogszabályi háttere}

A jelzálog-hitelintézet müködésének jogszabályi hátterét a többször módosított 1997. évi XXX. törvény a jelzálog-hitelintézetről és a jelzáloglevélről képezi (továbbiakban Jht.).

Fontosabb fejezetei:

- JELZÁLOG-HITELINTÉZET

- A jelzálog-hitelintézet alapítása

- A jelzálog-hitelintézet fogalma, tevékenységi köre

- Jelzáloghitelezés

- Befektetések korlátozása

- Ingatlanbefektetések korlátozása

- A JELZÁlogLEVÉL

- Jelzáloglevél kibocsátásának módja, feltételei

- A jelzáloglevelek fedezete

- Jelzáloglevélből eredő kötelezettség átszállása

- Vagyonellenőr megbízása

- A vagyonellenőr tevékenységi köre, kötelezettségei

- Tájékoztatási kötelezettség

- FIZETÉSKÉPTELENSÉG ESETÉRE IRÁNYADÓ SZABÁLYOK

- Jelzálog-hitelintézet felszámolása

- Jelzálog-hitelintézet elleni végrehajtási eljárás

- A FELÜGYELET ELLÁTÁSÁNAK ESZKÖZEI

- A jelzálog-hitelintézet különleges felügyelete

- Intézkedés és kivételes intézkedés

- Bírságok 
A Jht. célja: a gazdasági növekedéshez szükséges hosszú lejáratú kölcsönnyújtás lehetőségének javítása. Alkalmazni a Magyarországon alapított és müködő jelzálog-hitelintézetre és a jelzáloglevélre kell.

A jelzálog-hitelintézet tevékenysége kettős: egyik oldal a pénzügyi szolgáltatási, a másik a befektetési szolgáltatási és kiegészítő befektetési szolgáltatási tevékenységcsoport. Ez világosan mutatja az intézményi forma kettős jellegét is: az első a hitelintézeti jelleg, míg a másik a befektetési jelleg.

A jelzálog-hitelintézet alapítására, működésére, felügyeletére a hitelintézetekről és a pénzügyi vállalkozásokról szóló 2013. évi CCXXXVII. törvény (a továbbiakban: Hpt.), a jelzálog-hitelintézet befektetési szolgáltatási tevékenységére és befektetési szolgáltatási tevékenységet kiegészítő szolgáltatására a befektetési vállalkozásokról és az árutőzsdei szolgáltatókról, valamint az általuk végezhető tevékenységek szabályairól szóló 2007. évi CXXXVIII. törvény rendelkezéseit kell alkalmazni.

Jelzálog-hitelintézet legalább hárommilliárd forint induló tőkével alapítható, melyet pénzben kell befizetni.

Jelzálog-hitelintézet nem köteles csatlakozni az Országos Betétbiztosítási Alaphoz.

A továbbiakban tekintsük át a Jelzálog-hitelintézet fogalmát és tevékenységi körét:

A jelzálog-hitelintézet pénzkölcsönt nyújt Magyarország, az Európai Unió más tagállama vagy az EGT-államok területén lévő ingatlanon alapított jelzálogjog - ideértve az önálló zálogjogként alapított, átalakításos önálló zálogjoggá átalakított, valamint a különvált jelzálogjogot is - fedezete mellett, amelyhez forrásait alapvetően jelzáloglevél kibocsátásával gyüjti.

A jelzálog-hitelintézet az alábbi pénzügyi szolgáltatási, befektetési szolgáltatási, illetve kiegészítő befektetési szolgáltatási tevékenységeket végezhet:

- visszafizetendő pénzeszköz nyilvánosságtól történő elfogadása, ide nem értve a betét gyüjtését,

- pénzkölcsön nyújtása, ingatlanon alapított jelzálogjog fedezete mellett,

- jelzálogjog kikötése nélküli kölcsönök nyújtása állami készfizető kezességvállalás esetén, 
- kezesség, garancia és egyéb bankári kötelezettség vállalása (együttesen: bankári kötelezettség),

- letéti szolgáltatás, saját kibocsátású értékpapírhoz kapcsolódóan értékpapír-letétkezelés, letéti őrzés, értékpapír-számla vezetés, ügyfélszámla vezetés,

- saját kibocsátású jelzáloglevél, kötvény, továbbá letéti jegy forgalomba hozatalának szervezése és az ehhez kapcsolódó szolgáltatás nyújtása.

A jelzálog-hitelintézet az előzőekben felsorolt pénzügyi, befektetési, illetve kiegészítő befektetési szolgáltatáson kívül üzletszerüen kizárólag ingatlanok forgalmi és hitelbiztosítéki értékének meghatározását végezheti.

A törvény 2006. évi módosítása a tevékenység lehetőségeit kiterjeszti a Magyarországon kívüli EGT-államok területére is. Meghatározza, hogy ott lévő ingatlanfedezet mellett akkor nyújthat pénzkölcsönt (EGT-jelzáloghitel), illetve vásárolhat meg, előlegezhet meg és számítolhat le jelzáloghitelt (EGT-jelzáloghitel-vásárlás), ha a fedezetként szolgáló ingatlant a jelzálog-hitelintézet javára alapított olyan jelzálogjog terheli, amely a zálogjogosult részére a magyar jog szerinti jelzálogjoggal azonos biztonságot nyújt és ezen feltételeket részletesen felsorolja.

Lényeges korlátozás, hogy a jelzálog-hitelintézet bankári kötelezettséget csak ingatlan fedezet kikötése mellett és kizárólag azon ügyfele részére vállalhat, akinek (amelynek) jelzáloghitelt nyújtott. Ez a korlátozás érvényes a letétkezelési tevékenységre is: jelzálog-hitelintézet letéti szolgáltatást kizárólag azon ügyfele részére végezhet, akinek (amelynek) jelzáloghitelt nyújtott.

A Jht. rögzíti a jelzáloghitelezési tevékenység fedezettségre vonatkozó szabályait is:

A jelzáloghitel ügylet létrejöttekor, vagyis a kölcsönszerződések megkötésekor, a jelzáloghitelek megvásárlásakor, a különvált jelzálogjog fedezete mellett történő pénzkölcsönnyújtáskor, és az önálló és átalakításos önálló zálogjog megvásárlásának időpontjában a legalább ötéves futamidejű jelzálog-hitelintézeti követelések aránya a hitelállományban nem lehet kevesebb nyolcvan százaléknál.

A jelzáloghitelekből, a refinanszírozási jelzáloghitelekből, valamint az önálló zálogjog visszavásárlásából eredő, továbbá a különvált zálogjog átruházásával 
biztosított követelésállomány nem haladhatja meg a fedezetül szolgáló ingatlanok együttes hitelbiztosítéki értékének hetven százalékát.

A jelzálog-hitelintézet által kötött jelzáloghitel-szerződést, az azonos vagy külön okiratba foglalt zálogszerződéssel együtt, kötelező közjegyzői okiratba foglalni.

A törvény részletesen szabályozza, hogy a jelzálog-hitelintézet

- milyen jellegű jelzáloghitel-szerződésből vagy kapcsolódó kölcsönszerződésből eredő követelést vásárolhat meg pénzügyi intézménytől, illetve biztosító részvénytársaságtól;

- milyen jellegü - Magyarország területén lévő ingatlanon alapított - önálló zálogjogot vásárolhat meg;

- milyen jellegü - Magyarország területén lévő ingatlanon alapított - különvált zálogjog fedezete mellett nyújthat hitelintézetnek refinanszírozási jelzáloghitelt és mely feltételekkel.

Jelzálog-hitelintézet által szerezhető befektetések szabályai: csak olyan gazdasági társaságban szerezhet, illetve tarthat meg tulajdoni hányadot, amely ingatlanok kezelésével, hasznosításával, értékesítésével összefüggő tevékenységet végez, de együttes mértéke nem haladhatja meg a jelzálog-hitelintézet szavatoló tőkéjének tíz százalékát.

Ugyanígy erősen korlátosak az ingatlanbefektetések feltételei is:

- Jelzálog-hitelintézet a szavatoló tőkéje öt százalékát meghaladó mértékben ingatlanokat - a közvetlen banküzemi célt szolgáló ingatlanokon kívül - kizárólag

a) a pénzügyi szolgáltatásból származó veszteség mérséklése, illetve elhárítása érdekében hitelingatlan csereügylet, továbbá

b) az adósa ellen indított felszámolási vagy végrehajtási eljárássorán szerezhet.

- A megszerzett ingatlanokat hat éven belül nyilvános árverésen el kell idegeníteni.

- A mező- és erdőgazdasági földek forgalmáról szóló törvény szerinti mezőés erdőgazdasági hasznosítású földnek minősülő ingatlan a jelzálog-hitelintézet tulajdonába csak átmenetileg, a szerzés időpontjától számított legfeljebb egy éves időtartamra, felszámolási vagy végrehajtási eljárás útján kerülhet. 
- Ha a jelzálog-hitelintézet a tulajdonába került földet a szerzés időpontjától számított egy éven belül nem tudja értékesíteni, a föld az állam tulajdonába és a Nemzeti Földalapba kerül.

A jelzáloglevél kizárólag a jelzálog-hitelintézet által a törvény alapján kibocsátott névre szóló, átruházható értékpapír. A Magyarország területén előállított jelzáloglevélre a kötvényre vonatkozó jogszabályi rendelkezéseket kell alkalmazni.

A jelzáloglevélnek az alábbi tartalmi elemeket kell magában foglalnia:

a) a jelzáloglevél elnevezést;

b) a kibocsátó megnevezését és cégszerű aláirását;

c) a jelzáloglevél tulajdonosának megnevezését;

d) a jelzáloglevél sorozatának betűjelét, a jelzáloglevél kódját, sorszámát;

e) a jelzáloglevél névértékét;

f) a kamat mértékét, a kamatszámítás módját;

g) változó kamatozás esetén:

- az induló kamatláb mértékét,

- a kamatláb változtatásának elveit,

- a kamat számításának módját;

h) a jelzáloglevél lejáratát;

i) a kamatfizetés és a beváltás (törlesztés) időpontjait és mértékét;

j) az átruházásra vonatkozó esetleges korlátozást;

k) a kibocsátott sorozat össznévértékét;

1) a jelzáloglevél kibocsátásának helyét és idejét;

m) a vagyonellenőr igazolását az elöírás szerinti fedezet meglétéről és annak fedezet-nyilvántartásba történt bejegyzéséről.

A visszavásárolt jelzálogleveleket ismételten nem lehet forgalomba hozni, azok fedezetét a jelzálog-hitelintézet nem köteles biztosítani.

A jelzálog-hitelintézetnek mindenkor rendelkeznie kell a forgalomban levő jelzáloglevelek még nem törlesztett névértéke és kamata összegét meghaladó (vagyis 100\%-ot meghaladó) értékủ fedezettel. A fedezet rendes fedezetet és pótfedezetet tartalmazhat. 
Rendes fedezet figyelembe vehető föbb elemei:

- Azon jelzáloghitelből, illetve refinanszírozási jelzáloghitelből eredő tőkekövetelés, a szerződés alapján járó kamat, a fennálló tőkekövetelés százalékában meghatározott, a kölcsönszerződés szerint a futamidö alatt rendszeresen felszámítható kezelési költség, amely fedezetéül kikötött jelzálogjog a jelzálog-hitelintézet javára az ingatlan-nyilvántartásba bejegyzésre került.

- Rendes fedezetként a visszavásárlási vételár, a kapcsolódó kölcsönrészből eredő tőkekövetelés és a szerződés alapján járó kamat, valamint kamat jellegű bevétel, továbbá a származtatott (derivatív) ügylet értéke.

- Refinanszírozási jelzáloghitelből eredő tőkekövetelés, illetve önálló zálogjog vásárlása-visszavásárlása esetén a visszavásárlási vételár, továbbá a szerződés alapján járó kamat és kamat jellegü bevétel abban az esetben vehető figyelembe rendes fedezetként, ha az önálló zálogjog alapítása, illetve jelzálognak átalakításos önálló zálogjoggá való átalakítása és ezeknek, illetve a jelzálognak különvált zálogjogként a jelzálog-hitelintézet javára történő átruházása érvényesen megtörtént, és a jelzálog-hitelintézet feltétel nélkül jogosult kezdeményezni a különvált zálogjog, valamint az önálló zálogjog átjegyzését a saját javára az ingatlan-nyilvántartásban.

Ha a jelzáloglevelek és a fedezetek devizaneme eltérő, a jelzálog-hitelintézet köteles az árfolyamkockázatot származtatott (derivatív) ügylet megkötésével kiküszöbölni.

A rendes fedezetbe vont származtatott (derivatív) ügyletekből fennálló követelések és kötelezettségek jelenértéken számított egyenlege nem haladhatja meg a forgalomban lévő jelzáloglevelekből származó kötelezettségek jelenértékének 12\%-át.

Ha a jelzáloghitelből, a refinanszírozási jelzáloghitelből eredő tőkekövetelés, illetve a visszavásárlási vételár összege a fedezetül lekötött ingatlan hitelbiztosítéki értékének hatvan százalékát meghaladja, rendes fedezetként a tőkekövetelés, illetve a visszavásárlási vételár összege legfeljebb annak 60\%-áig vehető figyelembe. Ha a fedezetül lekötött ingatlan lakóingatlan, akkor a jelzáloghitelből és a refinanszírozási jelzáloghitelből eredő tőkekövetelés, illetve visszavásárlási vételár összege a hitelbiztosítéki érték 70\%-áig vehető rendes fedezetként figyelembe. 
(A hitelbiztositéki érték valamely ingatlannak az óvatos becslés elvén meghatározott értéke, amely döntő jelentőséggel bír a jelzálog alapú hitelezési tevékenység biztosítéki rendszerében, hiszen egyrészt ez az érték határolja be a bank lehetséges kötelezettségvállalásának mértékét, másrészt ez nyújt biztosítékot valamely követelésre és annak járulékaira.)

A hitelbiztosítéki érték megállapításának alapja a forgalmi érték, amely háromféle módszerrel határozható meg:

- A piaci összehasonlító adatok elemzésén alapuló értékeléskor más, hasonló jellegü, adottságú és környezetben elhelyezkedő ingatlanok forgalmi adatait vetik össze.

- A hozamszámításon alapuló értékelés az ingatlannal kapcsolatos üzleti tevékenység jövedelemtermelő képességét állapítja meg.

- A költségalapú értékeléskor az ingatlan elméleti, újbóli létrehozásának költségeit veszi figyelembe a bank (ez csak termőföldnek nem minősülő ingatlan esetén alkalmazható értékelési módszer).

A fedezeten belül a rendes fedezet aránya nem lehet kevesebb nyolcvan százaléknál. A pótfedezet a rendes fedezet kiegészítésére szolgál, szigorúan megjelölt elemekből állhat, melyek között elsődleges: a Magyar Nemzeti Banknál elkülönített, zárolt pénzforgalmi számlán tartott pénz, meghatározott bankok, államok által kibocsátott értékpapír, a Magyar Állam készfizető kezességvállalása mellett kibocsátott értékpapír.

A jelzálog-hitelintézetnek jelentenie kell a Magyar Nemzeti Banknak, ha

a) a forgalomban lévő jelzáloglevelek fedezete nem a törvény szerinti,

b) a fedezeten belül a rendes fedezet aránya nem éri el a nyolcvan százalékot.

A rendes és a pótfedezeti értékekről a jelzálog-hitelintézetnek fedezet-nyilvántartást kell vezetni, melyben a fedezeteket egyedileg kell kimutatni. A nyilvántartáshoz kapcsolódóan a Magyar Nemzeti Bank által jóváhagyott szabályzattal is rendelkeznie kell a hitelintézetnek.

A jelzálog-hitelintézet az átalakítása vagy felszámolása esetén valamennyi, a kibocsátott jelzáloglevelekkel és a megkötött derivatív ügyletekkel kapcsolatos szerződésből származó jogát és kötelezettségét a Magyar Nemzeti Bank engedélyével egészben vagy részben más jelzálog-hitelintézetre átruházhatja. 
A vagyonellenőrnek kiemelt szerepe van a jelzálog-hitelintézetek müködésében, megbízásához a Magyar Nemzeti Bank engedélye szükséges.

Vagyonellenőri megbízatást csak könyvvizsgáló társaság vagy természetes személy kaphat. Vagyonellenőri feladatokkal csak olyan könyvvizsgáló társaság bízható meg, amely rendelkezik a jogszabályokban meghatározott feltételekkel és a jelzálog-hitelintézet számára nem végez más könyvvizsgálói feladatot.

Vagyonellenőri megbízást természetes személy is kaphat, amennyiben megfelel a törvényben meghatározott feltételeknek.

A vagyonellenőr határozott időre, legfeljebb öt évre kaphat megbízatást, de a megbízás időtartamának lejárta után ismételten is megbízható. A megbízási szerződés nem mondható fel a Magyar Nemzeti Bank engedélye nélkül.

A vagyonellenőr feladata, hogy folyamatosan ellenőrzi és igazolja:

a) a jelzáloglevelek elöírás szerinti fedezete mindenkori rendelkezésre állását;

b) a jelzáloglevelek rendes fedezetét biztosító zálogtárgyak, azok ingatlan-nyilvántartási adatai és hitelbiztosítéki értéke, továbbá a rendes és a pótfedezet fedezet-nyilvántartásba történő bejegyzését.

A vagyonellenőr haladéktalanul írásban jelenti a Magyar Nemzeti Banknak, ha a forgalomban lévő jelzáloglevelek fedezete nem felel meg a törvényben elöírtaknak.

Jht. további részei szabályozzák a tájékoztatási kötelezettséget, a jelzáloghitelintézet felszámolási, végrehajtás szabályait.

A jelzálog-hitelintézeti szabályozás jelentős állomása az 2016. október 1-jén hatályba lépett a 20/2015. (VI. 29.) MNB rendelet a hitelintézetek forint lejárati összhangjának szabályozásáról.

A deviza alapú fogyasztói jelzáloghitelek forintosítása következtében a pénzügyi rendszer stabilitása javult. Az MNB összesen mintegy 9,6 milliárd eurót bocsátott a bankok rendelkezésre 2014-ben és 2015-ben anélkül, hogy a nemzetközi sztenderdek elvárt szintje alá csökkent volna a jegybanki tartalékmegfelelés. „A forintosítás és az elszámolás következtében jelentősen erősödött Magyarország pénzügyi stabilitása, a kockázatok »kézben tartottsága érdemben nőtt. A lakossági devizahitelek kivezetése - kiemelten az önfinanszírozási programmal együtt - ezért lehetett az egyik olyan intézkedés, amelyet a hitelminősítők 
a magyar adósság befektetési kategóriába sorolásakor tételesen is a felminősítés indokaként nevesítettek." (Kolozsi et al. 2017)

Az árfolyamkockázat, mint kockázati tényezö, megszünt, ugyanakkor a forintosítás mellékhatásaként likviditási kockázatok jelentek meg a bankrendszerben.

A Rendelet bevezeti a jelzáloghitel-finanszírozás megfelelési mutatót (JMM), melynek elöírt értéke 2018. szeptember 30-ig 0,15 volt, 2018. október 1-jétől 0,20 a megkívánt érték.

Az MNB fél év felkészülési időt biztosított a bankrendszernek, 2016. október 1-jéről 2017. április 1-jére tette a rendelet hatályba lépését. Egyidejűleg egy ún. de minimis szabály is megjelent, mely szerint három milliárd forintnál alacsonyabb - tehát rendszerszinten nem jelentős - nettó lakossági jelzáloghitel-állománnyal rendelkező intézmények mentesülnek a JMM elöírás teljesítése alól.

A Rendelet közvetlen célja, hogy mérsékelje a deviza jelzáloghitelek forintosítását követően a bankrendszerben kialakult forint eszközök és források közötti lejárati eltérést úgy, hogy elöírja, legalább mekkora százalékban szükséges hoszszú lejáratú értékpapírokkal, főként jelzáloglevelekkel finanszírozni az eszközoldali tételeiket.

A forintra konvertált jelzáloghitelek döntő többségének hátralévő futamideje több, mint 10 év, miközben a bankrendszerben rendelkezésre álló forint források - nagyrészt betétekből - éven belüli lejáratúak voltak. Ez indokolta a JMM bevezetését és negyedévenkénti mérését. Az MNB kezdeti becslése szerint, mintegy 300 milliárd forintnyi új jelzáloglevél kibocsátása szükséges a cél eléréséhez.

A JMM bevezetése és mértékének fokozatos emelése lényeges prudenciális eszköz is egyben, hiszen, az egyre erősödő lakástámogatási kormányintézkedéseknek a hatásaként a lakáshitelállomány jelentős növekedése várható. Az adósságfék szabályok hatásmechanizmusa kettős. Egyrészt visszafogják a túlzott hitelkiáramlást, így a ciklikus jellegü kockázatok felépülésének lehetőségét és mértékét csökkentik. Másrészt közvetlenül csökkentik a nemteljesítési kockázatot, mivel akadályozzák a túlzott eladósodottság kialakulását. Lényeges, hogy a lakástámogatási intézkedések következtében és a piaci alapon növekvő lakáspiaci kereslet oldalán hatékonyan fejtik ki hatásukat a hitelpiacon. 
A JMM számítási módja a 20/2015. (VI. 29.) MNB Rendelet szerint:

1. A jelzáloghitel-finanszírozás megfelelési mutató a lakossági jelzáloghitelek fedezete mellett bevont forint források és az 1 éven túli hátralévő lejáratú lakossági forint jelzáloghitel-állomány hányadosaként számítandó ki.

2. A jelzáloghitel-finanszírozás megfelelési mutató számlálójában az alábbi források vehetők figyelembe:

a) a hitelintézeti csoport jelzálog-hitelintézet tagja által kibocsátott jelzáloglevél állomány,

b) a hitelintézeti csoport tagja által a lakossági jelzáloghitelek fedezete mellett, a hitelintézetekre és befektetési vállalkozásokra vonatkozó prudenciális követelmények és vonatkozó EU rendeletek szerint kibocsátott értékpapírok állománya,

c) a kapott refinanszírozási jelzáloghitelek,

d) az önálló zálogjog értékesítése okán fennálló visszavásárlási vételár-tartozás.

3. A jelzáloghitel-finanszírozás megfelelési mutató számlálójában - a 4. pontban foglaltak kivételével - azok a 2. pontban meghatározott források vehetők figyelembe, amelyek

a) forintban denomináltak,

b) lakossági jelzáloghitel vagy lakóingatlanon alapított zálogjog fedezete vagy eladása mellett kerültek bevonásra,

c) a jelzáloglevél vagy a 2. pont b) alpontja szerinti értékpapír kibocsátásakor, az önálló zálogjog eladásakor vagy a refinanszírozási jelzáloghitel felvételekor

ca) 2018. szeptember 30-ig legalább egyéves,

cb) 2018. október 1-jétől 2019. szeptember 30-ig legalább kétéves,

cc) 2019. október 1-jétől legalább hároméves

futamidővel rendelkeztek,

d) nem ugyanazon hitelintézeti csoport tagjának mérlegében vannak nyilvántartva (kivételekkel).

4. a) A forintban denomináltságot nem kell vizsgálni a 2015. március 31. elött, devizában kibocsátott értékpapírok esetében,

b) a 3. pont $d$ ) alponttól eltérően a jelzáloghitel-finanszírozás megfelelési mutató számlálójában a következő feltételekkel figyelembe vehetők:

ba) a jelzálog-hitelintézettel összevont alapú felügyelet alá tartozó intéz- 
mény mérlegében nyilvántartott, az MNB vagy az Európai Központi Bank által elfogadott fedezetek körébe tartozó, 2015. március 31. elött kibocsátott jelzáloglevél állomány, az MNB vagy az Európai Központi Bank által mindenkor alkalmazott befogadási érték 20 százalékáig;

bb) 2018. október 1-jétől a jelzálog-hitelintézettel összevont alapú felügyelet alá tartozó lakás-takarékpénztár mérlegében nyilvántartott jelzáloglevél-állomány.

5. A jelzáloghitel-finanszírozás megfelelési mutató számlálójában figyelembe vett forrásokat a mérlegben kimutatott értékük alapján kell beszámítani. A beszámolókészítésre a magyar számviteli standardokat alkalmazó intézmények esetében ezen érték számításakor a kibocsátott forráshoz kapcsolódó elhatárolások értékét is figyelembe kell venni.

6. A jelzáloghitel-finanszírozás megfelelési mutató számlálójából levonandó a jelzálog-hitelintézet által a saját hitelintézeti csoporton kívüli intézmény részére nyújtott refinanszírozási jelzáloghitelek, illetve a saját hitelintézeti csoporton kívüli intézmény által fizetendő visszavásárlási vételár összege.

6a. A jelzáloghitel-finanszírozás megfelelési mutató számlálójának 2-6. pont szerint számított értékét csökkenteni kell a következő képlet szerint számított értékkel, kivéve, ha ezen érték negatív előjelü:

$\mathrm{J}-\mathrm{SF} \times \mathrm{A}$, ahol

J: hitelintézeti csoportba nem tartozó hitelintézet esetében a hitelintézet tulajdonában lévő, Magyarországon székhellyel rendelkező jelzálog-hitelintézet által kibocsátott, forintban denominált jelzáloglevelek mérlegben kimutatott értékének összege; hitelintézeti csoportba tartozó intézmény esetében az ugyanazon hitelintézeti csoportba tartozó jelzálog-hitelintézet által kibocsátott jelzáloglevelek 2-6. pont szerinti értékének és a saját hitelintézeti csoporton kívüli, Magyarországon székhellyel rendelkező jelzálog-hitelintézet által kibocsátott, forintban denominált jelzáloglevelek mérlegben kimutatott értékének összege, amennyiben azok ugyanazon hitelintézeti csoport valamely tagjának tulajdonában vannak, ide nem értve az ugyanazon hitelintézeti csoporthoz tartozó lakástakarék-pénztár mérlegében nyilvántartott jelzáloglevelek értékét; SF: a jelzáloghitel-finanszírozás megfelelési mutató számlálójának 2-6. pont szerint számított értéke;

A = J-nek a szabályozott piacra bevezetett részaránya $\times 0,9+$ J-nek a szabályozott piacra be nem vezetett részaránya $\times 0,85$. 
7. A jelzáloghitel-finanszírozás megfelelési mutató nevezője az éven túli hátralévő lejáratú, lakossági forint jelzáloghitel-állomány könyv szerinti nettó értéke.

8. A jelzáloghitel-finanszírozás megfelelési mutató nevezőjéből a hitelintézeti csoport lakástakarék-pénztár tagja éven túli hátralévő lejáratú, lakossági forint jelzáloghitel-állományának könyv szerinti nettó értéke levonható. A levonható jelzáloghitel-állományt csökkenteni kell a lakástakarék-pénztár részére a saját hitelintézeti csoport tagja által nyújtott hitelek mérlegben kimutatott értékével.

A Rendelet a közvetlen cél elérése mellett hatékonyan támogatja a hazai jelzáloglevél-piac újjáéledését is.

2016 folyamán három új jelzálogbank alakult és több sikeres jelzáloglevél-kibocsátás is megvalósult. A JMM biztosítja a bankrendszerben a lakossági jelzáloghitelek jelzáloglevelekkel történő hosszú lejáratú stabil finanszírozását.

Az élénkülő lakáshitelezés miatt és a jelzálogbanki, illetve a refinanszírozási infrastruktúra kiépülését követően szükségessé vált a JMM elöírás szigorítása. Az MNB Pénzügyi Stabilitási Tanácsának döntése értelmében 2018. október 1-jétől a JMM szabályozás négy területen változott. A JMM minimum elvárt szintje 15-ről 20 százalékra emelkedett, így a bankok mérlegen belüli lejárati eltérése tovább mérséklődik, és a várható jelzáloglevél-kibocsátásoknak köszönhetően tovább mélyül a jelzáloglevél-piac. A szigorúbb szabályozás alapján a beszámítható források elvárt futamideje 1-ról 2 évre emelkedett, illetve a bankok által megvásárolt jelzáloglevelek részlegesen „nettósításra” kerültek a rendelet szerint beszámítható forrásokkal szemben, ami a rendszerszintű, bankszektoron kívüli forrásbevonásra ösztönzi a piaci szereplőket. Végül, 2018 októberétől, a lakás-takarékpénztárak által lejegyzett jelzáloglevelek valódi stabil forrásbevonásként vehetők figyelembe.

Az új előírásoknak való megfelelésre az MNB felkészülési időt biztosított a bankoknak.

A következő másfél évben összesen csaknem 600 milliárd forintnyi új jelzáloglevél-kibocsátás valósulhat meg. Az egyre élénkebb és fejlettebb jelzáloglevél-piac segíti a hosszabb kamatperiódusú, fix kamatozású hiteltermékek elterjedésén és a kamatköltségek csökkenésén keresztül a lakossági lakáshitelek további növekedését. 


\subsection{A jelzálog-hitelintézet müködése}

A jelzáloghitelezés elsődleges garanciáit a biztonságos müködés érdekében a jelzálogtörvényben rögzített szigorú szabályok jelentik. A jelzálog-hitelintézetek kockázatvállalási tevékenységüket a kereskedelmi bankoktól és az egyéb szakosított hitelintézetektől eltérő feltételrendszerben végzik, külön törvényben foglalt keretek között.

A jelzálogbank kihelyezett hiteleinek forrásait jelzáloglevél kibocsátásával teremti elő. A jelzáloglevél kizárólag jelzálog-hitelintézet által kibocsátott névre szóló, átruházható, hitelviszonyt megtestesítő értékpapír. Leginkább a hosszabb lejáratú államkötvényekhez hasonlítható, hiszen megközelítőleg olyan biztonságos, mint az állampapírok. Kötvény jellegü, így kölcsönügyletre épülő értékpapír, ami a befektetők számára hosszú lejáratú befektetési eszközként jelenik meg. A jelzáloglevél befektetője valójában kölcsönügyletet létesít a bankkal, amit az értékpapír testesít meg.

A jelzáloglevél mégis alapvetően különbözik mind az állampapíroktól, mind a közönséges vállalati vagy banki kötvényektől. A jelzáloglevél mögött ugyanis különleges fedezet áll, melynek folyamatos meglétét vagyonellenőr ellenőrzi és igazolja. A vagyonellenőr pecsétje nélkül nem lehet jelzáloglevelet kibocsátani.

A jelzáloglevél kibocsátásakor a bank az általa felvett hitelt tehát nem egy konkrét jelzálogjoggal biztosítja, hanem az összes kintlévő hitelek zálogjogának az összességét nyújtja az általa felvett hitel biztosítékaként (fedezeti elv).

A jelzáloglevél dematerializált értékpapír, nem kerül kinyomtatásra, hanem értékpapírszámlán tartják nyilván.

A jelzáloglevél, mint befektetés jellemzői:

- Hosszúlejáratú, ugyanakkor mégis likvidnek tekinthető, igen alacsony kockázatú, ugyanakkor az államkötvényeknél jellemzően magasabb hozamot biztosító értékpapír. 
- A hosszú lejáratú jelzáloglevél bármikor eladható és vehető, hiszen a forgalmazó bankfiókjaiban és a Budapesti Értéktőzsdén biztosított a folyamatos árjegyzés.

- Fix kamatozásnál előre kiszámítható jövedelmet ad.

- Változó kamatozásnál a piaci kamatokhoz igazítható.

\subsection{A magyar intézményi szabályozás hasonlítása más modellekhez}

Az alapján, hogy milyen típusú hitelintézet jogosult jelzáloglevél kibocsátására Európában négy szabályozási modellt különböztethetünk meg (Papp, 2005):

1. Francia modell: A jelzáloglevél fedezeteként szolgáló eszközöket a jelzáloghitelt nyújtó bank egy külön, önálló bankként müködő, de csak a fedezetek „örzésével” megbízott banknak átadja. A hitelező banké továbbra is a müködtetés és az adminisztráció, de a jelzálogleveleket nem a hitelező bank bocsátja ki. Ez a konstrukció biztosítja, hogy a fedezeteket a jelzáloglevél-követelések kielégítésére használják fel a hitelező bank csődje esetén. Ezt a modellt alkalmazzák: Franciaország, Finnország, Írország, Norvégia és részben Svédország.

2. Német modell: A jelzáloglevél kibocsátására csak jelzálogbankok jogosultak, amelyek a biztosítékok mellett egyéb eszközöket is birtokolhatnak. A megvásárolt eszközök mellett saját hitelnyújtásra is lehetőségük van. A fedezetek müködtetése, adminisztrációja a jelzálogbank feladata. Németországban (később megváltozott), Dániában, Luxemburgban, Lengyelországban, Magyarországon és részben Svédországban is ezt a modellt vezették be.

3. Univerzális bank, felügyeleti engedély alapján: Az univerzális bankok (Lettországban, Oroszországban, valamint Szlovéniában és később Németországban) adott feltételek teljesítése esetén engedélyt kaphatnak a felügyelettől arra, hogy bizonyos eszközök finanszírozására jelzáloglevelet bocsáthassanak ki. Ez a modell rugalmasabb, mint az előzőek, ugyanakkor számos kiegészítő szabályozás megalkotását, pontosítását teszi szükségessé a befektetők védelme érdekében.

4. Univerzális bank engedély nélkül: Ebben az esetben vagy nincs szükségük a bankoknak felügyeleti engedélyre, vagy a hatóságok nem állítanak fel különleges feltételeket az engedély megszerzéséhez. Az előbbi áll fenn Bulgária, Csehország, 
Litvánia és Spanyolország esetében, az utóbbi pedig Szlovákia szabályozására jellemző. Az elöző modellhez hasonlóan itt is kiegészítő törvények, rendeletek szükségesek a befektetők biztonságának garantálásához.

Hazai szempontból a korábbi német példa tekinthető mintának, a szabályozásunk alapvetően erre a modellre, ill. az EU szabályozására épült, ugyanakkor a magyar jelzálogpiac fejlődésével egyéb nemzetközi gyakorlat elemeinek átvétele is történik.

\section{Az amerikai modell}

A jelzálogkölcsön fogalmán az Egyesült Államokban is ingatlan jelzálogjoggal fedezett, előre rögzített törlesztésű és kamatozású kölcsönt értenek. A jelzálogkölcsön-piac részaránya Amerikában jelentős.

$\mathrm{Az}$ amerikai jelzáloghitel piac egy liberalizált, kétszintű jelzálogpiac, ahol pénzügyi intézmény szintjén különválik a jelzáloghitelezés a jelzáloglevél kibocsátástól. Erre szakosodott külön intézmények végzik a jelzáloghitelezők követeléseinek felvásárlását és az erre alapozott jelzáloglevél-kibocsátást. Ez a szisztéma egységes központi jelzáloghitel intézmény(ek) létrehozását és müködését kívánja meg. Az ilyen központi jelzáloghitel intézmény bármely hitelintézet által nyújtott, előre pontosan meghatározott feltételeknek megfelelő hitelt refinanszíroz, csak ilyen hiteleket vásárolhat meg a bankoktól. Az amerikai rendszerben a jelzáloghitelek csak a hozzájuk fedezetként kapcsolódó ingatlanokhoz kötődnek. A kihelyező bank jelzálog követeléseit átruházhatja, így azok egy liberalizált, másodlagos piacon önálló életre kelnek, ahol az erre szakosodott cégek a piaci igényeknek megfelelö „csomagokat” állítanak össze belölük, majd ezeket a „csomagokat” az értékpapír kibocsátásával eladják a befektetőknek. A jelzáloghitel-piac nagysága miatt az így finanszírozott magánberuházások meghatározó jelentőséggel bírnak a gazdasági konjunktúra szempontjából.

Az amerikai jelzáloghitel piac legfontosabb szereplői:

- hitelfelvevők,

- jelzáloghitelezők,

- jelzálogkölcsön vásárlók,

- jelzálogkölcsön kezelők, jelzálogbrókerek,

- jelzálogkölcsön biztosítók. 


\section{A jelzáloghitelező}

A jelzáloghitel eredeti folyósítója a jelzáloghitelező. Ilyen tevékenységet az USAban kereskedelmi bankok, takarékpénztárak (takarékszövetkezetek), jelzáloghitelbankok, biztosítópénztárak és nyugdíjalapok végezhetnek. A felsoroltak közül az első három intézménytípus nyújtja a jelzálogkölcsönök túlnyomó többségét.

A jelzáloghitelező a kölcsön folyósítása után választhat, hogy a hitelt saját portfoliójában tartja, értékesíti azt egy másik befektetési intézmény részére, amely azt egyéb hitelekkel együtt egy alapba (pool) helyezi, és ezzel fedezi értékpapír kibocsátását (mortgage backed securities), vagy saját maga bocsát ki a hitelekkel fedezett értékpapírokat.

\section{A jelzálogkölcsön vásárlók}

A jelzálogkölcsön vásárlók között két állami, illetve több magántársaság is megtalálható. Ez a két állami szervezet: a Government National Mortgage Association (beceneve „Ginnie Mae”), valamint a Federal Home Loan Mortgage Corporation („Freddie Mac”), amelynek csak a saját szabályaikkal megegyező, vagyis az abban megfogalmazott feltételeknek megfelelő jelzáloghiteleket vásárolnak meg.

A jelzáloghitelek vásárlásával foglalkozó magántársaságok un. nem konform jelzáloghiteleket is vásárolnak, de elsősorban azért, hogy értékpapírosítva továbbadják azokat.

\section{A jelzálogkölcsön kezelök, jelzálogbrókerek}

A jelzálogkölcsön kezelők feladata a hitelekkel kapcsolatos pénzügyi elszámolási feladatok ellátása. Ennek keretében beszedik a havi adósszolgálati kifizetéseket, továbbítják azt a kölcsön tulajdonosának, fizetési felhívást küldenek ki, illetve felszólítják az adóst, ha időben nem teljesít és nyilvántartást vezetnek a tartozások állásáról. A jelzálogkölcsön kezelők általában kereskedelmi bankokhoz, takarékszövetkezetekhez kapcsolódó intézmények, de elöfordulhat, hogy maguk a jelzáloghitel-bankok is végeznek ilyen tevékenységet.

\section{A jelzálogkölcsön biztosítók}

A hitelező intézmény a fizetőképesség és a fedezet alapján bírálja el a hitelkérelmet, de emellett kikötheti kötelezően jelzáloghitel biztosítás megkötését is, amelynek a költségét a hitelfelvevő viseli. Jelzáloghitel-biztosítással kormányügynökségek és magántársaságok is foglalkoznak. A hitelfedezeti biztosításokat tekintve lehet élet- vagy betegbiztosítást kötni a hiteltörlesztést befolyásoló várat- 
lan problémák megelözése érdekében. A magánbiztosítók törlesztési fedezetet is biztosítanak abban az esetben, hogyha valaki önhibáján kívül veszíti el a munkáját, vagy egyéb okból (pl. betegség, elhalálozás) nem tudja hitelét törleszteni.

Az amerikai piac működésének máig meghatározó intézményei:

- Federal Housing Administration (FHA, 1936): ez az intézmény állami garanciát biztosít a „megfelelö” (conforming) jelzáloghitelek számára.

- Federal National Mortgage Association (rövid nevén Fannie Mae, 1938): A Fannie Mae kezdetben kizárólag az FHA által garantált, azaz „megfelelő" hiteleket refinanszírozott, mint állami intézmény. A Fannie Mae-t 1968-ban privatizálták.

- Federal Home Loan Bank (FHL, 1932): a takarékszövetkezeti szektor refinanszírozására hozták létre.

- 1968-ban létrejött a Government National Mortgage Association, azaz Ginnie Mae, az intézmények közül az egyetlen, amelyik egyértelmüen központi kormányzati, azaz állami tulajdonban van. Az intézmény létrehozásának egyik célja az volt, hogy a Fannie Mae korábbi szerepét átvegye.

- A privatizált Fannie Mae versenytársaként 1970-ben létrehozták a Federal Home Loan Mortgage Corporationt, becenevén Freddie Macet, amely a Fanniehoz hasonlóan „megfelelő” (conforming) jelzáloghiteleket értékpapírosító, azaz főként a másodpiacon müködő magánintézmény.

\begin{tabular}{|c|c|c|}
\hline Szempontok & Amerikai rendszer & Európai Uniós szabályozás \\
\hline $\begin{array}{l}\text { A jelzáloglevél } \\
\text { kibocsátója }\end{array}$ & $\begin{array}{l}\text { Elsősorban nem bankok, hanem társaságok } \\
\text { bocsátják ki. }\end{array}$ & Hitelintézetek bocsáthatják ki. \\
\hline $\begin{array}{l}\text { Törvényi elöírások, } \\
\text { felügyelet }\end{array}$ & $\begin{array}{l}\text { Kevésbé szigorúak a kibocsátásra vonatkozóan és } \\
\text { e tevékenységet a bankfelügyelet sem ellenőrzi. }\end{array}$ & $\begin{array}{l}\text { A hatóságok speciális felügyeletének } \\
\text { tárgyát képezik. }\end{array}$ \\
\hline Forrásszerzés módja & $\begin{array}{c}\text { Az elsődleges hitelnyúitó mérlegéből a követelés } \\
\text { kikerül, s a pénzbevétel lehetővé teszi az újabb } \\
\text { hitelnyúitást. }\end{array}$ & $\begin{array}{c}\text { Az elsődleges hitelnyújtó mérlegében } \\
\text { benne marad a hitel is és a jelzáloglevél } \\
\text { is, a jelzáloglevél finanszírozza az újabb } \\
\text { hitelnyújtást. }\end{array}$ \\
\hline \multirow{2}{*}{ Egyéb szempontok } & $\begin{array}{l}\text { A piacra való ki- és belépés egyszerúbb } \\
\text { és gyorsabb. }\end{array}$ & - \\
\hline & - & $\begin{array}{l}\text { A kötvénytulajdonosok a kibocsátó csődje } \\
\text { esetén előnyt élveznek. }\end{array}$ \\
\hline
\end{tabular}

1. táblázat: Összehasonlítva az amerikai és az európai rendszert, a legfontosabb különbségek

Forrás: Éliás (2011) 


\subsection{A magyar jelzáloghitelezés története a kezdetektől a hatályos törvény megjelenéséig}

A jelzáloghitelezés kialakulásához voltaképpen két alapfeltétel teljesülésére volt szükség. Az egyik egy olyan nyilvántartási rendszer létrehozása, amely közhiteles és alkalmas arra, hogy a teher egyértelmüen azonositható, bejegyeztethető. A másik az elzálogosítandó ingatlan jogilag akadálymentes értékesíthetősége, ennek hiánya több országban, köztük Magyarországon is, sokáig késleltette a jelzáloghitelezés létrejöttét.

Európai környezetünkben, Ausztriában a XVII. században létrejött a földregiszter.

Az első jelzálog-hitelintézetnek tekinthető intézmény II. Frigyes porosz császár 1769. évi rendeletével függ össze, mely rendelet rögzítette, hogy a jelzáloglevél készpénzt helyettesít. A későbbi jelzálogbanki forma ősének a Sziléziai Landschaft Bank tekinthető, mely 1770-ben jött létre. (Éliás, 2011)

A XIX. század első felétől egyre több európai országban jött létre jelzáloghitelezést végző pénzintézet: Hollandiában 1823-ban, Ausztriában 1841-ben, Franciaországban 1852-ben, Oroszországban 1861-ben. (Éliás, 2011)

A hitelezés kezdeti technikája a zálogjegyekkel történt. A tartományi jelzálogintézetek a földbirtok zálogjogi terhelését követően bocsátották ki a bemutatóra szóló zálogjegyeket. A kölcsönfelvevő a kölcsönt zálogjegy formájában kapta meg. Amennyiben az ingatlan tulajdonosa a kölcsön törlesztését és a kamatok fizetését nem volt képes az elöre ütemezett módon megfizetni, annak beszedése, végső soron a fedezetként szolgáló ingatlan értékesítése révén történt meg.

A XIX. századi európai polgárosodási folyamatok Magyarországot is elérték. A reformkorban megindult a harc a fejlődés akadályainak elhárításáért, ennek keretében a birtokra történő hitelszerzési lehetőségekért.Mindez élesen ütközött bele a magyar történelem legősibb törvényeinek egyikébe, az ősiség törvényébe. Az ősiség törvénye azzal, hogy ellehetetlenítette a földalapú jelzáloghitelezés elterjedését, konzerválta az elavult forráshiányos birtokrendszert.

Az ősiség szellemisége az addigi teljes magyar történelem része volt, lényegében a honfoglalásig vezethető vissza, hogy elkülönültek az ősi és a szerzett javak örökösödési formái. Nagy Lajos király 1351-ben hozott rendkívül fontos törvé- 
nye a maga idejében lényegre törően védte az öröklött ősi birtokot, azzal, hogy a földbirtok feletti rendelkezést szigorú korlátok közé szorította. Az évszázadok elmúltával a törvény lett a bilincs, mely konzerválta a birtokviszonyokat.

Gróf Széchenyi István 1830-ra Hitel című művét véglegesítette, kifejtette, hogy az elavult birtokrendszer modernizálásához hitel felvételére van szükség. A hitel alapja a föld maga, de meg kell teremteni a hitelezhetőségét. Kimondta, hogy az ősiség törvényének ideje lejárt, el kell törölni, annak érdekében, hogy a birtok hitelezhetővé váljon. A föld szabadon vásárolható kell, hogy legyen.

Első részeredménynek az 1840. évi XXI. törvénycikk tekinthető, mely lehetőséget teremtett az adóssági követelések elsőbbség végetti betáblázására.

További áttörést jelentett, hogy az 1844. évi IV. törvénycikk kimondta, hogy nemesi javakat nem csak nemesek birtokolhatnak. Az ösiség törvénye lazult ezáltal, de meg nem szűnt. Az eltörlését 500 év után az 1848. évi XV. törvénycikk mondta ki. E törvény egyidejűleg megbízta a minisztériumot, hogy az ősiség teljes eltörlésének alapján polgári törvénykönyvet dolgozzon ki és azt terjessze a legközelebbi országgyülés elé.

A kibontakozó szabadságharc miatt a következő lépés 1952-ben történt: az ősiség megszünését az 1852. november 29-én kelt „ősiségi nyílt parancs” (ősiségi pátens) szabályozta. Az öröklésre vonatkozó korábbi rendelkezések helyébe a magyar öröklési elvekkel megegyező, azonban szintén az ősiség eltörléséről szóló 1848. XV. törvényhez igazított szabályozást léptetett.

Ezt követően megkezdődött a jelzáloghitelezés rendszerének kialakítása, a föld hitelezhetősége elől elhárult az alapvető akadály, a forgalomképességét korlátozó jogszabály megszűnt.

1855-ben megkezdődött az ingatlanok felmérése, a december 15-én kelt rendelet elöírta a telekkönyvi rendszer bevezetését.

A jelzálog- és földhitelintézetek száma nőtt. A nagybirtokok hitelezésére hozták létre a Magyar Földhitelintézetet, alapszabálya 1860 elejére készült el, az alapítási engedélyt 1862. szeptember 20-án kapta meg és 1863 áprilisában megkezdte működését.

1876-ban az összes szövetkezeti vagy részvénytársasági formában működő bankra kiterjesztették a záloglevél kibocsátásának a jogát. Meghatározták, hogy 
kibocsátás előtt minimum mekkora pénzalapot kell képezni és annak húszszorosáig lehetett hitelt nyújtani.

1879-ben felállították a Kisbirtokosok Országos Földhitelintézetét, de a kisbirtokosok hitelfelvevő kedvét nem sikerült megnövelni. A tőkepiac magas kockázatúnak értékelte a zálogleveleit. (Huszár, 2006)

A záloglevél kibocsátás 1890-1910 között fejlődött leggyorsabban. A kibocsátást az 1876. évi XXVI. majd később az 1928. évi VII. tc. szabályozta.

Az első világháborús időszakban összeomlott a jelzálog üzletág. Feléledése az 1920-as években lassan indult meg, de a gazdasági világválság ismételten viszszavetette.

A második világháború idején a tevékenység megszűnt, az azt követő időszak szellemiségében, tulajdonviszonyaiban nem volt helye a jelzáloghitelezési tevékenységnek.

Magyarországon az egyszintű bankrendszerben, 1950-től megszűnt a jelzáloghitelezés intézményi háttere. A kétszintű bankrendszer 1987. január 1-jén történt létrehozása teremtette meg ismét az elvi lehetőséget.

Az 1990-es évek elejére ismét előtérbe került a mezőgazdaság fejlesztésének igénye, vele együtt a földalapú finanszírozás kérdésköre.

Az újonnan létrehozott kereskedelmi bankok közül 1992 februárjában a mezőgazdaság finanszírozásában érdekelt csoport létrehozta a Földhitelintézet Alapítványt.

A Földhitelintézet Alapítvány alapítói és fenntartói az Agrobank Rt., a Kereskedelmi és Hitelbank Rt., a Mezőbank Rt. és a takarékszövetkezeteket képviselő Országos Takarékszövetkezeti Szövetség. Feladatuk a jelzáloghitelezés felélesztése érdekében a jogszabályok előkészítése, a múltbéli tapasztalatok hasznosíthatóvá tétele volt.

1996. október 11-én öt kereskedelmi bank - Corvinbank Rt., Kereskedelmi és Hitelbank Rt., Magyar Befektetési és Fejlesztési Bank Rt., Mezőbank Rt., Postabank és Takarékpénztár Rt. - megalapította a Jelzálog Hitelintézetet Előkészítő Részvénytársaságot, amelynek feladata a Földhitel- és Jelzálogbank Rt. létrehozása volt. 
1997. április 29-én az Országgyülés elfogadta az 1997. évi XXX. törvényt a jelzálog-hitelintézetről és a jelzáloglevélről. A törvény alapvetően a német modell elemeit vette át.

1997. október 21-én megtörtént a Földhitel- és Jelzálogbank Rt. alapító okiratának aláírása. A 3 milliárd forintos alaptőkével létrehozott bank tulajdonosai: Magyar Állam (36,67\%), Magyar Fejlesztési Bank Rt. (48,33\%), Pénzintézeti Központ Bank Rt. (10\%), Mezőbank Rt. (3,33\%), Postabank és Takarékpénztár Rt. (1,67\%).

\subsection{A magyar jelzálog-hitelezés intézményei}

A 20/2015. (VI. 29.) MNB rendelet a hitelintézetek forint lejárati összhangjának szabályozásáról kihirdetésének időpontjában Magyarországon 3 jelzálogbank létezett: FHB Földhitel- és Jelzálogbank (1997), Unicredit Jelzálogbank (1998) és OTP Jelzálogbank (2001).

A saját jelzálogbankkal nem rendelkezö, érintett kereskedelmi bankoknak döntést kellett hozniuk, hogy miként szerzik be az elöírt forrásokat: vagy alapítanak saját jelzálogbankot vagy más jelzálogbankkal müködnek együtt a refinanszírozásban. Mindkét megoldásra van példa.

\section{A jelenlegi magyar jelzálog-hitelintézetek}

Takarék Jelzálogbank Nyrt., korábbi nevén FHB Földhitel- és Jelzálogbank Az FHB Földhitel- és Jelzálogbankot (FHB), mint szakosított pénzintézetet 1997 októberében alapította 3 milliárd forint alaptőkével négy bank és a Pénzügyminisztérium azzal a céllal, hogy kialakuljon Magyarországon a hosszú lejáratú finanszírozás, létrejöjjenek a hosszabb távú befektetési lehetőségek és fejlődésnek induljon az ingatlan piac, lehetőséget teremtve az agrárgazdaság finanszírozására is. Az FHB 1998 márciusában kapta meg müködési engedélyét, ezt követően országszerte elérhetővé tette a jelzálog-alapú finanszírozást.

Az FHB fontos szerephez jutott a kormány 1999-ben elindított lakásfinanszírozási, lakástámogatási szabályozásának köszönhetően. 2001 végére a magyar lakásfinanszírozási piac jelentős szereplőjévé lépett elő egyrészt saját hitelügyeletei, másrészt a lakossági lakáshitel finanszírozásban résztvevő kereskedelmi bankokkal és takarékszövetkezetekkel kialakított együttmüködései révén. 
A Jelzálog-hitelintézetről és a jelzáloglevélről szóló törvény 2001. évi módosítása lehetővé tette a kereskedelmi bankok jelzáloghiteleinek refinanszírozását önálló zálogjog megvásárlásán keresztül. Ennek eredményeként az FHB kereskedelmi bankokkal kötött refinanszírozási keretszerződéseket, de ekkor alapította meg az OTP saját jelzálogbankját, majd rövid idő alatt a piac legnagyobb szereplője lett.

Az állami szabályozásnak köszönhetően 2005 végére a refinanszírozási hitelek adták a jelzáloghitel-állomány 60\%-át.

2001 tavaszán az FHB jelzálogleveleit bevezették a Budapesti Értéktőzsdére. A belföldi tőkepiac korlátozott volta miatt 1 milliárd euró értékü jelzáloglevél kibocsátást indított el Luxemburgban. Az Európai Jelzálogszövetség 2001. november 29-én megtartott közgyülésének döntése nyomán az FHB a szervezet társult tagja lett.

Az FHB privatizációja 2003-ban kezdődött meg, majd az ÁPV Rt. tulajdoni hányada 53,2\%-ra csökkent.

2006-tól vált a stratégia részévé a banki tevékenységek szélesítése, fiókhálózat kiépítése és megalapította leánybankját, az FHB Kereskedelmi Bank Zrt.-t. Ezzel az FHB Csoport jelentősen kibővítette a nyújtható pénzügyi szolgáltatásai körét. 2011-ben, a kivásárlást követően, az Allianz Bank beolvadt az FHB Kereskedelmi Bankba. 2013-ban az FHB Jelzálogbank több akvizíciót is végrehajtott, így tovább bővült a leányvállalatok, és ezáltal a Bankcsoport által végzett tevékenységek köre.

2014 elején az FHB Jelzálogbank NyRt. 25\%-os részesedést szerzett a Magyar Takarék Befektetési és Vagyongazdálkodási (MATAK) Zrt.-ben, ezen keresztül 13,76\%-os közvetett befolyásoló részesedéshez jutott a Magyar Takarékszövetkezeti Bank Zrt.-ben (Takarékbank).

2016 negyedik negyedévében jelentősen tovább módosultak a tulajdonlások, és 2017-ben zárult le az FHB Jelzálogbank és az FHB Kereskedelmi Bank 2015 őszén elkezdődő beilleszkedése a Szövetkezeti Hitelintézetek Integrációjába.

Ezt követően az FHB Bankcsoport jelentős szervezeti és szerkezeti átalakításon ment keresztül, hogy integrálódjon a Takarék Csoportba. A Takarék Csoport központi banki funkciói a Takarékbankhoz kerültek, a kereskedelmi banki feladatokat a Takarék Kereskedelmi Bank (korábban FHB Kereskedelmi Bank) látja 
el, míg a Takarék Jelzálogbank Nyrt. (korábban FHB Földhitel- és Jelzálogbank) letisztult jelzálogbanki tevékenységet végez. Jelenleg a Takarék Jelzálogbank Nyrt. az ország második legnagyobb jelzálogbankja. ${ }^{1}$

OTP Jelzálogbank Zrt.

Az OTP Jelzálogbank Zrt.-t (OTP Jelzálogbank) a forrásoldali állami támogatású hitelek jogszabályainak megjelenését követően alapította az ország kiemelkedő piaci részesedéssel bíró, piacvezető kereskedelmi bankja, az OTP Bank. 2001 márciusában született meg a döntés, hogy 3 milliárd forint jegyzett tőkével, 100\%-os tulajdonosi részesedéssel, megalapítják az OTP Jelzálogbankot, mely működését 2002. február 1-jén kezdte meg.

A rohamosan bővülő hitelállomány szükségessé tette, hogy több lépcsőben, viszonylag rövid idő alatt, összesen 27 milliárd forintra emeljék fel az OTP Jelzálogbank jegyzett tőkéjét.

Az OTP Jelzálogbank tevékenysége három területre összpontosul:

- Lakáscélú ingatlanok fejlesztésének, vásárlásának finanszírozása, birtokfejlesztési hitelek, szabad felhasználású jelzáloghitelek nyújtása.

- Jelzáloglevél kibocsátása.

- Ingatlan-értékelési üzletág.

Az OTP Jelzálogbank és az OTP Bank között szoros az együttműködés, elsősorban a hiteltermék-értékesítés, kapcsolódó ügyfélkiszolgálás a számvitel, pénzügy, kontrolling és tervezési területen, valamint az IT és a kockázatkezelési területeken.

Az OTP Jelzálogbank Zrt. piaci részesedése a magyarországi jelzálog-hitelintézetek között mind a kibocsátott jelzáloglevél állomány, mind a jelzáloghitel-állomány tekintetében $70 \%$ feletti.

Az ingatlanfedezetű hitelek állománya a működés első évének végére elérte a 186 milliárd forintot.

2009-re pedig elérte csúcspontját, mely 1500 milliárd forint volt.

2014. év végi záró állomány 1115 milliárd forint, 2015 első negyedév végére a portfólióban minimálisra csökkent a devizahitel állománya.

1 https://www.takarek.hu 
Jelenleg az állomány ismét növekszik, erőteljesen összefügg a kormányzati lakástámogatásokkal.

A hitelállományhoz hasonló dinamikus növekedés jellemezte a Jelzálogbank jelzáloglevél kibocsátási tevékenységét is. Az első kibocsátások zárt körben történtek, a jelzálogleveleket az OTP Bank jegyezte le. A hitelállomány növekedésével a jelzáloglevél kibocsátások is nyilvánossá váltak és a befektetői kör is bővült. A bankcsoport egyéb tagjain kívül hazai intézményi befektetők is jelentős összegeket jegyeztek le. Az OTP Jelzálogbank az első üzleti évben 177,1 milliárd forint jelzáloglevelet bocsátott ki, 2002 decemberében a tőzsdére is bevezették. A lakossági jelzáloglevelek értékesítése 2004 elején kezdődött, az új befektetési forma sikeresnek bizonyult, a következő év végére mintegy 70,5 milliárd forintnyi állomány került a lakosság birtokába.

2004-ben nemzetközi kibocsátási program indult: 200 millió eurós kibocsátással az OTP Jelzálogbank megjelent a nemzetközi tőkepiacon, mely jelenlét azóta is aktív.

Az elmúlt években az OTP Jelzálogbank jelzáloglevél-kibocsátásai a hitelportfólió változásának dinamikáját követik. ${ }^{2}$

\section{UniCredit Jelzálogbank Zrt.}

Az UniCredit Jelzálogbank Zrt.-t (Unicredit Jelzálogbank) 1998. június 8-án 3 milliárd forint alaptőkével a Bayerische Vereinsbank AG alapította, cégbírósági bejegyzése HVB Bank Hungary Rt. néven történt 1998. augusztus 3-án.

Müködési engedélyét 1999. június 11-én kapta meg.

A jelenlegi UniCredit Jelzálogbank egyszemélyes tulajdonosa az UniCredit Bank Hungary Zrt., a kereskedelmi bank.

Tevékenységei közül a következők emelendők ki:

- Refinanszírozási tevékenység: hagyományosan a legsikeresebb üzletág a partnerbankok lakáshiteleit refinanszírozó terület. A Jelzálogbank rendszeresen bocsát ki jelzáloglevelet, jellemzően 1, ill. 5-10 év futamidővel. A forgalmazó a kereskedelmi bank, az 1 éves lejáratú jelzáloglevelekkel a lakossági befektetőket célozzák. 2018 december eleji állapot szerint a

2 https://www.otpbank.hu 
forintban denominált jelzáloglevelek forgalomban lévő állománya 158,1 milliárd forint.

- Önálló zálogjog vásárlása: önálló zálogjog vásárláson alapuló együttmüködések keretében a Jelzálogbank üzleti partnerei számára lakáscélú, illetve üzleti ingatlanok finanszírozásához köthetö forint és deviza refinanszírozást kínál. ${ }^{3}$

Erste Jelzálogbank Zrt.

Az Erste Jelzálogbank Zrt.-t (Erste Jelzálogbank) az Erste Bank Hungary Zrt. alapította 2015-ben. Müködési engedély dátuma 2016. június 30.

Az Erste Jelzálogbank által üzletszerüen végzett tevékenységek a következők:

- Refinanszírozás:

Az Erste Jelzálogbank, mint szakosított hitelintézet, Magyarország területén levő ingatlan fedezete vagy állami készfizető kezességvállalás biztosítéka mellett nyújt pénzkölcsönt pénzügyi intézmények részére.

A Magyarország területén levő ingatlanon alapított jelzálogjoggal biztosított fedezetek (jelzáloghitelek) refinanszírozása önálló zálogjog vásárlásán/viszszavásárlásán keresztül történik.

- Ingatlanok forgalmi és hitelbiztosítéki értékének megállapítása:

A jelzálog-hitelintézetek a Jht.-ban meghatározott pénzügyi, befektetési, illetve kiegészítő befektetési szolgáltatásokon kívül üzletszerüen kizárólag ingatlanok forgalmi és hitelbiztosítéki értékének meghatározását végezhetik

2016. március 21. óta minden hitelintézetnek a termőföldnek nem minősülő ingatlanok hitelbiztosítéki értékének meghatározására vonatkozó módszertani elvekről szóló 25/1997. (VIII. 1.) PM rendelet alapján kell megállapítania a fedezetül felajánlott ingatlan forgalmi értékét.A rendelet elöírásai korábban kizárólag a jelzálog-hitelintézetekre voltak irányadók.

Az Erste Jelzálogbank az Erste Bankcsoporton belül vagyonértékelési kompetencia-centrumként müködik, de piaci szereplők számára üzletszerüen is nyújt ingatlan vagyon-értékelési szolgáltatást:

3 https://www.jelzalogbank.hu 
1. Pénzügyi hitel- és kölcsön-ügyletekhez kapcsolódóan ingatlanfedezetek forgalmi és hitelbiztosítéki értékének megállapítása;

2. Szakértői vélemények (értékbecslések, müszaki- és projektellenőri jelentések) elkészítésének megrendelése és elkészítése, már elkészült szakvélemények tételes vizsgálata a megbízóval egyeztetett tartalmi és formai követelmények alapján;

3. Ingatlanok külső- és belső helyszíni szemlével történő értékelése, tételes újraértékelése;

4. Rendkívüli ingatlanpiaci események hatására történő tömeges újraértékelés statisztikai módszerek felhasználásával.

- Jelzáloglevél kibocsátás:

Az Erste Jelzálogbank az általa kibocsátott jelzálogleveleket alapvetően nyilvános módon hozza forgalomba, de lehetőség van zártkörü forgalomba hozatalra is. A befektetők egyaránt találkozhatnak tőzsdére bevezetésre kerülő, illetve szabályozott piacra be nem vezetett jelzáloglevelekkel.

Az értékpapírok kamatozás szempontjából fix vagy változó kamatozásúak.

Ha a jelzáloglevél kibocsátására az Erste Jelzálogbank kibocsátási programja alapján kerül sor, a jelzáloglevelet erre szakosodott befektetési szolgáltatók, mint forgalmazók értékesítik. ${ }^{4}$

KઐH Jelzálogbank Zrt.

A K\&H Jelzálogbank Zrt.-t 2016. január 6-án kizárólagos tulajdonosként a K\&H Bank alapította. Müködési engedélyének dátuma 2016. szeptember 30. A K\&H Jelzálogbank lakossági ügyfeleket közvetlenül nem szolgál ki, engedélyét kizárólag pénzügyi intézményügyfelek részére történő szolgáltatásnyújtás korlátozással kapta.

A K\&H Jelzálogbank a K\&H Bank lakossági jelzáloghiteleinek refinanszírozását végzi, mely fedezet terhére jelzálogleveleket bocsát ki annak érdekében, hogy a K\&H Bank 2017. április 1-jétől eleget tegyen a JMM mindenkori elöírásainak, amelyet a hitelintézetek forint lejárati összhangjának szabályozásáról szóló MNB rendelet tartalmaz. ${ }^{5}$

4 https://www.erstebank.hu

5 https://www.kh.hu/csoport/jelzalogbank 
MKB Jelzálogbank Zrt.

Az alapítás dátuma: 2016. 02. 19. Alapító az MKB Bank, kisebbségi részvényes a Gránit Bank.

Az MKB Jelzálogbank jelenleg végelszámolás alatt áll. Az MKB Bank a Takarék Jelzálogbank tulajdonosi köréhez tartozik.

\subsection{Irodalomjegyzék}

Éliás János (2011): Jelzáloghitel-intézetek. In: Tatay T., Vágyi F. R., Varga J. (szerk.) A pénzügyi intézményrendszer Magyarországon. Sopron: A Soproni Felsőoktatásért Alapítvány.

Huszár Lilla (2006): Jelzáloghitelezési rendszerek és a lakáspolitika kapcsolatának bemutatása, nemzetközi összehasonlítás. Doktori értekezés. Sopron: Nyugat-Magyarországi Egyetem.

Kolozsi Pál Péter - Lentner Csaba - Parragh Bianka (2017): Közpénzügyi megújulás és állami modellváltás Magyarországon. Polgári Szemle, 13. évf., 4-6. szám, 28-51., DOI: 10.24307/psz.2017.1204

Papp Mónika (2005): A jelzáloglevél alapú finanszírozás helyzete Magyarorszá-

gon pénzügyi stabilitási szempontból. MNB Mühelytanulmányok 36. Magyar

Nemzeti Bank. ISSN 1585-5651 (on-line)

1997. évi XXX. törvény a jelzálog-hitelintézetről és a jelzáloglevélről

2007. évi CXXXVIII. törvény a befektetési vállalkozásokról és az árutőzsdei szolgáltatókról

2013. évi CCXXXVII. törvény a hitelintézetekről és a pénzügyi vállalkozásokról 2013. évi V. törvény a Polgári Törvénykönyvről

20/2015. (VI. 29.) MNB rendelet a hitelintézetek forint lejárati összhangjának szabá-

lyozásáról valamint az általuk végezhetö tevékenységek szabályairól

25/1997. (VIII. 1.) PM rendelet a termőföldnek nem minősülő ingatlanok hitelbizto-

sítéki értékének meghatározására vonatkozó módszertani elvekről

https://www.mnb.hu

https://www.takarek.hu

https://www.otpbank.hu

https://www.jelzalogbank.hu

https://www.erstebank.hu

https://www.kh.hu/csoport/jelzalogbank 


\section{Lakástakarékpénztárak}

\subsection{A lakástakarékpénztárak és kialakulásuk}

A modern állam jóléti funkciói közé tartozik - többek között - az általános jólét és társadalmi egyenlőség biztosítása, melynek része a lakhatás biztosítása, támogatása. A kormányok mindig is foglalkoztak országuk lakásállományával, főleg a költségvetési politika eszközein keresztül. Ennek okai részben közgazdaságiak, részben szociálisak. Egyrészt egy ország lakásállománya a nemzet vagyonának része, ennek bővítése gazdasági értelemben multiplikátor-hatású, másrészt e vagyonelem biztosítja a lakhatási feltételek biztosítását, a társadalmi egyenlőség szolgálatát. Mindenkinek közös érdeke e vagyonelemek bővítése és a lakástulajdonhoz, lakásbérlethez való hozzájutás redisztribúciós eszközökkel történő támogatása. A modern polgári államok jelentős összegeket költenek rá, az Európai Uniós átlag jelenleg kb. a GDP 1,5-2\%-a (Ferencz, 2008).

A mindenkori kormányoknak el kell dönteniük, hogy milyen formában támogatják az állampolgárok lakáshoz jutását, ugyanis folyó bevételeikből és megtakarításaikból a lakásvásárlás egyszeri nagy költségét kevesen tudják kifizetni. A lakáspolitikai célkitűzések elérésének eszközei nagyon sokfélék lehetnek, például kamattámogatás, törlesztési támogatás, banki költségek támogatása, adókedvezmények, garancianyújtás (pl. fecskeház program), költségek mérséklése (forgalmi adó visszatérítés, illetékcsökkentés), kedvezmények (pl. gyermekek után, mozgáskorlátozottaknak).

\subsection{A magyarországi lakáspiac}

Magyarországon az 1960-as évektől figyelhető meg a lakáshiány kialakulása, ennek megoldására növelték a lakásépítésekre fordított állami kiadásokat, felgyorsult a bérlakásépítés, középpontba került a saját tulajdonú építés támogatása. A hatvanas években a lakások számának mennyiségi növelése volt a cél, azaz a lakosság gyors lakáshoz juttatása, de az elkészült lakások minősége, majd későbbi korszerüsítése, felújítása már nem volt fontos. A vélt megoldást a paneltechnológia megjelenése jelentette, amely nagyon sok embernek nyújtott elfogadható árú lakhatást (Huszár, 2006). (A panellakásokat és -technológiát sokan „temették” 
már, de a mai napig nagyon közkedvelt lakhatási forma, melyben nagy szerepe volt a Panel Plusz programoknak és más korszerüsítési támogatásoknak.)

1971-ben került bevezetésre a szociálpolitikai kedvezmény és a kamattámogatás mellett nyújtott lakáskölcsön, illetve a kamatmentes munkáltatói kölcsön. A szociálpolitikai kedvezmény, bár az óta több változtatáson is keresztülment - más néven -, napjainkban is a lakástámogatási rendszer egyik alapeleme. Magyarországon az építkezési csúcs 1975-ben volt, abban az évben 99588 új lakást építettek. 1989-re a lakásokkal kapcsolatos költségvetési támogatások már elérték a magyar GDP 6\%-át (Dániel, 1996).

A rendszerváltás után teljesen más kép alakult ki a lakáspiacon, az állam lassan teljesen kivonult a lakásépítésekből, a kamatok piaci alapokra helyeződtek át, magas kamatszint alakult ki. Az állami kivonulás világosan látszik abból, hogy az állami lakásépítés részaránya 1991-ben 4,7\%, míg 1995-ben már csak 0,7\% az összes lakásberuházásból, a többi magánberuházás. A támogatási rendszer három pilléren nyugodott: a vissza nem térítendő támogatásokon, a törlesztési támogatáson és a kamatmentes hiteleken. A vissza nem térítendő támogatások körébe tartozott a szociálpolitikai segély, a fiatalok otthonteremtési támogatása, illetve az önkormányzati és vállalati hitelek.

A rendszerváltás után nagyon gyorsan átalakult az ingatlanpiac, a nagy építőipari vállalatok felbomlottak, privatizálták őket, liberalizálták az addig gyakran hiánnyal küszködő építőanyag kereskedelmet, jelentős mértékű volt a lakásprivatizáció. Az önkormányzatokra szállt az állami lakásvagyon, de ennek jelentős részét eladták, kevés önkormányzati lakás épült az utóbbi 20-25 évben. Elmondható, hogy az átalakulási folyamat nem volt gördülékeny, visszaestek a lakásépítések, a lakásállomány állapota romlott, megmaradtak és súlyosbodtak a felújítás problémái (Huszár, 2006).

A válságjelenségek között a legfeltűnőbb a hitelek szerepének a csökkenése volt, az új kihelyezések állománya nem érte el a törlesztések értékét. A lakáshitelezés válságát mutatja, hogy az 1990-es években a hitel/beruházás arány 22\%ról 3\%-ra, a lakáshitel/lakásállomány mutató pedig 9\%-ról 2\%-ra esett vissza (Hegedűs, Várhegyi, 1999). 


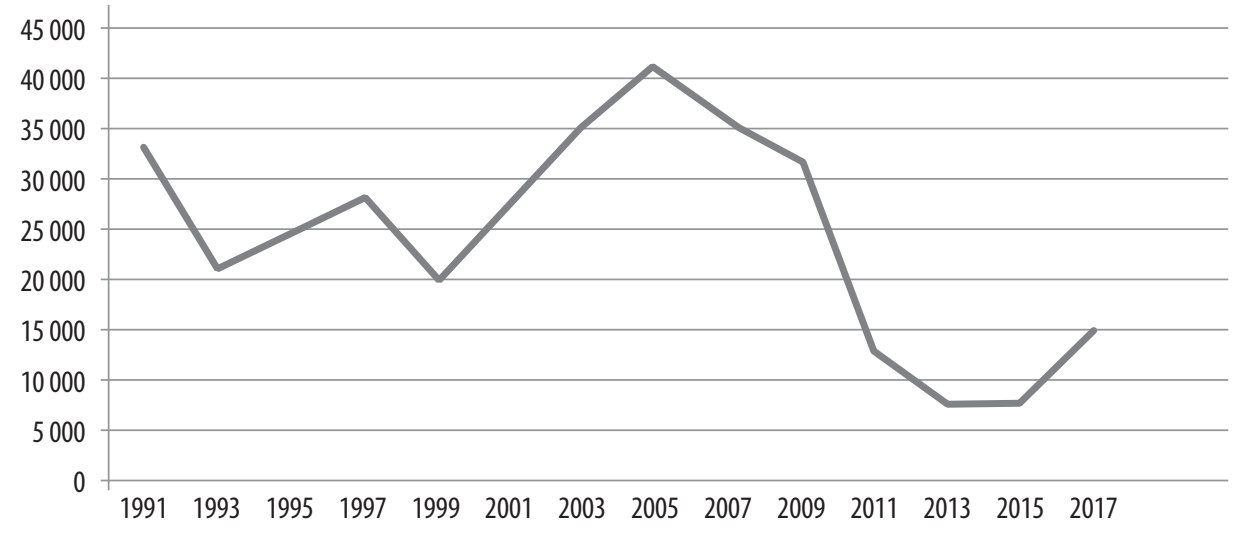

\section{1. ábra: Lakás- és üdülőépítések száma}

Forrás: Saját szerkesztés, KSH alapján (2018)

Ezeket a folyamatokat tökéletesen mutatja az 1. ábra. 1999-ben már csak 19287 új lakás készült. Ezt követően az építkezések száma fellendült, ám ennek a növekedésnek határt szabott a 2007-ben kirobbant gazdasági-pénzügyi válság.

A válságot követően lassan növekedett ez a szám, amit nagyban befolyásolt és befolyásol a mai napig is - a kedvezményes áfa (mértéke) és a súlyosbodó vagy nagyfokú munkaerőhiány, mely az építőiparban is érezteti hatását. Ennek ellenére „dübörög az építőipar”, folyamatosan nő a lakásépítési és használatbavételi engedélyek száma. A 2000-2008 közötti - válság előtti - időszak átlagát idén már el fogja érni a lakáspiaci tranzakciók száma. Az árakkal kapcsolatosan is hasonló a helyzet, a vásárlási kedv növekedésével drágultak a lakások, Budapesten és a megyeszékhelyeken már meghaladják a válság előtti szintet ${ }^{1}$.

1 https://www.oc.hu 


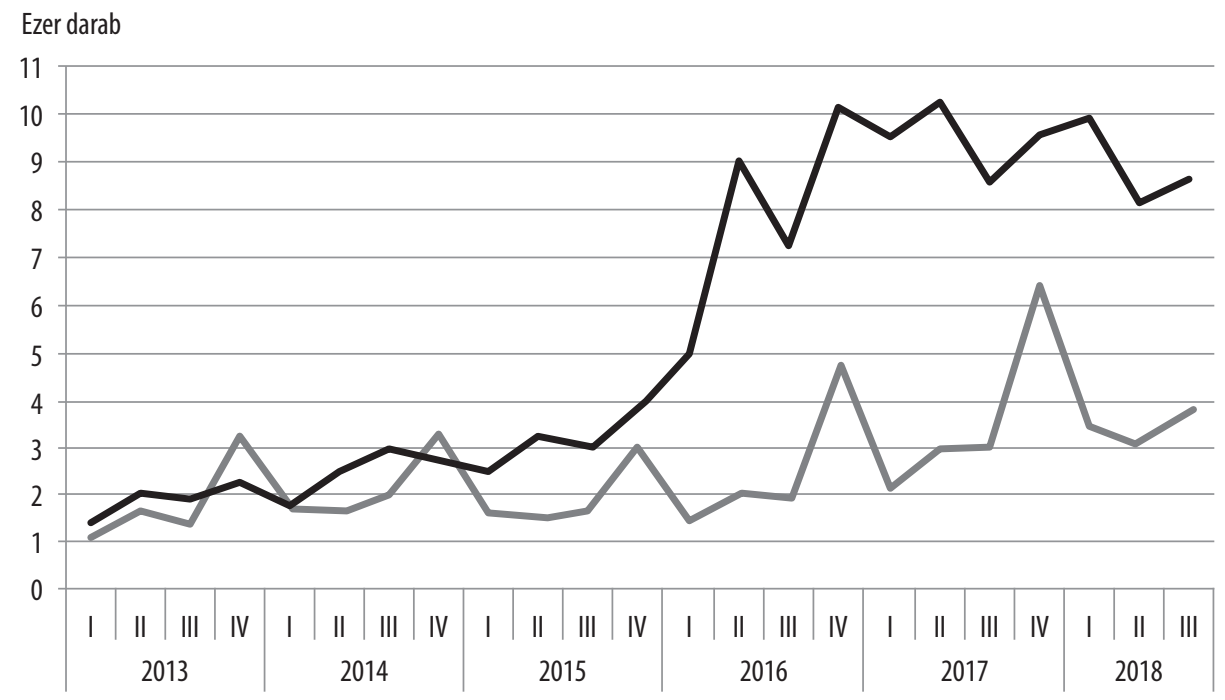

A kiadott lakásépítési engedélyek és egyszerū bejelentések száma A használatba vett lakások száma

\section{2. ábra: Lakásépítések száma}

Forrás: KSH Gyorstájékoztató, Lakásépitések, épitési engedélyek, 2018. I-III. negyedév

Magyarországon jelenleg kb. 4 millió lakás található, a lakások átlagéletkora 100 év, így a 100 év alatti megújuláshoz évente 40 ezer új otthonnak kellene felépülnie és ezzel még csak a jelenlegi szint tartható fent. A 2. ábrán látható, hogy még nagyon messze vagyunk ettől a szinttől. Magyarországon a lakásállomány éves megújulási rátája (a felépült lakások száma a lakásállományhoz viszonyítva) a 2008-ban 0,85\%, 2013-ban 0,17\%, 2017-ben 0,33\%, ami régiós összevetéseben sajnos a legalacsonyabb érték. (Ausztriában ez 10,4\%, Lengyelországban 1,25\%, Szlovákiában 0,9\%, Csehországban és Romániában 0,6\%.) (Fellner, Bereczki, Kovalszky, Winkler, 2018)

Elmondhatjuk, hogy szinte senki sem egy általa vásárolt lakásban kezdi életét. Először természetszerűen a szüleivel lakik, majd feltehetően bérel, később önerőből vagy támogatással vásárol vagy építkezik, ezek a fázisok időben egymást követő állapotok.

Magyarország a legkisebb bérlakás-szektorral rendelkező országok közé tartozik, ez az arány kb. 12\%, jelenleg is csökkenő tendenciát mutatva. Ennek egyik 
oka az, hogy a magyarok inkább a saját tulajdonú lakást preferáljak, a belső mobilitás sokkal kisebb, mint tőlünk nyugatra. A bérlakások hiányát legfőképpen a pályakezdő fiatalok érzik.

A lakásépítések és felújítások ösztönzésére született 1996-ban a lakástakarékpénztárakra vonatkozó törvény. A törvény hatályba lépése után, 1997 tavaszán megalakult az első három lakás-takarékpénztár: a Lakáskassza Első Általános Lakástakarék-pénztár (névváltoztatás után Lakáskassza-Wüstenrot Rt.), a Fundamenta Magyar-Német Lakás-takarékpénztár Rt. és az OTP Lakás-takarékpénztár Rt. (Ez a piac később négy majd újra háromszereplős lett.) 1998-ban az állami támogatás 40\%-ról 30\%-ra csökkent, ami megnehezítette a lakáspiac működését (Horváthné Kökény, 2009).

Több mint egy évtizedes szünet után került sor az új hiteltámogatási forma bevezetésére, 2000-től kamattámogatást lehetett igénybe venni az új építésủ lakásokhoz felvett jelzáloghitelekre. Első körben csak az új építésű lakásokat támogatták, és a piacon azok a hosszú távú jelzáloghitelek váltak uralkodóvá, melyek fix kamatperiódusúak és nem elötörleszthetők voltak, és ez megdrágította az ingatlanokat. A későbbiekben a kormányzat a támogatásokat kiterjesztette a használt lakásokra is, 2001-ben a lakáshitel kihelyezés már elérte a havi 15 milliárd forintot. 2003-tól szigorodtak a lakáshitel felvétel és folyósítás feltételei, melynek célja a kormányzati kiadások csökkentése volt, ezzel együtt a háztartások kamatterhe növekedett, a bankok profitja csökkent, ez az állami támogatású hitelek arányának csökkenéséhez vezetett (Kiss, Vadas, 2006).

Ezzel párhuzamosan a piacon új termékként megjelent a devizaalapú lakáshitel, jóllehet a nyilvánvaló kockázatok ellenére is egyre több család választotta ezt a hiteltípust, amelynek oka természetesen az alacsonyabb nomináliskamat volt. Ezt követően a lakástakarékpénztárak is megjelentek a devizahitelekkel kombinált előtakarékossági formákkal. A devizahitelek a kedvezőbb kamatszint miatt kiszorították a magas kamatozású forinthiteleket, jelentősen emelkedett a lakossági hitelek állománya, elindult az eladósodási folyamat.

A 2008-as pénzügyi-gazdasági válság kirobbanása után jelentősen megnövekedtek a havi törlesztőrészletek, jelentős stabilitási kockázatot jelentve a lakosságnak és általuk az egész nemzetgazdaságnak. A helyzet rendezésére több intézkedés is született (pl. a végtörlesztés, árfolyamgát), ám ezt véglegesen csak 
a devizahitelek rendezésével sikerült megoldani. A devizahitelek kivezetésére két ütemben került sor, először a lakossági devizaalapú és deviza jelzáloghitelek, majd az egyéb lakossági devizahitelek esetében. Az ehhez szükséges kb. 10 milliárd eurónyi devizalikviditást a Magyar Nemzeti Bank 2014 őszétől bocsájtotta a kereskedelmi bankok rendelkezésére. Ahogy a 3. ábrán látható, ennek eredményeképpen az említett bankok mérlegeiből kikerültek a fedezetlen lakossági devizahitelek, azokat átváltották, forintosították (Parragh, 2017).

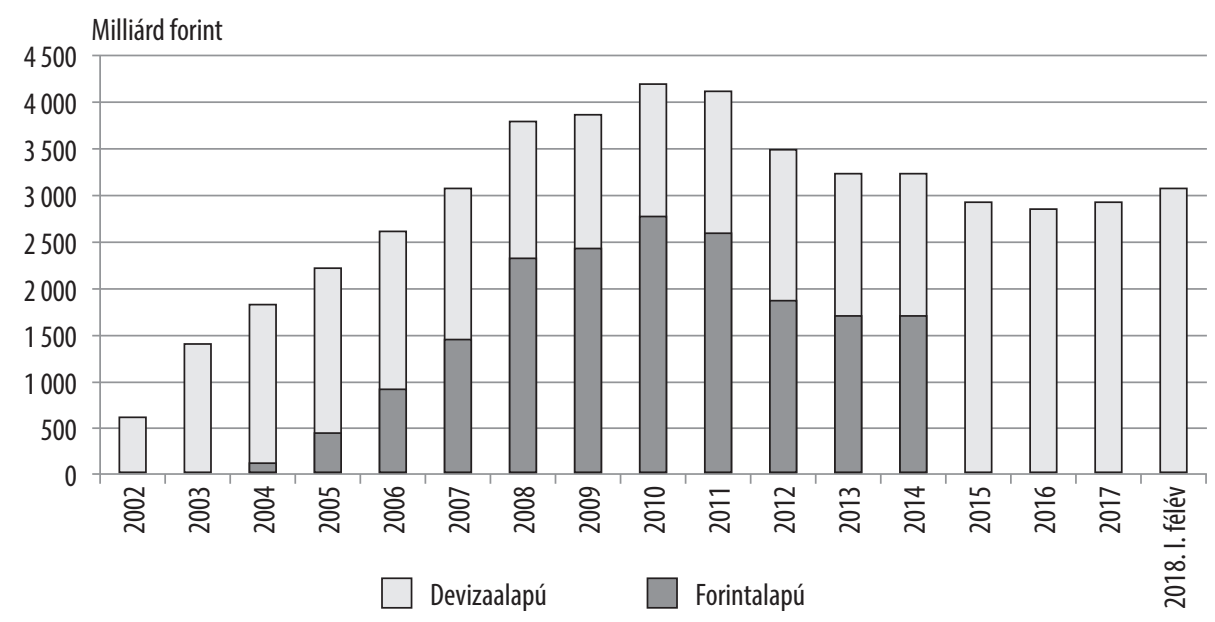

3. ábra: A lakáscélú hitelek állományának alakulása

Forrás: KSH Statisztikai tükör, 2018. október

\subsection{A lakástakarékpénztárak kialakulása}

A lakástakarékpénztáraknak három fő modellje alakult ki Európában: a német, az angolszász és a francia modell.

\section{Német modell}

A lakástakarékpénztár Németországban már régóta elterjedt finanszírozási forma. A kollektív előtakarékosság elvében rejlő lehetőségeket felismerve, az első német lakástakarékpénztárat még 1885-ben (a magyarországinál 102 évvel korábban) alapították Bielefeld városában (Észak-Rajna-Vesztfália tartomány), „Mindenki Építési Takarékpénztára” elnevezésű intézményként. 
A lakáskölcsön folyósítása ebben a modellben más betétesek megtakarításaiból, illetve azoknak az ügyfeleknek a törlesztéseiből történik, akik korábban már megkapták a kölcsönt. Ennek a „Bauspar” modellnek a müködését az az összefogás alapozza meg, hogy a tagok egy közös cél - lakáscél megvalósítása, finanszírozása - érdekében fognak össze. Ez azt jelenti, hogy a német pénztárak zárt rendszerben müködnek, azaz eleve csak azok kaphatnak hitelt, akik már korábban betétet helyeztek el, azaz korábban megtakarítottak valamelyik lakástakarékpénztárnál. Ez adja a rendszer biztonságát, és ezzel együtt egy sajátos finanszírozási körforgás jön létre. Amennyiben a betétekből, az állami támogatásból, a lakáskölcsönök tőketörlesztéséből álló kiutalási összeg nem elegendő az összes hiteligénylő kérelmének teljesítésére, a megtakarításaik alapján sorba állított ügyfelek egy részének várnia kell a kiutalásra. (Ezt a kezdeti években sorsolással helyettesítették, de azt gyorsan eltörölték.)

A napjainkban is müködő zárt lakástakarékpénztári rendszer első formái azonban „csak” az 1920-as években jelentek meg Németországban, azóta lakás-előtakarékossági konstrukcióval kizárólag az e célra létrehozott intézmény foglalkozhat. A német rendszer a lakáshitel-piacot elválasztja a pénzügyi piac többi részétől, amit úgy valósít meg, hogy a kölcsönkért kiutalható összeget a felhalmozott előzetes megtakarítás függvényében határozzák meg, és csak az állami támogatás folyik be a rendszerbe a megtakarításokon, illetve korábbi hitelek törlesztő részletein kívül, azaz a rendszer gyakorlatilag zárt. A zárt rendszer előnye, hogy lehetővé teszi az infláció, illetve a pénz- és tőkepiac alakulásától független fix kamatlábak alkalmazását mind a betéteknél, mind a hiteleknél. A betét- és hitelösszegeket csak lakáscélra lehet felhasználni. Mivel a betéti és hitelkamat szintje rögzített, egy ilyen rendszer csak stabil gazdasági-pénzügyi viszonyok között múködöképes. Abban az esetben, ha a kamatszint folyamatosan változik, csak állandó magas állami támogatással érhető el a likviditás alapját képező betétek folyamatos elhelyezése.

A pénztárak kb. egyharmad része közjogi formában működik, azaz tartományi bankok keretében folytatják tevékenységüket. A kialakult lakástakarékpénztári rendszer német nyelvterületen ma is igen elterjedt és nagy népszerüségnek örvend. Ma már Németországban a lakástakarékpénztárak szerepe olyannyira megerősödött, hogy elképzelhetetlen lenne az ingatlanpiac nélkülük (Huszár, 2006). 


\section{Angolszász modell}

Hasonló intézményi háttér kialakulása Angliában már a 19. század közepén megkezdődött, az úgynevezett „Building Society” (azaz építési társulás) néven.

Az építési társaságok tagjai, illetve jelzáloghitel felvevői a közgyűlésen szavazati joggal rendelkeznek, minden tagnak egy szavazata van, függetlenül a befektetett összeg, illetve a hitel nagyságától. Az, hogy a működés a megfelelő stratégia mentén történjen, az az építési társulás igazgatóságának a felelőssége. A társulások abban különböznek a bankoktól, hogy nem vállalkozási formában működnek, nincsenek bejegyezve a tôzsdén, így nem a tulajdonosok érdekei vezérlik, nem kell osztalékot fizetni. Mindez alacsonyabb költséggel való müködést tesz lehetővé számukra, jelzáloghiteleik olcsóbbak, a betéti kamatok magasabbak voltak versenytársaikénál (Szondi, 1999, Huszár, 2006).

Az 1990-es évek második felében változás történt az építési társulások piacán, több nagytársulás bankká alakult, működésük költségesebb lett, ezáltal vesztettek versenyelőnyükből, 2008-ban ez vezetett a brit Northern Rock összeomlásához.

Általánosan megfigyelhető tendencia, hogy az építési társaságok diverzifikálják tevékenységüket, azaz egyre több terméket kínálnak tagjaik számára, például biztosításokat közvetítenek, egyéb befektetési lehetőségeket biztosítanak, hitelkártyát, utazási csekket bocsájtanak ki, elszámolási betétszámlát vezetnek, vagy éppen ingatlanközvetítéssel foglalkoznak (Huszár, 2006).

Napjainkban Nagy Britanniában több mint 40 építési szövetkezet müködik, 34000 alkalmazottal, 308 millió fontos eszközállománnyal, és 185 millió fontos jelzáloghitel kihelyezéssel. (Az elmúlt 25 évben nagyon sok lakástakarékpénztár és fiók megszűnt, bezárt.)

\section{Francia modell}

Ez a modell eredetileg zárt rendszer volt, de az 1970-es években nyitottá alakították annak érdekében, hogy a hosszú távú megtakarítások növekedjenek. Itt - Németországgal ellentétben - a lakástakarékpénztárak nem szakosított pénzintézetekként működnek.

A nyílt rendszerben működő francia modellben a megtakarító személy a megtakarítási idő lejártakor lehívhatja a kölcsönét, de ahhoz, hogy ez a rendszer 
müködjön, az szükséges, hogy legyen elég számú olyan megtakarító, aki nem szándékozik lakáscélú hitelt igénybe venni és betéteiket nem lakáscélra használják fel. A nyitott rendszerek, bár sikeresek lehetnek a források növelésében, de ugyanakkor jelentős támogatást igényelnek. Müködésének lényege, hogy ezt a konstrukciót kereskedelmi bankok és takarékpénztárak ajánlják ki ügyfeleknek, amiben az előtakarékoskodók összegyüjtött pénzét más, a rendszeren kívüli személyeknek is felkínálják lakáscélú hitelként.

A megtakarítók a betéti szakasz letelte után azonnal, „sorban állás” nélkül hozzájuthatnak pénzükhöz. A felhasználási kör szűkebb a magyarénál, csak új vagy használt lakás vásárlására, vagy energia-megtakarítást célzó létesítmény létrehozására lehet felhasználni, lakásfelújításra például nem (Novotny, 2006).

\section{A zárt rendszer müködése}

A zárt rendszerü kollektív takarékoskodás lehetővé teszi, hogy a takarékoskodók megtakarítási céljaikat átlagosan előbb érjék el, mintha egyénileg takarékoskodnának.

Például, ha tíz személy maga gyüjtene lakásra, és tíz év kellene mindegyiknek a vételár összegyüjtésére. Feltételezzük az egyszerűség kedvéért, hogy a vételárak és a félretett összegek azonosak. Ha a tíz személy kollektíven takarékoskodik, akkor egyikőjük már az első év végén lakáshoz juthat. A következő évben a második, és így tovább. A tíz év megtakarítási idő mellett, az átlagos várakozási idő tíz évről öt és fél évre csökken. Kérdés persze, miként állithatók sorba a megtakarítók, amikor el kell dönteni, kik is legyenek azok, akik az előnyöket korábban élvezni fogják. Régebbi időkben, Németországban volt olyan pénztár, ahol egyszerü sorsolással választották ki az előnyt élvező személyeket. A mai lakástakarékpénztárak ennél sokkal kifinomultabb módszereket alkalmaznak.

A sorrend meghatározásának általános alapelve, hogy az előtakarékoskodók a megtakarítás ideje alatt mennyiben járultak hozzá a kollektív megtakarításhoz. A betétek kifizetésének, a kölcsönök nyújtásának rendje a pénztárak biztonságos müködését is jelentősen befolyásolják. Az állami támogatás igénybevétele szintén igényli, hogy bizonyos kötöttségek érvényesüljenek a kifizetések ütemezésénél. 


\subsection{A lakástakarékpénztárak magyarországi kialakulása}

Törvényi háttér:

- 1996. évi CXII. tv. a Hitelintézetekről és a pénzügyi vállalkozásokról

- 1996. évi CXIII. tv. a Lakástakarékpénztárakról

- 215/1996 (XII. 23.) kormányrendelet a lakás-előtakarékosság állami támogatásáról

- 47/1997 (III. 12.) kormányrendelet a lakástakarékpénztár általános szerződési feltételeiről

- 2018. évi LXIII. tv. a Lakástakarékpénztárakról szóló 1996. évi CXIII. tv. módosításáról

A „lakástakarékpénztár” elnevezést a törvény (1996. évi CXIII. tv.) nevesíti, a 4. bekezdése szerint: „A lakástakarékpénztár elnevezést, e fogalom jelzős alakját, továbbá rokon értelmű vagy idegen nyelvü megfelelőjét csak az e törvényben elöírtaknak megfelelően alapított és működtetett szakosított hitelintézet használhatja." A lakástakarékpénztár a jelenlegi hazai pénzügyi szabályozás szerint szakosított hitelintézetnek minősül, a jelzáloghitelintézetekkel együtt (Baka et al. 2012, Ligeti et al. 2019). A szakosított hitelintézetek új definiálását és szabályozását - a többi pénzügyi intézménytípussal együtt - az eggyel kisebb sorszámmal elfogadott, a Hitelintézetekről és a pénzügyi vállalkozásokról szóló 1996. évi CXII. törvény tette meg (Kovács, 2011).

Hazánkban bő két évtizede jelentek meg a lakástakarékpénztárak, melyek a kollektív előtakarékosság elve alapján müködnek. A lakástakarékpénztári rendszer létrehozásának célja az volt, hogy létrejöjjön egy olyan intézményi keret, amely ösztönzi a lakáscélok megvalósítását saját tőkéből elősegítő előtakarékosságot, elősegítse a lakásvagyon állomány értékének megőrzését, megteremtse a lakás-előtakarékosság zárt és elkülönült rendszerben, biztonságos keretek között, állami támogatással történő lebonyolításának feltételeit. A pénztárak tulajdonképpen egy kölcsönalapból nyújtanak kölcsönöket, ennek az alapnak egy része a pénztártagok előtakarékossági befizetéseiből, másik része a betétek után felgyülemlett kamatokból, harmadrésze pedig az állami támogatásokból áll, a negyedik rész pedig a lakáskasszától felvehető kedvezményes lakáshitel.

A lakástakarékpénztári modell lényege, hogy a pénztári tagok egy része befizet, másik része pedig hitelt vesz fel, vagyis az egyik finanszírozza a másikat, egy 
sajátos önfinanszírozó rendszer jön létre. Abban az esetben, ha az új tagok belépése folyamatosan biztosított, az alap önfenntartóvá válik. Már a kezdetekben, azaz a szerződés aláírásakor rögzítik, hogy az ügyfelek a jövőbeni felvehetö kölcsönösszegük hány százalékát kötelesek elötakarékossággal kifizetni. A konstrukció előnye, hogy mind a betétek, mind pedig a kölcsönök fix kamatozásúak, azaz a szerződők számára a betéti és hitelkamatlábak előre rögzítettek, azaz a tőkepiac változásainak nincsenek kitéve (Horváthné Kökény, 2009).

Ezekből is látszik, hogy a magyar rendszer a német mintát követve alakult ki, zárt rendszerü, tehát a lakáskölcsönök folyósítását a betétesek megtakarításból, illetve a már hitelt kapott ügyfelek törlesztéseiből valósítják meg.

A magyar pénztárak már 2000-ben 55 milliárd forint értékű megtakarítást és 13 milliárd forint állami támogatást kezeltek. A már említett, ezredfordulón bevezetett új lakástámogatási rendszer visszaesést okozott számukra, a nyújtott állami támogatással igénybe vehető hitelek összege lecsökkent, amit tovább tetézett a lakásárak folyamatos növekedése is. Mindezek következtében a pénztárak veszítettek versenyképességükből. Később, a támogatás mértékének megemelése segített valamelyest megerősíteni piaci helyzetüket. A piacon eredetileg négy pénztár tevékenykedett, 2004-ben az integrációk következtében két szereplö maradt a piacon (OTP Lakástakarék Zrt., Fundamenta Lakáskassza Zrt.), majd 2011-ben az ERSTE Lakástakarék Zrt., 2013-ban pedig az Aegon Lakástakarékpénztár kezdte meg müködését (az Aegon Lakástakarékpénztár 2018. október 1-jével felfüggesztette értékesítési tevékenységét).

A Fundamenta Lakáskassza 2017. év végén 780000 betétszerződést kezelt (ez mintegy félmillió háztartást jelent), 2362 milliárd forint szerződéses összeg értékben. 2017 végére 343 milliárd forintra emelkedett a Fundamenta hitelállománya, ezzel ez a társaság fedi le a teljes magyarországi lakáshitel-állomány mintegy 11 százalékát, betétállománya meghaladta a 434 milliárd forintot, az ügyfeleknek (hitel, megtakarítás és állami támogatás formájában) 210 milliárd forintot fizettek ki. (2018 év végére a hitelállomány mintegy 400, a betétállomány mintegy 5000 milliárd forintra növekedett, 900000 ügyféllel.)² Az OTP Lakástakarékpénztár betétállománya 2017 végén meghaladta a 285 milliárd forintot, és 5 milliárd forintra emelkedett a lakáshitelállománya, egy évvel korábban

2 https://www.portfolio.hu 
105000 szerződést kötöttek. Az ERSTE Lakás-takarékpénztár 2016-ban közel 150 milliárd forint szerződéses összegben értékesített LTP-s megtakarítási terméket. Az AEGON Magyarország Lakástakarékpénztár 2015-ös 42 milliárd forintnyi új szerződéses összege 2016-ra 53,5 milliárd forintra emelkedett, darabszámát tekintve pedig 13 626-ról 14 746-ra nőtt (Palkó, 2017).

Jelenleg Magyarországon több mint egymillióan rendelkeznek lakás takarékpénztári szerződéssel, és ahogy az 1. táblázatban is látható, a lakáscélú hitelekből a lakáskasszák 385 milliárd forinttal, mintegy 12,26\%-kal részesednek.

\begin{tabular}{|l|r|c|}
\hline Hitelintézet & Összesen & Ebböl: devizaalapú \\
\hline Bank & 1773 & 3,3 \\
\hline Jelzáloghitel-intézet & 873 & 0,6 \\
\hline Takarékszövetkezet & 109 & 0,0 \\
\hline Lakás-takarékpénztár & 385 & - \\
\hline Összesen & $\mathbf{3 1 4 0}$ & $\mathbf{3 , 9}$ \\
\hline
\end{tabular}

1. táblázat: A lakáscélú hitelek állománya, 2018. június 30.

(milliárd forint)

Forrás: KSH Statisztikai tükör, 2018. október

A hazai lakástakarék termékek penetrációja jelenleg 12 százalék körüli, mely jóval alacsonyabb, mint a környező országokban, ez Németországban 40\%, Ausztriában 65\%, Csehországban 45\%, Szlovákiában 20\%. Az éves befizetésekre adott támogatás mértéke Magyarországon 30 százalék volt, jelenleg Csehországban 10\%, Szlovákiában 8,5\%, Ausztriában 1,5\%, Németországban pedig 8,8\% (Palkó, 2013).

\subsection{A lakástakarékpénztárak tevékenysége}

A lakástakarékpénztárak alaptevékenysége tehát a lakás-előtakarékossági szerződés alapján végzett betétgyüjtés és hitelnyújtás. A megtakarítók a pénztárakon keresztül állami támogatáshoz is jutnak (a 2018. október 16. előtt kötött szerződések esetében, lásd még utolsó alfejezet). A megtakarítási időszakban részöszszeget kivenni nem lehet, felmondáskor az állami támogatás nem jár. A magyar modellben a szerződők számára a betéti és hitelkamatlábak is rögzítettek, így a tőkepiac változásainak nincsenek kitéve. 
Nézzük, hogy leszünk szerződő tagok. A lakástakarékpénztár lakás-előtakarékossági szerződést köt ügyfelével. Szerződéskötéssel lakáselőtakarékoskodóvá válhat magánszemély (természetes személy), lakásszövetkezet, társasházi közösség. A szerződés egyrészt betéti szerződés, másrészt hitelígérvényt tartalmaz, egy meghatározott összegre, a szerződéses összegre szól. A szerződéses összeg a betétbefizetésből, a betéti kamatokból, az állami támogatásból, valamint a lakáskölcsönből tevődik össze. A betéti és hitelkamatokat a szerződéskötéskor rögzítik, ekkor megállapítják a kölcsönhöz kapcsolódó hiteldíj mutatót is³ .

Az állami támogatás mértékét jogszabály határozza meg. A támogatás mértékének esetleges későbbi változtatása a már megkötött szerződéssel rendelkezők támogatását nem érinti. A támogatás mértéke a rendszer indulásának évében a befizetések 40\%-a volt, 1998-tól a befizetések 30\%-a, 2018 októberében az állami támogatás megszűnt. Természetesen csak az állami támogatás összege korlátozott nagyságú, a szerződéses összeg nem. Az állami támogatás feltétele a minimum 48 hónap megtakarítási idő és a megtakaritás lakáscélú felhasználása, ez Magyarország területén érvényes, maximum 10 évig jár, adó- és járulékmentes. Az állami támogatás csak akkor illeti meg az előtakarékoskodót, ha a megtakarítását lakáscélra használja fel, azaz lakás-, ház-, tanya-vásárlásra, felújításra, bővítésre, közüzem kialakítására, szerelésére stb. (bővebb felsorolást lásd a törvényben) (Kiss, 1996a, 1996b).

Magyarországon a lakástakarékpénztári konstrukció mindenki számára elérhető, és négy részből tevődik össze: az ügyfél rendszeres megtakarításaiból, az adott évben befizetett betétekre évente jóváírt 30\%-os, magánszemélyek részére maximum évi 72000 Ft-os (adó és járulékmentes) állami támogatásból (a 2018. október 16-a előtt kötött szerződések esetében, lásd még utolsó alfejezet) és az ezekre jóváírt kamatból, valamint a megtakarítási idő lejártát követően a fix kamatozású forint alapú lakáshitelből. (Kivételek a társasházak, illetve lakóközösségek, ahol 241-nél több lakásos épület esetén a maximális állami támogatás értéke 324000 forint/év, a 2018. október 16-a elött kötött szerződések esetében.) Az állami támogatás kizárólag lakáscélú felhasználás esetén vehető igénybe (Ferencz, 2008).

Az előtakarékoskodó befizetési kötelezettségét teljesítheti egy összegben, vagy részletekben. A kedvezményes kölcsön igénybevételéhez a megtakarítási

3 www.mnb.hu 
időszaknak legalább négy évnek kell lennie. Az előtakarékoskodó bizonyos esetekben szüneteltetheti a befizetéseket, például, ha az ügyfél munkanélkülivé válik, de a szüneteltetés ideje nem tartozik bele a megtakarítási időbe, ennek szabályozása lakáskasszánként eltér.

A lakástakarékpénztár üzletszabályzatában köteles a szerződés szerinti betétgyüjtési és hitelnyújtási tevékenység és az áthidaló kölcsön nyújtásának általános szerződési feltételeit meghatározni úgy, hogy az legalább a következőket tartalmazza: a lakás-előtakarékoskodó és a lakástakarékpénztár által teljesítendő szolgáltatások mértéke és gyakorisága, a késedelmes teljesítés jogkövetkezményei, a szerződés alapján teljesítendő betételhelyezés után járó kamat mértéke, a lakáskölcsön igénybevételének feltételei, a minimális megtakarítási hányad, a minimális értékszám (lásd később), a hitelképesség vizsgálata során figyelembe vett szempontok, a lakáskölcsön megtagadásának esetei, a lakáskölcsön kamatozása, illetve a teljes hiteldíj mértéke, a lakáskölcsönt igénylők között felállított sorrend meghatározásának módja, a kiutalásra kerülő szerződések meghatározása, a lakáskölcsön esedékessége és folyósításának lebonyolítása, a szerződés módosításának, különösen a szerződéses összeg felemelésének vagy csökkentésének, illetve a rendkívüli betételhelyezés feltételei és jogkövetkezményei, a szerződés felmondásának esetei és jogkövetkezményei, a betételhelyezés szüneteltetésének feltételei és maximális időtartama, valamint a betét átruházásának feltételei, az áthidaló kölcsön igénybevételének lehetőségei, és a lakáscélú felhasználás bizonyításának okiratai.

A lakástakarékpénztár köteles általános szerződési feltételeit oly módon meghatározni, hogy azok hosszú távon biztosítsák a lakás-előtakarékoskodók és a lakástakarékpénztár által vállalt kötelezettségek összhangját. (Az általános szerződési feltételek módosításához az MNB engedélye szükséges.)

Léteznek olyan konstrukciók is, amelyekkel az előtakarékoskodás és a várakozási idő kiküszöbölhető. Ha a banki lakáshiteleknél alacsonyabb törlesztő részletekre vágyunk, akkor érdemes lehet a lakástakarékpénztári és a „sztenderd" banki szisztéma ötvözetét kipróbálni. Ebben az esetben az ügyfél azonnal hitelt kap a banktól, és közben elkezd előtakarékoskodni a lakástakarékpénztári szerződése értelmében, majd 4 év után a pénztár törleszti a banki hitelt az ügyfél helyett. A lakástakarékpénztárból ugyanis elvileg csak leghamarabb négy év 
előtakarékoskodás után juthatunk hitelhez (illetve két év elteltével úgynevezett áthidaló kölcsönhöz, lásd később).

A lakástakarékpénztári konstrukció előnye, hogy vissza nem térítendő állami támogatás is jár hozzá (a 2018. október 16. előtt kötött szerződések esetében, lásd még utolsó alfejezet). Az állami támogatás családon belül ráadásul megtöbbszörözhető volt, tehát érdemesebb volt négy, 20-20 ezer forintos havi betétösszegű szerződést kötni, mint egy havi 80000 forintos lekötést, ekkor ugyanis négyszer $72000 \mathrm{Ft}$ kerül pluszban a család számlájára. A minimális megtakarítási időszak 4 év, a maximális 10 év. Ha a megtakarítási időszak lejárt, de a 10 év még nem telt el, és nem szeretné felhasználni az összegyüjtött pénzt, akkor tovább takarékoskodhat.

2009. július 1-jén a magyar Országgyülés módosította a lakástakarékpénztárakról szóló törvényt, mely értelmében a 2009. június 30-a után kötött lakás-előtakarékossági szerződéseknél megszűnt a 8 éves futamidejű konstrukció szabad felhasználásának lehetősége. Ennek célja az volt, hogy a támogatással egybekötött kontrakció valóban lakáscélú megtakarítási és támogatási forma legyen. (A többi feltétel és kedvezmény - állami támogatás, magas hozam, az egész futamidőre rögzített, kiszámítható feltételek, kedvező hitelkamatok és a kamatadó-mentesség - nem változott.)

Az ügyfél, amennyiben teljesíti a szerződésesben rögzített feltételeket, jogosulttá válik a kedvezményes hitel felvételére, mely nem kötelezettség, csak lehetőség. A hitel kiutalása azonban nem történik meg automatikusan, mivel a lakáskassza kiutalási időpontokat állapít meg. Azaz a pénztár határozza meg, hogy mely ügyfeleknek lehet a szerződéses összeget kifizetni, tehát kiszámítja a rendelkezésére álló kiutalási összeget. Ez a betétbefizetésekből, az állami támogatásokból, ezek hozamaiból, és a korábbi hitelekből visszakapott törlesztésekből számolják ki. A kiutalási összeg nagyságától függ, hogy a lakástakarékpénztár mennyi hiteligényt tud kielégíteni. Azt se felejtsük el, hogy a kiutalási összegből kell kifizetni a betéteket, az állami támogatást, ezek kamatait, a tőkepiacról felvett kölcsönök törlesztését, és ezek kamatait. Csak a fennmaradó rész szolgálhat fedezetül a kedvezményes kölcsönök folyósítására és mivel a kiutalási összeg nagyságát a pénztár nem tudja előre pontosan meghatározni, így nem vállalhat kötelezettséget arra, hogy pontosan mikor folyósítja egyes ügyfeleinek a kölcsönt. 
Ezért csak azt a körülbelüli kifizetési időpontot közlik, amikor optimális esetben kapná az ügyfél a lakáskölcsönt (Huszár, 2006.).

A lakáskölcsön folyósításának feltételeit is teljesítenie kell az elötakarékoskodónak. Az előtakarékoskodónak meg kell takarítania a szerződésben rögzített összeget, a betétesnek el kell érnie a minimális megtakarítási időt, a szerződőnek el kell érnie az előírt minimális értékszámot (lásd később) és az ügyfélnek hitelképesnek kell lennie. (A hitelképesség vizsgálat a banki hitelezésnél szokványos szempontokra terjed ki, mint a jövedelem, fedezet, kezesek, stb.)

Azok között a kölcsönigénylők között, akik az alapfeltételeknek megfelelnek, sorrendet állapítanak meg. A sorrend megállapításának alapja az egyes ügyfelekhez rendelt értékszám. Az alkalmazott értékszám számítási módját az egyes lakástakarékpénztárak maguk határozzák meg. A pénztárak azonban nem azokat részesítik előnyben, akik nagyobb összeget takarítanak meg, hanem az jelent előnyt, ha a szerződő a szerződéses összeg minél magasabb hányadát takarítja meg, illetve a szerződéskötést követően, minél előbb befizeti a vállalt megtakarítást. A pénztár meghatározza a különböző konstrukcióinál érvényesítendő minimális értékszámot. Ennek az adott konstrukcióhoz kell illeszkednie, úgy, hogy biztosítsa a várható befizetések és kifizetések egyensúlyát.

Amennyiben a kiutalási összeg nagysága elegendő, minden, az alapkövetelményeket kielégitő hiteligénylő számára folyósítják a kölcsönt. Előfordulhat azonban az a helyzet, amikor a kiutalási összeg nem teszi lehetővé minden igény kifizetését. Ekkor játszik szerepet az értékszám által meghatározott sorrend. A pénztár megállapítja azt az értékszámot, amely teljesülése esetén (vagy az ezt meghaladó érték felett), kielégíti az ügyfelek hiteligényét, ez az értékszám a célértékszám (Szondi, 1999).

A lakástakarékpénztárak nyújthatnak áthidaló hitelt is ügyfeleiknek. Az áthidaló hitel nyújtására akkor kerül sor, amikor az ügyfél még nem érte el a megtakarítási időt, de számára szükséges a hitelfelvétel. (Például kedvező lehetősége nyílik lakásvásárlásra.) Az áthidaló kölcsön akkor nyújtható, ha a megtakarítási időszakból legalább két év eltelt, a szerződő a szerződéses összeg 25\%-át megtakarította, az eddigiekben a szerződéses kötelezettségeinek eleget tett, és hitelképes. Az áthidaló kölcsön piaci kamatozású, ezt a pénztár folyósíthatja szabad eszközei terhére, vagy a tőkepiacról felvett forrásból. Az ügyfél a hitelfelvételt 
követően tovább folytatja a megtakarítást, törleszti a hitelt és fizeti annak kamatait. A későbbiekben, amikor jogosulttá válik a kedvezményes lakáskölcsön felvételére, ezzel kiválthatja piaci kamatozású hitelét (Szondi, 1999).

\subsection{A lakástakarékpénztárak müködése}

Létrehozásuk elsődleges célja az volt, hogy megteremtsék az állami támogatással rendelkező lakás-előtakarékosság zárt, biztonságos rendszerben történő lebonyolításának feltételeit.

A lakástakarékpénztárak a hatályos szabályozás szerint legalább kétmilliárd forint induló jegyzett tőkével alapíthatók kizárólag részvénytársasági formában, alaptevékenységként pedig csak betétgyüjtést és hitelnyújtást végezhetnek. A lakástakarékpénztárak tulajdonképpen specializálódott pénzintézetek, csak lakás-előtakarékossági üzleti tevékenységgel foglalkozhatnak, ugyanakkor a lakástakarékpénztárakon kívül más pénzintézet nem végezhet ilyen tevékenységet. A lakáscélú betétgyűjtés és hitelezés zárt körben történő szervezése ugyanis nagy biztonságot és speciális üzletpolitikát kíván, amit specializálódott pénzintézetek tudnak igazán biztosítani ${ }^{4}$.

\section{A lakástakarékpénztárak müködésének általános jellemzői:}

A kollektív előtakarékosság elve, zárt rendszerü müködés

A német modellt követő magyar lakástakarékpénztárak zárt rendszerben müködnek, ami azt jelenti, hogy a lakáskölcsön folyósítása más betétes megtakarításából, illetve a már hitelt kapott ügyfelek törlesztéseiből történik. A közös cél - lakáscél megvalósítása, finanszírozása - érdekében történő összefogás alapozza meg a lakástakarékpénztár müködését. Hitelt csak az kaphat, aki maga is részt vett a kollektív előtakarékosságban, ezzel sajátos finanszírozási körforgás jön létre.

4 1996. évi CXIII. törvény 


\section{$\underline{\text { Fix, alacsony kamatlábak }}$}

A lakástakarékpénztárak sajátossága az alacsonynak mondható, illetve a pénzpiac alakulásától független fix kamatlábak alkalmazása mind a betéteknél, mind a hiteleknél, amit a zárt, a tőkepiactól elkülönült rendszerük tesz lehetővé. A betéti oldalon elszenvedett kamatveszteséget az alacsony kamattal nyújtott hitel lehetősége kárpótolja. A magyar lakástakarékpénztáraknál kialakult meghatározó kamatszint betétnél évi -1 - 1\%, hitelnél évi 5 - 8\%.

Szigorú müködési szabályok

A kollektív előtakarékosság és a zárt rendszerű működés miatt várhatóan felmerülő várakozási és finanszírozási problémák miatt szigorú működési szabályokat határoztak meg. A szabad - hitelezésre időlegesen fel nem használt - pénzeszközök jelentős hányadát állampapírban kell tartani. A szabad pénzeszközök befektetéséből származó hozamnak a lakáskölcsönök kamatát meghaladó részét kiegyenlítési céltartalékba kell helyezni legalább a betétállomány 10\%-ának eléréséig. A lakástakarékpénztár ugyanakkor teljes mértékben mentesül a kötelező jegybanki tartalék képzése alól.

\section{Állami támogatás}

A lakástakarékpénztári konstrukcióhoz állami támogatási rendszer tartozik (a 2018. október 16-a előtt kötött szerződések esetében). A betéthez közvetlen - adó és járulékmentes - állami támogatás kapcsolódik, amely ellensúlyozza a betétek alacsony kamat miatti reálértékvesztését. Ez a fajta támogatás a lakáshoz jutáshoz, felújításhoz stb. szükséges saját forrás előteremtésére ösztönöz, tehát azt támogatja, aki saját lakásproblémája megoldása érdekében képes és hajlandó erőfeszítéseket tenni.

\section{Szakosított pénzintézeti müködés}

A lakástakarékpénztárak specializálódott pénzintézetek, csak lakás-előtakarékossági üzleti tevékenységgel foglalkozhatnak, ugyanakkor a lakástakarékpénztárakon kívül más pénzintézet nem végezhet ilyen tevékenységet.

A lakáscélú betétgyüjtés és hitelezés zárt körben történő szervezése ugyanis nagy biztonságot és speciális üzletpolitikát kíván, amit specializálódott pénzintézetek tudnak igazán biztosítani. Lakástakarékpénztárt minimum 2 milliárd forint jegyzett tőkével szakosított pénzintézetként lehet létrehozni, kizárólag zártkörüen működő részvénytársasági formában. 


\section{Biztonságos müködés}

A lakástakarékpénztárak esetén, más pénzügyi szervezetekhez hasonlóan, kiemelt jelentőségü a biztonságos müködés, ezt több szabályozási elem is szolgálja. A szabályozás a pénztárak vagyonai értékének megőrzését, fizetőképességük fenntartását célozzák.

A lakástakarékpénztár a törvényben meghatározott szerződés szerinti betétgyüjtésen és hitelnyújtáson, valamint áthidaló kölcsön nyújtásán kívül kizárólag a következő tevékenységeket végezheti:

- a lakástakarékpénztár szavatoló tőkéjének összesen 10\%-át meg nem haladó mértékig tulajdoni részesedést szerezhet a Hpt. szerinti járulékos vállalkozásokban,

- a lakástakarékpénztár az MNB engedélyével, zárt rendszerű betétgyüjtés és hitelnyújtás esetén (csak a betétet elhelyezők részére nyújt hitelt), a szavatoló tőkéjének összesen 20\%-át meg nem haladó mértékig tulajdoni részesedést szerezhet a Magyar Köztársaság területén székhellyel rendelkező lakástakarékpénztárban, vagy olyan devizakülföldinek minősülő hitelintézetben, amelynek fő tevékenysége lakás-előtakarékossági szerződés alapján történő betétgyüjtés és hitelnyújtás,

- lakáscélú finanszírozáshoz közvetlenül kapcsolódóan más pénzügyi intézmény, illetve biztosítóintézet részére pénzügyi szolgáltatás közvetítését (ügynöki tevékenységet) végezhet,

- lakáshitelnyújtáshoz kapcsolódóan ingatlanértékelési tevékenységet végezhet (Novotny, 2006).

A pénztár szabad eszközeinek legalább 50\%-át készpénzben, számlapénzben, kincstárjegyben, a magyar állam által kibocsátott vagy garantált kötvényben kell tartani. A belföldi hitelintézeti bankközi betét, illetve az áthidaló kölcsön nyújtására szolgáló hányad nem lehet 20\%-nál nagyobb. A lakástakarékpénztár szabad eszközei előző hónap utolsó napján meglévő állományának legfeljebb 30\%-át fektetheti be jelzálog-hitelintézet által kibocsátott jelzáloglevélbe.

A lakástakarékpénztár által felvett kölcsönök, illetve az általa kibocsájtott hitelviszonyt megtestesítő értékpapírok állománya alapesetben nem haladhatja meg a folyósított áthidaló kölcsöneinek állományát. A felvett kölcsönök állománya a kölcsönfelvételkor, illetve a hitelviszonyt megtestesítő értékpapír kibocsá- 
tásakor nem haladhatja meg a betétállomány 40\%-át. A felvett kölcsönök állományának alakulásáról a lakástakarékpénztárnak folyamatos adatszolgáltatás körében jelentést kell tennie a MNB-nek.

Továbbá az is egyfajta fékező erő, hogy a lakás-előtakarékoskodókkal kötött, érvényben lévő szerződések együttes szerződéses összege az új szerződések megkötésének időpontjában nem haladhatja meg a lakástakarékpénztár elöző hónap utolsó napján érvényben lévő összes szerződéséből eredő szerződéses összeg 15\%-át. A pénztárnak az ügyfelek védelmében egyfajta beépített „fékként” a már említett kiegyenlítési céltartalékot kell képezni, amennyiben a szabad eszközök hozama meghaladja a lakáskölcsönök átlagos kamatát. A tartalék abban a későbbi kedvezőtlen esetben kerülhet felhasználásra, ha a pénztár a lakáskölcsönök folyósítására piaci hitelt vesz fel, és ennek kamata meghaladja az ügyfelek által befizetett lakáskölcsön utáni kamatot.

A hosszú távú biztonságos működés érdekében a lakástakarékpénztáraknak egyéni és kollektív teljesítménymutatót kell megállapítani, amelyek elöírt mértékeit a pénztáraknak teljesítenie kell. A kollektív teljesítménymutató azt fejezi ki, hogy az adott évben az állományból kikerülő összes szerződésre vonatkozóan mekkora az ügyfelek befizetéseinek és a kölcsönöknek az aránya, figyelembe véve a megtakarítási és a törlesztési időszakok hosszát is 5 .

A mutató számítása:

$$
K=\frac{\sum_{i=1}^{n}\left(\begin{array}{l}
a_{i} \\
r_{i}
\end{array}\right)}{\sum_{j=1}^{m}\left(\begin{array}{l}
b_{j} \\
p_{j}
\end{array}\right)}
$$

ahol

$\mathrm{K}=$ a kollektív teljesítménymutató

$\mathrm{a}_{\mathrm{i}}=\mathrm{az}$ állományból kikerülő i. szerződésre kifizetett összes betéti kamat, ami tartalmazza az állami támogatás után jóváírt betéti kamatot is

$\mathrm{r}_{\mathrm{i}} \quad=\mathrm{az}$ i. szerződés betéti kamatlába

$\mathrm{n}=$ az állományból adott évben kikerülő szerződések száma

5 1996. évi CXIII. törvény, 215/1996. Kormányrendelet,4/1997. Kormányrendelet 
$b_{j} \quad=a j$. kiutalt szerződés lakáskölcsöne után fizetendö összes kamat és a lakáskölcsönhöz kapcsolódó kezelési költség

$\mathrm{p}_{\mathrm{j}} \quad=\mathrm{a}$ j. kiutalt szerződés lakáskölcsönére számított teljes hiteldíj mutató

$\mathrm{m}$ = azoknak a szerződéseknek a száma, amelyekre a szerződéses összeget az adott évben kiutalták.

A kollektív teljesítménymutatónak el kell érnie legalább 1,0 értéket.

Az egyéni teljesítménymutató azt mutatja meg, hogy egy szerződés várható lefutása esetén miként alakul a vállalt megtakarítás és az igényelt hitel aránya, szem elött tartva a megtakarítási és a törlesztési idő hosszát. Az egyéni teljesítménymutató számítása:

$$
E=\frac{a / r}{b / p}
$$

ahol

$\mathrm{E} \quad=$ egyéni teljesítménymutató

$\mathrm{a}=\mathrm{az}$ adott szerződésre kifizetendő összes betéti kamat, ami tartalmazza az állami támogatás után jóváírt betéti kamatot is

$\mathrm{r} \quad=\mathrm{az}$ adott szerződés betéti kamatlába

$\mathrm{b}=\mathrm{az}$ adott szerződés lakáskölcsönére kifizetendő összes hitelkamat és a lakáskölcsönhöz kapcsolódó kezelési költség

$\mathrm{p}=$ az adott szerződés lakáskölcsönére számított teljes hiteldíj mutató

A mutatónak 0,8 és 1,0 érték közé kell esnie. A mutató értékét a szerződéses feltételek megállapításakor tudják a pénztárak befolyásolni (Szondi, 1999).

A lakástakarékpénztárak müködését a MNB folyamatosan figyelemmel követi. A lakástakarékpénztáraknak jelentéseket kell készíteni a MNB számára. A MNB a pénztárakhoz ellenőrt nevez ki, aki a pénztáraknál vizsgálja azok tevékenységét. Magyarországon a lakástakarékpénztárak az OBA (Országos Betétbiztosítási Alap) tagsági körébe tartoznak. Közösségi betétek (mint például lakásszövetkezetek betétei) esetén a kártalanítás összege a közösséget alkotó személyek száma szerint többszöröződik. A kártalanítás független a közösséget alkotó magánszemélyek egyéb betéteire fizethető kártalanítástól. Ezáltal megfelelő védelmet élveznek azok a közösségek, amelyek létrehozásának célja valamely, az állam számára is fontos érdek. 


\subsection{Az állami támogatás megszüntetése}

2018. október 15-én nyújtották be az Országgyülés elé a lakástakarék-pénztárakról szóló törvény módosítását, melynek lényege a megtakarítási konstrukció állami támogatásának megszüntetése volt. A döntés nem érintette a már megkötött lakás-előtakarékossági szerződéseket, állami támogatás a 2018. október 16-a után, azaz a törvény hatályba lépését követően megkötött, illetve meghosszabbított szerződések esetében már nem jár ${ }^{6}$.

A támogatás megszűntetésének indoklása az volt, hogy az LTP-k által szervezett megtakarításokból nem túl sok új lakás épült, melynek egyik oka az, hogy alapvetően kis összegű konstrukciókról beszélhetünk, a másik pedig, hogy a megtakarítási periódusok végén felvehetö összegek felhasználása túlságosan sokrétű volt (Domokos, 2019). A lakásépítések és otthonteremtések támogatása a Kormány szándéka szerint nem szünik meg, csak nem a lakáskasszákon keresztül történik, illetve egy mostani törvényjavaslat szerint a lakáspénztárak állampapírt forgalmazhatnak saját jogon vagy közvetítőként.

A továbbiakban is lehet lakástakarékpénztári megtakarítást kötni, ám az állami támogatás megszűnése miatt a régi kondíciókkal negatív a lakástakarékpénztárak által a megtakarítóknak kínált hozam. (Akciókat indíthatnak - a Fundamenta indított is -, ezekben pl. kamatbónuszokkal pozitív, bár alacsony hozam elérhetö.) Egy kivétel van, az Aegon Magyarország Zrt. 2018 szeptemberében bejelentette, hogy október 1-jétől felfüggesztette értékesítési tevékenységét, új szerződéseket nem fogad el, melynek legfőbb oka az, hogy minden évben veszteséget termelt. Az is biztosra vehető, hogy az állami támogatás megszüntetése miatti szerződéskötés zuhanás és a lassan elfogyó üzletkör miatt a lakástakarékok számára elsődleges feladat költségeik optimalizálása, csökkentése ${ }^{7}$.

2018. évi LXIII. törvény

7 https://bank360.hu 


\subsection{Irodalomjegyzék}

Baka Istvánné, Dancsó József, Ligeti Sándor, Vágyi Ferenc Róbert, Szarvas Ferenc, Varga József, Kürthy Gábor, Baka Istvánné (szerk.), Kürthy Gábor (szerk.) (2012): Bankismeretek: Egyetemi tankönyv. Budapest: Tanszék Kft., 2012. 105 p. ISBN: 978-963-88777-4-1

Dániel Zsuzsa (2004): Állam és piac - lakástámogatás, lakásfinanszírozás, reformok. Közgazdasági Szemle, LI. évf., 2004. február.

Domokos László (2018): Lakástakarékok: már csak néhány napja maradt, ha lépni akar! Letöltve 2019. március 16-án a https://www.napi.hu/magyar_gazdasag/lakas-ltp-tamogatas-megszuntetes-szigorirtas.671616.html.671616.html linkröl.

Fellner Zita, Bereczki Ákos, Kovalszky Zsolt, Winkler Sándor (2018): Lakáspiaci jelentés. Letöltve 2019. április 18-án a https://www.mnb.hu/letoltes/lakaspiaci-jelentes-2018-november-hu.pdf linkröl.

Ferencz Iván (2008): A lakáscélú hitelezés és a lakás-takarékpénztárak. Pázmány Péter Tudományegyetem, Heller Farkas Közgazdaságtudományi Intézet. Letöltve: 2019. február 18-án a https://jak.ppke.hu/uploads/articles/13884/file/ pp6.ppt linkről.

Hegedűs József, Várhegyi Éva (1999): A lakásfinanszírozás válsága a kilencvenes években. Közgazdasági Szemle, XLVI. évf., 1999. február

Horváthné Kökény Annamária (2009): A lakástakarékpénztári törvény és változásának hatásai. Szolnoki Tudományos Közlemények XIII., Szolnok. Letöltve: 2019. március 11-én a https://docplayer.hu/546706-Horvathne-kokeny-annamaria-1.html linkröl.

Huszár Lilla (2006): Jelzáloghitelezési rendszerek és a lakáspolitika kapcsolatának bemutatása, nemzetközi összehasonlítás. Doktori $(\mathrm{PhD})$ értekezés, NYME-KTK, Sopron.

Kiss Gergely, Vadas Gábor (2006): A lakáspiac szerepe a monetáris transzmisszióban. Közgazdasági Szemle, LIII. évf., 2006. május.

Kiss Kornélia (1996): A lakáselőtakarékosság új rendszere. Bankszemle, 1996., XL. évf. 5. szám.

Kiss Kornélia (1996): A lakástakarékpénztárakról szóló törvény és a kapcsolódó rendeletek. Bankszemle 1996., XL. évf. 11-12. szám. 
KSH Lakás- és üdülőépítés (1960-). Letöltve 2019. március 14-én a http://www. ksh.hu/docs/hun/xstadat/xstadat_hosszu/h_zrs001.html linkröl.

KSH Gyorstájékoztató, Lakásépítések, építési engedélyek, 2018. I-III. negyedév. Letöltve 2019. március 14-én a http://www.ksh.hu/docs/hun/xftp/gyor/lak/ lak1809.html linkröl.

Kovács Tamás (2011): A hitelintézeti rendszer története 1990-2008. In: Tatay, Tibor; Vágyi, Ferenc Róbert; Varga, József (szerk.) A pénzügyi intézményrendszer Magyarországon 2011. Sopron, Magyarország : Soproni Felsőoktatásért Alapítvány, (2011) pp. 376-391.

Ligeti Sándor, Pesuth Tamás, Varga József (2019): Kereskedelmi bankok. In: Kürthy Gábor (szerk.) Pénzügytan. BUDAPEST: Budapesti Corvinus Egyetem, (2019) pp. 30-53., 24 p.

Novotny Ádám (szerk.) (2006): Bank- és biztosítástan. EKF, Gazdaságtudományi Intézet.

Palkó István (2017): Földindulásszerü változások a lakás-takarékpénztáraknál. Letöltve 2019. március 16-án a https://www.portfolio.hu/finanszirozas/bankok/foldindulasszeru-valtozasok-a-lakas-takarekpenztaraknal.255493.html linkről.

Palkó István (2013): Így is lehet: nyerésre áll a lakás-előtakarékosság. Letöltve 2019. március 14-én a https://www.portfolio.hu/finanszirozas/bankok/ igy-is-lehet-nyeresre-all-a-lakas-elotakarekossag.185305.html linkről.

Parragh Bianka (2017): Monetáris hitviták. Pénzügyi Szemle, 2017/2. Letöltve 2019. március 11-én a https://www.penzugyiszemle.hu/documents/parraghb-uj-atirt-2017-2-mpdf_20170717153013_89.pdf linkről.

Szondi Ildikó (1999): Lakás-takarékpénztárak Magyarországon. ACTA UNIVERSITATIS SZEGEDIENSIS: ACTA JURIDICA ET POLITICA 57. Letöltve: 2019. február 20-án a http://acta.bibl.u-szeged.hu/7034/1/juridpol_057_ fasc_010_001-026.pdf linkröl.

1996. évi CXIII. törvény a lakástakarékpénztárakról.

215/1996. Kormányrendelet a lakáselőtakarékosság állami támogatásáról.

4/1997. Kormányrendelet a lakástakarékpénztár általános szerződési feltételeiről.

2018. évi LXIII. törvény a lakástakarékpénztárakról szóló 1996. évi CXIII. törvény módosításáról.

https://www.mnb.hu/fogyasztovedelem/dontenem-kell/ongondoskodas/lakastakarek 
Gazdasági hírek (letöltve 2019. március 1-16. között):

https://bank360.hu/blog/lakastakarekpenztarak-mi-varhato-az-allami-tamogatas-megszunese-utan

https://bankmonitor.hu/cikk/lakasvasarlas-nagyon-gondold-meg-mielott-belevagnal-a-lizingbe/

https://www.oc.hu/ingatlanpiac/hirek/elemzesek/lakaspiaci-tanacsado-12 http://www.okoshitel.hu/Lakashitel/Ingatlanlizing.html

https://www.portfolio.hu/finanszirozas/bankok/nagy-bejelentest-tett-a-fundamenta.324415.html 


\section{A szövetkezeti hitelintézetek Magyarországon}

\subsection{A szövetkezeti hitelintézet, a hitelintézetek sajátos megjelenési formája}

A startup-ok korában vélhetően kevesen tudják mi a „szövetkezeti hitelintézet” jelentése és miben különbözik más pénzügyi intézményektől, annak ellenére, hogy ez a banki szolgáltatások nyújtására kialakult társas vállalkozási forma és szociális közösség az általánosan elterjedt részvénytársaságok mellett közel 170 éve van jelen a magyar gazdaságban és társadalomban. Ez idő alatt maguk a szövetkezeti hitelintézetek is több megjelenési formát (segélyegylet, hitelszövetkezet, takarékszövetkezet stb.) öltöttek és még a közelmúltban is volt olyan jogalkotói aktus, ami alakította ezen szövetkezeti társulások tartalmát. A köztudatban számos fogalommal azonosítják a szövetkezeti hitelintézeteket, nem minden esetben helyesen: önsegélyező egyletek, hitelszövetkezetek, népbankok, Raiffeisen-bankok, takarékpénztárak, takarékszövetkezetek, szövetkezeti bankok, takarékbank. A 2013. évi CXXXV. törvény (SZHItv.) 1. \$ (1) t) pontja alkalmazásában szövetkezeti hitelintézet bármilyen vállalkozási formában működő hitelintézet lehet:

„szövetkezeti hitelintézet: a takarékszövetkezet, a hitelszövetkezet és minden olyan egyéb hitelintézet is, amelynek müködését vagy amelynek betéteit 2013. január 1-jén Önkéntes Takarékszövetkezeti intézményvédelmi alapok valamelyike védte, valamint az a hitelintézet is, amelyet a 3. \$ (2) bekezdésének megfelelöen az Integrációs Szervezethez benyújtott csatlakozási kérelme alapján a Központi Bank igazgatóságának elözetes egyetértése, továbbá a Felügyelet elözetes jóváhagyását követöen felvettek az Integrációs Szervezetbe;...”.

A szövetkezeti hitelintézet tradicionális fogalma és a hatályos szabályozás meghatározása eltér. Utóbbi semmilyen szövetkezeti jelleget, identitást nem szab feltételként, csupán a hitelintézeti formát. A megelőző hazai és a szupranacionális szabályozás a szövetkezeti értékekkel való azonosulás mellett általában megköveteli a szövetkezeti formát, megengedve a részvénytársasági társulást is, ameny- 
nyiben azt szövetkezetek részvételével és azok müködésének koordinálására, integrálására hozták létre, vagy szövetkezetek érdekében müködtetik, ugyanakkor ezekre a szervezetekre, tevékenységükre utalva alkalmazzák a bank kifejezést is.

Ahhoz, hogy megértsük a különbséget a szövetkezeti és más hitelintézetek között, elsőként a szövetkezés jelentését szükséges tisztázni (Moizs, 2015):

„A szövetkezés célszerüsége és hasznossága végeredményben abból az alapgondolatból vezethetö le, hogy a társadalom több, hasonló gazdasági, egzisztenciális, vagy szociális célért küzdö tagja összefogásával elérhetö eredmények meghaladják a külön-külön elérhetö eredmények összességét, tehát olyan additív értékek keletkeznek, amelyek a tagok számára izolált tevékenységük által nem lennének elérhetők. (....) A szövetkezet olyan személyek autonóm társulása, akik önként egyesültek abból a célból, hogy közös gazdasági, társadalmi és kulturális (vagy egyéb) céljaikat kollektív tulajdonú és demokratikusan irányított vállalkozás útján megvalósítsák."

Amíg ez a meghatározás egyértelmüen a szövetkezet személyegyesítő jellegét emeli ki, addig a hatályos hazai szabályozás ${ }^{1}$ a tőkeegyesítést is fontosnak tartotta hangsúlyozni:

„A szövetkezet a tagok vagyoni hozzájárulásából álló tőkével alapitott, a nyitott tagság és a változó tőke elvei szerint müködö, a tagok gazdasági és társadalmi szükségleteinek kielégitésére irányuló tevékenységet végzö jogi személy, amelynél a tag kötelezettsége a szövetkezettel szemben vagyoni hozzájárulásának szolgáltatására és az alapszabályban meghatározott személyes közremüködésre terjed ki."

A Ptk.-ban foglalt fenti definícióról fontos megjegyezni, hogy

- egyrészt deskriptív jellegü, azaz a szövetkezet fogalmát a jelenleg müködő szövetkezetek karaktere alapján azonosítja, nem elérendő, vagy elöírt (normatív) célokkal,

- másrészt leíró jellegéből következően jogszuverenitási és jogpolitikai követelménynek tesz eleget, amikor a föhatalom (szuverenitás) aspektusából kizárólag a tényleges térbeli-, időbeli-, és perszonális hatályra van tekintettel, figyelmen kívül hagyva a genetikus megközelítés szerinti szövetkezeti sajátosságokat.

1 2013. évi V. törvény a Polgári Törvénykönyvröl (a továbbiakban: Ptk.) 3:325 \$ (1) bekezdés 
A szövetkezeti hitelintézetek mibenlétének megértéséhez nem tekinthetünk el a szövetkezet fogalmának komparatív és teleologikus megközelítésétől sem, mivel ezek a szervezetek évszázadok óta életképesek, más szociális és gazdálkodási tevékenységet végző társulásoktól eltérően - nyilvánvalóan más és más megjelenési formában -, de az antiktól a posztmodern társadalmakig szinte minden közösségi együttélésben szerepet játszottak. A szövetkezetek önmagukat leggyakrabban elvekkel és értékekkel azonosítják, melyek közül azok, amelyek időbeli és földrajzi megjelenésüktől függetlenül általánosságban minden szövetkezeti formációra jellemzőek: az önkéntesség, a tagok egyenjogúsága, a tevékenységben való aktív tagi közreműködés, önkormányzatiság, szolidaritás és önsegélyezés. Tevékenységét tekintve a szövetkezeti forma a gazdasági és a társadalmi élet szinte minden területét átfogja (mezö- és erdőgazdaság, halászat, ipar, alternatív energia szektor, kereskedelem, munkaerőpiac, oktatás, bank stb.) és számos társadalmi- és gazdasági problémára jobb választ tudott adni az alternatív, tisztán statális, vagy kompetitív megoldásoknál. A szövetkezeti mozgalomban világszerte 1 milliárd tagot tartanak nyilván ${ }^{2}$, becslések szerint a szövetkezetek közel 3 milliárd ember megélhetését biztosítják, és meghatározó szerepet töltenek be a helyi közösségek gazdasági és társadalmi életében. A szövetkezetek világszerte 100 millió munkahelyet teremtettek, 20 százalékkal többet, mint a multinacionális társaságok.

A szövetkezeti hitelintézetek tehát általános és teleologikus értelemben szövetkezeti identitással rendelkező pénzügyi szolgáltatást nyújtó társas vállalkozások. A Szövetkezeti Bankok Európai Szövetsége (ECBA) ${ }^{3}$ szerint a szövetkezeti bankok kulcsszereplői az európai gazdaságnak, mivel szolgáltatásaik helyi szinten és kontinens szerte egyaránt elérhetőek, több mint 53000 kirendeltségükön és 719000 munkavállalójukon keresztül szoros és kivételes kapcsolatban állnak ügyfeleikkel.

Az ICBA megfogalmazásában ${ }^{4}$ „ „A szövetkezeti bankok mélyen gyökereznek a helyi térségekben és közösségekben. Részt vesznek a helyi fejlesztésekben, hozzájárulnak közösségeik fenntartható fejlödéséhez, mivel tagjaik és a vezetöség azokhoz a közösségekhez tartoznak, ahol tevékenységüket gyakorolják. A fokozott banki

2 A fejezetben szereplö adatok különbözö forrásokból kerültek összegyüjtésre 2007-töl, beleértve a Nemzetközi Szövetkezeti Szövetség statisztikai adatlapjait, a szövetkezeti szervezetek közzétett adatait, a szövetkezetek és kormányzati statisztikai hivatalok által készitett kimutatásokat, illetve az ICA http://ica.coop/en/whats-co-op/co-operative-facts-figures oldalát.

3 http://www.eacb.coop/en/co-operative-banks.html 2019. 03. 18.

4 International definition of Cooperative Banks adopted by the ICBA (International Co-operative Banking Association), ICBA 2008. október 20-i közgyülése. 
részvétellel azokon a területeken és piacokon, ahol más bankok kevésbé vannak jelen - kisvállalkozások, vidéki régiók farmerei, közepes-, vagy a városi alacsony jövedelmü háztartások - a szövetkezeti bankok csökkentik a banki kirekesztést és emberek millióinak segítik gazdasági boldogulását. Befolyásoló szerepet játszanak azoknak az országoknak a gazdasági növekedésében, amelyekben müködnek és növelik a nemzetközi pénzügyi rendszer hatékonyságát. Sajátos, a szervezet fent említett elveiben bizó vállalkozási formájuk sikeres bizonyitást nyert mind fejlettségükben, mind az ország fejlödésében".

Napjaink világgazdasági környezetében is szemléletes bizonyítékát láthatjuk - persze kivételekkel ${ }^{5}$ - a szövetkezetek, ezek között a szövetkezeti hitelintézetek „kiegyenlitő erőnek” nevezett (Moizs, 2009a), a gazdaságra, társadalomra, szociális viszonyokra jótékony hatást gyakorló, ellensúlyokat képező működési mechanizmusainak ${ }^{6}$. A fogalom a piacgazdaságokban a szövetkezetek működése eredményeképpen kialakuló - a gazdaság egészére nézve - olyan kívánatos hatást jelent, ami annak köszönhető, hogy a szövetkezetek nem kizárólag piaci szempontok által vezérelt döntéseik által mérsékelik a versenynek azokat a folyamatait, amelyek hosszabb távon a gazdaság instabilitását, torzulását és szereplöi gazdasági potenciáljának nagyfokú differenciálódását okozzák. A szövetkezetek kiegyenlítő ereje abból fakad, hogy a profitorientáltsággal szemben olyan szervezeti célokat részesítenek előnyben, melyek az egyén és mikrokörnyezetük boldogulását segítik, az előállított javak nem szervezeti szinten (pl. tőkefelhalmozás, struktúra bővítés, brandépítés), hanem egyéni szinten (olcsóbb szolgáltatások, kollektív javak, személynek szóló szubvenciók) jelennek meg, és az eltérő motivációk miatt a különböző gazdasági ciklusokhoz köthető jelenségekre, más gazdasági szereplőkhöz képest eltérő, vagy semleges reakciókat adnak.

A 2008-ban kirobbant gazdasági válság hatására ezért egyértelművé vált, hogy megfelelő jogszabályalkotással elő kell segíteni a szövetkezetek, így a szövetkezeti identitású pénzintézetek müködését is, hiszen küldetésüknél fogva nagymértékben hozzájárulhatnak a sokat emlegetett lehetséges harmadik irány, a szociális gazdaság kialakulásához. Ehhez azonban biztosítani kell a szövetkezeti bankok hagyományos értékrendje szerinti működést, aminek legfontosabb

5 Lásd az osztrák Volksbank AG és Volksbank International AG esetét, ahol a VB Csoport a lokális értékektöl elszakadva már nem bírta elviselni a válság hatásait és külsö segitségre szorult.

6 Szemléletes példa erre a székely közösségi kártya müködése ld. Varga et al. 2017. 
eszközei a szövetkezeti értékrendet elismerő és támogató szabályozás, a mélyebb integráció és a fokozott tagi szerepvállalás.

\subsection{Szövetkezeti hitelintézetek Magyarországon ${ }^{7}$}

Magyarországon az első szövetkezeti hitelintézetek a nyugati államokkal szinte egyidőben (1851) tüntek fel. Az első magyarországi szövetkezetek erdélyi hitelszövetkezetek voltak, amelyek döntően nemzetiségi alapon (magyar, szász) szerveződtek.

Az erdélyi magyar hitelszövetkezetek kialakulását követően jött létre a győri (1864) hitelszövetkezet és a szintén szövetkezeti jegyeket hordozó Első Magyar Általános Tisztviselő Egylet (1865). A mezőgazdasági hitelek széles körü biztosítása érdekében az ország más régióinak nagyobb városaiban (Győr, Székesfehérvár, Debrecen) már működő hitelszövetkezetek mintájára 1886-ban Károlyi Sándor vezetésével megalakult a később országos hatáskörűvé vált Pestmegyei Hitelszövetkezet, majd a kisebb településeken is megkezdett országos szervezőmunka eredményeképpen 1894-re Pest megyében 80, országszerte pedig összesen 752 hitelszövetkezet működött mintegy háromszázezer taggal.

A törvényhozás 1898-ban megalkotta a gazdasági és ipari hitelszövetkezetekről szóló XXIII. törvénycikket, és még a törvénycikk megszületésének évében megalakult az Országos Központi Hitelszövetkezet (OKH), amelyben a Károlyi által kezdeményezett hitel- és iparszövetkezeti mozgalom egyesült. Az OKH alapításához az állam jelentős tőkével és kedvezmények biztosításával járult hozzá. Feladata a hitelszövetkezetek működésének szervezése, felügyelete, valamint általuk a vidéki mezőgazdasági- és kisiparos tevékenységgel összefüggö hiteligények kielégítése volt. Az OKH-ban integrált hitelszövetkezetek száma 1917-ben már meghaladta a 2400-at, 635 ezer taggal, 1942-ben a tagság már megközelítette a 800 ezret és a pénzügyi szolgáltatások 4360 településen voltak hozzáférhetők.

7 Moizs(2007a) szerzői müböl. 
A második világháború több szempontból is kedvezőtlen fordulópontot jelentett a hazai hitelszövetkezetek fejlődésében. A háború a személyi állomány és az infrastruktúra jelentős részét elpusztította, a határrendezés nyomán a hitelszövetkezetek száma 943-ra, a taglétszám 549 ezer före csökkent.

Az új diktatúra ideológiájával nem fért össze a magántulajdonon alapuló szövetkezeti autonómia és a szövetkezeti önkormányzás. A hitelszövetkezetek, főként taglétszámuk által túlzottan nagy súlyt képviseltek ahhoz, hogy az állam a gazdasági és társadalmi szerkezet direkt állami eszközökkel történő átalakításánál figyelmen kívül hagyja, a hitelszövetkezetek feletti teljes kontroll hiánya rontotta volna a gazdasági átszervezés hatásfokát. Az időközben megszületett Alkotmány elismerte ugyan a szövetkezeti tulajdont, de egyértelművé tette azt is, hogy a végrehajtó hatalom kezében céljai elérésének egyik leghatásosabb eszköze az állami bankrendszer lesz, ennek értelmében megkezdte, illetve 1953-ra befejezte a hitelszövetkezetek tervszerü felszámolását.

Hamar világossá vált azonban, hogy az OTP nem képes betölteni a vidék életében a hitelszövetkezetek szerepét, a mezőgazdasági termelés kibontakozásához szükség volt a helyi igényeket kielégítő hitelintézetekre. Megjelent a pénzügyminiszter 11/1956. (X. 5.) számú rendelete a falusi takarékszövetkezetekről és nem kellett sokat várni az első takarékszövetkezet megalapítására sem (Dunaföldvár, 1956). A dunaföldvári takarékszövetkezet példáját követve 1957 végéig további 69 szövetkezeti hitelintézet alakult meg, 1971-ben 388 takarékszövetkezet már 1143 kirendeltséget működtetett, a 881 ezer fös taglétszám pedig a teljes lakosság 20,6 százalékának felelt meg8 .

A rendszerváltozás, a kétszintü bankrendszer újraszervezése (1987) és az 1991. évi LXIX. törvény a pénzintézetekröl és a pénzintézeti tevékenységről hatálybalépése alapvetően új kihívások elé állította a takarékszövetkezeteket. Az 1992. évi I. törvény hatályba lépésekor az összesen 5\%-os piaci részesedéssel rendelkező 260 takarékszövetkezet 1752 fiókban nyújtott egyre szélesebb körü szolgáltatásokat, tagjainak száma elérte az 1780000 főt. Bár a takarékszövetkezetek által kezelt betét- és hitelállományok intenzíven növekedtek, a piacgazda-

8 Az alapszabályt és az ügyviteli szabályokat a Szövetkezetek Országos Szövetsége a pénzügyminisztériummal egyetértésben állapitotta meg, az ellenörzés jogkörét a pénzügyminiszter felhatalmazása alapján részben az OTP gyakorolta. Az ügyviteli szabályokban megállapított határ feletti pénzösszeget a takarékszövetkezet köteles volt az OTP-nél tartani. 
ság által teremtett új kihívásokat a formálódó fiatal kereskedelmi bankrendszer és a kibővült ügyfélkörrel működő takarékszövetkezetek nem tudták maradéktalanul lekezelni, ami az 1992-1993. évi bank- és adóskonszolidációhoz ${ }^{9}$ vezetett. A takarékszövetkezetek is levonták konszolidáció tanulságait: nyilvánvalóvá vált, hogy önállóan egyre kevésbé képesek a versenyhelyzetnek megfelelni, és a nemzetközi gyakorlatnak megfelelően szükséges a feladatok egy részének központosítása. Felismerték, hogy a közös termékfejlesztés, az egységes arculat kialakítása, az informatikai beruházások, a tőkeallokáció, a nemzetközi és hazai elszámolási és pénzforgalmi feladatok bonyolítása, az intézményvédelem, az érdekérvényesítés olyan tevékenységek, amelyek összefogással kisebb költségek mellett és hatékonyabban valósíthatók meg. Különösen igaz ez a gyorsan változó fizetési forgalom újabb és újabb ügyleteire (Kolossváry-Varga 2014, Varga 1994). Ennek következtében felerősödtek azok az integratív törekvések, amelynek első eredménye az 1989-ben a takarékszövetkezetek által létrehozott csúcsbank, a Takarékbank, majd az Országos Takarékszövetkezeti Szövetség (OTSZ) létrehozása és 1993-ban a 256-ból 246 takarékszövetkezet integrációs szerződést írt alá. Létrehozták az Országos Takarékszövetkezeti Intézményvédelmi Alapot (OTIVA), amely a konszolidációs tőke, majd a takarékszövetkezetek által rendelkezésre bocsátott összegből szabályozott feltételek mellett támogatást nyújtott a tagok részére.

A közös szervezetek alapítása és közös célok kitüzése ellenére azonban a folyamatosan változó külső hatásokra eltérően reagáltak a szövetkezetek, ami föleg az eltérő adottságoknak és a menedzsment színvonalának volt betudható. A szövetkezeti hitelintézetek az SZHItv. hatályba lépésekor a hitelintézeti szektor 31111 milliárd forint mérleg-föösszegéből 1753 milliárd forint (5,6\%) eszköz-állománnyal részesedtek, a betétek 10,2 százalékát (1 498 milliárd forint) kezelték, a hitelekből 4,2 százalékot (696 milliárd forint) nyújtottak. A szelekció és polarizálódás, illetve bankká alakulás eredményeképpen az SZHItv. hatályosulásáig a szövetkezeti hitelintézetek száma 124-re olvadt.

9 A többszintü bankrendszer kialakulását követöen rövidesen állami beavatkozás vált szükségessé a vállalkozások és bankok jelentös részének pénzügyi konszolidációjához, újra tökésitéséhez. 
Az SZHItv. hatálybalépésekor a szövetkezeti hitelintézeti rendszer intézményei az alábbiak voltak (Moizs és Szabó, 2016):

- Takarékszövetkezet: a magyar szövetkezeti hitelintézeti rendszer domináns megjelenési formája. Jogilag független, önálló gazdálkodást és üzletpolitikát folytató hitelintézetek, a kereskedelmi bankokéval közel azonos jogosítványokkal (Baka et al. 2012). Elméletben alapelvei megegyeztek a (feljebb már hivatkozott) Nemzetközi Szövetkezeti Banki Szövetség által 2008. október 20-án közzétett elvekkel (nyitott tagság és önkéntesség, belső demokrácián alapuló tagi ellenőrzés, tagi részvétel a gazdálkodásban, önállóság és függetlenség, folyamatos oktatás-képzés, szövetkezetek szövetkezése, törődés a közösséggel), azonban ezek gyakorlati megvalósulása igen változatos és gyakran ellentmondásos képet mutatott. Eredetileg lokális alapon - egy-egy faluhoz kötődően - alakultak 1956-tól. A takarékszövetkezetek földrajzi elkülönülésüket, kizárólagos működési területük sérthetetlenségét integrációs szerződésben rögzítették. Főbb jellemzői: minimum 200 tag (ebből legalább 67\% természetes személy), 1 részjegy értéke legfeljebb 10 ezer forint, egy tag-egy szavazat és 1 tag legfeljebb 1 másik tagot képviselhet a közgyülésen.

- Hitelszövetkezet: politikai felszámolásukig, 1953-ig Magyarországon széles körben elterjedt, jelentős múltra visszatekintő, nagy tömegbázissal rendelkező, hagyományos értékrendű, klasszikus szövetkezeti hitelintézeti forma, ami ugyan a takarékszövetkezetek alapítását követően ismét megjelent, azonban korábbi szerepét már nem tudta betölteni és ezek a szervezetek az SZHItv. hatálybalépéséig gyakorlatilag eltűntek a hazai pénzügyi szolgáltatók piacáról. Leglényegesebb eltérés a takarékszövetkezettől, hogy (a pénzváltást kivéve) csak saját tagjai számára végezhet szolgáltatást.

- Regionális takarékszövetkezeti szövetségek: több megyére kiterjedő az országos és helyi szint közötti szerveződések, önálló költségvetéssel és feladatokkal.

- Országos érdekképviseleti szövetségek: OTSZ, TÉSZ ${ }^{10}$

10 Takarékszövetkezetek Országos Érdekképviseleti Szövetsége 
- Intézményvédelmi alapok: a kötelező intézményvédelmi tagság 2003-ban a hitelintézeti törvény módosításával ${ }^{11}$ - megszünt, azonban szövetkezetek közül is többen szorgalmazták a kötelezés visszaállítását, tekintettel arra, hogy a kívülállók nagy reputációs kockázatot ${ }^{12}$ hordoztak a szektor egészére nézve. A kötelezés megszűnésétől függetlenül a szövetkezeti hitelintézetek jellemzően tagjai voltak valamely intézményvédelmi alapnak. Az egyes alapok az érdekképviseletek mellé szerveződtek (OTSZ - OTIVA, TÉSZ - TAKIVA, hitelszövetkezetek - HBA), vagy éppen a közös intézményvédelmi szervezetben jutott kifejezésre az együttmüködésük (REPIVA $\left.{ }^{13}\right)$.

- Központi Bank: a Takarékbank Zrt. legnagyobb tulajdonosi és üzleti bázisát az OTSZ integráció tagjai adták, de a többi takarékszövetkezet nagy része is tulajdonos volt, illetve üzleti alapon igénybe vette szolgáltatásait. A Takarékbank a legtöbb takarékszövetkezet fö számlavezetője volt és minden üzleti területen szoros együttmüködést folytattak: közös termékfejlesztés, forrás allokáció megtakarításokon, konzorciális hiteleken és devizaügyleteken keresztül, teljes együttmüködés a bankkártya üzletágban, informatikai területeken, hazai és nemzetközi utalásokban, készpénzellátási és más (pl. marketing) területeken.

A szövetkezeti hitelintézeti szektor az Integrációs törvény hatálybalépését megelőzően ennek megfelelően négy szintre tagolódott:

- Lokális szintre: alkotóelemei a takarékszövetkezetek, hitelszövetkezetek, országos takarékszövetkezeti szövetség tagjaiként müködő átalakult (részvénytársasági formában tovább működő) takarékszövetkezetek.

- Regionális szintre, amelynek alkotóelemei a regionális takarékszövetkezeti szövetségek.

11 2002. évi LXIV törvény 57. \$ (1)

12 Az intézményvédelmi alapokhoz nem csatlakozott szövetkezeti hitelintézetek esetében - de tényszerüen meg kell állapítani, hogy egyes esetekben az alapok tagjainál is - hiányzott az a rendszeres és független intézményvédelmi kontroll tevékenység, amivel még időben felismerhetők és megelözhetők lettek volna a válsághelyzetek. Hiányzott továbbá az a pénzügyi alap, ami az esetleg kialakult válsághelyzetben képes lett volna fenntartani a szövetkezet fizetőképességét, likviditását és tőkeegyensúlyát, ezért ezeknél a szövetkezeteknél nagyobb volt az esélye egy esetleges csődhelyzet kialakulásának, ami közvetlen hatást gyakorolt az egész szektor megitélésére.

13 A Regionális Pénzintézetek Intézményvédelmi Alapját közös érdekkörbe tartozó hat takarékszövetkezet és egy korábbi takarékszövetkezetböl átalakult kereskedelmi bank alapitotta. 
- Nemzeti szintre, alkotóelemei az

- országos szövetségek,

- intézményvédelmi alapok,

- Takarékbank Zrt.

- Szupranacionális szintre az OTSZ, mint az ICBA (Szövetkezeti Bankok Nemzetközi Szövetsége) tagságával.

Az SZHItv. hatálybalépésével, több lépcsőben és gyökeresen átalakult szövetkezeti hitelintézeti rendszer, az Integráció intézményei a következők:

1. Takarékszövetkezetek

2. Szövetkezeti identitású bankok

3. Nem szövetkezeti identitású bankok (FHB Csoport, MFB Zrt.)

4. Nemzeti szintü szövetségek, szervezetek (SZHISZ, OTSZ)

5. Tökefedezeti Közös Alap (TFKA)

6. Központi Bank (Takarékbank Zrt.)

Lokális szint:

1. Takarékszövetkezetek

2. Szövetkezeti identitású bankok

Nemzeti szint:

3. Nem szövetkezeti identitású bankok

4. Nemzeti szintű szövetségek: A TÉSZ 2018-ban beolvadt az OTSZ-be, az OTSZ tagjai számának és funkcióinak csökkenésével fokozatosan elvesztette súlyát, csak formálisan működik.

Szövetkezeti Hitelintézetek Integrációs Szervezete (SZHISZ): saját tőkéje hozzávetőleg 175 milliárd forintot tesz ki. Az SZHItv. erejénél fogva ebbe a jogi személybe olvadtak az önkéntes intézményvédelmi alapok, az SZHISZ lett az Integráció kötelező intézményvédelméért felelős szervezete. Szövetkezeti hitelintézet müködési engedéllyel csak az intézményvédelmi alap tagjaként rendelkezhet. Az SZHISZ tagjai a szövetkezeti hitelintézetek, a Központi Bank, az MFB, valamint az Integrációs Szervezet tagjai közé felvett személy vagy szervezet. A Központi Bank, az Integrációs Szervezet, valamint a szövetkezeti hitelintézetek a Hpt. szerinti összevont alapú felügyelet alatt állnak. Az SZHISZ az Integráció tagjaira (MFB Zrt. kivételével), kapcsolt vállalkozásaira kötelező érvényű szabályzatokat, 
irányelveket fogad el, meghatározza a követeléskezelés rendjét, utasításokat ad ki, határozatokat hoz, korlátozhatja a kockázatvállalásokat, felügyeli és ellenőrzi az intézményeket, szükség esetén válságkezelési tervet készít, központi adat- és jelentésszolgáltatást biztosít, felfüggesztheti a vezető tisztségviselőket, csődbiztost nevezhet ki. A leírtak alapján az integrációt szabályozó, felügyelő csúcsszerv, aki a Központi Bankkal együtt gyakorolja irányító funkcióit, azonban hatáskörét és jogosítványait tekintve (különösen a 2016. évi LV. törvény hatálybalépését követően) az integráció legfelső szervének tekinthető tekintettel arra is, hogy a Központi Banknak az SZHItv. 15/D. \$-a alapján beszámolási kötelezettsége van az SZHISZ felé, illetve az SZHISZ előírja számára a tőkemegfelelés minimális szintjét.

5. Szövetkezeti Hitelintézetek Tökefedezeti Közös Alapja

Tagjai alapításkor a Takarékbank, SZHISZ és a szövetkezeti hitelintézetek (ideértve a szövetkezeti identitású bankokat is), később csatlakozott az FHB Kereskedelmi Bank Zrt. és az FHB Jelzálogbank Nyrt. (jelenlegi nevükön Takarék Kereskedelmi Bank Zrt. és Takarék Jelzálogbank Nyrt.). Az Alapot az SZHItv. értelmében hozták létre abból a célból, hogy a garanciaközösség bármely tagjánál elhelyezett megtakarításokért a közösség összes tagja mögöttes és egyetemleges felelössége mellett elsődlegesen az Alap álljon helyt az OBA által ki nem fizethető követelésekért, így egy, az ügyfeleknek a korábbi alapoknál nagyobb biztonságot nyújtó garanciaközösség jött létre.

6. Takarékbank Zrt.: központi és kereskedelmi bank szabályozó, felügyeleti és üzleti funkciókkal, azonban jogosítványainak jelentős részét az SZHISZ jóváhagyásával gyakorolhatja. Irányítja az Integráció üzleti tevékenységét (többek között megalkotja a kockázati stratégiát és kockázatvállalási politikát, terméket fejleszt, szervezi a pénzügyi-, kiegészítő pénzügyi és befektetési szolgáltatásokat, kiadja az üzletszabályzatokat, koordinálja az üzleti tervezést, előzetesen jóváhagyja a szövetkezeti hitelintézetek éves beszámolóit), felelős az informatikai rendszerek egységes működéséért és a konszolidált szintű adatszolgáltatásért, apex banki szolgáltatásokat nyújt (számlavezetés, devizaügyletek, értékpapír, marketing, beszerzések, stb.), emellett önálló kereskedelmi banki tevékenységet végez és felügyeli az Integráció egyéb vállalkozásait is. 
$\mathrm{Az}$ átalakulás folyamata azonban a mai napig nem ért véget, mert az eredetileg az SZHItv.-ben meghatározott célok nem kerültek maradéktalanul megvalósításra. A szektor állami szerepvállalással megvalósítandó átalakításának célja a törvény Indokolása alapján:

- a szövetkezeti hitelintézetek modernizációja,

- hosszú távú prudens müködésének intézményi garantálása,

- a szövetkezeti hitelintézetek szavatoló tőkéjének biztosítása.

A 2014. évi XXXIX. törvénnyel az SZHItv.-be iktatott 1/A. \$-a a fentieken túlmenően már egyéb célokat is megjelenít, vagy ha úgy tetszik konkretizálja az Indokolásban foglalt általános célokat a következők szerint:

a) „az egyetemlegesség alapján működő vidék bankjának a létrehozása, amelynek egyes tagjai lehetőleg helyi magántulajdonosok és amely központi professzionális irányítással biztosítja a hatékony és méretgazdaságos müködést,

b) a szövetkezeti hitelintézeti szektor versenyképessé szervezése,

c) a szövetkezeti hitelintézeti szektor kockázatkezelésének javítása,

d) a szövetkezeti hitelintézeti szektor integrált müködésének, az ehhez szükséges infrastruktúrának a biztosítása,

e) a működési szabályzatok egységesítése,

f) a szövetkezeti hitelintézetek intézményvédelmének biztosítása,

g) a hitelintézetekre vonatkozó nemzetközi és európai követelményeknek, jogszabályoknak, szabványoknak, illetve szokványoknak történő megfelelés biztosítása."

A szövetkezeti hitelintézeti szektor az SZHItv. hatálybalépése óta, több lépcsőben és gyökeres változáson ment át, ezért is érdemes áttekinteni, mi valósult meg az eredeti célokból az elmúlt közel hat évben és merre tartanak a szövetkezeti hitelintézetek. 


\subsection{A szövetkezeti hitelintézetek átalakításának aktuális állapotáról}

Az alábbi fejezet rövid áttekintést ad az SZHItv.-ben megfogalmazott jogalkotói célok megvalósításának állapotáról, az Integrációo ${ }^{14}$ státuszáról.

a) „az egyetemlegesség alapján müködő vidék bankjának a létrehozása, amelynek egyes tagjai lehetőleg helyi magántulajdonosok és amely központi professzionális irányitással biztositja a hatékony és méretgazdaságos müködést"

Az egyetemlegesség a garanciaközösséggel megvalósult, de jelentősége átmeneti, mindössze addig értelmezhető, amíg a szövetkezeti hitelintézetek autonóm szervezetek, önálló kockázatvállalással és kockázatkezeléssel. Konszolidált tőkemegfelelés, egységes kockázati politika és központi követeléskezelés esetén ilyen szempontból a garanciaközösség tagjai egységes bankcsoportként viselkednek. A tagok egy bankba tömörülésével ez a formális felelösségi viszony is megszünik.

Az SZHItv. hatálybalépésétől 2018. év végéig eltelt időszakban a fiókok száma jelentősen csökkent, a korábbi 1640 fiókból majdnem minden harmadik bezárt, jellemzően kistelepüléseken. A Magyar Posta és az Integráció közötti feladatmegosztás ésszerü alternatívaként került megfogalmazásra, de tudva, hogy a Posta hálózata is hasonló utat járt be, sok kistelepülés a korábbi kettő helyett hagyományos értelemben vett szolgáltató nélkül maradhat. Az Integráció jelenlegi üzleti modelljének két hangsúlyos problémája, nevezetesen, hogy ügyfélállománya a hagyományokból eredően (például sokáig városokban nem is nyithattak fiókot) ma is inkább a kistelepüléseken koncentrálódik, illetve, hogy a digitalizáció és az elektronikus/virtuális banki szolgáltatások területén lemaradásban van versenytársaihoz képest, kételyeket támasztanak a vidék bankja koncepció életképességével kapcsolatban. További problémát jelent ezzel összefüggésben, hogy a kis fiókok bezárásával együtt járó létszámleépítések elvágják a sokszor egyetlen közvetítő szálat a mikroközösségekkel. Ezek helyett újat felépíteni pedig ugyanakkora esélye van bármelyik banknak, mint az Integrációnak.

14 Az SZHItv. hatálybalépését követö idöszakra tudatosan alkalmazom a szövetkezeti hitelintézeti „szektor” kifejezés helyett a törvény szóhasználatát („Integráció”), egyrészt az átalakult tartalmat jelezve, másrészt szem elött tartva, hogy a piaci szereplők számosságának csökkenése és egymáshoz való viszonyuk miatt már indokolatlan a „szektor” megjelölés, „bankcsoportként” való definiálásuk alkalmasabb szóhasználat. 
A taglétszám az SZHItv. hatálybalépésétől függetlenül is folyamatosan csökkent az elmúlt évtizedekben. Ennek okai a korábbi menedzsmentek kiszorító politikája a tulajdonosi koncentráció érdekében, a betéti hozamoknál sokszor alacsonyabb vagy egyáltalán nem alkalmazott osztalékfizetés és nem utolsósorban a hitelszövetkezeti jelleg elvesztése, azaz a szövetkezeti bankban az ügyfelek igényei már nem találkoznak a tulajdonosok igényeivel, mivel a szövetkezet ügyfele már jellemzően nem tulajdonos. Ennek következményeképpen a szövetkezeti hitelintézetek fő célja nem a szolgáltatás, hanem a nyereség értékének maximalizálása. A szövetkezeti hitelintézetek tulajdonosainak száma mára elenyésző az ügyfélszámhoz képest, és addig is gyakran csak formális tulajdonosi pozíciójukat az SZHItv. tovább redukálta, de továbbra is elég ahhoz, hogy az Integrációs tervek megvalósításakor - mint kezelendő stratégiai kérdéssel - számolni kelljen velük.

\section{b) „a szövetkezeti hitelintézeti szektor versenyképessé szervezése”}

Tényként említhetjük, hogy a mérlegföösszege, állományai és bevételei alapján a hazai bankszektorban 4-5. helyet elfoglaló Integráció költséghatékonysági mutatója (CIR) $86 \%{ }^{15}$ költséghányaddal a rosszabbak között van, hasonló a helyzet a tőkearányos megtérüléssel (ROE) is.

A hagyományos szövetkezeti küldetés, azaz fizikai jelenlét a kistelepüléseken és a hatékonyság egymással rivalizáló célok, ennek megfelelően választani kell: vagy kompromisszum születik a fiókszám és a hatékonyság arányaiban vállalva ezzel a versenyhátrányt, vagy a bankok többségéhez hasonlóan tisztán piaci szempontokat érvényesít, vállalva ezzel a hagyományos értékekkel való szakítást.

Az Integráció által a közelmúltban elfogadott és bemutatott, 2019-2023 időszakra vonatkozó megújított stratégi ${ }^{16}$ alapján már nem a szektor versenyképessé szervezése a stratégiai cél, hanem egy versenyképes kereskedelmi bank létrehozása. A nyilvánosság számára elérhető információk alapján a kirendeltségek és a munkatársak számának tervezett csökkentése a költségszintet csökkentik, de ez automatikusan nem jelent hatékonyság javulást, ehhez szükség lesz arra is, hogy az egyéb költségek szinten maradjanak, vagy a bevételek a költségszintet meghaladó mértékben növekedjenek, ehhez pedig a kieső fiókhálózat helyett más értékesítési csatornákat kell erősíteni.

15 2017-es adat (Takarékbank Zrt.).

16 Ld. a Budapesti Értéktözsde honlapján 2018.11.30-án közzétett rendkivüli tájékoztatást: https:// bet.hu/newkibdata/128117422/Rendk_v_li_t_j_koztat_s_HU.pdf 
Az Integráció azon szándéka, hogy „innovatív” digitalizált bankká alakuljon át, nem elsősorban stratégiai kérdés - hiszen a fogyasztói szokások és a költségek féken tartása miatt minden bank kimondva, vagy kimondatlanul jövedelmezösége megőrzése érdekében erre kényszerül -, hanem ismét hatékonysági: egységnyi megvalósított technológiai beruházás a versenytársakhoz képest milyen arányú jövedelem elöállítására képes, milyen hasznosan sikerült a pénzt elkölteni? A versenytársak ezen a területen már régebb óta komoly tapasztalatokkal és kipróbált háttérrel rendelkeznek.

A digitális csatornák mellett a másik publikált alternatív értékesítési alternatíva a közösségi bankok mintájára a mikrocsoportok (helyi szervezetek, közösségek), vagy elemi csoportok (család, generációk) számára nyújtott szolgáltatások és a lokális piachoz sorolható a szövetkezeti hitelintézetek hagyományos agrár ügyélköre is.

c) „a szövetkezeti hitelintézeti szektor kockázatkezelésének javitása”

A szövetkezeti hitelintézetekkel kapcsolatban szakmai körökben gyakran hangzott el az a megállapítás, hogy bizalmi alapú hitelezést folytatnak és kockázatvállalási sztenderdjeik és folyamataik nem felelnek meg a korszerü banki struktúrák követelményeinek. Bár ahogy sok más területen, a szövetkezeti hitelintézetek itt sem mutattak egységes képet, a 2008-ban kirobbanó gazdasági-pénzügyi válság általánosságban, vagy részben igazolta ezeket az állításokat és az Integráció nem teljesítö (minősített) állománya még jelenleg is valamivel a bankszektor átlaga felett van ${ }^{17}$. Noha a szabályozói környezet átalakulása is jelentös változásokat követelt meg a szövetkezeti hitelintézetektöl, majd az Integráció egészétöl az elmúlt 10 év során, a nettó kamatszint ugyanerre az idöszakra tehetö tartós csökkenése minden korábbinál hatékonyabb belsö kockázatvállalási sztenderdeket követelt meg a veszteségviselö képesség minimális szintje és a tökekövetelmények változása miatt. Bár a kockázatok kezelése minden tekintetben (különösen a működési- és piaci kockázatok kapcsán és a workout tevékenység hatékonysága

17 Meg kell jegyezni, hogy a hitelszövetkezetek, majd később a takarékszövetkezetek kialakulásának egyik oka éppen az volt, hogy a jellemzöen városokban müködő bankok elégtelen információkkal rendelkeztek a rurális piacról és csekély hajlandóságot mutattak a vidék hitelezésére. A helyi kötődésü pénzintézetek rendelkeztek azzal a helyismerettel, ami részükröl lehetövé tette a vidéki kockázatvállalást. Azonban ezen - jelentős részben szubjektív - adatforrások aránya akkor is jelentős maradt, amikor a pénzpiacok fejlődése már szofisztikáltabb módszereket követelt volna meg a kockázatok valós becsléséhez. 
terén) javításra szorult, de a célok megfogalmazásakor legalább ennyire indokolt lett volna a kockázatvállalási szabályozás és folyamatok megújításának szükségességét is hangsúlyozni, mert ezen a területen, ha lehet még nagyobb volt a szektor elmaradása. Az Integráció központi szervei kidolgozták a közös politikát és szabályozást, azonban eltérően például a német szövetkezeti hitelintézetek gyakorlatától, a szubszidiaritás elvét és érvényesülését nem sikerült hatékonyan megvalósítani, ami a kockázatvállalás területén az ügyfélkapcsolatokra, a követeléskezelés területén a behajtási hatékonyságra lehet kedvezötlen hatással.

d) „a szövetkezeti hitelintézeti szektor integrált müködésének, az ehhez szükséges infrastruktúrának a biztositása"

Az integrált müködés az elmúlt közel 6 év során, különösen a hierarchikus viszonyok jogszabály általi meghatározottsága, a központi intézmények definiálása, a garanciaközösség létrejötte, az egységes és átfogó szabályozás bevezetése, a közös termékek kialakítása, az együttes piaci megjelenés és kommunikáció, a központi beszerzések, a közös és konszolidált üzleti tervezés, illetve központi adatszolgáltatás, az egyesülések, stb. által jelentős részben megvalósult, azonban ismert, hogy a jelenleg kialakult intézményrendszer egy köztes állapot, így a leírtakat a végső intézményi struktúra szempontjából érdemes értékelni.

Ami az infrastruktúrát illeti, ennek leglényegesebb eleme a SZHItv.-ben előírt egységes informatikai rendszer, ami a kifejezés szakmai értelmében teljes egészében nem valósult meg sem a törvényi határidőre sem azt követően.

e) „a müködési szabályzatok egységesitése”

A müködési szabályozás kérdésében az SZHISZ és a Központi Bank hatáskörénél fogva elvégezte a jogszabály által ráruházott feladatot, az egységesítés megvalósult. A központi kötelezően alkalmazandó mintaalapszabály, a közvetlen és közvetett hatályú szabályzatok, üzlet- és termékszabályzatok, irányelvek és utasítások a szövetkezeti hitelintézetek müködésének, hitelintézeti tevékenységének minden területét átfogják.

f) „a szövetkezeti hitelintézetek intézményvédelmének biztositása”

Az SZHItv. elvitathatatlan érdeme, hogy a korábbi önkéntes és eltérő hatékonyságú intézményvédelmi alapok helyett létrehozta az egységes elveken nyugvó alapot, kötelezően előírt tagsággal. Az intézményvédelem keresztgaranciális 
rendszeren alapul, mely garanciaközösségbe átvilágítást követően kerülhettek be a tagszervezetek. Az SZHISZ folyamatosan felügyeli a szövetkezeti hitelintézeteket és a Központi Bankot, továbbá közremüködik tagjainak Magyar Nemzeti Bank által ellátott összevont alapú felügyeletében. Az SZHISZ és a Szövetkezeti Hitelintézetek Tőkefedezeti Közös Alapja hatásköre, illetve funkciója az elöző fejezetben került bemutatásra.

g) „a hitelintézetekre vonatkozó nemzetközi és európai követelményeknek, jogszabályoknak, szabványoknak, illetve szokványoknak történő megfelelés biztositása."

A szövetkezeti hitelintézetek tekintetében ennek a jogalkotói célnak nem tulajdonítható disztingvált jelentéstartalom.

\subsection{A szövetkezeti hitelintézetek jövője a magyar pénzügyi piacon}

A szövetkezeti hitelintézetek rendszere jelentős átalakuláson ment át a válság kirobbanását követően és ez a folyamat várhatóan rövidesen lezárul. Az integrációs szándék eltökélt abban, hogy a jelenlegi szövetkezetekből és részvénytársaságokból egy univerzális hitelintézetet hozzon létre, ez a folyamat várhatóan 2019-ben lezárul.

A publikált új struktúrában a szövetkezeti vagyon az integrációs vagyon részeként a szövetkezetek formai egyesülésével egy tulajdonosi holding szövetkezetben maradna.

Ezzel a lépéssel a szervezeti struktúra leegyszerüsödik, hiszen pénzügyi szolgáltatóként az univerzális kereskedelmi bank mellett a jelzálogbank, illetve egyéb szolgáltatókként a leányvállalatok müködnek. Müködésüket a tulajdonosi pozíciókat fenntartó Központi Bank koordinálja, aminek „központi” tevékenysége szövetkezeti hitelintézetek híján mindössze erre a koordinációra korlátozódik, banki liszensze fenntartásának szükségessége is átgondolható.

Az SZHISZ és a Tőkefedezeti Közös Alap szerepe is jelentősen redukálódik, hiszen eltűnnek a rendszerből azok az intézmények, akiknek érdekében létrehozták őket. Szükségességük ebben a formában megkérdőjelezhetö, funkcióik és vagyonuk a központi bankba olvaszthatók lennének a banki liszensz megtartása esetén. 
A hagyományos értelemben vett szövetkezeti hitelintézetek a jelenlegi stratégia alapján több mint másfél évszázados müködésüket követöen eltünnek a magyar pénzügyi piacról. A klasszikus - robusztus ügyfél-tulajdonos bázison alapuló - hitelszövetkezeti és takarékszövetkezeti formációk megszünésével valójában nem beszélhetünk szövetkezeti hitelintézetekről Magyarországon, hiszen dacára a stratégiában megfogalmazott céloknak a létrejövő intézményegyüttes a feljebb már hivatkozott és a következőkben bemutatott ICBA által megfogalmazott szövetkezeti banki értékekkel ${ }^{18}$ nem azonosítható:

- Ügyfél-tulajdonlás: „A szövetkezeti bankban az ügyfelek igényei találkoznak a tulajdonosok igényeivel, mivel a szövetkezet tagja mindkettő. Ennek következményeképpen a szövetkezeti bank fö célja nem a nyereség maximalizálása, hanem a lehető legjobb termék és szolgáltatás a tagjai számára. Néhány szövetkezeti bank csak tagjainak szolgáltat, de legtöbbjük nem tag ügyfeleket is fogad banki és pénzintézeti szolgáltatásainak igénybevételére."

- A publikált célok világosak a nyereségorientáció tekintetében, a domináns ügyfél-tulajdonlás pedig a hitelszövetkezetekkel együtt tűnt el.

- Demokratikus tagi ellenőrzés: „A szövetkezeti bankok tagjaik tulajdonában és ellenőrzése alatt állnak, akik demokratikusan választják az igazgatótanácsot. A tagok általában egyenlő szavazati jogokkal rendelkeznek összhangban az egy tag - egy szavazat szövetkezeti elvvel.”

- A nem tőkearányos döntéshozatal a személyegyesítő szervezetekre, így a szövetkezetekre jellemző, az új szisztémában erről nincsen szó.

- Nyereségfelosztás: „Egy szövetkezeti bankban az éves nyereség jelentős része, haszon és felesleg tartalékba kerül. A nyereség más része a szövetkezeti tagok számára kerül kiosztásra, a legtöbb esetben jogilag, vagy törvényileg behatárolva akár vásárlói osztalék formájában, ami összefügg azzal, hogy a szövetkezet termékeit és szolgáltatásait minden tag igénybe veszi, akár kamat vagy osztalék formájában, ami az összes tag által jegyzett részvények számának függvénye."

18 International definition of Cooperative Banks adopted by the ICBA (International Co-operative Banking Association), ICBA 2008. október 20-i közgyülése. 
- Az osztalék mellett/helyett a tulajdonosok számára a szövetkezeti bank kedvezményes árú, vagy tartalmú szolgáltatást nyújt, ami az ügyfél-tulajdonlást feltételezné.

- „A szövetkezeti bankok mélyen gyökereznek a helyi térségekben és közösségekben. Részt vesznek a helyi fejlesztésekben, hozzájárulnak közösségeik fenntartható fejlödéséhez mivel tagjaik és a vezetöség azokhoz a közösségekhez tartoznak, ahol tevékenységüket gyakorolják. A fokozott banki részvétellel azokon a területeken és piacokon, ahol más bankok kevésbé vannak jelen - kisvállalkozások, vidéki régiók farmerei, közepes, vagy alacsony jövedelmü háztartások a városi területeken - a szövetkezeti bankok csökkentik a banki kirekesztést és emberek millióinak segitik a gazdasági boldogulását. Befolyásoló szerepet játszanak azoknak az országoknak a gazdasági növekedésében, amelyekben dolgoznak és növelik a nemzetközi pénzügyi rendszer hatékonyságát. Sajátos, a szervezet fent emlitett elveiben bizó vállalkozási formájuk sikeres bizonyítást nyert mind fejlettségükben, mind az ország fejlődésében."

Az Integrációs stratégia szintén épít a helyi közösségekre, azonban nem a szövetkezeti bankokéval egyező tartalommal. A megcélzott közösségek közel azonosak, azonban amíg a szövetkezeti hitelintézetek regionálisan müködnek és vezetőik ezeknek a közösségeknek elismert tagjai, addig az Integráció elképzeléseiben az országos univerzális bank részben társadalmi szerepvállalásként, részben üzleti előnyökért kívülről építi ezeket a kapcsolatokat, tipikusan a közösségi bankok mintájára, amelyek nem tévesztendök össze a szövetkezeti bankokkal.

Ilyen értelemben „az egyetemlegesség alapján müködö vidék bankjä”-nak koncepciója helyett egy univerzális, nagyvárosokra hangsúlyosabban támaszkodó bank valósulhat meg.

A versenyképesség és hatékonyság javítása egyezően a stratégia kidolgozóinak véleményével komoly feladat lesz az Integráció számára. Mint arra évekkel ezelött is utaltam ${ }^{19}$, ha a szövetkezeti modellel szakít a szektor, azaz nem a modell átalakítása, modernizálása valósul meg, hanem kereskedelmi bankká és fiókhálózattá szervezése, akkor teljesen új kihívásokkal fog szembesülni.

19 Ld. Moizs (2015). 
„Egy ilyen, valós tartalmában nem szövetkezeti hálózat, hanem kereskedelmi bank állami beavatkozás nélkül már középtávon is csak olyan áron lehet versenyképes a professzionális kereskedelmi bankokkal, amilyen költségek mellett új bankot is létre lehetne hozni."

Megítélésem szerint legalább ugyanennyi munkával, de talán alacsonyabb üzleti és reputációs kockázattal, illetve a szövetkezeti jelleg megőrzésével is hatékony Integrációt lehetett volna kialakítani, ami az SZHItv. eredeti célkitűzéseinek is jobban megfelelt volna. Ráadásul a DGRV ${ }^{20}$ - akinek ernyője alatt növekvő taglétszám (mintegy 18,5 millió) mellett ma is több mint 900 regionális szövetkezeti bank müködik Németországban - mintája sok tekintetben hazánkban is alkalmazható lett volna.

\section{A szövetkezeti hitelintézetek tehát a hatékonysági verseny mellett tették le} a voksukat a stratégia elfogadásával, amit ráadásul viszonylag dinamikus növekedési pálya és a jelenlegit sokszorosan meghaladó jövedelmezöség mellett kívánnak néhány éven belül megvalósítani a naturáliák, állományok és bevételek alapján számított legalább 4. pozíció megszerzése/megtartása érdekében. Ezek azonban - amennyiben a tervezett növekedés a piac méretének növekedését meghaladja - egymással versengö célok.

A költségek racionalizálását elsősorban a fiókmodell és az ügyfélszegmentáció újragondolása szolgálja, aminek eredményeképpen a csökkenő számú fizikai (hagyományos) fiókok mellett megjelenhetnek a digitális és a postáéhoz hasonló mobil fiókok, illetve müködő külföldi modellekhez hasonlóan a Takarékbank müködésétől sem idegen tanácsadói hálózat. Az átalakítás során megfelelő szelekció és szegmentáció esetén a fizikai jelenlét megszünése miatt bekövetkező esetleges ügyfélvesztés ellenére sem kell veszteséggel számolni, hiszen egyes ügyfélcsoportokon a határköltségek magasak a realizálható bevételekhez képest, sőt a megcélzott és megmaradó csoportok esetében nagyobb ügyfélelégedettség is elérhető. Azonban ez még nem jelenti azt, hogy addicionális jövedelmek keletkeznek, ahhoz az új értékesítési csatornáknak stagnáló piacon versenyképesebbnek, növekvő piacon azonos hatékonyságúnak kell lennie a közvetlen versenytársakhoz mérten.

20 Deutscher Genossenschafts- und Raiffeisenverband e. V. https://www.dgrv.de/en/home.html 2019.03.25. 
1. Az első kritikus pont tehát az értékesitési csatornák átalakítása az ügyfeleken realizált bevételek egyidejü extenzív növelése mellett.

2. A kivonulási, illetve hálózatszükitési stratégia reputációs kockázatot hordoz, ebben az esetben a márkanév ismertsége negatív hatással is lehet a megítélésre, mivel a piac nagyobb része szembesül negatív élménnyel, így ez szintén kritikus eleme a stratégiának.

3. Általában az expanziós stratégia ár és/vagy kockázati versenyt jelent, amiből az árverseny a szintén célként megfogalmazott jelentős jövedelemnövelésre van kedvezötlen hatással, a kockázati verseny hosszú távon szintén extra költséget jelenthet értékvesztés, céltartalék, vagy tökeszükséglet növekmény formájában.

4. A fenti célok együttesen a globális- és nemzeti gazdasági konjunktúra pályák felívelő szakaszaira tervezhetők, azonban az előttünk álló néhány évben semmi nem garantálja ezt a forgatókönyvet ${ }^{21}$, maga az Integráció is piaci konszolidációra készül, ezért az egyidejü megvalósítás helyett $\boldsymbol{a}$ differenciált értékválasztás növelhetné a megvalósithatóság esélyeit.

5. Az Integráció jövőképében felvonultatja azokat a korszerű elemeket, amik modern bankká tehetik, de nincs olyan terület, beleértve a közösségi banki szerepkört is, ami mérhető versenyelőnyt biztosíthat számára valamelyik szegmensben, ezzel szemben megvalósítás előtt állnak olyan időigényes feladatok, mint az innovációs folyamatok szervezeti értékké fejlesztése, alkalmazása és a digitalizáció beépítése az üzleti modellbe. Az egységes informatikai rendszer megvalósításából kiindulva az SZHItv. által előírt modernizáció és ennek feltételeként a széleskörü digitalizáció megvalósítása lehet az egyik legkomolyabb kihívás az Integráció számára.

6. A jól működő szövetkezeti hitelintézeti szektor egyik jellemzője a megfelelő tőkepótló képesség. Mivel a tulajdonosi és szövetkezeti érdek a magyar szövetkezeti hitelintézeti szektorban már évtizedek óta csak marginálisan kapcsolódott (a tulajdonosi érdek a helyben szolgáltató bankfiókkal, esetleg osztalékra való jogosultsággal volt azonosítható), valódi tőkepótló képességről az SZHItv. megszületését megelőzően sem beszélhettünk.

21 Lásd bövebben Moizs (2019). 
Ezzel szemben rendelkezésre állt az ún. „generációs alap” (Moizs, 2011a), így a felhalmozott tartalékok a szektor tőkeellátottságát a korábbi követelmények szerint viszonylag magas szinten tartották, jellemzően alacsony kockázati étvágy mellett. A tőkeigény viszont jelentősen nőhet a jelenlegi kamatkörnyezetben, ahol egységnyi bevétel elérése magasabb tőkével valósítható meg, de a trendek alapján minden tevékenységi körben szükülő hozamok várhatóak egy esetleges dekonjunktúrától függetlenül is. A szektor átalakítása során a Magyar Állam jelentős összeggel járult hozzá az Integráció feltőkésítéséhez, de a Nemzetközi Pénzügyi Beszámolási Standardok ${ }^{22}$ életbelépése és az átalakítási folyamat elhúzódása miatt a növekedési stratégia tökeigényének biztosítása újabb mérföldkövet jelenthet az Integrációs stratégiában, hiszen sem az Âllamtól, sem a „generációs alapot” szolgáltató tagságtól további tőkeinjekció nem várható el, így a tőkepótlás a többi tulajdonosra hárulhat.

\section{5. Összefoglalás}

A szövetkezeti hitelintézetek jelentős átalakuláson mentek át az elmúlt években és a reorganizáció várhatóan még 2019-ben egy új szervezeti struktúra felállításával teljesedik ki.

A létrejövő új szisztéma a hagyományos értelemben nem tekinthető szövetkezeti rendszernek, mert nincsenek benne regionálisan és szövetkezeti formában működő pénzügyi szolgáltatók, így elmondható, hogy a klasszikus értelemben vett szövetkezeti hitelintézetek eltűnnek a pénzügyi szolgáltatók palettájáról.

A publikált Integrációs stratégia ambiciózus, tevékenységi köre a jelzálogbankkal és a leányvállalatokkal univerzális. Szervezeti rendszere a stratégiai elképzeléseken túlmenően a szövetkezeti hálózat helyébe lépő kereskedelmi- és jelzálogbankok mellett tovább egyszerüsíthető, racionalizálható.

Az igazi munka most kezdődik, hiszen a következő évek adnak választ arra, hogy a stratégia feljebb megfogalmazott kritikus elemeinek megoldására megvan-e a képesség az Integrációban, a szövetkezeti hitelintézeti szektor átalakítására vonatkozó jogalkotói szándék megvalósul-e.

22 IFRS 


\subsection{Irodalomjegyzék}

Ádám Antal (2006): Az értékek pluralitása és versengése, In: Jog - Értékek - Erkölcs. (Acta Humana Studiosorum) Budapest, Emberi Jogok Magyar Központja Közalapítvány. 54. p.

Baka Istvánné, Dancsó József, Ligeti Sándor, Vágyi Ferenc, Szarvas Ferenc, Varga József, Kürthy Gábor. Baka Istvánné, Kürthy Gábor (szerk.) (2012): Bankismeretek: Egyetemi tankönyv. Budapest: Tanszék Kft., 105 p. ISBN 978-96388777-4-1

Bossu, Wouter; Cortavarria-Checkley, Luis; Fonteyne, Wim; Giustiniani, Alessandro; Gullo, Alessandro; Hardy, Daniel; Kerr Seán (2010): Crisis Management and Resolution for a European Banking System. IMF Working Paper No. 10/70.

Botos Katalin (1996): Elvesz(t)ett illúziók. Közgazdasági és Jogi Könyvkiadó Rt., Budapest.

Kispál-Vitai Zsuzsanna (2013): A szövetkezet átalakulása befektetői tulajdonú társasággá - elkerülhetetlen jövő? Gazdálkodás 2013/3. sz. 260-269. o.

Kiss György Kálmán (2009): A „vidék bankja” megteremtésének dilemmái Magyarországon. Hitelintézeti Szemle 2009/6. sz. 496-515. o.

Kolossváry Ádám, Varga József (1994): Fizetési forgalom. In: Sulyok-Pap Márta (szerk.). Banküzemtan: Egyetemi tankönyv. 314 p. Budapest: Tanszék Kft., 1994. pp. 139-178. [közread. a] Budapesti Közgazdaságtudományi Egyetem Pénzügyi Tanszék. További kiadásai: 1998, 2003, 2006.

Lukács Gergely Sándor (1994): A magyar takarékszövetkezetek története és modernizációja. Mezőgazdasági Szaktudás Kiadó, Budapest.

Majoros Anna (1985): A takarékszövetkezetek története. SZÖVOSZ Oktatási és Továbbképzési központja. Budapest.

Moizs Attila (2007a): A takarékszövetkezetekről. In: PhD Tanulmányok 6. PTE Állam- és Jogtudományi Karának Doktori Iskolája, Pécs 2007. 343-388. o.

Moizs Attila (2009a.): „Rabobank: A szövetkezetek kiegyenlítő ereje”. Takarék 2009. 1. sz. 44-46. o.

Moizs Attila (2009b): A takarékszövetkezetek fejlődési irányai. PhD Tanulmányok 8. PTE Állam- és Jogtudományi Karának Doktori Iskolája, Pécs 2009. 349-385. o. 
Moizs Attila (2009c): A vagyonnevesítés etikai és jogi problémái a takarékszövetkezeteknél. JURA 2009. 1. sz. 86.-93. o.

Moizs Attila (2009d): Előadás dokumentuma. ÖGV-TÉSZ konferencia. Bécs, 2009.10.14.

Moizs Attila (2010): Heterogenesis. PhD Tanulmányok 9. PTE Állam- és Jogtudományi Karának Doktori Iskolája, Pécs 2010. 487.-523. o.

Moizs Attila (2011a): The Reorganization of Ownership Relations in Savings Cooperatives. JURA 2011. 1. sz. 90-98. o.

Moizs Attila (2015): A Szövetkezeti hitelintézetek szerepe és jogi helyzete, Doktori értekezés 2015, Pécsi Tudományegyetem Állam- és Jogtudományi Kar.

Moizs, Attila (2019): New crisis - new answers. In: An in depth look at Hungary (ed. Esperanta Rompa) Nova Science Publishers New York 2019 ISBN: 9781-53615-351-4

Moizs Attila - Szabó G. Gábor (2012): A szövetkezeti hitelintézetek Magyarországon. Hitelintézeti Szemle 2012/1. sz. 67-85. o.

Moizs, Attila - Szabó, Gábor G. (2016): The history, the current system and the special features of savings cooperatives in Hungary, Credit Cooperative Institutions in European Countries (ed. Karafolas, Simeon), SPRINGER 2016 ISBN 978-3-319-28783-6

Onofreiu, Adrian (2004): Istoricul cooperatiei de credit din judetul Bistrita-Nasaud. Complexul Muzeal Judetean Bistrita-Nasaud, Editura George Cosbuc, Bistrita.

Rabobank Nederland Economic Research Department: Countervailing power of cooperative banks. Working Paper 2008.

Varga József, Bánóczy János, Fejér-Király Gergely, Katalin Péter Emőke (2017): The Working Mechanism of the "Zöld Székely" Local Card from Odorheiu Secuiesc. SELYE E-STUDIES 8:(2) pp. 32-41.

Varga József (1994): Belföldi pénzforgalmi szolgáltatások. Budapest: Nemzetközi Bankárképző Központ Zrt., 1994. 60 p. (Bankárképző dobozok). 4., Bankszakmai alapismeretek: [a Bankárképző felsőfokú bankszakmai kurzusának távoktató tananyaga] ISBN 963-04-4291-4

Wyman, Oliver (2008): Co-operative bank - Customer champion. EACB.

Wyman, Oliver (2014): Co-operative Banking, Leveraging the co-operative difference to adapt to a new environment. EACB. 


\section{Egyéb banki müveletek és szereplök}

A fejezet olvasása elött felmerülhet a kérdés: mit is értünk egyéb banki müveletek alatt? Számos módon tudjuk csoportosítani a banki/pénzügyi müveleteket, szolgáltatásokat. Klasszikus értelemben az aktív, passzív és semleges szolgáltatási csoportokat különítjük el, ez a csoportosítás leginkább arra utal, hogy a bank mérlegére milyen hatással van az adott szolgáltatás. A pénzügyi szolgáltatásokat azonban jelen esetben abból a szempontból közelítjük meg, hogy egy pénzintézet, pénzügyi vállalkozás életében milyen nagyságrendet képviselhet. A hitelezés és betétgyüjtés a legklasszikusabb szolgáltatások közé tartoznak, ugyanakkor a lízing szolgáltatás és faktorálás sem elhanyagolható, de jellegüket, sajátosságaikat tekintve mégis célszerü külön kezelni és foglalkozni a témával. A lízing és a követelés megvásárlás fontos aktív szolgáltatás, azonban ezen szolgáltatások művelői között nem csak bankokat és más hitelintézeteket találunk meg, hanem pénzügyi vállalkozásokat, vagy akár más vállalkozásokat is, melyek közvetítők révén nyújtják ezen szolgáltatásokat. A könyv jelen fejezetében az egyéb pénzügyi, banki szolgáltatás vonatkozásában a lízing, a faktorálás és a forfetírozás sajátosságaival ismerkedünk meg. A részfejezetek végén bemutatásra kerülnek a lízing és faktorpiac aktuális adatai, melyek jól mutatják a szolgáltatások iránti kereslet nagyságát.

\subsection{Pénzügyi vállalkozások}

A hitelintézetek és pénzügyi vállalkozások által üzletszerüen végzett tevékenységet nevezzük pénzügyi szolgáltatásnak, melyet az intézmények forintban és más fizetési eszközben is nyújthatnak ügyfeleik részére. A hitelintézetek alapvető és kiegészítő pénzügyi szolgáltatásokkal állnak ügyfeleik rendelkezésére. Nagyon fontos kritérium, hogy pénzügyi szolgáltatást kizárólag pénzügyi intézmény végezhet, szigorú alapítási és müködési kritériumok teljesítése mellett. Az intézmények alapításának, valamint működésének engedélyezése, később pedig a folyamatos működési kontroll biztosítását az MNB felügyeleti tevékenysége garantálja. Hazánkban a pénzügyi intézmény lehet hitelintézet, valamint pénzügyi vállalkozás. A kizárólagosság elve alapján hitelintézet jogosult betét gyüjtésére, saját tőkéjét meghaladó mértékben más visszafizetendő pénzeszköz nyilvá- 
nosságtól való elfogadására, valamint pénzváltási tevékenység végzésére. Ezen szolgáltatásokra tehát még pénzügyi vállalkozás sem kaphat jogosultságot a tevékenység engedélyező szervtől, vagyis a jegybanktól. A pénzügyi vállalkozások többségében aktív szolgáltatásokkal állnak az ügyfelek rendelkezésére, többek között a lízing és faktorálás, forfetírozás, hitel és pénzkölcsönnyújtás terén, de közremüködhetnek pénzügyi szolgáltatások közvetítésében is. Jelen fejezetben a két legjellemzőbb szolgáltatással, a lízinggel és a faktorálással ismerkedünk meg, hiszen a hitelezés a bankoknál is megjelenő meghatározó szolgáltatás, ugyanakkor egy hitelintézet lízing vagy követelés megvásárlásra inkább egy saját pénzügyi vállalkozást hoz létre, mintsem egy szervezeten belül nyújtaná ezeket a szolgáltatásokat. Erre példa többek között az OTP csoport tagjaként müködő Merkantil Bank, ami kifejezetten eszközfinanszírozással foglalkozik, vagy a Budapest Lízing Zrt., ami a Budapest Bankhoz kapcsolható, a Raiffeisen Corporate Lízing Zrt, amely a Raiffeisen csoporthoz tartozik. Pénzügyi vállalkozás kivéve a pénzügyi holding társaságot és a fizetési rendszert működtető pénzügyi vállalkozást - legalább ötvenmillió forint induló tőkével alapítható. Pénzügyi holding társaság legalább kettőmilliárd forint induló tőkével alapítható, a fizetési rendszert működtető pénzügyi vállalkozás legalább ötszázmillió forint induló tőkével hozható létre.

Az 1. ábrán jól látható, hogy a pénzügyi vállalkozások száma viszonylag kiegyenlített létszámot mutat. 2018. decemberi adatok alapján 1947 milliárd forint mérlegföösszeggel rendelkeztek, ami 5\%-os bővülést jelent 2015. év végéhez képest. Az 1. ábra jól mutatja az adózott eredmény alakulását is. 


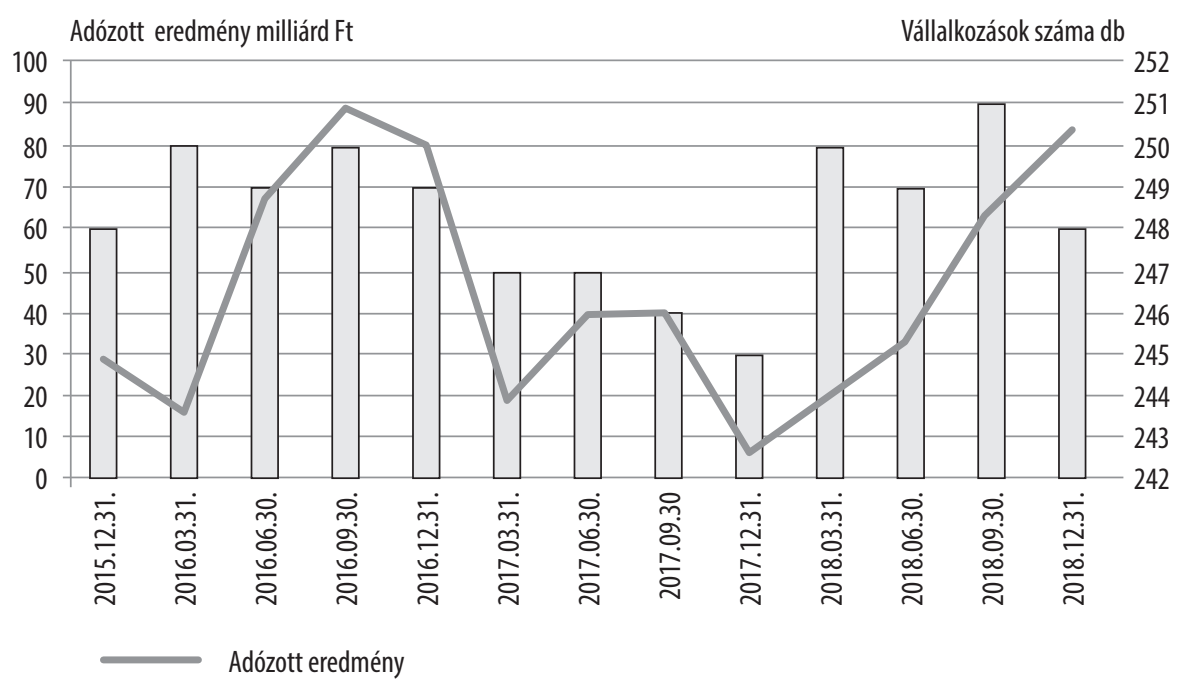

1. ábra: Pénzügyi vállalkozások száma és adózott eredményük alakulása Magyarországon

Forrás: MNB (2019) idösorai alapján saját szerkesztés.

\subsection{A lízing fogalma, története, típusai}

\subsubsection{A lízing története}

Michael Marek „Lízing története” címü könyvében arról ír, hogy a lízinghez hasonló gondolatok több mint 5000 évvel ezelőttről származnak. A Sumérok Kr.e. 3000 évvel a Tigris és az Eufrátesz folyókhoz kapcsolódó építkezéseknél, mezőgazdasági munkáknál alkalmaztak bérlethez/lízinghez hasonló ügyleteket. Az első jogi szabályokat Hammurapi törvényei tartalmazták. Több mint 1400 évvel ezelőtt a mai Olaszország területén az üzleti lízing elődje fejlődött ki, a kereskedelmi hajózás terén. A 19. században lízingszerződéseket kötöttek ingóságokhoz kapcsolódóan. A modern kor első lízingkonstrukciója 1877-re vezethető vissza, amikor is a Bell Telephone Company telefonkészülékeket adott bérbe, és a társaság szervízszolgáltatást biztosított a készüléket bérlők részére. A lízing történetének következő jelentősebb állomása az 1950-es évek, amikor is a jelentős gazdasági fejlődés folyamatos beruházást várt el a vállalkozásoktól, azonban ehhez nem volt elegendő tőkéjük. Az a vállalkozás, aki nem akart termelési színvonalban lemaradni a gépek bérlését/lízingelését választotta. Az első lízingtársaság az USA-ban jött létre 1952-ben. A napjainkban is érvényben lévő 
szabályok az Unidroit egyezményhez kapcsolhatók. Magyarországon a rendszerváltást követően vett nagyobb lendületet a lízing, mint finanszírozási forma. Az Unidroit egyezményt Ottawában fogadták el 1988-ban. Hazánkban az 1997. évi LXXXV. törvény keretében valósult meg a nemzetközi követelés-vétel, valamint az 1997. évi LXXXVI. törvény szerint a nemzetközi pénzügyi lízing alapszabályainak rögzítése. ${ }^{1}$

\subsubsection{A lízing fogalmának meghatározása a hazai jogszabályi környezetben}

A jogi, kereskedelmi szótár szerint a lízing szó jelentése az alábbi: „kölcsönbérlet, hosszú időre szóló bérlés, ami megvásárlással végződik. A szó angol eredetü.” ${ }^{2}$

A következőkben megismerkedünk a lízing tranzakció szereplőivel és a szolgáltatás napjainkban alkalmazott jogi szabályaival.

\section{A lízing tranzakció részvevői:}

- Lízingbeadó: az a vállalkozás, amely tulajdonosa annak a lízingtárgynak, amit lízingbe ad.

- Lízingbevevő: az a vállalkozás, amely lízingeli, használja a lízingtárgyat, amelynek fejében lízingdíjat fizet.

- Eladó (szállító): az a kereskedő, aki forgalmazza a lízingbevevő által lízingelni kívánt lízingtárgyat.

A lízing tehát egy finanszírozási forma, amely esetében a lízingbeadó, más néven finanszírozó, a lízingbevevő által megnevezett tárgyat határozott időre a lízingbevevő használatába adja. A lízingbevevő a lízingszerződésben előre rögzített lízingdíjak megfizetésére vállal kötelezettséget. A lízingszerződés elsődleges fedezete maga a lízing tárgya, amelynek tulajdonjoga csak a finanszírozási futamidő végén, a teljes lízingdíj, valamint ún. maradványérték megfizetését követően száll át a lízingbevevőre. ${ }^{3}$

A finanszírozás teljes futamideje alatt a lízingbeadó a finanszírozott lízingtárgy tulajdonosa. A lízingtárgy fedezetet jelent a lízingbeadó számára a lízing teljes futamideje alatt, lízingbevevő számára kitermeli a lízingköltségét.

\footnotetext{
1 https://www.competence-site.de/geschichte-des-leasing-abriss-einer-beeindruckendenentwicklung/; http://www.debrecenijogimuhely.hu/archivum/2_2009/a_lizing_torteneti_ fejlodesel

2 http://lizing.szojelentese.com/

3 http://www.leasingmarket.hu/hu/fogalomtar/
} 
A lízing szolgáltatás a lízingbeadó és a lízingbevevő közötti megállapodás, amelynek keretében a lízingbeadó egy adott összeg megfizetése vagy fizetések sorozata ellenében átadja a lízingbevevőnek azt a jogot, hogy egy adott eszközt a szerződésben meghatározott ideig használhasson. A pénzügyi lízing egy olyan lízing, amely lényegileg az eszköz tulajdonlásával járó összes kockázatot és hasznot átadja. A tulajdonjog végül vagy átadásra kerül vagy nem (Pataki - Gyurcsik, 2017).

A lízing definiálása a hitelintézetekről és pénzügyi vállalkozásokról szóló 2013. évi CCXXXVII. törvény (a továbbiakban Hpt.) alapján következőképpen foglalható össze.

A Hpt. lényegében a szakirodalom által ismert lízing formák közül egy típusra, a pénzügyi lízingre fókuszál. A definíciót a törvény 6 . $\$(1)$ bekezdés 89. pontja tartalmazza, ennek értelmében pénzügyi lízing az a tevékenység, amelynek során a lízingbeadó a tulajdonában lévő ingatlant vagy ingó dolgot, illetve vagyoni értékű jogot a lízingbevevő határozott idejü használatába adja oly módon, hogy a használatba adással a lízingbevevő:

- viseli a kárveszély átszállásából származó kockázatot,

- a hasznok szedésére jogosulttá válik,

- viseli a közvetlen terheket (ideértve a fenntartási és amortizációs költségeket is),

- jogosultságot szerez arra, hogy a szerződésben kikötött időtartam lejártával a lízingdíj teljes tőketörlesztő és kamattörlesztő részének, valamint maradványérték megfizetésével a dolgon ő vagy az általa megjelölt személy tulajdonjogot szerezzen. Ha a lízingbevevő nem él e jogával, a lízing tárgya visszakerül a lízingbeadó birtokába.

- A felek a szerződésben kötik ki a lízingdíj tőkerészét - amely a lízingbe adott vagyontárgy, vagyoni értékü jog szerződés szerinti árával azonos -, valamint kamatrészét és a törlesztésének ütemezését. (Hpt.)

A lízingbeadók és a lízingbevevők számára további iránymutatást a 2013. évi V. számú törvény a Polgári törvénykönyv (Ptk.) LIX. fejezet 6:409. \$ ide vonatkozó szabályai adnak, ennek alapján elsőként a pénzügyi lízingszerződés tartalmát tekintjük át. 


\subsubsection{A pénzügyi lízingszerződés}

Pénzügyi lízingszerződés alapján a lízingbeadó a tulajdonában álló lízingtárgyat, amely lehet dolog vagy jog, határozott időre használatba adja a lízingbevevő részére. A lízingbevevő a lízingtárgy átvételére és lízingdíj fizetésére köteles. A törvény azt a határozott ideig tartó használatot minősíti pénzügyi lízingnek, amely esetén a lízing futamideje eléri vagy meghaladja a lízingtárgy hasznos élettartamát; illetve a futamidő nem éri el a gazdasági élettartamot, de a lízingbevevő a lízingtárgy szerződéskori piaci értékénél jelentősen alacsonyabb áron (maradványértéken) megszerzi vagy megszerezheti a lízingtárgy tulajdonjogát.

A definíció alapján felmerülhet a kérdés mit tekintünk hasznos élettartamnak? „Az immateriális javak, a tárgyi eszközök hasznos élettartama az az időtartam, amely alatt a gazdálkodó az adott eszközt várhatóan használni fogja. Az eszköz maradványértékkel csökkentett bekerülési értékét értékcsökkenési leírásként ezen időszak alatt számolják el.” (Aktuális kérdések, KPMG, 2014)

A lízingekre vonatkozó IAS17 nemzetközi számviteli standard definiálja mind a hasznos élettartamot, mind pedig a gazdasági élettartamot. Hasznos élettartam alatt a magyar számviteli törvény is azt érti, amíg az eszközt a gazdálkodó várhatóan használni fogja, az eszközben megtestesülő gazdasági hasznokat a gazdálkodó felhasználja. A gazdasági élettartam ennél hosszabb, azt mutatja, hogy maga az eszköz gazdaságilag meddig használható. ${ }^{4}$

A definíciók értelmezéséhez nézzünk egy egyszerü példát. Egy fuvarozással foglalkozó vállalkozás vásárol egy teherautót, mellyel külföldi fuvarozást fog lebonyolítani. A tulajdonos úgy gondolja, hogy biztosággal külföldi fuvarokat 1 millió kilométerig tud vállalni. Vagyis 1 millió kilométer megtétele után még nem kell a teherautót a MÉH telepre vinni, de azt a célt, amit eredetileg szántak neki, azt már nem tudja teljesíteni. Tehát a hasznos élettartam jelen esetben az az idő, ami alatt a teherautó eléri az 1 millió megtett kilométert.

A lízingbeadó esetén a futamidő alatt fizetendő lízingdíjak összege eléri a lízingtárgy piaci értékét, függetlenül attól, hogy a futamidő hogyan viszonyul a lízingtárgy gazdasági élettartamához, illetve, hogy történik-e a futamidő végén tulajdonszerzés.

4 https://lizing.blog.hu/2016/02/01/a_penzugyi_lizing_es_az_operativ_lizing_elhatarolasa_az_ uj_ptk_alapjan 


\section{Mit tekintünk gazdasági élettartamnak?}

A gazdasági élettartam vagy az az időszak, amely alatt egy eszköz egy vagy több használó számára várhatóan gazdaságilag használható; vagy azoknak a termelési vagy hasonló teljesítményegységeknek a száma, amelyek az eszköz révén egy vagy több használó által várhatóan kinyerhetők. Vagyis az előző példát folytatva, a vállalkozás 1 millió kilométer után nem használja a teherautót külföldi fuvarba, de belföldön rövidebb távolságokon még használható, azonban ezen használat során már nem termel annyi jövedelmet, mint az eredeti célja szerint, de azért még működik. A hasznos életartam rövidebb, mint a gazdasági élettartam. A lízingelés során a futamidő hosszát maximum a hasznos élettartamig határozzák meg.

\section{A lízing biztosítéka}

Ha a lízingtárgy ingatlan, a lízingbeadó köteles a lízingbeadás tényét és a lízingbevevő személyét a tulajdonjog bejegyzésével egyidejüleg az ingatlan- nyilvántartásba bejegyeztetni. Ha a lízingszerződés megkötésekor a dolog a lízingbeadó tulajdonában van, a bejegyzésre a birtokátruházásig kell, hogy sor kerüljön. Ha a lízingtárgy ingó dolog vagy jog, a lízingbeadó köteles a lízingbeadás tényét és a lízingbevevő személyét a hitelbiztosítéki nyilvántartásba bejegyezni. Ha az ingó dolog tulajdonjogát vagy a jog fennállását közhiteles nyilvántartás tanúsítja, és jogszabály a dolog vagy jog elzálogosítását a nyilvántartásba való bejegyzéshez köti, a lízingbeadó köteles a lízingbeadás tényét és a lízingbevevő személyét a megfelelő lajstromba bejegyeztetni.

Maradványérték definiálása az IAS 17 Lízingek c. Nemzetközi Számviteli Standard szerint: a maradványérték az a becsült összeg, amelyet a gazdálkodó egység jelenleg kapna az eszköz elidegenítésekor, csökkentve az elidegenítés becsült költségeivel, ha az eszköz életkora és állapota olyan lenne, mint ami annak hasznos élettartama végén várható.

\section{A lízingbeadó/lízingbevevő kötelezettségei}

A lízingbeadó szavatol azért, hogy harmadik személynek nincs a lízingtárgyon olyan joga, amely a lízingbevevőt a használatban korlátozza vagy a lízingtárgy használatát megakadályozza. Erre a kötelezettségre a jogszavatosság szabályait azzal az eltéréssel kell alkalmazni, hogy a lízingbevevő elállás helyett a szerződést felmondhatja. A lízingtárgy hibája miatt a lízingbeadót kellékszavatosság 
akkor terheli, ha közremüködött a lízingtárgy kiválasztásában, vagy a lízingtárgy megszerzésére irányuló szerződésből fakadó szavatossági jogairól a lízingbevevő hozzájárulása nélkül lemondott. Ebben az esetben a kellékszavatosság szabályait azzal az eltéréssel kell alkalmazni, hogy a lízingbevevőt az elállás helyett a felmondás joga illeti meg és a lízingbevevő a lízingtárgy kicserélését nem követelheti. A lízingbevevő köteles értesíteni a lízingbeadót, ha a kellékszavatosság kötelezettje a kijavításra vagy kicserélésre vonatkozó kötelezettségnek nem tesz eleget, vagy ha a hiba miatt árleszállításnak vagy elállásnak van helye.

A lízingbevevő a szerződés megkötésétől, dolog esetén a birtokátruházástól szedi a lízingtárgy hasznait, viseli a lízingtárggyal járó terheket, költségeket és azt a kárt, amelynek megtérítésére senkit nem lehet kötelezni. A lízingtárgy használatára és átruházására a bérleti szerződés szabályait kell alkalmazni. A lízingbevevő a lízingtárgy használatának átengedésére a lízingbeadó hozzájárulásával jogosult. Ha a lízingbevevő a lízingtárgyat a lízingbeadó engedélyével más használatába adta, a használó magatartásáért úgy felel, mintha a lízingtárgyat maga használta volna. Ha a lízingbevevő a lízingtárgyat a lízingbeadó engedélye nélkül engedi át másnak használatra, felelős azért a kárért is, amely e nélkül nem következett volna be. Ha a lízingbevevő jogosult a lízingbe vett dolog tulajdonjogának vagy jognak a megszerzésére, e jogát a lízingbeadó hozzájárulása nélkül jogosult harmadik személyre átruházni.

\section{Lízingszerződés felmondása}

A lízingbevevő a díjat a szerződésben meghatározott időszakonként elöre köteles megfizetni. Arra az időre, amely alatt a lízingbevevő a lízingtárgyat a saját érdekkörén kívül felmerült okból nem használhatja, lízingdíj nem jár. A lízingbeadó jogosult a szerződést felmondani, ha a lízingbevevő:

- a fizetőképességére vonatkozó vizsgálatot akadályozza;

- vagyoni helyzetének lényeges romlása vagy a fedezet elvonására irányuló magatartása veszélyezteti kötelezettségének a teljesítését;

- a lízingbeadó felhívása ellenére folytatja a nem rendeltetésszerü vagy a szerződésnek egyébként nem megfelelő használatot;

- szavatossági jogainak érvényesítésére irányuló kötelezettségének felhívás ellenére nem tesz eleget;

- az öt terhelő lízingdíj, költség vagy teher megfizetését elmulasztotta, és a 
lízingbeadó a lízingbevevőt megfelelő határidő kitűzésével és a következményekre való figyelmeztetéssel a fizetésre felszólította, és a lízingbevevő e határidő elteltéig sem fizetett.

Ha a lízingszerződést a lízingbeadó felmondja, a lízingbeadó köteles a lízingbevevővel a zálogjog érvényesítésére vonatkozó szabályok szerint elszámolni. A lízingbevevő jogosult a szerződést felmondani, ha a lízingbeadó szavatossági elállási jogának érvényesítésére vonatkozó kötelezettségének felhívás ellenére nem tesz eleget. (Ptk.)

A lízing jogszabályi hátterének áttekintését követően áttekintésre kerülnek az egyes lízing típusok.

\subsubsection{Lízing fajtái}

A pénzügyi lízing esetén egyik szereplő - nevezetesen a lízingbeadó - pénzügyi intézményként működik. A lízingügylet másik szereplője a lízingbevevő, akinek vállalkozása működtetéséhez, bővítéséhez nagy értékű eszközre van szüksége. A lízingbevevő vállalkozás kihasználva a pénzügyi lízing adta lehetőségeket nem költ jelentős összeget a gép beszerzésére, ehelyett megkeres egy lízingeléssel foglalkozó pénzügyi intézményt, aki megveszi számára a szükséges gépet, berendezést. A lízingbeadó által megvásárolt eszközt a lízingbevevő használatba veszi a megkötött lízingszerződés alapján. A lízinget lényegében áruban nyújtott hitelként is tudjuk definiálni. A lízingszerződés tárgyát képező gép képezi az ügylet fedezetét, tehát külön fedezet nem kerül elkülönítésre, lekötésre (Gyulai, 2013).

Egy lízing akkor minősül pénzügyi lízingnek, ha a lízingbeadó az összes, a tulajdonlással járó kockázatot és hasznot átadja a lízingbevevőnek. Egy lízing akkor minősül operatív lízingnek, ha lízingbeadó nem adja át lényegileg az összes, a tulajdonlással járó kockázatot és hasznot a lízingbevevőnek.

\section{A pénzügyi lízing altípusai:}

1. Nyílt végü pénzügyi lízing esetén a lízingbevevő választhat a szerződés végén, hogy egyrészt a lízingszerződés lejártát követően megvásárolja az általa használt eszközt, vagy nem él a további használati lehetőséggel. Természetesen akár úgy is dönthet a lízingbevevő, hogy a meglévő lízingszerződést meghosszabbítják. 


\section{A nyíltvégü pénzügyi lízing jellemző tulajdonságai:}

- A futamidő alatt a lízingtárgy tulajdonosa a lízingbeadó, lízingbevevő kizárólag a lízingtárgy használatára jogosult, lízingdíj fizetés ellenében.

- A lízingtárgyat a lízingbevevő veszi fel könyveibe, tartja nyilván és számolja el az amortizációt, illetve a lízingdíjak kamat részét költségként a mindenkori számviteli szabályoknak megfelelően.

- A havi lízingdíjak tőketörlesztő részét ÁFA terheli. A vételár ÁFA tartalmát a lízingbeadó visszaigényelheti/levonásba helyezheti a hatályos számviteli szabályoknak megfelelően. Személygépjármű finanszírozás esetén 2012. 01. 01-től a lízingdíjakra eső ÁFA értéke a lízingbevevő által visszaigényelhető/levonásba helyezhető.

- A lízingszerződés alapján a lízingbevevő megszerezheti a lízingtárgy tulajdonjogát a teljes tartozás és a maradványérték megfizetésével. A maradványértéket úgy kell meghatározni, hogy a lízingtárgy futamidő végi valós piaci értéket tükrözze, de minimálisan reális opciót jelentsen a lízingbevevő számára.

2. Zárt végü pénzügyi lízing: a lízingszerződésben arról határoznak, hogy a lízingelt eszköz a lízingbevevő tulajdonát képezi a lízingszerződés lejártával.

\section{A zártvégü pénzügyi lízing jellemzö tulajdonságai:}

- A konstrukció célja a lízingtárgy tulajdonjogának lízingbevevő által történő megszerzése a futamidő végén.

- A futamidő alatt a lízingtárgy tulajdonosa a Lízingbeadó, az ügyfél kizárólag a lízingtárgy használatára jogosult, lízingdíj fizetése ellenében.

- A lízingbevevő a futamidő végén a teljes lízingtartozás (összes lízingdíj) megfizetése után a lízingtárgyon automatikusan tulajdonjogot szerez.

- A lízingtárgyat a lízingbevevő veszi fel könyveibe, tartja nyilván és számolja el az amortizációt, illetve a lízingdíjak kamat részét költségként a mindenkori számviteli törvényeknek megfelelően.

- A lízingbevevőnek teljes ÁFA fizetési kötelezettsége van a futamidő elején, amely a lízingtárgy átadás-átvételekor esedékes és később visszaigényelhetö/levonásba helyezhető a mindenkori számviteli törvényeknek megfelelően. Az ÁFA összege a lízingtárgy teljes nettó értékére kerül felszámításra.

- A havi lízingdíjakat további ÁFA nem terheli. 


\section{Az operatív lízing sajátosságai}

Az operatív lízinget speciális bérletként szoktuk emlegetni, ugyanis a lízingbeadó nem tartósan bocsájtja az eszközt a lízingbevevő használatába, rendszerint ez átmeneti időre szolgál. A bérlettel ellentétben itt lehetőséget kap a lízingbevevő a vásárlásra, amennyiben a lízingszerződés lejár. A pénzügyi lízinghez képest nagyobb kockázatot hordoz magában a lízingbeadó szempontjából. A kockázat abból adódik, hogy a visszaadott lízing tárgyat milyen feltételekkel tudja újra lízingbe adni. A lízing tárgy kihelyezési kockázata miatt magasabb kockázati felárral dolgoznak a lízingbeadók, mint a pénzügyi lízing esetén.

\section{Az operatív lízing (tartós bérlet) jellemzö tulajdonságai:}

- A lízingtárgy tulajdonosa a lízingbeadó, lízingbevevő kizárólag a lízingtárgy használatára jogosult a lízing futamidő alatt, lízingdíj fizetés ellenében.

- A lízingtárgyat a lízingbeadó tartja nyilván a könyveiben és számolja el az amortizációt.

- A vételár áfa tartalmát a lízingbeadó igényli vissza.

- A lízingbevevő a nettó bérleti díjat a mindenkori számviteli törvények szerint számolhatja el költségként.

- A havi lízingdíjakat áfa terheli.

- Lejáratkor a lízingbevevő a lízingtárgyat a lízingbeadó birtokába adja, a lízingtárgy a lízingbevevő tulajdonába a futamidő végén sem kerülhet.

- A lízingdíjak kalkulációja a lízingtárgy futamidő végi, reális piaci értéket tükröző maradványérték figyelembevételével készül, amely nem lehet nulla. lízingbeadónak nyitott pozíciója (maradványérték kockázata) csökkentése érdekében (vissza)vásárlási megállapodás megkötésére van szüksége jellemzően az eladóval (vagy bármely más független 3. féllel). 


\begin{tabular}{|c|c|c|}
\hline Szempontok & Pénzügyi lízing & Operatív lízing/Tartós bérlet \\
\hline A lízingbeadó oldaláról & $\begin{array}{l}\text { - A lízingbeadó célja a rendelkezésre álló } \\
\text { pénzeszköz kihelyezése. } \\
\text { - A lízingszolgáltatás a pénzügyi kihelyezéshez } \\
\text { kapcsolódó kiegészítő szolgáltatás. } \\
\text { - A tervezett jövedelem nagy részét } \\
\text { a kamatjövedelem képezi. }\end{array}$ & $\begin{array}{l}\text { - Komplex szolgáltatás, } \\
\text { üzemeltetési kockázatot is vállal. } \\
\text { - A jövedelem a lízingszolgáltatás } \\
\text { dija, nem a kamatjövedelem. }\end{array}$ \\
\hline $\begin{array}{l}\text { A lízingbevevő } \\
\text { oldaláról }\end{array}$ & $\begin{array}{l}\text { - A lízingbevevő számára forrásszerzést jelent, az új } \\
\text { eszköz beszerzését tervezi késleltetett fizetéssel. } \\
\text { - Tulajdonjog megszerzése az elsődleges cél. }\end{array}$ & $\begin{array}{l}\text { - Elsődlegesen használatra } \\
\text { tart igényt. } \\
\text { - A tulajdonjog megszerzése } \\
\text { nem elsődleges szempont. }\end{array}$ \\
\hline Résztvevők & $\begin{array}{l}\text { - Lízingbeadó } \\
\text { - Lízingbevevő } \\
\text { - Eladó }\end{array}$ & $\begin{array}{l}\text { - } \quad \text { Lízingbeadó } \\
\text { - Lízingbevevő } \\
\text { - Eladó }\end{array}$ \\
\hline $\begin{array}{l}\text { Lejárta elótti szerződés } \\
\text { felmondás }\end{array}$ & $\begin{array}{l}\text { - A lízingszerződés a lízingbevevő által akkor } \\
\text { mondható fel, ha a teljes lízingtartozás } \\
\text { kiegyenlítésre került. }\end{array}$ & $\begin{array}{l}\text { - A lízingügylet rendes } \\
\text { felmondással nem szüntethető } \\
\text { meg. }\end{array}$ \\
\hline Amortizációs & $\begin{array}{l}\text { - A lízingbevevő amortizálja amortizációs kulcsok } \\
\text { alapján. }\end{array}$ & $\begin{array}{l}\text { - A lízingbeadó könyveiben } \\
\text { szerepel és ő amortizálja. }\end{array}$ \\
\hline $\begin{array}{l}\text { Biztosítás és egyéb } \\
\text { költségek }\end{array}$ & - Lízingbevevőtt terhelik. & $\begin{array}{l}\text { - Lízingbeadót terhelik, de a } \\
\text { lízingdíjakba beépitésre kerül. }\end{array}$ \\
\hline
\end{tabular}

\section{1. táblázat: Pénzügyi és operatív lízing összehasonlítása}

Forrás: https://lizing.raiffeisen.hu/lizing/lizing-fogalma, letöltve 2019. 03. 12.

\section{Egyéb lízing fajták jellemzői}

A visszlízing elsősorban nehéz pénzügyi helyzetben, likviditási gondokkal küszködő vállalkozások átmeneti forráshoz jutásának egyik lehetősége lehet. A lízingtárgy tulajdonosa a müködéséhez nélkülözhetetlen ingatlant, gépet vagy berendezést nem adja el véglegesen, hanem keres egy „befektető" aki a lízingtárgyat megvásárolja, majd később lízingszerződés keretében a rossz anyagi helyzetbe került vállalkozásnak lízingbe adja. A sajátos ügylet során a lízingelt tárgy eredeti tulajdonosa forráshoz jut, melyből tudja rendezni tartozásait vagy azok egy részét, ugyanakkor a müködését biztosító eszközről, épületröl nem kell lemondania. A lízing szerződés lehetővé teszi, hogy amennyiben rendeződik a lízingbevevő vállalkozás anyagi helyzete, a lízingszerződés végén visszavásárolhatja eszközét. 
A szervizlízing keretében a lízingbeadó vállalja, hogy a lízingtárggyal kapcsolatos javítási, karbantartási műveleteket, szolgáltatásokat biztosítja a lízingbevevő részére. Ez a lízingszolgáltatás kapcsolódhat a pénzügyi lízinghez is vagy más lízingtípushoz.

Közvetlen lízing: a lízingbeadó megegyezik a lízing tárgy beszerzőjének személyével.

Közvetett lízing: A lízingelt tárgyat beszerző cég nem adja lízingbe az eszközt, a lízingbeadó egy erre szakosodott intézmény lesz. (Gál, 2013)

Az allízing keretében a lízingbevevő a lízingtárgyat a lízingbeadó beleegyezésével egy második lízingbevevőnek lízingbe adja. A „fơ” lízingelő általában anyagi lehetőségei miatt több eszközt tud egyszerre lízingelni, amit később alvállalkozóknak ad tovább szintén lízing formájában.

A határon átnyúló lízing esetén a lízingbeadó és a lízingbevevő két különböző országban található. ${ }^{5}$

A fel nem mondható lízing olyan lízing, amely csak akkor mondható fel, ha:

- valamilyen esetleges függő esemény bekövetkezik;

- a lízingbeadó hozzájárul;

- a lízingbevevő ugyanazzal a lízingbeadóval ugyanarra, vagy egy azzal egyenértékủ eszközre vonatkozóan új lízingmegállapodást köt; vagy

- a lízingbevevő megfizet egy olyan további összeget, amely alapján a lízing kezdetekor a lízing folytatása ésszerű mértékben biztosnak látszik.

\subsubsection{A lízing tárgya}

Jellemzően olyan eszközök melyeknek likvid másodlagos piacuk van, biztosítva ezáltal a lízingbeadót, hogy amennyiben a lízingbevevő nem tudja lízingdíját fizetni, így fedezetből, vagyis a lízingtárgy értékesítéséből kellő finanszírozási háttér legyen biztosítva. A lízing tárgyát a lízingbevevő a saját igényei, szükségletei, lehetőségei szerint választja ki, mérlegelve, hogy a pénzügyi lehetőségei milyen kereteket szabnak.

5 http://ecopedia.hu/lizing 
Jellemző lízingeszközök:

- személy és kishaszonjármü,

- tehergépjármü,

- mezőgazdasági gép,

- építöipari gép,

- IT-irodai gépek,

- egyéb gépek,

- lakás,

- ingatlan,

- hajó, vasút, repülő. ${ }^{6}$

A Magyar Lízingszövetség adatai szerint (lásd 2. ábra) a hazai ingatlan piac finanszírozásában a lízing nem bír nagy jelentőséggel, mindössze 3,5 milliárd forintra tehető az ebben a formában finanszírozott ügyletek értéke 2018-ban.

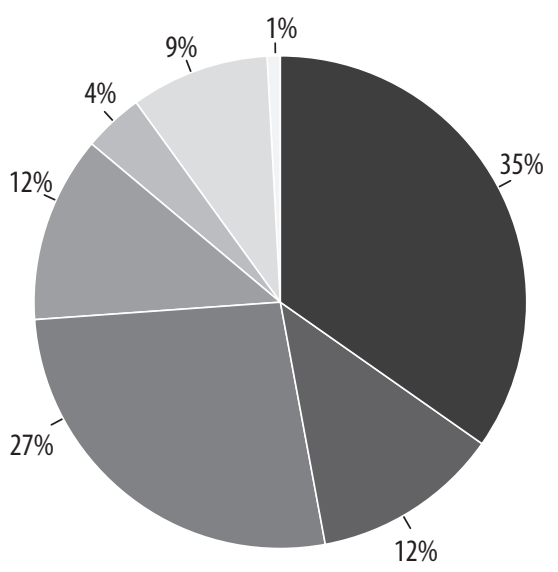
Ingatlan
IT, egyéb
Építőipar
Mezőgazdaság
Tehergépjármü
Flotta
Szgk. + kishaszon gk.

\section{2. ábra: A lízing piac szerkezete eszköz kategóriánként 2018-ban}

Forrás: A Magyar Lízingszövetség adatai alapján saját szerkesztés, adatok letöltése: http://lizingszovetseg.hu/hasznos/elemzesek, 2019. 03. 09.

6 http://lizingszovetseg.hu/hasznos/elemzesek 
A személygépkocsik és kisteherautók finanszírozása 2018-ban a kihelyezett finanszírozási összeg 35\%-ot, a tehergépjármüvek mintegy 27\%-os részarányt képviselnek. A finanszírozás nem csak az új, de használt gépjárművekre is vonatkozik.

2018-ban 136000 db új gépkocsit értékesítettek, a lízing keretében megvalósult ügyletek száma 39782 db volt, azaz közel 30\%-a az adásvételeknek lízing keretében került finanszírozásra. A céges vásárlások összege 127758 millió forint összeget tett ki, míg a magánszemélyek esetén ez 57869 millió forint. A magánszemélyek lízing iránti megnövekedett érdeklődését mutatja, hogy 2016 első negyedévében új autó finanszírozáshoz 4752 millió forint összegű finanszírozást vettek igénybe a lízingen keresztül, addig ez 2018. negyedik negyedévében 14317 millió forint volt (lásd 3. ábra).

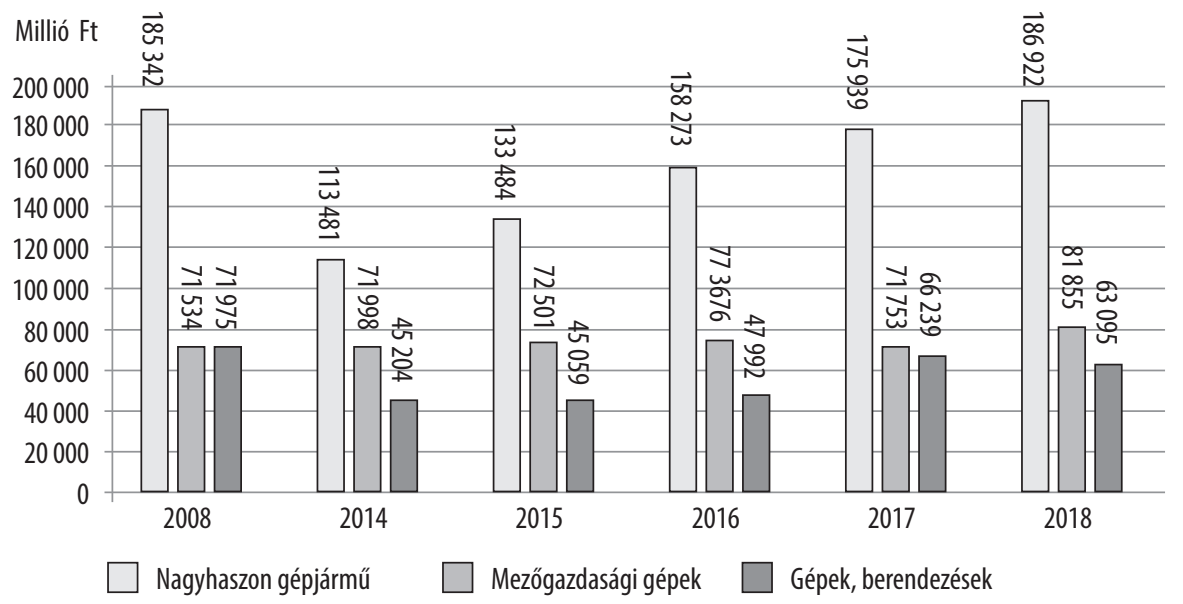

3. ábra: A lízing keretében kihelyezett eszközfinanszírozás értéke Forrás: A Magyar Lizingszövetség adatai alapján saját szerkesztés, adatok letöltése: http://lizingszovetseg.hu/hasznos/elemzesek, 2019. 03.09.

\subsubsection{A lízing ára}

A lízing költségeinek becsléséhez alkalmaznak egy úgynevezett lízingszorzó mutatót, ami megmutatja, hogy a teljes lízingdíj hányad része a beszerzési árnak. Minél kisebb az érték annál kedvezőbb lehet a lízingelés. A mutató nem kalkulál a pénz időértékével. 


\section{Lízingszorzó = Fizetendő teljes lízindíj / A lízingtárgy beszerzési ára}

A lízing árának nagyságát meghatározza a lízing futamideje, a lízingelt eszköz értéke, az önerő nagysága. Az önerő nagysága csökkenti a lízingbeadó kockázatát, az önerő meghatározása a lízingbeadó döntése alapján kerül meghatározásra, rendszerint a lízingbevevő fizetőképessége alapján. Zárt végű pénzügyi lízing esetén a teljes általános forgalmi adót meg kell fizetnie a lízingbevevőnek. A lízing finanszírozható forint alapú és deviza alapú forrásokból. A források kamatlába lehet fix vagy változó. Amennyiben forint alapú és változó kamatozású a lízing ebben az esetben a kamat legtöbb esetben a Budapesti Bankközi Forint Hitelkamatlábhoz (BUBOR) képest változik. Deviza alapú hitelek esetén a LIBOR (London Inter-bank Offered Rate), vagy a CIRR (Commercial Interest Reference Rate) gyakran alkalmazott irányadó kamatláb. A CIRR referencia kamat 1 éves LIBOR kamatlábon alapul és minden év elején az Európai Bizottság közzéteszi az adott évre vonatkozóan. Ezt követően a referencia kamat mértéke csak akkor változik, ha a megelőző három hónap alapján számított átlagos kamatláb több mint 15\%-kal eltér az érvényben lévő kamatlábtól. A kamat csak EUR és más uniós devizákra kerülhet megállapításra, USD vagy más harmadik országbeli devizára vonatkozóan nem. ${ }^{7}$

A lízing kamatára állami támogatás is igényelhető bizonyos esetekben, ezzel jelentősen kedvezőbbé válhatnak a finanszírozás keretei. A kamattámogatást a finanszírozó intézmény által kiállított igazolás esetén a Nemzeti Adó és Vámhivatalnál lehet visszaigényelni.

A lízingdíj: a lízingbevevő által rendszeresen (havonta, negyedévente, szezonálisan) fizetett összeg, használati díj, amely tőkerészből és kamatrészből áll. Az operatív lízing esetén nem különül el a kamat és a tőkerész a lízingdíjon belül. A lízindíj megfizetése történhet egyenlő részletekben, annuitás formájában, vagy egyenlő tőketörlesztéssel. Ez jellemzően változó kamatozású ügyleteknél fordul elő. Mezőgazdasági vállalkozások a szezonális árbevételre tekintettel egyedi lízingdíj megfizetést is kérhetnek.

A lízingből történő finanszírozás költségei tovább csökkenthetők, amenynyiben a Magyar Nemzeti Bank Növekedési Hitelprogramja keretében hirdetett NHP Fix konstrukciót válasszák az ügyfelek. Az MNB 2019. januártól indította

7 https://exim.hu/hasznos/arfolyamok-es-kamatlabak 
ezt az új konstrukciót, melyet mikro-, kis- vagy középvállalkozások igényelhetnek többek között lízingfinanszírozás céljából is. Maximum 2,5\%-os kamattal kiszámítható, a futamidő alatt végig fix kamatozású finanszírozás valósulhat meg forint alapú finanszírozás keretében, árfolyamkockázat nélkül.

\section{A maradványérték}

- Operatív lízing esetén a lízingtárgy becsült piaci értéke a futamidő végén. A maradványérték figyelembevételével kalkulálják ki a lízingdíj összegét.

- A nyílt végü pénzügyi lízing esetén a futamidő végi díj, amelynek megfizetésével lízingbevevő tulajdonjogot szerezhet az általa használt lízing tárgy felett.

- A zárt végü pénzügyi lízing esetén általában nincsen, de bizonyos esetekben a lízingbevevő kérésére az utolsó lízingdíj egy magasabb összegben kerül megállapításra, ami így csökkenti a futamidő alatti lízingdíjakat. A lízingbeadó speciális feltételeket is elöírhat a lízingbevevő részére, melyek garanciát nyújthatnak a folyamatos fizetésre. Ilyen szerződéses kötelezettségvállalás lehet a devizaalapú lízing esetén, hogy a lízingbevevő legalább akkora árbevételre tesz szert devizában, mint amekkora a fizetési/ törlesztési kötelezettsége.

\subsubsection{A lízing és a hitel, mint eszközfinanszírozás jellemzői}

- A lízing nem igényel külön fedezetet, a hitel esetében elkülönült fedezetröl, biztosítékról kell gondoskodni.

- A hitel összegéből, pl. egy szabad felhasználású jelzáloghitelből, bármit vásárolhatunk, nincs meghatározva a vásárolt eszköz. A lízing esetén egy konkrét, előre meghatározott eszközbeszerzésre kerül sor.

- A hitelből vásárolt eszköz tulajdonosa és használója nem válik el, pl. gépjárművásárlás esetén a törzskönyvben a tulajdonos az, aki használja az eszközt. A lízing esetén a lízing tulajdonosa és az eszköz használója eltér egymástól, a törzskönyv példájánál maradva, a tulajdonosként a finanszírozó kerül feltüntetésre. A lízingbevevő jogot formálhat az eszköz megvásárlására.

- A lízing nem igényel egy összegű, jelentős pénzlekötést a lízingbevevő részéről, a hitelből történő vásárlásnál a teljes vételárat ki kell fizetni, igaz nem feltétlenül kell hitelből, lehet saját forrásból is finanszírozni, de ekkor is jelentős egy összegü forrást kell a vásárlás pillanatában biztosítani. 
- A lízing típusára tekintettel sajátos adózási és számviteli szabályokat lehet érvényesíteni. A hitel esetén a kamatokat és felmerülő banki költségeket lehet költségként elszámolni.

A lízing futamideje: a lízingtárgy hasznos élettartamától és fedezeti értékének alakulásától függően változhat, de jellemzően minimum 1 év, mezőgazdasági eszközöknél 72 hónap is lehetséges. A finanszírozott összeg nagyságára is lehetnek minimum, illetve maximum elöírások. ${ }^{8}$ (Hpt., Ptk.)

\section{Lízing példa}

Lizing nélküli eset:

Egy kis- és középvállalkozási körbe tartozó cég bruttó, azaz áfával növelt értéken 15000000 forint összegért szeretne kisteherautót vásárolni. Az anyagi lehetősége lehetővé teszi a készpénzből történő teljes önerős vásárlást, azonban szeretné megtudni, hogy milyen kondíciók mellett tudja használatba venni gépjárművét, ha zártvégü pénzügyi lízinget választana. A vállalkozás a $27 \%$-os áfát visszaigényelheti. Az ügylet áfa tartalma 3188976 forint. Tehát ha teljesen önerös finanszírozást választ, akkor lényegében az áfa összegén kívül nem tud további elszámolást eszközölni.

Zárt végü pénzügyi lízing esetén:

Kiindulási adatként a vállalkozás 48 hónapos futamidőre, $0 \%$ önerő mellett, 2,5\% ügyleti kamatra szeretné lízingelni a 15000000 forintba kerülő kisteherautót. A kamattal növelt bruttó ráfordítás összege 15389052 forint. Az áfa összege 3188976 forint, ami szintén visszaigényelhető. Adókedvezmény értéke a 1996. évi LXXXI. törvény a társasági adóról és osztalékadóról alapján 100\%-ban igénybe vehető, ennek értéke 389052 forint. Lényegében az a vállalkozás, amelynek keletkezik társasági adója, az ingyen használhatja a bank pénzét, hiszen társasági adóból leírható a kamat összege, ugyanakkor nem kell a saját forrást lekötni, más célra is fordítható. ${ }^{9}$

8 http://lizingkalkulator.hu/2017/06/22/gepjarmu-hitel-lizing-esetleg-taros-berlet-1-resz/

9 A http://nyiltlizing.hu/alapján saját számítás. 
2019. január elsejétől változott a nyílt végü pénzügyi lízing és az operatív lízing áfa szabályozása: az üzleti és magánhasználatban egyaránt álló lízingelt autók lízingdíja áfa tartalma a következőképpen vonható le:

A lízingbevevő választhat a részletes kimutatással alátámasztott tényleges üzleti használat arányában történő levonás vagy az 50\%-os átalány használata között. Ehhez nem szükséges útnyilvántartást vezetni. A választás gépjárművenként lehetséges és a futamidő alatt változhat. A korábban kötött szerződésekre is vonatkozik, de csak a 2019-től járó díjakra. ${ }^{10}$

\subsection{Faktorálás}

\subsubsection{A faktorálás fogalma, jogi szabályozása}

A faktorálás, azaz követelés megvásárlás, mint szolgáltatás az USA-ban alakult ki az 1950-es évek elején, hazánkban az 1970-es években jelent meg az exporttal foglalkozó vállalkozások életében. A kétszintű bankrendszer kialakulásától jelentős fejlődésnek és elterjedésnek indult a szolgáltatás. Már az Unidroit megállapodás is rögzíti 1988-ban, hogy milyen feladatai vannak a faktornak, többek között a hitelezés, számlavezetés, követeléskezelés (Unidroit Convention On International Factoring).

A faktorálás lényege, hogy az eladó a számlában foglalt követelését az esedékesség előtt megkapja. Amennyiben a vevő a követelés eladását követően szerez tudomást a faktorálás tényéről, akkor csendes faktorálásról beszélünk. A faktorálás segítheti az eladót likviditási problémáinak rendezésében. A faktorálás mögött külön bankári biztosíték nincs, ezért ezt nyitva szállításnak is nevezzük. A követelés eladása rendszerint nem csak egyetlen ügyletre vonatkozik, ezért az eladó és a követelés megvásárló között egy keretmegállapodás jön létre, amelynek keretében a követelés értékesítésére sor kerül, ezáltal az eladó likviditása folyamatosan biztosítható.

„Faktorálás = faktoring, követelésvásárlás - mindegyik szó ugyanazt a fogalmat takarja: egy vállalkozás a még ki nem egyenlített, de a jövőben befolyó számlakövetelését eladja egy pénzügyi szolgáltatónak, aki ezt az összeget előre kifizeti neki"11

10 http://lizingszovetseg.hu/hasznos/elemzesek

11 https://cegfinanszirozas.hu/faktoralas 
A faktorálásra - hasonlóan a lízinghez - a jogszabályi keretet a Polgári Törvénykönyvről szóló 2013. évi V. törvényben találjuk meg. A Polgári Törvénykönyv alapvetően a visszkeresetes faktoringot nevesíti, vagyis:

„Faktoring szerződés alapján a faktor meghatározott pénzösszeg fizetésére, az adós harmadik személlyel szembeni követelésének a faktorra engedményezésére köteles; ha az engedményezett követelés esedékességekor a kötelezett nem teljesít, az adós a kapott összeg visszafizetésére és kamat fizetésére, a faktor a követelés visszaengedményezésére köteles."

A faktor jogosult a szerződést felmondani, ha

- Az adós a fizetőképességére és az átruházott követelés jogi helyzetére vonatkozó vizsgálatot akadályozza.

- Az adós vagyoni helyzetének lényeges romlása vagy a fedezet elvonására irányuló magatartása veszélyezteti megtérítési kötelezettségének a teljesítését.

- Az átruházott követelés kötelezettjének vagyoni helyzete oly mértékben romlik, hogy az veszélyezteti a követelés teljesítését.

- A szerződés felmondása esetén az adós köteles a faktor által fizetett összeget és kamatot megfizetni a faktornak, a faktor pedig köteles a követelést visszaengedményezni az adósra.

- Több követelés átruházása esetén a faktor jogosult egyes követelések tekintetében felmondani a szerződést.

- A szerződésre egyebekben a kölcsön kifizetésének megtagadására, a kölcsönösszeg igénybevételének elmaradására és a kölcsön rendelkezésre tartására vonatkozó szabályokat kell alkalmazni.

- A felek, vagyis az eladó és vevő nem vitatják a számlakövetelés tartalmát.

\subsubsection{Milyen jellemzői vannak a faktorálásnak?}

- Az eladó rövid időn belül hozzájut az általa követelt összeg egy részéhez, ez jellemzően a követelés $80 \%$-a, a maradék összeggel a követelés teljesülése esetén számol el a faktorcég és az eladó.

- Az eladásra kerülő követelés futamideje éven belüli, rövid lejáratú.

- Az eladó faktordíjat fizet a faktor számára, ez magában foglalja az egyszeri összegben meghatározott faktordíjat. Ez független attól, hogy sikerül-e a követelés értékét határidőben megkapni vagy sem, illetve hogy mekkora a 
fizetési határidőig hátralévő napokra számított pénz használati díja, vagyis a kamat összege. A faktordíjból kell a faktornak megoldani a követelés nyilvántartásával, kezelésével, beszedésével kapcsolatos kiadásokat.

- Az eladónak nem kell foglalkoznia a követelés nyilvántartásával, annak kezelésével, a követelés eladásával, ez a feladat átkerül a követelés megvásárlójához, azaz a faktorcéghez.

- Az eladónak nem kell kivárnia amíg a vevő 60, esetenként a 90 napos fizetési határidő leteltével teljesíti a fizetési kötelezettségét. Természetesen előfordulhat, hogy a vevő még a határidő lejáratát követően sem fizet, ez a probléma azonban az eladót már nem érinti.

- A követelést értékesítő vállalkozás forgóeszközgazdálkodása/pénzgazdálkodása javul, mert ahelyett, hogy pénzére vár, azt megkapva termelésre/szolgáltatásnyújtásra tudja fordítani.

- A faktor számára a vevő fizetőképessége a lényeg, mivel ő vállalja át a nemfizetés kockázatát az eladótól.

- Az eladó úgy jut forráshoz, hogy külön biztosítékról nem kell gondoskodnia.

- Azok a kis- és közepes vállalkozások is gondolkodhatnak ebben a finanszírozási módban, amelyek még működésük kezdeti fázisában vannak, hiszen a faktorcég nem az eladó fizetőképességére és készségére kíváncsi, hanem a vevőére.

\subsubsection{A faktoring fajtái}

a) Visszkeresettel biztosított faktoring/visszterhes faktoring:

Amennyiben a faktor nem tudja a vevőtől a követelést beszedni, úgy az eladó köteles azt visszavásárolni. Lényegében a faktor a kockázatokat csak részben vállalja. Ezt a típust akkor alkalmazzák a faktorcégek, amikor az eladó pénzügyi helyzete nem teszi lehetővé banki hitel felvételét, ugyanakkor azok a vevők, akiknek értékesít, megbízhatóak, ezáltal a velük szemben keletkezett követelés nagy valószínüséggel megtérül. A faktoring cég türelmi időt hagy a vevőnek a fizetésre, mely alatt többször felszólítja. Amennyiben nem tesz továbbra sem eleget a fizetésnek, úgy az eladó köteles visszavenni a követelést. 


\section{b) Visszkereset nélküli faktorálás:}

A faktorcég végérvényesen vállalja a követeléssel kapcsolatos nyilvántartást és az ebből eredő következményeket. A faktorcég amennyiben nem kapja meg a követelés összegét, úgy ezt a kockázatot és veszteséget teljes egészében neki kell viselnie. A követelés eladója nem vásárolja vissza a korábban eladott követelést, csak azért, hogy a faktorcég vesztesége csökkenjen. A faktorcéget az esetleges veszteségtől külön megkötött biztosítás óvhatja.

c) Belföldi faktoring:

Az ügyletek szereplői azonos országon belül bonyolítják le az ügyleteket.

d) Nemzetközi faktoring:

Külföldi vevőkkel szembeni követelés és annak finanszírozása.

e) Építőipari faktoring:

Kisebb tőkével rendelkező építőipari vállalkozások juthatnak rövid határidővel forráshoz úgy, hogy ügyfeleikkel szembeni követelésüket értékesítik követelés megvásárló cégeknek. Ezáltal forgótőkéjük növekszik, és újabb beruházásba kezdhetnek.

f) EU-s támogatások faktoringja:

Beruházások vagy egyéb pályázatok esetén az elnyert összeg napokon belül rendelkezésre áll a faktorcég közremüködésével, általában 80\%-os finanszírozással lehet kalkulálni. 2019-es adatok szerint egy 10000000 forint támogatási összeg esetén faktoring keretében 30 napos határidővel 8000000 forint kerül kifizetésre, 83333 forint faktoring költség mellett.

g) Önkormányzattal, egyéb állami szervezettel szembeni követelés faktoringja:

10000000 forint összegü adóvisszatérítés faktoring keretében történő finanszírozása esetén a követelés eladója 8000000 forint összeghez jut, 60 napos fizetési határidő esetén ez 166667 forint faktoring költség mellett tud megvalósulni.

h) Kereskedelmi, termelöi faktoring:

Multinacionális kereskedelmi cégek irányába történő értékesítésből eredő követelések megfinanszírozása faktoring keretében. ${ }^{12}$

12 https://cityfaktor.hu/szolgaltatas/kereskedelmi-es-termeloi-faktoring 


\section{A faktorálási tranzakció folyamata}

- A visszkeresetes faktoring esetén az eladó hitelképességének vizsgálata. A finanszírozási keretösszeg megállapítása.

- Vevők kiértesítése az eladó által az engedményezés tényéröl, ennek hiányában csendes faktorálásról beszélünk.

- A vevő nyilatkozik a faktorálás elfogadásáról.

- Számlák benyújtása a faktor részére.

- Számlák vételárának megelőlegezése és átutalása az eladó (szállító) számlájára.

- Amennyiben sikeres volt az ügylet, vagyis a vevő fizetett a faktornak úgy a vevői számlából fennmaradt vételár-hátralék elszámolására kerül sor.

- A vevő nemfizetése esetén a biztosító kárfizetésének érvényesítése. Természetesen itt is kiköthetö az önrész, minél nagyobb ez az összeg annál kisebb lesz a biztosítói kártérítés a faktor részére, ugyanakkor a biztosítási szolgáltatás olcsóbb lesz. ${ }^{13}$

\section{Forfetírozás jellemzői}

A forfetírozás exportból származó, bank által garantált követelések visszkereset nélküli megvásárlását jelenti, amely a halasztott fizetésü ügyletet azonnali fizetésűvé változtatja, így mentesíti az exportőrt a követelésből eredő

- kereskedelmi,

- ország (azaz politikai és transzfer-),

- árfolyam-, valamint

- beszedési kockázatoktól.

Az exportköveteléseknek feltétel nélküli, visszavonhatatlan bankári instrumentumok által megtestesített vagy garantált követelésnek kell lenniük (pl.: halasztott fizetésủ akkreditív, bankgarancia). Az adott bank elfogadhatósága esetén további biztosítékokra nincs szükség. Az ügylet gyorsan megköthető és igen egyszerü dokumentációt igényel, így nincsenek jelentős adminisztrációs és jogi költségek. ${ }^{14}$

13 http://www.globalfaktor.hu/?contentid=2

14 https://exim.hu/component/k2/item/41-forfetirozas-rovid-lejaratu-biztositott-

kovetelesvasarlas? Itemid $=230$ 
- A faktorcég által megvásárolt követelés futamideje közép vagy hosszúlejáratú;

- a forfetírozás tárgya számla vagy váltókövetelés;

- nagy összegü követelésekre vonatkozik;

- kizárt a visszkereseti jog, tehát a faktorcég a teljes követeléskockázatot átvállalja. ${ }^{15}$

\subsubsection{Faktorpiaci kitekintő}

2018-ban a Magyar Faktor Szövetség által közölt statisztika alapján az első tíz faktorcég listája található meg az alábbi táblázatban. A tíz vállalkozás adja a piac 99\%-át, az első öt tag részesedése $91 \%$. A faktorált ügyletek együttes értéke 2 220,61 milliárd forint volt.

\begin{tabular}{|c|l|}
\hline 1 & OTP BANK NYRT. \\
\hline 2 & UNICREDIT BANK HUNGARY ZRT. \\
\hline 3 & CIB BANK ZRT. \\
\hline 4 & MKB BANK ZRT. \\
\hline 5 & DÍJBESZEDŐ FAKTORHÁZ ZRT. \\
\hline 6 & RAIFFEISEN BANK ZRT. \\
\hline 7 & TAKARÉK FAKTORHÁZ ZRT. \\
\hline 8 & BUDAPEST BANK ZRT. \\
\hline 9 & MAGNET FAKTOR ZRT. \\
\hline 10 & LAURUS ZRT. \\
\hline
\end{tabular}

2. táblázat: A faktorpiaci szereplök rangsora a lebonyolított forgalomból való részesedés alapján 2018-ban

Forrás: Magyar Faktoring Szövetség adatai alapján saját szerkesztés http://www.faktoringszovetseg.hu/html/statisztika.html 2019.03.10.

2018-ban faktorálás keretében értékesített követelések megoszlása látható a 4. ábrán ágazatonként bemutatva. Az ábrából jól látszik, hogy a kereskedelem élt leginkább a faktorálás adta lehetőségekkel, ezt követte az ipar, majd a mezögazdaság. A követelés értékesítés $94 \%$-a belföldi ügyletekhez köthetö, az export követelések értékesítése 4,5\% az import pedig 1,5\%.

15 https://docplayer.hu/4934073-Faktoring-ugylet-forfait-ugylet-lizing.html 


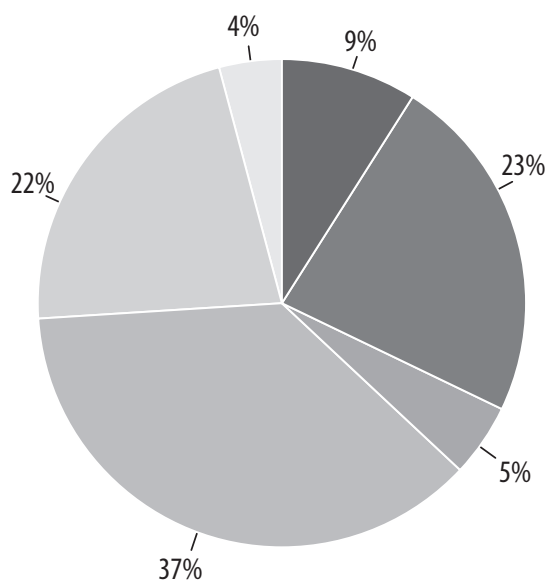
Szolgáltatás
Építőipar
Mezőgazdaság
Kereskedelem
Ipar
Egyéb

\section{4. ábra: Faktorügyletek megoszlása ágazatonként 2018-ban}

Forrás: Magyar Faktoring Szövetség adatai alapján saját szerkesztés

http://www.faktoringszovetseg.hu/html/statisztika.html 2019.03.10.

\begin{tabular}{|c|c|c|}
\hline Vállalkozás formái & Részesedés & Részesedési nagyság, milliárd forint \\
\hline Mikro & $5 \%$ & 119,92 \\
\hline Kis & $9 \%$ & 189,66 \\
\hline Közép & $44 \%$ & 981,13 \\
\hline Nagy & $42 \%$ & 929,91 \\
\hline
\end{tabular}

\section{3. táblázat: A faktorügyletek csoportjai a vállalkozás mérete alapján}

\section{8-ban}

Forrás: Magyar Faktoring Szövetség adatai alapján saját szerkesztés http://www.faktoringszovetseg.hu/html/statisztika.html 2019. 03. 10.

A 3. táblázat adataiból látszik, hogy bár a szakirodalom nem köti vállalkozás mérethez a faktorálást, mint szolgáltatást, mégis a nagy és közepes vállalkozások tudnak élni ezen forrásszerzési lehetőséggel. A vizsgált tíz év alatt jelentősen nőtt a faktorálás keretében megvalósult követelés értékesítés, ez különösen 2014-től vett nagyobb lendületet. A pénzügyi gazdasági válság negatívan hatott a faktor- 
tevékenységre is, ugyanakkor az ügyfélszám 2017-ig többnyire csökkenést mutat, újabb lendület 2018-ban következett be (lásd 5. ábra).

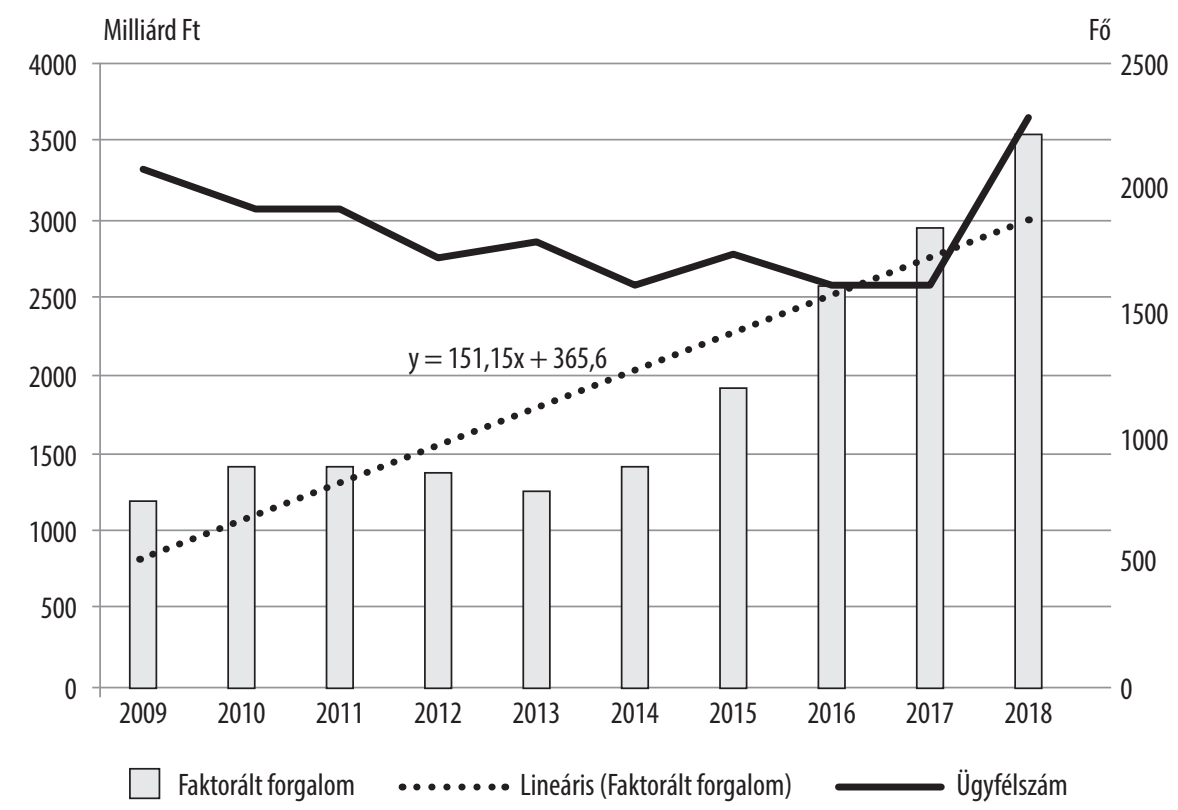

5. ábra: A faktorált forgalom és ügyfél szám alakulása 2009 és 2018 között Forrás: Magyar Faktoring Szövetség adatai alapján saját szerkesztés http://www.faktoringszovetseg.hu/html/statisztika.html 2019.03.10.

\subsection{Irodalomjegyzék}

Gál Erzsébet (2013): Hitelkérelem, banki ismeretek https://www.tankonyvtar. hu/hu/tartalom/tamop412A/0007_d3_hitelkerelem_jav_scorm/6_4_2_a_lizing_fajtai_6Tbyki5IG7xOWlJE.html letöltve 2019. március 8.

Gyulai László (2013): A kis- és középvállalkozások üzleti finanszírozása. - https://www.tankonyvtar.hu/hu/tartalom/tamop412A/0007_d2_1080_1082_ smeuzletifin/adatok.html Letöltve 2019. 03.08.

KPMG (2014): Aktuális kérdések - egy kis ez, egy kis az. Kérdőjelek hírlevél, 2014. április. KPMG. https://assets.kpmg/content/dam/kpmg/ pdf/2016/08/20140429-Kerdojelek-hirlevel.pdf letöltve: 2019.03.09.

Marek, Michael (2001): Geschichte des Leasing. Neue Folge Nr. 73. ISSN 1438-

4620 https://www.competence-site.de/geschichte-des-leasing-abriss-einer-beeindruckenden-entwicklung/

Pataki László - Gyurcsik Petronella (2017): Pénzügyi tervezés teoretikus és em- 
pirikus megközelítése a finanszírozás és a tökeszerkezet kontextusában. Gazdaság és Társadalom. 9. évf. 3-4 sz. -http://dx.doi.org/10.21637/GT.2017.34.01

A határon átnyúló lízing, http://ecopedia.hu/lizing 2019. 03. 08.

CIRR tartalma: https://exim.hu/hasznos/arfolyamok-es-kamatlabak letöltve: 2019. 03.09

http://lizingkalkulator.hu/2017/06/22/gepjarmu-hitel-lizing-esetleg-taros-berlet-1-resz/

http://lizingkalkulator.hu/\#kalkulator

A pénzügyi és az operatív lízing elhatárolása az új Ptk. alapján. https://lizing. blog.hu/2016/02/01/a_penzugyi_lizing_es_az_operativ_lizing_elhatarolasa_ az_uj_ptk_alapjan

IAS17 Nemzetközi Számviteli Standard - Lízingek - exkss.com/devel/huHU/ifrskno/showtopicgroupview?...en...Gazdasági\%20élettartam

http://nyiltlizing.hu/ letöltve 2019.03.09.

2013. évi CCXXXVII. törvény (Hpt.) https://net.jogtar.hu/jogszabaly?docid=A1300237.TV

Polgári Törvénykönyvről szóló 2013. évi V. törvény (Ptk.) https://net.jogtar.hu/ jogszabaly?docid=A1300237.TV

Elemzések, adatok: http://lizingszovetseg.hu/hasznos/elemzesek letöltve 2019.03.09.

Faktoring típusok: https://cityfaktor.hu/szolgaltatas/kereskedelmi-es-termeloi-faktoring letöltve 2019. 03. 09.

Faktorálás fogalma: https://cegfinanszirozas.hu/faktoralas letöltve 2019.03.10.

http://www.globalfaktor.hu/?contentid=2

Faktoring ügylet: https://docplayer.hu/4934073-Faktoring-ugylet-forfait-ugylet-lizing.html letöltve: 2019. 03. 14.

Forfetírozás: https://exim.hu/component/k2/item/41-forfetirozas-rovid-lejaratu-biztositott-kovetelesvasarlas? Itemid=230

Unidroit Convention On International Factoring: https://mkogy.jogtar.hu/jogszabaly?docid=99700085.TV 997. évi LXXXV. törvény a nemzetközi követelés-vételről szóló, Ottawában, 1988. május 28-án kelt UNIDROIT Egyezmény kihirdetéséről, letöltve: 2019. 03. 16.

MNB (2019): A Magyar Nemzeti Bank által felügyelt szektorok adatainak idősorai: Pénzügyi vállalkozások. https://www.mnb.hu/felugyelet/idosorok/i-penzes-hitelpiaci-szervezetek/penzugyi-vallalkozasok-idosorai 2019.03.23. 


\section{A bankszektor számviteli sajátosságai}

\subsection{Bevezetés}

A 2018-as év a szektor fő szereplői, a hitelintézetek számára hatalmas változásokat hozott. Egyrészt ekkor vált kötelezővé többségük számára az egyedi beszámolók IFRS-ek szerint történő elkészítése, másrészt ugyanezen év a szektor fő eszköz- és forrásállományát képező pénzügyi instrumentumokra vonatkozóan ezen belül is új megközelítést és módosult szabályokat hozott, hiszen hatályba lépett a korábbi előírást felváltó új standard, az IFRS 9.

A számviteli sajátosságok bemutatásának kisebb része így a pénzügyi vállalkozások tovább élő hazai elöírásait mutatja be, míg jelentős részében már a meghatározó szerepet betöltő IFRS-elöírásokat tárgyalja. Az első fejezetet az IFRS-ek iránt érdeklődő olvasók számára is ajánljuk, hiszen a Hpt. előírásai, így a sajátos tartalékképzési szabályok minden hitelintézetre vonatkoznak.

A bankok 2018-ra vonatkozó, és így ezen új szabályok szerint készített beszámolói, a könyv megírásakor jellemző módon még nem állnak rendelkezésre, így az új szabályok gyakorlati alkalmazásának bemutatására a standard elöírásai, valamint a már közzétett évközi pénzügyi kimutatások alapján kerül sor.

A fejezetben a hagyományos magyar szakkifejezéseket és az IFRS-ek szerinti fogalmakat - ahol az elfogadható - szinonimaként használjuk majd, ezek felsorolását, valamint a fejezetben szereplő rövidítések listáját a Függelék tartalmazza.

A könyvrészlet megírása során - terjedelmi okokból sem - törekszünk a hitelintézetek számviteli problémáinak teljeskörű bemutatására, még a pénzügyi instrumentumokat illetően sem, egyéb - természetesen szektorsemlegesen alkalmazandó - standardok elöírásainak ismertetését pedig kifejezetten kerüljük, kivéve akkor, amikor az szorosan kapcsolódik a pénzügyi intézmények müködéséhez. 


\subsection{A hitelintézetek és pénzügyi vállalkozások beszámolójára és könyvvezetésére vonatkozó számviteli elöírások}

A hitelintézetek és pénzügyi vállalkozások működésének szabályait az ezen intézményekről szóló 2013. évi CCXXXVII. törvény (továbbiakban Hpt.) szabályozza, amely kitér a könyvvezetéssel (113. rész) és a könyvvizsgálattal (114. rész) kapcsolatos fontosabb követelmények megfogalmazására is.

A könyvvezetésre vonatkozóan előírás, hogy annak magyar nyelven és a magyar számvitelre vonatkozó szabályoknak megfelelően kell megtörténnie úgy, hogy lehetővé tegye a felügyeleti és jegybanki ${ }^{1}$ ellenőrzést is. A magyar számviteli előírások ebben az esetben - mint később látni fogjuk - a Sztv. alapján vagy a 250/2000. kormányrendeletet, vagy pedig az IFRS-eket takarják. A könyvvezetésnek - bármely szabályrendszer alkalmazása esetén - biztosítania kell a belső ellenőrzés müködését, a hatékony és prudens vezetést, irányítást, valamint elő kell segítenie a tulajdonosok, a felügyelet és a könyvvizsgáló tevékenységét, a jogszabályi előírások és a szerződések teljesítését.

A jogszabály alapján az auditált éves beszámolót és az adózott eredmény felhasználására vonatkozó határozatot annak elfogadásától számított 15 napon belül, de legkésőbb május 31-ig meg kell küldenie a felügyeletnek. Ezen előírás harmadik országbeli pénzügyi intézmények fióktelepei esetén a magyar nyelvre fordított saját beszámolóra 30 napos határidővel vonatkozik.

A Hpt. azonban nem ad eligazítást a beszámoló fajtájára, formájára, annak tartalmára és a szerepeltetett tételek értékelésére vonatkozóan, ezeket ugyanis jellemzően a Számviteli törvény (továbbiakban Sztv.) fogalmazza meg. E törvényben találunk is elöírásokat a hitelintézetekre és pénzügyi vállalkozásokra vonatkozóan, ám azok elsősorban éppen arra vonatkoznak, hogy milyen más szabályozók mentén készítendő el ezen gazdálkodói kör beszámolója.

A Sztv. 9/A.\$-a alapján a hitelintézetek és az azzal egyenértékű prudenciális szabályokat alkalmazó pénzügyi vállalkozások számára kivétel nélkül az Európai Unió által befogadott IFRS-ek szerinti éves beszámoló összeállítása kötelező, de erre lehetősége van minden, az MNB felügyelete alá tartozó gazdálkodónak, így a pénzügyi és befektetési vállalkozásoknak is.

1 A fejezet megírásának időpontjában a két hatóság azonos, mindkét feladatkört az MNB látja el. 
A Sztv. további részeit az ezt az előírást alkalmazó intézményeknek csak anynyiban kell alkalmazniuk, hogy ha az Sztv. speciális közzétételeket ír elö, amelyek az IFRS-ek szerinti beszámolóban annak szabályrendszere alapján kötelezően nem volnának szerepeltetendők, akkor azokat az IFRS-ek szerinti beszámolóban is teljesíteni kell, illetve azon esetekben, amikor a nemzetközi standardok nem adnak elegendő iránymutatást, akkor azokkal összhangban a Sztv. elő́rásai alkalmazandók.

A Sztv. 114/H. \$-a az IFRS-ekre áttért pénzügyi intézmények számára a fökönyvi kivonat havi elkészítését és analitikával való alátámasztását írja elő, ám az átértékelést a pénzügyi vállalkozások devizás tételeire vonatkozóan csak negyedévente teszi kötelezővé. A devizaeszközök és -források értékelésekor az elöírás szerint csak az MNB által közzétett hivatalos devizaárfolyam alkalmazható.

A 114/I. \$ az IFRS-ek szerinti kiegészítő megjegyzések tartalmát bővíti ki azzal, hogy kötelezően előírja olyan tartalmi elemek szerepeltetését, melyek közzétételét szükségesnek tartja. Ilyen például az adózott eredmény felhasználására vonatkozó döntés, a kötelező könyvvizsgálatra történő hivatkozás, a könyvvizsgálónak különböző jogcímeken fizetett díjak bemutatása, a részvényesekre és a beszámoló aláirására kötelezettekre, valamint a közzététel helyére vonatkozó információk. E bekezdés értelmében a könyvvizsgálat hiányát, illetve az elutasító záradék tényét az alábbi szövegrészlet feltüntetésével kell deklarálni a kiegészítő megjegyzések között: „A közzétett adatok könyvvizsgálattal nincsenek alátámasztva.”

Az Sztv. ezen része előírja az üzleti jelentés készítését is a hitelintézetek számára a törvény szerinti szokásos tartalommal.

Az IFRS-ek szerinti egyedi beszámolót készítő pénzügyi intézményekre is vonatkozik a Sztv. 114/B. \$-ának saját tőke megfeleltetési tábla készítésének kötelezettsége, melynek fö funkciója, hogy a gazdálkodást és müködést szabályozó egyéb hazai jogszabályokban alkalmazott saját tőke tartalma és annak értéke egyértelműen meghatározható legyen ezen gazdálkodók pénzügyi kimutatása alapján is, kapcsolatot teremtve a Sztv. hagyományos saját tőkeelemei és az IFRSek szerinti beszámoló ilyen tételei között.

A fentieken kívül a Sztv. 178. \$ (1) bekezdése lehetőséget ad a kormánynak, hogy az MNB előzetes véleményének figyelembevételével rendeletben szabályozza többek között, a hitelintézetek és pénzügyi vállalkozások beszámolójára 
és könyvvezetésére alkalmazandó elöírásokat, fogalmakat. E felhatalmazás alapján a kormány megalkotta a 250/2000. kormányrendeletet, mely azonban csak címében vonatkozik a hitelintézetekre, a gyakorlatban - a 9/A. \$ alapján - csak azon pénzügyi vállalkozások beszámolását és könyvvezetését hivatott szabályozni, amelyek nem választották az IFRS-ek szerinti egyedi beszámolókészítés lehetőségét. A kormányrendelet főbb előírásait a következő alfejezetben ismertetjük.

\subsection{A hazai számviteli szabályozás}

Az IFRS-ekre át nem térő pénzügyi vállalkozások számviteli kötelezettségeit a 250/2000. kormányrendelet (a továbbiakban számviteli kormányrendelet) határozza meg. E rendelet nem csak a mérleg- és eredménykimutatás sajátos felépítését, a Cash Flow kimutatás formai lehetőségeit tartalmazza, de a kiegészítő melléklet Sztv.től eltérő tartalmán túl sajátos értékelési és könyvvezetési kötelezettséget is elöír, melyek közül a legfontosabbakat az alábbiakban ismertetjük.

A kormányrendelet hatálya az 1 . $\$$ alapján a hitelintézetekre és pénzügyi vállalkozásokra terjed ki, ám - mivel a hitelintézetek a Sztv. 9/A. \$-a alapján az IFRS-ek szerinti beszámoló készítésére kötelezettek -, számukra az itt ismertetett előírások nem relevánsak. Mégis érdemes bemutatni ezeket az előírásokat, hiszen ez jelenti azt az alapot, amelyre a hitelintézetek IFRS-ek szerinti pénzügyi kimutatásai épülnek, másrészt néhány olyan könyvvezetési elöírást is tartalmaz, amelynek alkalmazása az IFRS-ek esetén is elfogadható.

A kormányrendelet a Sztv.-hez képest eltérő mérleg- és eredménystruktúrát ír elő, melynek célja a szabályozott gazdálkodói kör müködési sajátosságainak minél szemléletesebb bemutatása.

A mérlegséma már formailag is eltér a Sztv. előírásaitól, csak arab számokkal jelzett, egyenrangú sorok szerepelnek benne, még az éven belüli és éven belüli elkülönítés is csak az összegző sor alábontásaként jelenik meg, különösen feltűnő ez a forrásoldalon, ahol még a saját tőke elemei sem kerülnek elkülönítésre. Az információk biztosítása érdekében az egyes mérlegsorok lejárat szerint megbontásra kerülnek, s ugyanez a megközelítés érvényes a részesedési viszony jellegére, a kereskedés formájára (tőzsdei tőzsdén kívüli), valamint a szolgáltatásra (pénzügyi-befektetési), melynek következtében az adott tétel keletkezett. 
A mérlegben szereplő eszközök sorrendje alapvetően a hitelintézetek - betétesek és befektetők szempontjából - legfontosabb szempontját, a likviditást tükrözik, s ugyanez a szemlélet - a kiegyenlítési sorrend - jelenik meg a forrásoldalon is.

A mérleg egyes tételeinek tartalma eltérhet attól, amit a Sztv. alapján várunk² Így például a fizetendő kamatok elhatárolása nem minden esetben szerepel a Költség, ráfordítás passzív elhatárolása soron, a mérlegkészítésig esedékes részek ugyanis a kötelezettség részeként mutatandók ki.

A forrásoldal saját tőke elemei között kiemelten jelenik meg a 11. Általános tartalék, ami a Sztv. elöírásai között nem szerepel. E tartalék képzését a Hpt. 83. $\$$-a írja elő, melynek értelmében a tárgyévi adózott eredmény 10\%-ából Általános tartalék képzendő, melyet a hitelintézet csak a „a tevékenységéből eredő veszteségek rendezésére" használhat fel. Mivel a hitelintézetek számviteli kormányrendelet szerinti beszámolót 2019-től már nem készíthetnek, a pénzügyi vállalkozások pedig nem kötelezettek az általános tartalék képzésére, e sor az ezt alkalmazó gazdálkodók beszámolójában üres lesz.

A mérleg mindkét oldalán azon sorokhoz kötődően, ahol ez értelmezhetö, „/A”, illetve „/B” jelzéssel megtalálhatók a valós értékelés ${ }^{3}$ különbözeteit tartalmazó sorok.

A hitelintézetek és pénzügyi vállalkozások életében kiemelt szerepet játszanak a mérlegen kívüli eszközök és kötelezettségek, melyek alapvetően az alábbiak lehetnek.

A függő követelések közé azok az eszközjellegü tételek tartoznak, amelyek mérlegben való szerepeltetése egy a jövőben bekövetkező eseménytől függ. Ilyenek jellemzően a biztosítékként, óvadékként kapott eszközök, kapott garanciák, valamint az opciós ügyletek jövőbeni követelései. A függö kötelezettségek közé tartoznak az opciós ügyletek jövőbeni kötelezettségein kívül azok a kötelezettségek, melyek mérlegben történő szerepeltetése későbbi esemény függvénye.

2 A pénzeszközökre vonatkozó ilyen elöírás már nem releváns, hiszen a hitelintézetek már nem ezt a mérleget készítik el, a pénzügyi vállalkozások pénzeszköz fogalma pedig megegyezik a Sztv. által meghatározott fogalommal.

3 Tapasztalataink szerint e sorok jellemzöen üresek, azaz a kormányrendelet hatálya alá tartozó gazdálkodók a hazai szabályok által engedélyezett valós értékelés lehetöségével általában nem éltek. 
Ilyen kötelezettség pl. a bank által nyújtott hitelkeret, vállalt garancia, visszavásárlási kötelezettségek.

A biztos jövőbeni követelések és kötelezettségek a határidős és swap ügyletek kapcsán keletkeznek, hiszen pl. egy forint-euró devizacsere ügylet a szerződés alapján biztosan bekövetkezik, s a majdani fizetendő összeg biztos jövőbeni kötelezettséget, míg a járó összeg biztos jövőbeni követelést jelent. Ezen kívül e tételek nyilvántartására nem csak a kockázatok bemutatása érdekében, hanem a nyitott deviza- és kamatkockázatok számszerüsítése és kezelése miatt is szükség van.

A pusztán nyilvántartási célokat szolgáló számlák közé tartoznak a függő kamatok nyilvántartását szolgáló, kizárólag a számviteli kormányrendelet (17. §) elöírása alapján képzett tételek, valamint a befektetési szolgáltatásokhoz kötődően az ügyfelek értékpapírjainak nyomon követését szolgáló főkönyvi számlák is. (Veres-Gulyás, 2008. 3.2. fejezet)

A kormányrendelet az eredménykimutatás formáját is a gazdálkodás sajátosságaihoz igazítja, így a legfontosabb eredménytételek - a kamatbevételek és -ráfordítások ${ }^{4}$ - kerülnek a kimutatás elejére, majd ezt követi a többi eredménytétel. A kimutatás egy sajátos forgalmi költséges eredménykimutatásnak tekinthető, hiszen a 8. Általános igazgatási költségek csak azon költségeket tartalmazhatják, melyek a pénzügyi és befektetési szolgáltatásokhoz közvetlenül nem kapcsolódnak, de igaz ez az értékcsökkenési leírásra is.

A szektor kiemelt eredménytételét jelenti az értékvesztés és a céltartalék, melyet az ezt tartalmazó négy kiemelt sor (11-14. sorok) is jól tükröz. Az itt szereplő 12/A Általános kockázati céltartalék felhasználás már csak kifutó sor, a régi Hpt. 87. $\$$ (2) bekezdése értelmében a mérlegfőösszeg 1,25\%-ában megképzett tartalék felhasználását mutatja ${ }^{5}$.

Az értékvesztés a forgatási célú értékpapírok esetén nem ezen a soron jelenik meg, azt a Pénzügyi műveletek nettó eredménye sor tartalmazza, együtt a devizaárfolyam változásából adódó különbözetekkel.

4 A kifejezetten kamatnak nevezett tételeken kívül ide tartoznak a kamatjellegü tételek is, melyek olyan pénzügyi szolgáltatáshoz kapcsolódó jutalékbevételek, illetve jutalékráfordítások, amelyekhez kamatbevétel, illetve kamatráfordítás is kapcsolódik. (Kormányrendelet, 10. \$ (2) f.)

5 Az általános kockázati céltartalék képzésének lehetősége a pénzügyi vállalkozások számára nem állt fenn, így a jövöben e sor - az Általános tartalékkal azonosan - üres marad. 
A szokásos tevékenység eredményébe tartozó tételek természetesen a mérleghez hasonlóan tovább bontandók, hiszen tükrözniük kell az azokat eredményező szolgáltatás típusát (pénzügyi vagy befektetési), illetve a részesedési viszony jellegét.

Az eredménykimutatás - a Sztv.-vel ellentétben - továbbra is lehetővé teszi a rendkívüli tételek elkülönült kimutatását, melynek szabályai az ottani korábbi elöírásokkal azonosak.

Az eredménykimutatás nem a megszokott Adózott eredmény sorral fejeződik be, aminek oka a mérlegtételeknél már bemutatott Általános tartalék, melynek képzése - egyfajta lekötött tartalékként - épp az adózott eredményt csökkenti, azaz az osztalék fizetésére is felhasználható Eredménytartalék csak a tárgyévi eredménnyel nőhet.

A számviteli kormányrendelet is kötelezővé teszi a hatálya alá tartozók számára a cash flow-kimutatás kiegészítő melléklet részeként történő elkészítését négy különböző módon is. E négy lehetőség közül a „D” típusú kimutatás hasonlít a Sztv. elöirásaihoz leginkább mind felépítésében, mind pedig elkészítésének módjában.

\begin{tabular}{|c|c|c|c|c|}
\hline Megnevezés & „A" típus & „B" típus & ${ }_{\text {"C" típus }}$ & „D" típus \\
\hline \multirow{3}{*}{$\begin{array}{l}\text { Cash flow } \\
\text { kategóriák }\end{array}$} & Múködési pénzáramlás & Pénzforrások & Pénzforrások & $\begin{array}{c}\text { Múködési tevékenység } \\
\text { pénzáramlása }\end{array}$ \\
\hline & Nettó pénzáramlás & Pénzfelhasználások & Pénzfelhasználások & $\begin{array}{l}\text { Pénzügyi szolgáltatás } \\
\text { pénzáramlása }\end{array}$ \\
\hline & & & & $\begin{array}{c}\text { Befektetési tevékenység } \\
\text { pénzáramlása }\end{array}$ \\
\hline Levezetés & $\begin{array}{c}\text { Kevert } \\
\text { (azon belül a } \\
\text { Működési CF indirekt) }\end{array}$ & Kevert & Kevert & $\begin{array}{l}\text { Múködési: direkt } \\
\text { Pénzügyi: kevert } \\
\text { Befektetési: direkt }\end{array}$ \\
\hline
\end{tabular}

\section{1. táblázat: A cash flow-kimutatás jellemzői}

Forrás: Veres-Gulyás $(2008,94$.

A kormányrendelet sajátos értékelési szabályai közül - véleményünk szerint - a két legfontosabbat emeljük ki: a kamatrealizáláshoz és a kitettségek értékeléshez kapcsolódó előírásokat. 
A kormányrendelet az értékvesztés és céltartalék képzésére már nem tartalmaz részletes elöírásokat, azokat ugyanis részben kiváltotta az ügyfél- és partnerminősítés, valamint a fedezetértékelés prudenciális követelményeiről szóló 40/2016., és a nem teljesítő kitettségre és az átstrukturált követelésre vonatkozó prudenciális követelményekről szóló 39/ 2016. MNB rendelet. E rendeletek részletesen szabályozzák a hitelintézetek és pénzügyi vállalkozások ügyletminősítéssel kapcsolatos feladatait, alapvetően abban a szellemben, hogy a leminősítés a megadott feltételek bármelyikének fennállása esetén megtörténhet, míg a felminősítés csak az összes elöírt feltétel együttes teljesítésének esetén hajtható végre. A 39/2016. rendelet 5. \$ (1) értelmében nem teljesítő kitettségnek minősül egy kitettség, ha a késedelmes rész jelentős és a késedelem meghaladja a 90 napot, vagy ettől függetlenül akkor, ha előre láthatólag szükség lesz a fedezet érvényesítésére a követelés teljes összegű törlesztéséhez.

A rendeletek előírásai nem csak a számviteli elszámolásokat, a képzendő értékvesztés és céltartalék összegét és mértékét befolyásolják ${ }^{6}$, de hatással vannak a tőkemegfeleléssel kapcsolatos számításokra is. További sajátos előírás hiányában az értékvesztés összegének meghatározására a Sztv. szabályai alkalmazandók. A kormányrendelet 7. melléklete ugyanakkor elöírja, hogy milyen szabályzatokat kell készítenie a pénzügyi intézménynek és mik e szabályzatok kötelező tartalmi elemei. E mellett az előírások kötelezően előírják az értékvesztés és céltartalék összegének negyedéves felülvizsgálatát és hangsúlyozzák a megfelelő dokumentációval való alátámasztás szükségességét. A kormányrendelet hatálya alá tartozó vállalkozónak a szabályzatban kell megadnia azt is, hogy a tárgyévi és előző évi értékvesztések összegét, illetve a tárgyévben viszszaírt előző évi értékvesztés összegét milyen módon kezeli. Az évesnél gyakoribb értékvesztés-képzés e szabályok nélkül az eredménykimutatás vonatkozó sorainak aránytalan növelését eredményezhetné. Ezért - a kormányrendelet korábbi előírásainak megfelelően - a tárgyévben keletkező értékvesztés viszszaírását praktikus lehet a ráfordítások csökkenéseként, míg a korábbi években keletkezett tételek visszaírását bevétel növekedésként kezelni. A kormányrendelet értelmében a devizás tételek értékvesztésének meghatározásakor az ér-

6 A rendeletek az értékvesztés meghatározására nem tartalmaznak szabályokat, ami érthető is, hiszen e rendeletek nem csak a magyar számviteli szabályokat, hanem az IFRS-eket alkalmazó pénzügyi intézményekre is vonatkoznak. 
tékvesztés alapjának fordulónapi árfolyamon figyelembe vett értékét kell alapul venni, így az értékvesztés képzésére minden esetben a fordulónapi árfolyamon kerül sor ${ }^{7}$.

A kamatbevételek és kamatjellegü jutalékok eredményben való elismerésére általánosságban nem fogalmazódnak meg külön szabályok, azokat a szerződött összegben, szükség esetén az időbeli elhatárolások alkalmazásával kell realizálni. Azon követelések esetén azonban, amelyek késedelmes napjainak száma eléri a 30 napot, vagy a követelés minősítése bármely okból kifolyólag nem teljesítővé vált és nem is folyt be, a kormányrendelet értelmében nem lehet kamatot realizálni, a már realizált kamatokat - akár követelésként, akár bevétel aktív elhatárolásként jelentkeztek - sztornó tételként ki kell vezetni a könyvekből és a mérleg alatt nyilvántartásba kell azokat venni. Év végén a szabály még szigorúbb, itt az előzőkön kívül függővé kell tenni a mérlegkészítésig esedékes és be nem folyt kamatokat és kamatjellegü jutalékokat is. Az elöírás ilyenkor tehát nem csak a tőkekövetelésekre képzett értékvesztés elöírásával, hanem a pénzügyileg nem realizált kamatok törlésével hangsúlyozottan követi az óvatosság elvét.

Ezen előíráshoz szorosan kötődik a kormányrendelet 10. \$ (4) bekezdésének elöírása, mely szerint akkor, ha a követelés egynél több kamatidőszakának esedékes kamat- és/vagy tőkeösszege nincs kiegyenlítve, akkor a befolyó összeget - ideértve az érvényesített fedezetet is - elöször a legrégebbi kamat törlesztésére kell fordítani, s tőketörlesztésre csak az összes kamatkövetelés kiegyenlítése ${ }^{8}$ után kerülhet sor.

A hitelintézeti kormányrendelet a könyvvezetésre vonatkozóan számos elöírást tartalmaz, melyek közül a 9. $\$(2)$ bekezdés az IFRS-ek szerinti beszámolót készítő hitelintézetek által is egyértelmủen alkalmazott. Ennek értelmében a „kizárólag devizaeszköz-, illetve devizaforrás-változással járó ügyletek esetén a (....) napi átértékelést végzö hitelintézet dönthet úgy, hogy az ügyletet annak keletkezésekor csak az adott devizanemben rögzíti nyilvántartásában, és a napi átértékelés során átszámított forintértékben könyveli a főkönyvi számlára a devizaeszköz és a devizakötelezettség összegét."

7 A hóvégi zárás eme két lépésének - a devizaátértékelés és az értékvesztés-képzés - sorrendje befolyásolja az eredmény szerkezetét, és hatással lehet az egyes részlegek tevékenységének értékelésére is.

8 Az elöírás ugyan a számviteli kormányrendeletben szerepel, ám forrása nem számviteli, hanem polgári jogi szabály. Lásd Ptk. 6:46. S. 


\subsection{Az IFRS-ek szerinti szabályozás}

Az IFRS-ek nem határoznak meg sajátos beszámolási és értékelési szabályokat a hitelintézetek számára, az egyes számviteli, illetve beszámolási standardok nem szektor-specifikusak, hanem minden - az adott típusú vagyonnal, eseménnyel rendelkező - gazdálkodó számára kötelezők.

Terjedelmi okokból nincs módunk az összes standard részletes bemutatására, ezért csak azok vázlatos ismertetésére kerül sor, amelyek kiemelt szereppel bírnak a hitelintézetek számára. A következőkben röviden bemutatjuk a hitelintézetek pénzügyi kimutatásainak tartalmát és felépítését az „IAS 1 A pénzügyi kimutatások prezentálása”, valamint az „IAS 7 Cash-flow kimutatások” standardok alapján, majd figyelmünket a hitelintézeti vagyon legnagyobb részét jelentő pénzügyi instrumentumokra fordítjuk. E témakör ismertetésekor az alábbi standardokra támaszkodunk:

- IAS 32 Pénzügyi instrumentumok - bemutatás,

- IFRS 9 Pénzügyi instrumentumok, ezek egyik legfontosabb értékelése,

- IFRS 13 Valós értékelés,

- IFRS 7 Pénzügyi instrumentumok: közzétételek.

Az IFRS 9 standard ugyan már felváltotta az IAS 39-et, de bizonyos elszámolásoknál e standard továbbra is alkalmazható, ezért említése nem elkerülhető. A mérlegen kívüli tételek jelentős szerepe miatt megemlítjük az IAS 37 Céltartalékok, függő kötelezettségek és függő követelések standard szerepét a hitelintézetek számvitelében. A fentieken túl a sajátos hazai szabályozói környezet szükségessé teszi az IAS 20 Állami támogatások elszámolása és az állami közreműködés közzététele alkalmazása szükségességének bemutatását is.

A fejezetben tehát nem törekszünk minden részlet ismertetésére, és kifejezetten a bankok szempontjából vizsgáljuk és mutatjuk be a vonatkozó elöírásokat.

Csakúgy, mint a hazai számviteli és beszámolási szabályok ismertetésekor, itt is bemutatjuk a pénzügyi kimutatások tartalmát, a velük szemben választott követelményeket, valamint az értékelési elveket és eljárásokat is.

Az IAS 1 standard alapján a beszámoló felépítése némileg eltér a magyar szabályoktól: szerepel ugyan benne a mérleg, az eredménykimutatás, és a kiegészítő melléklet is, ám ezek tartalma és elnevezése is kissé eltérő. Így például az Átfogó 
jövedelemkimutatás tartalma bővebb, mint az eredménykimutatásé, valamint a hazai kiegészítő melléklet részeként elkészítendő cash flow-kimutatás és saját tőke változását bemutató tábla pedig önálló kimutatásként jelenik meg.

A következőkben a pénzügyi kimutatások egyes részeit mutatjuk be.

\subsubsection{A mérleg - pénzügyi helyzet kimutatás - felépítése}

A mérleg természetesen az eszközöket és forrásokat - ideértve a saját tőkét és a kötelezettségeket - tartalmazza, bár ez utóbbi fogalom helyett annak két alkotóeleme jelenti a mérleg forrásoldali föösszegét, s bizonyos esetekben a mérlegképesség tartalma is eltér a hazai értelmezéstől.

A standard alapján lehetséges a befektetett és a forgóeszközök, valamint az éven túli és éven belüli kötelezettségek elkülönítése és ebben a sorrendben történő megjelenítése, de a vagyonelemek mérlegbeni sorrendje tükrözheti a likviditási szempontokat is, ami a hitelintézetek számára megfelelő megoldás. Az IAS 1 által elöírt kötelezően bemutatandó mérlegsorok jelentős része nem, vagy jelentéktelen összegben fordul elő a hitelintézetek életében, ám a standard lehetővé teszi a tételek további részletezését, amivel a bankok jellemzően élnek is. Így például a pénzügyi eszközök és kötelezettségek megbonthatók típusuk és értékelési módjuk szerint, s ezt a gyakorlatot a bankok jellemzően követik is. A hitelintézeti mérlegben egészen biztosan szerepelniük kell a valós értékelés alá tartozó tételeknek mind az eszköz, mind pedig a forrás-oldalon, mivel a hazai szabályokkal ellentétben a valós értékelés a pénzügyi instrumentumok egyes típusai esetén kötelező.

A magyar szabályoktól eltérően a mérlegben nem csak a tényleges, hanem a halasztott adókövetelések, - kötelezettségek is szerepelnek, valamint az értékesítésre tartott befektetett eszközök és az ezekhez kapcsolódó kötelezettségek elkülönítetten kerülnek bemutatásra.

A mérlegben a Saját tőke részét képező tőkeelemek kötelezően nem definiáltak, de legalább a Jegyzett tőke, az Eredménytartalék és Egyéb tartalékok címen megjelenítendők. Az egyéb tartalékok természetesen tovább bonthatók, így - akár a kiegészítő megjegyzésekben - elkülönülten kiemelhető az ázsió, vagy a halmozott egyéb átfogó eredmény (OCI), ami a hazai értékelési tartalékhoz hasonló tartalmú tételt jelent. A Jegyzett tőkéhez kötődően az IAS 1 standard 
kötelezően előírja a kibocsátott részvények számának, névértékének, a befizetett és be nem fizetett részének bemutatását mennyiségben és értékben, ideértve a visszavásárolt saját részvényeket is. Szükséges bemutatni az osztalékot, a részvényekre vonatkozó különféle jogokat/korlátozásokat, valamint a jóváhagyott, de ténylegesen még ki nem bocsátott részvények számát, összegét és feltételeit.

Amennyiben a pénzügyi kimutatásokban a mérleghez kiegészítő megjegyzések kapcsolódnak, azokat egyes mérlegsorokhoz tartozó egyértelmű hivatkozással kell ellátni. Egy lehetséges IFRS-ek szerinti hitelintézeti mérlegsémát a 4. függelékben mutatunk be.

\subsubsection{Mérlegen kívüli tételek}

A hitelintézetek azon tételei, melyek a magyar számviteli szabályok szerint mérlegen kívüli tételként voltak kimutatandók, természetesen az IFRS-ek szerint is létező tételek, hiszen azokat nem a számviteli szabályrendszer hozta létre. A kérdés az, hogy ezek nyilvántartása milyen módon történhet az IFRS-ek szerinti beszámoló esetén. Alapvetően leszögezhetjük, hogy a nyilvántartási célokat szolgáló (pl. deviza- vagy kamatpozíciót kimutató, a kitettségeket teljessé tevő, vagy az értékvesztett ügyletek kamatrealizálási szabályainak sajátosságai miatti) nyilvántartások természetesen vezethetők - és vezetendők is - a hitelintézetek által, ám ezeket a pénzügyi kimutatásokban - ideértve a kiegészítő megjegyzéseket is - nem feltétlenül szabad bemutatni.

Alapelv, hogy azok az események, tételek, melyek bármely ok - akár céltartalék képzése, akár valós értékelés alkalmazása - miatt a mérlegben és az átfogó eredménykimutatásban már szerepelnek, még egyszer - mérlegen kívül sem nem jeleníthetők meg a beszámolóban, hiszen akkor az általuk tükröztetett kockázatot duplán mutatnánk be.

Mivel a valós értékelés - mint később látni fogjuk - a derivatívák teljes körére kötelező az IFRS 9 szerint, az ezekhez kötődő függő és biztos jövőbeni követelések és kötelezettségek már nem mutathatók be mérlegen kívüli tételként.

Ugyanígy csak azok a mérlegen kívüli kitettségek jelentenek mérlegen kívüli kötelezettséget is egyben, amelyek nem felelnek meg a céltartalék definíciójának, vagy mert létrejöttük csak lehetőség, vagy mert a jövőbeni pénzkiáramlás nem valószínü és/vagy összege nem becsülhető megbízhatóan. A hazai - mérlegelést 
nem engedő - szabályokkal ellentétben az IFRS-ek szerint (IAS 37) függő kötelezettséget is csak akkor kell közzétenni a beszámolóban, ha a pénzkiáramlás bekövetkezésének valószínűsége nem elhanyagolható. A pénzügyi instrumentumnak minősülő nyújtott kezességek, garanciák nem jelentenek függő kötelezettséget.

A kapott fedezetek, garanciák, biztosítékok mérlegben való szerepeltetésének szabálya szimmetrikus a függő kötelezettségeknél megismertekkel, azaz a már lényegileg biztos eszközök a mérlegben, a kapcsolódó bevételek az eredményben mutatandók ki. Amíg bekövetkezésük valószínűsége elhanyagolható, addig a mérlegen kívül sem mutatandók ki e tételek, míg a két valószínűség között mérlegen kívüli követelés jelenítendő meg.

\subsection{3. Átfogó jövedelem-kimutatás}

Az IFRS-ek szerinti „eredménykimutatás” teljes neve az Átfogó jövedelemkimutatás, amely nem csak a realizált eredményt, hanem a nem realizált értékelési tartalékok tárgyévi változását - az Egyéb átfogó jövedelmet (OCI) - is tartalmazza.

A realizált eredmény az IFRS-ek szerinti beszámoló esetén is a beszámolási időszak bevételeinek és az azokhoz kapcsolódó ráfordításoknak a különbsége. A kimutatásnak tartalmaznia kell a gazdálkodó bevételeit, pénzügyi ráfordításait, az amortizált bekerülési értéken nyilvántartott pénzügyi instrumentumok kivezetéséből származó eredményt, a pénzügyi ráfordításokat, a tőkemódszerrel konszolidált vállalkozásokból a gazdálkodóra jutó eredményt, a pénzügyi eszközök átsorolásából származó bizonyos eredményeket, a jövedelemadó-ráfordítást, a nettó (adózott) eredményt, valamint a megszűnő tevékenységekből származó eredményt. Az eredmény meghatározásakor a levonandó ráfordítások akár azok fajtája, akár funkciója szerint csoportosíthatók. Az IFRS-ek befektetőket előtérbe helyező jellegét tükrözi az egy részvényre jutó eredmény (EPS) bemutatásának kötelezettsége.

Az egyéb átfogó jövedelem (eredmény) kimutatása elsősorban a saját tőkével szemben valósan értékelt mérlegtételek évközi változását tartalmazza, s így közvetlen kapcsolatban van a mérleg saját tőke elemei között szereplö halmozott egyéb átfogó jövedelemmel. Itt jelennek meg a konszolidáció során a keletkező devizaárfolyam-különbözetek, valamint a cash-flow fedezeti ügyletek fedezeti instrumentumának eredménye is. Az ide kerülő tételek egy része - a magyar 
gyakorlattal azonosan - az adott instrumentum kikerülésekor megszűnik, és teljes egészében az eredményben (eredménykimutatáson át) realizálódik, más része azonban az eszköz kikerülésekor közvetlenül az eredménytartalékba sorolandó át. E kétféle OCI a kimutatásban elkülönítetten mutatandó be. Ezzel ellentétben a tőkemódszerrel konszolidált vállalkozások egyéb átfogó eredményéből való részesedését egy összegben kell kimutatni.

Ezen elöírások lehetővé teszik a hitelintézetek számára, hogy a tevékenységüket leginkább tükröző módon állítsák össze eredménykimutatásukat. Ezért a hitelintézetek jellemzően a kamatbevételek és kamatráfordítások, valamint jutalékbevételek és jutalékráfordítások különbségéből indulnak ki, a közvetett működési ráfordításaikat összevontan mutatják be és kiemelt helyet szánnak a képzett értékvesztésnek és céltartaléknak.

Egy lehetséges IFRS-ek szerinti hitelintézeti eredménysémát az 5. függelékben mutatunk be.

\subsubsection{CF és Saját tőke-változás (SOCIE) kimutatás}

A hazai beszámolóval ellentétben e két kimutatás nem a kiegészítő megjegyzések része az IFRS-ek szerinti pénzügyi kimutatásokban, hanem önálló számszaki rész, melyeket a hitelintézetek is az általános szabályok szerint kötelesek elkészíteni. A cash flow-kimutatás főbb kategóriái megegyeznek a Sztv. kategóriáival, ám alapvető eltérés, hogy nem csak a pénzeszközök, hanem a pénzeszköz-egyenértékesek változását is tartalmazza. Ez utóbbiba azok a maximum 3 hónap lejáratú, magas likviditású befektetések tartoznak, melyek könnyen készpénzre válthatók és az értékváltozás kockázata elhanyagolható. Tőkeinstrumentum nem kezelhető pénzeszköz-egyenértékesként. A kimutatás előállításánál a direkt módszert részesíti előnyben a standardalkotó, ám a gyakorlatban a vegyes módszer terjedt el.

A saját töke változás kimutatása a gyakorlatban egy mozgástábla, amelynek célja a saját tőkében bekövetkezett tárgyévi változások bemutatása. Kötelezöen szerepeltetendő benne az átfogó eredménykimutatás végösszege, minden a mérlegben szereplö tőkeelem nyitó- és záróértéke, valamint a közzétett adatok egyeztetéséhez szükséges információk, mint pl. az adott időszaki eredmény és egyéb átfogó eredmény, a tulajdonosokkal szembeni tranzakciók (osztalék, tőkeemelés, részvényvisszavásárlás), visszamenőleges módosítások hatásai, a leányvállalatokban lévő érdekeltségek változása. 


\subsection{Pénzügyi instrumentumok}

\subsubsection{A pénzügyi instrumentumok fogalma}

A hitelintézetek vagyonának legnagyobb részét a pénzügyi instrumentumok teszik ki, ezért a következő fejezetekben ezen tételekkel foglalkozunk. Az IAS 32 alapján pénzügyi instrumentum egy olyan szerződés, ami az egyik félnél pénzügyi eszközt, a másiknál pénzügyi kötelezettséget, vagy tőkeinstrumentumot keletkeztet. Így pénzügyi eszközök a pénzeszközök, részesedések (tőkeinstrumentumok) más társaságban, jogok pénzeszköz átvételére (követelés jellegủ tételek), pozitív valós értékủ származékos ügyletek, pénzügyi kötelezettségek pedig egy pénzügyi eszköz átadására vonatkozó kötelmek (tartozások) és a negatív valós értékü származékos ügyletek.

Amennyiben az egyik félnél pénzügyi eszköz, a másiknál pedig tőkeinstrumentum keletkezik, tőkeinstrumentumról beszélünk. Az ilyen besorolás feltétele, hogy az így keletkező instrumentum fejében annak kibocsátója sem közvetlenül, sem közvetetten nem kötelezett pénz, vagy más pénzügyi eszköz átadására. Természetesen egy közönséges részvény esetén is fizethet osztalékot a kibocsátó, ám ez a saját döntése, nem pedig szerződésben foglalt kötelezettsége. A tőkeinstrumentumok esetén tehát a szerződés alapján rögzített mennyiségű tőkeinstrumentum fejében rögzített összeg fizetendő, s ha ez nem áll fenn, akkor a kibocsátónál pénzügyi kötelezettség keletkezik. A származékos ügyletek akkor sem tekinthetők tőkeinstrumentumnak, ha a mögöttes termék tőkeinstrumentum is.

A tőkeinstrumentum tehát a gazdálkodó összes eszközének és összes kötelezettségének a különbsége. A forrásoldalon ez a beszámolót készítő gazdálkodó saját tőkéjét jelenti, melynek értékelése nem tartozik az értékelést szabályozó IFRS 9 standard hatálya alá.

Bizonyos pénzügyi instrumentumok azonban kötelezettség és saját tőke tulajdonságokkal is bírnak, s mivel ezek értékelése eltérő, szükséges az ilyen öszszetett pénzügyi instrumentumok szétválasztása. Ilyen pénzügyi instrumentum lehet például egy átváltoztatható kötvény, amely megjelenhet a bankoknál mind az eszköz - vásárlás esetén -, mind pedig a forrás - kibocsátás esetén - oldalon. A szétválasztás során az instrumentum kötelezettség és saját tőke elemének értékét úgy határozzuk meg, hogy az instrumentum értékéből levonjuk a csak 
kötelezettséget tartalmazó instrumentum értékét, így a saját tőkeinstrumentum értéke a különbözet lesz. Az értékelés a továbbiakban az adott részekre vonatkozó standardok szerint elkülönülten történik.

A hitelintézetek által nyújtott pénzügyi szolgáltatások közül a hitelkeret nyújtása és a garancia vállalása csak akkor tartozik az IFRS 9 standard hatálya alá, ha a gazdálkodó valós értéken értékeltként jelölte meg azokat, vagy a hitelkeret esetén a hitelintézet a piaci kamatlábnál alacsonyabb kamatú kölcsön folyósítására vállalt kötelezettséget.

Az IFRS 9 az értékelési szabályokban kevés - főleg részletekben rejlő - változást eredményezett, így a pénzügyi instrumentumok továbbra is a következő értékelési elvek mentén szerepeltethetők a könyvekben:

- Amortizált bekerülési érték;

- Valós érték saját tőkével (egyéb átfogó eredménnyel) szemben;

- Valós értéke eredménnyel szemben.

Az amortizált bekerülési érték alkalmazása esetén - akár eszközről, akár kötelezettségröl van szó - a kihelyezett vagy kapott összegnek egyetlen hozama, illetve ráfordítása van, mégpedig a kamat. A tőkeösszeg nem a szerződés szerinti névleges tőkeösszeget takarja, hanem azt az összeget, amit bármilyen jogcímen, de az ügylethez szorosan kapcsolódóan kapott/adott a gazdálkodó. Egy nyújtott hitel esetén a bank pl. kaphat szerződéskötési dijat, az ügylet megszerzéséért pedig fizethet üzletszerzési jutalékot. E két összeg a magyar szabályok szerint nem része a tőkekövetelésnek, a kapcsolódó bevétel és költség a futamidő alatt azonban az összemérés elve alapján elhatárolandó. Az amortizált bekerülési érték alkalmazásakor tőkének a kapcsolódó tranzakciós költségekkel, a fizetett/kapott diszkontokkal/prémiumokkal ${ }^{9}$ módosított összeget tekintjük, így az ügylethez egyetlen eredménytétel, a kamat kapcsolódik. A kamat mértéke - azaz az időszak elején fennálló tőkéhez viszonyított értéke - a futamidő alatt állandó, és effektív kamatlábnak (EIR) nevezzük, melynek értéke megegyezik az ügylethez kapcsolódó pénzáramok belső megtérülési rátájával. A kezdeti bekerülési érték ekkor a valós érték - amit jellemzően a kezdeti pénzmozgás tükröz -, módosítva a kapcsolódó tranzakciós költségekkel.

9 A gyakorlatban a tranzakciós költségek inkább az adott/kapott hitelekre jellemzök, míg a diszkontok/prémiumok az értékpapírok vásárlása/kibocsátása esetén fordulnak inkább elő. 
Ez a megközelítés azt eredményezi, hogy a szerződésben kikötött olyan megállapodások, amelyek a kamatot ettől eltérítik - pl. állandó tőketörlesztőrészlet elöírása, előre rögzített lépcsőzetesen változó kamat alkalmazása, vagy akár csak a kamatszámítás tény/365 naptól való eltérítése -, az eredményre nem gyakorolnak semmilyen hatást.

Amennyiben az ügylet kezdeti bekerülési értéke meghaladja a névleges tökeösszeget, akkor az EIR alacsonyabb a szerződésben foglalt kamatnál, ellenkező irányú eltérés esetén pedig éppen fordítva.

A hitelintézet természetesen köteles a névleges kamatot elszámolni az ügyféllel, hiszen ez a pénzmozgás alapja, ám az eredményben nem ezt, hanem az EIR alapján számított kamatbevételt/ráfordítást jelenítheti csak meg. E kétféle kamat közötti különbözet a futamidő alatt jelenik meg az eredményben, s teljes összege éppen megegyezik a bekerülési érték és a névleges tőkeösszeg különbségével. A futamidő alatt történő kamatrealizálást a standard a diszkont lebontásának nevezi, függetlenül annak irányától.

Tegyük fel, hogy 1000 ezer forintos névleges kölcsönösszeg folyósítására kerül sor, s a bank kap 50 ezer forint szerződéskötési díjat, valamint 100 ezer forint üzletszerzési jutalékot fizet az üzletkötőnek. A futamidő 4 év, a törlesztés évente egyszer esedékes, a szerződött kamatláb 5\%.

Az ügylet kalkulációját a 2. táblázat tartalmazza.

\begin{tabular}{|c|c|c|c|c|c|c|c|c|c|c|}
\hline & $2,93 \%$ & & $5 \%$ & & & & $2,93 \%$ & & & -50 \\
\hline $\begin{array}{l}\text { 픔 } \\
\text { 흥 }\end{array}$ & 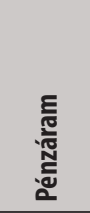 & 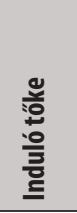 & 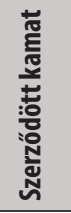 & 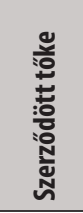 & 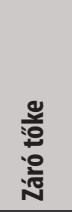 & 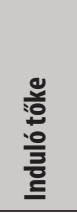 & 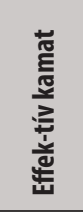 & 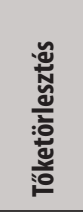 & 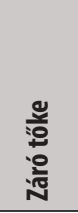 & 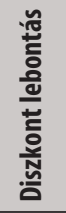 \\
\hline 2018.04.01. & -1000 & & & -1000 & 1000 & & & -1000 & 1000 & \\
\hline 2018.04.01. & 50 & 1000 & & & 1000 & 1000 & & 50 & 950 & \\
\hline 2018.04.01. & -100 & 1000 & & & 1000 & 950 & & -100 & 1050 & \\
\hline 2019.04.01. & 282 & 1000 & 50 & 232 & 768 & 1050 & 31 & 251 & 799 & -19 \\
\hline 2020.04 .01$. & 282 & 768 & 38 & 244 & 524 & 799 & 23 & 259 & 540 & -15 \\
\hline 2021.04.01. & 282 & 524 & 26 & 256 & 269 & 540 & 16 & 266 & 274 & -10 \\
\hline 2022.04.01. & 282 & 269 & 13 & 269 & 0 & 274 & 8 & 274 & 0 & -5 \\
\hline
\end{tabular}

2. táblázat: Amortizált bekerülési érték kalkuláció

Forrás: Saját készités 
A táblázat dátumok utáni első oszlopa tükrözi a kapcsolódó pénzáramokat és ezek belső megtérülési rátáját, a következő 4 oszlop a szerződés szerinti, míg az utána következő négy oszlop az effektív kamatlábbal számított kalkulációt mutatja be. Ez esetben a kamatszámítás annuitásos módszerrel történik. Az utolsó oszlop a kétféle kamat közötti különbözetet tükrözi, melynek összege éppen a szerződött (1 000) és a tényleges (1 050) tőke közötti különbséget adja.

A fenti kalkulációt a standard elöírásai szerint a jövőbeni becsült cash flow-k alapján kell elvégezni, ami a gyakorlatban jellemzően a szerződött pénzárammal azonos lesz, de bizonyos esetekben - pl. hitelkeret díja, lehívási arány, vagy folyószámlahitel esetén - valóban becslésre van szükség.

A futamidő alatt az effektív kamatláb tehát állandó, ami alól szerződésmódosítás nélkül csak a referencia-kamatlábhoz kötött változó kamatozású ügyletek jelentenek kivételt, ekkor ugyanis a jövőbeni pénzáram módosulása miatt csak az EIR módosul, a tőkeösszeg állandó marad.

Az EIR változására csak olyan szerződésmódosítás esetén van lehetőség, ha az új ügyletet eredményez, azaz az ügylet a standard kivezetési szabályai alapján ${ }^{10}$ kivezetendő a könyvekből, ám azt új ügyletként ki kell mutatni, mivel a követelés/kötelezettség még fennáll.

Amikor a szerződésmódosítás nem eredményez új ügyletet, akkor a módosítás következtében megváltozott új jövőbeni pénzáramokat az eredeti effektív kamatlábbal diszkontálva, a könyvekben szereplő értéktől eltérő tőkeösszegben kell kimutatni, és a különbözet (a kezdeti valós érték különbözet) azonnal az eredményben jelenítendő meg.

Az amortizált bekerülési értéken nyilvántartott eszközök esetében szükség lehet az értékvesztés elszámolására is, ami azt eredményezi, hogy az amortizált bekerülési érték a bruttó könyv szerinti érték és az elszámolt értékvesztés különbségeként határozható meg.

Az értékvesztés képzése a várható veszteségek becslésén alapszik, abból a feltételezésből kiindulva, hogy valamekkora veszteségre minden kihelyezésnél van esély. Az ügyletek keletkezésekor és mindaddig, amíg a hitelkockázat jelentősen

10 A kivezetés nem feltétlenül a követelés/kötelezettség jogi megszüntetését jelenti, hanem azt is, ha az eredeti ügylet olyan mértékü módositáson ment keresztül, hogy új ügyletnek minösül, ezért az eltérő feltételeket a könyvekben meg kell jeleniteni. 
nem nő meg, ez az értékvesztés az éven belüli bedőlési valószínűség (PD) alapján határozandó meg. Az e kategóriába - stage 1 - tartozó ügyletek értékvesztése jellemzően csoportosan, a szegmensre jellemző adatok alapján határozható meg.

A hitelkockázat jelentös növekedése következtében az ügylet besorolása stage 2-re változik, így már a teljes élettartamra meghatározott PD alapján kell a várható veszteséget megbecsülni. A hitelkockázat jelentős növekedésének tényét a hitelintézetek számviteli politikájukban rögzített módon határozzák meg, de amennyiben a veszteségre utaló jelek - pl. 30 napos fizetési késedelem ${ }^{11}$ - megjelennek, kötelező az átsorolás. A hitelkockázat növekedésének megítélésekor a hitelintézet nem csak a konkrét ügylet jellemzőit, mint pl. bevonható fedezetek értékét és a bedőléskori várható veszteséget, hanem makrogazdasági tényezők változását is figyelembe veheti. Amennyiben a bedőlési valószínűség alacsony, akkor feltételezhető, hogy a hitelezési kockázat nem nőtt jelentősen.

Az e státuszba került ügyletek esetén is lehetőség van az értékvesztés csoportos képzésére, de ekkor már az egyedi - ügyletszintü - értékvesztésképzés is felmerülhet, melynek módszerét a következő státusznál mutatjuk be.

A nem teljesítö ügyletek körének meghatározására vonatkozó előírásokat a standard, a Bázel III és az MNB-rendelet elöírásaival összhangban a számviteli politikában rögzíti a hitelintézet. Ilyen kiemelt szabály a 90 napon túli jelentős követelésrész késedelme, vagy a fedezet érvényesítésének várható szükségessége, melyek következtében az ügylet értékvesztetté válik, és besorolása stage 3 lesz. Ekkor is lehetőség van az értékvesztés csoportos képzésére, de a standard alapvető előírásai alapján az értékvesztés összege az ügylet jövőben várhatóan realizálható pénzáramainak eredeti effektív kamatlábbal diszkontált összege és a könyv szerinti érték közötti különbözet. Az eljárás alapja tehát a jövőbeni pénzáramok becslése, mely a különféle kimenetek bekövetkezési valószínűség szerinti súlyozásával történhet meg. A várható pénzáramokba a fedezetek érvényesítéséből származó pénzáramok is beleszámítanak. A becslés során nehézséget jelentenek nem csak az összegek, de azok időpontjának becslése is.

Az értékvesztett követelések után a kamat - mivel számításának alapja az amortizált bekerülési érték - csak az értékvesztéssel csökkentett nettó összegre realizálható. Gyakorlati egyszerüsítésként lehetőség van arra, hogy a kamatszá-

11 A standard a hitelkockázat növekedésének megcáfolható jeleként emliti a 30 napos késedelmet. 
mítás továbbra is a bruttó könyv szerinti értékre történjen meg, ám az így meghatározott kamatot az értékvesztés mértékével csökkenteni kell.

A már értékvesztettként bekerülő, a gazdálkodó által vásárolt vagy keletkeztetett ügyletek $^{12}$ (POCI) esetén a bekerüléskor értékvesztés számolandó el, a kamat meghatározása a hitelezési veszteséggel korrigált effektív kamatlábbal történik, így ekkor a kamat realizálása csak az amortizált bekerülési értékre, azaz a nettó könyv szerinti értékre történik.

Az értékvesztés elszámolásával kapcsolatban technikai szabályok nem jelennek meg a standardban, ám a hazai elszámolási problémáknál leírtak itt is felmerülnek, és alkalmazhatók. Szükség lehet az előző évben és a tárgyévben képzett értékvesztés visszaírásának elkülönítésére, valamint a devizás és devizaalapú ügyletek értékvesztésének változásában a devizaárfolyam és a hitelkockázat változásából származó rész elkülönítésére.

A hitelnyújtási elkötelezettségek és pénzügyi garancia esetén is alkalmazandók az IFRS 9 értékvesztésre vonatkozó előírásai azzal a különbséggel, hogy ekkor a mérlegben még nem szereplő összegekre nem értékvesztés, hanem céltartalék képzendő, és az értékvesztésnél megismert tényezőkön kívül a követelés keletkezésének valószínűsége is figyelembe veendő.

A saját tőkével szemben valósan értékelt adósságinstrumentumok esetén az eszköz realizált eredménye továbbra is - az amortizált bekerülési értékhez hasonló módon - az eredménykimutatásban jelenik meg, míg a valós érték és a könyv szerinti érték különbözete az egyéb átfogó jövedelem halmozott értékét módosítja. Ekkor a valós értékváltozáson belül az értékvesztés összege is meghatározandó, ám az nem érintheti az eszköz könyv szerinti értékét, csupán az addig OCI-ban elszámolt tételek és az eredménykimutatás tételei közötti átsorolást eredményezheti ${ }^{13}$. Az e csoportba sorolt instrumentumok könyvekből történő kikerülése esetén az addig a saját tőkében kimutatott valós érték különbözetek arányos része az eredménykimutatáson keresztül az eredménytartalék részévé válik.

12 Ilyen ügyletek voltak például a 2015-ös kötelezö forintositás és kamatelszámolás során módositott, korábban már értékvesztett lakossági hitelek, mert a módositás olyan mértékü volt, hogy azokat új ügyletként volt célszerü kezelni.

13 Ez technikailag jelentheti az OCI „visszaforgatását” és az értékvesztés szokásos módon történo” könyvelését is. 
A saját tőkével szemben valósan értékelt tőkeinstrumentumok esetén a tranzakciós költségek az eszköz értékében figyelembe veendők és a járó osztalék is az eredményben realizálandó. Minden egyéb értékváltozás, így a kibocsátó hitelkockázatának változása, valamint a devizaárfolyam változás hatása is az egyéb átfogó eredményben jelenik meg és az eszköz kikerülésekor sem jelenik meg az eredménykimutatásban, hanem közvetlenül átsorolandó az eredménytartalékba. A könyv szerinti érték és a kapott ellenérték különbözete ekkor is az eredményt érinti.

A pénzügyi kötelezettségek esetén az eredménnyel szembeni valós értékelés során a kötelezettség értékének csökkenését és az eredmény növekedését jelentő saját hitelkockázat változását az egyéb átfogó jövedelem növekedéseként, a saját tőkében kell kimutatni. A kötelezettség kivezetésekor ezen összegek közvetlenül - az eredménykimutatás érintése nélkül - kerülhetnek át az eredménytartalékba.

\subsubsection{A valós érték}

Az előző fejezetben mind a saját tőkével, mind pedig az eredménnyel szemben valósan értékelt instrumentumok esetén adottságként kezeltük a valós érték fogalmát. Az IFRS 13 standard értelmében a valós érték az az ár, amit piaci szereplők szokásos tranzakció során egy eszközért kapnának, vagy egy kötelezettség átruházásáért fizetnének az értékelés időpontjában.

Alapvetően az elsődleges (ahol a legtöbbet kereskednek az instrumentummal), vagy a legelőnyösebb (ahol a legnagyobb nyereség érhető el) piacon érvényes kilépési ár a mérvadó.

A piaci ár akkor kezelhető valós értékként, ha az ügyletek jól tájékozott szereplők között, nem kényszerű feltételek esetén létrejöhetnek. A valós értéknek nem része a tranzakciós költség.

A valós érték meghatározható piaci megközelítés ${ }^{14}$ alapján, amikor kifejezetten az instrumentumok árai, hasonló instrumentumok árai, mutatószámok, árazási eljárások alapján határozzuk meg azt. A jövedelem alapú megközelítés ${ }^{15}$ esetén az adott instrumentumhoz kötődö, elkülönült pénzáramok diszkontált értéke jelenti

14 Piaci megközelités alkalmazható például a tözsdén forgalmazott értékpapírok jegyzett árai esetén.

15 Jövedelem-alapú megközelités alkalmazható például a kölcsönök értékelése során, ahol a jövőbeni szerződött pénzáramok az aktuális kamatfeltételek, kamatgörbék mentén diszkontálhatók. 
a valós értéket, míg a költségalapú megközelítés esetén arra keressük a választ, hogy a pótlás, helyettesítés, kiváltás mennyibe kerülne a gazdálkodónak.

A diszkontálás során lehetőség van a legvalószínűbb jövőbeni pénzáramok hasonló instrumentumok kamataiból számított kamatlábbal történő diszkontálására, vagy a valószínűségekkel súlyozott pénzáramok szisztematikus kockázatot tükröző kamatlábbal való diszkontálására.

Alapelv, hogy lehetőség szerint több - akár különböző megközelítéseken alapuló - becslést érdemes készíteni, melyekből kiválasztható a legnagyobb valószínűséggel érvényes érték.

A számítás módszerén túl fontos kérdés, hogy mennyire megbízható inputok alapján történik a valós érték meghatározása. Ez egyrészt támogatja a beszámoló olvasóját az információk értékelésében, másrészt - mint később látni fogjuk közvetlen hatással van az amortizált bekerülési értéken értékelt ügyletek nyilvántartására.

Amennyiben ismert az adott instrumentum aktív piacon jegyzett ára, akkor az input a legmegbízhatóbb (level 1) kategóriába tartozik. Aktív piacról akkor beszélhetünk, ha megfelelő a kereskedés volumene, gyakorisága, ezért az így meghatározott valós érték megegyezik-e az értékelés időpontjában érvényes eladási árral. A legjobb példát a részvények, kötvények jelentik.

Amennyiben az aktív piacon csak hasonló instrumentumra van megfigyelhető adat, vagy a piac nem aktív, vagy nem konkrét árak, hanem más megfigyelhető inputok (pl. hozamgörbe, kamatláb, kockázat) alapján történik a valós érték kiszámítása, az már kevésbé megbízhatónak tekinthető. Ekkor a számítás alapját képező inputokat a 2. szintbe (level 2) soroljuk. Végül, ha a számítást nem megfigyelhetö inputok, a piacról, az ott szereplők feltételezéseiről alkotott saját, de megbízható feltételezések alapján végzi el a gazdálkodó, akkor ezen inputok a legkevésbé megbízhatóak (level 3). A megbízhatóság alapján felállított besorolás a valós érték hierarchia.

Amennyiben nem áll rendelkezésre megbízható valós érték, a bekerülési ár alkalmazandó.

$\mathrm{Az}$ amortizált bekerülési érték alkalmazásakor feltételeztük, hogy az ügylet induló értéke a valós érték és a tranzakciós költségek összege. Előfordulhat 
azonban, hogy az ügylet valós értéke már a kezdetekkor sem egyezik meg az amortizált bekerülési értékkel, így a két összeg között egy kezdeti valós érték különbözet - nyereség, vagy veszteség - keletkezik. E különbözet mindenképp az eredményben jelenítendő meg, ám ennek időzítése a valós érték meghatározásához használ inputok szintjétől függ. 1. és 2 . szintű inputok esetén a különbözet a keletkezés időpontjában megjelenítendő az eredményben, míg 3. szintű inputok alkalmazásakor azt a futamidő alatt szisztematikusan kell realizálni. A szisztematikus realizálás egyszerű módja lehet az időarányos elszámolás, ám véleményünk szerint jobb választás - kivitelezhetőség esetén - az effektív kamattal arányos elszámolás. (IFRS 9, B5.2.1- B5.2.2.)

\subsubsection{A pénzügyi instrumentumok besorolására vonatkozó elöírások}

Az, hogy az egyes pénzügyi eszközökre az elöző fejezetekben megismert értékelési elvek közül melyik alkalmazandó, az alábbi logika mentén ragadható meg.

\begin{tabular}{|c|c|c|c|c|c|}
\hline \multirow{2}{*}{} & \multicolumn{4}{|c|}{ Adósságinstrumentum } & \multicolumn{2}{c|}{ Tókeinstrumentum } \\
\cline { 2 - 6 } & \multicolumn{3}{|c|}{ Igenzköz } & Nem \\
\hline SPPI teszt & \multicolumn{3}{|c|}{$\begin{array}{c}\text { Nözleti modell } \\
\text { Tóke és kamat } \\
\text { Tóke és kamat } \\
\text { beszedése } \\
\text { beszedése, valamint } \\
\text { értékesités }\end{array}$} & Egyéb & Döntés van \\
\hline Értékelési elv & ABÉ & FVTOCl & \multicolumn{2}{|c|}{ FVTPL } & FVTOCI \\
\hline
\end{tabular}

3. táblázat: Pénzügyi eszközök besorolása és értékelése Forrás: Saját készités, IFRS 9 alapján

A fenti táblázat nem a standard szó szerinti besorolási logikáját, hanem annak gyakorlati leképezését tükrözi, hiszen az SPPI teszt a tőkeinstrumentumok esetében nem értelmezhető. A táblázat nem tartalmazza a származékos ügyletekből származó eszközöket, melyek eredménnyel szemben valósan értékelendők.

A besorolás első lépése annak eldöntése, hogy adósság-, vagy tőkeinstrumentumról van-e szó. Amennyiben az instrumentum összetett, meg kell határozni az adósságinstrumentum és a tőkeinstrumentum elkülönített értékét.

$\mathrm{Az}$ adósságinstrumentumok esetében az SPPI teszt során vizsgálni kell, hogy a szerződéses pénzáramok ténylegesen csak a tőkét és annak kamatait fedik-e le, vagy tartalmaznak valamilyen más elemet, kockázatot, netán extra vo- 
latilitást, amit a kamat nem tartalmazhat. Kamatnak csak az a pénzáram számít, ami a pénz időértékén kívül csak a hitel- és likviditási kockázatra, a hitelhez kötődő költségekre és a hitelnyújtó hasznára nyújtanak fedezetet. A standard tipikus - és Magyarországon gyakran előforduló - példái közé tartozik a tőkeösszeg devizanemétől eltérő devizához kötött kamatozás, az olyan változó kamatozású ügyletek, ahol az átárazódás gyakorisága és az átárazódáskor alkalmazandó kamatláb nincs összhangban egymással, illetve bizonyos konstrukciók, amelyek extra volatilitást visznek a törlesztés összegébe. Az ilyen konstrukciók léte nem feltétlenül jelenti azt, hogy a pénzáramok nem csak kamatot tartalmaznak, de ennek megállapítása további vizsgálatot igényel. Kivétel lehet ez alól az állam által szabályozott kamatláb, amely „a pénz időértékével kapcsolatos elem megfelelöjének tekintendő ... akkor, ha a szabályozott kamatláb az idő múlásának nagyjából megfelelő ellenértéket képvisel, és a szerződéses cash flow-k tekintetében nem képvisel kockázatoknak vagy volatilitásnak való olyan kitettséget, amely inkonzisztens egy alapvető kölcsönmegállapodással." (IFRS 9, B4.1.9E)

Ha az instrumentum az SPPI teszten megfelelt, a következő lépés az üzleti modell meghatározása. Az üzleti modell nem azonos a keletkeztetés, beszerzés céljával, ennek meghatározásához szükséges az eszköz (üzletág, elkülönült portfólió-rész) kezelésének elemzése. Ennek során többek között olyan tényezőket kell figyelembe venni, mint a tényleges események, értékesítés nagyságrendje, gyakorisága, a vezetői jelentések tartalma, vagy akár a felelős vezető teljesítményértékelésének kritériumai. Ennek alapján a következö üzleti modellek és a kapcsolódó értékelési elvek határozhatók meg:

- Ha az üzleti modell a futamidő alatt a tóke és a kamat beszedése a modell, az amortizált bekerülési érték alkalmazandó ${ }^{16}$.

- Ha az üzleti modell a tőke és a kamat beszedésén kívül az értékesités lehetőségét is tartalmazza, akkor a saját tőkével szembeni valós értékelés követendő.

- Bármely egyéb üzleti modell - pl. kereskedési portfólió esetén - az eredménnyel szembeni valós értékelés követendő.

16 A hitelintézetek hosszú távra nyújtott kölcsönei jellemzően ebbe a kategóriába tartoznak, de az értékpapir-portfóliónak is lehet ilyen - gyakran éppen a hitelek futamidejének függvényében tartott - része. 
A tőkeinstrumentumok esetén a gazdálkodó visszavonhatatlanul dönthet úgy, hogy a valós érték változást nem az eredménnyel, hanem a saját tőkével szemben kívánja kimutatni. E választás hátterét a standard mélyebben nem határozza meg, ám kereskedési cél és üzleti kombinációhoz kötődő függő ellenérték esetén nem engedi azt.

A pénzügyi kötelezettségek esetén az alapvető értékelési elv az amortizált bekerülési érték, de a származékos ügyletek miatti, valamint a kereskedési célú kötelezettségeket eredménnyel szembeni valós értéken kell értékelni, és lehetőség van a valós értékelés választására egyéb esetekben is.

\subsubsection{Fedezeti ügyletek}

A fedezeti ügyletek megkötésével a gazdálkodó célja, hogy a különféle (deviza-, kamatláb-, likviditási) kockázatokat kivédje, azaz a fedezett és a fedezeti ügyletek kockázatai egymást semlegesítsék. Számviteli következményeként pedig eredményhatásuk egymással ellentétes lesz és ugyanabban az időszakban és eredménykategóriában jelenik meg. A fedezeti ügylet létrejöhet cash-flow fedezeti, valós érték-fedezeti ügyletként, vagy külföldi nettó befektetések értékváltozásának ellentételezésére.

Fedezett tétel lehet megjelenített eszköz vagy kötelezettség, meg nem jelenített biztos elkötelezettség, elörejelzett nagyon valószínű ügylet, ezek csoportja, vagy ezek kombinációja valamely származékos termékkel. A fedezett tétel általában a teljes tétel, vagy annak bizonyos komponense.

A fedezeti instrumentum általában származékos termék, eredménnyel szemben valósan értékelt nem származékos pénzügyi eszköz vagy kötelezettség. Fedezeti instrumentum általában a teljes instrumentum, de lehet több instrumentum együttesen, vagy akár ezek arányos része is.

A fedezeti ügyletek ekként való elszámolásának feltétele, hogy mind a fedezett, mind a fedezeti instrumentumok megfeleljenek a kritériumoknak és a hitelintézet elkészítse a formális dokumentációt, amely bizonyítja, hogy az ügylet a kockázatkezelési célokkal és stratégiával összhangban jött létre.

A fedezeti elszámolás fő kritériuma annak bizonyítása, hogy a fedezés hatékony, azaz megfelelően semlegesíti a fedezni kívánt kockázatot. A hatékonyság dokumentálása során bizonyítani kell, hogy a fedezett és a fedezeti tételek között 
gazdasági kapcsolat van, ez a kapcsolat a tételek teljes élettartama alatt fennáll és az értékváltozásban a hitelkockázat nem tölt be domináns szerepet. Az IFRS 9 az elöretekintő hatékonyságvizsgálatot írja elö, amely alapulhat a kulcsfontosságú jellemzők elemzésén, vagy különféle kvantitatív módszerek alkalmazásán.

A valós érték fedezeti ügyletek teljes eredményhatása az eredménykimutatásban jelenítendő meg, míg a másik két típus esetén itt csak a nem hatékony rész hatása jelentkezhet, a hatékony rész eredményhatása a saját tőkében jelenik meg tartalékként.

A bankszektorban előfordulnak a kockázatkezelés fenti módjai, de jellemzőbb az, hogy az intézmény a pénzügyi instrumentum-portfólió kamatlábkockázatára - és nem az egyes ügyletekre - köt fedezeti ügyletet. Ezt a hitelintézet - mivel az IFRS 9 erre vonatkozóan nem tartalmaz elöírást - még az IAS 39 standard alapján teheti meg. Az ilyen ügyletek valós érték fedezeti ügyletekként kezelendők, a fedezett portfólió tartalma szabadon meghatározható, így eszközt és kötelezettséget is tartalmazhat, ám minden elemnek önmagában is fedezeti ügyletként megjelölhetőnek kell lennie. Nettó pozíció - az eszközök és kötelezettségek különbsége - nem jelölhető meg fedezett tételként, de ez kiküszöbölhető azzal, hogy a magasabb értékű portfóliónak a nettó pozíció összegével azonos részét jelölik meg. Kijelölendö a fedezni kívánt kamatlábkockázat, valamint a fedezeti instrumentum, ami átárazódási periódusonként eltérő lehet. A makrofedezeti ügyletek eredményhatása az eredménykimutatásban jelenik meg.

\subsubsection{Magyar sajátosságok következményei}

A hazai sajátosságok egy jelentős része az amortizált bekerülési értéken történő értékelést megalapozó SPPI teszt kapcsán merül fel. A hitelkonstrukciók egyes fajtáinál ugyanis nem állnak fenn az SPPI teszt követelményei, vagy csak külön tesztekkel lehet igazolni a megfelelést. Ez leggyakrabban az állam által meghatározott támogatási célú hitelek esetében fordul elö, pl. energiatakarékossági támogatásoknál gyakoriak a forintban denominált, de euriborhoz kötött változó kamatozású hitelek, míg a lakhatási támogatások esetén az extra volatilitást eredményező (pl. CSOK-hitel) ügylettípusok.

A valós értékelés alapjait bemutató fejezet végén szó volt kezdeti valós érték különbözet elszámolásának lehetséges módjairól, ám azt nem vizsgáltuk, hogy mi lehet ezen eltérés oka. A hazai viszonyok között az egyik igen gyakori ok a 
kapott állami támogatás, amikor a refinanszírozási források árazása a piacinál kedvezőbb feltételek mentén - akár kamatmentesen ${ }^{17}$ - történik. Ekkor a fizetendő kamatok realizálása a piaci kamatlábon alapuló amortizált bekerülési érték mentén történik, a különbözet pedig nem más, mint a kapott állami támogatás.

Az állami támogatások az IAS 20 standardban foglalt szabályok szerint akkor realizálandók az eredményben, amikor észszerüen bizonyossá válik, hogy a gazdálkodó egység teljesíti a támogatás feltételeit és a támogatást meg fogja kapni. Jelen esetben a feltételek jellemzően a futamidő alatt időszakról időszakra teljesülnek, így a piaci kamatok meg nem fizetése miatt a kamatkülönbözet öszszegével azonos támogatás minden időszakban realizálható.

Amennyiben a támogatás összegét a gazdálkodó ugyan rendszeresen megkapja, ám a feltételek teljesítése és az ésszerü bizonyosság csak később igazolódik be, a kapott összeg kötelezettségként mutatandó ki, eredményben való realizálása nem az alapul szolgáló pénzügyi instrumentum futamidejétől, hanem a feltételek teljesítésének valószínűségétől függ ${ }^{18}$.

A legjobb becslés ellenére is előfordulhat, hogy a már realizált támogatást vissza kell fizetni, mert a feltételek mégsem teljesültek. Ebben az esetben visszamenőleges módosításra nincs szükség, az elszámolást becslésmódosításként kell kezelni, és az aktuális időszakban kell a könyvekben megjeleníteni. (Lakatos et al., 2018, p. 294)

Az állami támogatások kimutatására a standard bruttó és nettó módon is lehetőséget nyújt, ez utóbbi esetben a kapott támogatás önálló módon nem jelenik meg. Az ismertetett esetekben bevétel helyett a kamatráfordítások csökkenéseként mutatandó be.

A gyakorlatban olyan ügyletek is előfordulhatnak, amik együttesen értelmezhetők. Amennyiben pl. a bank a felvett kedvezményes forintban denominált hitel

17 Ilyen lehettek pl. a Növekedési Hitel Program keretében az MNB által nyújtott nulla \%-os kamatozású refinanszírozási hitelek. Ekkor a teljes kamatráfordítás állami támogatásnak minősül. Hasonlóan a futamidő alatt kapott és további feltétel nélküli támogatásnak minősülhet az MNB-nél elhelyezhetö preferenciális betét, melynek kamata meghaladja a normál piaci kamatokat.

18 E körbe tartozhatnak a HIRS termékek, ahol az ügylet természetéböl kifolyólag évente kétszer megtörtént a kamatok pénzügyi rendezése, ám a kedvezmény összege csak akkor vált végleges támogatássá, amikor a hitelintézet a feltételeket - kihelyezések megfelelö mértékü növelése teljesitette. 
mellé egy devizaswap ügyletet kö $\mathrm{t}^{19}$, az - a feltételek fennállása esetén - számára egy devizában felvett hitellel egyenértékü. Ebben az esetben a tényleges gazdasági tartalmú ügylet - a deviza refinanszírozási hitel - könyvelendő, de felmerülhet a valós érték fedezeti ügyletként való kezelés is. (MKVK PTPT, 2016.)

$\mathrm{Az}$ itt bemutatott példák esetén felmerül annak kérdése is, hogy mennyire tükrözi a gazdasági tartalmat az ügyletek önmagában való minősítése, besorolása, hiszen az esetek többségében a bank csak közvetítő szerepet tölt be az állam és a kölcsön felvevője közöt $\mathrm{t}^{20}$, ezért a tényleges megoldások mélyebb elemzést követelnek meg.

\subsubsection{Közzétételi kötelezettségek}

A kötelező közzétételi kötelezettségek rögzítésének célja, hogy a gazdálkodó mindenképp bemutassa a pénzügyi instrumentumok jelentőségét a bank vagyoni és jövedelmi helyzete szempontjából, láthatóvá tegye a kockázatokat, azok mértékét, jellegét, alakulását. E közzétételek közül csak a legfontosabbakat mutatjuk be.

A közzététel általános követelményei szerint be kell mutatni a számviteli politika főbb elemeit, a fedezeti elszámoláshoz kötődő információkat, valamint a valós érték meghatározását. A mérleghez kötődően többek között bemutatandók a pénzügyi instrumentumok értékelési kategóriánként aszerint elkülönítve, hogy a kategóriába kerülés a standard alapján kötelező vagy választható módon dőlt-e el, valamint a pénzügyi eszközök hitelezési veszteségeinek az alakulása, ugyanezen kategóriák mentén.

Az eredménnyel szemben valósan értékelt eszközök esetén bemutatandó a maximális hitelkockázati kitettség, valamint az ennek csökkentésére alkalmazott derivatívák hatása, ennek változása, hitelkockázat változásának összesített hatása, valamint az eredménnyel szemben valósan értékelt kötelezettségek saját tőkében kimutatott hitelkockázat változásának kumulált összege, a könyv szerinti érték és a fizetendő összeg különbsége, valamint a saját tőkében történt átsorolások és ezek indoka, valamint annak bemutatása, hogy hogyan történt a saját hitelkockázat elkülönítése. Az IFRS 9 szabályai alapján az értékelési kategóriák közötti átsorolás nagyon ritka, ezért ezek megtörténtét és hatásait is közzé kell tenni.

19 Ide tartoznak az NHP hitelek mellé az MNB-vel köthető CCIRS ügyletek.

20 Az NHP hitelek esetén a bank a nulla százalékos kamatú refinanszírozási hitellel az ügyfeleinek nyújtott hitel kedvezményes - maximum 2,5\%-os - kamatát biztosítja, így az állami támogatást a valóságban nem ö, hanem ügyfele kapja meg. 
Az eredménykimutatáshoz kötődően a mérlegben szereplő kategóriákkal azonos bontásban kell bemutatni a pénzügyi instrumentumok nettó eredményét, így a kamatbevételeket és kamatráfordításokat, a kamatban nem szereplö dijbevételeket és -ráfordításokat, az értékvesztett eszközök kamatbevételét, az értékvesztés miatti veszteséget, valamint az amortizált bekerülési értéken szereplö pénzügyi eszközök kivezetésének eredményhatását is.

A valós értékhez kötődően bemutatandó az instrumentumok időszak végi valós értéke az inputok szintje alapján, valamint az esetleges átsorolások és azok indoka. Ismertetni kell az alkalmazott értékelési eljárásokat, folyamatokat, valamint a 3. szintü inputok esetén a nem megfigyelhető inputokat, a záróérték levezetését, a szöveges és számszerű érzékenységvizsgálat eredményét.

A pénzügyi eszközök átadásához kötődően be kell mutatni a teljesen és részlegesen kivezetett, valamint a folytatódó részvétel miatti eszközöket, és kötelezettségeket. Az átadás előtti és utáni könyv szerinti értéken, valamint az elszámolt eredménytételeken kívül közzé kell tenni, hogy a hitelintézet milyen kockázatokat adott át és tartott meg.

A hitelintézetek számára a fenti - a beszámoló egyes tételeinek különféle szempontok szerinti alábontását tartalmazó - közzétételek mellett jelentős szerepe van a pénzügyi instrumentumok kockázatainak és ezen kockázatok kezelésének bemutatásával foglalkozó közzétételeknek.

E közzétételek kvalitatív részében be kell mutatni a kockázati kitettségeket, a kockázatkezeléssel kapcsolatos célokat, politikákat és eljárásokat, valamint a bekövetkezett változásokat.

A kockázatok számszerűen is közzéteendők, így a hitelintézeteknek be kell mutatniuk a kockázati kitettség összegét, az egyes kockázattípusok sajátos tulajdonságait, valamint a kockázat koncentrációját. A számszaki bemutatás tartalmazza a hitelkockázat-kezelési gyakorlat összefüggését az értékvesztés és céltartalék-képzéssel, a gazdálkodó saját szabályait az értékvesztési státuszok közötti átsorolásra, az egyedi és csoportos képzés hatókörére és módszertanára vonatkozóan. Be kell mutatni a behajthatatlan követelések definícióját és az értékvesztés számszerűsítésére alkalmazott módszereket, valamint a hitelkockázatot a biztosítékok figyelembevétele nélkül és azzal csökkentve is. 
A likviditási kockázatot tükröző számszaki részben bemutatandó a nem származékos és származékos ügyletek lejárati struktúrája, a kötelezettségek lejárati struktúrája, a likviditási kockázat kezelésének módja. A lejárati összhangot a jövőbeni pénzáramok diszkontálatlan értéke alapján kell előre jelezni.

A piaci kockázat érzékeltetésére közzé kell tenni az érzékenységvizsgálatok eredményét az üzleti tevékenység egészére, azok eredményre és saját tőkére gyakorolt hatásaival együtt. Ismertetni kell a kockázati tényezőket és azok várható következményeit is.

\subsection{Függelékek}

\subsubsection{Azonos jelentéssel használt kifejezések és rövidítések}

\subsubsection{Szinonimák}

- beszámoló - pénzügyi kimutatások

- mérleg - pénzügyi helyzet kimutatás

- kiegészítő melléklet - kiegészítő megjegyzések

\subsubsection{Röviditések}

IFRS-ek = International Financial Reporting Standards = a nemzetközi számviteli standardok alkalmazásáról szóló, 2002. július 19-i 1606/2002/EK európai parlamenti és tanácsi rendeletben foglalt eljárás alapján az Európai Unió Hivatalos Lapjában rendeleti formában kihirdetett nemzetközi számviteli standardok (Sztv., 3.\$ (10) 2.)

$\mathrm{PNL}=\mathrm{P} \& \mathrm{~L}=$ Profit and loss statement $=$ eredménykimutatás

FVTOCI $=$ FVOCI $=$ Fair Value to Other Comprehensive Income $=$ Egyéb átfogó jövedelemmel szemben elszámolt valós érték

FVTPNL $=$ FVPNL $=$ Fair Value to Profit and Loss $=$ Eredménnyel szemben elszámolt valós érték

$\mathrm{CF}=$ Cash Flow

$\mathrm{OCI}=$ Other Comprehensive Income $=$ Egyéb átfogó jövedelem

SOCIE $=$ Statement of Changes in Equity $=$ Saját tőke változás tábla

SPPI $=$ Solely Payment of Principal and Interest $=$ Csak kamat- és tőke fizetést tartalmazó pénzáramok

Sztv. =2000. évi C. törvény a számvitelről 
Hpt. = 2013. évi CCXXXVII. törvény a hitelintézetekröl és a pénzügyi vállalkozásokról

EPS $=$ Earnings per Share $=$ egy részvényre jutó nettó eredmény

POCI $=$ Purchased or Originated Credit Impaired asset $=$ Vásárolt, vagy a gazdálkodó által keletkeztetett értékvesztett eszközök

\subsubsection{A számviteli kormányrendelet szerinti mérlegséma}

\begin{tabular}{|c|c|}
\hline ESZKÖZÖK (aktívák) & FORRÁSOK (passzívák) \\
\hline 1. Pénzeszközök & 1. Hitelintézetekkel szembeni kötelezettségek \\
\hline 2. Állampapírok & $\begin{array}{l}\text { 1/A. Hitelintézetekkel szembeni kötelezettségek értékelési } \\
\text { különbözete }\end{array}$ \\
\hline 2/A. Állampapírok értékelési különbözete & 2. Ügyfelekkel szembeni kötelezettségek \\
\hline 3. Hitelintézetekkel szembeni követelések & $\begin{array}{l}\text { 2/A. Ügyfelekkel szembeni kötelezettségek értékelési } \\
\text { különbözete }\end{array}$ \\
\hline 3/A. Hitelintézetekkel szembeni követelések értékelési különbözete & 3. Kibocsátott értékpapírok miatt fennálló kötelezettség \\
\hline 4. Ügyfelekkel szembeni követelések & 4. Egyéb kötelezettségek \\
\hline 4/A. Ügyfelekkel szembeni követelések értékelési különbözete & 4/A. Származékos ügyletek negatív értékelési különbözete \\
\hline 5. Hitelviszonyt megtestesítő értékpapírok & 5. Passzív idóbeli elhatárolások \\
\hline 5/A. Hitelviszonyt megtestesítő értékpapírok értékelési különbözete & 6. Céltartalékok \\
\hline 6. Részvények és más változó hozamú értékpapírok & 7. Hátrasorolt kötelezettségek \\
\hline $\begin{array}{l}\text { 6/A. Részvények és más változó hozamú értékpapírok értékelési } \\
\text { különbözete }\end{array}$ & 8. Jegyzett tőke \\
\hline 7. Részvények, részesedések befektetési célra & 9. Jegyzett, de még be nem fizetett tőke (-) \\
\hline 7/A. Befektetési célú részvények, részesedések értékelési különbözete & 10. Tőketartalék \\
\hline 8. Részvények, részesedések kapcsolt vállalkozásban & 11. Általános tartalék \\
\hline 9. Immateriális javak & 12. Eredménytartalék ( \pm ) \\
\hline 10. Tárgyi eszközök & 13. Lekötött tartalék \\
\hline 11. Saját részvények & 14. Értékelési tartalék \\
\hline 12. Egyéb eszközök & 15. Tárgyévi eredmény ( \pm ) \\
\hline \multicolumn{2}{|l|}{ 12/B. Származékos ügyletek pozitív értékelési különbözete } \\
\hline \multicolumn{2}{|l|}{ 13. Aktív időbeli elhatárolások } \\
\hline Eszközök összesen & Források összesen \\
\hline Ebből: & Ebből: \\
\hline - FORGÓESZKÖZÖK & - RÖVID LEJÁRATÚ KÖTELEZETTSÉGEK \\
\hline \multirow[t]{2}{*}{ - BEFEKTETETT ESZKÖZÖK } & - HOSSZÚ LEJÁRATÚ KÖTELEZETTSÉGEK \\
\hline & - SAJÁT TŐKE \\
\hline
\end{tabular}




\subsubsection{A számviteli kormányrendelet szerinti eredménykimutatás felépítése}

\section{EREDMÉNYKIMUTATÁS}

1. Kapott kamatok és kamat jellegú bevételek

2. Fizetett kamatok és kamat jellegü ráfordítások

\section{KAMATKÜLÖNBÖZET (1-2)}

3. Bevételek értékpapírokból

4. Kapott (járó) jutalék- és díjbevételek

5. Fizetett (fizetendő) jutalék- és dijjáfordítások

6. Pénzügyi múveletek nettó eredménye

7. Egyéb bevételek üzleti tevékenységből

8. Általános igazgatási költségek

9. Értékcsökkenési leírás

10. Egyéb ráfordítások üzleti tevékenységből

11. Értékvesztés követelések után és kockázati céltartalék-képzés a függő és biztos (jövőbeni) kötelezettségekre

12. Értékvesztés visszairása követelések után és kockázati céltartalék felhasználása a függő és biztos (jövőbeni) kötelezettségekre

12/A. Általános kockázati céltartalék felhasználás értéke

13. Értékvesztés a befektetési célú, hitelviszonyt megtestesitő értékpapírok, kapcsolt-, jelentős tulajdoni részesedési és egyéb részesedési viszonyban lévő vállalkozásban való részvények, részesedések után

14. Értékvesztés visszairása a befektetési célú, hitelviszonyt megtestesíto értékpapírok, kapcsolt-, jelentős tulajdoni részesedési és egyéb részesedési viszonyban lévő vállalkozásban való részvények, részesedések után

\section{Szokásos (üzleti) tevékenység eredménye}

Ebből: - PÉNZÜGYI ÉS BEFEKTETÉSI SZOLGÁLTATÁS EREDMÉNYE

- NEM PÉNZÜGYI ÉS BEFEKTETÉSI SZOLGÁLTATÁS EREDMÉNYE

16. Rendkívüli bevételek

17. Rendkívüli ráfordítások

\section{Rendkívüli eredmény (16-17)}

19. Adózás előtti eredmény $( \pm 15 \pm 18)$

20. Adófizetési kötelezettség

\section{Adózott eredmény $( \pm 19-20)$}

22. Általános tartalékképzés, felhasználás ( \pm )

\section{Tárgyévi eredmény (21-22)}




\subsubsection{Egy lehetséges IFRS szerinti bankmérleg}

\begin{tabular}{|l|l|}
\hline \multicolumn{1}{|c|}{ ESzKözöK (aktívák) } & \multicolumn{1}{c|}{ FORRÁsOK (passzivák) } \\
\hline Pénzeszközök & Hitelintézetekkel és állammal szembeni kötelezettségek \\
\hline Bankközi kihelyezések & Ügyfélbetétek \\
\hline Ügyfélhitelek & Kibocsátott értékpapírok \\
\hline $\begin{array}{l}\text { Egyéb átfogó jövedelemmel szemben valósan értékelt } \\
\text { pénzügyi eszközök }\end{array}$ & $\begin{array}{l}\text { Eredménnyel szemben valósan értékeltként megjelölt } \\
\text { pénzügyi kötelezettségek }\end{array}$ \\
\hline Eredménnyel szemben valósan értékelt pénzügyi eszközök & Kereskedési célú származékos ügyletek kötelezettségei \\
\hline Kereskedési célú származékos ügyletek eszközei & Fedezeti célú származékos ügyletek kötelezettségei \\
\hline Fedezeti célú származékos ügyletek eszközei & Egyéb kötelezettségek \\
\hline Befektetések & Alárendelt kölcsöntőke \\
\hline Befektetések társultt és közös vállalkozásokban & Kötelezettségek összesen \\
\hline Tárgyi eszközök & Jegyzett tőke \\
\hline Immateriális javak & Eredménytartalék és más tartalékok \\
\hline Halasztott adó követelések & Halmozott egyéb átfogó jövedelem \\
\hline Egyéb eszközök & Visszavásárolt saját részvények \\
\hline & Saját tóke összesen \\
\hline Eszközök összesen & Kötelezettségek és saját tőke összesen \\
\hline & \\
\hline
\end{tabular}




\subsubsection{Az Átfogó jövedelemkimutatás egy lehetséges felépítése}

\section{EREDMÉNYKIMUTATÁS \\ Kapott kamatok és kamat jellegú bevételek \\ Fizetett kamatok és kamat jellegú ráfordítások}

\section{KAMATKÜLÖNBÖZET (Nettó kamatbevétel)}

Értékvesztés képzés/visszaírás a hitelezési veszteségekre

\section{Nettó kamatbevétel értékvesztés után}

Amortizált bekerülési értéken nyilvántartott pénzügyi eszközök kivezetéséből származó nettó eredmény

Nettó jutalék és díj eredmény

Pénzügyi múveletek nettó eredménye

Adminisztratív költségek

Tőkemódszerrel konszolidált vállalkozásokból származó eredmény

Adózás előtti eredmény

Nyereségadó

Nettó (Adózott) eredmény

- $\quad$ ebből az anyavállalat tulajdonosainak járó eredmény

- $\quad$ ebböl a nem kontrolláló érdekeltségre jutó eredmény

\section{Egy részvényre jutó eredmény}

- alap

- $\quad$ hígított

\section{EGYÉB ÁTFOGÓ JÖVEDELEM-KIMUTATÁS}

\section{A jövöben az egyéb átfogó jövedelemböl az eredményben realizálható tételek}

Egyéb átfogó eredménnyel szemben értékelt adósságinstrumentumok tárgyévi valós érték különbözete

Egyéb átfogó eredménnyel szemben értékelt adósságinstrumentumok tárgyévi valós érték különbözetének halasztott adója

Cash Flow fedezeti ügyletek

\section{Ajövöben az egyéb átfogó jövedelemböl az eredményben NEM realizálható tételek}

Egyéb átfogó eredménnyel szemben értékelt tőkeinstrumentumok tárgyévi valós érték különbözete

Egyéb átfogó eredménnyel szemben értékelt tőkeinstrumentumok tárgyévi valós érték különbözetének halasztott adója

Egyéb átfogó jövedelem

Nettó átfogó eredmény 


\subsection{Irodalomjegyzék}

2000. évi C. törvény a számvitelről - https://net.jogtar.hu/jogszabaly?docid=A0000100.TV utolsó letöltés időpontja: 2019. március 11.

2013. évi CCXXXVII. törvény a hitelintézetekről és a pénzügyi vállalkozásokról - https://net.jogtar.hu/jogszabaly?docid=A1300237.TV, utolsó letöltés időpontja: 2019. március 11.

2013. évi V. törvény a Polgári Törvénykönyvről, 6:46. \$ https://net.jogtar.hu/jogszabaly?docid=A1300005.TV, utolsó letöltés: 2019. március 24.

250/2000. (XII. 24.) Korm. rendelet a hitelintézetek és a pénzügyi vállalkozások éves beszámoló készítési és könyvvezetési kötelezettségének sajátosságairól, https://net.jogtar.hu/jogszabaly?docid=A0000250.KOR utolsó letöltés idöpontja: 2019. március 11.

39/2016. (X. 11.) MNB rendelet a nem teljesítő kitettségre és az átstrukturált követelésre vonatkozó prudenciális követelményekről, http://njt.hu/njtlink.php?njtcp=ee6eg 1ed8em7er2ei5dx8cj9cy0bm7dw0eh3dv0eb9dw8cj1bx4cf9cd6cd1cb6cb7bm8en7dv8eh7dw2dx9cj2by3f utolsó letöltés: 2019. március 31 .

40/2016. (X. 11.) MNB rendelet az ügyfél- és partnerminősítés, valamint a fedezetértékelés prudenciális követelményeiről, http://njt.hu/njtlink.php?njtcp=ee1eg8ed7em6er5ei0dx5cj0cy9bm0dw7eh4dv9eb2dw1cj2bx7cf2cd3cd6cb7cc2bm5en8dv1eh0dw7dx2cj3by8g, utolsó letöltés: 2019. március 31.

A BIZOTTSÁG 1126/2008/EK RENDELETE (2008. november 3.) az 1606/2002/

EK európai parlamenti és tanácsi rendelettel összhangban egyes nemzetközi számviteli standardok elfogadásáról (EGT-vonatkozású szöveg), https://eurlex.europa.eu/legal-content/HU/TXT/?uri=celex:32008R1126, utolsó letöltés: 2019. március 25.

IFRS 9 - Financial Instruments, A BIZOTTSÁG (EU) 2016/2067 RENDELETE (2016. november 22.) az 1606/2002/EK európai parlamenti és tanácsi rendelettel összhangban egyes nemzetközi számviteli standardok elfogadásáról szóló 1126/2008/EK rendeletnek az IFRS 9 nemzetközi pénzügyi beszámolási standard tekintetében történő módosításáról (EGT-vonatkozású szöveg), https://eur-lex.europa.eu/legal-content/HU/TXT/?uri=CELEX\%3A32016R2067 2019. március 23. 
IFRS 9 for banks - Illustrative disclosures - https://inform.pwc.com/?action=informContent\&id=1758231802155468, utolsó letöltés: 2019 . március 23.

Lakatos László Péter - Kovács Dániel Máté - Mohl Gergely - Rózsa Ildikó - Madarasiné Szirmai Andrea (2018): A Nemzetközi Pénzügyi Beszámolási Standardok elmélete és gyakorlata. Magyar Könyvvizsgálói Kamara, Budapest.

MKVK PTPT: A Pénz- és Tőkepiaci Tagozat tájékoztatása hitelintézeteknél előforduló NHP és PHP hitelezési konstrukciók IFRS szerinti elszámolása kapcsán, 2016. https://www.mkvk.hu/szervezet/tagozatok/ptt/tagozatihirek/Felhivas_NHP_elszamolas_20160401 utolsó letöltés 2019. március 24.

Veres Judit - Gulyás Éva (2008): Bankszámvitel. Budapest: Alinea kiadó. 



\section{II. rész \\ A tőkepiac müködése}




\section{A tőkepiac és a tőzsde}

\subsection{A tökepiac szerepe a gazdaságban}

A pénzügyi rendszernek és azon belül a tőkepiacoknak kiemelt szerepe van a gazdaság fenntartható növekedésében, hiszen a fejlett tőkepiac és tőzsde az innovatív gazdaságok nélkülözhetetlen pillérét adják. Jelen fejezet a tőkepiac elméleti hátterét és működési mechanizmusait a tőzsde - mint a tőkepiac legmeghatározóbb eleme - müködésének keretében mutatja be. Ehhez kapcsolódóan a gazdaság finanszírozási igényét és szerkezetét áttekintve a hitelciklusok velejáróit (hitelezés lassulása, illetve élénkülése) és a gazdaság konjunkturális kihívásait sem hagyja figyelmen kívül. A fejezet a hazai sajátosságokon túl régiós és nemzetközi kitekintésben mutatja be a gazdaságok elmúlt évtizedekben jellemzö finanszírozási sajátosságait, illetve a korábbi válságtanulságok talaján képződő, stratégiai jelentőséggel bíró válsággal szembeni ellenállóképességet növelő eszközöket, intézkedéseket.

A pénzügyi piacon belül két fö piacot különböztetünk meg: a pénzpiacot és a tökepiacot.

Míg a pénzpiacok szereplői a hitelintézetek, pénzügyi vállalkozások és pénzügyi szolgáltatók, amelyek pénzügyi szolgáltatásokat és kiegészítő szolgáltatásokat nyújtanak, addig a tökepiacon befektetési szolgáltatók, brókercégek, a tőzsde és a központi értéktár müködnek, amelyek az értékpapírok (részvények, kötvények, befektetési jegyek) forgalomba hozatalával, tőzsdére történő bevezetésével és kereskedésével foglalkoznak.

Megközelíthetjük a megtakarítások szemszögéből is a pénzügyi piacokat:

A megtakarítások két módon juthatnak el azokhoz, akiknek finanszírozási igényük keletkezik:

- a bankrendszer által (a bankrendszer közvetít a megtakarítók és az adósok között),

- a tőkepiac által (a tőkepiac szereplői megtakarításokat csatornáznak a finanszírozási igénnyel rendelkező szereplők számára). 
A tőkepiacot az is megkülönbözteti a pénzpiactól, hogy általában hosszabb lejáratú (1 éven túli), vagy lejárat nélküli megtakarítási lehetőségek jellemzik müködését, mely egyúttal a bankbetétek kockázati jellemzőitől jelentősen eltér.

A tőkepiac két fö fajtája:

- Elsődleges piac: Itt új értékpapír kibocsátások történnek, amelyek által a pénzügyi megtakarítások közvetlenül jutnak el a megtakarítótól az értékpapír kibocsátójához. A kibocsátásnál megkülönböztethetünk nyílt és zártkörü kibocsátást. Zártkörü esetén a kibocsátó egy előre kiválasztott, többnyire szűk befektetői kört céloz meg, míg a nyílt kibocsátásnál a befektetők egy széles körét célozza meg a kibocsátó, a hirdetések, forgalmazók által minél szélesebb befektetői kör elérése a cél.

- Másodlagos piac: Itt a már kibocsátott értékpapírok kereskedése zajlik. „Másodkézből” lehet az adott értékpapírt megvásárolni, tehát olyan befektetőktől, aki korábban jutott hozzá az értékpapírhoz.

Az aktív másodlagos piac szerepe meghatározó, mivel kiegészíti az elsődleges piac funkcióját is. A másodlagos piac biztosítja az adott értékpapír likviditását. A másodlagos piac lehet OTC (over-the-counter), tehát nem, vagy alig szabályozott; vagy központosított és szabályozott, amely a tőzsdét jelenti.

A tőkepiac főbb szereplőit, és a közöttük lévő kapcsolatot szemléletesen mutatja be a Pénziránytű Alapítvány által kiadott Iránytű a pénzügyekhez tankönyv (Merényi et al., 2016) ábrája:

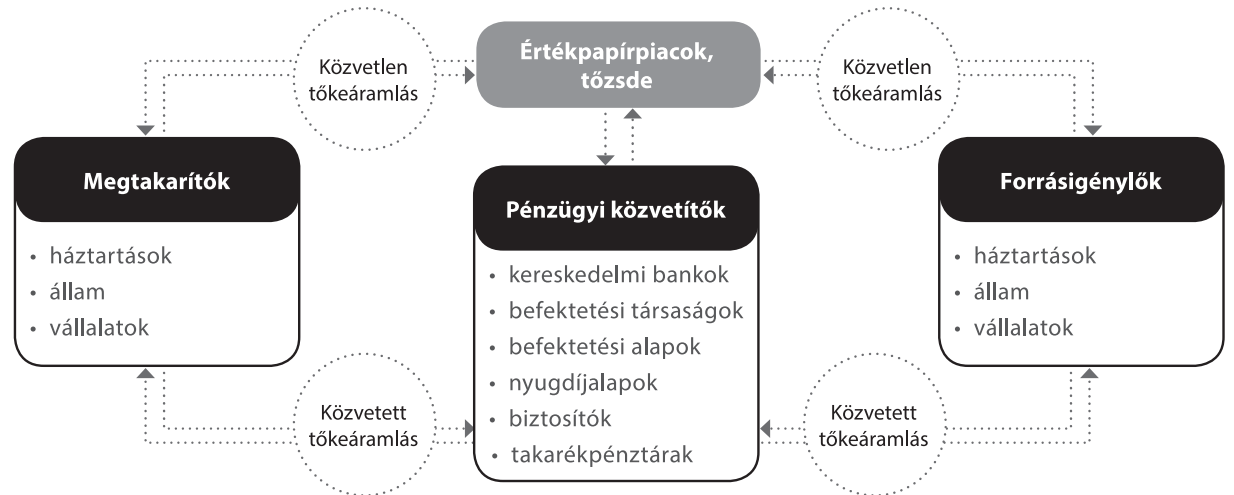

1. ábra: Pénzügyi közvetítés a gazdaságban

Forrás: Merényi et al. (2016) 
A következőkben a tőkepiac szerepét és müködését a Budapesti Értéktőzsde gazdaságösztönzésben és tőkepiac-fejlesztésben betöltött szerepe aspektusában szemléltetjük.

A Budapesti Értéktőzsde (későbbiekben: BÉT) által elfogadott 2016-2020 közötti időszakra vonatkozó stratégia középpontjában a tőkepiacfejlesztés áll: „egy jól működő tőzsde elősegíti a részvény- és kötvényági finanszírozást, ami különösen a hitelezés lassulása idején, a banki hitelezésből kiszoruló vállalatok számára kritikus jelentőségü. A tőzsde megköveteli a vállalatok transzparens működését, ami nagyban hozzájárul a gazdaság kifehéredéséhez." $\mathrm{A}$ tőzsdének fontos szerepe van a szereplők közötti bizalom megteremtésében, amelyet érdemes makrogazdasági dimenzióba helyezni, sikeres tőzsdefejlesztés nem képzelhető el bizalom nélkül: „A növekedéshez helyre kell állítani az állam és az üzleti élet közötti bizalmat. Az üzleti vállalkozások képesek beruházni, munkahelyet teremteni, termelni és adót fizetni, de megrendült a bizalmuk az állam működésében, ezért ma lehetőségeik alatt teljesítenek." - fogalmazta meg Matolcsy György az MNB elnöke még 2010-ben (Matolcsy, 2010). A 2010 óta végrehajtott versenyképességi fordulatok (Matolcsy, 2017a) megteremtették a versenyképességi fordulat eléréséhez szükséges sikeres tőzsdefejlesztés előfeltételeit.

A BÉT által tett meghatározás pontosan definiálja a tőzsde és tágabb értelemben a tőkepiacok szerepét a gazdaságban.

A tökepiacokat olyan pénzügyi piacnak tekinthetjük, amelyek megkönnyítik a tőkebefektetést, lehetővé téve a tőkeemelést a gazdaság finanszírozásához, és támogatják a másodlagos piacon keresztül történő kockázatátadást. A másodlagos piacon eladók és vevők együtt kereskednek részvényekkel, kötvényekkel, derivatívokkal, valutákkal és egyéb pénzügyi eszközökkel. A tőzsdék szabályozott, tiszta és átlátható piacterek, ahol a vállalatok a befektetőknek adott hozamért cserébe tőkéhez jutnak. A tőzsde intézménye biztosítja az infrastruktúrát, és alternatív forrást kínál a banki finanszírozás mellett.

1 https://bet.hu/Rolunk/a-budapesti-ertektozsderol/bet-strategia-2016-2020/betstrategia-2016-2020 
A tőzsdék három fő tevékenység által járulnak hozzá a gazdaság növekedéséhez és a pénzügyi stabilitáshoz:

- Finanszírozás: lehetővé teszik a vállalatok számára, hogy tőkét szerezzenek be a nyilvános piacokon történő jegyzéssel.

- Kereskedés és árképzés: a befektetők számára lehetővé teszi a pénzügyi eszközök átlátható piacon történő megvásárlását és eladását az árképzés kínálatával.

- Kockázatkezelés és pénzügyi stabilitás: a vállalatok és a befektetők számára hozzáférést biztosítanak a kockázatok menedzseléséhez olyan termékek és szolgáltatások által, mint például a derivatívok és elszámolóházak.

\subsubsection{Finanszírozás}

A banki hitelezés és a tőkepiac növekedést támogató szerepe egyértelműen kimutatható (lásd például 4. ábra, Cournede és Denk (2015) alapján). A kontinentális Európában a bankközpontú, fejlett angolszász országokban, jellemzően a tőkepiaci finanszírozás a meghatározó. A hazai vállalatok finanszírozása a kontinentális modellnek megfelelően a bankszektorra koncentrálódik, melyet a 2. és 3. ábrák számszerüsítve is szemléltetnek.

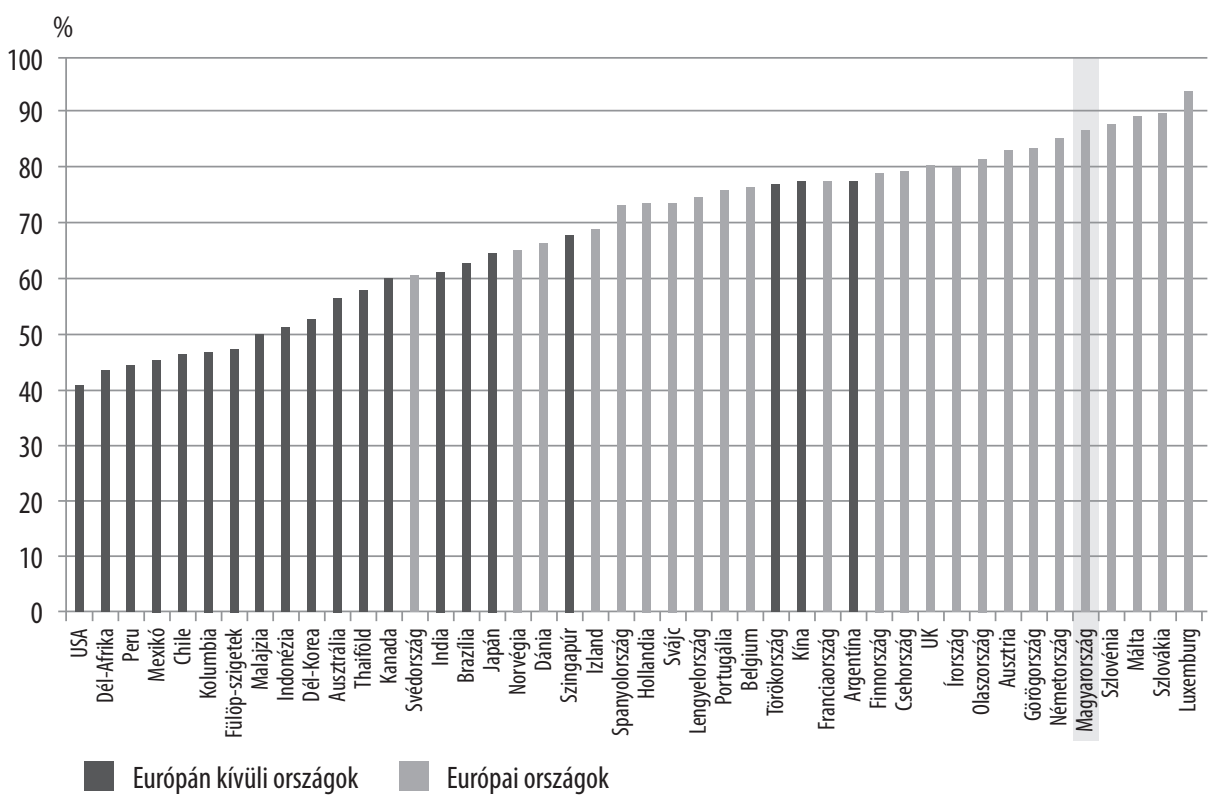

2. ábra: A banki finanszírozás aránya a banki és a piaci finanszírozáson belül nemzetközi összehasonlításban (2011-es adatok alapján)

Forrás: MNB ábra Worldbank és EKB alapján Langfield - Pagano (2015) alapján 


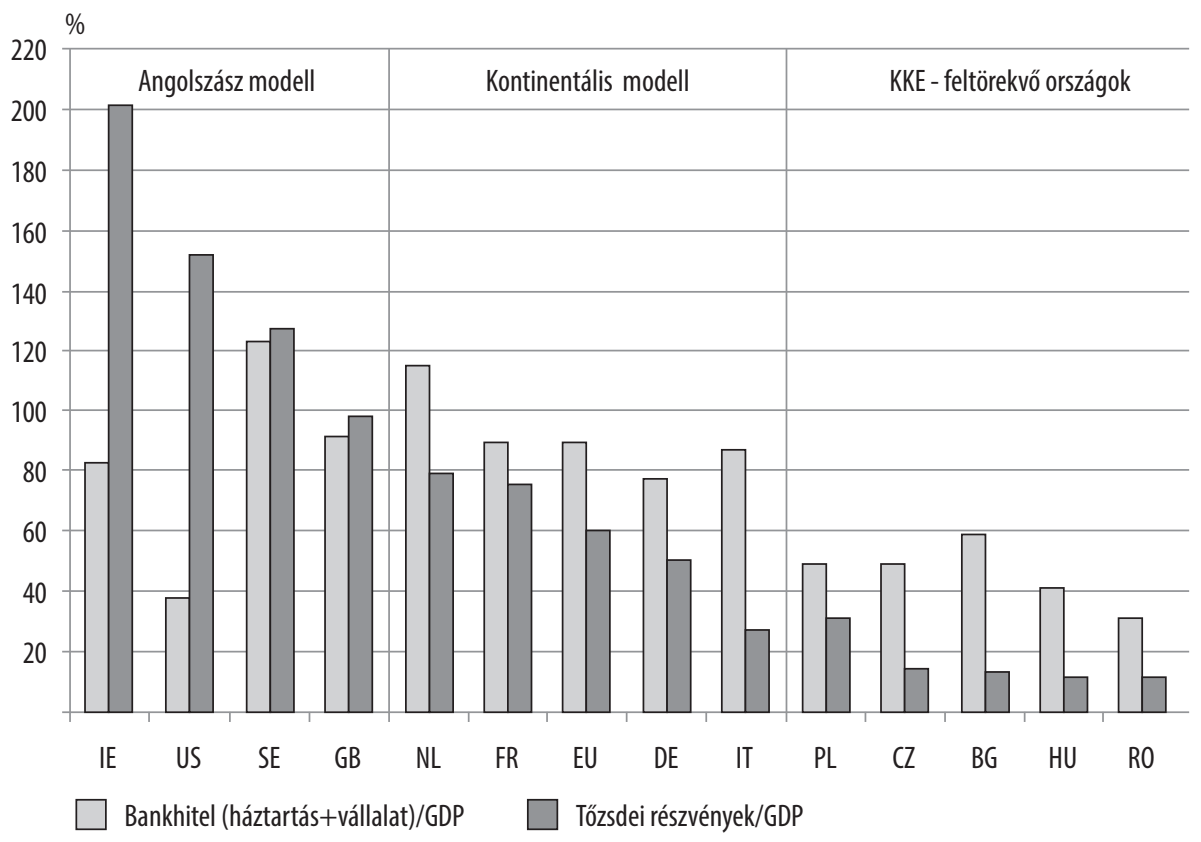

\section{3. ábra: Banki és tőzsdei finanszírozás GDP-hez mért aránya}

Forrás: MNB szerkesztés

Az 1. táblázat is jól mutatja Európa, Ázsia és az Egyesült Államok tőkepiacai közötti különbséget:

\begin{tabular}{|l|l|c|c|c|c|}
\hline & & EURÓPA & EU27 & US & ÁZSIA \\
\hline \multirow{3}{*}{ Elsődleges piac } & Tókeági finanszírozás (GDP \%) & $73 \%$ & $56 \%$ & $147 \%$ & $98 \%$ \\
\cline { 2 - 6 } & Vállalati hitel finanszírozás (GDP \%) & $82 \%$ & $78 \%$ & $114 \%$ & $45 \%$ \\
\hline \multirow{3}{*}{ Másodlagos piac } & Tóke forgási sebessége & $83 \%$ & $96 \%$ & $146 \%$ & $126 \%$ \\
\cline { 2 - 6 } & Tőke forgás (GDP \%) & $60 \%$ & $50 \%$ & $210 \%$ & $120 \%$ \\
\cline { 2 - 6 } & Vállalati hitel forgási sebesség & $25 \%$ & $22 \%$ & $80 \%$ & N/A \\
\cline { 2 - 6 } & Vállalati hitel forgalom (GDP \%) & $20 \%$ & $17 \%$ & $91 \%$ & N/A \\
\hline
\end{tabular}

$\square$ Alacsony $\square$ Közepes $\square$ Magas

\section{1. táblázat: Tőkepiaci statisztikák, 2016}

Forrás: Peterhoff et al. (2017)

A BÉT elemzői által készített 2. táblázat a visegrádi országok Európai Unión belüli makrogazdasági helyzetére világít rá. A V4-ek aránya a teljes EU lakosságához viszonyítva alig haladja meg a 12 százalékot, kevésbé fejlett gazdaságuk GDP-ből vett részaránya ennek mindössze fele, a tőkepiac kapitalizációja pedig kisebb, mint egyhatod részt képvisel. 


\begin{tabular}{|c|c|c|c|c|c|c|c|}
\hline & 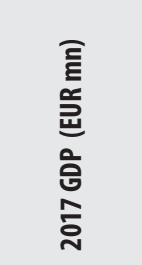 & 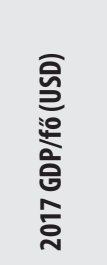 & 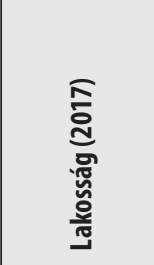 & 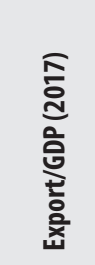 & 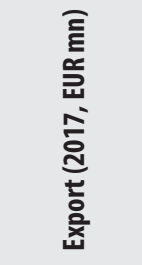 & 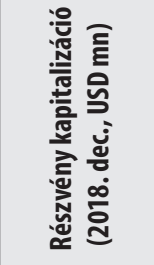 & 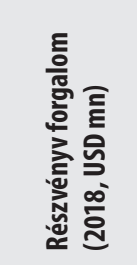 \\
\hline EU & 15383066,1 & 33723,3 & 512461290,0 & $44,71 \%$ & 6877768,85 & 10392858,10 & 8238401,46 \\
\hline Csehország & 191721,8 & 20368,1 & 10591323,0 & $79,45 \%$ & 152322,97 & 27340,25 & 5401,45 \\
\hline Szlovákia & 84850,9 & 17605,0 & 5439892,0 & $82,21 \%$ & 69755,92 & 2801,92 & 7,16 \\
\hline Magyarország & 124050,3 & 14224,9 & 9781127,0 & $90,09 \%$ & 111756,92 & 28944,80 & 10239,40 \\
\hline Lengyelország & 467167,0 & 13863,2 & 37975841,0 & $54,29 \%$ & 253624,96 & 160482,60 & 57037,70 \\
\hline V4 összesen & 867790,0 & & 63788183,0 & & 587460,8 & 219569,6 & 72685,7 \\
\hline V4 aránya & $5,6 \%$ & & $12,4 \%$ & & $8,5 \%$ & $2,1 \%$ & $0,9 \%$ \\
\hline
\end{tabular}

2. táblázat: A V4 országok tőkepiacai

Forrás: BÉT szerkesztés World Bank és Eurostat alapján

A diverzifikált pénzügyi rendszer kiépítése azért is kiemelten fontos, mert egy bizonyos ponton túl a bankrendszer támogató szerepe csökken a növekedésben, a hitelezés akár negatívan is hathat a növekedésre. Pénzügyi válságok esetén a fejlett tőkepiaccal rendelkező országok ellenállóbbak.
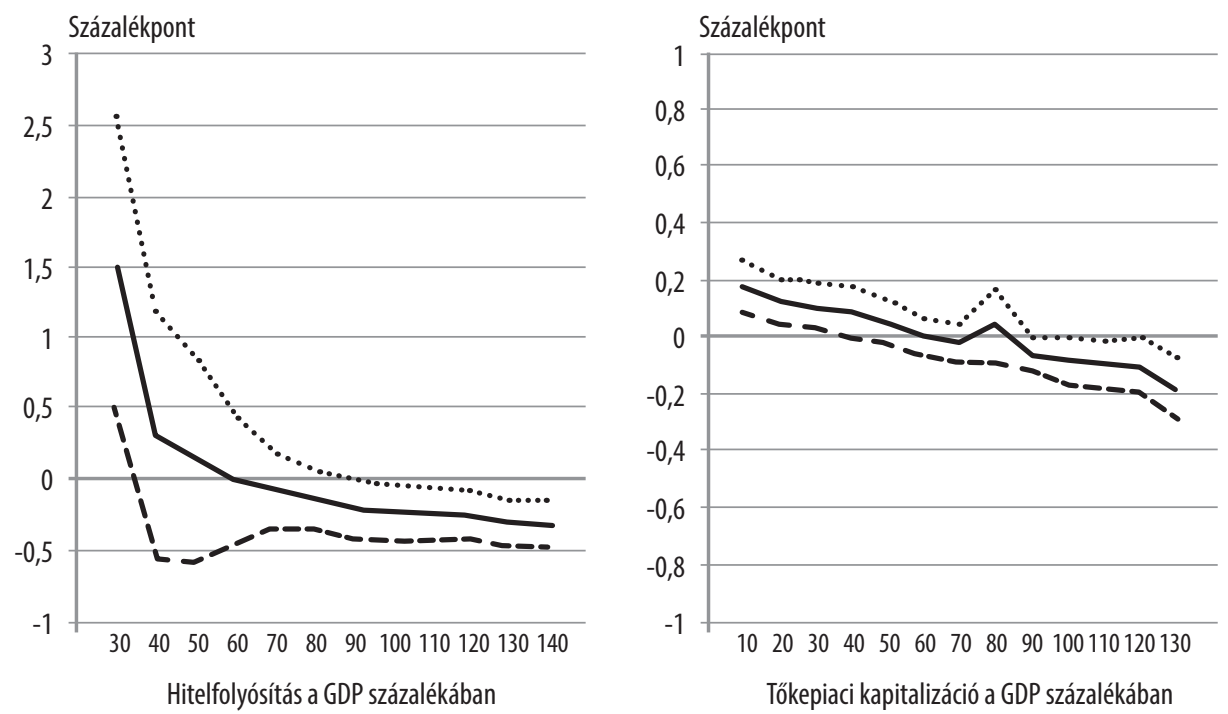

4. ábra: Finanszírozási csatornák hatása az egy főre jutó GDP növekedésre Forrás: MNB, Cournede - Denk (2015) alapján 
Cournede és Denk 2015-ös tanulmánya részletesen vizsgálja az OECD és a G20 országok pénzügyi fejlettsége és a gazdasági növekedés közötti kapcsolatot 1961 és 2011 közötti hosszú idősoron. Megállapításaik közé tartozik, hogy bizonyos szint felett a pénzügyi szektornak negatív hatása lehet a növekedésre, miközben a tőkepiaci fejlettség mindvégig pozitív kapcsolatban áll a növekedéssel. Megállapításaik szerint a GDP mintegy 100 százalékára rugó hitelállomány felett válhat kontraproduktívvá a további aktivitás. A hitelezés elsősorban az alacsony és közepes jövedelmű országoknál javítja a növekedést (lásd 4. ábra)

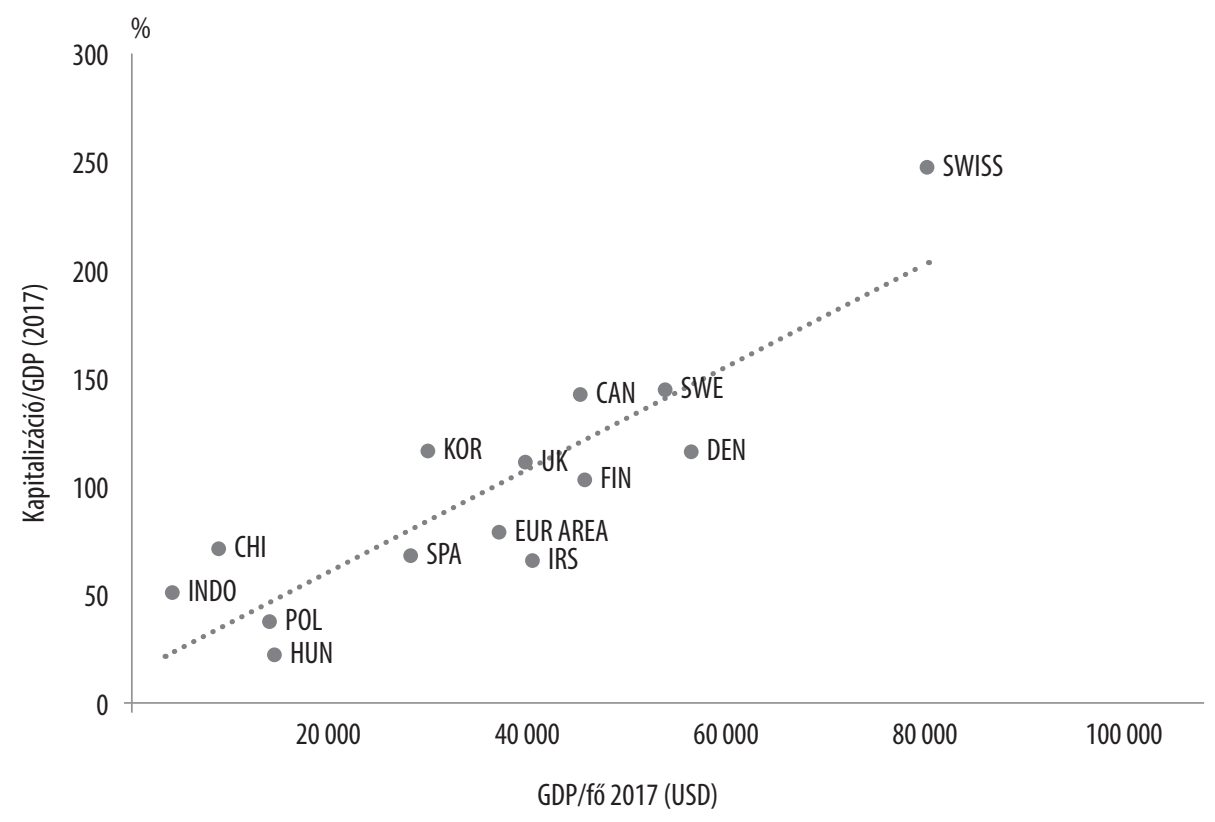

\section{5. ábra: Kapitalizáció/GDP arány 2017-ben}

Forrás: BÉT, Világbank (2018)

A tőkepiaci kapitalizáció és a gazdasági fejlettség között szoros pozitív kapcsolat van (5. ábra). „Az egy före jutó GDP alakulása a fejlett tőkepiaccal rendelkező országok esetében többnyire magasabb. Emellett a gazdaság abszolút értéke és a tőkepiac fejlettsége között is felfedezhető kapcsolat, ebből pedig ismét az következik, hogy a magas GDP-vel rendelkező országok általában fejlettebb tőkepiaccal rendelkeznek. Az is megfigyelhető, hogy egy bizonyos nagyságú GDP elérése után a tőkepiac fejlettsége és a gazdaság növekedése között már nem olyan erős a kapcsolat, jóllehet a statisztikai adatok alapján az egyértelműen megállapítható, hogy a 225 milliárd dollárnál nagyobb GDP-vel rendelkező országok és az annál keveseb- 
bel rendelkező országok tőkepiaci fejlettsége közötti különbség a legmarkánsabb (a magyar GDP értéke nagyságrendileg mintegy 130 milliárd USD). Ez a statisztikai adatokból levonható következtetés hasonló a Banai és szerzőtársai (2016) által a hitelállomány bővülésére tett megállapításokkal. Kirajzolódik, hogy a tőkepiac növekedésének a gazdasági növekedésre kifejtett hatása jelentős a kisebb gazdasággal és tőkepiaci kapitalizációval rendelkező országokban, azonban a hatás egyre lelassul mindaddig, amíg be nem áll egy egyensúlyi állapot. Ezeket alapul véve azzal a várakozással élhetünk Magyarország tekintetében, hogy a túlzottan egyoldalú banki finanszírozás növekedésének határhaszna elmaradhat az alacsony bázissal rendelkező tőkepiac által vezérelt gazdasági növekedéstől.

Amennyiben a hazai részvénypiac kapitalizációja a tőzsdefejlesztési stratégiai céloknak megfelelően a GDP 30 százalékos szintjére növekszik, az 0,2-0,3 százalékponttal növelheti a potenciális kibocsátás szintjét." (Parragh - Végh, 2018)

A tőzsdei kapitalizáció és az innovációs képesség között szintén szoros kapcsolat áll fenn, melyet a 6 . ábra szemléltet.

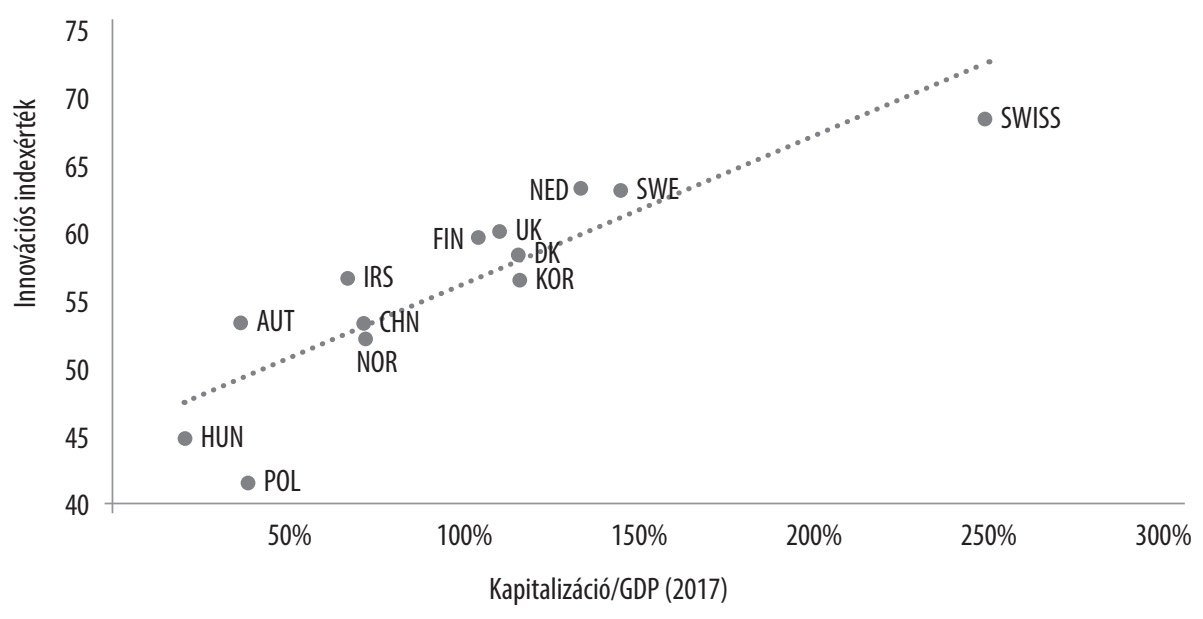

\section{6. ábra: A tőkepiac és az innovációs kapacitás közötti kapcsolat}

Forrás: BÉT saját szerkesztés Világbank, Global Innovation Index 2018 alapján

\subsubsection{Kereskedés és árképzés}

A tőzsdéken a korábban szakirodalmi megközelítésben bemutatott elsődleges és másodlagos piac működik, témánk szempontjából mégis érdemes nagyobb részletességgel feltárni működési sajátosságaikat, különös tekintettel a vállalatok forrásbevonási és növekedési lehetőségeire. 
Az elsődleges piac lehetőséget ad a vállalatoknak a mély és diverzifikált befektetői bázis kiépítésére, illetve a kiegyensúlyozott forrásszerkezet megvalósítására részvények, kötvények kibocsátása által.

Az elsődleges piac a következőkben segíti a vállalatokat a növekedésben:

- a tőkebevonás folyamatos javítása, amely a szerves növekedéshez vagy a felvásárlások finanszírozásához használható;

- az indexekbe való felvétel jogosultsága;

- a vállalatok hírnevének és profiljának javítása mind külső, mind belső szinten, vagyis a tőzsdén kereskedésre felvett értékpapíroknak meg kell felelniük a szigorú kezdeti és folyamatos közzétételi követelményeknek, valamint az uniós jogszabályok által elöírt számviteli és könyvvizsgálati szabványoknak;

- lehetővé téve a vállalatok számára, hogy növeljék láthatóságukat mind az ügyfelek, mind a munkavállalók vonzása érdekében;

- a társaságok részvényopciós ösztönzők felajánlása, ami növeli a kiváló minőségű tehetségek vonzását, alkalmazását és megtartását.

A másodlagos piacok helyet biztosítanak a vevők és az eladók közötti nyitott és hatékony interakciónak. Bizalmat és biztonságot teremtenek azáltal, hogy az ott kereskedett eszközökről valós idejü, megbízható és átlátható módon képzett adatokat szolgáltatnak.

A tőzsdék központi piacot jelentenek a tőzsdei eszközök kínálatának és keresletének összehangolásával, árképzést és árterjesztést biztosítanak. A tőzsdék erösen szabályozott szervezetek, amelyekre a piac integritását biztosító harmonizált európai szabályok vonatkoznak.

\subsubsection{Kockázatkezelés}

A tőzsdén kereskedhető eszközök széles lehetőséget nyújtanak a kockázatok menedzselésére, amihez a tőzsdék maguk is hozzájárulnak saját nyilvános és transzparens müködésük által.

A tőzsdék nyílt és átlátható platformot biztosítanak a pénzügyi eszközök iránti kereslet és kínálat összehangolására. Az értékpapírok ára a tőzsdei árképzés során kerül meghatározásra, aminek a transzparenciáját az biztosítja, hogy a nyilvános kereskedési platformok minden ajánlatot nyíltan (ajánlati könyv 
láthatósága) és egyenlően kezelnek. A tőzsdén meghatározott árak átláthatóvá teszik a kereskedési és vállalati információkat, egyenlő hozzáférést biztosítanak minden kereskedésben résztvevőnek, robusztus rendszereket és erős felügyeletet biztosítva. Ezáltal a nyilvános piacok az árfolyamok következetes és összehasonlítható referenciáit képviselik. Ezek a referenciaárak valamennyi kereskedési típus esetében a „világítótorony” szerepét töltik be. Az árképzés megvalósításához kulcsfontosságú a transzparencia, amely a tőzsdén keresztül folytatott többoldalú kereskedelmet jellemzi. A tőzsdék versenyeznek egymással az árképzés minőségében és megbízhatóságában, kifinomult informatikai és megfelelőségi rendszerek kerülnek bevezetésre, hogy biztosítsák a méltányosabb és leghatékonyabb eredményt a brókerek, valamint a lakossági és intézményi befektetők számára. A tőzsdéknek kulcsszerepük van abban, hogy összekapcsolják a különböző piaci szegmenseket, kereskedési érdekeket és a befektetési perspektívákat, áthidalják az elsődleges piacokon a tőkeemelés szükségessége és a másodlagos piacokon történő árfelismerés és kockázatátadás közötti szakadékot.

A tőzsdén kereskedhető eszközök négy fó eszközosztályba sorolhatók: részvények, származékos termékek (derivatívok), tőzsdén kereskedett alapok és kötvények.

\section{Részvények:}

A részvény értékpapírok olyan pénzügyi instrumentumok, amelyek a társaság nettó eszközeinek tulajdonjogát képviselik. A társaságok részvényeket bocsátanak ki a tőke emelése céljából a tulajdonuk egy részének feladásával. A részvényeket szavazati jogaik szerint lehet besorolni, pl. törzs- vagy elsőbbségi részvények körébe. A nyilvános tőkeemelés lehetővé teszi a vállalatok számára, hogy pénzt szerezzenek, biztosítva számukra a magán- és intézményi befektetők nagy részének hozzáférését. A részvények magasabb hozamot kínálnak, mint más értékpapírok a magasabb kockázatért cserébe.

A részvények értékét olyan jövőbeli (tehát bizonytalan) tényezők határozzák meg, mint a társaság jövőbeli pénzáramlása, nyeresége és jövőbeli kilátása. A transzparencia az árképzésben és a vállalatirányításban ezért kiemelten fontos.

\section{Származékos termékek (derivatívok):}

A származékos értékpapírok olyan pénzügyi instrumentumok, amelyek értéke egy mögöttes eszköz teljesítményéből származik. A kockázatokat az egyik féltől a 
másikra ruházzák át, lehetővé téve a tulajdonjog és a piaci értékben való részvétel elkülönítését.

A származékos termékek olyan lehetőségeket hoznak létre, mint például a fedezeti ügyletek - a pénzügyi pozíció megőrzése váratlan fejlemények ellen csakis származékos ügyletek által lehetséges. A származtatott áruügyleteket a mezőgazdasági termelők és a gyártók egyfajta biztosítási termékként hasznosíthatják: a mezőgazdasági termelő például rögzítheti a termék jövőbeli árát.

A származtatott ügyletek lehetnek szabályozott tőzsdei ügyletek (ETD), vagy kétoldalú tőzsdén kívüli ügyletek (OTC). Utóbbi esetben kevésbé szabványosított termékek cserélnek gazdát magasabb partnerkockázat mellett. Ezzel szemben az ETD-k részesülnek a tőzsdék átláthatósága és a szabványosítottság nyújtotta előnyökből, valamint a központi partner vagy klíringház által átvállalt partnerkockázat nyújtotta előnyökből.

A pénzügyi válság előtt a derivatív ügyletek nagy része OTC volt. A válság utáni időszakban a G20 országok (a világ 19 legnagyobb gazdaságát, valamint az Európai Uniót képviselő országok csoportja) elkötelezték magukat az átláthatóság növelése mellett azáltal, hogy az OTC tranzakciókat a szabályozott tőzsdére terelik, ahol a kötelezö központi elszámoló fél biztosítja az elszámolás rendben létét, kezeli a nem fizetésből adódó kockázatokat.

\section{Alapok / tözsdén kereskedett alapok (ETF):}

Folyamatos árképzéssel és likviditással rendelkezö pénzügyi eszközök, amelyek nyomon követik az index teljesítményét, vagy konkrét befektetési stratégiákat követnek. Az ETF-ek részesülnek a tőzsdei likviditásból és transzparenciából, az adott mögöttes portfólió teljesítményhez arányos hozamot adnak.

Az ETF-ek adó- és költséghatékonyságot biztosítanak, mivel nem viselik az aktív menedzsment költségeit. Ezen kívül a befektetők számára a diverzifikációhoz való könnyü hozzáférést biztosítják az eszközosztályok széles körének lefedésével.

\section{Kötvények:}

Olyan pénzügyi eszközök, amelyek lehetővé teszik a közszféra (azaz kormányok, regionális és helyi hatóságok, szupranacionális intézmények) vagy cégek számára, hogy adósságot szerezzenek tulajdonjog átruházása nélkül. A kormá- 
nyok kötvényeket bocsátanak ki, hogy pénzt kölcsönözzenek a bevételi és kiadási oldal közötti hiány fedezésére. A nem állami entitások kötvényeket bocsátanak ki a befektetések finanszírozásához (pl. bővítés, növekedés) tulajdonjogról való lemondás nélkül.

A vállalatok számára a banki hitelek alternatíváját jelentik. A kötvények általában lehetővé teszik a nagymértékű tőkeemelést. A kötvénypiacok nagyrészt az elsődleges kibocsátásra összpontosítanak. A kötvények forgalma jelentősebb, mint más eszközöké. Befektetői oldalon hitelezők állnak, akik pénzt kölcsönöznek egy magánvállalatnak vagy egy állami szervnek. Összehasonlításképpen: a tőkebefektetők részvényesi tulajdonnal rendelkeznek. A kötvénybefektetők stabil és kiszámítható hozamot kapnak befektetésükért.

Hagyományosan a kötvénykereskedelem a brókerek között telefonon zajlott. Az elektronizálás az 1990-es években kezdődött. A kötvénypiacok fokozatosan egyre inkább digitalizálódtak, és átláthatóbbak lettek. A tőzsdék és más kereskedési helyszínek biztosítják az átlátható és semleges árképződést. Mindazonáltal a kötvények több mint 90\%-a még ma is tőzsdén kívüli (OTC) piacon folyik.

A tőzsdei befektetések biztonságát a tőzsdei vállalatok által követett felelös társaságirányitási irányelvek is biztosítják. A tőzsdei részvénytársaságok tevékenységének saját tagságán túlmutató következményei lehetnek, ezért fogalmazódott meg a felelős társaságirányítás igénye. A BÉT mellett müködő Felelős Társaságirányítási Bizottság 2004-ben kezdte meg munkáját. A 2018-ban kiadott legutóbbi Ajánlásukban ${ }^{2}$ olyan irányelveket fogalmaztak meg, amelyek a részvényes jogait, és a közgyülés lebonyolítását, a javadalmazást érintik, melyeket 2019-től kell figyelembe venni. A BÉT-re bevezetett vállalatok minden évben jelentést tesznek „betart vagy indokol” elv alapján.

\section{A fentiek alapján a tözsdék nemzetgazdaságban betöltött szerepe a következö} szempontok szerint foglalható össze:

- Forrásbevonási alternatíva a vállalkozások számára, a tőke hatékony allokációjának terepe;

- Csökkenti a finanszírozás költségeit;

- Kiszállási lehetőség kisebbségi vagy többségi részesedés megtartása mellett;

2 Budapesti Értéktőzsde Felelős Társaságirányitási Bizottság (2018): Felelős Társaságirányítási Ajánlások. 
- Hatékony árképzés és információ aggregálás;

- Növeli a tőzsdei vállalatok átláthatóságát;

- Emeli a cégek müködési hatékonyságát;

- Növeli a vállalatok innovációs képességét;

- Piacot teremt a megtakarítások elhelyezéséhez;

- A gazdasági folyamatok indikátora.

\subsection{A tőzsde régen és ma - A tőzsde fejlödése napjainkig}

Ahogy az előzőekben láthattuk, a pénzügyi közvetítésnek, azon belül is a tőkepiacoknak, kiemelt szerepük van a gazdasági növekedésben. A tőzsde elsődleges feladata, hogy tőkeági forrást biztosítson a vállalatok számára, és így váljon a modern piacgazdaság egyik motorjává. Ennek okán Magyarországnak is kiemelkedő jelentőséget szükséges tulajdonítani a megfelelő tőkepiaci környezet kialakítására, mely hozzájárul a gazdaság hosszútávú növekedéséhez. Ezen cél eléréséhez az egyes piaci szereplők együttműködésére és érdekközösségére van szükség.

A klasszikus értelemben vett tőzsdék létrejötte az 1500-as évekre tehető, jóllehet már az 1100-as évektől szerveződtek olyan piacok, amelyek több szempontból is hasonlóságokat mutatnak a részvénypiaccal (Smith, 2004). Kezdetben Franciaországban egyes cserekereskedők a banki felhatalmazással kezeltek bizonyos mezőgazdasági tartozásokat, mely történelmi példaként szolgál a bróker tevékenység végzésére, mivel gyakorlatilag a tartozások hatékony kereskedése valósult meg. Később, a 13. század eleji Velencében kezdődött az állampapírok kereskedése, melyet ezután a közeli olasz városok bankjai is átvettek és bevezettek. 1602-ben a Holland Kelet-Indiai Társaság a világ első nagyvállalataként a befektetők számára tényleges vállalati részvénykibocsátást valósított meg az Amszterdami Értéktőzsdén, amellyel egyben létrehozta a modern tőzsde intézményét is. Ebben az időben a kereskedés még nem egy hivatalos, kifejezetten erre a célra fenntartott helyen zajlott, hanem különböző kávéházak biztosították a helyszínt a befektetők széles körének, hogy részvényekkel kereskedjenek. Számos tanulmány megemlíti, hogy az ipari forradalom idején a technológia fejlődése mellett a tőkeáramlás felgyorsulása játszott óriási szerepet az akkori világ teljes megváltoztatásában. Ez az állítás máig is helytállónak tekinthető, és az egyre fejlődő technikai újítások mellett a töke minél hatékonyabb allokációja jelenti a növekedés motorját az egyes nemzetgazdaságok számára. 
A hazai tőkepiac és ezen belül a tőzsde intézménye több mint 150 éves múltra tekint vissza (Korányi - Szeles, 2005). A magyar tőzsde 1864. január 18-án kezdte meg müködését Pesten, a Pesti Lloyd Társulat Duna-parti székházában. A tőzsdét előkészítő bizottságot Kochmeister Frigyes vezette, akit a tőzsde első elnökévé (1864-1900) is választottak. Az intézmény először értékpapír-tőzsdeként jött létre, de négy évvel később magába olvasztotta a gabonakereskedelem központját, a Gabonacsarnokot. Ezután felvette a Budapesti Áru- és Értéktőzsde (BÁÉT) nevet, és ezen a néven 80 éven át Európa egyik vezető tőzsdéjeként működött. Az első világháború előtti időszakot a prosperálás jellemezte, az első világháború kezdetére közel 500 féle értékpapírral kereskedtek a tőzsdén, amely ekkorra Európa vezető gabonatőzsdéjévé is vált. Az I. világháború, Európa számos országához hasonlóan, Magyarországon is a tőzsde bezárását hozta 1914. július 27-én, ám ez a kereskedésnek nem vetett gátat, így az alkuszok a háború alatt is folytatták az üzletelést, a részvényárak pedig 1914-től tartós emelkedést mutattak. A BÁÉT a két világháború között is megőrizte kiemelkedő szerepét a gazdaságban. A világháborút kísérő sokk után, és a pengő 1925-ös bevezetését követően ismét stabil müködés jellemezte, majd a nemzetközi trendekkel összhangban az 1929-es gazdasági világválság - ugyan késéssel, de hatását tekintve hosszan - a harmincas évek végéig éreztette hatását Magyarországon. A tőzsde a második világháború alatt is aktívan müködött, egészen Budapest ostromának kezdetéig, 1944. december közepéig. A tőzsdét hivatalosan 1946 augusztusában, a forint augusztus 1-jei bevezetésekor nyitották meg ismét. Mivel a korábban kibocsátott, koronában és pengőben jegyzett kötvényekre nem teljesítettek kifizetéseket, a részvénytársaságok pedig a háborús veszteségek miatt nem fizettek osztalékot, az árfolyamok erőteljesen estek. Végül két hónappal a magyar ipar államosítása után, 1948. május 25-én, a kormány hivatalosan is feloszlatta a Budapesti Áru- és Értéktőzsdét. A tőkepiac e rendkívül jelentős szereplője ezzel évtizedekre kiesett a pénzügyi közvetítőrendszerből.

Az 1989 októberében hozott kormánydöntéssel kezdetét vette az értékpapírtörvény előkészítése. A törvényjavaslat 1990 januárjában került a parlament elé, és március 1-jével lépett érvénybe. A hatálybalépéssel egyidejűleg tűzték ki június 21-re a Budapesti Értéktőzsde alakuló közgyűlését, amely eredményeként még aznap, 1990. június 21-én újra megnyitotta kapuit a Tőzsde, szorosan kapcsolódva az ország rendszerváltás utáni új (gazdaság) történeti korszakához. A tőzsde rendszerváltás utáni történetében felívelő és stagnáló szakaszok váltották egymást. 
A kilencvenes évek eleji időszakra tehetők az állami tulajdonú vállalatok fejlődése szempontjából meghatározó tőzsdei bevezetések. A régióban elsők között történt meg az állami vállalatok (közöttük a kiemelten fontos OTP, MOL, Richter, MATÁV) sikeres tőzsdére vitele, ekkortájt a tőzsde kapitalizációja, a kétezres évek elején, a GDP 30 százalékát is elérte. A hazai nagyobb vállalatok privatizációjában a tőzsdének igen jelentős szerep jutott. A tőzsdei tranzakciók a privatizációs bevételekhez 40 százalékot meghaladó mértékben járultak hozzá. A privatizált állami vállalatok az Uniós csatlakozás idejére a BÉT összforgalmának 95-96 százalékát adták, részesedésük a tőzsdei kapitalizációban elérte a 90 százalékot. A költségvetés azonnali finanszírozási igényét, és a rövid távon elérhető bevétel maximalizálását szem előtt tartva, a privatizációk ugyanakkor nálunk inkább szakmai befektetőnek egyben történő értékesítés útján haladtak: a több ezer állami cég közül nagyságrendileg mindössze 30 jelent meg a BÉT-en. Ezzel szemben a későbbi tapasztalatok megmutatták, hogy a lépcsőzetes, egyre magasabb árakon történő tőzsdei értékesítések segítségével végül nagyobb bevételhez jutott az állam, mintha az első értékesítés időpontjában szakmai befektetőnek egyben értékesítette volna, a tőzsdei árhoz képest akár egy 30\%-os kontroll prémium elérése mellett. A Budapesti Értéktőzsde szempontjából még ezzel együtt is meghatározó volt az a néhány tőzsdén privatizált nagyobb vállalat - előbb nemzeti bajnokok, később már régiós szinten is jelentős cégcsoportok -, melyek ma is a forgalom és a kapitalizáció szempontjából meghatározó blue chip részvényeket adják.

\subsection{A Budapesti Értéktőzsde müködési környezete és sajátosságai 2019 elején}

„A Budapesti Értéktőzsde Zrt. (BÉT) a hazai pénz- és tőkepiac központi szereplőjeként pénzügyi forrásbevonási lehetőséget nyújt a gazdasági élet szereplőinek, egyúttal a befektetési eszközök széles tárházát biztosítja a befektetők számára. A Tőzsde missziójának tekinti a stabil és független finanszírozásra épülő magyar gazdaság megteremtését és a hazai lakosság és a vállalati szektor pénzügyi kultúrájának folyamatos fejlesztését.” - fogalmazza meg misszióját a BÉT.

3 https://bet.hu/Rolunk/a-budapesti-ertektozsderol/bemutatkozas 
A BÉT legfontosabb adatait tartalmazza a 3. táblázat:

\begin{tabular}{|c|c|}
\hline \multicolumn{2}{|l|}{ Általános adatok } \\
\hline Piaci kapitalizáció (2019 január) & 8450 Mrd HUF \\
\hline Kapitalizáció/GDP & $20,60 \%$ \\
\hline Napi átlagos részvényforgalom (2018) & 11,4 Mrd HUF \\
\hline Részvények forgási sebessége (2018) & $36 \%$ \\
\hline Részvénykibocsátók & 40 \\
\hline $\begin{array}{l}\text { Tózsdetagok } \\
\text { I Vendorok száma }\end{array}$ & $--\frac{26}{106}--\frac{1}{1}$ \\
\hline -ebből NOW ügyfél & 76 \\
\hline I Professzionális végfelhasználók száma & 5041 \\
\hline I Magán végfelhasználók száma & $10344 \ldots$ \\
\hline
\end{tabular}

\section{3. táblázat: A BÉT legfontosabb mutatói, 2019. január}

Forrás: BÉT

Közép-európai összehasonlításban a BÉT közepes méretünek tekinthető. A régió legfontosabb szereplői Varsó és Bécs (lásd 7. ábra).

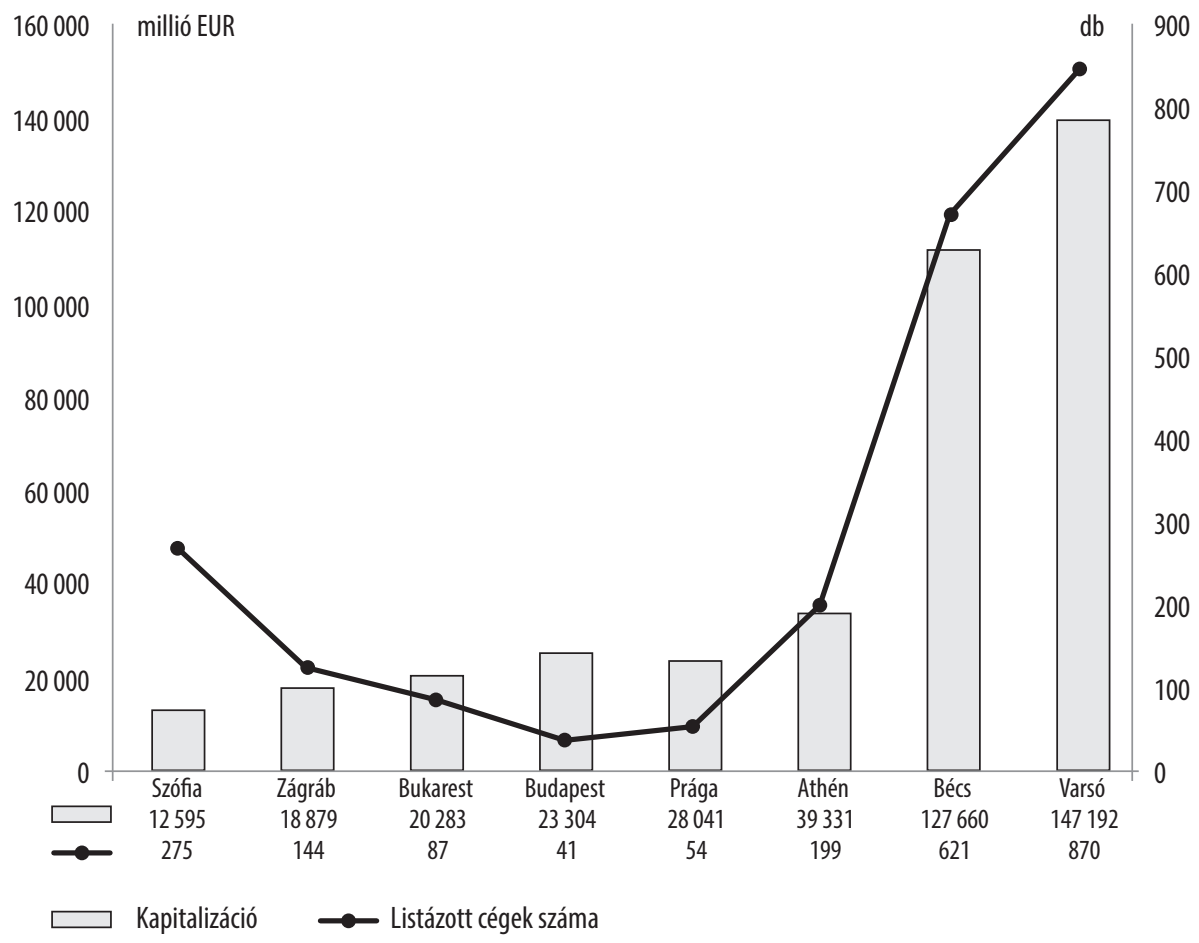

7. ábra: Részvénykapitalizáció és listázott cégek száma

Forrás: FESE 
A BÉT tulajdonosi szerkezetét mutatja be a 8. ábra. A Budapesti Értéktőzsde legnagyobb tulajdonosa 2015. december óta a Magyar Nemzeti Bank. Nemzetstratégiai jelentőséggel bír, hogy ettől az időponttól kezdődően került ismét többségi nemzeti tulajdonba a tőzsde.

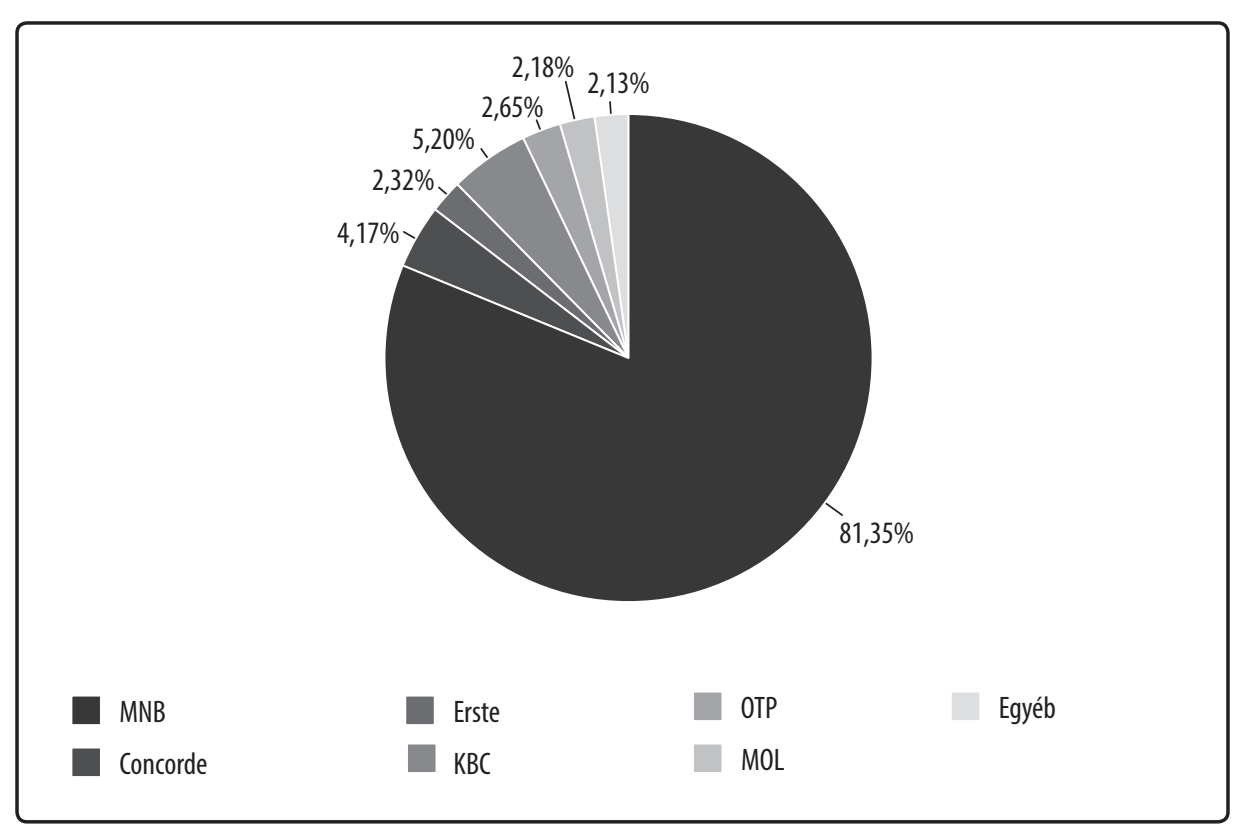

8. ábra: A BÉT tulajdonosi szerkezete, 2019

Forrás: BÉT

A BÉT-en forgalmazott termékek kereskedése négy szekcióban zajlik.

\begin{tabular}{|c|c|c|c|}
\hline Részzény szekció & Hitelpapír szekció & Származékos szekció & Áru szekció \\
\hline Részvények & Állampapírok & Határidős termékek & Azonnali termékek \\
\hline Befektetési jegyek & Jelzáloglevelek & Opciós termékek & Határidős termékek \\
\hline ETF & Vállalati kötvények & & Opciós termékek \\
\hline \multicolumn{4}{|l|}{ Strukturált termékek } \\
\hline Kárpótlási jegyek & & & \\
\hline
\end{tabular}

\section{9. ábra: A BÉT szekciói}

Forrás: BÉT 
A hazai részvénypiac igen koncentrált, mind a kapitalizáció, mind a forgalom tekintetében. A 3 legnagyobb kibocsátó (OTP, MOL, Richter) 2018-ban a kapitalizáció 83\%-át, a forgalom 86\%-át adták (lásd 10. ábra).

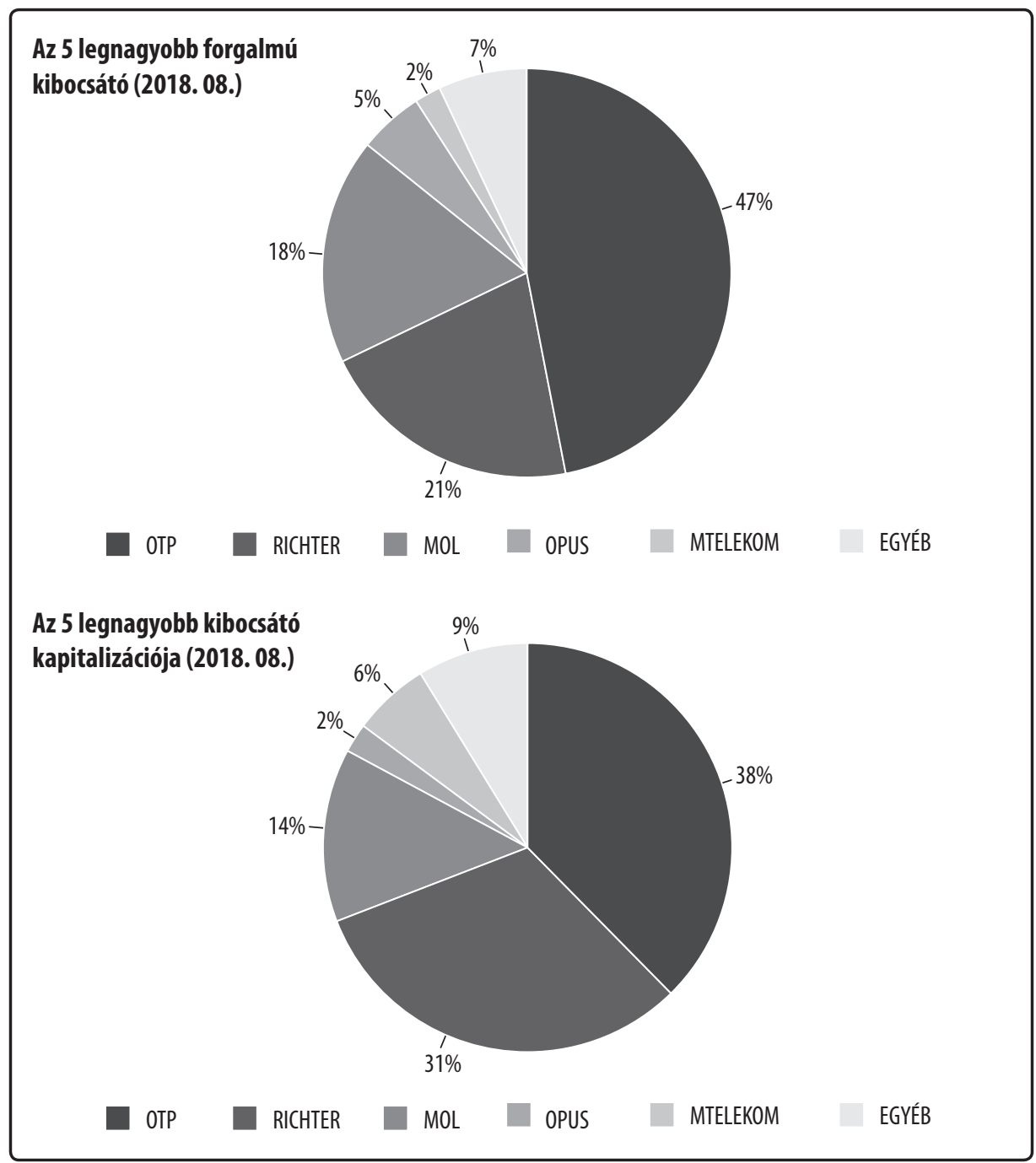

10. ábra: A BÉT részvényeinek forgalmi és kapitalizáció adatai Forrás: BÉT

A hazai részvényeket többségében külföldi befektetők birtokolják (63\%), a hazai háztartások részesedése mindössze 7\% körül van. Ugyanakkor a forgalomból a lakosság részesedése ennél jóval magasabb, mintegy $22,4 \%$. 


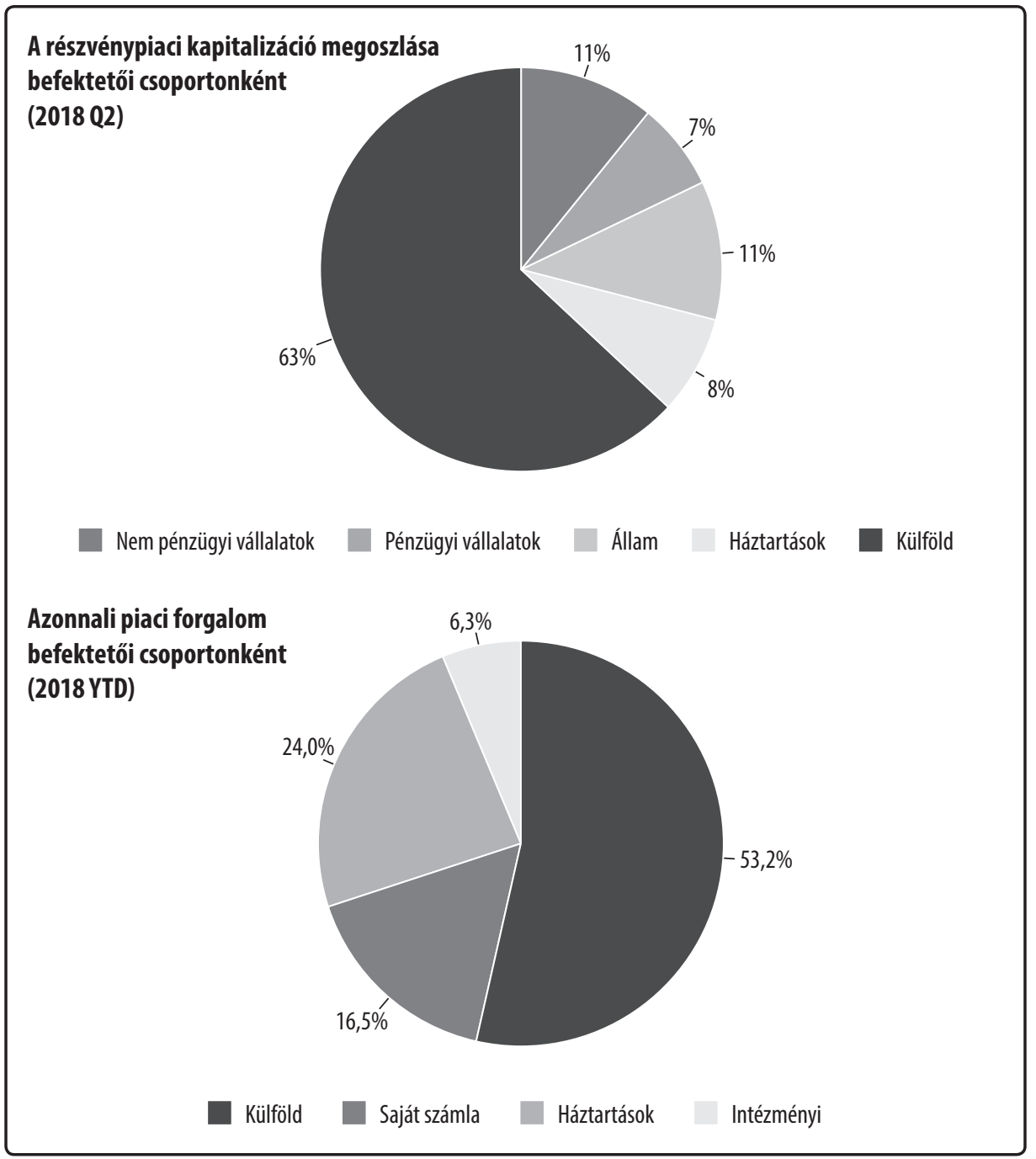

\section{1. ábra: Befektetői összetétel - a BÉT részvényei Forrás: BÉT}

A hazai befektetői rétegen belül az intézményi befektetőket alacsony hazai részvénykitettség jellemzi. A Befektetési Alapkezelők és Vagyonkezelők Magyarországi Szövetségének (BAMOSZ) kimutatása alapján (13. ábra) az intézményi vagyon mindössze $4 \%$-át tartják hazai részvényben. Lakossági oldalon szintén a konzervatív szemlélet a jellemző, a háztartási vagyon mindössze 1,6\%-a van hazai részvényben (lásd 12. ábra). 


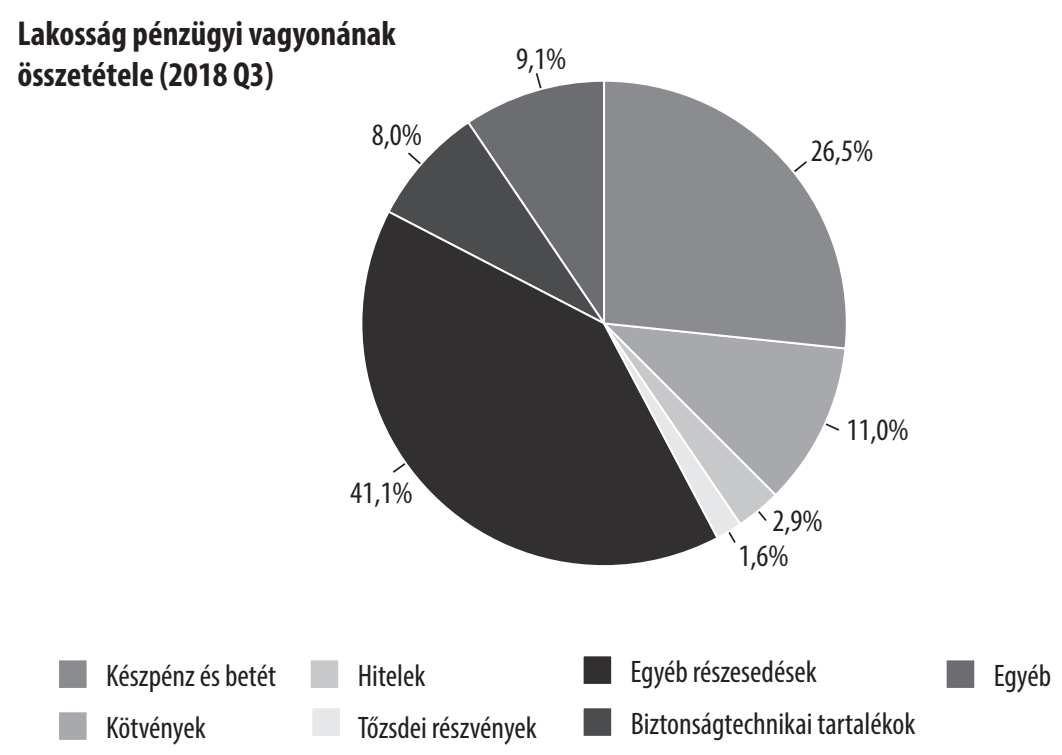

12. ábra: Lakosság pénzügyi vagyona 2018 Q3

Forrás: MNB, EUROSTAT

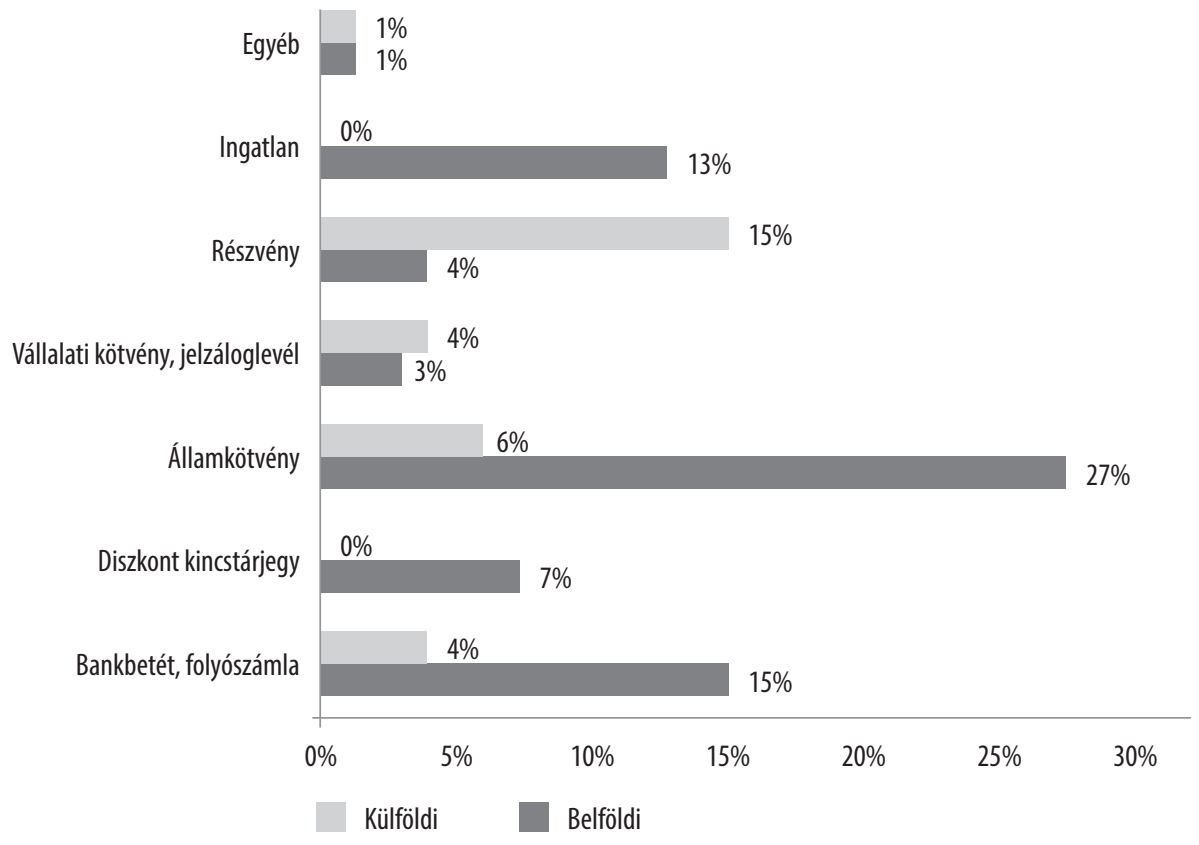

13. ábra: Hazai intézményi vagyon szerkezete 2019 Q1

Forrás: BAMOSZ 
A keresleti oldal fejlődése szorosan összefügg a kínálati oldallal, így a BÉT célja, hogy a vállalkozások is egyre nagyobb számban válasszák a tőzsdét növekedésükhöz. Az MNB 2015-ös tulajdonszerzése, és a BÉT új stratégiájának meghirdetése óta a korábban stagnáló új bevezetések és tökeemelések értéke növekedett, amint a 14. ábra is mutatja:

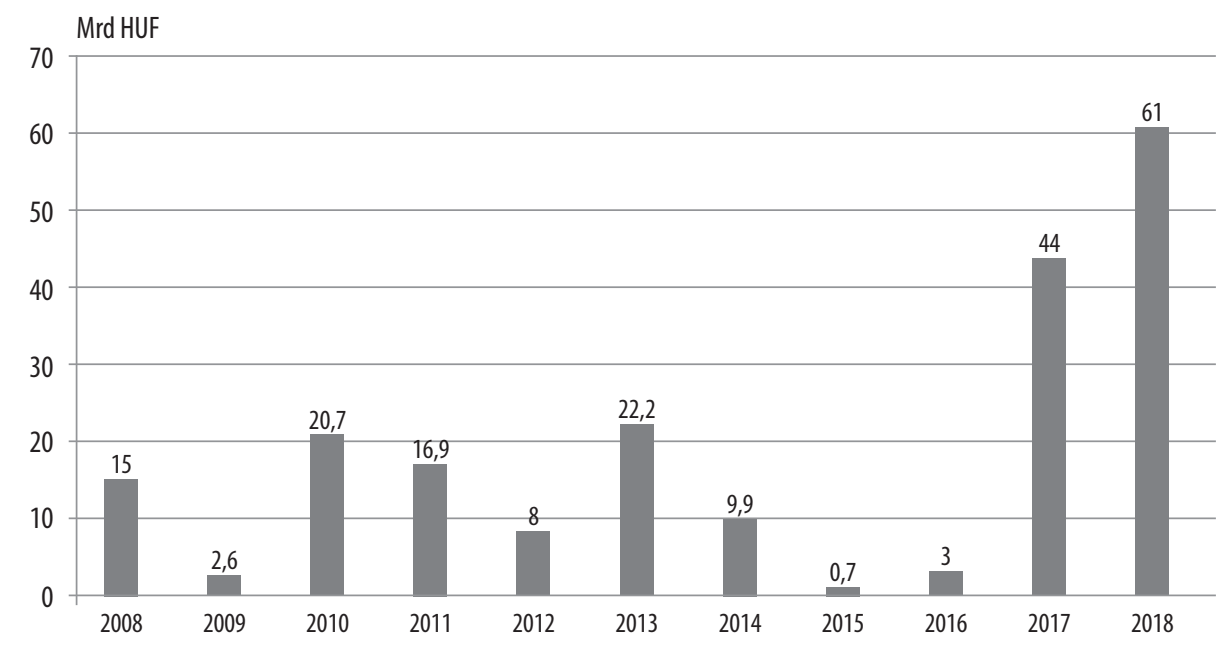

14. ábra: Részvénypiaci bevezetések értéke és száma 2008 és 2018 között Forrás: BÉT

\subsection{A Budapesti Értéktőzsde piacfejlesztési stratégiája 2016-2020}

Az eddigiekből világosan látszik a tőkepiacok fontossága a nemzetgazdaságban. A BÉT „ötéves, 2016-2020-as időszakra vonatkozó stratégiájának alapvető célja egy olyan átfogó tőzsdefejlesztési program kidolgozása és megvalósítása Magyarországon, melynek eredményeképpen a tőkeági forrásbevonás szerepe növekszik a magyar vállalatok finanszírozásában, hatékonyan kiegészítve a jelenleg túlsúlyban lévő banki hitelezést. A BÉT célja, hogy a versenyképes, sikeres hazai vállalatok legfontosabb platformjává váljon.” ${ }^{A} \mathrm{~A}$ részletes stratégia és az eddigi eredmények nyomon követhetőek a BÉT honlapján. ${ }^{5}$

A sikeres tőzsdefejlesztés szorosan összefügg a makrogazdaság állapotával:

4 https://www.bet.hu/Rolunk/a-budapesti-ertektozsderol/bet-strategia-2016-2020/betstrategia-2016-2020

5 https://www.bet.hu/Rolunk/a-budapesti-ertektozsderol/bet-strategia-2016-2020/betstrategia-2016-2020, illetve a minden évben megjelenő Stratégiai Jelentés: https://www.bet.hu/ Rolunk/a-budapesti-ertektozsderol/bet-strategia-2016-2020/BET-Strategiai-Jelentes-2018. 
„A 2010-2014 közötti szakaszban a magyar pénzügyi konszolidáció és gazdasági stabilizáció egyik legfontosabb tanulsága az, hogy nem elegendő egyetlen varázsszó, amely elöhívja a sikert, több lényeges gazdaságpolitikai és monetáris eszközt kell egyszerre és azonos irányban müködtetni a fordulatok érdekében” (Matolcsy, 2015, p. 515). Ezen eszközök egyike a tőzsde.

A tőzsde legfőbb kihívásai a következő szempontok alapján foglalhatók össze:

- Erős és egészséges tőkepiacok segitik a gazdaság növekedését. A nagyobb tőkepiaccal rendelkező országok fejlettebbek és gazdagabbak is. Mind a magyar lakosság számához, mind a gazdaság méretéhez képest túl kicsi a magyar tőkepiac. A 2030-ra megcélzott nagyjából 70 ezer milliárd forintos GDP szint eléréséhez erős tőkepiacokra van szükség.

- A tözsde fejlesztése fontos, a háztartások megtakaritásainak nagyobb részaránya szükséges a vállalati finanszírozásban, mely a lakossági vagyon növekedésére is pozitívan hat. A megtakarítások gazdaságba történő hatékonyabb becsatornázásához komoly szemléletformálás szükséges.

- Versenyképes vállalatok. A tőzsdei jelenlét korszerűbb vezetői tudással, fejlettebb vállalatirányítási ismeretekkel jár, ezzel is elősegítve a vállalatok versenyképességét. Kiemelten fontos elem a tőzsdeérett vállalatok azonosítása, kiválasztása és támogatása a tőzsdére felkészülés folyamata során. A tőzsdei megjelenés megfelelő eszköz lehet az állami tulajdonban lévő vállalatok számára, és nem csorbulnak a vállalati profitmaximalizáláson sokszor túlmutató nemzetgazdasági célok sem.

- Hazai vállalati növekedés és vagyonosodó háztartások. Az innovatív vállalatok a magas tőkepiaci fejlettséggel rendelkező országokban könnyebben szereznek finanszírozást, $s$ később ezek a gazdaság motorjaivá válhatnak. A tőzsdei cégek a befektető elvárások miatt növekedést keresnek, innoválnak, ambiciózus terveket tüznek ki maguk elé. A hazai vállalatok sikereiből részesednek a háztartások, mert vagyonuk nő, mely által erősödik a vállalatok versenyképessége, javul a társadalmi kohézió, s erősödik a pozitív jövőkép. 
- A hazai részvénykitettséget növelni szükséges mind a lakossági, mind az intézményi oldalon, mivel a jelenlegi alacsony részvényhányad nem eredményez hosszútávon hatékony portfóliókat sem az intézményi, sem a háztartási vagyon tekintetében. Jelenleg a hazai intézményi vagyon alig egyhatoda van részvényben, a hazai részvények aránya alig 4 százalék, a hazai háztartási vagyonnak pedig mindössze 1,6 százaléka van részvényben. Ugyanakkor látszik az is, hogy a lakosság pénzügyi vagyona dinamikusan növekszik, az elmúlt hét év alatt 57\%-kal nőtt, tehát a lakosság anyagi lehetősége biztosított a tőkepiaci befektetésekhez.

- A hazai nyugdíjvagyon aránya a lakossági pénzügyi vagyonon belül Magyarországon nemzetközi összehasonlításban igen alacsony, ezen belül is minimális a részvénykitettség értéke. Mindkettő arányszámot szükséges növelni, hiszen a nyugdíjcélú megtakarítások alapvető építőpillérei a hoszszútávú öngondoskodásnak. Ausztriában és Lengyelországban a nyugdíjvagyon aránya mintegy háromszorosa a magyar értéknek, a skandináv országokban pedig 7-10-szeres értékeket találni.

- Magyarországon alacsony a tőkepiaci, tőzsdei aktivitás mind a kibocsátói, mind a befektetői oldalon. Célzott jogszabályi rendelkezésekkel könnyíthető a piacra lépés, és növelhető a kínálati és keresleti oldali motiváció. A bankok és egyéb vállalatok tőzsdére lépésének ösztönzésére, valamint a banki felvásárlások, összeolvadások segítésére felügyeleti engedélyek és hatályos jogszabályi keretek kialakítása szükséges.

- A tökepiaci finanszírozás mélyitése szükséges. A Londone Stock Exchange-el közösen bevezetett ELITE program mélyítésével rövid-középtávon emelhető a listázott cégek száma. A cégek könnyebben találhatnak befektetőt, majd intézményi befektetővel sikeresebb IPO-t hajthatnak végre a BÉT-en.

- Magyarországon a nem pénzügyi vállalati kötvények állománya nagyon alacsony mind a GDP, mind a vállalatok teljes forrásszerkezetének arányában, a régióban csupán Romániában van kisebb kitettség. A kötvényfinanszírozás térnyerése könnyítene a banki mérlegeken is, így lehetővé téve a 
banki finanszírozás súlypontjának eltolódását a nagy-vállalati szegmensből a kkv szegmens felé. A kötvénykibocsátásokon keresztül a vállalati szegmens forrásszerkezete diverzifikáltabbá válhat, ami hozzájárul ahhoz, hogy válságállóbbá tegye a magyar gazdaságot. ${ }^{6}$

A tőzsdefejlesztési stratégia ezen kihívásokra reagál. A BÉT kiemelten fontosnak tartja a hazai kkv-k megerősítését, amelyet az MNB, mint fö tulajdonos kiemelten fontosnak tart a gazdaság versenyképessége szempontjából: „a Budapesti Értéktőzsde fejlődését hosszabb távon a sikeres kis- és középvállalatokra (kkv) kell alapozni, a tőzsde dinamikus fejlődésének gerincét a kkv-k kell, hogy adják ${ }^{7 ”}$. A Stratégiai Jelentésben is megtalálható legfontosabb félidős eredményeket a kkv piachoz kapcsolódóan Parragh Bianka és Végh Richárd 2018-as tanulmánya (Parragh - Végh, 2018) is összefoglalja:

- Az ELITE Program azokat a nagy növekedési potenciállal rendelkezö vállalkozásokat célozza, amelyek a terveik megvalósításához külső finanszírozás (EU-s forrás, hitel, kockázati tőke, magántőke vagy akár tőzsdei finanszírozás) igénybevételét tervezik, vagy vállalatirányítási ismereteiket bővítenék, esetleg egész egyszerűen csak üzletszerzési lehetőséget keresnek, generációváltást menedzselnek, vagy nemzetközi kapcsolatrendszerüket bővítenék, melyhez növekedést megalapozó tudást és kapcsolatrendszert tesz elérhetővé. A program, hazai sajátosságokkal kiegészítve, tulajdonosok és felső vezetők számára történő adózási, szabályozási, finanszírozási ismeretek átadását jelenti.

- Xtend - középvállalati finanszírozási platform: A középvállalatokat támogató új kereskedési platform 2017-ben valósult meg. Az Xtend piac a szabályozott piachoz képest egyszerübb feltételeket nyújt a kibocsátóknak, a befektetővédelmi szempontok érvényesülését a kijelölt tanácsadói rendszer biztosítja. Ezek a kijelölt tanácsadók (nomad - nominated advisor) egyrészt segítik a vállalat felkészülését a bevezetési folyamat legelejétől,

6 A vállalatikötvény-piac likviditásának növelése érdekében az MNB - a jelenlegi nemkonvencionális monetáris politikai eszköztárát, illetve az NHP fixet kiegészítve - 2019. július 1-jétöl elindítja a Növekedési Kötvényprogramot (NKP). Az MNB a kötvénypiac likviditásának növelésével javitani kívánja a monetáris politikai transzmisszió hatékonyságát, továbbá elő kívánja segíteni, hogy a gazdasági szereplők a bankhitelek mellett megfelelő mértékben támaszkodjanak erre a típusú finanszírozásra is. https://www.mnb.hu/letoltes/novekedesikotvenyprogram-hatteranyag.pdf

7 Matolcsy György beszéde a BÉT50 konferencián - Matolcsy (2017b): A skandináv modell lehet a példa. vs.hu, https://vs.hu/gazdasag/osszes/matolcsy-a-skandinav-modell-lehet-a-pelda-0920 
másrészt folyamatos támogatást nyújtanak a szabályozói megfeleléshez. Az Xtend piaci kibocsátók olyan dinamikusan fejlődő középvállalatok lehetnek, amelyek hajlandók a nyilvános léttel járó kötelezettséget vállalni, ugyanakkor fejlettségük és pénzügyi hátterük alapján még nem állnak készen egy nagy léptékü nyilvános kibocsátásra.

- Nemzeti Tözsdefejlesztési Alap (NTfA) létrehozása: Az NTfA tőkebefektetések megvalósításával támogatja a kkv-k tőzsdei megjelenését, tőkeági finanszírozásának elősegítését. A cél azon, elsődlegesen az Xtend piacon jelen lévő vállalatok számának növelése, amelyek tőkeági forrásból finanszírozzák növekedési elképzeléseiket, ezzel hozzájárulva a nemzetközi piacra lépéshez. Az NTfA befektetéseivel co-investment formában von be magántőkét a cégekbe, mely a tőzsdei felkészülés költségeiben is segítséget nyújthat. Az NTfA több oldalról erősíti az Xtend piac eredményességét. Befektetései által a célvállalatok minőségbeli és méretbeli szintet léphetnek, közelebb kerülve a tőzsdei bevezetéshez, vagy egy későbbi kategóriaváltáshoz, másrészről a keresletet is serkentheti, hiszen maga is jegyezhet részvényeket az IPO alatt. Az Alap további pozitív hozadéka, hogy nemcsak pénzbeli hozzájárulással támogatja a célvállalatot, hanem egyfajta bizalmat, stabilitást kölcsönöz a piac szereplőinek, hiszen befektetése tükrözi a cég jövőbeli potenciálját is.

- Mentoring Program: A Mentoring Program keretében a hazai kis- és középvállalatok gyorsabb és tervezettebb növekedés mellett hamarabb érhetik el a tőzsdeérettség fázisát. A tőzsdei megjelenésre való felkészülés és megvalósítása támogatásával elsődleges cél azon növekedési fázisban lévő kkv-k megerősítése, melyek nyitottak a transzparens tőzsdei müködés felé. A magyar vállalati szektor döntően hitelági finanszírozásból valósítja meg a fejlődéséhez szükséges lépéseket, éppen ezért fontos, hogy a gazdaság szereplőit a BÉT összefogja, és elősegítse azok megismerkedését a tőkeági finanszírozás előnyeivel és lehetőségeivel, majd erre valós alternatívát is nyújtson számukra. 
A Magyar Nemzeti Bank Versenyképességi Programjában ${ }^{8}$ is fontos szerepet kap a tőkepiac megerősítése. A 330 pontból 14 kifejezetten a hazai tőkepiac megerősítésével foglalkozik:

- Állami vállalatok bevezetése kisbefektetői részvényprogrammal;

- Bankok tőzsdei bevezetésének ösztönzése;

- Modern vállalati kötvénypiac kiépítése;

- Állami szerepvállalás a hazai részvénypiac fejlesztésében;

- A tartós befektetési számla (TBSZ) adómentességének biztosítása új tőzsdei részvény esetén;

- Kkv-kra specializált kereskedelmi platform elindítása;

- Tőzsdére lépés költségeinek levonhatósága a társasági adóból;

- A tőkepiaci szabályok és az általános EU-s gyakorlatok összhangjának biztosítása;

- Digitális platformok elérhetőségének javítása;

- Tőzsdefejlesztési kormány- vagy miniszteri biztos vagy megbízott kinevezése;

- A tőzsdei osztalék adómentessége;

- Munkavállalói részvényprogram ösztönzése;

- Jóléti alapok létrehozása a nyugdíj- és az egészségmegtakarítások fúziójával;

- NYESZ számlán is osztalékadó mentesség.

\subsection{Irodalomjegyzék}

Budapesti Értéktőzsde honlapja, www.bet.hu

Budapesti Értéktőzsde Felelős Társaságirányítási Bizottság (2018): Felelős Társaságirányítási Ajánlások, 2018, https://www.bet.hu/Kibocsatok/Ajanlasok-kibocsatoknak/Felelos-tarsasagiranyitasi-ajanlasok

Budapesti Értéktőzsde (2019): Stratégiai Jelentés 2018, 2019

Cournede, Boris - Denk, Oliver (2015): Finance and economic growth in OECD and G20 countries, OECD Economics Department Working Papers No. 1223.

Korányi G. Tamás - Szeles Nóra (2005): Tőzsde születik, Budapesti Értéktőzsde, 2005

Magyar Nemzeti Bank (2016): Versenyképesség és növekedés, Magyar Nemzeti Bank.

8 Magyar Nemzeti Bank (2019): Versenyképességi program 330 pontban. 
Magyar Nemzeti Bank (2017): A magyar út - célzott jegybanki politika. Magyar Nemzeti Bank.

Magyar Nemzeti Bank (2018): Növekedési jelentés, Magyar Nemzeti Bank, 8485. o.

Magyar Nemzeti Bank (2019): Versenyképességi program 330 pontban. Magyar Nemzeti Bank.

Magyar Nemzeti Bank (2019): A Növekedési Kötvényprogram elindításának jegybanki szempontjai és a konstrukció főbb jellemzői, Magyar Namzeti Bank, https://www.mnb.hu/letoltes/novekedesi-kotvenyprogram-hatteranyag.pdf

Matolcsy György (2010): A bizalom helyreállítása. A siker a versenyre való képesség függvénye. Heti Válasz, április 22.

Matolcsy György (2015): Egyensúly és növekedés. Kairosz Kiadó.

Matolcsy György (2017a): Gazdaságtörténeti siker nyolc év alatt, tizenkét lépésben, Magyar Idők, https://www.magyaridok.hu/velemeny/gazdasagtorteneti-siker-nyolc-ev-alatt-tizenket-lepesben-2568427/

Matolcsy György (2017b): A skandináv modell lehet a példa, BÉT50 konferencia beszéd, 2017, https://vs.hu/gazdasag/osszes/matolcsy-a-skandinav-modell-lehet-a-pelda-0920

Merényi Zsuzsanna - Vasné Botár Ágnes - Fritz Sepúlveda Pablo Arnoldo (2016): Iránytű a pénzügyekhez. Pénziránytü Alapítvány.

Parragh Bianka - Végh Richárd (2018): Megújuló állam - megújuló tőkepiac: A gazdaságösztönzés új dimenziói. Polgári Szemle, 14. évf. 4-6. szám, 48-78.

Smith, B. Mark (2004): A History of the Global Stock Market: From Ancient Rome to Silicon Valley, University of Chicago Press.

Peterhoff, Daniela - Upadek, Kai - Wuergler, Tobias - Goddard, Quinton -Riess, Rainer - Gardiner, Richard - Marqués, Carlos López - Ortega, José Manuel Santamaría - Tomm, Niels - Brab, Niels - Jezek, Robin - Grange, Tim - Combe, Kirstina - Aigrot, Ludovic - Cornwall, Ian (2017): Strengthening Europe's Position In Global Capital Markets. Oliver Wyman and Federation of European Securities Exchanges. https://www.oliverwyman.com/content/ dam/oliver-wyman/v2/publications/2017/jun/Strengthening_Europes_Position_in_Global_Capital_Markets.pdf 


\section{Befektetési alapok}

\subsection{A befektetési alapok rövid története a kezdetektől napjainkig}

Az első befektetési alapot 1774-ben indította útjára Adriaan van Ketwich Hollandiában. Az alapnak az „Egységben az ero”” nevet adta. Az alap sok befektetőtől gyüjtötte össze tőkéjét, amit aztán különböző kötvényekbe fektetett. Az alap célja az volt, hogy kisbefektetők pénzét gyüjtse össze, és a továbbiakban azt alacsony költséggel kezelje. Lehetőség nyílt arra, hogy a kisbefektetők pénzét több befektetésbe megosztva helyezzék el. Az alap vagyonát elsősorban kötvényekbe fektették. A vagyonban volt német, osztrák, dán, orosz, svéd és amerikai kötvény is. Az alap tőkegyüjtésére kibocsájtott papírjait korlátozottan váltotta vissza, de ezeket a tulajdonosaik más befektetőknek szabadon eladhatták. Az első befektetési alap egészen 1824-ig müködött.

A XIX. század során Európa más országaiban is indultak befektetési alapok, így Svájcban 1849-ben, Angliában 1868-ban. Ehhez képest az Egyesült Államokban viszonylag későn, 1893-ban indult az első alap.

Az alapok a XX. század előtti időszakban nem jutottak el széles rétegekhez, amelynek oka lehetett müködési formájuk. A zártvégű müködési elv miatt az alapok tőkebevonása viszonylag rugalmatlan volt, és a befektetők sem tudtak egyszerűen befektetésük ellenértékéhez jutni. A befektetési alapok újkori története azonban áttörést hozott. Az első nyíltvégű elven működő alap az Egyesült Államokban 1907-ben létrehozott Alexander Fund volt. Igaz az alap szabályzata szerint az alap befektetési jegyeiből csak évente kétszer lehetett vásárolni, de a papírokat az alap már bármikor visszaváltotta. A mai értelemben véve teljesen nyíltvégünek tekinthető alap aztán 1924-ben indult el Massachusetts Investors Trust néven. Az 1929-33-as gazdasági világválság megtépázta a befektetési alapokat is. A válság előtt a világon mintegy 700 zártvégü és 19 nyíltvégü alap volt. A válságot csak néhány alap vészelte át. Az 1950-es évek elejére az alapok piaca kezdett helyreállni, az Egyesült Államokban hozzávetőleg 100 alap működött. A következő két évtizedben aztán számuk több mint 3,5-szörösére nőtt. Az 1970es évek elején bekövetkezett olajválság ismét jelentős hatást gyakorolt a piacra. 
A domináns befektetési célként részvényeket választó alapok mellett megjelentek a rövid lejáratú hitelpapírokba és bankbetétekbe fektető alapok. Ez lehetővé tette, hogy a befektetők alacsony kockázatú, esetlegesen tőkegarantált alapokba helyezzék el pénzüket.

A színesedő befektetési alap piac az 1980-as évek elejétől óriási dinamikával bővült. Jellemző adat, hogy míg az 1980-as évek elején az Egyesült Államok háztartásainak 5,7\%-a tartott befektetési jegyeket, addig 2010-re ez az arány már 44\%-ra bővült (Rouwenhorst, 2004). A befektetési alapok száma 2019 elején az Egyesült Államokban 8088 volt, az általuk kezelt vagyon nagysága 27337 milliárd dollárt tett ki. ${ }^{1}$

A nyíltvégű befektetési alapok összesített eszközértéke a világban 2017 végén 49300 milliárd dollár értéket ért el (ICI, 2018). Magyarországon az 1990-es évek elején jelentek meg a befektetési alapok. Az első létrejövő magyar alap neve: CA értékpapír Magyar Állami Értékpapírokba Befektető Alap. 1992. április 9-én vették nyilvántartásba 1,74 milliárd forint saját tőkével. Zártvégü alapként öt éves futamidővel indult. Portfólióját államadósságot megtestesíto értékpapírokból alakították ki. Átmenetileg szabad tőkéjét bankbetétekben helyezték el, illetve olyan értékpapírokat vásároltak, amelyeket a jegybank bármikor visszavásárol. Ez az alap az érdeklődőknek olyan befektetési formát kínált, amely biztonságos, és hozama viszonylag magas. A befektetési jegyek likviditását azok tőzsdei bevezetésével teremtették meg.

A CA Állampapír Alap sikerét hamarosan követték az 1992. novemberdecember folyamán lejegyzett Prémium Alap, Budapest Első Befektetési Alap, Hunnia Befektetési Alap, az első nyíltvégü alap a Buda Alap, és előkészítése alatt állt az Első Magyar Ingatlan Alap is. A Buda Alap kivételével a többi, már bejegyzett alap is elsősorban a biztonságra törekedett. Portfóliójuk nagy részét államkötvények tették ki, kiegészítve állami és nagybanki garanciális gazdálkodói kötvényekkel, illetve kifogástalan adósnak tekinthető gazdálkodó szervezetek kötvényeivel. A Buda Alap szakemberei nem akartak megállni ezen a szinten, ők ugyanis alapjuk összegyüjtött pénzének nagy részét az állampapírok mellett részvényekbe szerették volna fektetni.

1 Trends in Mutual Fund Investing January 2019. https://www.ici.org/research/stats/trends/ trends_01_19 Letöltés: 2019. március 5. 
Az 1992-es év meghozta a befektetési alapok elindulását és beigazolta célját, nagyfokú biztonság mellett, az adókedvezménnyel kiegészítve elegendö hozamot biztosított a befektetők számára, valamint levette a magánemberek válláról a pénzük befektetésével kapcsolatos terheket. Az elsőként megjelent befektetési alapok mögött olyan nagybankok álltak, amelyek a „kisbefektetők” előtt ismertek, népszerüek voltak, ami szintén a befektetési alapok iránti bizalmat növelte.

Az 1993-as év jelentette Magyarországon az induló befektetési alapok igazi térhódítását. Az adókedvezmény, amelyet más értékpapír közvetlen vásárlása esetén nem lehetett igénybe venni, a bankbetéteknél magasabb hozam biztosítása és mindezek mellett a relatív biztonság vonzotta a befektetőket ezen befektetési forma felé. Ez az év a zártvégü alapok sikerét hozta meg. A korábbi évben alapult alapkezelők közül szinte mindegyik a második alapját indította útnak. 1993-ban is tartott az állampapírok előnye az alapok portfóliójában, bár a hosszabb lejáratú is az újonnan kibocsátott alacsonyabb kamatozású állampapírok a befektetési alapok hozammutatóit is visszavetették. Az ebben az évben alakult befektetési alapok kissé merészebbek voltak az előző évhez képest a portfóliójuk kialakításában. Az állampapírok mellett fokozatosan megjelentek a vállalati kötvények. A részvényportfólió azonban még mindig váratott magára a csekély kínálat és a nagyobb kockázat miatt.

1994-től az alapok részéről egyre inkább a részvényekbe való befektetés szándéka került előtérbe. Az első próbaképpen megalakuló részvényalap a Millennium II. elsősorban részvényekbe, illetve mivel a törvényi szabályozás lehetővé tette kárpótlási jegyekbe fektette tőkéjének jelentős részét. Az alap tervei között szerepelt az árfolyam-emelkedési várakozások idején spekulációs célzattal fellépni a részvénypiacon, illetve az állami vagyonkezelő szervek által meghirdetett kárpótlási jegy-részvény cserékben részt venni. Az állampapír alapok alapítása visszaesett azévben, hiszen a tíz új alap közül öt részvényalapnak tekinthetö, legalábbis a befektetett tőkéje felét tulajdoni jogokat megtestesítő papírokba kívánta befektetni, a másik pedig az alaptőke visszafizetését biztonságban tudva a megszokott állampapírba. Az évi újdonságként említhető több alap tekintetében az anyabankok által vállalt tőke-visszafizetés garancia, amit a kockázatosabb részvényportfólió miatt vállaltak. Ez azt jelenti, hogy az alap veszteségessé válásakor a letétkezelő a befektetési jegyek névértékét visszafizeti. További újdonság volt a CA Növekedési Alap kezdeményezése, ami abban nyilvánult meg, hogy a CA a kezelési díj helyett úgynevezett „sikerdíjat” számolt fel. 
A befektetési alapok működésének természetesen jogi keretet kellett adni. A rövid történeti áttekintés mindezt sugallja is. Az 1990-es évek elejének átalakuló pénzügyi intézményrendszerének szabályozásában az egyik fontos mérföldkő a befektetési alapok jogi hátterét megteremtő törvény, az 1991. évi LXIII. törvény a befektetési alapokról. A törvény 1992. január 1-jén lépett hatályba.

A törvény célja az volt, hogy megteremtse a feltételeit a befektetési alapok legfontosabb fajtáinak, az értékpapír- és ingatlanalapoknak Magyarország területén való létrehozásának, kezelésének és működtetésének. Meg kívánták határozni a működtetést biztosító, a felügyeletet ellátó szervezetek kereteit, hatásköreit, személyi és tárgyi feltételeit.

Cél volt ezáltal egy olyan befektetési forma létrehozása, amely hatékonyan és az addigi formákkal versenyezve volt képes bevonni a lakossági és egyéb szervezeti megtakarításokat a tőkepiacok vérkeringésébe. A szabályozás célkitűzése volt tehát a megtakarítók és a tőkét bevonni kívánó gazdasági szereplők érdekeinek együttes kiszolgálása a gazdaság fejlődése érdekében.

A jogszabály meghatározta az alapokat létrehozó és kezelő szervezetek, az alapkezelők szervezeti kereteit. Rögzítette az alapok tőkegyüjtésére szolgáló értékpapírok kibocsájtásának és forgalmazásának feltételeit. Meghatározásra kerültek a befektetési alapok fajtái, az ezekre vonatkozó befektetési elvek és korlátok. Kidolgoztak egy, a befektetők védelmét célzó többszintű garanciarendszert.

A törvény hatályba lépésével Magyarországon is megteremtődött a kerete egy viszonylag mérsékelt kockázattal a tőkepiacok hozamlehetőségeit felkínáló befektetési forma létrejöttének, amely egyben a gazdaság tőkeigényének kielégítését kínálta. Ezzel erősödött a pénz- és tőkepiacok transzmissziós funkcióját biztosító intézményi bázis.

A következő ábra a Magyarországon bejegyzett befektetési alapok vagyonának alakulását mutatja az utóbbi évekre. 


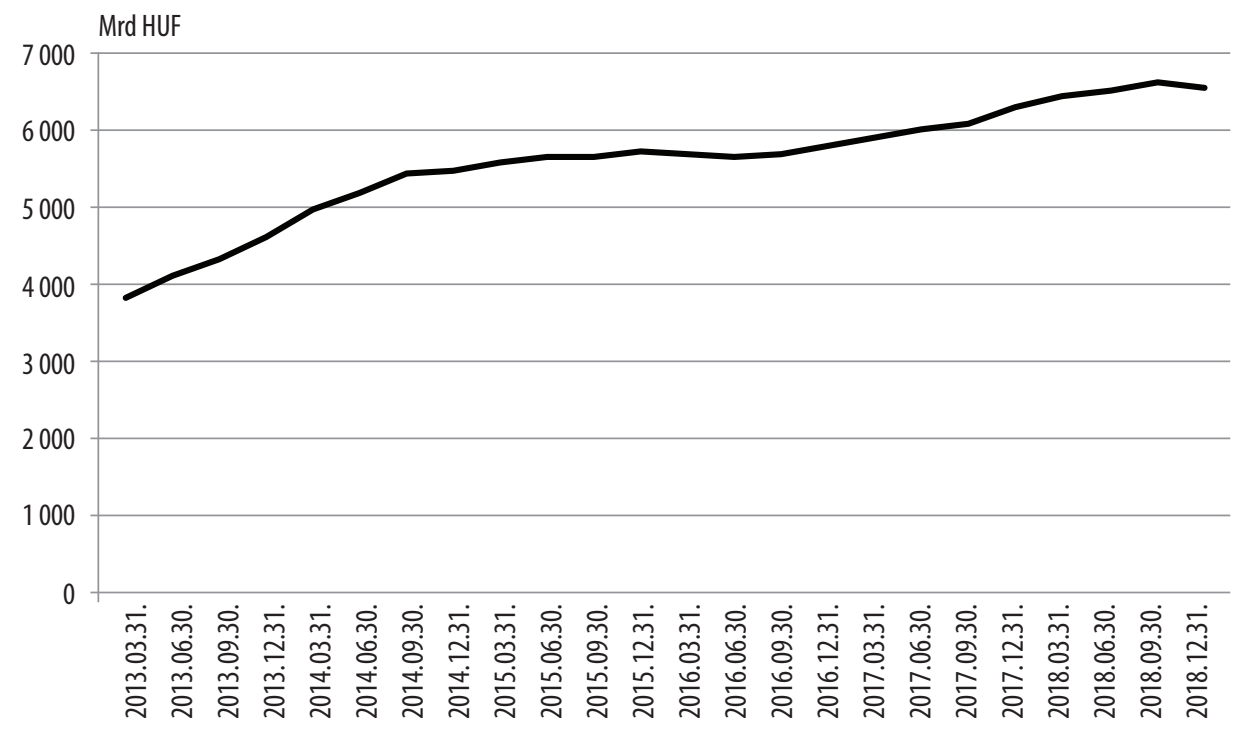

1. ábra: A Magyarországon bejegyzett befektetési alapok vagyonának alakulása 2012. I. negyedéve és 2018. IV. negyedéve között Forrás: Saját szerkesztés az MNB adatai alapján (2019)

2018 végére a befektetési alapok száma Magyarországon 691 volt, az alapokban összegyült vagyon 6558,376 milliárd forintot tett ki.

A jogi háttérszabályozás változására 2001-ben került sor, amikor a befektetési alapok müködési szabályai a 2001. évi CXX. törvényben kerültek rögzítésre. A szabályozást 2011-ben a 2011. évi CXCIII. törvény vette át. Majd ezt követte 2014. évi hatálybalépéssel a 2014. évi XVI. törvény. A 2000-es évek jogalkotásai az alapok szabályozásának korszerűsítését, illetve az Európai Uniós jogharmonizációt szolgálták.

\subsection{A befektetési alapok, mint portfólióbefektetések}

Bár már az első befektetési alap létrehozásakor megjelent az a szándék, hogy az alapban összegyűlt vagyont több értékpapírba fektetve megosszák a kockázatokat, de a kockázat-hozam optimalizálás elméleti hátterét csak a XX. század közepén dolgozták ki. A portfólió elméletet azóta széleskörüen alkalmazzák a befektetési alapok befektetéseinek kiválasztásakor. 
A kockázatok áthárítására már évszázadok óta léteznek technikák, mint például a biztosítások. A pénzügyi kockázatok mérésének, kezelésének tudományos megalapozása viszont csak a XX. század közepére tehetö. Természetesen voltak előzmények, de a pénzügyek „tudományossá” válása, majd a tudományos eredmények gyakorlatba való átültetése csak ezután következett. 1952-ben Harry Markowitz volt az egyike azoknak, aki matematikai eszközök alkalmazását vezette be a pénzügyi területen. Ő volt az, aki a kockázat kvantitatív meghatározásában úttörő szerepet játszott. Markowitz a korábbi részvénybefektetési stratégákkal szembeni kritikaként azt fogalmazta meg, hogy azok csak a várható hozamok alapján részesítik előnyben az egyik, vagy a másik részvényt. Az elméleti fejtegetések arra szorítkoztak, hogy a befektetők ki tudják választani a legmagasabb várható hozamú papírokat. Ez azonban ellentmondani látszott az addigi befektetői gyakorlatnak is, mivel a befektetők általában nemcsak egy maximális várható hozamú papírba fektettek. A különböző kockázatérzékenységü szereplők ráadásul eltérő eszközökbe fektettek, ösztönösen feltételezve az eszközök eltérő kockázatát. Markowitz a részvényekbe való befektetéseket elemezte. A részvények hozama mellett azok kockázatát is be kívánta vonni az optimális befektetések kialakításakor döntési szempontként.

A múltbeli adatsorokat vizsgálva a hozamok nem állandóak, hanem ingadoznak. Bizonyos hozamértékek gyakrabban előfordulnak, ezektől szélsőségesen eltérő hozamértékek viszont nagyon ritkán adódnak. A hozamokat előfordulási gyakoriságuk szerint sorba véve, eloszlásukat grafikusan ábrázolhatjuk.

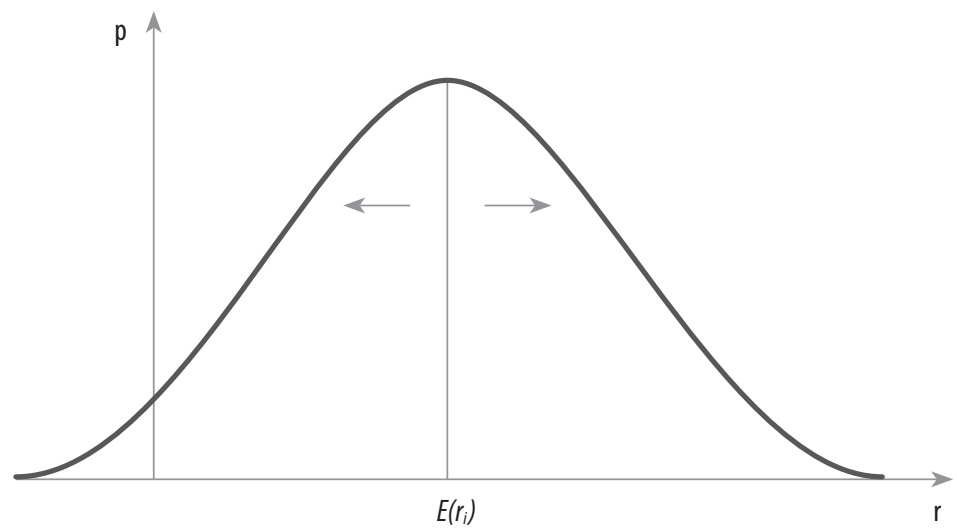

2. ábra: A hozamok eloszlása

Forrás: Saját szerkesztés 
Az ábra koordináta rendszerében a vízszintes tengelyen a hozamot ( $\mathrm{r}$ ), a függőleges tengelyen az adott hozam előfordulási valószínűségét (p) tüntetjük fel.

Ha a hozamok eloszlását normálisnak tekintjük, akkor két jól megragadható értéket számolhatunk egy-egy részvényhez kapcsolódóan. Az egyik a hozam várható értéke, illetve a hozamok ingadozását jellemző variancia. A várható hozamot a múltbeli hozamok átlagával lehet becsülni. A variancia a hozamok átlagtól való négyzetes eltérésének átlaga. A variancia négyzetgyöke a szórás.

A hozam varianciája, illetve szórása a kockázat mérésére alkalmasnak bizonyult mérőszámok. Markowitz a kockázat kvantifikált megragadása mellett azt is vizsgálta, hogyan alakulna egy befektető kockázata amennyiben többféle részvénybe fektetne be. A tapasztalatok azt mutatják, hogy a részvények hozamai nem mozognak teljes mértékben együtt, sőt a hozamok akár ellentétesen is alakulhatnak.

Egy kereskedő például a nyári szezon előtt beszerezhet napolajat és esőkabátokat. Napos idő esetén a napolaj, esős idő esetén pedig az esőkabát fogy jobban. Amennyiben a kereskedő csak napolajat tartana, napos időnél nyeresége magas volna, de esős idő beálltakor nyeresége alacsony lenne. Ha csak esőkabátot tartana a napos idő okozna részére veszteséget, és esős időjárásnál realizálna magas hasznot. Ezekben az esetekben a nyereség szélsőségesen alakulna. Amennyiben a kereskedő raktárában napolaj és esőkabát egyaránt volna, akkor bármely időjárás bekövetkeztekor hasonló profitot érhet el. Igaz a nyereség nem lenne semelyik esetben sem kiugróan magas, hiszen vagy a napolaj, vagy a kabát maradna a nyakán, csökkentve az értékesítésen elért nyereséget. A következmény mindenesetre a hozamingadozás csökkenése. A példa úgyis értelmezhető, hogy a két áruval való kereskedést külön üzletágként felfogva, a két üzletágba való együttes befektetés csökkenti a hozam volatilitását.

A befektetők természetesen kialakíthatnak akár sok részvényből álló portfóliókat is. A részvények egymástól eltérően alakuló hozamingadozásai kiegyenlíthetik egymást, ezért a portfólió egészének hozamingadozása akár kisebb lehet, mint a benne szereplő bármelyik részvény hozamingadozása. Ugyanakkor a hozam meghaladhatja a legkisebb kockázatú részvény hozamát. 
A portfólió várható hozamát és hozamának szórását a következők szerint lehet kiszámítani:

$$
E\left(r_{P}\right)=\sum_{i=1}^{n} a_{i} E\left(r_{i}\right)
$$

ahol

$E\left(r_{p}\right)$ : a portfólió várható hozama

$n$ : a részvények száma

$a_{i}$ : az i részvény aránya a portfólióban

$E\left(r_{i}\right): \mathrm{Az}$ i részvény hozamának várható értéke

$$
\sigma\left(r_{P}\right)=\sqrt{\sum_{i=1}^{n} \sum_{j=1}^{n} a_{i} a_{j} \rho_{i j} \sigma\left(r_{i}\right) \sigma\left(r_{j}\right)}
$$

ahol

$\sigma\left(r_{p}\right)$ : a portfólió hozamának szórása

$n$ : a részvények száma a portfólióban

$a_{i}$ : az i részvény aránya a portfólióban

$p_{i j}$ : az i és j részvények hozamai közti korrelációs együttható

$\sigma\left(r_{i}\right)$ : az i részvény hozamának szórása

Látható, hogy a portfólió hozama a benne szereplő részvények hozamától és azok arányától függ. A portfólió szórása függ a részvények súlyarányától, azok egyedi szórásától, illetve a hozamok közti korrelációtól. A korreláció azt mutatja meg, hogy a részvények hozamai milyen együtt mozgást mutatnak. Negatív az értéke, ha a hozamok ellentétesen változnak, azaz, ha az egyik részvény hozama növekedést mutat, a másiké csökken. Ha a változások azonos irányúak, akkor a korrelációs együttható pozitív értéket vesz fel. Természetesen a piaci adatokból számolva az tapasztalható, hogy bármely irányú együttmozgás tendenciaszerü, nem determinisztikus. A hozamingadozások a portfólió szélesítésével, a bevont részvényfajták számával csökkenthető. 


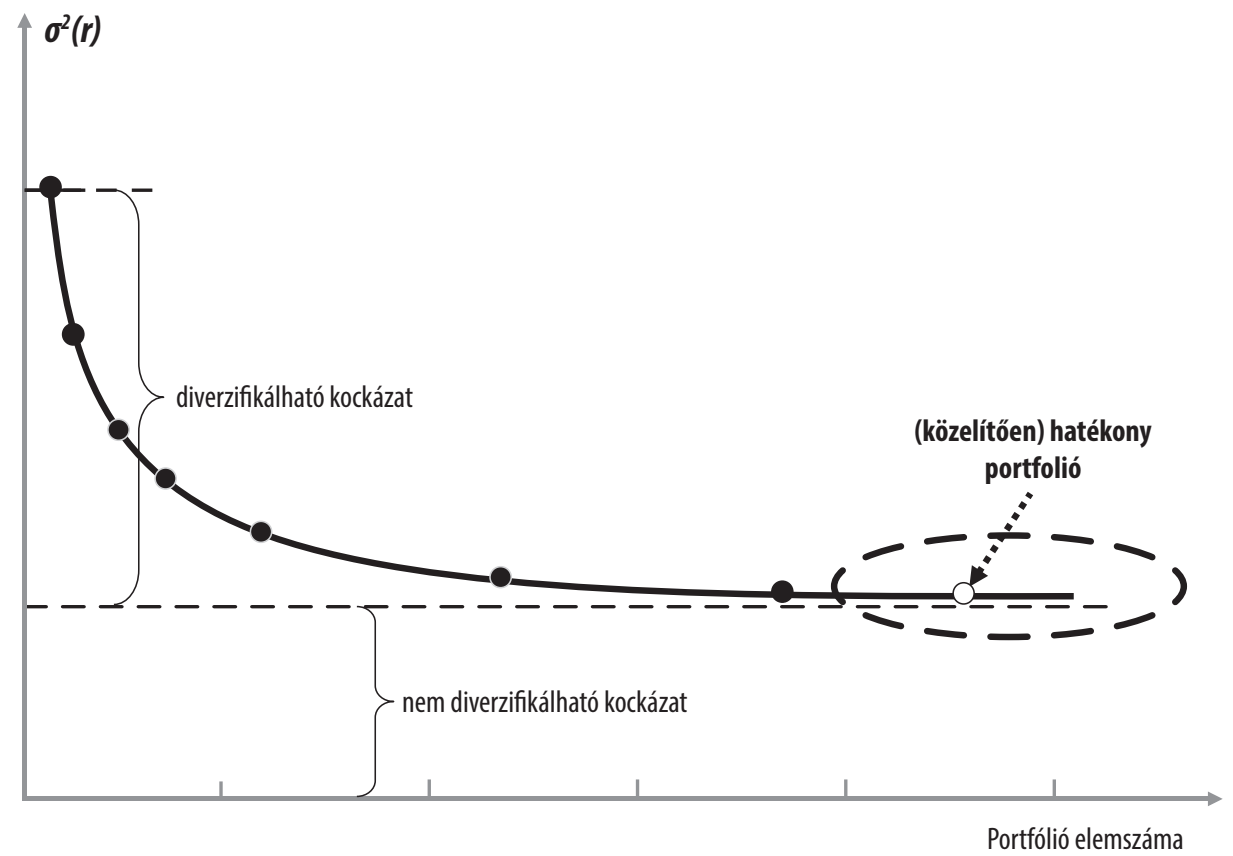

3. ábra: A diverzifikáció és a kockázat kapcsolata

Forrás: Saját szerkesztés

A portfólió szélesítésével, a diverzifikációval a kockázat egy része küszöbölhető ki. Ezt a hányadot diverzifikálható kockázatnak nevezzük. A kockázat másik része a nem diverzifikálható vagy szisztematikus kockázat. Diverzifikációval ez nem tüntethető el, mivel a részvények hozamaira bizonyos tényezők egyformán hatnak, a hozamokat egyirányba mozdítják el. Ilyenek például a makrogazdasági hatások, mint mondjuk az adózási változások hatása, nyereségadó csökkentése több osztalék kifizetését teszi lehetővé a részvényesek javára.

A fentiek ismeretében feltehető az a kérdés, hogy a piacon levő részvények milyen arányban szerepeljenek egy optimális portfólióban. A kérdés megválaszolásához ki kell számítani a részvények várható hozamait, hozamaik szórását, illetve a hozamok közti korrelációs együtthatókat. Ezek után a részvények portfólióbeli súlyait változtatva fel kell írni a lehetséges portfóliók várható hozamát és szórását a fenti képletek segítségével. A lehetséges kockázat-hozam párokat az alábbi ábra szemlélteti: 


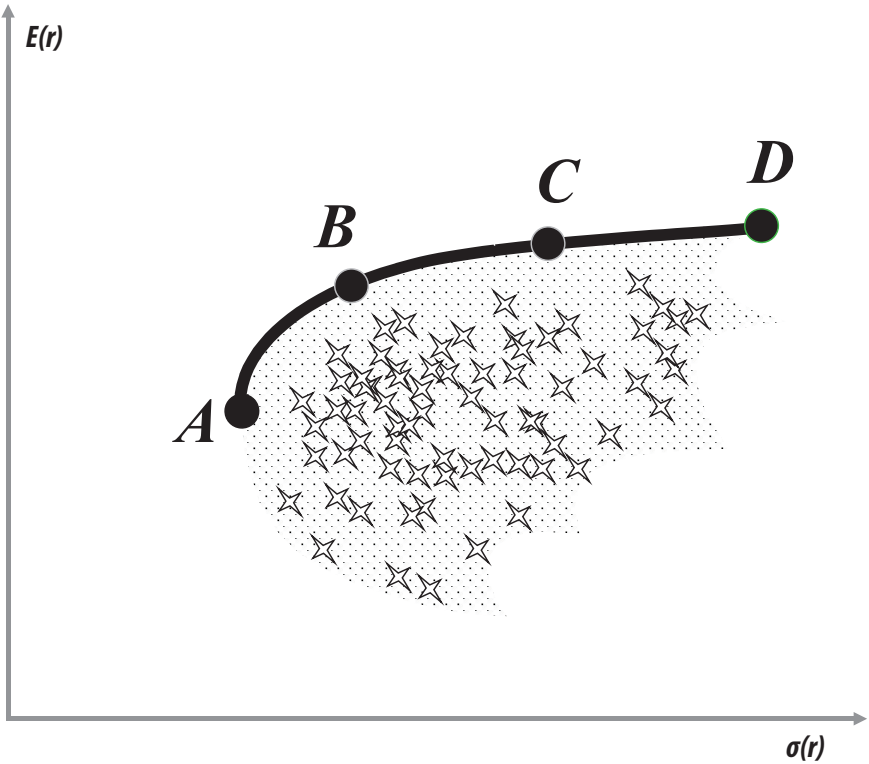

4. ábra: A lehetséges portfóliók kockázat-hozam párjai

Forrás: Saját szerkesztés

A lehetséges kockázat-hozam párok végtelen halmazát egy burkológörbe határolja. Ezen a határon a „tojáshéj” felső felén helyezkednek el azok a portfóliók, amelyek az adott kockázat mellett a legmagasabb hozamot biztosítják. Ezek az optimális, vagy hatékony portfóliók. Ilyen portfóliók az A, B, C és D portfóliók is. A hatékony portfólióban minden részvény valamilyen pozitív súllyal szerepel (Markowitz, 1952).

Rendelkezésre áll tehát egy olyan portfólióválasztási modell, amely lehetővé teszi a kockázatok és hozamok együttes optimalizálását.

James Tobin az elmélethez azzal járult hozzá, hogy kiterjesztette az elgondolást a részvényeken túl más értékpapírokra. Tobin szerint a befektetők a kockázatmentesnek tekintett (USA) állampapíroktól kezdve, a kockázatos részvényekig bármely értékpapírba tarthatják vagyonukat. Az értékpapírok kiszélesített körére volt feltehető most már az a kérdés, hogy melyek a kockázatokat és hozamokat számba véve az optimális portfóliók (Tobin, 1958).

$\mathrm{Az}$ elméleti hátteret napjainkra a fenti elgondolások alapjain továbbfejlesztették, és a befektetési alapok portfólióinak kialakításakor is alkalmazzák. 
A befektetési alapokba fektetők az alapokon keresztül diverzifikált portfóliók tulajdonosaivá válhatnak. Természetesen napjaink befektetési alapjai az 1950es évek után a piacokon széleskörben kereskedett újabb instrumentumokat is választhatják portfóliójukba. Ilyen instrumentumok például az opciók vagy a határidős termékek.

\subsection{A befektetési alapok létrehozása, müködése}

A befektetési alap kollektív befektetési forma. A befektetési alapba a befektetőktől összegyüjtött vagyont egységesen kezelik a befektetők általános felhatalmazása alapján, előre meghirdetett elvek szerint. A vagyon egységes kezelése valósul meg, a bevont eszközöket nem különítik el. A vagyon gyüjtése kollektív befektetési értékpapírok, befektetési jegyek kibocsájtásával történik. (Lentner, 2012)

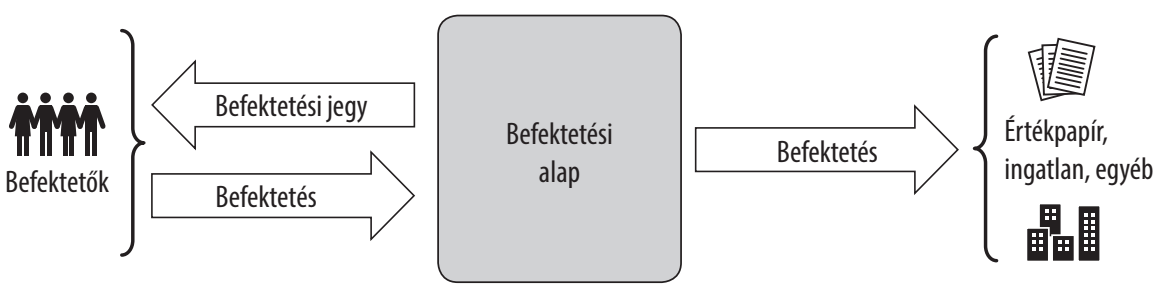

5. ábra: A befektetési alapok tőkegyüjtése és tőkekihelyezése Forrás: Saját szerkesztés

A befektetési alapok létrehozói és működtetői a befektetési alapkezelők. A befektetési alap jogi személy, de nem rendelkezik szervezettel. Az alap létrehozásához és működtetéséhez kapcsolódó feladatokat a befektetési alapkezelő látja el.

A befektetési alap létrehozatalakor az alap vagyonát befektetési jegyek kibocsájtásával gyűjtik össze. A befektetési jegy olyan értékpapír, amelyet befektetési alap bocsájthat ki tőkegyüjtés céljából. A befektetési jegy sorozatban kibocsájtott értékpapír. Tulajdonosai részére az alappal szembeni, az alap kezelési szabályzatában meghatározott követelést és egyéb jogokat testesít meg. A befektetési jegyet a forgalomba hozatala során keletkeztetik és juttatják első tulajdonosának birtokába. A tulajdonos a későbbiekben a befektetési jegyeket másra átruházhatja.

Az alapkezelő végzi a befektetéskezelési tevékenységet is. A befektetéskezelés a befektetési politikának megfelelően a befektetési (eszközallokációs) döntések meghozatala és végrehajtása, vagyis a portfóliókezelés. A lehetséges befektetések körét a jogszabályi háttér adja meg tágabb keretként. Ezen a kereten belül a be- 
fektetési alap lefektetett befektetési politikája szabja meg részleteiben, hogy mely instrumentumok lehetnek a befektetési célpontok.

A befektetési alapkezelök a befektetéskezelésen túl további feladatokat is ellátnak. Ellátják a kollektív befektetéskezeléshez kapcsolódó adminisztratív feladatokat. Végezhetnek könyvviteli és jogi feladatokat. Szolgáltathatnak információkat a befektetők részére. Értékelhetnek és árazhatnak eszközöket, intézhetnek adóügyeket. Vezethetik a befektetőkhöz kapcsolódó nyilvántartásokat és fizethetik részükre a hozamokat. Feladatkörükben lehet a megkötött ügyletek teljesítése.

Az alapkezelő az általa kezelt befektetési alapok vagyonához kapcsolódóan köteles letétkezelőt megbízni letétkezeléssel. Az alap tulajdonában levő értékpapírokat, egyéb pénzügyi eszközöket a letétkezelőnél nyitott letéti számlán kell elhelyezni. A letétkezelőhöz nem transzferálható instrumentumok, mint származtatott termékek, bankbetétek vonatkozásában a letétkezelőnek számlát kell nyitnia az adott eszközöket nyilvántartó szervezetnél. A letétkezelő követi nyomon az alap pénzmozgásait. Ez értendő a befektetési jegyek kibocsájtásához kapcsolódó pénzmozgásokra és az alap befektetéseihez kapcsolódó pénzmozgásokra is. Folyamatosan nyilvántartást vezet az alap eszközeiről. Ellenőrzi, hogy a befektetési alap vagyona megfelel-e a jogszabályi előírásoknak és a saját befektetési politikájában foglaltaknak. A letétkezelő végrehajtja az alapkezelő az alap eszközeire vonatkozó utasításait. A letétkezelő értékeli az alap eszközeinek és kötelezettségeinek az értékét, és ennek alapján megállapítja az alap nettó eszközértékét. Biztosítja, hogy az alap eszközeihez kapcsolódó, valamint a befektetési jegyek forgalmazásából származó bevételek az alaphoz határidőre befolyjanak. Az ingatlanokba fektető alapok esetén az ingatlanok átruházásához és megterheléséhez engedélyt ad, ha az ügyletek szabályosak. A letétkezelö, amennyiben az alap müködésével kapcsolatosan bármilyen szabálytalanságot észlel, azt jelzi a felügyeleti szervnek.

A befektetési alap szabályszerü gazdálkodásának külső ellenőrzésére könyvvizsgálót kell alkalmazni. A könyvvizsgáló ellenőrzi, hogy az alapkezelő az alap létrehozásakor és működtetése során a vonatkozó jogszabályoknak és az alap szabályzatainak megfelelően jár el a gazdálkodásban. Az alap nyilvántartásai biztosítják-e a működés áttekinthetőségét, a nyilvántartásokat az előírtaknak megfelelően vezetik-e. A könyvvizsgáló ellenőrzi a befektetési alap jelentéseinek és beszámolóinak jogszabályi megfelelőségét. 


\subsection{A befektetési alapok csoportosítása}

A jogszabályi háttér többféle szempontból értelmezi a létrehozható alapokat. Ugyancsak értelmes csoportosítani az alapokat a befektetőknek abból a célból, hogy az alapok teljesítményét, költségeit összehasonlíthatóvá lehessen tenni.

A befektetési alapok müködési formája szerint eltérő a befektetési jegyek forgalomba hozatali módja. A befektetési alapok működhetnek zártkörű vagy nyilvános alapként. A zártkörűen müködő alapok befektetési jegyeit nem szerezheti meg bármelyik befektető, csak a befektetők előre meghatározott köre válhat tulajdonosukká. Ezzel szemben a nyilvános befektetési alapok befektetési jegyeihez korlátozás nélkül hozzájuthat minden befektető.

A forgalmazási kör alapján a befektetési alap lehet lakossági vagy szakmai befektetők részére forgalmazott.

A befektetési jegyek visszaválthatósága alapján megkülönböztetve a befektetési alapok lehetnek nyíltvégü és zártvégű alapok. A nyíltvégü alapok befektetési jegyeit a befektetők az alap müködési ideje alatt bármikor megvásárolhatják az alaptól. A befektetési jegyek kibocsájtása folyamatos. A befektetési jegyek ugyanakkor a kezelési szabályzatban rögzített feltételekkel mindenkor visszaválthatók. A nyiltvégü alapok befektetési jegyeinek folyamatos adásvétele a nettó eszközértéken történik. Ezt a letétkezelő állapítja meg úgy, hogy az alap bruttó eszközértékéből levonja az alap kötelezettségeinek értékét, majd az így megállapított nettó eszközértéket elosztja a forgalomban levő befektetési jegyek számával. A nyíltvégü befektetési alap forgalomban levő befektetési jegyeinek száma a folyamatos adásvétel miatt változhat az alap müködési ideje alatt. A zártvégü befektetési alap befektetési jegyei ellenben nem válthatók vissza a befektetők kezdeményezésére. Az alapkezelő azonban jogosult az alap futamideje alatt is visszaváltási lehetőséget biztosítani a befektetőknek. Az alapkezelö, ha ezt a kezelési szabályzatban korábban rögzítették, jogosult lehet a befektetési jegyek meghatározott feltételekkel való bevonására.

A befektetési alap futamideje alapján lehet határozott vagy határozatlan futamidejü. A határozott futamidejü alap müködési idejének tartamát elöre rögzítik. A határozatlan futamidejü alap müködési idejét ezzel szemben előre nem határozzák meg. 
A befektetési alapok megkülönböztethetők az alap által megszerezhető elsődleges eszközök szerint. Az alapok lehetnek értékpapíralapok, ingatlanalapok. (Megjegyezzük, hogy a jelenleg - 2019 márciusában - hatályos jogi szabályozás felsorolja még a kockázati tőkealapokat és a magántőkealapokat, amelyeket ebben a fejezetben nem tárgyalunk.) Az értékpapíralapok értékpapírokat, illetve egyéb pénzpiaci és pénzügyi eszközöket tarthatnak portfóliójukban. Az ingatlanalapok közvetlenül ingatlanokba fektethetnek és birtokolhatnak olyan vállalati részesedéseket, amelyek ingatlanvagyonnal rendelkeznek. A továbbiakban az alapok portfóliójában megjelenő instrumentumok körét még részletesebben érintjük.

A befektetési alapok megkülönböztethetők még az értékpapír-befektetéseik szabályozása szerinti eltérés alapján. Ebből a szempontból a befektetési alapok lehetnek átruházható értékpapírokkal foglalkozó kollektív befektetési vállalkozások (ÁÉKBV) és alternatív befektetési alapok (ABA). Az ÁÉKBV olyan nyilvános nyíltvégü befektetési alap, amely megfelel a vonatkozó jogszabály szerinti befektetési szabályoknak. Az ÁÉKBV-nek nem minősülő befektetési alapok az alternatív befektetési alapok. ${ }^{2}$

A jogszabályi keretek figyelembevételével az alapkezelők maguk alakítják ki a befektetési alapok befektetési politikáját a piaci igények alapján. A számos befektetési alap közül valószínüleg nem lehetne két olyat találni, amelyek portfóliója akár időlegesen is pontosan egyezne. A befektetők azonban igénylik, hogy az alapok teljesítménye összemérhető legyen. A Befektetési Alapkezelők és Vagyonkezelők Magyarországi Szövetsége (BAMOSZ) 2013-ban aktualizálta az alapok kategorizálására tett ajánlásait. Az ajánlásokat a BAMOSZ tagjai alkalmazzák alapjaik megnevezésében. A BAMOSZ a besorolások alapján hozza nyilvánosságra az alapokra vonatkozó adatokat. A következőkben áttekintjük ezeket a

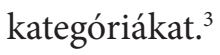

Az alapok kategorizálásának alapja, hogy milyen instrumentumok a befektetési célpontjaik, vagyonukat milyen módon allokálják.

2 2014. évi XVI. törvény a kollektív befektetési formákról és kezelöikről, valamint egyes pénzügyi tárgyú törvények módosításáról

3 www.bamosz.hu Letöltve: 2019.03.04. 
A hagyományos alapok közé kell sorolni azokat a befektetési alapokat, amelyeknél a tökeáttétel (leverage) nem éri el a 30\%-ot. A tökeáttétel az a hatás, amely megnöveli a befektető várható hozamát ahhoz képest, mintha saját tőkéjét közvetlenül részvényekbe, kötvényekbe, devizákba, árukba fektetné. Tökeáttétel többféleképpen érhető el. Ilyen lehetséges módszer például, ha a befektetési alap az összegyüjtött tőke mellé hitelt vesz fel, vagy határidős ügyletet köt. A tőkeáttétel azonban a kockázatot is növeli, a tőkeáttétel növekedésével jellemzően nő a hozamok ingadozása. A hagyományos alapoknál a tőkeáttétel tehát nem haladhatja meg a 30\%-ot, míg a speciális alapoknál ez az arány ennél nagyobb lehet. A speciális alapok közé soroltak az árukba, illetve ingatlanokba fektető alapok is, amennyiben a portfólióban levő ingatlanok vagy áruk aránya meghaladja a 40\%-ot.

A kategorizálás alapja még az is, hogy a befektetési alap portfóliójában a fix, előre kalkulálható hozamot biztosító, illetve az előre nem kalkulálható hozamú eszközök aránya mekkora. Elöre kalkulálható hozamú eszköz a kötvény, a bankbetét, az egyéb kötvény jellegü értékpapír. Nem kalkulálható hozamú instrumentumok a részvények, befektetési jegyek, áruk.

Lényeges csoportosítási szempont, hogy a portfóliónak milyen a lejárati szerkezete. Ebből a szempontból az is lényeges, hogy egy előre meghatározott lejárattal rendelkező instrumentum futamidejéből mekkora időszak van hátra.

A hagyományos és speciális felosztás szerinti befektetési alapok további kategorizálása a fenti szempontok figyelembevételével a következő táblázatokban szerepel. 


\section{Pénzpiaci alapok}

Likviditási alapok: A portfólióban lévő eszközök átlagos hátralévő futamideje a 60 napot, az eszközök átlagos hátralévő élettartama a 6 hónapot nem haladhatja meg.

Pénzpiaci alapok: A portfólióban lévő eszközök átlagos hátralévő futamideje a 6 hónapot, az eszközök átlagos hátralévő élettartama a 12 hónapot nem haladhatja meg.

\section{Kötvényalapok}

Rövid kötvényalapok: A portfólióban lévő eszközök átlagos hátralévő futamideje

6 hónap és 3 év közötti.

Hosszú kötvényalapok: A portfólióban lévő eszközök átlagos hátralévő futamideje meghaladja a 3 évet.

Szabad futamidejü kötvényalapok: Olyan alapok, amelyek nem ragaszkodnak egy elöre meghatározott durációs limithez.

\section{Vegyes alapok}

Kötvénytúlsúlyos (vagy óvatos) vegyes alapok: A portfólióban lévő nem kötvény típusú eszközök aránya nem haladja meg a 35\%-ot. A nem részvény típusú eszközök kategóriánként (pl. ingatlan típusú, árupiaci típusú, stb.) legfeljebb 20\%-ot tehetnek ki - ebből a szempontból a befektetési jegyek teljes egészében a kategóriának megfelelő kitettséget jelentenek, függetlenül az alap feltöltöttségétől.

Kiegyensúlyozott vegyes alapok: A portfólióban lévő nem kötvény típusú eszközök aránya 35-65\%. A nem részvény típusú eszközök kategóriánként (pl. ingatlan típusú, árupiaci típusú, stb.) legfeljebb 40\%-ot tehetnek ki - ebből a szempontból a befektetési jegyek teljes egészében a kategóriának megfelelő kitettséget jelentenek, függetlenül az alap feltöltöttségétōl. Dinamikus vegyes alapok: A portfólióban lévő nem kötvény típusú eszközök aránya meghaladja a 65\%-0t. A nem részvény típusú eszközök kategóriánként (pl. ingatlan típusú, árupiaci típusú, stb.) legfeljebb 40\%-ot tehetnek ki - ebből a szempontból a befektetési jegyek teljes egészében a kategóriának megfelelő kitettséget jelentenek, függetlenül az alap feltöltöttségétốl.

\section{Résziényalapok}

A portfólióban lévő részvény típusú eszközök aránya meghaladja a 80\%-0t.

\section{1. táblázat: A hagyományos befektetési alapok kategóriái} Forrás: BAMOSZ (2019) 


\section{Árupiaci alapok}

Azon alapok, amelyek legalább 50\%-ban árupiaci kitettséget jelenítenek meg (ami lehet alapokon vagy származékos ügyleteken keresztül).

\section{Abszolút hozamú alapok}

Azon alapok, amelyek tôkepiaci környezettốl független pozitív hozam elérésére törekednek, és kiinduló pontként a kockázatmentes hozam meghaladását tekintik.

\section{Tókevédett alapok}

A hozamot, illetve tőkemegóvást ígérő, illetve garantáló alapok.

\section{Származtatott alapok}

Azon származtatott ügyletekbe fektető alapok, amelyek nem tartoznak a fenti alapok közé.

\section{Ingatlanalapok}

Közvetlen ingatlanokba fektető alapok: Azon alapok, amelyek az ingatlankitettséget közvetlen ingatlanok tartásával valósítják meg.

Közvetett ingatlanokba fektető alapok: Azon alapok, amelyek a 40\%-ot meghaladó ingatlankitettséget közvetett módon (alapokon, ingatlanrészvényeken, stb.) keresztül valósítják meg.

\section{2. táblázat: A speciális befektetési alapok kategóriái}

Forrás: BAMOSZ (2019)

A BAMOSZ a fentieken túlmenően további ajánlásokat is tett az alapok kategorizálására. Ezek a befektetések földrajzi, devizális kitettségére vonatkoznak. Az ajánlás értelmében a befektetési alapoknak a besorolásuk szerinti kategória megnevezést nevükben szerepeltetni kell. A besorolásra vonatkozó megtévesztő elnevezést nem szabad használni.

\subsection{A hozamok és kockázatok összemérésének gyakorlati kérdései}

A korábbiakban utaltunk a befektetések hozamai és kockázatai közti összefüggésekre. A befektetőknek el kell döntenie, hogy a befektetési alapokba való befektetéskor milyen kockázatot kívánnak vállalni. A piacon versenyző alapok kínálatából való választáskor megvizsgálhatják, hogy mely alap teljesített a hasonló befektetési profilúakból jobban, azaz melyik biztosított magasabb hozamot. Természetesen a múltbeli hozamok ismert mértéke nem jelent garanciát arra, hogy a jövőben is ugyanazt a teljesítményt éri el az alap.

A befektetési jegyek tulajdonosai, a befektetők az alap eredményéből többféleképpen tehetnek szert hozamra. A hozamok realizálásának módja az alapok 
kezelési szabályzatából olvasható ki. A nyereség, amennyiben a szabályzat úgy rendelkezik, közvetlenül kifizethető az elöre meghatározott időpontokban a befektetők részére. Ilyen megoldást a piaci tapasztalatok szerint legfeljebb a zártvégü alapoknál alkalmaznak. A bevett gyakorlat alapján a keletkező eredmény az alap vagyonában marad. A nyíltvégű alapok befektetési jegyeinek tulajdonosai hozamot akkor realizálhatnak, amikor befektetési jegyeiket visszaváltják. A hozam a befektetési jegyek eladási és visszaváltási értékének különbözetéből adódik. A zártvégű alapok befektetési jegyeinek - de akár a nyíltvégű alapok befektetési jegyeinek - tulajdonosai is a befektetési jegyek másra való átruházásakor realizálhatnak hozamot. A hozam a befektetési jegy értékesítésekor szintén az eladási és a korábbi vételi árfolyam különbözetéből számolható. A zártvégű és egyben határozott futamidejü alapoknál a futamidő végén, az alap megszűnésekor a vagyon felosztásakor realizálható a befektető hozama. Nem szabad elfeledni, hogy a befektetési alapok vagyonában levő instrumentumokat is a piac folyamatosan átértékeli, így a befektetési jegyek tulajdonosai nemcsak pozitív hozamot érhetnek el, de a hozam lehet negatív is.

A befektetési alapok teljesítményének értékelésekor általában a portfóliók értékváltozásából számolható hozamokat szokták megvizsgálni. A hozam ebből a szemszögből az egy befektetési jegyre jutó nettó eszközérték változását jelenti. A hozamok kiszámítását követően az azonos kategóriákba sorolt befektetési politikájú alapok hozamait ésszerü összevetni. Vizsgálható, hogy egy alap a piaci átlaghoz képest milyen teljesítményt nyújtott. Értékelhető az alapok teljesítménye valamilyen referencia indexhez viszonyítottan is. Ilyen referencia érték lehet például egy tőzsdeindex.

Magyarországon 1996-ban alkották meg a MAX indexet az államkötvények hozamváltozásának tükrözésére. Jelenleg az Államadósság-Kezelő Központ müködteti és teszi közzé. A különböző futamidejű magyar állampapírhozamok alakulását mutató indexcsaládot építettek fel. A likviditási alapok referencia indexe a ZMAX, a náluk kissé hosszabb futamidejü állampapírokba befektető alapok referencia indexe az RMAX. A rövid kötvényalapok indexe a MAX Composite, a hosszú kötvényalapoké a MAX index. ${ }^{4}$

4 http://abszoluthozam.hu/tudastar/lexikon/max_index.php Letöltve: 2019.03.05. 
A befektetőknek az alapok közti választáshoz szüksége van bizonyos költségek ismeretére, amelyek az alap hozamára csökkentően hatnak majd, illetve a befektetőknek meg kell fizetniük. A befektetőket terhelő költségek a befektetési jegyek vásárlási és visszaváltási jutalékai, az alapkezelési díj, a letétkezelési díj, a sikerdíj és egyéb díjak. A vételi jutalék a befektetési jegyek forgalomba hozatalához kapcsolódó egyszeri díj. A visszaváltási díj a befektetési jegyek alap általi visszaváltásához kötődő egyszeri díjtétel. Az alapkezelő az alap működtetéséért alapkezelési díjat számolhat fel az alap terhére. A befektetési alapnak, mint korábban láttuk, letétkezelőt kell alkalmaznia. Ennek az alap számára felmerülő költsége a letétkezelési díj. Az alapkezelő felszámíthat sikerdíjat, amennyiben egy elöre meghatározott mértékű hozamot ér el az alap. Az egyéb díjak például a könyvvizsgálói díj, a bankköltség.

Az összes költségterhelést a TER mutató (Total Expense Ratio) foglalja öszsze egy mérőszámban. A TER mutatót és az alapok költségeit részletesen be kell mutatni a befektetőknek. A befektetési alapok TER mutatóit és az ezek számítási alapját képző költségeket a magyarországi befektetési alapok esetén a Magyar Nemzeti Bank is közzéteszi. A nyilvános nyíltvégű alapoknak közzé kell tennie a Kiemelt Befektetői Információkat tartalmazó kétoldalas dokumentumot (Key investor information document, KIID). A dokumentumban fel kell tüntetni a TER mutatót is a korábbi időszakokra. Természetesen a befektetők számára az alacsonyabb költségek a kedvezőbbek.

A hozamok ismerete mellett a már tárgyaltak szerint a befektetőknek szüksége van a vállalt kockázatok ismeretére is. A Portfólió elmélet megalkotása óta a hozam szórásán és varianciáján túl egyéb mérőszámokat is kialakítottak a kockázatok értékelésére. A továbbiakban ezek közül kettőt említenénk, amiket szokásosan a befektetési alapok kockázatának értékeléséhez használnak a piaci szereplők. A két mutató a Sharpe ráta és a Sortino ráta.

A Sharpe ráta azt mutatja meg, hogy a befektetési alap hozama a kockázatmentes hozamon felül mekkora hozamot biztosít egységnyi hozamszórásra vetítve. A mutató tehát a kockázati prémiumot vetíti a hozam ingadozására. A számításnál alkalmazhatjuk kockázatmentes hozamként például az egyéves futamidejű állampapír hozamát, vagy a MAX index hozamtartalmát. 
A Sharpe ráta számításának képlete:

$$
\begin{aligned}
& \text { Sharpe ráta }=\frac{r_{i}-r_{f}}{\sigma\left(r_{i}\right)} \\
& \text { ahol }
\end{aligned}
$$

$r_{i:}$ az i befektetési alap hozama

$r_{f}$ : a kockázatmentes hozam

$\sigma\left(r_{i}\right):$ az i befektetési alap hozamának szórása

A Sharpe ráta hibájaként azt szokták fóként felróni, hogy a pozitív irányú hozamkimozdulásokat is problémaként kezeli. Pedig a befektetők számára ezek a pozitív irányú kilengések kedvezőek. A mérés ilyen torzítását hivatott kiküszöbölni a Sortino ráta. A mutató meghatározásakor csak az elvárt hozamszinttől (küszöbértéktől) alacsonyabb hozamszintek szórását vesszük figyelembe. Az elvárt hozamszint lehet például a kockázatmentes hozam. A Sortino ráta számításának képlete:

$$
\text { Sortino ráta }=\frac{r_{i}-r_{f}}{\sigma^{*}\left(r_{i}\right)}
$$

ahol

$r_{i:}$ az i befektetési alap hozama

$r_{f}$ : a kockázatmentes hozam

$\sigma^{\star}\left(r_{i}\right)$ : az i befektetési alap küszöbérték alatti hozamainak szórása

Mindkét ráta alkalmazásánál a magasabb érték mutatja a befektető részére a kedvezőbb befektetési lehetőséget.

Bár a múltbeli hozamok alakulása nem ad pontos képet a jövőben várható értékekről, de a befektetők számára mégis tájékozódási pontot jelent az alapok teljesítményéről. A fenti mérőszámok lehetőséget adnak a befektetőknek a vállalt kockázatok átgondolására és áttekintést biztosítanak a portfóliókezelők közti eltérések vizsgálatára. 


\subsection{Irodalomjegyzék}

BAMOSZ (2019): https://www.bamosz.hu Letöltve: 2019.03.06.

ICI Investment Company Institute (2018): Investment Company Fact Book. 58 th edition

Lentner Csaba (szerk.) (2012): Bankmenedzsment - Bankszabályozás - Pénzügyi fogyasztóvédelem. Nemzeti Közszolgálati és Tankönyvkiadó, Budapest.

Markowitz, Harry (1952): Portfolio Selection. The Journal of Finance, Vol. 7, No. 1. (Mar., 1952), 77-91. o.

MNB (2019): A Magyar Nemzeti Bank által felügyelt szektorok adatainak idősorai: Befektetési alapok. https://www.mnb.hu/letoltes/befalap-idosor.xls Letöltve: 2019.03.05.

Rouwenhorst, K. Geert. (2004): The origins of mutual funds. Yale ICF Working Paper No. 04-48.

Tobin, James (1958): Liquidity Preference as Behavior Towards Risk. The Review of Economic Studies, Vol. 25, No. 2. (Feb., 1958), 65-86. o. 


\section{Kockázatitőke-alapok}

\subsection{Fogalmi értelmezés}

A kockázati tőke és a magántőke kapcsán a szakirodalomban, az érintett szervezeteknél és a jogi területen egységes, teljes körü definíció egyelőre nincsen, mint ahogy a terület szakszavainak írásmódja is változatos. Az iparági berkekben gyakori az angol nyelvű kifejezések használata, amelyek közül egyeseknek nincs is magyar nyelvü megfelelője, vagy az nem adja vissza megfelelően az adott angol nyelvü kifejezés valódi tartalmát (MNB, 2015). Glavanits (2012) az angol venture capital/risk capital más nyelvekben való használatával is foglalkozik röviden, $\mathrm{s}$ ennek kapcsán kitér a magyarban elterjedt elnevezésre. Szerencsésebbnek találná, ha esetleg a „kockázatvállaló” tőke került volna bevezetésre anno.

A fogalmi zavarhoz a befektetések, ügyletek jellegének változása, bővülése is hozzájárult. Az innovációfinanszírozás és a kockázati tőkével (venture capital) történő finanszírozás fogalmának szoros összetartozása csak az 1980-as évek közepéig volt jellemző. Manapság a befektetők nemcsak az újdonsággal jelentkező vállalkozásokat, hanem a terjeszkedni kívánó társaságokat, az átfordítást végrehajtó cégeket, valamint vezetői be- és kivásárlásokat finanszíroznak. Tulajdonképpen ez már a tágabb magántőke (angolul private equity) kategóriája. (Kovács, 2013)

A szakirodalomban a kockázati és magántőke jellemzőinek megragadásával történő körülírásra vállalkoznak a szerzők. Például, a teljesség igénye nélkül, Fenn, Liang és Prowse (1995) szerint a magántőke magában foglal minden olyan ügyletet, amely professzionálisan kezelt tőkebefektetést jelent társaságokba. A magántőke-befektetők nagy tulajdoni részt szereznek, aktív monitoring tevékenységet látnak el, és tanácsokat adnak a célvállalatnak. Sok esetben vezető pozíciókat is betöltenek.

Az Invest Europe (korábbi nevén European Private Equity \& Venture Capital Association, EVCA) az ágazat európai szereplőinek érdekvédő, promotáló, összefogó szervezete is már hasonlóan definiál (pl. EVCA 2011): a magántőke magában foglal minden olyan tulajdonosi finanszírozást, amelyet egy külső befektető hajt végre egy általában tőzsdén nem jegyzett vállalkozás számára azzal 
a céllal, hogy növelje a vállalkozás értékét. A magántőkealapok rendszerint zártkörü, meghatározott időre létesített vagyontömegek. A „tőzsdén nem jegyzett vállalkozás számára” mondatrész elé fontos kitenni az „általában” szót, ugyanis, bár a többi típushoz képest elenyésző a számuk, de vannak olyan esetek, amikor a befektető tőzsdén szereplö vállalatban szerez részesedést, utána viszont onnan ki is vezeti a céget.

A venture capital szigorúan értelmezve a magántőke egy részét képezi, és olyan tulajdonosi tőkebefektetést jelent, ahol a célvállalat az induló, a korai fejlesztés vagy terjeszkedés fázisában van. (EVCA, 2011; EVCA, é.n.)

Karsai (2012, p. 11.) a private equity négy alapvető tulajdonságát a következőképpen fogalmazza meg'

„1. A kockázati tőke pénzügyi közvetítő szerepet lát el, azaz mások tőkéjét összegyüjtve azt közvetlenül befekteti vállalkozásokba.

2. Csak olyan cégekbe fektet be, amelyek részvényei a befektetést követően nem szerepelnek a tőzsdei kereskedelemben.

3. Résztulajdonosként aktív szerepet játszik az általa finanszírozott cégek életében. ${ }^{2}$

4. Végül elsődleges célja annak a hozamnak a maximalizálása, amit az általa finanszírozott vállalkozások értékesítésekor realizál, azaz amikor tulajdonosként kilép a cégekből."

A Magyar Kockázati és Magántőke Egyesület (MKME) a honlapján ${ }^{3}$ úgy határozza meg a kockázati tökét (venture capital), hogy az olyan professzionális befektetés, mely a tulajdonossal társulva finanszíroz egy korai fázisban ${ }^{4}$ levő vállalkozást. A befektető a magasabb kockázatért cserébe az átlagosnál magasabb hozamot vár el. A magántőke címszó alatt a tőzsdén nem jegyzett cégek számára történő részvénytőke biztosítása jelenik meg, amelyet új termékek kifejlesztésére, új technológiák bevezetésére, forgótőke bővítésére, felvásárlásokra, vagy a cég mérlegének javítására nyújtják. A magántőke-befektetés a tulajdonosi viszonyokat, illetve a cég vezetését is átrendezheti. Egy családi vállalkozásban az utódlás,

1 Karsai (2012) valójában a kockázati tőke kifejezést használja itt, de később pontositja, hogy a tőkeközvetító ágazat egészére (private equity) használja az elnevezést.

2 Az aktivitás persze nagyon eltérő intenzitású lehet a különböző esetekben (saját megjegyzés).

3 Szakkifejezések aloldalon: https://www.hvca.hu/szakkifejezesek/

4 A korai fázison belül még megkülönböztetik a magvetö (seed) és az induló (start up) fázist. 
vagy tapasztalt vezetők ki- és bevásárlásai szintén megoldhatók magántőke bevonásával. A kockázati tőke szigorúan véve csak egy részhalmaza a magántőkének, a cégek indításához, korai fázisban történő fejlesztéséhez vagy terjeszkedéséhez használt magántőke-befektetéseket nevezik így.

A célvállalatok jellemzően egy tőkealapból kapják a finanszírozást, amelyet egy alapkezelő irányít.

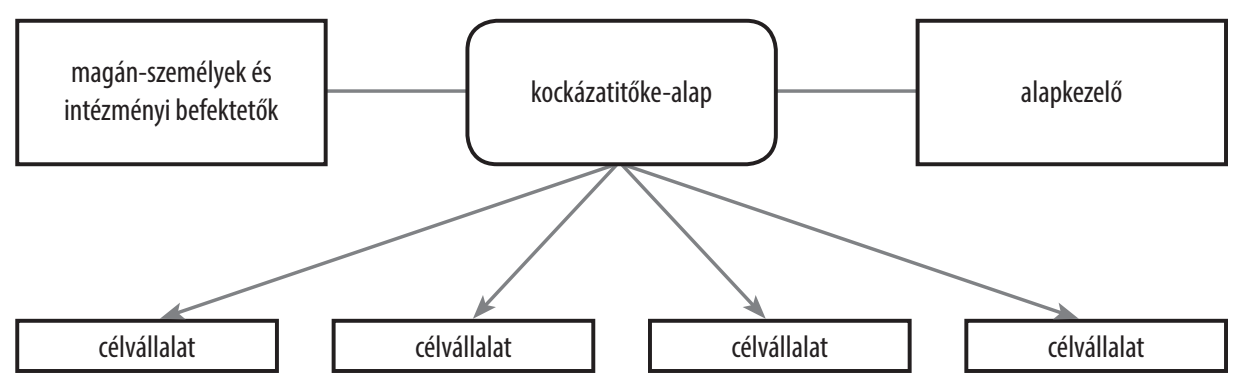

1. ábra: Befektetési struktúra

Forrás: saját szerkesztés

Természetesen a jogi aspektust sem hagyhatjuk ki. A kollektív befektetési formákról és kezelőikről, valamint egyes pénzügyi tárgyú törvények módosításáról szóló 2014. évi XVI. törvény (Kbftv.) szerint a kockázatitőke-alap olyan zártvégü alternatív befektetési alap $(\mathrm{ABA})^{5}$, amelyet vállalkozásfejlesztés finanszírozásának céljából hoztak létre. Befektetési politikája szerint az összesített tőke hozzájárulása, és a le nem hívott tőkéje legalább 70\%-át a vállalati fejlődés kezdeti szakaszában lévő vállalkozásokba fekteti, amelynek kollektív befektetési értékpapírjait zártkörűen, kizárólag szakmai befektetők részére hozzák forgalomba, és amely nem tőkeáttétellel finanszírozott. A magántőkealap pedig „olyan zártvégü $\mathrm{ABA}$, amelyet vállalatok, vállalatrészek megszerzésének finanszírozása (ideértve az akvizíciót is) céljából hoztak létre, kollektív befektetési értékpapírjait zártkörűen kizárólag szakmai befektetők részére hozzák forgalomba, és amely nem tőkeáttétellel finanszírozott, valamint az eredeti befektetés időpontját követő öt éven belül nem gyakorolhatók visszaváltási jogok”. E szerint a kockázati tőke nem része a magántőkének. Az alapkezelök elnevezésében azonban már nem tesz különbséget a törvény: a kockázati tőkealap-kezelő rendszeres gazdasági tevékenységként kizárólag kockázati tőkealapot, illetve magántőkealapot kezelő 5 A befektetési alapokkal bövebben az elözö fejezet foglalkozik. 
alternatív befektetési alapkezelö (ABAK) között. A Kbftv. alapján ilyen tőkealapok legalább hat teljes naptári éves futamidőre hozhatók létre. A gyakorlatban általában 10 éves futamidő szokott lenni.

Az MKME az alapok befektetési típusait és azok jellemzőit a következő táblázatban foglalja össze:

\begin{tabular}{|c|c|c|c|}
\hline BEFEKTETŐ TÍPUSA & TŐKEBEFEKTETÉS TÍPUSA & VOLUMENE (€) & TÖKEBEFEKTETÉS CÉLJA \\
\hline & KORAI FÁZIS (EARLY STAGE) & & INDULÓ CÉGEK FINANSZÍROZÁSA \\
\hline $\begin{array}{l}\text { Üzleti angyal, } \\
\text { kockázati tőke }\end{array}$ & Magvető (seed capital) & $50-500$ ezer & Üzleti koncepció, prototípus \\
\hline \multirow[t]{2}{*}{$\begin{array}{l}\text { Üzleti angyal, } \\
\text { kockázati tôke }\end{array}$} & Induló finanszírozás (start up) & $\begin{array}{l}200 \text { ezertôl } \\
3 \text { millióig }\end{array}$ & $\begin{array}{l}\text { Termékfejlesztés, piackutatás, } \\
\text { értékesítés felfuttatása }\end{array}$ \\
\hline & KÉSŐBBI FÁZIS (LATER STAGE) & & $\begin{array}{l}\text { MÁR MÜKÖDÖ VÁLLALKOZÁSOK } \\
\text { TOVÁBBI FEJLÖDÉSÉHEZ NYÚJTOTT } \\
\text { BEFEKTETÉS }\end{array}$ \\
\hline $\begin{array}{l}\text { Kockázati tőke / } \\
\text { magántőke }\end{array}$ & $\begin{array}{l}\text { Növekedési fázis } \\
\text { (expansion or growth capital) }\end{array}$ & $\begin{array}{l}\text { 1-10 millió / } \\
1-100 \text { millió }\end{array}$ & $\begin{array}{l}\text { Növekedés, terjeszkedés; nagyobb } \\
\text { gyártási kapacitások, termék- } \\
\text { fejlesztés }\end{array}$ \\
\hline \multirow[t]{2}{*}{ Magántôke } & Kivásárlási tôke (buy out) & $\begin{array}{l}\text { 1-100 millió + } \\
\text { (akár több milliárd) }\end{array}$ & $\begin{array}{l}\text { Vezetői kivásárlás (MBO), vezetői } \\
\text { bevásárlás (MBI), intézményi } \\
\text { kivásárlás (IBO), tőkeáttételes } \\
\text { kivásárlás (LBO) }\end{array}$ \\
\hline & SPECIÁLIS FINANSZÍROZÁS & & SPECIÁLIS FINANSZÍROZÁSI CÉLOK \\
\hline $\begin{array}{l}\text { Kockázati tőke / } \\
\text { magántőke }\end{array}$ & $\begin{array}{l}\text { Helyettesítő vagy másodlagos } \\
\text { finanszírozás } \\
\text { (replacement capital / secondary } \\
\text { buy-out) }\end{array}$ & több millió & $\begin{array}{l}\text { Egy korábbi szakaszban befektetőtól } \\
\text { egy cég üzletrészét/részvényeit egy } \\
\text { másik kockázati vagy magántőke- } \\
\text { befektető veszi meg }\end{array}$ \\
\hline $\begin{array}{l}\text { Kockázati tőke / } \\
\text { magántőke }\end{array}$ & $\begin{array}{l}\text { Tőzsdei bevezetés előtti } \\
\text { finanszírozás (bridge financing, } \\
\text { pre-IP0) }\end{array}$ & több millió & $\begin{array}{l}\text { Tőzsdére történő bevezetésre való } \\
\text { felkészítés }\end{array}$ \\
\hline $\begin{array}{l}\text { Kockázati tőke / } \\
\text { magántőke }\end{array}$ & $\begin{array}{l}\text { Restrukturálási befektetés } \\
\text { (turnaround) }\end{array}$ & 1 millió + & Üzleti nehézségekkel küldő cég \\
\hline
\end{tabular}

\section{1. táblázat: Kockázati és magántőkealapok befektetési típusainak jellemzői} Forrás: MKME (2018)

Az egyes céltársaságokba történő befektetések időtávja 5-10 év is lehet, ugyanis jó esetben ennyi idő alatt ér el a befektetés megfelelő értéknövekedést (EVCA, é.n.). A kockázati tőkést, mint minden profitorientált befektetőt a várható hozam ösztönzi a befektetésre. ${ }^{6} \mathrm{~A}$ befektető kiszálláskor a hozzáadott értéket realizálja.

6 Az állami tulajdonú társaságoknál jelennek meg a profitszerzésen kívül egyéb célok is. 
A kiszállás alapvető módszere a következő öt egyike lehet: ${ }^{7}$

- tözsdei bevezetés, nyilvános részvénykibocsátás;

- a cég, tulajdonosok vagy a vezetés általi visszavásárlás;

- a cég értékesítése stratégiai befektetőnek;

- értékesítés más kockázatitőke-befektetőnek vagy más pénzügyi intézménynek;

- a vállalkozás felszámolása.

\subsection{Jogi szabályozás}

Magyarországon elöször az 1998. évi XXXIV. törvény rendelkezett a kockázatitőke-befektetésekről, a kockázati tőketársaságokról, valamint a kockázatitőke-alapokról. A törvény meghatározta a kockázatitőke-alap, mint jogi személyiséggel rendelkező vagyontömeg, a kockázati tőkealap-kezelő, a kockázati tőketársaság, valamint a kockázatitőke-befektetés fogalmát. Utóbbit valójában csak a törvény egészében ismerhetjük meg, hiszen az értelmező rendelkezések csak ennyit mondtak: „a kockázati tőketársaság, illetve a kockázati tőkealap e törvénynek megfelelő tulajdon szerzése korlátolt felelősségü társaságban vagy részvénytársaságban”. A törvény végül sikertelennek bizonyult, amit jól érzékeltet az a tény, hogy érvényessége alatt csak egy szervezet (az is állami ${ }^{8}$ ) tartozott a hatálya alá. Ennek legföbb oka, hogy olyan többletkötelezettségeket rótt a befektetőkre, amelyek meghaladták a különböző kedvezmények alapján biztosított elönyöket. (Kovács, 2013)

A 2005. évi CLXXXVI. törvény a tőkepiaci törvény (2001. évi CXX. törvény, Tpt.) kereteiben helyezte el a piac szabályozását. Az előzőhöz képest rugalmasabb követelményeket a piac pozitívan fogadta. Például a kockázatitöke-alapok teljes jegyzett tőkéjét nem kellett induláskor befizetni. A pénzbeli hozzájárulás az össznévérték legalább tíz százalékának, de legkevesebb 250 millió forintnak kellett lennie a létrehozáskor, viszont a fennmaradó összeget az alapkezelési szabályzat rendelkezései szerint később (de legkésőbb az alapítástól számított hat éven belül) kellett befizetni.

7 Az Invest Europe statisztikáiban a kilépéseket ennél részletesebben veszi számba.

8 Ez a 2002-ben létrehozott Informatikai Kockázati Tökealap-kezelö Zrt. és a csak állami forrásból létrehozott Informatikai Kockázati Tökealap. 
A következő, máig érvényben lévő jelentős változás már uniós szintű lett. A 2000-es évek végi válságra adott egyik válaszaként és a további válságok megelőzése érdekében döntött úgy az Európai Unió, hogy szabályozza az ABAK-ok tevékenységét. A pénzügyi stabilitást erősíteni kívánó, és nem csak a magántőkepiacot érintő szándék a 2011/61/EU irányelvben (Alternative Investment Fund Managers Directive, AIFM irányelv) öltött testet. A direktíva érinti az alapkezelők engedélyezési feltételeit, müködését, az általuk igénybe vett szolgáltatások nyújtóival kialakítandó kapcsolataikat, a letétkezelői kereteket, a céltársaságok értékelésére vonatkozó eljárásokat, a kockázat- és likviditáskezelési gyakorlatot, a hitelfelvételi korlátozásokat és a javadalmazási politikát. (Karsai, 2013) Az irányelv átláthatósági követelményei között tájékoztatási és jelentéstételi kötelezettséget ír elő az ABAK-ok számára a befektetők és a felügyeleti hatóság felé. A direktíva cikkeinek többsége viszont csak a legnagyobb ABA-kat kezelőkre vonatkozik: ha a kezelt eszközérték nem haladja meg az 500 millió eurót, akkor - néhány egyéb feltétel együttes teljesülése mellett - az ABAK-oknak ezen irányelv csak néhány bejegyzési, információszolgáltatási és tájékoztatási kötelezettséget ír elö.

Az irányelv bevezette az ún. uniós útlevelet, ami annyit jelent, hogy ha egy tagállam hatósága engedélyt ad egy alapkezelőnek, akkor az az EU egész területén - külön más tagországi engedély nélkül - végezheti tevékenységét.

Az AIFM direktíva teljesítése nagyon szigorú és költséges követelményeket támasztott volna a kisméretű kockázatitőke-alapok kezelőivel szemben, így azok hátrányba kerültek volna a piacon, és az EU egész területének elérése sem lett volna számukra lehetőség. (Karsai, 2013) A szabályozottság és a hátrányok elkerülésének kívánalma az európai kockázatitőke-alapokról szóló rendeletben ${ }^{9}$ teljesült. A rendelet célja a „kockázatitőke-alap” európai értelmezésének meghatározása, a kockázatitőke-alapok határokon átívelö forrásbevonását előmozdító európai rendszer létrehozása, valamint az ilyen alapokat szabályozó egységes megközelítés kidolgozása. Az „európai kockázatitőke-alap” megjelölés alatt müködő alapok mindegyike egységes szabályok és minőségi standardok szerint müködik. (MNB, 2013) Az ún. minősített kockázatitőke-alapok (EuVECA), amelyek tőkéjük legalább 70\%-át a vállalati fejlődés kezdeti szakaszában lévő

9 Az Európai Parlament és a Tanács 345/2013/EU rendelete, Regulation on European venture capital funds, röviden EVCFR. 
kisvállalkozásokba fektetik, és nem használnak tőkeáttételt (leverage), könnyebb feltételek mellett végezhetik tevékenységüket az egész Unió területén.

2018. március 1-jétől pedig még kedvezőbb feltételek mellett müködhetnek az EuVECA-k és kezelőik, ugyanis ekkortól hatályos az Európai Parlament és a Tanács (EU) 2017/1991 rendelete, mely módosítja az EVCF rendeletet. Az új jogszabály bővíti a támogatható társaságok választékát, valamint csökkenti az alapok forgalmazásához társuló költségeket, és egyszerűsítik a regisztrációs folyamatokat.

Hazánkban az uniós jogi aktusoknak való megfelelést a már említett Kbftv. biztosítja 2014. március 15-től. A törvény a befektetési alapkezelőkről és a kollektív befektetési formákról szóló, három évvel korábban alkotott 2011. évi CXCIII. törvény helyére került. $\mathrm{Az} \mathrm{ABA}$ fogalmába beépült az újonnan bevezetett magántőkealap és - az addig a Tpt.-ben kezelt - kockázatitőke-alap is.

A Kbfvt. 67-68. \$-a alapján ilyen tőkealapok szakmai befektetőknek határozott futamidőre, vissza nem váltható befektetési jegyek zártkörü forgalomba hozatalával, legalább hat teljes naptári éves futamidőre hozhatók létre. A futamidőt - amennyiben azt a kezelési szabályzat lehetővé teszi - meg lehet hosszabbítani, legfeljebb az eredeti futamidőt nem meghaladó időtartammal. A kockázati tőkealap és a magántőkealap pénzkölcsönt nyújthat olyan vállalkozás részére, amelyben részesedéssel rendelkezik. A legkisebb induló tőke 250 millió forint, amely kizárólag pénzbeli hozzájárulást tartalmazhat. A jegyzett tőkéje legalább 10\%-át, de legkevesebb 250 millió forintot (tehát a legkisebb tőkekövetelménynek megfelelő összeget) a befektetési jegyek jegyzésekor kell befizetni.

\subsection{A piac számokban - az elmúlt négy év rövid áttekintése}

Kockázatitőke-befektetések statisztikái a 90-es évekre nyúlnak vissza, de a fejezet most csak a Kbftv. hatályba lépését követő, 2015-től kezdődő piaci adatok egy részét ismerteti. A korábbi évek kapcsán érdemes az MKME statisztikáit és Karsai Judit elemzéseit megismernie az Olvasónak.

A felügyeleti engedélyhez kötött működési modell alapján tevékenykedő alapkezelők száma 29 darab volt 2015. I. negyedévének végén. Ez a szám kisebb ingadozásokkal és stagnálásokkal 2019. március 31-re 35 darabra növekedett 
(1. ábra). Döntő többségük kockázatitőke-alapok kezelésével foglalkozott, és a nagy részük a 2010-től kezdődően több körben futó JEREMIE ${ }^{10}$ Kockázati Tőke Program keretében jött létre (MNB. 2018)

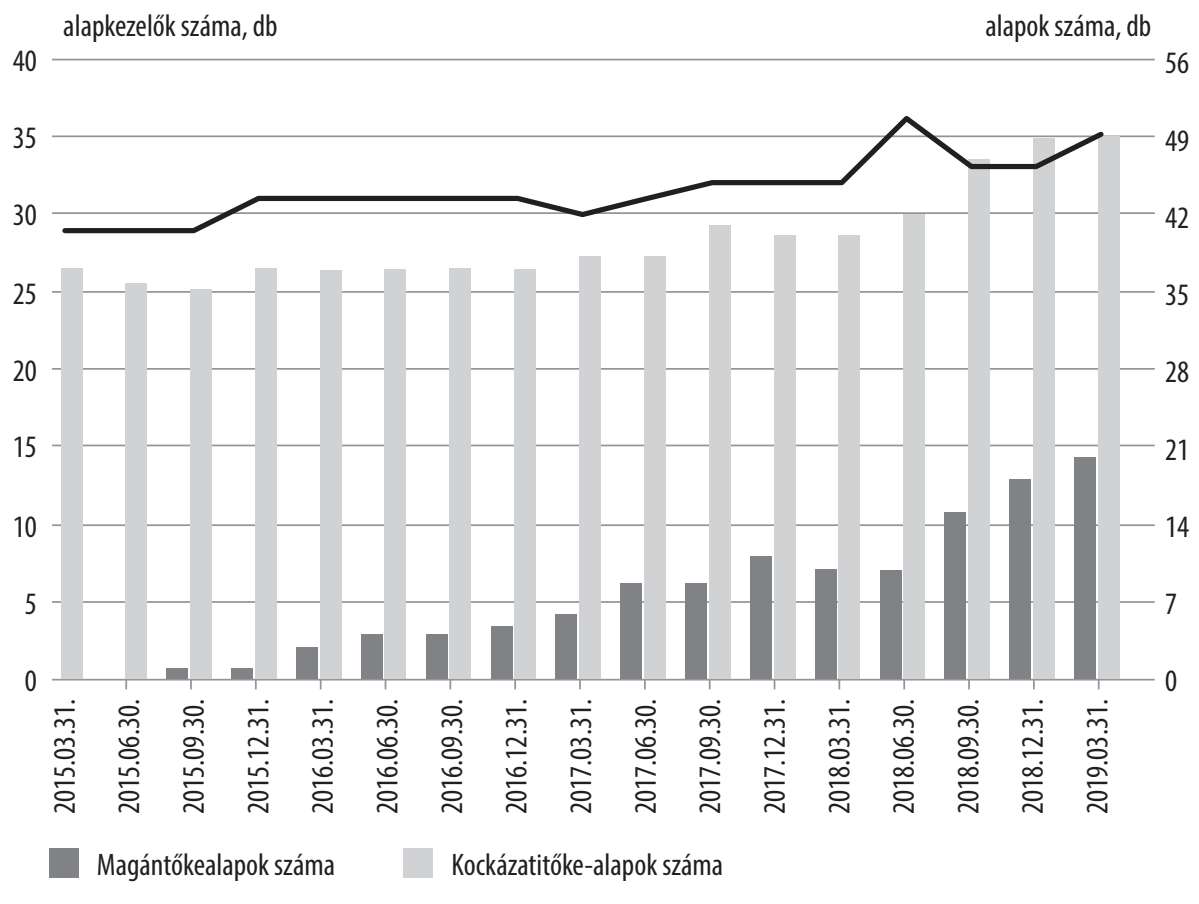

Kockázati tôkealap-kezelők száma

\section{1. ábra: A Kbftv. szerinti alapok és alapkezelők számának alakulása 2015. I. negyedéve és 2019. I. negyedéve között Forrás: saját szerkesztés az MNB (2019) adatai alapján}

A kockázatitőke- és magántőkealapok nettó eszközértéke 2015 márciusának végén 103 milliárd forintot tett ki, ami 2019. március 31-re 380 milliárd forintra emelkedett (2. ábra). A 2017. év végi nagy ugrás két új magántőkealap létrehozásának köszönhető, míg a vizsgált időszak utolsó három negyedévében létrejövő dinamikus növekedés 10 új magántőkealapnak és 7 új kockázatitőke-alapnak tudható be.

10 A JEREMIE (Joint European Resources for Micro to Medium Enterprises) az Európai Bizottság által kezdeményezett program a kis- és középvállalkozások pénzügyi forráshoz való jobb hozzáférésének megteremtése érdekében. Keretében nem csak kockázatitöke-program, hanem mikrohitel-és garanciaprogram is müködik. 


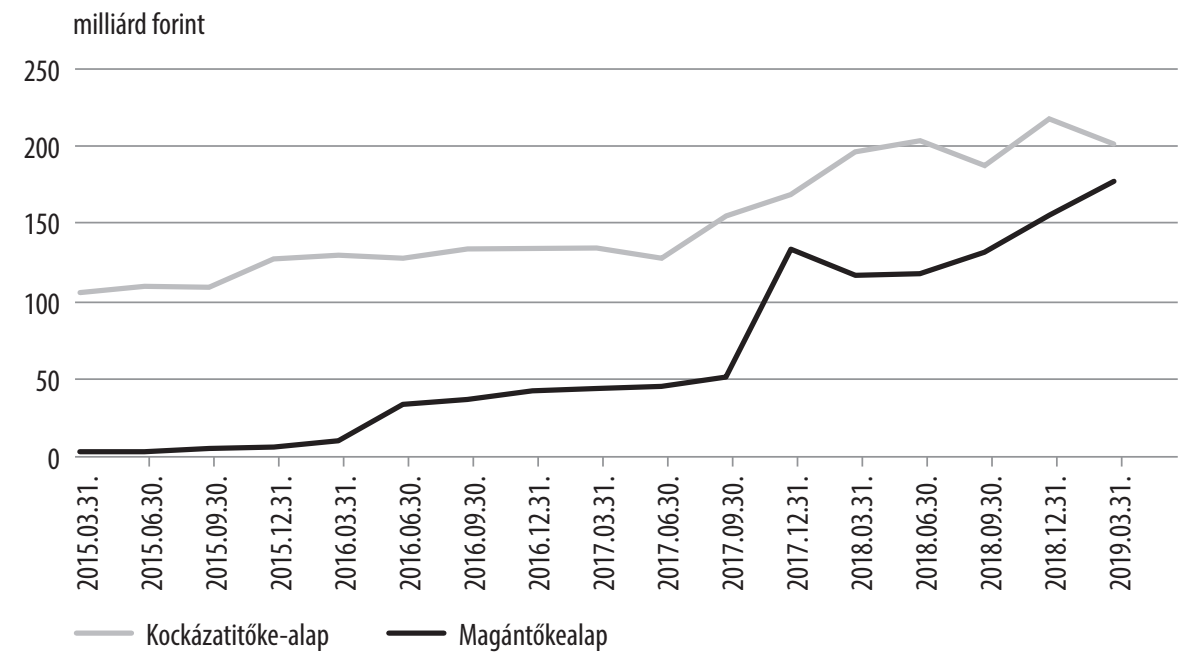

2. ábra: A Kbftv. szerinti kockázatitőke-alapok és a magántőkealapok vagyonának alakulása 2015. I. negyedéve és 2019. I. negyedéve között Forrás: saját szerkesztés az MNB (2019) adatai alapján

Az utóbbi évek folyamatos növekedése az ország gazdasági helyzetében és vállalkozásaiban rejlő megnövekedett potenciálra utal. Az évtized eleji „JEREMIE boom" után a nagyobb alapok száma is növekedésnek indult. 2018-ban létrejöttek olyan alapok is magyarországi székhellyel és hazai forrással, amelyeknek kimondott célja nemzetközi befektetések végrehajtása, és hosszú távon európai portfólió kiépítése.

Különlegesség, hogy a hazai kis- és középvállalatok forrásbevonásának, forrásdiverzifikációjának és a megfelelő menedzsment képességeik fejlesztése érdekében a Budapesti Értéktőzsde csatlakozott a Milánói Tőzsdéről 2012-ben indult ELITE nemzetközi programhoz. Az Budapesti Értéktőzsde ELITE Programja azokat a nagy növekedési potenciállal rendelkező vállalkozásokat célozza, amelyek a terveik megvalósításához külső finanszírozás (EU-s forrás, hitel, kockázati tőke, magántőke vagy akár tőzsdei finanszírozás) igénybevételét tervezik, vagy vállalatirányítási ismereteiket bővítenék, esetleg egész egyszerüen csak üzletszerzési lehetőséget keresnek, generációváltást menedzselnek, vagy nemzetközi kapcsolatrendszerüket bővítenék. ${ }^{11}$

11 Lásd részletesen a tőkepiacról és a tözsdei programokról: Parragh - Végh (2018): Megújuló állam - megújuló tökepiac: A gazdaságösztönzés új dimenziói. 
Összefoglalásként elmondható, hogy az uniós és hazai források (pl. MFB Invest által) továbbra is biztosítottak a piaci források mellé, amelyek az alapkezelök segítségével még több vállalkozáshoz juthatnak el a jövőben. A hazai piac Középés Kelet-Európában továbbra is az élbolyban maradhat, a támogató környezetben pedig a vállalatok megerősíthetik a tőkeági finanszírozási lábukat.

\subsection{Irodalomjegyzék}

EVCA (2011): Central and Eastern Europe Statistics 2010. Brüsszel. European Private Equity \& Venture Capital Association.

EVCA (é.n.): The little book of private equity. Brüsszel. European Private Equity \& Venture Capital Association. Letöltve 2019. május 14-én https://www.investeurope.eu/media/19732/Little-book-of-Private-Equity.pdf linkről.

Fenn, George W. - Liang, J. Nellie - Prowse, Stephen D. (1995): The Economics of the Private Equity Market. Board of Governors of the Federal Reserve System. Washington, DC.

Glavanits Judit (2012): A kockázati tőkebefektetések egyes jogi aspektusai. Doktori értekezés. Győr: SZE ÁJDI. 245 p. - http://dx.doi.org/10.15477/SZE. ÁJDI.2012.006

Karsai Judit (2012): A kapitalizmus új királyai. Kockázati tőke Magyarországon és a közép-kelet-európai régióban. Budapest: Közgazdasági Szemle Alapítvány; MTA KRTK Közgazdaság-tudományi Intézet. 249 p.

Karsai Judit (2013): Válság után: változó állami szerep a kockázatitőke-ágazatban. Külgazdaság, LVII. évf., 2013. május-június (12-34. o.)

Kovács Tamás (2013): A kockázatitőke-befektetések hatása a gazdaságra. Doktori értekezés. Nyugat-magyarországi Egyetem Széchenyi István Gazdálkodásés Szervezéstudományok Doktori Iskola. 157 p. - http://dx.doi.org/10.13147/ NYME.2014.036

MKME (2018): Tőkebevonási kalauz. Budapest: Magyar Kockázati- és Magántőke Egyesület. Letöltve 2019. május 14-én a https://www.hvca.hu/documents/ TBKalauz_2018_IMPRIMATURA_Final_21_January.pdf linkröl.

MNB (2013): Tájékoztató az európai szociális vállalkozási alapokról és az európai kockázatitőke-alapokról szóló rendeletekről. Magyar Nemzeti Bank. Letöltve 2019. május 22-én a https://www.mnb.hu/archivum/ Felugyelet/root/ 
fooldal/intezmenyeknek/befektetesi_szolgaltatok/hirek/szocialis_vallalkozasi_kockazati_toke_alap_130801 linkről.

MNB (2015): Elemzés a hazai kockázati tőkealap-kezelők és alapok müködéséről. Magyar Nemzeti Bank, p. 57. Letöltve 2019. május 20-án a https://www. mnb.hu/letoltes/elemzes-a-kovkazati-tokealapkezeloi-szektorrol-0202.pdf linkről.

MNB (2018): Biztosítási, pénztári és tőkepiaci kockázati jelentés. Magyar Nemzeti Bank. Letöltve 2019. május 21-én a https://www.mnb.hu/ letoltes/kockazati-jelentes-2018-0613-vegleges.PDF linkröl.

MNB (2019): A Magyar Nemzeti Bank által felügyelt szektorok adatainak idősorai: befektetési alapok. Magyar Nemzeti Bank. Letöltve 2019. május 23-án https://www.mnb.hu/letoltes/befalap-idosor.xls linkről.

Parragh Bianka - Végh Richárd (2018): Megújuló állam - megújuló tőkepiac: A gazdaságösztönzés új dimenziói. Polgári Szemle, 14. évf. 4-6. szám, 2018, 48-78., DOI: 10.24307/psz.2018.1205 Letöltve 2019. május 24-én a https:// polgariszemle.hu/aktualis-szam/157-gazdasagpolitika/985-megujulo-allam-megujulo-tokepiac linkröl.

2014. évi XVI. törvény a kollektív befektetési formákról és kezelőikről, valamint egyes pénzügyi tárgyú törvények módosításáról

Az Európai Parlament és a Tanács 2011/61/EU irányelve az alternatívbefektetésialap-kezelőkről, valamint a 2003/41/EK és a 2009/65/EK irányelv, továbbá az 1060/2009/EK és az 1095/2010/EU rendelet módosításáról

Kockázati- és magántőkével kapcsolatos szakkifejezések: https://www.hvca.hu/ szakkifejezesek/ 



\section{III. rész \\ Biztosítási szektor}




\section{A biztosítási piac jellemzői és szereplői}

\subsection{Bevezetés}

A biztosítás egy emberi szolidaritáson alapuló összefogás, melynek célja, hogy a bekövetkező nem várt események által okozott károkat enyhítse. A biztonság iránti vágy a szükségletek hierarchiájában közvetlenül a fiziológiás szükségletek után következik. Nap, mint nap veszélybe kerülhet életünk, vállalkozásunk, vagy akár vagyonunk egy-egy váratlan eseménynek köszönhetően. A veszélyek és kockázatok az ember életének és gazdálkodásának nem kívánt, de legtöbbször elkerülhetetlen tényezői. A biztosítás célja a bizonytalanságok ellen összefogással védekezni, tehát a közös kockázatkezelés.

A biztosítási piac keresleti oldalán tehát azok a magánszemélyek és jogi személyek állnak, akik hajlandóak és képesek a lehetséges károk bekövetkezésére egy közös kasszába meghatározott összeget fizetni. A kínálati oldalon pedig azok a szervezetek jelennek meg, akik képesek egy kockázati közösségbe szervezni a tényleges és potenciális vevőket és biztosítási szolgáltatást nyújtanak. Hozzájárulnak ahhoz, hogy az anyagi szükség a vállalkozási és gazdálkodási folyamatokat ne zavarja lényegesen, fellépő veszteségeket csökkenti, kiszámíthatóvá és tervezhetővé kívánja tenni.

A biztosító tehát a veszély által fenyegetettektöl átvállalja a bekövetkezés kockázatát és ennek fejében biztosítási díjat szed. A biztosítók lényegében megkönynyítik a magánszektor életét, hiszen nagyobb szabadságot, nagyobb kockázatvállalási hajlandóságot tesznek lehetővé.

A kockázati vagy veszélyközösség lényege, hogy ha nem egyedül készülünk fel egy esetleges káreseményre - lásd óvatossági pénzkereslet -, akkor egyénenként sokkal kisebb hozzájárulással vagyunk képesek az anyagi károkat enyhíteni.

A biztosítási tevékenység alapvető sajátossága és a kockázatmegosztás lehetőségének meghatározó feltétele, hogy csak számos egyedi eset ismeretében lehet elöre kiszámítani bizonyos események bekövetkezését. 
A biztosítás közgazdasági hátterével, gazdasági szerepével és jelentőségével a biztosításelmélet/biztosítástudomány foglalkozik. Ezt jelen könyvben nem tárgyaljuk.

A biztosítás funkciója révén (Tóth, 2007):

- Kielégíti a biztonság szükségletét, korlátozza teljes elvesztését.

- Biztosítja a vállalkozások tevékenységének folyamatosságát.

- Redisztribúciós funkciója által a kártalanítás folyamatában sok szereplőt ér el. Szükségtelenné teszi a felhalmozást, ezzel fokozza a nemzetgazdaság teljesítményét.

- Allokációs mechanizmust segít elő a biztosítónál felhalmozott források hasznosításával. A gazdaság vérkeringésébe tehát több eszköz jut, a biztosítás ily módon emelni tudja a fizetőképes keresletet is.

- A biztosítási alapok képzésével nagy összegű, ideiglenesen felesleges vásárlóerőt köt le, és ezzel is hozzájárul a termelés és fogyasztás összehangolásához.

- A biztosítótársaságok egyre nagyobb hányadát kezelik a megtakarításoknak, amelyek intézményi befektetőként a pénz- és tőkepiacon jelennek meg.

- Csökkenti az állam tervezhetetlen kiadásainak körét. A szélsőséges időjárás miatt bekövetkező káreseményre nem kell feltétlenül kártalanítania, ha arra biztosításokat kötöttek.

- A biztosítás a lakosság pénztakarékosságának egyik eszköze.

- Kötelező előírásai révén a kár hányadának csökkentése érdekében kármegelözéssel igyekszik megóvni az eszközöket az elemi csapások, károk következményeitől és ezzel anyagi értékek pusztulását előzi meg. Jelentős eszközöket fordít a biztosítási alapból a kármegelözésre, mely az anyagi javak megmaradása folytán előbb-utóbb a gazdaság egészének megtérül.

\subsection{Kockázatok}

A kockázat számos definíciója és formája létezik. A biztosítások szempontjából relevánsnak tekinthetjük az alábbi két fogalmi meghatározást (Banyár, 2013):

I. A kockázat valamely cselekvéssel, vállalkozással járó veszély, anyagi veszteség, kár lehetősége. 
II. A kockázat az a tendencia, hogy egy vizsgált folyamat tényleges kimenetelei különbözhetnek az elöre várt kimeneteltől.

Az első megközelítés aszimmetrikus, a másik szimmetrikusnak tekinthető. A köznyelvben mindkét értelemben szoktuk használni a kockázat fogalmát. Kockázaton értsük azt, hogy a bizonytalanság valamely kedvezőtlen következménnyel, azaz kárral fenyeget. A kár tehát olyan gazdaságilag hátrányos következmény, amely valamely, a szokásostól eltérő szükséglet keletkezésével jár.

A biztosítás intézménye a kockázati tényezők meghatározásán alapszik, ezek két nagy csoportba sorolhatók:

- Objektív tényezők: természeti, gazdasági körülmények, adottságok, amelyek az érintettől függetlenül befolyásolják a kockázat következtében kialakuló kár nagyságát, terjedelmét stb. (időjárás, közlekedési balesetek).

- Szubjektív tényezők: a szereplők viselkedésén, magatartásán, kockázathoz való viszonyán keresztül befolyásolják a kockázati helyzet kialakulását, illetve következményeit.

A szubjektív kockázati tényezők két folyamata azonosítható:

- Autoszelekció: a kockázatot felismerő és azt esetleg túlértékelő érintettek igyekeznek biztosítást kötni. Ennek következtében a valós (átlagos) kockázati viszonyoktól eltérő összetételü lesz a biztosítottak csoportja.

- Antiszelekció: olyan érintettek kötnek biztosítást, akik felismerték kockázataikat, de magatartásukkal, esetleg bizonyos adatok eltitkolásával befolyásolják a kár bekövetkezését vagy mértékét.

A kockázat kezelése (Risk Management) a társadalom és a gazdaság szereplői számára mindennapos feladat akkor is, ha a társadalmi, gazdasági változásokra adott válaszok során nem is így nevezik. A gazdálkodó szervezetek esetében a gyakorlatban egy olyan vállalati funkcióról van szó, amely értékeli és összefogja a vállalat valamennyi kockázatát. A kockázatkezelés folyamatában feltárják a különböző típusú kockázatokat, meghatározzák azok bekövetkezésének várható következményeit. Gondoljunk csak bármely pályázati kírásra, ahol a kockázatok részletes bemutatása és kezelésének módja jelentős részét képezi a dokumentációnak (pl. partnerkockázat, természeti kockázat, pénzügyi kockázat stb.). 


\section{A kockázatkezelés módjai:}

- Kockázatkerülés: a kockázatkezelés legjobb módszere. Az árvízkockázat elkerülése érdekében például biztosra megyünk, ha nem építünk házat a folyó árterébe. A kockázatkerülő ember „biztosra megy”. A piaci szereplők részéről egy lehetséges új, bár kockázatos beszállító elkerülése.

- A kár megelőzése: kármegelöző magatartással úgy szervezzük a vállalkozási tevékenységünk különböző feladatait, hogy a káresemény ne, vagy csak minimális valószínűséggel következzen be. Betartjuk a tűzvédelmi, vegyvédelmi szabályokat, megszervezzük a vagyonbiztosítást stb. A prevenció tehát csökkenteni igyekszik a káresemény bekövetkezésének esélyét.

- Önbiztosítás: a kockázatnak kitett egyén takarékossága vagy tartalék képzése az előre nem látható veszteségek pótlására. Ennek intézményes formája a biztosító.

\subsection{A biztosítási piac és szereplői}

A magyar biztosítási piac fejlődésének első lépcsőfoka az Állami Biztosító monopolhelyzetének megszűntetése 1986-ban, ami annak ellenére, hogy a két utódvállalat még egy évig nem versenyezhetett egymással, megalapozta a magyar biztosítási piac fejlődését.

A piac szerkezetének átalakítása ágazati alapon történt. A nevét megőrző Állami Biztosítónál maradt a lakosság, állami gazdaságok, a költségvetési szervek állománya, valamint a szövetkezeti, nem gépjármű vagyonbiztosítási ágazatok, valamint a teljes életbiztosítási állomány. Mellette a Hungária Biztosító örökölte az állami vállalatok vagyonbiztosítását, a gépjármű biztosítást, a nemzetközi biztosítást, az exporthitel biztosítást, valamint a viszontbiztosítási üzletágat.

Azóta fejlett pénzügyi rendszerű országokból érkező társaságok léptek a piacra, vagy vették át a hazai piacon tevékenykedő társaságok irányítását, így a piac szerkezete jelentősen megváltozott.

Hazánkban a 2014. évi LXXXVIII. a biztosítási tevékenységről szóló törvény alapján a biztosító az a szervezet, amely a hatályos magyar jogi szabályozás vagy valamely hatályos tagállami szabályozás szerint biztosítási tevékenység végzésére jogosult és többek között kiterjed a biztosítási üzletág további szereplőire. 
„A Magyarország területén székhellyel rendelkező biztositó és viszontbiztositó által végzett biztositási és viszontbiztositási tevékenységre, továbbá e biztositónak és viszontbiztositónak a biztositási és viszontbiztositási tevékenységgel közvetlenül összefüggő tevékenységére, továbbá a tevékenységi engedély visszavonása után a biztositó és viszontbiztositó biztositási és viszontbiztositási szerzödésekböl eredő kötelezettségeinek teljesitésével kapcsolatos tevékenységére".

Kimondja még, hogy a biztosítási szerződésben alapuló kötelezettségvállalás egy időben távoli, bizonytalan esemény elleni védekezés, amit egy kockázati díj ellenében áthárít, és amelynek során a tevékenységet végző

- az azonos vagy hasonló kockázatoknak kitett személyek közösségét szervezi meg (veszélyközösség);

- a biztosítható kockázatokat felméri statisztikai és matematikai eszközökkel;

- és a kockázati díjakat megállapítja.

A jogszabály tehát definiálja a biztosítási piac szereplőit, meghatározza a feladatait, felelősségeit, illetve a piacra való belépésnek, illetve a piacon való maradásnak a feltételeit.

A biztosítási piac szereplői kínálati oldalon a

1. szolgáltató szervezetek:

- részvénytársaságok,

- külföldi székhelyü biztosító magyarországi fióktelepe,

- egyesületek,

- szövetkezetek (jelenleg Magyarországon nem müködik).

2. közvetítők (MNB alapján):

- biztosítási alkusz (bróker): az ügyfél megbízásából eljáró független biztosításközvetítő. Az alkusz kizárólag a biztosító ezirányú hozzájárulása esetén, az ügyfél megbízásából jogosult a biztosítási díj átvételére, valamint a biztosító hozzájárulása vagy az ügyfél felhatalmazása alapján a kockázat felmérésében, a szerződésből eredő jogaik és kötelezettségek teljesítésében és lebonyolításában való közremüködésre.

- biztosítási ügynök: a biztosító megbízásából eljáró függő biztosításközvetítő. A törvény értelmében ügynöki tevékenység végzésére csak felsőfokú végzettséggel, vagy külön jogszabályban meghatározott szakképzettséggel rendelkezik. 
- vezérügynök: függő biztosításközvetítő. A szabályozás egyértelművé akarja tenni a vezérügynök különleges jogosítványát, így például azt a jogát, hogy a biztosító olyan teljes körű felhatalmazással bíró ügynöke legyen, aki a biztosító üzletviteléhez szükséges jogkört teljes mértékben elláthatja. A törvény - figyelemmel az e felhatalmazás különösen széles terjedelmére - elöírja, hogy a vezérügynök kizárólag a Felügyelet engedélyével foglalkoztatható. A vezérügynök kiemelt szerepére tekintettel a törvény az ügynökre vonatkozó szabályokon túl további személyi feltételek teljesítését írja elő a vezérügynöki tevékenység irányítója számára.

- többes ügynök: több biztosító megbízásából eljáró, egymással versenyző termékeket is közvetítö független biztosításközvetítő. A többes ügynök alkuszi tevékenységet nem végezhet.

- biztosítási szaktanácsadó: írásos megbízási szerződés alapján, kizárólag a megbízótól származó tanácsadói díj ellenében, a biztosítási tevékenységgel összefüggő biztosítási szaktanácsot nyújt és személyesen is közreműködik annak megvalósításában. A szaktanácsadó biztosítási (viszontbiztosítási) szerződést nem közvetíthet. Szaktanácsadói tevékenységet kizárólag olyan természetes személy vagy gazdálkodó szervezet végezhet, akit a Felügyelet nyilvántartásba vett.

3. szakmai érdekképviseleti szervek:

- Magyar Biztosítók Szövetsége (MABISZ),

- Magyarországi Nonprofit Biztosító Egyesületek Szövetsége,

- Független Biztosítási Alkuszok Szövetsége,

- Magyar Aktuárius Társaság.

\section{A keresleti oldalon}

1. biztosítási szolgáltatás vevői (biztosított, szerződő, kedvezményezett):

- háztartások - magánszemélyek,

- vállalkozások - profitorientált szervezetek,

- non-profit szervezetek,

- kormányzat, önkormányzat,

- civil szervezetek. 
2. vevők érdekképviseleti szervezetei

3. felügyeleti szervek:

- Magyar Nemzeti Bank,

- Gazdasági Versenyhivatal,

- Nemzeti Fejlesztési Minisztérium és illetékes kormányhivatalok (bizonyos fogyasztóvédelmi esetekben).

\section{Magyar biztosítási piac számokban}

A biztosítási szektor intézményeinek szerződésállománya folyamatosan emelkedett az elmúlt években. A táblázatban látható 2017. évi növekedést 2018. év végére további 3,6\%-os növekedés követte. Ezzel egyidejűleg a díjbevételek 7,1\%-os növekedése kísérte a 2017. évhez képest, amivel elérte az 1024,1 milliárd forintot, mely a közel 3,5\%-os életági, valamint az ennél jelentősebb 10,5\%-os nem életági díjbevétel növekedés okozta. 


\begin{tabular}{|c|c|c|c|c|}
\hline & \multicolumn{4}{|c|}{ Biztosítási szektor } \\
\hline & \multicolumn{3}{|c|}{2017} & 2016 \\
\hline & & & Összesen & Összesen \\
\hline \multirow{6}{*}{ Intézmények száma (db) } & Összes S2-es biztosító & 25 & \multirow{5}{*}{41} & \multirow{5}{*}{43} \\
\hline & Élet & 7 & & \\
\hline & Nem-élet & 9 & & \\
\hline & Kompozit & 9 & & \\
\hline & Kis biztosító-egyesület & 16 & & \\
\hline & Élet ág & Nem-élet ág & Összesen & Összesen \\
\hline $\begin{array}{l}\text { Díjbevétel (milliárd forint) } \\
\text { (fiókteleppel együtt) }\end{array}$ & $\begin{array}{c}462,8 \\
(483,3)\end{array}$ & $\begin{array}{c}487,3 \\
(520,5) \\
\end{array}$ & $\begin{array}{c}950,2 \\
(1003,8)\end{array}$ & $\begin{array}{c}888,4 \\
(936,1)\end{array}$ \\
\hline Szerződésszám (ezer db) & 2403 & 11037 & 13441 & 12393 \\
\hline Mérlegföösszeg (milliárd forint) & & & 2628,2 & 2524,6 \\
\hline Tőkefeltöltöttség (\%) & & & 224 & 215 \\
\hline Eredmény (milliárd forint) & & & 64,5 & 50,4 \\
\hline $\begin{array}{l}\text { Biztositástechnikai tartalék } \\
\text { (milliárd forint) }\end{array}$ & 1771,6 & 256,2 & 2027,8 & 1915,2 \\
\hline $\begin{array}{l}\text { Államkötvények aránya a saját } \\
\text { eszközökön belül (\%) }\end{array}$ & & & $77 \%$ & $76 \%$ \\
\hline $\begin{array}{l}\text { Új szerződések állománydija } \\
\text { (milliárd forint) }\end{array}$ & 46,4 & 181,1 & 227,5 & 205,3 \\
\hline Állománydij (milliárd forint) & 304,0 & 457,0 & 761,1 & 711,4 \\
\hline \multirow[t]{3}{*}{$\begin{array}{l}\text { Egy szerződésre jutó állománydíj } \\
\text { (ezer forint) }\end{array}$} & 126,5 & 41,4 & 56,6 & 55,0 \\
\hline & \multicolumn{4}{|c|}{ Kis biztosítóegyesület } \\
\hline & \multicolumn{3}{|c|}{$2016^{*}$} & 2015 \\
\hline Intézmények száma (db) & \multicolumn{3}{|c|}{16} & 16 \\
\hline Díjbevétel (millió forint) & \multicolumn{3}{|c|}{385,9} & 351,5 \\
\hline $\begin{array}{l}\text { Államkötvények aránya } \\
\text { a biztosítástechnikai } \\
\text { tartalékokhoz képest (\%) }\end{array}$ & \multicolumn{3}{|c|}{45,8} & 43,6 \\
\hline Szerződésszám (db) & \multicolumn{3}{|c|}{472} & 389 \\
\hline
\end{tabular}

* A kis biztosítóegyesületek 2017-es éves adatszolgáltatása még nem állt rendelkezésre.

\section{1. táblázat: A biztosítási szektor legfontosabb adatai Forrás: MNB (2018a)}

A biztosítók piaci koncentrációja 2008 és 2014 között folyamatosan csökkent, ami a fogyasztók szempontjából kedvező, hiszen a versenyhelyzet korlátozta a díjtételek emelkedését. A piaci koncentrációt jól szemléltető HerfindahlHirschman-index (HHI) alapján a koncentráció évek óta tartó csökkenése megállt, ahogy az az ábrán is látható. A TOP 5 piaci részesedése 2008 óta most emelkedett először, és a HHI értéke 2014 óta nem volt ilyen magas szinten. 


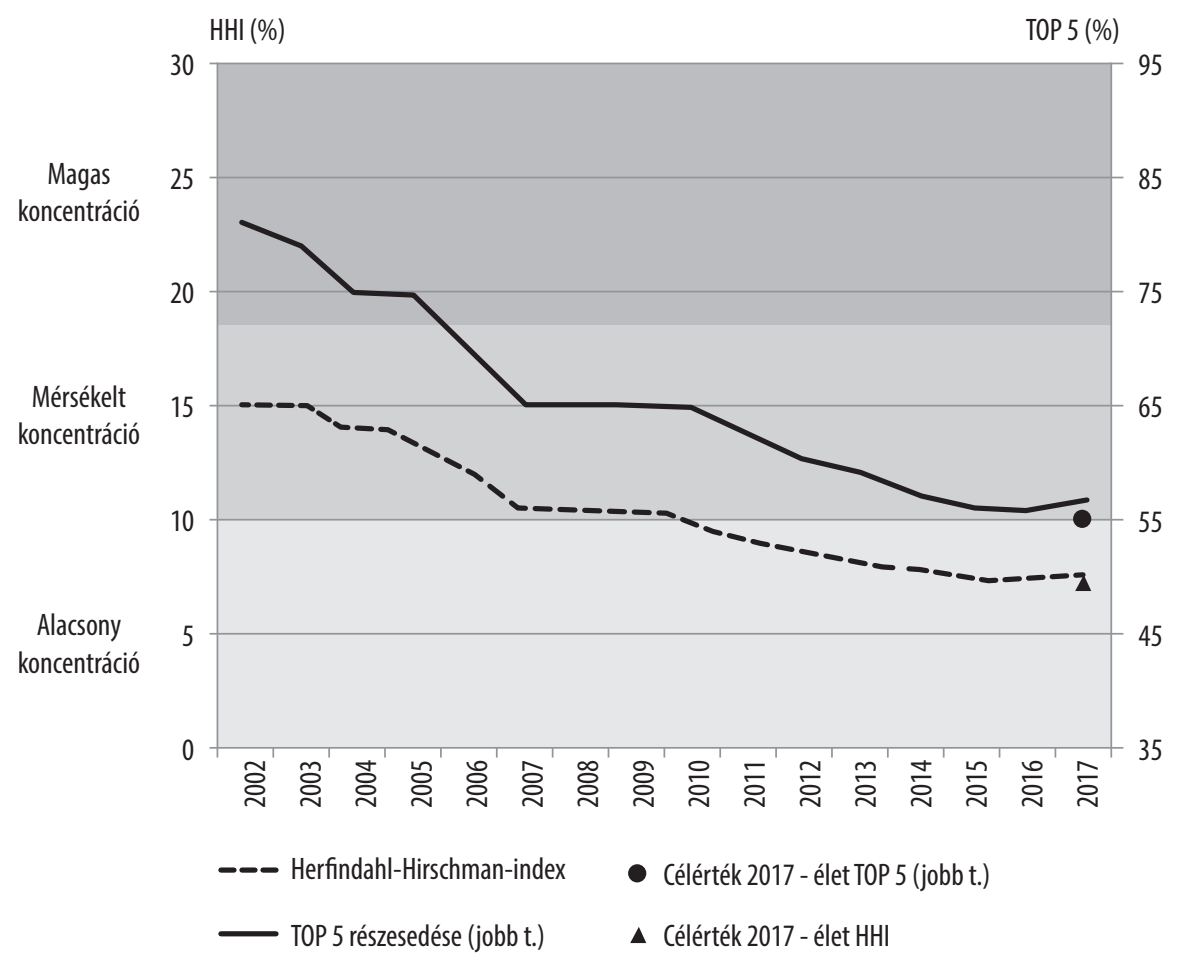

\section{1. ábra: A TOP5 biztosító részesedése és a teljes szektor} Herfindahl-Hirschman-indexe bruttó díjbevétel alapján Forrás: MNB (2018a)

A biztosítók eredményességét a magánszemélyektől származó biztosítási díjbevételek még mindig jelentősen befolyásolják. A fióktelepeknél vásárolt szolgáltatások mértéke jelentős. Az elmúlt években lezajlott átalakulás, mely szerint néhány biztosító társasági formából fiókteleppé alakult, piaci csökkenést nem okozott. A szektor színtű bevételek elérték az 1004 milliárd forintot. A fióktelepek megszolgált díjai 12,5 \%-kal emelkedtek az előző évhez képest, amely jelentősen meghaladta a felügyelet alá vont intézmények 6,7\%-os növekedését. A magas növekedési ütem ezidáig nem volt jellemző, hiszen 2012-2017 között évente átlagosan 3,1\%-kal csökkent. A szektor egészét tekintve, ha a hazai felügyelet alatt álló intézményeket és a fióktelepeket összességükben nézzük, a 2007-2012 közötti időszakot jellemző csökkenést (évente átlagosan 3,2\%) 2012-2016 között növekedési periódus követte (évente átlagosan 4,3\%). 2017-ben az MNB által kívánatosnak vélt mértéktől elmaradt a növekedés, de meghaladta a reál GDP 
növekedés és az infláció összességét.

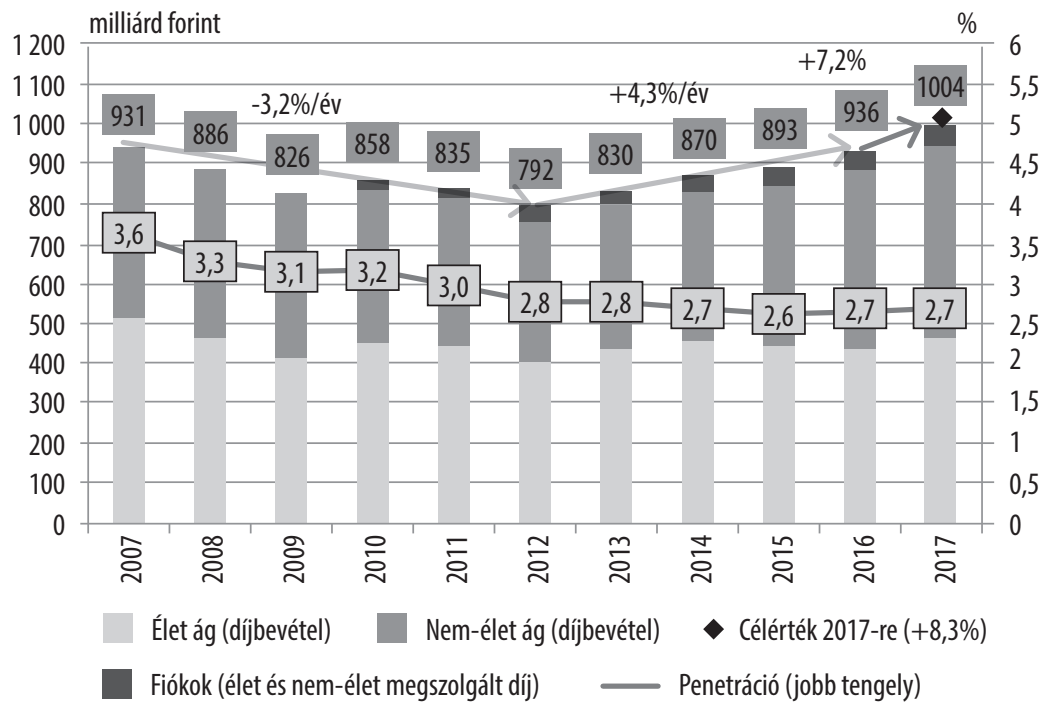

2. ábra: A bruttó díjbevétel és penetráció alakulása a biztosítási szektorban Forrás: MNB (2018a)

Fontos kérdés a likviditás és szolvencia szempontjából is, hogy a biztosítók a szerződésállományhoz kapcsolódó pénzeszközeiket befektetésként milyen eszközökben kamatoztatják, tartalékolják. 2018. év végi adatok szerint a befektetéseikre jellemzö, hogy az eszközkitettségük az államkötvény (50,7\%), a befektetési jegyek (kollektív befektetési vállalkozások 33,1\%) továbbá a részvények $(4,1 \%)$ jellemzik. Az államkötvények 97,3\%-a 3 magyar államkötvény. 


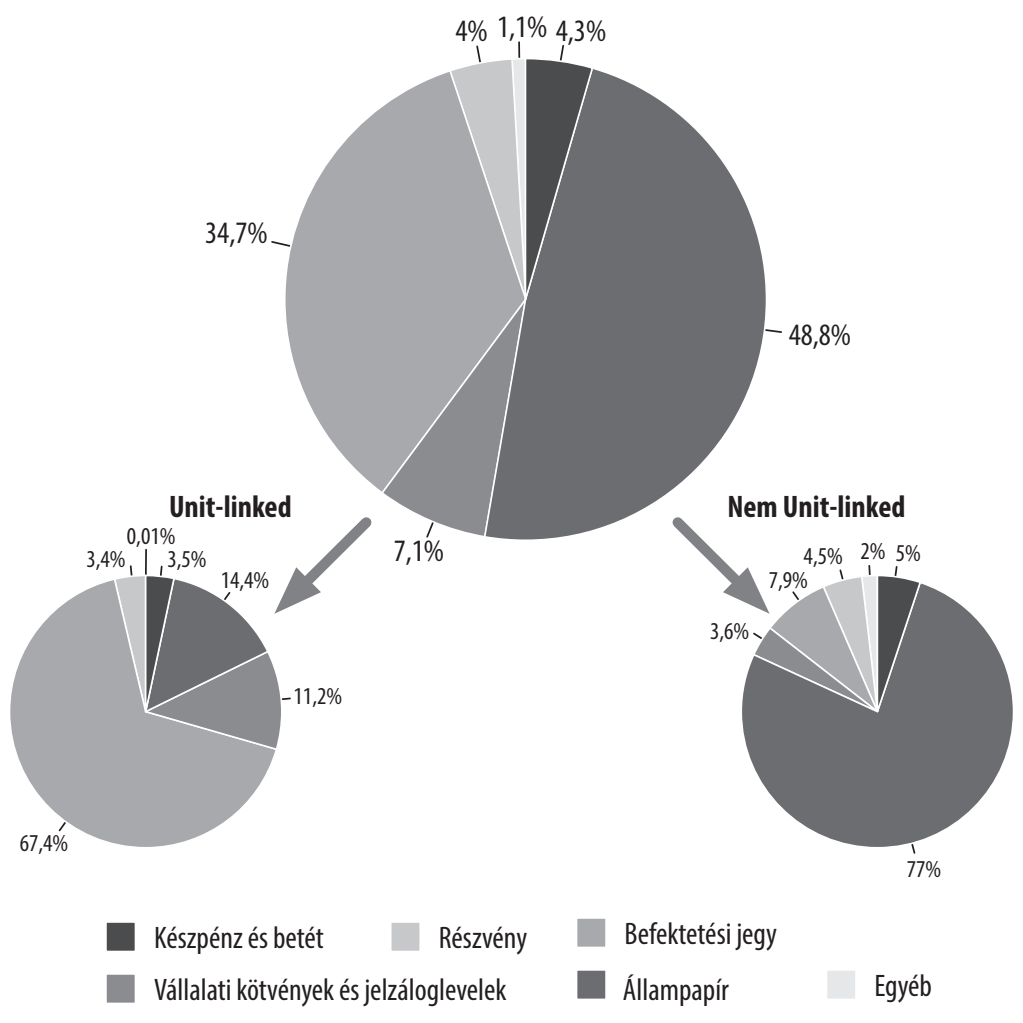

\section{3. ábra: A biztosítási szektor eszközösszetétele}

Forrás: MNB (2018a)

\section{A biztosítási piac jövője}

Az MNB tanulmány alapján megerősíthetjük, hogy a biztosítási piac szereplőinek tevékenységét és eredményességét az üzletágakon túl a közvetítői piac átalakulása és egyben digitális fejlődése is jelentősen meghatározza. A közvetítői piac felbontható hagyományos, ügynöki csatornákra (függő ügynök, többes ügynök, alkusz (nem online, egyéb) és innovatív csatornákra (bankbiztosítás, direkt értékesítés, online közvetítés).

Innovatív kategóriában sorolják az olyan ügyfélszerzési módokat, amelyek új üzleti modellek müködését biztosítják. Az egyre kedveltebb és költséghatékony értékesítési csatornák aránya összesen $37 \%$, amely előrejelzések szerint elérheti az 50\%-ot a következő 10 évben. A hagyományos csatornák szerepe kissé áta- 
lakulni látszik, mert az ügyfelek egyre magasabb szintű tájékoztatást, szakmai hozzáértést várnak el. A fogyasztók tudatosabb viselkedése összetettebb pénzügyi tranzakcióik révén egyre gyakrabban köti össze a biztosítási és a pénzügyi termékeket szolgáltatói szinten is, gondoljunk csak a megtakarítási célú életbiztosításokra.

A nem életbiztosítási ágon az ügyfelek szeretnének egyre kevesebb ráfordítással termékeket elérni, gyakran az elektronikus ügyintézést, vagy az alkuszi segítséget választják. Az utasbiztosítások közel 75\%-át (2016-ban) online módon értékesítették, míg a lakásbiztosítások ennek csupán töredéke.

A biztosítók részéről költséghatékony megoldás, ha az életbiztosításokat egy bankfiókon keresztül értékesíti, míg a nem életbiztosítási ágban a gyors kompakt termékcsomagot tartalmazó online kereskedést preferálja.

A biztosítási piac felügyeletét ellátva a Magyar Nemzeti Bank 2018-ban az alábbi stratégiai tervet fogalmazta meg (2. táblázat). A 7 fö tématerülethez, mint az öngondoskodás, piacméret, piacszerkezet, értékesítés, költséghatékonyság, jövedelmezőség és tőkefeltöltöttség, indikátorokat rendelt és 10 év alatt teljesíthető célértékeket határozott meg. 


\begin{tabular}{|c|c|c|c|c|}
\hline Elérendő cél & Célváltozó & Múlt & 2016 & $\begin{array}{c}\text { Célérték/ } \\
\text { Optimális érték }\end{array}$ \\
\hline \multirow{2}{*}{$\begin{array}{l}\text { 1. Széleskörú öngondoskodás } \\
\text { Több megtakaritás, nagyobb } \\
\text { biztonság }\end{array}$} & $\begin{array}{l}\text { életbiztosítás és } \\
\text { ÖNYP szerződések/ } \\
\text { gazdaságilag aktívak }\end{array}$ & $\begin{array}{l}79 \% \\
(2007)\end{array}$ & $54 \%$ & $\begin{array}{l}80 \% \\
\text { fölött }\end{array}$ \\
\hline & $\begin{array}{l}\text { tartalékok aránya a } \\
\text { GDP-hez (életbizttech. } \\
\text { + ÖNYP fedezeti) }\end{array}$ & $\begin{array}{l}8,8 \% \\
(2007)\end{array}$ & $8,7 \%$ & $\begin{array}{l}10 \% \\
\text { fölött }\end{array}$ \\
\hline $\begin{array}{l}\text { 2. Felzárkózó piacméret } \\
\text { Vissza a régió élmezönyébe }\end{array}$ & penetráció & $\begin{array}{l}3,6 \% \\
(2007)\end{array}$ & $2,5 \%$ & $\begin{array}{l}3,0 \% \\
\text { fölött }\end{array}$ \\
\hline $\begin{array}{l}\text { 3. Versengő piac } \\
\text { Erösödö verseny }\end{array}$ & TOP 5 részesedése & $\begin{array}{l}66 \% \\
(2007)\end{array}$ & $60 \%$ & $\begin{array}{l}55 \% \\
\text { alatt }\end{array}$ \\
\hline $\begin{array}{l}\text { 4. Hatékony értékesités } \\
\text { Minden második értékesités } \\
\text { innovatív csatornában }\end{array}$ & $\begin{array}{l}\text { innovatív csatornák } \\
\text { aránya }\end{array}$ & nincs adat & $37 \%$ & $\begin{array}{l}50 \% \\
\text { fölött }\end{array}$ \\
\hline \multirow{3}{*}{$\begin{array}{l}\text { 5. Mérethatékony intézmények } \\
\text { Költséghatékonyan müködö } \\
\text { intézmények csökkenő marzsok } \\
\text { mellett }\end{array}$} & $\begin{array}{l}\text { UL szerződések TKM } \\
\text { értékei }\end{array}$ & $\begin{array}{l}0,5-13,79 \% \\
(2015)\end{array}$ & 0,53-9,97\% & $\begin{array}{c}0,5-5,75 \% \\
\text { tartósan }\end{array}$ \\
\hline & $\begin{array}{c}\text { nem-élet ági kombinált } \\
\text { mutató } \\
\text { (adó nélkül számolva) }\end{array}$ & $\begin{array}{l}87 \% \\
(2007)\end{array}$ & $81 \%$ & $\begin{array}{l}85-90 \% \\
\text { tartósan }\end{array}$ \\
\hline & költséghányad & $\begin{array}{l}26 \% \\
(2007)\end{array}$ & $30 \%$ & $\begin{array}{l}20-30 \% \\
\text { tartósan }\end{array}$ \\
\hline $\begin{array}{l}\text { 6. Tisztességes és versenyképes } \\
\text { jövedelmezőség } \\
\text { Bizalom és stabilitás hosszú } \\
\text { távon }\end{array}$ & ROE & $\begin{array}{l}21,8 \% \\
(2007)\end{array}$ & $19,50 \%$ & $\begin{array}{l}10-15 \% \\
\text { tartósan }\end{array}$ \\
\hline $\begin{array}{l}\text { 7. Tókeerős biztosítók } \\
\text { Biztonságos és prudens } \\
\text { müködés }\end{array}$ & tőkefeltöltöttség & $\begin{array}{c}169 \% \\
(2015 \mathrm{~S} 1)\end{array}$ & $\begin{array}{l}215 \% \\
(S 2)\end{array}$ & $\begin{array}{l}>150 \% \\
\text { tartósan }\end{array}$ \\
\hline
\end{tabular}

2. táblázat: A biztosítási piac stratégiai terve

Forrás: MNB (2018b)

\section{A biztosítók felügyelete}

A Felügyelet jelentős átalakuláson ment végbe a biztosítási piac fejlődése során. A szektorban felgyülemlö pénzügyi források nagysága, a keresleti oldal egyre növekvő köre, és ezekkel együtt a gazdaságpolitika folyamatai indokolják fejlődését. 
A felügyelet formáit tekintve lehet kontinentális (német) típusú, amikor a biztosítási piac minden szereplöére kiterjed. Inkább bürokratikus folyamatokkal ellenőrzi a müködés körülményeit, szervezeti, személyi és pénzügyi elemeit. $\mathrm{Az}$ angolszász típusú felügyelet az intézmények szolvenciáját vizsgálja kiemelten.

Magyarországon a biztosítási tevékenységek felügyeletét a biztosítás államosítása (1949, illetve 1950-52) után a Biztosítási Főigazgatóság, majd 1986-tól az Állami Biztosítási Felügyelet látta el kontinentális formában. A 1995. évi XCVI. törvény a biztosítási tevékenységről az uniós irányelveknek megfelelő angolszász típusú felügyeletet látta szükségesnek. 2000. április 1-jétől az Állami Biztosítási Felügyelet feladatát a Pénzügyi Szervezetek Állami Felügyelete (PSZÁF) látta el, ahogy a pénzintézetekét is.

2013. október 1-jével az Országgyülés döntése nyomán lépett életbe a Magyar Nemzeti Bankról (MNB) szóló új törvény, amely a jegybankba integrálta a pénzügyi felügyeleti feladatokat. Az MNB a jogszabály szerint folyamatos felügyeletet gyakorol a pénzügyi ágazati törvények hatálya alá tartozó szervezetek és személyek felett.

Feladatkörébe tartozik a prudenciális felügyelet, valamint a piacfelügyelet és a fogyasztóvédelem eszközeivel figyeli a pénz- és tőkepiaci intézmények, pénztárak, biztosítók, s a pénzügyi infrastruktúrát alkotó intézmények (szabályozott piac, elszámolóház, központi értéktár) tevékenységét, szükség esetén pedig intézkedéseket hoz. A felügyelet célja a kockázatok időben történő felismerése és megfelelő kezelése, elkerülendő, hogy azok veszélyeztessék a rendszer stabilitását és a pénzügyi közvetítő rendszerbe vetett bizalmat. A folyamatos felügyelet során nyert információkat az MNB beépíti a kockázatértékelésbe. A kockázat- és intézményértékelés adatai meghatározzák az adott pénzügyi intézmény felügyeleti kezelésének módját és intenzitását, illetve a további vizsgálatok ütemezését és azok fókuszpontjait. ${ }^{1}$

Feladata többek között:

- ellenőrizni a pénzügyi intézmények a pénzmosás és terrorizmus finanszírozásának megelőzésével és megakadályozásával kapcsolatos tevékenységét;

- az informatikai felügyelet;

- a jogosulatlan pénzügyi szolgáltatók kiszürése;

1 https://www.mnb.hu/felugyelet/ 
- fellép a fogyasztók jogainak érdekvédelméért, ennek érdekében azonosítja a fogyasztók számára hátrányos jelenségeket;

- fogyasztóvédelmi vizsgálatait széles körben végzi és kezeli a rendszerszintü fogyasztóvédelmi rendellenességeket.

\begin{tabular}{|l|c|c|c|}
\hline Megnevezés & 2016. év & 2017. év & 2018. év \\
\hline Felügyeleti adatszolgáltatást teljesítő biztosítók száma (darab) & 27 & 25 & 23 \\
\hline - életbiztosító & 8 & 7 & 6 \\
\hline - nem életbiztosító & 10 & 9 & 9 \\
\hline - kompozit biztosító & 9 & 9 & 8 \\
\hline
\end{tabular}

3. táblázat: Felügyeleti adatszolgáltatást teljesítő biztosítók száma (darab) Forrás: MNB (2018c)

A felmerülő viták rendezését az MNB mellett működő szakmailag független, alternatív vitarendezési fórum, a Pénzügyi Békéltető Testület végzi. A szervezet célja, hogy gyors és olcsó megoldásokat nyújtson a fogyasztók és a velük szerződéses kapcsolatban álló pénzügyi szolgáltató közötti anyagi, polgári eljárást igénylő jogvitákban.

A jegybank naprakész mikroprudenciális felügyeleti eszközrendszere és módszertana révén érvényesíti az átfogó rendszerkockázati célkitűzéseket, s megfelel a megváltozott uniós és hazai szabályozás követelményeinek is (például CRD IV.), valamint válaszolnak a szabályozások várható kihívásaira (például Szolvencia II.).

A Szolvencia II. szabályozórendszer szerinti szavatoló tőke feltöltöttségi szintje 220,9\%, mely az előző év azonos időszakához képest 4,5 százalékpontos csökkenést mutat. A biztosítási szerződésekhez kapcsolódó mögöttes eszközök több mint felét államkötvények tették ki 2018 végén. Eredményességüket igazolja, hogy a biztosítóintézetek 2018. évi előzetes adózott eredménye 12,7\%-kal nőtt. 


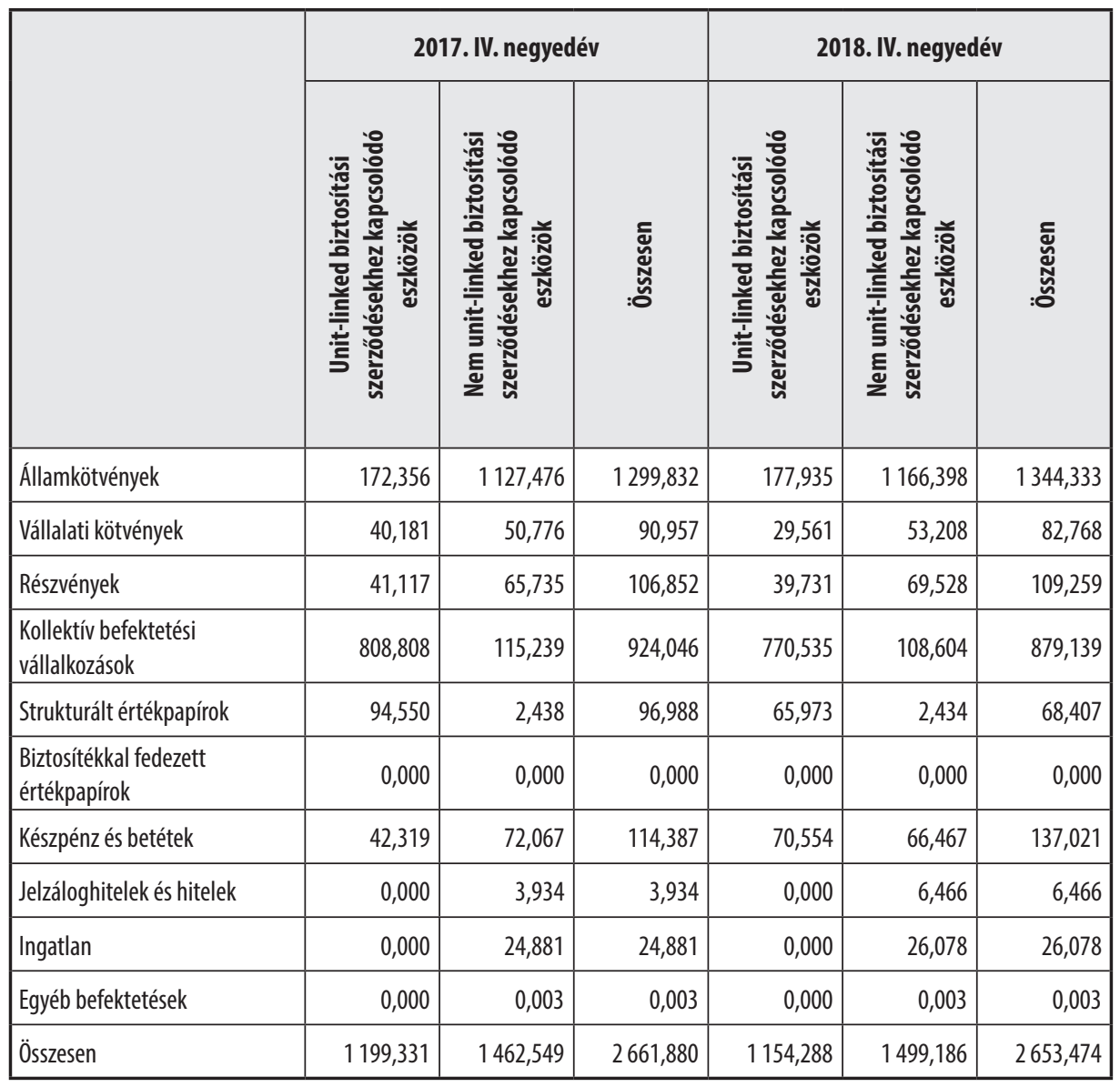

4. táblázat: A biztosítóintézetek (kivéve kisbiztosító-egyesületek) Szolvencia II értékelési elvek szerinti eszközei (milliárd forint) Forrás: MNB (2018c) alapján 


\subsection{Irodalomjegyzék}

2014. évi LXXXVIII. törvény a biztosítási tevékenységről

Banyár József: A biztosítás gazdaságtan alapjai- A biztosításról általában, http://penzsztar.hu/wp-content/uploads/A-biztos\%C3\%ADt\%C3\%A1sr\%C3\%B31-\%C3\%A1ltal\%C3\%A1ban.pdf

Magyar Nemzeti Bank (2018a): Biztosítási, pénztári és tőkepiaci kockázati jelentés 2018. Magyar Nemzeti Bank. https://www.mnb.hu/letoltes/kockazati-jelentes-2018-0613-vegleges.PDF

Magyar Nemzeti Bank (2018b): A biztosítási szektor 10 éves jövőképe 7 pontban - öngondoskodási kitekintéssel. Magyar Nemzeti Bank. https://www.mnb. hu/letoltes/biztosi-ta-si-szektor-jo-vo-je-pst-online.pdf

Magyar Nemzeti Bank (2018c): Tájékoztató a biztosítókról a 2018. IV. negyedévi felügyeleti célú adatszolgáltatás alapján. Magyar Nemzeti Bank. https://www. $\mathrm{mnb}$.hu/letoltes/tajekoztato-biztositok-2018-ivne.pdf

Tóth Gábor (2007): Biztosítási ismeretek-vállalkozások biztosítása. https://kgk. uni-obuda.hu/sites/default/files/BTjegyzet-07.pdf

A biztosítási piac egyes közreműködő szereplői: https://www.mnb.hu/archivum/ Felugyelet/root/fooldal/fogyasztoknak/biztositasok/kozremukodo_szerepek Felügyeleti keretrendszer: https://www.mnb.hu/felugyelet/felugyeleti-keretrendszer 


\section{4. Élet- és nem-életbiztosítások}

A tudatosan viselkedő modern ember képes megfigyelni környezetét és felmérni a létezését, jövőjét, mindennapi tevékenységét fenyegető kockázatok többségét. A biztosítási szerződés megkötésével kockázatot igyekszünk csökkenteni. Kockázatról egyaránt beszélhetünk akkor, amikor valamely anyagi veszteség bekövetkeztétől vagy pedig hasznunk elmaradásától tartunk. Kockázatra kell gondolnunk azonban olyankor is, amikor anyagiakban nem, vagy csak nehezen kifejezhető, nem anyagi természetű sérelemtől tartunk.

A kockázatok két alapvető csoportosítását a tiszta kockázat és a spekulatív kockázat jelentik. Tiszta kockázatról akkor beszélünk, ha a kár bekövetkezte két esélyes, vagyis bekövetkezik, vagy pedig nem következik be. Ezzel szemben a spekulatív kockázatnak lehet pozitív vagy negatív eredménye is. A biztosítás mindig csak tiszta kockázattal foglalkozik. A kockázat átvállalásakor a biztosítók díjfizetés ellenében a kár bekövetkeztekor kártérítést fizetnek.

A tiszta kockázatokat a biztosítás szempontjából további három részre bonthatjuk:

- személyi kockázat,

- vagyoni kockázat,

- felelősségi kockázat.

A biztosítók olyan kockázatokat vállalnak, amelyek a nagyszámú, általában hosszú időn keresztüli megfigyelés eredményeként biztosításmatematikai módszerekkel becsülhetők. Az így kiválasztott kockázatoknak homogéneknek kell lenniük és véletlenszerüen kell bekövetkezniük. A bekövetkező károknak egyértelműen meghatározhatóknak és körülírhatóknak kell lenniük.

A kockázatokat fedezhetjük a társadalombiztosítás, vagy pedig magánbiztosítás keretei között. A társadalombiztosítás az állampolgárok szociális biztonságának megteremtését célozza. Kötelező jellegü és elsősorban a személyi kockázatokra terjed ki. Nem szükséges az írásbeliség, és a gondoskodás elve az elsődleges anélkül, hogy a nyereség lenne a múködés célja.

A magánbiztosítás ezzel szemben önkéntes, biztosításmatematikai módszerek alapján működő, üzleti jellegű, profitra törekedő üzleti vállalkozás. Szerve- 
zeti formája lehet részvénytársaság, biztosító egyesület, szövetkezet vagy fióktelep. Újabban megjelenő különleges szolgáltatási formának számít a külföldön bejegyzett biztosítótársaság határon átnyúló tevékenysége keretében nyújtott biztosítási szolgáltatás.

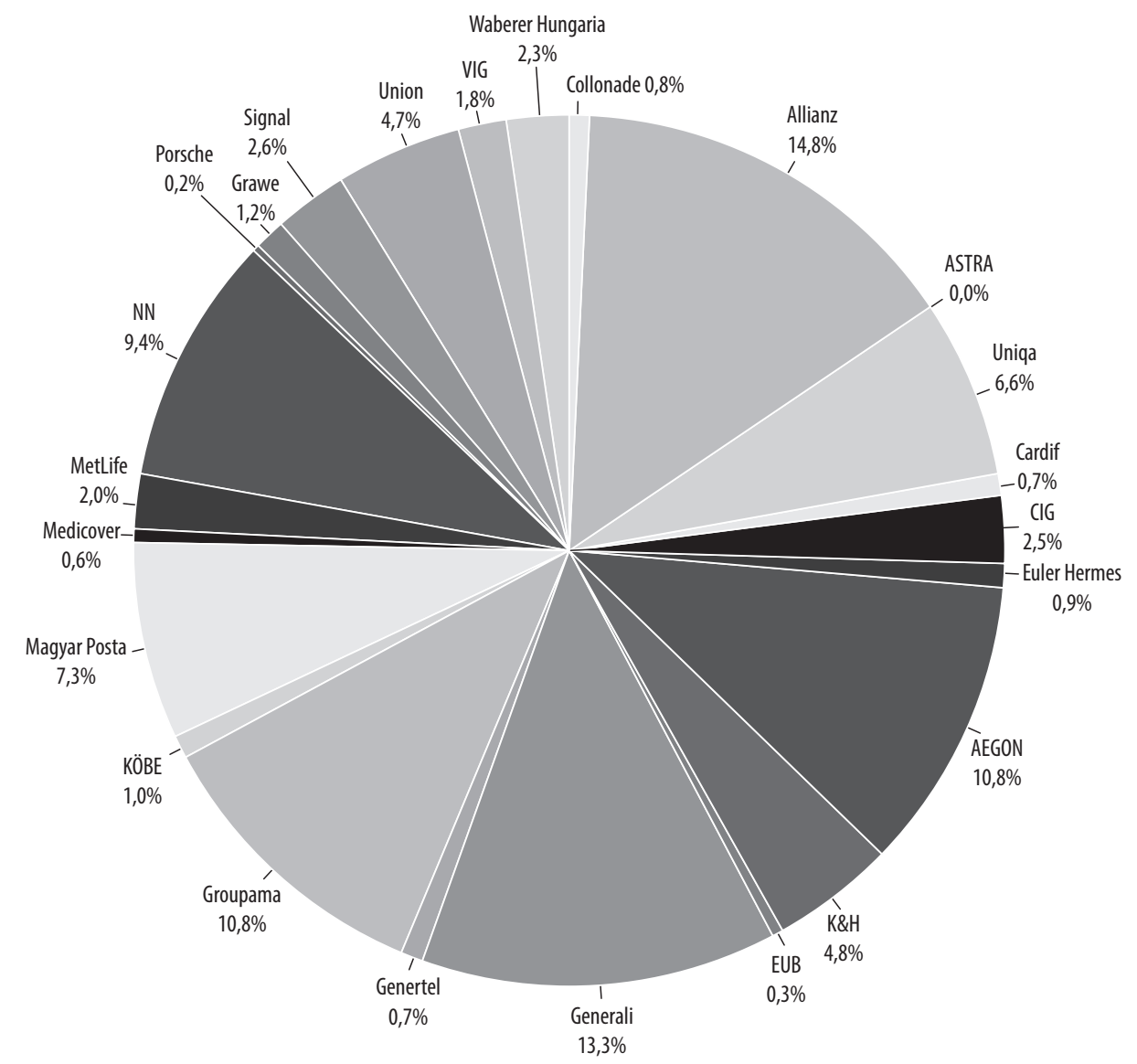

1. ábra: Biztosítók részesedése 2017 végén, díjbevétel alapján Forrás: MABISZ jelentés, Biztositási piac 2017. IV. negyedév

A biztosítási szektor a gazdaság és a társadalom meghatározó szereplője. A már megszerzett vagyon védelme ugyanis a legtöbb ember számára teljesen természetes. Ezen alapszik például a lakás-, a gépjármü- vagy a vállalkozói vagyonbiztosítások, illetve a szállítmánybiztosítások piaca. Egyre többünk számára világos az is, hogy egyes kikerülhetetlen helyzetekben okozhatunk kárt másoknak, amelyért felelősséggel tartozunk. Ezen károk enyhítésére szolgálnak például a felelősségbiztosítások. Utazásaink során kerülhetünk olyan helyzetbe, amikor or- 
vosi ellátásra szorulunk, vagy poggyászaink, értéktárgyaink vesznek el, sérülnek meg. Ilyen esetekre érdemes például utasbiztosítást kötni. Hosszú ideig elképzelhetetlen volt, de ma természetes, hogy autónkra köthetünk segítségnyújtásra vonatkozó biztosítást is.

Az életbiztosítások vásárlása azonban még sajnos ma sem ennyire egyértelmü valamennyiünk számára. Az egyének, illetve a családok pénzügyeinek tervezésekor az életbiztosítások gyakran számos más prioritás mögött következnek csak a sorban. Az életbiztosítás lényegében azon kockázat kezelése, amely a biztosított halálának bekövetkezése vagy be nem következése az elöre meghatározott biztosítási tartam során. A mai kor emberének azonban nem elegendő csupán ezen szűk elméleti körben gondolkodnia az életbiztosításokról. Ezen szerződések ugyanis hosszútávú megtakarítási lehetőséget jelentenek a biztosítók ügyfeleinek. Ez különösen nagy jelentőséggel bír a nyugdíjaskori bevételek tervezésénél, vagy speciális élethelyzetekre, mint például házasságra, lakásvásárlásra, gyermek taníttatására való felkészüléskor. Az X generációba tartozók számára a személyes konzultáció volt a természetes és hatásos tájékozódási forma a biztosítási döntések meghozatala előtt. A biztosítási tanácsadók és üzletkötők adták a hitelesnek vélt információkat a biztosítási szerződés megkötése elött. Az Y, de különösen a Z generáció tagjai viszont már széleskörűen igyekeznek tájékozódni az elektronikus felületeken és különböző összehasonlító oldalakon. Számukra az ár/érték arány mellett a nagyfokú rugalmasság és a könnyü érthetőség egyaránt fontos döntési kritériummá alakult. Ráadásul a hosszútávú célok meghatározását követően ma már számos alternatív befektetési és megtakarítási forma is választható az átlagember számára is. Az azonban nem változott, hogy a tudatos ember számára az öngondoskodás egyik hatékony eszköze az életbiztosítás.

\subsection{Személybiztosítás}

A személyekre szóló biztosítások fontos jellemzője, hogy általában a család vagy a háztartás jövedelembiztonságát teremti meg. Speciális megkülönböztető jegye, hogy a szolgáltatási összeget, vagyis azt az összeget, amelyet a biztosítónak ki kell fizetni a kártérítés során, az egyén saját döntése alapján, élethelyzetéhez igazodva határozza meg. 
A személybiztosítások általánosságban lehetnek életbiztosítások, balesetbiztosítások vagy pedig egészségbiztosítások.

Ezen biztosítások lehetnek tisztán kockázati jellegüek, vagy megtakarítási elemmel kombináltak is. Az életbiztosítások általában bővíthetők kiegészítő elemekkel, amelyek a legtöbb esetben baleseti vagy egészségbiztosítási fedezeteket jelentenek.

\section{2. Életbiztosítás}

Az életbiztosítás már nevében is egyértelmüen meghatározza, hogy életünkkel kapcsolatos fö kockázataink pénzügyi megoldásában nyújthat segítséget.

Korai halál bekövetkezése esetén a hátramaradottak pénzügyi biztonságát, magas életkor elérése esetén a biztosított életszínvonalának megőrzését segíti.

Korai halál esetére gondolva különösen fontos a hagyaték tervezése során nem csupán a temetés költségeivel kalkulálni, hanem az ingatlanvagyon, vállalkozások, jelzálogok terheinek fedezetére is megfelelö összegü biztosítással gondoskodni. Jelentős hitelkitettség esetén különösen fontos az ilyen jellegü biztosítás megkötése. Magas életkor elérése esetére készülve pedig a nyugdijaskori megélhetés költségei mellett érdemes biztosítással felkészülni a romló egészségi állapotunkból adódó költségek ellentételezésére is.

\subsubsection{Az életbiztosítások története}

Az életbiztosításokat egészen időszámításunk előtt 100-ig eredeztetik. A történetírók szerint Caius Marius római hadvezér csapataiban olyan kisebb csoportokat alkotott, amelyeknek tagjai a később bekövetkező temetés költségeihez elöre meghatározott módon hozzájárulást fizettek. Abban az esetben, ha a kisebb csoport valamely tagja elhunyt, úgy a temetése költségeit már a csoportban korábban összegyüjtött összegből, gyakorlatilag társai fedezték. Rómában ennek mintájára civil közösségek is alakultak, amelyek egy része már az elhunyt leszármazottainak is fizetett járandóságot.

A következő nagy lépést már a 17. században tette meg a világ, amikor egy angol textilkereskedő elméletet alkotott az egyes csoportokon belüli várható élethossz meghatározhatóságáról. Nem sokkal később pedig szintén Angliában 
megalkották az első halandósági táblát. Ettől a momentumtól kezdődően tudományos alapokra helyeződtek a biztosítási kalkulációk és új szakma is született, a biztosítási matematikus.

Az első életbiztosítások a megalakuló biztosítótársaságok palettáján a 18. században jelentek meg. Terjedésük innentől kezdődően már robbanásszerűként jellemezhetö.

A magyar biztosítástörténet az emberi életre szóló biztosítások eredetét a céhek ún. társládáihoz köti, amelyek segítségével a rászorulókat támogatták, illetve kórházak, vagy időskori menhelyek finanszírozását biztosították.

Az Első Magyar Általános Biztosító Társaság Pesten alakult meg 1857-ben. Az alapítás gondolata még Gróf Széchenyi Istvántól származott 30 évvel korábbról, de a tervet már Lévay Henrik későbbi vezérigazgató vitte véghez.

A 19. században sorra alakultak a társaságok és szövetkezetek, illetve egyesületek, amelyek életbiztosításokkal is foglalkoztak. Budapesten sétálva gyakran láthatók díszes feliratok belvárosi paloták és egykori bérházak homlokzatán biztosítótársaságok neveivel, amelyből következtethetünk az egykoron rendkívül színes biztosítói iparág történelmi jelentőségére is. A két világháború azonban alaposan átrendezte a piaci viszonyokat. Az új időszak 1952-ben vette kezdetét, amikor az Állami Biztosító monopóliumaként kaptak új lendületet az életbiztosítások hazánkban. A monopóliumnak 1986-ban lett vége, amikortól már a Hungária Biztosító is önálló tevékenységet folytathatott. Ezt követően sorra alakultak az új társaságok, majd a rendszerváltást követően megjelentek hazánkban is a multinacionális biztosítótársaságok leányvállalatai. Ma a magyar piacot a külföldi tulajdonban lévő társaságok dominálják. ${ }^{1}$

\subsubsection{Az életbiztosítási piac szereplöi Magyarországon}

A magyar életbiztosítási piac a szereplők száma és háttere alapján is komplexnek tekinthetö. A legnagyobb európai, illetve multinacionális biztosítótársaságok érdekeltségei különböző müködési formákban vannak jelen a magyar piacon.

A német és osztrák érdekeltségű vállalatok nagy száma közép-európai jellemzőnek is tekinthető. A legtöbb szereplő azonban nem csupán életbiztosítási, hanem nem-életbiztosítási tevékenységet is művel hazánkban, így ügyfélkörének

1 MABISZ, MNB 
igyekszik teljeskörủ szolgáltatást nyújtani. Az egy före jutó biztosítások tekintetében jelentős lemaradás tapasztalható a fejlett biztosítási kultúrával jellemzett országokhoz képest. Ez további fejlődési lehetőségeket rejt magában. Ugyanakkor az alacsony átlagdíjak és a rövid biztosítási tartamok miatt a piac jövedelmezősége alacsony, amely további integrációkat eredményezhet a közeli jövőben.

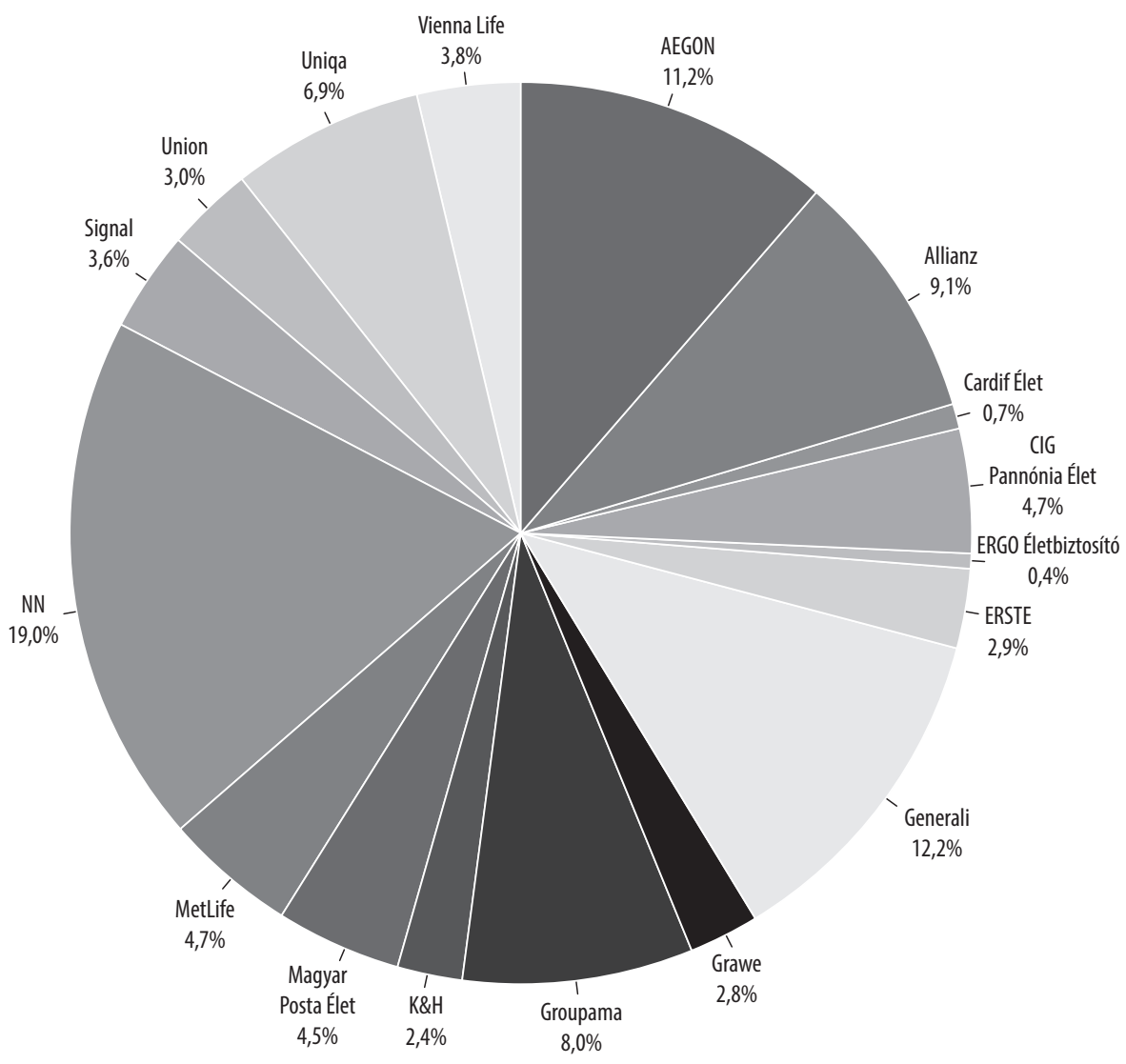

\section{2. ábra: Életbiztosítók részesedése 2017 végén}

Forrás: MABISZ jelentés, Biztositási piac 2017. IV. negyedév

\subsubsection{Az életbiztosítások célja}

Az emberi élet értékét anyagiakban kifejezni nem lehetséges. A veszteséget pedig semmiféle módon nem lehet pótolni. Az életbiztosítások célja, hogy segítséget nyújtsanak a biztosított számára azokban a váratlan élethelyzetekben, amikor anyagi helyzetének megváltozása ezt szükségszerüvé teszi, vagy a hátramaradottaknak ad lehetőséget arra, hogy képesek legyenek leküzdeni szerettük elvesztése 
okozta pénzügyi problémákat is. A biztosító tehát egy előre meghatározott összeget fizet, természetesen a szerződésben elöre rögzített feltételek mellett. Az életbiztosítás modern értelemben egyaránt eredményezhet kártérítést a szerződés időtartama alatt a biztosított életbenléte, de halála esetén is, attól függően, hogy milyen típusú az adott életbiztosítási szerződés. A biztosítások elöre meghatározott célja alapján a kifizetések történhetnek egyes élethelyzetek bekövetkeztéhez kapcsolódóan. Ilyen lehet például a nyugdíjba vonulás, felsőfokú tanulmányok megkezdése vagy például a házasságkötés is. Az ilyen célokhoz kötött szerződések esetében általánosságban elmondható, hogy a jelentős anyagi áldozattal járó élethelyzet változása az, ami miatt a szerződés eredetileg megkötésre kerül.

\subsubsection{Az életbiztosítási szerződés szereplői}

Szerződő: az a természetes vagy jogi személy, aki vagy amely az életbiztosításban a dífizetési kötelezettséget vállalja. Amennyiben a szerződő nem azonos a biztosítottal, úgy a szerződés megkötéséhez, illetve módosításához a biztosított hozzájárulása is szükséges. Egyes biztosítási típusokban lehetőség van a biztosítási tartam során a szerződés megtartása mellett a szerződő módosítására.

Biztositott: az a személy, akinek az életével kapcsolatos a kockázat, illetve akinek a biztosítási esemény bekövetkezése esetén a biztosító szolgáltat. A szolgáltatás az esetek döntő többségében pénzbeli szolgáltatást jelent. A biztosított kizárólag természetes személy lehet, a biztosítás megkötéséhez adott hozzájárulását bármikor visszavonhatja.

Kedvezményezett: a szerződő és a biztosított által közösen megjelölt személy, akinek a biztosító szolgáltat. A kedvezményezett megjelölése a szerződés megkötésével egyidejűleg történik, és a tartam során változtatható. A haláleseti kedvezményezett mindig a biztosítottól eltérő kell legyen.

Biztositó: az a speciális vállalkozás, amely dijfizetés ellenében vállalja, hogy a szerződés feltételei szerint a biztosítási esemény bekövetkeztekor szolgáltatást nyújt.

\subsubsection{Az életbiztosítások típusai}

Az életbiztosítások két alapvető típusa:

- haláleseti biztosítás,

- elérési biztosítás. 
A két alaptípusból számos egyéb szerződési forma is eredeztethető. Ilyenek például a járadékbiztosítások vagy a vegyes biztosítások.

A haláleseti biztositást a szaknyelvben kockázati biztositásnak is szokás nevezni. Ezen szerződés alapvető célja, hogy az elöre meghatározott szerződéses időszak (tartam) alatt a biztosított (akinek életére a biztosítási szerződés szól) halála esetén a kedvezményezett (már a szerződés megkötésekor előre meghatározott személy vagy személyek) egy elöre meghatározott összeget (biztosítási összeg) kapjon. Abban az esetben, ha a biztosított a tartam végén életben van, a szerződés kifizetés nélkül megszűnik.

A kockázati biztosítás megkötésének célja lehet akár egy bankhitel fedezete, esetleges hagyatéki költségek finanszírozása vagy a temetés költségeinek fedezete. A kockázati biztosítás speciális típusa a teljes életre szóló (whole life) életbiztosítás, amely szolgáltatása csak a biztosított halálakor válik esedékessé.

Az elérési biztositási szerződés esetén a biztosító egy előre meghatározott tartam végén, a túlélő biztosítottnak kifizeti az előre meghatározott biztosítási öszszeget. Amennyiben a biztosított életét veszti a tartam közben, úgy a biztosító a kedvezményezettnek vagy pedig az örökösöknek fizeti ki az addig befizetett díjakat és hozamait, és a biztosítás megszünik.

Az elérési biztositás és a haláleseti biztositás kombinációjaként született meg a vegyes életbiztositás. A vegyes életbiztositás kétféle szolgáltatási tartalommal bír:

1. Amennyiben a tartam elteltével a biztosított életben van, úgy a biztosító kifizeti az elérési szolgáltatás összegét.

2. Amennyiben a biztosított a tartam során az életét veszti, úgy a biztosító a kedvezményezettnek vagy az örökösnek kifizeti a haláleseti szolgáltatást.

A vegyes biztositás tipikus célja lehet például nyugdíj előtakarékosság, gyermekeink taníttatásának fedezete, családalapítás költsége vagy lakhatás anyagi feltételeinek elősegítése. A vegyes biztosítás köthető két biztosítottra is. Ez leggyakrabban házastársak közös szerződése. Ennek esetében a szerződés akkor szűnik meg, amennyiben az egyik biztosított meghal.

A járadékbiztositás egy előre, akár egy biztosítás keretében összegyűjtött összeg, a biztosító által kalkulált, rendszeres időközönként történő kifizetését célozza. Tipikus formája a nyugdíjaskori járadék, ahol általában havonta elöre 
meghatározott összeget fizet a biztosító a biztosított teljes hátralévő élete során, vagy egy előre meghatározott tartam során.

A biztosítási szakma gyakorta megkülönbözteti a term fix életbiztosítást, amely olyan előre rögzített tartamú életbiztosítást jelent, ami a szerződés lejáratakor mindenképpen kifizetéssel jár. A biztosított halála esetén a halál időpontjától kezdve nem kell fizetni a biztosítási díjat. Az ilyen biztosítást elsősorban a gyermek számára történő előtakarékosság céljából választják. A kedvezményezett ilyen szerződés esetében gyakorta egy előre meghatározott összeget kap a lejáratkor.

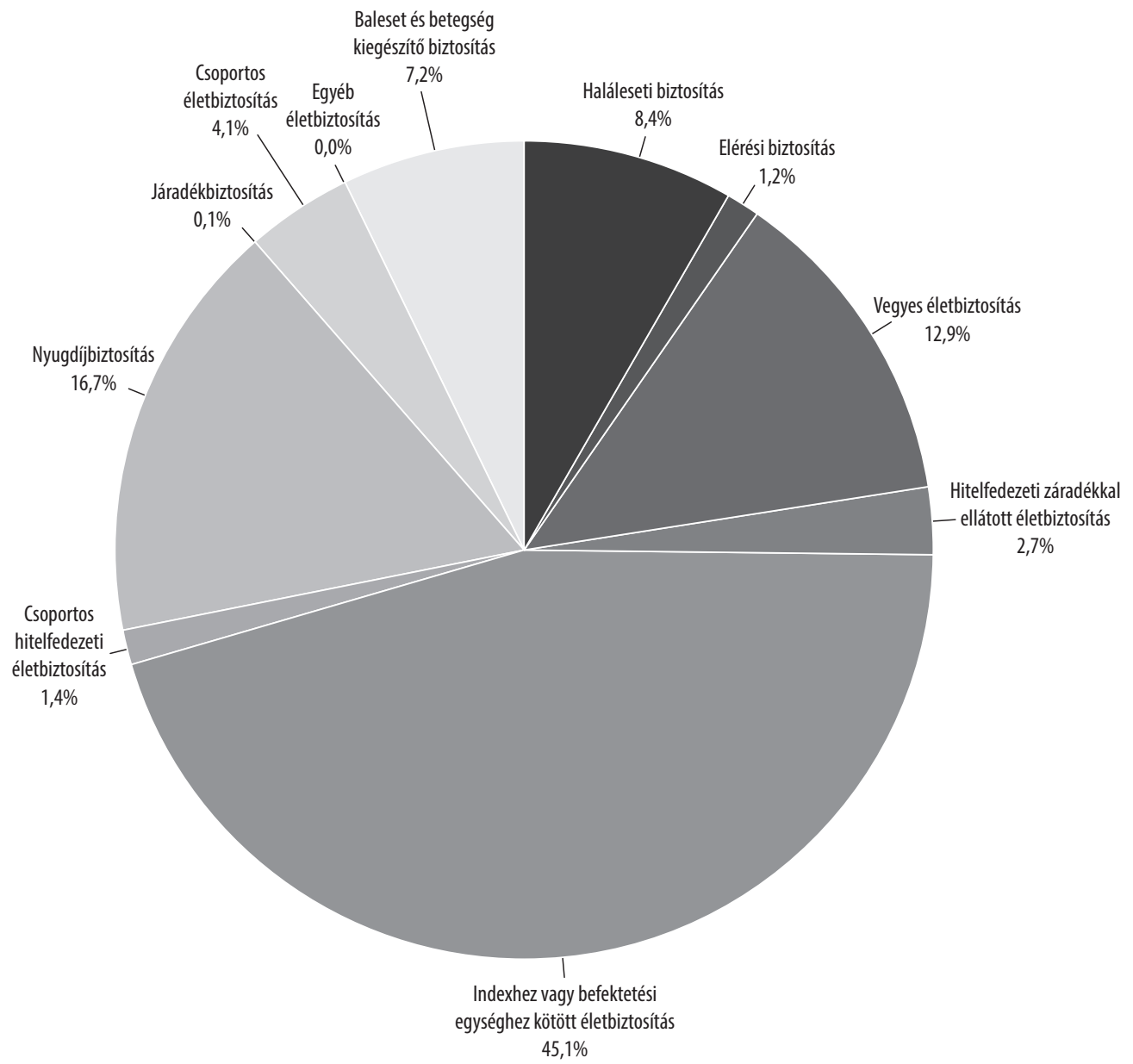

3. ábra: Életbiztosítási ágazatok részesedése záró állománydíj alapján 2017 végén

Forrás: MABISZ jelentés, Biztositási piac 2017. IV. negyedév 


\subsubsection{Kiegészítő biztosítások}

A legtöbb társaság az úgynevezett alapbiztosítás mellé kínál kiegészítő biztosításokat is. A kiegészítő biztosítás egyik fontos jellemzője, hogy általában csak az alapbiztosítással együtt értelmezhető, az alapbiztosítás megszűnésével általában a kiegészítő biztosítás is megszünik.

A legjellemzőbb kiegészítő biztosítások:

- Kiegészítö kockázati életbiztosítás: a biztosított tartam során bekövetkező bármely okú halála esetén téríti a kiegészítö biztosításban rögzített biztosítási összeget.

- Kiegészitö biztositás baleseti halál esetére: a biztosított tartam alatti balesetéből származó károsodásának megfelelően téríti a kiegészítő biztosításban rögzített biztosítási összeget.

- Kiegészitő biztositás baleseti rokkantság esetére: a biztosított tartam alatti TB szabályokban rögzített megrokkanása esetén téríti a kiegészítő biztosításban rögzített biztosítási összeget.

- Kiegészítö egészségbiztositás: a biztosított tartam alatti egészségügyi ellátása során téríti a kiegészítő biztosításban rögzített biztosítási összeget.

- Kiegészitö kórházi napi térités biztositás: a biztosított tartam alatti egészségügyi ellátása során téríti a kiegészítő biztosításban rögzített napi biztosítási összeget.

- Kiegészitö baleseti okú kórházi napi térités biztositás: a biztosított tartam alatti egészségügyi ellátása során téríti a kiegészítő biztosításban rögzített napi biztosítási összeget.

- Kiegészitő biztositás kritikus betegségek esetére: a biztosított tartam alatti egészségügyi ellátása során téríti a kiegészítő biztosításban rögzített biztosítási összeget a feltételben tételesen felsorolt diagnózisok esetén. Tipikusan a leggyakoribb szív és érrendszeri, illetve daganatos betegségekre vonatkoztatva.

- Kiegészitô mütéti térités biztositás: a biztosított tartam alatti műtéti ellátása során téríti a kiegészítő biztosításban rögzített biztosítási összeget.

- Kiegészitö biztositás munka- és keresőképtelenség esetén történő dijátvállalásra: a biztosított tartam alatti munka- és keresőképtelensége esetén megfizeti a biztosítás díjait a kiegészítő biztosításban foglaltak szerint. 
- Kiegészitö biztositás munkanélküliség esetére: a biztosított tartam alatti munkanélkülisége esetén téríti a kiegészítö biztosításban rögzített biztosítási összeget.

\subsubsection{Az életbiztosítások egyéb szempontú csoportosítása}

A biztosítottak száma alapján a szerződés lehet egyéni vagy csoportos biztosítás. A csoportos biztosítást gyakorta a munkáltatók, érdekképviseleti szervek kötik alkalmazottjaik, tagjaik számára.

Az életbiztosítások tartama szerint lehetséges élethosszig tartó (whole life) vagy pedig elöre meghatározott tartamú szerződésekről beszélni.

A díjfizetés gyakorisága szerint megkülönböztetünk folyamatos- vagy egyszeri dijfizetésü szerződéseket. A folyamatos díjfizetésű szerződések lehetnek havi, negyedéves, féléves, éves díjfizetési gyakoriságúak.

A díjfizetés módja szerint a biztosításokat csoportosíthatjuk csekkes, csoportos dijbeszedésü, banki átutalásos szerződésekként. A díjfizetés szempontjából egyre elterjedtebb a bankkártyás díjfizetés is.

\subsubsection{Az életbiztosítások specialitása}

A biztosítás hosszútávú szerződés. A tartama általában meghaladja a tíz évet. A nyugdíjbiztosítások esetében a szerződések tartama akár negyven esztendőnél is több lehet. A szerződés jellegéből adódóan a biztosítónak nincs joga a szerződést megszüntetni a tartam lejárata elött. Ezen speciális feltétel kifejezetten a biztosított érdekeinek védelmében alakult ki. A biztosító üzleti érdeke esetleg megkívánná, hogy a biztosított egészségi állapotának romlása esetén felmondja a szerződést, de életbiztosítás esetében erre nincs lehetőség.

A szerződő dönthet úgy, hogy nem kívánja tovább fizetni a biztosítás díját. Egyes szerződések esetében van lehetőség arra, hogy a biztosított, amennyiben nem azonos a szerződővel, folytassa a díjfizetést. Gyakorlati példái lehetnek ennek a megoldásnak az önálló életvitelre berendezkedő felnövő gyerekek esete, amikor a szülő kezdi fizetni a biztosítást, és később a tényleges díffizetés kötelezettsége átszáll a biztosított gyermekre. Ugyanilyen gyakorlati megoldás lehet a munkáltató által megkötött biztosítások esete. Amikortól a munkáltatónak már nem érdeke a díjfizetés, például a megszűnő munkaviszony okán, a korábbi munkavállaló átveheti a díjfizetést. 
A biztosítási szerződés tehát kétoldalú jogviszony. A szerződő azt vállalja, hogy díjat fizet a biztosítónak, ezzel szemben az életbiztosító vállalja, hogy a szerződésben meghatározott feltételek szerint kifizetést teljesít a kedvezményezettnek. A szerződő díjfizetési kötelezettségének különösen azért van jelentősége, mert a biztosító a veszélyközösség érdekeit képviselve, díjelmaradás esetén lépéseket tesz annak érdekében, hogy a díjfizetés folyamatos maradjon. A megtakarítási jellegü biztosítások esetében pedig, saját vesztesége minimalizálása érdekében, visszavásárlási táblákon előre meghatározott módon csökkenti a már felhalmozott összeg nagyságát. A visszavásárlási tábla az ügyfélnek megmutatja, hogy idő előtt megszüntetve a szerződését a felhalmozott összeg hány százalékát kapja meg. Ez az érték a száz százalékot csak közvetlenül a szerződés lejártát megelőző években éri el.

\subsubsection{A biztosítások költségei}

A biztosítók a biztosítás dijának egy számításokkal előre meghatározott és a szerződéskötéskor rögzített részét a saját költségeik fedezésére elvonják. A biztosítási díj általában tartalmaz egy vállalkozói díjrésznek nevezett elemet, amely a szerződéskötés költségeinek, az állományápolás költségeinek és a biztosító működési költségeinek fedezésére szolgál. Emellett általában elkülöníthető egy másik nagy díjcsoport, amelyet kockázati díjrésznek nevezünk. A kockázati díjrész szolgál fedezetül az azonnali károk kifizetésére, illetve a később bekövetkező károkra elkülönített díjtartalék megképzésére.

\section{A szerződéskötés költsége, jutalék}

A biztosítást ma még igen ritkán vásárolják meg anélkül, hogy valamilyen külső késztetés vagy figyelemkeltés ne előzné meg a szerződéskötést. Saját üzleti érdeküknél fogva a biztosítótársaságok értékesítésre szakosodott specialistákkal működnek együtt. Az értékesítők lehetnek függő közvetítők vagy független közvetítők. A függő közvetítők az esetek döntő többségében a biztosítótársaságok saját üzletkötői, akiket a társaságok regisztrálnak a felügyeleti szerveknél, gondoskodnak szakszerű felkészítésükről és támogatják értékesítési tevékenységüket. Hasonló szerepet játszanak az értékesítésben az úgynevezett többes ügynökök. E két értékesítési csoport közös tulajdonsága, hogy tevékenységükért a biztosítótársaság felel, az ügynök pedig a társaságot képviseli az ügyfelek elött. Az értékesítők másik nagy csoportja a független közvetítők, akik a köznyelvben 
biztosítási bróker, vagy biztosítási alkusz elnevezéssel illethetők. A biztosítási alkusz legfontosabb megkülönböztető jegye az, hogy tevékenységét saját felelősségére végzi, és az ügyfeleket képviseli a biztosítók elött.

Mindkét nagy csoport egyaránt díjazásért, az esetek többségében jutalékért végzi tevékenységét. $\mathrm{A}$ jutalékot a biztosítótársaság a termék árazásakor kalkulálja és azt döntően két nagy csoportba sorolja. A szerzési jutalékot a biztosítás megkötésekor fizetik ki, míg az ún. fenntartási jutalékot a szerződés tartama alatt, elosztva.

A szerződéskötéskor a biztosító egyik legnagyobb kockázata abban rejlik, hogy a szerződés az eredetileg tervezett tartam vége előtt megszünik, és így a teljes tartamra elosztott költségek nem térülnek meg. Ezen költségek legjelentősebb eleme a kezdetben azonnal jelentkező szerzési jutalék. Ezen kockázatok mérséklése mind a társaságok, mind pedig a szabályozó szervek közös érdeke. Az ehhez kapcsolódó rendelkezéseket külön is tárgyaljuk.

A szerzési jutalékot a biztosítók fizethetik rögtön a szerződéskötéskor, előre, anélkül, hogy befolyt-e az első éves teljes díj. Gyakori megoldás azonban, hogy a ténylegesen befolyt díj mértékének megfelelően, részletekben, „csepegtetett jutalék" formájában fizetik a közvetítőt.

A társaságok a jutalékokra vonatkozó belső szabályaikat, eljárásrendjüket általában az ún. jutalékszabályzatban rögzítik. Ez az a dokumentum, amely a vállalat aktuális szerzési gyakorlatát leginkább tükrözi. A jutalékszabályzatban meghatározott mértékek és ösztönzők ugyanis a függö közvetítők esetében egyértelműen meghatározzák azt, hogy mely termékeket kíván a társaság előtérbe helyezni saját portfóliója építésekor.

Ma már Magyarországon is megtalálható gyakorlat, hogy a független közvetítő nem kap jutalékot a biztosítótól. Ezzel szemben az ügyfele, akinek az érdekeit a biztosítók előtt képviseli, fizet számára előre meghatározott díjat az elvégzett szolgáltatás ellentételezésére.

A jutalékszabályzatok különösen fontos eleme a jutalékvisszaírásra vonatkozó rész. Abban az esetben, ha a közvetítő az elöre felvett jutalékot nem szolgálja meg, mert pl. az életbiztosítási szerződés idő előtt megszűnik, a biztosító viszszaköveteli a jutalék egy részét. Jellemző, hogy az első három évben a kezdetben 
kifizetett jutalékok egy elöre meghatározott része kerül visszakövetelésre, amely az első évben általában a teljes kifizetett jutalékot jelenti. Három év után a jutalékvisszaírás általában már nem terheli a közvetítőt.

Az elmúlt két évtizedben a magyar biztosítási szektor milliárdos nagyságrendben szenvedett veszteséget amiatt, hogy egyes közvetítők tudatosan károsították meg a társaságokat fiktív szerződések után járó jutalékok felvételével, majd a visszaírás tényleges aktusa alóli kibújással. Ennek a jövőbeni elkerülése érdekében a társaságok egyre szigorodó feltételek mellett hajlandók új partnerekkel együttműködésre lépni, ellenőrzési tevékenységük pedig egyre szigorúbbá vált. A még hatékonyabb fellépés gátja a szigorú adatvédelmi szabályozás, illetve az egyes piaci szereplők üzleti érdekei miatti torz piaci reakciók időről-időre való felerősödése.

\subsubsection{A díjtartalék}

A hagyományos életbiztosítások esetében tipikus, hogy a biztosító az ügyfél által befizetett díjaknak egy részét, a szerződés pontos típusától függően, folyamatosan gyüjti a később nyújtandó szolgáltatások fedezetére. Ezt a felhalmozott összeget nevezzük díjtartaléknak. A díjtartalék mindenkori aktuális összege általában kisebb, mint a befizetett és hozamokkal növelt díjak összege, mivel a biztosító a befizetett díjakból fedezi költségeit és a tartam közben bekövetkező szolgáltatások kifizetéseit is. A díjtartalékot a biztosító befekteti, és az elért többlethozam nagyobb részét (minimum 80\%) a szerződőnek, meghatározott metódus szerint visszaadja. A többlethozam nem más, mint a díjtartalék befektetéséből a technikai kamaton felül elért nyereség. A technikai kamat a biztosító által a biztosítási fedezetre garantált befektetési hozam. Az érvényes szabályozás értelmében a forintban meghatározott szerződések esetében 2016. július 1-jétől 2,3\%. A díjtartalék befektetési szabályai szigorú rendszerbe foglaltak, törvények által szabályozottak és a felügyeleti szervek szorosan nyomon követik a tartalékokhoz kapcsolódó tranzakciókat.

A jelenlegi különösen alacsony hozamkörnyezetben a technikai kamat különösen nagy jelentőséggel bír. Egyes biztosítótársaságok napjainkban már korlátozzák az ilyen jellegü biztosítások értékesítését. Egyes országokban az is elöfordul, hogy a társaságok egyáltalán nem bővítik tovább az ilyen portfóliójukat. Az ilyen tevékenységet nevezi a szakma általában „run off” vagy kifutó üzletnek. 
A dijtartalék az alapja a maradékjogoknak is, amelyek olyan az életbiztosítási szerződésekben rögzített jogosultságokat jelentenek, amelyek a díjfizetés esetleges elmaradása, illetve a szolgáltatás kifizetése nélküli megszűnése esetén is megmaradnak. Jellemző maradékjogok a díjmentes leszállítás, illetve a visszavásárlás.

A befektetési egységhez kötött (unit linked) életbiztosítások esetében a biztosító a biztosítási szerződés alapján képzett biztosítástechnikai tartalékot az általa létrehozott, önálló befektetési politikával rendelkező, elkülönítetten kezelt, azonos értékű, elméleti elszámolási részekből álló, eszközállományokba vagy más, befektetési alapkezelésre jogosult társaság által kezelt befektetési alapokba helyezi befektetés céljából. Az elszámolási részeket szokás befektetési egységeknek is nevezni. Az eszközalapokba történő befektetés a szerződő választásától függ és a szerződésben előre meghatározott szabályok szerint történik. Ezen szerződések esetében a szerződő megválaszthatja, hogy az általa befizetett díj egy részét, a unit linked életbiztosítási tartalékot, milyen típusú és kockázatú befektetési eszközalapokba helyezze el a biztosító. Az alapok teljesítményéről, és ehhez kapcsolódóan az aktuális eszközértékről, a biztosítók rendszeresen tájékoztatják ügyfeleiket. Egyes szerződések esetében a választható alapok száma több tucat is lehet, a befektetési hajlamú ügyfelek igényeit pedig számos döntéstámogató eszközzel pl. stop loss/start buy technikákkal is segítik.

\subsubsection{Az életbiztosítási piac gazdasági jelentősége}

Az életbiztosítások vásárlása megteremti a biztonságtudatot, segíti a családok és vállalkozások általános pozitív jövőképének alakulását. A gyakorta előforduló váratlan negatív hatások ellensúlyozásával megakadályozzák a hatások széleskörü továbbgyürüzését.

Kiválthatják a társadalombiztosítás egyes elemeinek felhasználását, ezzel általánosságban is javítják az ország gazdasági helyzetét. Megtakarítási jellegüknél fogva halasztott fogyasztást eredményeznek és ezzel az inflációra is hatással vannak.

A megtakarítási jellegű biztosítások tartalékainak felhalmozásával, azt nagy összegü befektethető tőkévé gyüjtik össze. Ezzel jelentős mértékben hozzájárulnak mind az állampapír piac, mind pedig a hazai tőzsde fejlödéséhez. A 2017. év végén az életbiztosítók díjbevétele meghaladta a 477 milliárd forintot, amely önmagában is mutatja a szektor gazdasági erejét. 
A 2015. év végén a Magyar Nemzeti Bank (továbbiakban: MNB) adatai szerint hosszú évek óta először pozitív, 28,3 milliárd forintos eredmény mutatkozott a szektor biztosítástechnikai eredményét illetően. Azóta is tovább növekedett az állampapírok szerepe a biztosítói befektetések körében: 2017 végén a szektor 1159 milliárd forintot fektetett közvetlenül állampapírba (MABISZ, Évkönyv 2018.).

\subsubsection{Az életbiztosítási piac intézményrendszere}

A magyar piacon jelenlévő biztosítótársaságok között találunk olyat, amely kizárólag életbiztosításokat kínál. A régebben alapított társaságok között azonban többségében vannak a kompozit biztosítók, amelyek mindkét biztosítási ágazatban kínálnak termékeket. Újonnan azonban már csak szakosodott biztosító alapítható. A 2016-os év végén 19 biztosító volt érdekelt Magyarországon életbiztosítás értékesítésében.

Speciális területe a biztosítási szakmának a viszontbiztosítás, amely a biztosítótársaságok kockázatát tovább porlasztja. A viszontbiztosító az életbiztosítások esetében azt vállalja, hogy extrém körülmények között, vagy különösen nagy összegủ károk esetén, előre meghatározott feltételek szerint, illetve limitek alapján megtéríti a biztosító kárainak egy részét. A viszontbiztosító ezt kockázati díj ellenében teszi.

A biztosítási szakma felügyeletét 2013-tól a Magyar Nemzeti Bank látja el. Az MNB legfontosabb feladatai ebben a vonatkozásban az engedélyezési tevékenység ellátása, a már engedéllyel bírók folyamatos ellenőrzése, az adatszolgáltatásokon keresztül pedig a prudens működés monitorozása. Kiemelten fontos terület a fogyasztóvédelemmel összefüggő tevékenységük.

A biztosítótársaságok saját érdekképviseletük okán, a szakmai tapasztalatok cseréjét is szem előtt tartva, hozta létre a Magyar Biztosítók Szövetségét (továbbiakban: MABISZ). Ez a szervezet képviseli a biztosítási szakmát az országos döntéshozatali fórumokon is. A MABISZ különleges tevékenysége a biztosítási szakma presztízsének növelését célzó kampányok szervezése, illetve a biztosítási kultúra növelése és az öngondoskodás szükségességének bemutatása. A MABISZ tagozataiban a biztosítási szakma jelenét és jövőjét meghatározó kérdésekről zajlik szakmai munka, amelyben a biztosítótársaságok szakértői és a MABISZ alkalmazottai közösen vesznek részt. 


\subsubsection{Az életbiztosítási piac szabályozása, etikus biztosítás}

Magyarországon 1,7 millió megtakarítási célú életbiztosítással számolhattunk 2017 végén. (MABISZ, Évkönyv 2018) Ezen biztosítások tényleges átlagos tartama alig haladta meg a 6,5 évet. Az ügyfelek gyakorta azért szüntették meg a szerződéseket idő elött, mivel a szerződések megkötése után értették meg pontosan, hogy milyen költségek terhelik az ilyen jellegü szerződéseket, illetve milyen megtakarítási eredményt várhatnak. Az esetek egy jelentős részében a biztosítást kötők sajnos nem voltak azzal sem tisztában, hogy a szerződések nem csupán megtakarítási, de jelentős kockázati fedezetet is tartalmaznak.

A Magyar Nemzeti Bank, amely 2013 óta látja el a biztosítási szektor felügyeletét, egy speciális ajánlással igyekszik sokkal átláthatóbbá tenni ezen biztosítások müködését. Az ajánlást a biztosítási piac a napi gyakorlatban „etikus ajánlás"-ként említi.

Ennek a szabályozásnak az egyik eleme, hogy egységesítik, és közérthetőbbé teszik a szerződések költségeinek elnevezését. Az ajánlással egyértelműen megtiltják a rejtett költségek felszámítását. A társaságok szabályzataikban és tájékoztatóikon a következő elnevezéseket kell, hogy használják 2017 januárját követően:

- szerződéskötési díj, amely alatt az értékesítési, vagy kezdeti költséget kell érteni és általában az ügyfél befizetéseiből az első 2-3 évben levont tényleges költségeket jelenti,

- vagyonkezelési díj, ami a teljes állományra vetített, a befektetési tevékenységhez szorosan köthető költséget jelenti,

- adminisztrációs díj, amely a biztosítási háttértevékenységek fedezetére szolgáló költségelemnek felel meg,

- díjbeszedési költség, amely a befizetések tényleges formájától (postai csekk, csoportos díjbeszedés, banki átutalás) függő költségek fedezetére szolgál.

Ezen kívül elkülönítésre kerül a kockázati díjrész és a megtakarítási díjrész is. Az etikus ajánlás eredményeként az életbiztosítók felülvizsgálták termékeiket, és számos terméket kivontak az értékesítésből 2017 januárjától.

\section{A Teljes Költség Mutató és annak szabályozása}

A biztosítási termékek szolgáltatási peremfeltételei, tényleges költségei a hétköznapi ember számára nem túl könnyen érthetők. Az évtizedek során, a szabá- 
lyozói környezet változásával együtt, a biztosítási szerződések feltételei is egyre hosszabbak lettek és szakkifejezésektől tarkítva kerülnek a leendő ügyfelek elé a szerződéskötés idején. Az elmúlt évtized válságai különösen előtérbe helyezték a pénzügyi kockázatok szabatos bemutatásának szükségességét. Az életbiztosításokat gyakran vásárolták annak tudatában, hogy egyszerű befektetési terméket kapnak az ügyfelek. Ezzel szöges ellentétben még a legegyszerübb életbiztosítás is tartalmaz kockázati díjrészt, amely az ügyfél tartam közbeni halála vagy súlyos sérülése esetén nyújtandó szolgáltatások fedezetéül szolgál. Ezen túlmenően pedig nem szabad elhanyagolni az üzletkötés tényleges költségeit sem. Az évek óta tartó alacsony hozamkörnyezet különösen fontossá teszi, hogy a költségek és a várható hozamok egymáshoz való viszonyulása ne csupán világos legyen az ügyfél számára, de ne is legyen lehetősége a biztosítótársaságoknak arra, hogy a kevéssé tájékozott ügyfelek számára, jelentős veszteséget is eredményezhető termékeket kínáljanak anélkül, hogy ez a nem kellően hozzáértők számára is világosan látható lenne. Ennek támogatására a Magyar Biztosítók Szövetsége önálló kezdeményezéseként került bevezetésre a Teljes Költség Mutató (TKM).

A TKM mutató egy olyan egyszerű tájékozódási eszköz, mely egyetlen szám segítségével fejezi ki az adott biztosítás költségeit. Egészen pontosan megmutatja, hogy adott paraméterek mentén megközelítőleg mekkora hozamveszteség éri az ügyfelet egy szigorúan csak elméletben létező, minden költségtől mentes terméken elérhető hozamhoz képest amiatt, hogy azt az adott befektetési egységhez kötött (unit linked) terméken érte el. Az ilyen jellegű elméleti veszteség azon biztosításszakmai specialitásokból adódik, hogy az életbiztosítások, bonyolultságuk miatt általában személyes értékesítéssel történnek, amelyért a biztosítók a közvetítőknek jutalékot fizetnek. Ezen túlmenően a termékekhez kapcsolódó összetett befektetési megoldásoknak gyakorta sokszorosan megjelenő költségei vannak. A TKM mutató segítségével - a típuspéldákon keresztül - az egyes társaságok unit-linked életbiztosítási termékeinek költségszintje összehasonlíthatóvá válik, így az ügyfelek - elméletben - tudatosabban választhatnak. Nem szabad azonban továbbra sem figyelmen kívül hagynunk azt a tényt, hogy az átlagos biztosítást vásárló ügyfél legtöbb esetben csak a biztosításközvetítőtől tájékozódik.

A fentiek ismeretében azonban hiba lenne túlzottan negatívan közelíteni ezen termékcsoporthoz. Az unit-linked termékek ugyanis egyszerü hozzáférést biztosítanak olyan befektetési alapokhoz is, amelyek az átlagember számára általában 
nem, vagy csak bonyolultan elérhetők. Addicionális előnyük lehet az is, hogy jól felkészült biztosítási tanácsadók kisérhetik végig a szerződés alakulását, akár a teljes tartam ideje alatt.

A Magyar Nemzeti Bank - túlmutatva az eredeti elképzelésen - kiterjesztette a Magyar Biztosítók Szövetsége által önszabályozó céllal bevezetett teljes költség mutatót az összes megtakarítási termékre. Bevezetésre került ezen kívül a tíz évnél hosszabb időtartamra szóló biztosításokra a tartamközi TKM-limit is, ez 2016-ban 6,25\% lehetett. Az élethosszig tartó (whole-life) szerződésekre pedig hivatalosan is a 15 éves TKM lesz a mérvadó, annak ellenére, hogy azon biztosítások tényleges tartama előre nem meghatározható. Az egyszeri díjas biztosítások szabályozására egy teljesen elkülönülő, 3,5\%-os TKM mutató lett az irányadó érték.

Az összetett szabályozás részeként az értékesítők jutalékának maximuma is további csökkentésre került. A 2015-től érvényes jutalékmaximum szabályozást követően a 14 havi szerzési jutalékmaximum 2018-tól 13 havira, 2019-től pedig már 12 havira csökken.

Gyakorta hallható kritika a pénzügyi ismeretek alacsony szintje, illetve az átlagember relatív tudatlanságával való visszaélés problematikája. A szerződést megkötők tájékoztatása is számos gyakorlati hiányosságot mutatott az elmúlt évek során. A biztosítók a friss szerződéssel rendelkező ügyfeleket, általában a saját call centerükön keresztül, felhívják és ellenőrzik, hogy mindent megértettek-e a szerződés feltételeiből. Ez az intézkedés is felügyeleti szinten elvárt és szabályozott folyamattá vált az ajánlásnak köszönhetően.

Emellett az ügyfél igénye szerint írásbeli, szóbeli és elektronikus úton is biztosítania kell a biztosítóknak, hogy az ügyfél áttekinthesse a szerződését még a kötés előtt, a nyilatkozatokat pedig beazonosíthatóvá kell tenniük. A biztosítótársaság képviselöjének kötelessége, hogy figyelmeztesse az ügyfelet arra, hogy olvassa el részletesen a szerződést.

Az elmúlt években felerősödött reklamációk kivédése érdekében az MNB ezen túlmenően azt is elvárja, hogy az eszközalapok összetétele az ügyfél egyedi megtakarítási ciklusához alkalmazkodjon. Tartva a hitelpiaci anomáliák ismétlődésétől, a nemkívánatos devizakockázatok csökkentése érdekében a biztosítótársaságoknak pedig rendelkezniük kell hazai kötvény- és részvényalapokkal a választható alapok között. 
Az MNB az átfogó szabályozástól azt várta, hogy a kifejezetten drága termékek egycsapásra eltűnjenek a piacról, a később kifejlesztésre kerülő termékek esetében pedig a társaságok sokkal hangsúlyosabban vegyék majd figyelembe az ügyfelek érdekeit.

A TKM limitrendszer bevezetése az egyedi szerződések profittartalmát várhatóan csökkenteni fogja, viszont hosszútávon a megnövekedett átlagos tartam remélhetően ezt pótolni tudja majd. Az MNB reményei szerint ugyanis átlagosan legalább 8-10 évig tartják majd meg az ügyfelek a szerződésüket, amely azonban még így is elmarad az átlagos szerződéskötéskori értékektől.

Tekintettel arra, hogy az EU csatlakozás óta folyamatosan igyekeznek a piaci szabályalkotók közelíteni a magyar szabályokat az uniós mintákhoz, ezért további változások várhatóak az elkövetkező évtizedben. A trendek alapján szigorúbb képzési szabályok kerülnek kialakításra, az üzletkötők engedélyezési minimumfeltételei pedig tovább közelednek majd a fejlett biztosítási kultúrával rendelkező országokéhoz.

\section{Nemzetközi szabályozók alkalmazása}

Solvency II.:

(Európai Parlament és Tanács 2009/138/EK irányelve (2009. november 25.))

A jogszabály célja, hogy a biztosítótársaságok fizetőképességük megőrzése, sőt javítása érdekében a fizetőképességi követelményeket a társaságok által vállalt kockázatokhoz igazítsák. A szabályozás három legfontosabb eleme a pénzügyi, kockázati és a közzétételi pillér.

A Szolvencia II. irányelv az eddigi szabály alapú tőkekövetelménnyel („Szolvencia I.") szemben komplex, kockázatalapú tőkekövetelményt, kockázatalapú felügyelési szabályrendszert vezet be európai szinten. Ennek megfelelően kockázatalapú szemlélet érvényesül a teljes követelményrendszerben. A kockázat-érzékeny szavatolótőke-szükséglet számítás mellett az üzleti tervezésbe, a pénzügyi helyzet értékelésébe is beépül a kockázatalapú szemlélet.

A biztosítótársaságok saját kockázat- és szolvenciaértékelés (Own Risk and Solvency Assessment, ORSA) keretében rendszeresen felmérik az általános szavatolótőke-szükséglet igényüket az elfogadott üzleti terveik alapján. Ezen riportokban külön szükséges kitérni az I. pillérrel le nem fedett (pl. likviditási), illetve a hosszú távú kockázatokra is. 
A kockázat alapú szemlélet megjelenik a minőségi követelmények vonatkozásában is. Ezek a szempontok teljesen új megközelítést jelentenek a biztosítók vezetö testületei számára. Új követelményként jelenik meg az információ nyújtását, a felügyeleti jelentés tartalmát illetően is. Külön érdekessége, hogy az EU egészére vonatkozóan egységes jelentési rendszer került bevezetésre. A jelentések gazdasági értékelési elven alapulnak, és föként a befektetésekről és a tartalékokról nyújtanak rendkívül részletes információt. A Szolvencia II. rendszerben a csoportszemlélet is előtérbe kerül, amely a magyar biztosítási szektor szempontjából különösen jelentős, hiszen szinte kivétel nélkül nemzetközi nagyvállalatok müködnek a piacunkon.

A Szolvencia II. irányelv hazai átültetése a biztosítási tevékenységről szóló 2014. évi LXXXVIII. törvénnyel történt. Ezzel párhuzamosan felértékelődött egy új szakma, a Risk Manager (kockázatkezelési vezető, illetve szakértő) funkciója is. MiFID:

(Markets in Financial Instruments Directive (2004/39/EC))

A szabályozott piacokra, a befektetési szolgáltatásokra és a többszintű kereskedési rendszerekre vonatkozó irányelv 2007 novembere óta hatályos. Az elmúlt években a pénzügyi piacokon tapasztalható nagyfokú változások indokolttá tették a MiFID rendszer felülvizsgálatát. Az uniós szervezet 2011 októberében véglegesítette új javaslatát, amely két részből állt: a MiFID irányelv módosításából (MiFID II irányelv) és egy rendelet kidolgozásából (MiFIR). Az irányelv és a rendelet végül 2014. június 12-én jelent meg az Európai Unió Hivatalos Lapjában.

A MiFID II a szabályozott piacok és a befektetési vállalkozások engedélyezési feltételeivel és müködési követelményeivel, valamint az illetékes hatóságok jogköreivel foglalkozik. A MiFIR a befektetési vállalkozások és a használt kereskedési helyszínek nyilvánosságra hozatali követelményét, az illetékes hatóságok részére küldendő transzparencia jelentések szabályait, a különlegesen kezelendő származtatott ügyletekre vonatkozó előírásokat, a pénzügyi eszközökre vonatkozó megkülönböztetés-mentes elszámolási követelményeket tartalmazza. A szabályozás magyar vonatkozásai döntően befolyásolják a biztosítási szektor, elsősorban az értékesítési szervezetek középtávú jövőképét. 
PRIIPs:

(Packaged Retail Investment and Insurance-Based Products)

A PRIIPs egy különösen tág kategóriája a pénzügyi termékeknek. Ezen csoportba tartozó befektetési jellegü termékeket széleskörüen értékesítettek az Európai Unió országaiban is. Az értékesítés elsősorban bankokon, de más pénzintézeteken keresztül történt és napjainkban is elérhetőek a potenciális ügyfelek számára. A szabályozás a definíció szerint lefedi a csomagolt, nyílt körben értékesített termékek azon körét, amelyek kitettek az alárendelt részvények és kötvények mindenkori tényleges teljesítményének. Ezen termékek elvárható teljesítménnyel bírnak és valamiféle beépített kockázatot is tartalmaznak. A kategória kifejezetten szabályozói céllal került megalkotásra az Európai Bizottság által. 2017. január 1-jét követően minden olyan intézménynek, közöttük a biztosítóknak is kötelességük a legfontosabb információkat tartalmazó dokumentumot készíteni ezen termékek mellé (KID: Key Information Document) az átláthatóság és könnyebb érthetőség érdekében.

KID:

(Key Information Documents for PRIIPs)

A szabályozás szerint a tájékoztató nem lehet hosszabb három oldalnál, és világos tájékoztatást kell tartalmazzon a termékről. Be kell mutatnia a termék és a terméket készítő pontos elnevezését, a termékben rejlő kockázatokat, a maximális várható veszteséget, hiteles várható teljesítmény scenáriókat, a termék költségeit és azon felügyeleti szervek elérhetőségeit, amelynél probléma esetén a termékkel kapcsolatban panasz tehető. Külön érdekesség, hogy a jobb érthetőség érdekében még egységes piktogramok használatát is elöírják a szabályalkotók.

IDD:

(Insurance Distribution Directive, Biztositásértékesítési Irányelv)

A jogszabályalkotók 2018. február 23-tól tették kötelezővé a biztosításközvetítésre vonatkozó iránymutatás alkalmazását hazánkban. A végrehajtás során számos jogszabály módosítása után a magyarországi biztosításközvetítésre vonatkozóan is egységes uniós szabályrendszer követése vált kötelezővé. Az irányelv különös figyelmet fordít a termékfejlesztési folyamatokra, és a termékek különböző tulajdonságainak egységes és transzparens megalkotására. Külön fejezet foglalkozik a közvetítők tanácsadási tevékenységének szabályaival. Kiemelt figyelmet fordítot- 
tak a jogszabályalkotók a javadalmazás módszertanára és az érdekellentétek kizárására, illetve a képzésre és minősítésre. Az irányelv sikeres bevezetését követően elvárható a szabatosabb és világosabb tájékoztatás, az ügyfelek érdekeinek hatékonyabb védelme, és a határokon átnyúló üzleti lehetőségek jobb kihasználása is.

Gender directive:

(Gender direktíva)

A 2012-től érvényes szabályozás tiltja a nemek közöti megkülönböztetést a biztosítási termékek árazásakor. A szabályozás hatálybalépése a kockázati típusú termékek újraárazását eredményezte, és ezzel eltünt a férfiak és nők várható élettartam különbségéből adódó árazási eltérés.

\subsection{Nem-életbiztosítások}

A biztosítási szektor nem-életbiztosítási ágának egyik legfontosabb jellemzője, hogy míg az életbiztosítási szerződés esetében egy káresemény (általánosságban a biztosított halála) következik be a teljes tartam során, addig a nem-életbiztosítási szerződések esetében több kár is bekövetkezhet az azonos szerződés megléte esetén. Ezek a káresemények ráadásul könnyen megfigyelhetők a hétköznapokban, valamennyien gyakorta részeseivé válhatunk. Ezzel is magyarázható, hogy a nem-életbiztosítások esetében az ügyfelek gyakorta saját maguk keresik a szerződés megkötésének lehetőségét szemben az életbiztosítási szerződésekkel.

A nem-életbiztosítások tipikus példája a vagyonbiztosítás. Az ilyen szerződés általában egy éves tartammal jön létre, de leggyakrabban évente megújul. A szerződés évfordulójának közeledtével általában felülvizsgálatra kerül a szerződésbe foglalt ingó vagy ingatlan vagyon értéke, majd pedig ehhez kerül igazításra az új időszakra vonatkozó biztosítási díj. (A korábban már említett baleset- és betegségbiztosítások a nem-életbiztosítások közé sorolandók tulajdonságaik alapján, annak ellenére, hogy tipikusan az életbiztosítások kiegészítő biztosításaiként kerülnek értékesítésre.)

A vagyonbiztosítások kalkulálásakor az adott évben befizetett díjak nyújtanak fedezetet az adott évben bekövetkezett károkra. Természetesen számos elöre meghatározott tartalék képződik ezen szerződések mögött is, mint például a nagy károk tartaléka. A vagyonbiztosítások káringadozása viszont magas, ezért ezen ágazat nyereségessége évről évre jelentősen változhat. 


\subsubsection{A nem-életbiztosítások története}

A kereskedelem a pénz megjelenésével gyorsan fölváltotta az egyszerű árucserét. $\mathrm{Az}$ áruszállítás azonban már a kezdetekben is számos veszéllyel járt. A szállítás során sérült vagy eladhatatlanná vált áru, vagy annak elvesztése jelentős kockázattal bírt. Az első biztosítások ennek megfelelően elsősorban a tengeri szállítás kockázatainak fedezésére szolgáltak és a szabályai még ma is felfedezhetők a modern biztosítások között.

Előre nem látható események sorozata nehezítette a kereskedők életét. A szállítmányt veszélyeztető viharok, támadások, rablások kárainak enyhítésére már két és fél évezreddel ezelőtt is megoldást találtak a korai biztosítások között. A szállítmánybiztosítás ma is komoly hányadát jelenti a nem-életbiztosításoknak.

A XIII-XIV. századtól már rendszeresen került sor olyan közös kockázatvállalásra, ahol utólagos kárenyhítési céllal, a kár bekövetkeztekor egy csoporton belül többen osztoztak meg a kár összegén. Ettől a gyakorlattól jelentősen eltér a kései középkor azon intézményrendszere, amelyet már a modern biztosítások elödjének tekinthetünk, hiszen előre meghatározott díj ellenében került sor a kártalanításra.

Ezek esetében például már nemcsak a rakományt, hanem a hajótestet is biztosították. Mérföldkőnek tekinthetjük, hogy Londonban 1668-ban megalakult a Lloyd's, az egyik leghíresebb angol társaság, amely még ma is őrzi a hagyományok jelentős részét. Országonként más és más károkra specializálódtak az ott alakuló szervezetek. Európában került fejlesztésre a jégkárbiztosítás. Svájcra jellemző az állattenyésztésre specializálódott mezőgazdasági szerződések fejlesztése. Franciaország a felelősség biztosítások szülőhazája, míg ugyanezt tartjuk Angliáról a balesetbiztosítások esetében.

Magyarországon az első vagyonbiztosításokat a Rév-Komáromi Hajózást Bátorságosító Társaság kötötte és szerződései a gabonakereskedelemhez kapcsolódtak. A jelenhez is kapcsolódik az 1843-ban alakult Jégverés Elleni Kölcsönös Biztosító Magyar Egyesület tevékenysége során szerzett tapasztalat. (MABISZ)

A motorizáció fejlődésével egyre speciálisabb területek jelentek meg, így ma már az egyik legelterjedtebb a kötelező gépjármủ felelősségbiztosítás, illetve a gépjárművekre köthető CASCO. Ma már célszerű megemlíteni, hogy ennek a 
szakmai részterületnek az egyik legnagyobb kihívója az önvezető autók megjelenésével együtt járó kockázatcsökkenés. Ez hosszú távon alapjaiban fogja befolyásolni az ágazat müködését.

Teljesen új területet jelent a biztosítás jövője szempontjából a cyber biztosítások fejlesztése, ahol az internetes kommunikációhoz, adatforgalomhoz kapcsolódó kockázatokra nyújtandó fedezetek jelentik a jövő kihívásait.

\subsubsection{A nem-életbiztosítási piac szereplői Magyarországon}

A piac az elmúlt 25 évben rendkívül sokat fejlődött. Ugyanakkor látnunk kell, hogy a 2008-at követő időszakban a háztartások jelentős része igyekezett kiadásait úgy is optimalizálni, hogy elhagyta egyes biztosításainak díjfizetését.

Általános trenddé vált, hogy a nem-életbiztosítások közül egyes elemeket újrakalkuláltattak, biztosítási összegeket csökkentettek a megtakarítás érdekében. Egyes termékek esetében pl. kötelező gépjármű felelősségbiztosításoknál a társaságok fokozott díjversenybe is kezdtek, amelynek eredménye a drasztikus díjcsökkenés lett. Ugyanilyen módon csökken az utóbbi pár évben a lakásbiztosítások piacán.

$\mathrm{Az}$ ágazatot ténylegesen művelő társaságok száma 24. Közöttük vannak egészen apró piaci részesedéssel bírók is, akiknek mérethatékonysága kétséges. Éppen ezért mondható ki, hogy ezen ágazatban is várható a társaságok koncentrációja. 


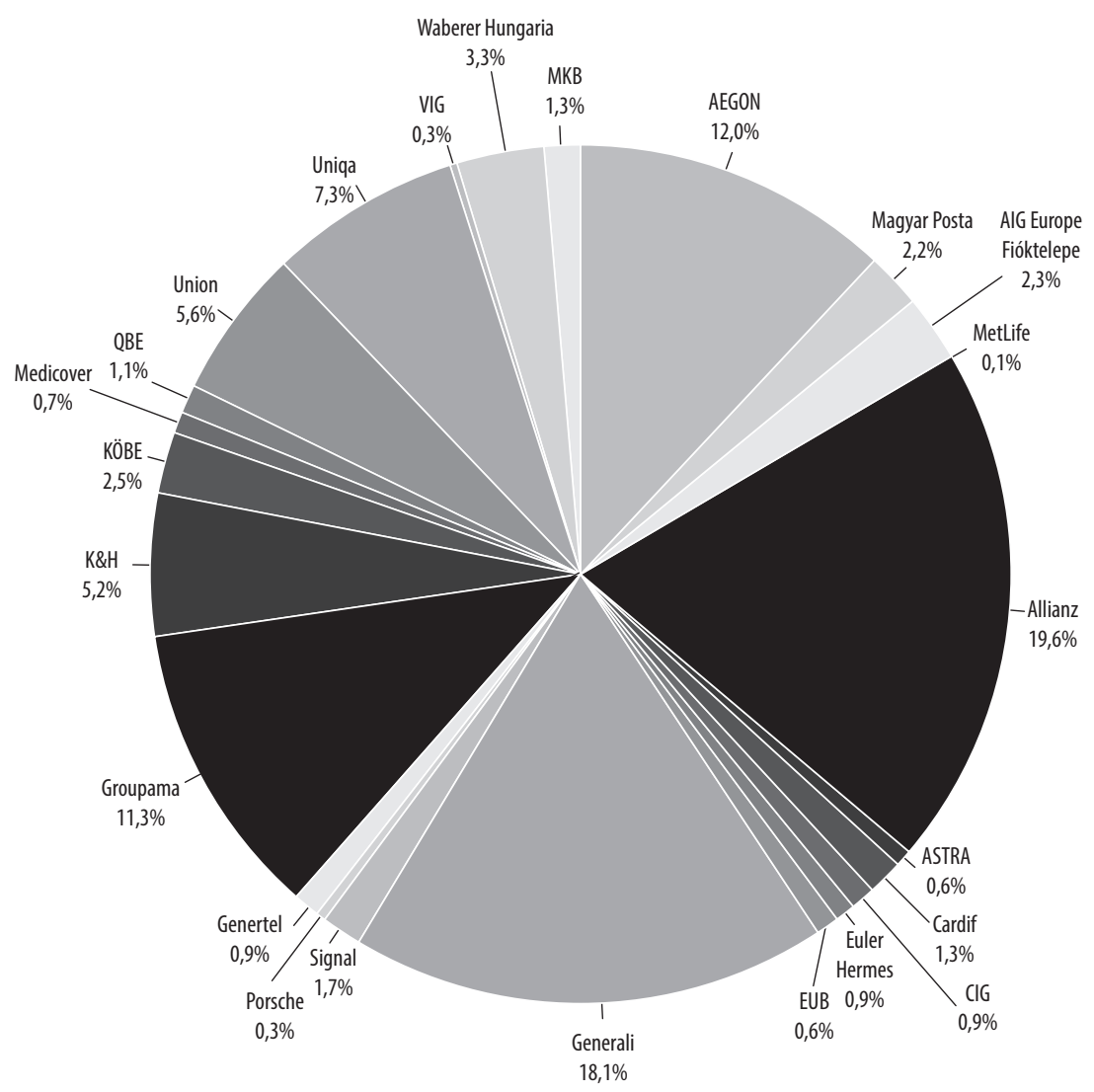

4. ábra: Nem-életbiztosítók részesedése 2017 végén

Forrás: MABISZ jelentés, Biztositási piac 2017. IV. negyedév

\subsubsection{A nem-életbiztosítások célja}

A nem-életbiztosítások esetében, amennyiben a szerződő rendben megfizeti a biztosítási díjat, addig a biztosító kártérítést nyújt egyes előre meghatározott események bekövetkeztekor keletkezett kár erejéig.

\subsubsection{A nem-életbiztosítási szerződés szereplői}

A nem-életbiztosítási szerződést olyan személy kötheti meg, aki érdekelt a vagyontárgy megvédésében. A tulajdonoson kívül érdekelt lehet mindenki, akinek a vagyontárgy sérülése, megrongálódása vagy eltünése ténylegesen hátrányosan érinthet. Ha a szerződő nem azonos a biztosítottal, úgy a biztosított a szerződés ideje alatt bármikor a szerződő helyébe léphet. A kedvezményezett a káresemény 
bekövetkeztekor a kártérítést kapja. Ez a szerződés záradékaitól függően lehet a tulajdonos vagy a hitelező is.

\subsubsection{A nem-életbiztosítások típusai}

\section{Balesetbiztositás:}

Balesetről akkor beszélünk, ha külső hatásra, a biztosított akaratától függetlenül, elöre nem látható módon hirtelen következik be testi sérülés. A balesetbiztosítás lehet egyéni vagy csoportos jellegü. A csoportos balesetbiztosítások esetében egy azonos körbe tartozó csoport kockázatait együttesen kezeli a szerződés. Jelenleg különösen hangsúlyos a munkahelyi balesetek fedezetére szolgáló és a munkáltatók által fizetett csoportos balesetbiztosítás. Ezen szerződések esetében általában halál és egészségkárosodás is egyaránt a fedezetek közé tartozik.

Betegségbiztositás (Egészségbiztositás):

A biztosítottak ezen szerződések esetében a társadalombiztosítás keretein kívüli szolgáltatásokra kötnek szerződést. A szerződés szabályzatában rögzített betegségek bekövetkeztekor a biztosító vagy egy előre meghatározott összeget fizet, vagy pedig megszervezi az adott káreseményhez kapcsolódó egészségügyi szolgáltatás lebonyolítását és annak költségeit részben, vagy egészben átvállalja. Különösen fontos az egészség megőrzése és a betegség megelözése érdekében a prevenciós szolgáltatással, szüréssel kiegészített egészségbiztosítási szerződés.

\section{Tüzkár biztositás:}

Az egyik legrégebbi biztosítási módozat, amely a nem rendeltetésszerü helyén keletkező, vagy az azt elhagyó és tovaterjedő tüz okozta károk megtérítésére szolgál.

\section{Viharkár biztositás:}

Olyan esemény alapján téríti a biztosító a káreseményt, amikor a szélerősség meghaladja a $15 \mathrm{~m} / \mathrm{s}$ szélsebességet és a szél közvetlenül kárt okoz.

\section{Vizkár biztositás:}

Ez a módozat az árvíz, belvíz, felhőszakadás, oltóvíz, csővezeték repedése vagy törése, illetve szökőár okozta károk megtérítését szolgálja. 
Földrengés biztositás:

Magyarországon a föld felszínén okozott jelenségek, elváltozások mértékét leíró MSK-64 vagy az EMS skála 6-os erejü rengését meghaladó érték esetén térítenek a biztosítók.

Földcsuszamlás vagy kőomlás biztositás:

A függőleges talajelmozdulás okán keletkezett károk fedezetére szolgál.

Mezőgazdasági biztosítások:

- Jégkár biztositás - a növényi kultúrákban a jégeső által okozott károk megtérítését szolgálja.

- Fagykár biztositás - a növénytermesztésbe vont területeken a téli, illetve tavaszi elfagyás okozta hozamveszteség elleni biztosítás.

- Állatbiztosítások - a haszonállatok elhullására szóló módozat.

Betöréses lopás- és rablásbiztositás:

Általában az épületekbe való jogellenes behatolás által okozott közvetlen károk, illetve a rongálás vagy vandalizmus károk fedezetére szolgálnak.

Üvegkár biztositás:

A beépített üvegezésekben keletkezett törések vagy repedések kárainak fedezetére szolgál.

Tüzüzemszünet-biztositás:

Termelő és szolgáltató vállalkozásokban a tűz okozta bevételkiesés megtérítését szolgálja.

Szállitmány biztositás:

A legősibb biztosítási módozatok közé tartozik. A vízi, légi és szárazföldi szállítmányozás, árumozgatás illetve szállítás során keletkezett károk fedezetét szolgálja.

Gépjármü biztositások:

A gépjárművekben keletkezett vagy általuk okozott káreseményekre vonatkozó szerződések. A két leggyakrabban használt módozat a CASCO, illetve a gépjármü-felelősségbiztosítás.

A CASCO biztositás a gépjármüben, mint vagyontárgyban keletkező károk fedezetét szolgálja. A díj megállapításakor fontos tényező a szerződő által választott önrész mértékének meghatározása, amely lehet százalékos vagy fix összegü 
is. A CASCO biztosításhoz számos kiegészítő módozat választható. Amennyiben banki hitelből fedezik a jármü vételárát, általános a CASCO kötése, a bank igénye alapján. Az elmúlt évek hitelezési hajlandóságának csökkenése rontotta a CASCO biztosítások állományának növekedési ütemét.

A gépjármü felelösségbiztositás nevéből következően a harmadik félnek okozott károk megtérítését szolgálja. Magyarországon ennek a szerződésnek a megkötése elengedhetetlen feltétele a jármű forgalomba helyezésének. Tulajdonosváltáskor pedig az új tulajdonos kötelessége az új szerződés megkötése. A MABISZ Elkülönített Szervezeti Egysége foglalkozik az ismeretlen károkozók vagy pedig a fedezetlen járművek által okozott károk megtérítésért. A megtérülés fedezetét egy olyan alap szolgálja, amelybe a módozatot művelő biztosítótársaságok piaci részesedésüknek megfelelően befizetnek. A teljes nem-életbiztosítási díjbevétel kb. egyharmada származik a kötelező gépjármű felelősségbiztosításokból.

Egyéb nem-életbiztositások

A technika, a gazdaság és a társadalom fejlődésével egyre több olyan vagyontárgy vonható biztosítási fedezetbe, amely korábban nehezen volt elképzelhető. Ma már természetes, hogy magánszemélyek is köthetnek biztosítást pl. hajóikra, repülőgépeikre.

A megfelelő szerződések kiválasztására a speciális esetekben általában biztosítási alkusz és specialista tanácsadását szokás igénybe venni. 


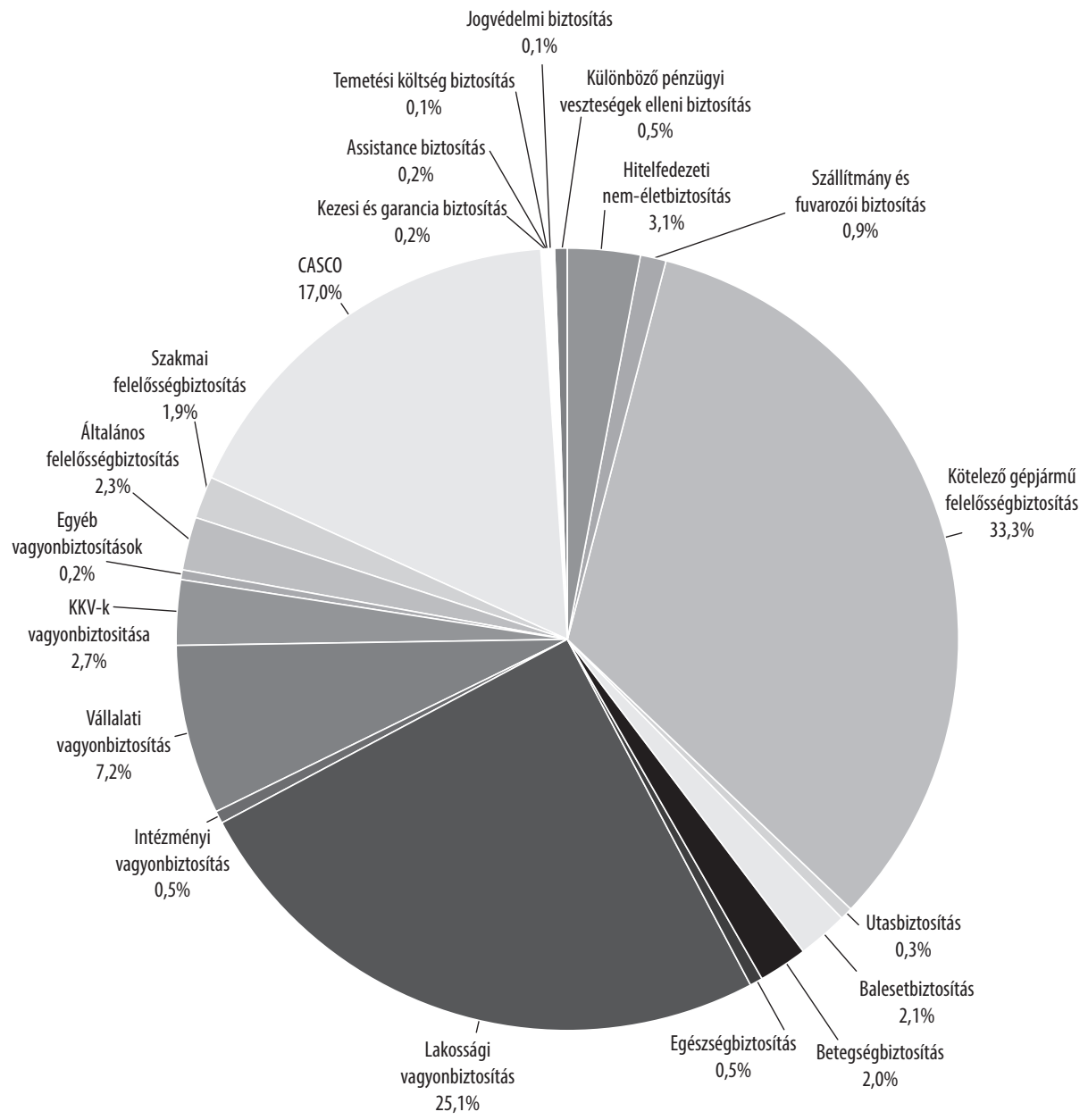

5. ábra: Nem-életbiztosítási ágazatok részesedése záró állománydíj alapján, 2017 végén

Forrás: MABISZ jelentés 2017. IV. negyedév

\subsubsection{Kiegészítő biztosítások}

A legtöbb társaság az úgynevezett alapbiztosítás mellé a nem-életbiztosítások esetében is kínál kiegészítő biztosításokat. A kiegészítő biztosítás egyik fontos jellemzője, hogy általában csak az alapbiztosítással együtt értelmezhető, az alapbiztosítás megszűnésével általában a kiegészítő biztosítás is megszünik. A kiegészítő biztosítások jellemzően életbiztosítások, de részkockázatokra vonatkozó nem-életbiztosítások is lehetnek. 


\subsubsection{A nem-életbiztosítások egyéb szempontú csoportosítása}

A vagyonbiztosítások kiterjedhetnek előre meghatározott veszélynemekre vagy ehelyett lehetnek bármely okú szerződések, amelyeket all risk biztosításnak nevez a szakma. Az all risk szerződések leggyakrabban a vállalkozások számára kínált termékek közé tartoznak, de már köthető lakásbiztosítás is all risk fedezettel.

Tartamuk alapján lehetnek határozott vagy határozatlan tartamú szerződések.

A kötvények tárgya alapján megkülönböztetünk vagyontárgyakra, vagyoni jellegü követelésekre, többlet kiadások fedezetére vagy elmaradt haszonra vonatkozó szerződéseket.

\subsubsection{A nem életbiztosítások specialitásai}

A nem-életbiztosítások esetében a káringadozás rendkívül magas. A természeti katasztrófák bekövetkezése bár kalkulálható, de mégis nehezen tervezhető. Magyarországon már a népi megfigyelések alapján is számíthatunk arra, hogy pl. minden év júniusának elején az ország egyes részein viharokra kell számítanunk. Annak intenzitása vagy tartama azonban rendkívül volatilis. Az ilyen időszakban bekövetkező viharkárok összege a néhány száz millió forinttól egészen a sok milliárdos határokig terjedhet. Ugyanígy nehéz előre tervezni pl. az árvízkárokat, amelyek ellen fel lehet készülni vagy bekövetkeztekor lehet védekezni, de semmiképpen sem lehet pontosan előre tervezni. A gépjármű biztosítások esetében például egy olyan téli időszak, amikor a köd vagy az ónos eső gyakran következik be, jelentősen emelheti a kárgyakoriságot.

A nem-életbiztosítási szerződés mivel általában egy éves tartamra jön létre, évente felmondható mindkét fél részéről. Ez lehetőséget ad mind a szerződő, mind pedig a biztosító számára, hogy újragondolja és igényei szerint változtassa a szerződés feltételeit, díját.

Az önrészesedés gyakran alkalmazott tulajdonsága az ilyen jellegü szerződéseknek. Az előre meghatározott százalékos vagy fix összegü önrész érdekeltté teszi a szerződőt, hogy aktívan vegyen részt a kármegelőzésben, illetve a kármentésben, és elkerülje a kis összegű vagy bagatell károk bejelentését.

A nem-életbiztosítások normális feltételek között olyan biztosítási összegre jönnek létre, amelyek megegyeznek a fedezetbe bevont vagyontárgy tényleges 
értékével. Ha a szerződés ettől nagyobb összegre jön létre, akkor az a túlbiztosítás. Amennyiben pedig a biztosítási összeg ettől alacsonyabb akkor pedig alulbiztosításról beszélünk.

Túlbiztosítás esetén a szerződés érvénytelen a valótlanul meghatározott értéktöbbletre. Ezzel együtt szükséges a biztosítási díj lecsökkentése is. Kivételt jelent az új értéken való biztosítás, vagy pedig a várható értékre szóló biztosítás. Alulbiztosításkor pedig csak a megfizetett díj mértékében van lehetőség a kártérítésre.

A szerződés megkötésekor a biztosító a kockázatok jelentős részét magára vállalja. A biztosított azonban köteles a kár mértékének enyhítésére minden olyan intézkedéssel, amelyre képességei alkalmassá teszik. Ezt nevezzük kárenyhítési kötelezettségnek. Amennyiben a biztosított a kármegelözési, illetve kárenyhítési kötelezettségének nem tesz eleget, úgy a biztosító arányosan mentesül a fizetési kötelezettsége alól.

A kár bekövetkeztét követően a károsodott vagyontárgyon csak annyiban változtathat a biztosított, amennyi a kárenyhítés miatt feltétlenül szükséges. A káresemény bekövetkezésének körülményeit és a károsodás mértékét is vizsgáló kárszakértők csak akkor tudnak érdemi munkát végezni, ha a biztosított betartja a változtatási tilalom elvét. Ellenkező esetben a biztosító mentesülhet a kártérítés alól.

A biztosító általában is mentesülhet a kártérítés alól akkor, ha a kárt jogellenesen, szándékosan vagy súlyosan gondatlanul okozzák. Különös tekintettel arra az esetre, ha a kárt a biztosított, a szerződő, vagy velük közös háztartásban élő hozzátartozójuk okozta. Jogi személy esetén pedig annak vezetője vagy a vagyontárgy kezelésével megbízott személy közrehatása lehet a mentesülés kiváltója.

\subsection{Viszontbiztosítás}

A biztosítások között meg kell különböztetnünk az elsődleges vagy direkt biztosítást, illetve a viszontbiztosítást. A direkt biztosítások esetében a biztosítóval természetes vagy jogi személy az érdekkörébe tartozó kockázatok fedezetére közvetlenül köt szerződést. A viszontbiztosítások esetében a biztosító egy másik biztosítóval köt szerződést az általa összegyüjtött direkt biztosítások kockázatai- 
nak porlasztása céljából. A biztosító díjat fizet a viszontbiztosítónak, amely ezért cserébe a különböző altípusokon keresztül a kockázatának egy részét magára vállalja.

A quota share típusú szerződés olyan megállapodás, melyben az érintett biztosító minden szerződés esetében a díj és a kockázat azonos arányát adja át a viszontbiztosítónak

A surplus típusú szerződés során meghatározott értékhatár feletti kárösszegek kerülnek átadásra.

Az excess of loss típusú szerződés esetén a viszontbiztosító csupán a meghatározott önrész feletti károkat téríti meg a direktbiztosítónak.

A stop loss típusú szerződés esetén pedig a biztosító összes kárára fedezetet nyújt a viszontbiztosító. Ebben az esetben a fedezet mértékét felső korláthoz köti.

\subsection{A biztosítási szektor kihívásai}

Vállalkozások sora jelent meg az elmúlt években a piacon olyan technológiai fejlesztésekkel, amelyek folyamatosan kihívást jelentenek a hagyományosan müködő biztosítótársaságok számára. Az úgynevezett okos eszközök általános használata a hétköznapi ember számára is lehetőséget ad arra, hogy önmaga tájékozódjon az elérhető termékek és fedezetek széles palettáján, de akár a kárrendezési folyamatba is képes aktívan belépni.

A legelső vállalkozások egyszerű díjat és szolgáltatást összehasonlító megoldásokat kínáltak. Ezekből fejlődtek ki a modern internetes platformokon dolgozó alkuszok. Ezen cégek a KGFB és lakásbiztosítási piacon éles díjversenyt generáltak a biztosítók között. Ezzel egyidőben természetesen a transzparencia megjelenésével jutalék és szolgáltatási verseny is kezdődött a platformokat müködtetők között.

A biztosítók közösen kezdtek el azon munkálkodni, hogy a kommunikációs egyensúlyt képesek legyenek fenntartani. A magyar és nemzetközi szövetségek, a multinacionális nagyvállalatok egyaránt aktívan dolgoznak azon, hogy a meglévő szerződők és reménybeli új felhasználók hiteles tájékoztatás alapján, széleskörü ismeretekre alapozva hozzanak biztosítási és kockázatkezelési döntéseket. 
A legújabb insurtech és fintech vállalkozások vagy egy-egy nagy társaság részeként, vagy teljesen önállóan, de az igényfelméréstől kezdődően a kárrendezésig teljes egészében képesek lefedni a biztosítási értéklánc minden elemét.

A jövő szerződői kényelmesen, megszokott környezetükben maradva fogják intézni biztosítási ügyeiket. Csak azon társaságok lesznek képesek az új generációkat kiszolgálni, amelyek erre tudatosan készülnek és anyagi és szervezeti áldozatokat is képesek ezért hozni.

\subsection{Irodalomjegyzék}

Banyár József (2001): Életpálya pénzügyi tervezése. BOI.

Banyár József (2003): Életbiztosítás. BOI.

MABISZ (2018): Biztosítási piac 2017. IV. negyedév. Magyar Biztosítók

Szövetsége, www.mabisz.hu

MABISZ Aranykönyv.

MABISZ (2018): Biztositasiszemle.hu online biztosításszakmai újság. Magyar

Biztosítók Szövetsége.

MNB (2018): Biztosítási, pénztári és tőkepiaci kockázati jelentés 2018. Magyar

Nemzeti Bank.

www.mabisz.hu

www.mnb.hu

www.generali.hu

www.aegon.hu

www.allianz.hu

www.nn.hu 



\section{IV. rész}

\section{Pénztári szektor}




\section{5. Önkéntes kölcsönös biztosító pénztárak}

A foglalkoztatási szerkezet folyamatos változásával mindinkább előtérbe kerülnek az öngondoskodás különböző formái. Az állami nyugdíjrendszer évröl évre egyre nagyobb hiányt termel, hiszen egyre kevesebb járulék befizetéséből kell egyre több embernek ellátást biztosítania.

A Központi Statisztikai Hivatal (KSH) adatközlése szerint 2018-ban az idős népesség eltartottsági rátája $28,5 \%$ volt $(\mathrm{KSH}, 2019)$. Azaz napjainkban 3,5 aktív korúra (15-64 éves) jut egy 65 év feletti. Az eddigi tendenciákat alapul véve 2050-re ez a szám könnyedén 2 alá csökkenhet. A jelenlegi középkorú és fiatal generációk számára az állami nyugdíjrendszer nem tudja majd biztosítani az aktív korban megszokott életszínvonalat. Így a nyugdíjas évek biztonságának megteremtése érdekében az öngondoskodási célú megtakarításokra egyre nagyobb szükség lesz.

Az önkéntes kölcsönös biztosító pénztárak a társadalombiztosítási ellátásokat egészítik ki az öngondoskodás elvén alapuló, egyéni megtakarításokból finanszírozott szolgáltatások segítségével. A jelenlegi tendenciákat alapul véve az állami ellátórendszer egyre kevésbé képes a megnövekedett igényekhez alkalmazkodni, így a kiegészítő ellátások egyre nagyobb jelentőséggel bírnak.

Először 1993 őszén fogadta el a parlament az azóta már többször módosított 1993. évi XCVI. törvényt az Önkéntes Kölcsönös Biztosító Pénztárakról (a továbbiakban: Öpt.). Az Öpt. meghatározása szerint az „önkéntes kölcsönös biztosító pénztár: természetes személyek által a függetlenség, kölcsönösség, a szolidaritás és az önkéntesség elve alapján létrehozott, társadalombiztosítási ellátásokat kiegészítő, pótló, illetve ezeket helyettesítő szolgáltatásokat, továbbá az egészség védelmét elősegítő ellátásokat szervező és finanszírozó társulás. A pénztár szolgáltatásait rendszeres tagdíjbefizetésekből, egyéni számlavezetés alapján szervezi, finanszírozza, illetve nyújtja."

Az Öpt. tevékenységüknek megfelelően eredendően háromféle önkéntes kölcsönös biztosító pénztár alapítására nyújtott lehetöséget: önkéntes nyugdíjpénztár, önsegélyező pénztár és egészségpénztár. Azonban 2016. január 1-jétől már lehetőség van egy új pénztártípus, az egészség- és önsegélyező pénztár létrehozására is, amely önsegélyező, valamint egészségpénztári feladatokat egyaránt elláthat. 


\section{1. Önkéntes pénztárak fejlődése Magyarországon}

Az önkéntes pénztárak az első időkben egymás után alakultak. 1995-ben már közel 200 pénztár müködött. Később ez a tendencia lelassult, majd megfordult, $s$ azt követően a folyamatokat már döntően a felszámolások, az egybeolvadás és a koncentráció jellemezte. 2003-ban már csak 159 pénztár működött, míg 2009re a számuk 101-re redukálódott. Napjainkban mindössze 62 önkéntes pénztár működik.

A taglétszám növekedését kezdetben nem jellemezte gyors felfutás. Az 1996os törvénymódosítás hatására azonban jóval kedvezőbbé váltak az önkéntes pénztárak alapításának és müködésének szabályai, valamint tagdíjtámogatások által ösztönözték a munkavállalókat a pénztárakba való belépésre. 1995 végén 250 ezer tagot számláltak az önkéntes pénztárak, és csak 5 évre volt szükség ahhoz, hogy a taglétszám elérje az 1 millió fót. A 2010-es évek elején már több mint 2 millió fő rendelkezett önkéntes biztosító pénztári tagsággal. Az utóbbi éveket a taglétszám stagnálása jellemezte. Önkéntes nyugdíjpénztári tagsággal 2018-ban több, mint 1,1 millió fö rendelkezett, míg önsegélyező, egészség-, vagy egészségés önsegélyező pénztárnak több mint 1 millió ember volt tagja.

A pénztárak vagyona is csak lassan gyarapodott, de a 2000-es évet követően ugrásszerűen megnövekedett. A vagyon piaci értéke 2001-ben érte el a 300 milliárd forintot és 2009-ben már meghaladta a 800 milliárd forintot. 2017-ben az önkéntes kölcsön biztosító pénztárak összvagyona már meghaladta az 1300 milliárd forintot.

Az önkéntes pénztárak legfontosabb adatait az 1. táblázat foglalja össze.

\begin{tabular}{|c|c|c|c|}
\hline \multirow{2}{*}{ Pénztárak típusai } & $\begin{array}{c}\text { Pénztárak } \\
\text { Száma (db) }\end{array}$ & $\begin{array}{c}\text { Taglétszám } \\
\text { (fö) }\end{array}$ & $\begin{array}{c}\text { Vagyon } \\
\text { (milliárd Ft) }\end{array}$ \\
\cline { 2 - 4 } & $\mathbf{2 0 1 8 . ~ I I . ~ n e ́ . ~}$ & $\mathbf{2 0 1 8 . ~ I I . ~ n e ́ . ~}$ & 2017. IV. né. \\
\hline Önkéntes nyugdíjpénztárak & 38 & 1139363 & 1270,226 \\
\hline $\begin{array}{c}\text { Egészség- és önsegélyezó pénztári } \\
\text { intézménycsoport }\end{array}$ & 24 & 1046507 & 61,786 \\
\hline Összesen & $\mathbf{6 2}$ & $\mathbf{2 1 8 5 8 7 0}$ & $\mathbf{1 3 3 2 , 0 1 2}$ \\
\hline
\end{tabular}

1. táblázat: Az önkéntes pénztárak föbb adatai Forrás: MNB (2019) alapján saját szerkesztés 


\subsection{Az önkéntes pénztárak müködési alapelvei}

Az Öpt. közös elöírásokat tartalmaz a pénztárak szervezetére és müködésére vonatkozóan, és külön fejezetben részletezi az egyes típusokra vonatkozó szabályokat. Az Öpt. 3. §-a az alábbi müködési alapelveket írja elő az önkéntes kölcsönös biztosító pénztárak számára:

- Önkormányzati müködés: kizárólag a pénztártagok jogosultak a pénztárra vonatkozó döntések meghozatalára, és a döntéshozatal során azonos jogokkal rendelkeznek.

- Zárt gazdálkodás elve:

a) a pénztár gazdálkodása csak a szolgáltatások szervezésére és teljesítésére irányulhat;

b) a pénztár alapokat képez és a tagok részére egyéni számlát vezet;

c) a szolgáltatásokra kizárólag a pénztártagok és azok jogán közeli hozzátartozóik jogosultak;

d) a pénztár a pénztárvagyon erejéig vállalhat más jogi, illetve természetes személyekkel szemben kötelezettséget;

e) a pénztár tartozásaiért saját vagyonával felel;

f) tagsági viszony megszűnése, illetve felszámolás esetén a pénztártag az egyéni számláján levő összeget követelheti;

g) a pénztár szolgáltatásait tagdíjfizetésből és egyéb bevételekből a közgyülés által elfogadott pénzügyi terv alapján finanszírozza.

- Kölcsönösség: a tagok közösen teremtik elő a szolgáltatások fedezetét, azonos jogok illetik meg őket, a pénztártag egyben a pénztár tulajdonosa is.

- Önkéntesség: a tagok szabad akaratból hozhatnak létre pénztárakat, az alapszabály szerint csatlakozhatnak, illetve léphetnek ki azokból.

- Függetlenség: a pénztárak a jogszabályi keretek között szabadon dönthetnek szolgáltatásaikról, üzletpolitikájukról.

- Szolidaritás: a tagdíj független a tagok egyéni kockázatától, a tagsági feltételeknek eleget tevő személy felvételi kérelme nem utasítható el.

- Társulási elv: nem alkalmazható vallási, faji, etnikai, politikai meggyőződés, kor és nem szerinti megkülönböztetés.

- Non-profit működés: az pénztár gazdálkodásának eredményét sem osztalék, sem részesedés formájában nem fizetheti ki, csak az alaptevékenység érdekében használhatja fel. 


\subsection{Az önkéntes pénztárak alapítása}

Önkéntes pénztárat kizárólag természetes személyek alapíthatnak és az alapításhoz legalább 15 tag szükséges. Az alakuló közgyülés határozza meg a pénztárak alapítását, továbbá az ő hatáskörükbe tartozik:

- az alapszabály és az induló gazdálkodási terv elfogadása,

- a tisztségviselők és könyvvizsgáló megválasztása,

- a tisztségviselők díjazásának megállapítása,

- valamint döntenek az alapítással kapcsolatos, az alakuló közgyülés időpontjáig felmerült költségek viseléséről.

Az alapszabályt, és annak módosítását közokiratba, vagy ügyvéd, vagy kamarai jogtanácsos által ellenjegyzett okiratba kell foglalni. A pénztár jogi személy, amelyet a székhelye szerint illetékes törvényszék (a továbbiakban: bíróság) veszi nyilvántartásba. A nyilvántartásba vételi kérelmet az alakuló gyülést követően 30 napon belül kell benyújtani a bírósághoz. A bíróság dönt a nyilvántartásba vételről és a kérelmezővel egyidejűleg az illetékes ügyészséget és a Magyar Nemzeti Bankot (MNB) is értesíti.

A pénztár a bírósági nyilvántartásba vétellel jön létre, az alakuló közgyülés időpontjára visszaható hatállyal. A nyilvántartásba vételig a pénztár nevében eljáró személyek egyetemlegesen felelnek a pénztár nevében vállalt kötelezettségekért. Ez a felelősség megszűnik, ha a közgyülés a kötelezettségvállalásokat utólag jóváhagyja.

A pénztárak törvényességi felügyeletét a rá irányuló jogszabályok szerint az ügyészség, pénzügyi felügyeletét a Magyar Nemzeti Bank látja el. A pénztár tevékenységét az MNB végleges tevékenységi engedélye birtokában kezdheti meg. A pénztár müködési alapja terhére felügyeleti díjat fizet, amely két részből tevődik össze:

- Alapdíj: az alapdíjegység és a pénztárakra vonatkozó szorzószám szorzataként határozható meg. Az alapdíjegység 50000 forint, a pénztárakhoz tartozó szorzószám pedig 2 . Azonban azon pénztárak esetén, melyek fedezeti alapja a tárgyévet megelőző év végén nem haladja meg az 50 millió forintot, a szorzószám 0,5 .

- Változó díj: a pénztár által fizetendő változó díj éves mértéke a pénztári vagyon piaci értékének 0,25 ezreléke. 


\subsection{A tagsági viszony}

Az Öpt. alapján a pénztár tagja az lehet, aki

- a 16. életévét betöltötte,

- az alapszabály rendelkezéseit magára nézve kötelezőnek ismeri el,

- a tagdíffizetést vállalja.

A belépés a pénztárhoz benyújtott belépési nyilatkozattal történik. A tagsági jogviszony, a tagdíffizetési kötelezettség, valamint a várakozási idő a belépési nyilatkozat pénztár általi záradékolásával kezdődik. A pénztár a belépési nyilatkozatot a benyújtástól számított 30 napon belül záradékolja, majd annak egy példányát vagy a tagsági okiratot az alapszabállyal együtt a tagnak átadja. Az alapszabály rendelkezhet úgy is, hogy a pénztártagsági jogviszony az első havi tagdíj befizetésével jön létre. Ekkor az első havi tagdíj elmulasztása esetén a belépni kívánót értesíteni kell a mulasztás jogkövetkezményeiről. A befizetés pótlására előírt határidő eredménytelen elteltét követően a személy adatait a nyilvántartásból kivezethetik.

A tagszervező az a természetes személy vagy jogi személy, aki a pénztárral kötött szerződés alapján a pénztár részére tagszervezést végezhet. A tagszervezésre vonatkozó szerződésnek tartalmaznia kell a díjazás mértékét, a díjazás nyújtásának és visszaírásának feltételeit, valamint a felelősség viselésének kérdéseit. A pénztár köteles kidolgozni és szabályzatban rögzíteni a tagszervezők oktatásának és ellenőrzésének rendszerét.

Munkáltatói tag az a természetes vagy jogi személy, aki a pénztárral kötött szerződés alapján munkavállalójának tagdíjfizetési kötelezettségét egészben vagy részben átvállalja (munkáltatói hozzájárulás). A munkáltatói tag a hozzájárulásból egyetlen olyan munkavállalóját sem zárhatja ki, aki nála legalább hat hónapja munkaviszonyban áll (a közszolgálati, a közalkalmazotti és a szolgálati jogviszony is). A munkáltató munkavállalóként mindhárom típusú pénztárban egyidejüleg is vállalhat hozzájárulási kötelezettséget. A hozzájárulás mértéke minden munkavállalóra nézve azonos összegü vagy a munkabér azonos százaléka. Utóbbi esetben a munkáltató meghatározhatja a hozzájárulás legkisebb és legnagyobb összegét is. A munkáltatói tag jogosult tanácskozási joggal a közgyűlésen részt venni. Ha egy munkáltatói tag munkáltatói hozzájárulása egy naptári évben eléri vagy meghaladja a pénztár tagdíjbevételének 50 százalékát, a munkáltató jogosult egy tagot legfeljebb 5 évre az ellenőrző bizottságba kijelölni. 
A pénztártag az általa vállalt tagdíj összegét a pénztárnak bejelenti, és fizetési kötelezettségének határidőre eleget tesz. A tagdíj összege az egységes tagdíjnál kevesebb nem lehet. A befizetett tagdíjak szolgáltatásokra fordítandó részét, valamint a tagok javára jóváirt egyéb összegeket egyénileg, az egyéni számlán kell nyilvántartani a pénztárakra vonatkozó számviteli és gazdálkodási szabályok szerint. A pénztártag számláján elhelyezett összegekre sem a pénztártag hitelezői, sem kívülálló harmadik személy hitelezői nem tarthatnak igényt, kivéve a pénztártag rendelkezése szerint az egyéni számlán lekötött összeget, amelyet hitelintézettel kötött szerződésében fedezetként felajánl (tagi lekötés).

A gazdálkodásról és a pénzügyi helyzetéről a pénztártagokat, a munkáltatói tagokat és a támogatókat évente egyszer tájékoztatni kell. A pénztártagok tájékoztatásának tartalmaznia kell az egyéni számla alakulását is.

A pénztártag tagsági viszonya megszűnik:

- a tag halálával;

- a tag kilépésével;

- ha a tag a tagdíjat az alapszabályban megjelölt időtartamon túl nem fizeti, és az alapszabály szerint a tagdíjhátralék utólagos rendezésére nincs lehetőség, vagy a tag e lehetőséget elmulasztja;

- más pénztárba történő átlépéssel;

- kizárással.

A tag halála esetén az egyéni számla hagyatékának nem része. A tag a halála esetére az alapszabályban foglaltak szerint természetes személy kedvezményezett(ek)et jelölhet meg a belépési nyilatkozaton, közokiratban vagy teljes bizonyító erejü magánokiratban (haláleseti kedvezményezett). Ha a tagnak a törvényes öröklés rendje szerint természetes személy örököse nincs, akkor az egyéni számlán lévő összeg a pénztárra száll. A kedvezményezett a tag halálának időpontjában az egyéni számla tulajdonosává válik, és jogosultságának igazolását követően írásban nyilatkozik, hogy a rá eső részt:

- egy összegben felveszi,

- az alapszabály rendelkezésének megfelelően saját nevén a pénztárban hagyja tagdíjfizetés folytatásával vagy anélkül,

- más, azonos típusú pénztárba átutaltatja. 


\subsection{Az alapszabályra vonatkozó elöírások}

Az alapszabály az önkéntes kölcsönös biztosító pénztárak legfontosabb alapdokumentuma. Az alapszabály legfőbb elemei az Öpt. alapján:

- a pénztár elnevezése;

- a pénztár székhelye és telephelyei;

- a pénztár által nyújtott szolgáltatások köre és az igénybevétel feltételei, a szolgáltatásokra elöírt várakozási idő;

- a tagsági kör meghatározása és a taggá válás feltételei;

- a tag jogai a pénztár szerveiben;

- a pénztártagok, a szolgáltatásra jogosult közeli hozzátartozóik, a kedvezményezettek, illetve örökösök jogai és kötelezettségei;

- a tagsági viszony megszünésének feltételei, jogkövetkezményei és a követendő eljárás;

- a pénztári bevételek (tartalékok) közötti megosztás arányai és elvei, az egységes tagdíj mértéke és a díjfizetésre vonatkozó szabályok;

- a tagdíjfizetés elmulasztásának joghatásai és az eljárás rendje;

- a tagdíjhátralék kiegyenlítésére rendelkezésre álló határidő és a tagsági jogviszony díjnemfizetés miatti megszünésének joghatásai, valamint a követendő eljárás;

- a pénztárvagyon kezelésének és befektetésének szabályai;

- a pénztári gazdálkodás eredménye felhasználásának alapelvei;

- a pénztár megszűnése esetén a vagyon felosztásának elvei;

- a pénztár szervezete és szerveinek működése;

- a pénztár képviseletének módja, a hatáskörök átruházásának módja;

- a közgyülés összehívásának módja, a közgyülés müködése;

- a minősített többséggel eldöntendő kérdések köre;

- a közgyülési határozatok közzétételének módja;

- elektronikus irat igénylésére vonatkozó elvek;

- mindaz, amit a törvény vagy a jogszabály a pénztár alapszabályába utal, vagy amit a közgyülés szükségesnek tart.

A módosított alapszabályt - a módosítások megjelölésével - a közgyűlés időpontját követő 30 napon belül meg kell küldeni a bíróságnak és a Magyar Nemzeti Banknak. 


\subsection{Az önkéntes pénztárak szervezete}

A pénztártag választhat és - ha az Öpt. vagy az alapszabály eltérően nem rendelkezik - választható a pénztár szerveibe.

Az önkéntes pénztárak szervei:

- a közgyülés, az alapszabályban meghatározott esetben küldöttközgyülés, részközgyűlés,

- az igazgatótanács,

- az ellenőrző bizottság,

- szakértői bizottságok, amelyek létesítését az alapszabály előírhatja.

Az igazgatótanács és az ellenőrző bizottság (együtt: vezető tisztségviselők) létszáma minden esetben páratlan számú. Általában 3-7 főből állnak, de a taglétszámra tekintettel az alapszabály ennél nagyobb létszámot is meghatározhat. Tagjaikat a közgyülés titkos szavazással választja meg legfeljebb 5 évre. A megbízás az érintett személy által való elfogadással jön létre. Az igazgatótanács és az ellenőrző bizottság elnöke a megválasztott igazgatótanácsi, illetve ellenőrző bizottsági tagok közül titkos szavazás útján kerül megválasztásra. Az igazgatótanács és az ellenőrző bizottság elnökének csak olyan személy választható meg, aki felsőfokú végzettséggel rendelkezik.

Az igazgatótanács a folyamatos feladatok ellátására ügyvezetőt alkalmazhat. Az ügyvezetőt - a személyét érintő kérdések kivételével - az igazgatótanács üléseire meg kell hívni, azon tanácskozási joggal vehet részt.

A vezető tisztségviselök, valamint az ügyvezető mindenkor az ilyen tisztséget betöltő személytől elvárható gondossággal, a tagok és a pénztár érdekeinek figyelembevételével, a jogszabályok szerint kötelesek eljárni.

Vezető tisztségviselő 18. életévét betöltött, büntetlen előéletű pénztártag lehet. Ha az alapszabály erre módot ad, díjazásban részesülhet a közgyűlés határozatának megfelelően. Az ellenőrző bizottságnak nem lehet tagja a pénztár ügyvezetője, alkalmazottja, illetve az igazgatótanács tagja, valamint e személyek közeli hozzátartozója. További összeférhetetlenségi szabályokat az alapszabályban kell meghatározni.

A vezető tisztségviselőket az adott testület döntéseiért egyetemleges felelösség terheli. De nem terheli felelősség azt a személyt, aki a határozat vagy intézkedés 
ellen tiltakozott, és tiltakozását a döntés meghozatalától vagy tudomására jutásától számított 8 napon belül írásban bejelentette.

\subsubsection{A közgyülés feladata és hatásköre}

A pénztár legföbb szerve a tagok összességéből álló közgyülés. Az alapszabály a nagy létszámra tekintettel előírhatja a tagok által közvetlenül vagy közvetett úton választott testület, a küldöttközgyülés müködését is. Az alapszabály a hatásköri és eljárási szabályok rögzítése mellett részközgyülések tartásáról is rendelkezhet.

A közgyülést évente össze kell hívni az éves beszámoló, illetve a pénzügyi terv elfogadására. Akkor is össze kell hívni, ha azt a bíróság elrendeli, a Felügyelet, vagy az ellenőrző bizottság, illetve a pénztártagok legalább tíz százaléka írásban indítványozza, illetve, ha az igazgatótanács szükségesnek látja. Az alapszabály más esetekben is elöírhatja közgyülés összehívását.

A közgyűlés összehívása az igazgatótanács feladata. A közgyülés, küldöttközgyülés összehívásának módjáról az alapszabályban kell rendelkezni. A hirdetmény közzétételének vagy a meghívó elküldésének a közgyưlés időpontja előtt legalább 15 nappal meg kell történnie. Az értesítésben meg kell jelölni a közgyülés helyét, idejét, napirendjét, valamint a napirendhez tartozó iratok hozzáférhetőségét. A közgyülésre az MNB képviselőjét is meg kell hívni, aki azon tanácskozási joggal vesz részt.

A közgyülés akkor határozatképes, ha azon a pénztártagok legalább fele jelen van, vagy képviselete biztosított. A tagot meghatalmazott is képviselheti. A közgyülésen mindegyik pénztártagnak egy szavazata van. Küldöttközgyülés működtetése esetén minden küldött annyi szavazattal rendelkezik, ahány tagot képvisel. Küldöttközgyülésen a pénztár tagja csak tanácskozási joggal vehet részt. Amennyiben a közgyülés határozatképtelen, úgy az összehívott új közgyülés az eredeti napirendi pontok tekintetében a megjelentek számától függetlenül határozatképesnek tekintendő. Amennyiben az eredeti hirdetmény ezt tartalmazza, akkor az eredeti és a megismételt közgyülés egy napon is megtartható.

A közgyülés a határozatait - ha a törvény vagy az alapszabály eltérően nem rendelkezik - a jelenlévő tagok egyszerủ szavazattöbbségével hozza. 
A közgyülés kizárólagos hatáskörébe tartozik:

- az alapszabály elfogadása és módosítása;

- az igazgatótanács tagjainak és elnökének megválasztása, visszahívása, díjazásuk megállapítása;

- az ellenőrző bizottság tagjainak és elnökének megválasztása, visszahívása, díjazásuk megállapítása;

- az igazgatótanács éves beszámolójának elfogadása, a mérleg megállapítása, döntés az eredmény felhasználásáról vagy az egyes alapokban mutatkozó hiány rendezéséről;

- a pénztár pénzügyi tervének elfogadása;

- a munkáltatói taggal (tagokkal) kötött szerződés jóváhagyása;

- a tevékenységi engedély véglegessé válása előtt kötött szerződések jóváhagyása;

- a tevékenységi engedély véglegessé válása előtt a pénztár nevében eljáró személyek, az igazgatótanács és az ellenőrző bizottság tagjai elleni kártérítési igény érvényesítése;

- intézkedés a pénztár képviseletére jogosultak ellen indított perekben a pénztár képviseletéről;

- döntés érdekképviseleti szervhez történő csatlakozásról, illetve az abból történő kiválásról;

- döntés a pénztár megszűnéséről, szétválásáról vagy más pénztárral történő egyesüléséről;

- a könyvvizsgáló társaság és a könyvvizsgáló természetes személy megválasztása és felmentése;

- döntés mindazon ügyekben, amelyeket az Öpt. vagy jogszabály hatáskörébe utal.

A közgyülésen jelenléti ívet kell felvenni és jegyzőkönyvet kell vezetni. A jegyzökönyv tartalmazza az elhangzott felszólalások lényegét és a hozott határozatokat. A jegyzőkönyvhöz csatolni kell az igazgatótanács és az ellenőrző bizottság beszámolóját.

A jegyzőkönyv egy példányát - a csatolt iratokkal együtt - meg kell küldeni az MNB-nek a közgyülést követő 30 napon belül. A közgyülési határozatok ellen a pénztártagok, illetve a küldöttek, valamint a Felügyelet a határozat meghozatalától számított 90 napon belül keresetet nyújthatnak be a pénztár székhelye szerint illetékes megyei bíróságon. 


\subsubsection{Az igazgatótanács feladata és hatásköre}

A pénztár ügyvezető szerve az igazgatótanács. Gondoskodik a közgyülés határozatainak végrehajtásáról, a pénztár könyveinek szabályszerü vezetéséről, üzletpolitikájának kialakításáról és a zavartalan működéséről. Az igazgató tanács a munkáltatói jogok gyakorlója az ügyvezető és - amennyiben ügyvezetőt nem alkalmaznak - a pénztár alkalmazottai felett is.

Az igazgatótanács legalább 3 havonként ülést tart. Az ülés akkor határozatképes, ha azon a tagoknak legalább a fele jelen van. Amennyiben az alapszabály másként nem rendelkezik, az igazgatótanács határozatait a jelen lévő igazgatótanácsi tagok szavazatainak egyszerü többségével hozza. Az elnök szavazata a döntő szavazategyenlőség esetén.

Az igazgatótanács feladata, hogy elkészítse és a közgyülés elé terjessze a pénztár:

- pénzügyi tervét, valamint

- mérlegét és éves beszámolóját.

A pénztárat képviselheti:

- az igazgatótanács elnöke önállóan;

- az igazgatótanács elnökön kívüli két tagja együttesen;

- a pénztár két képviseleti joggal felruházott alkalmazottja együttesen;

- amennyiben a pénztár alkalmaz ügyvezetőt, az igazgatótanács által kijelölt egy igazgatótanácsi tag az ügyvezetővel együttesen.

Az alapszabályban rögzített módon és mértékben az igazgatótanács hatáskörének gyakorlását - felelősségének érintetlenül hagyása mellett - az ügyvezetőre átruházhatja.

\subsubsection{Az ellenőrző bizottság feladata és hatásköre}

Az ellenőrző bizottság feladata, hogy a jogszabályi elöírások, a pénztár pénzügyi terve, az alapszabályában és szabályzataiban foglaltak megvalósulása érdekében rendszeresen vizsgálja és ellenőrizze:

- a pénztár gazdálkodását, számvitelét, ügyvitelét,

- a pénztár fizetöképességének, bevételeinek és kiadásainak, eszközeinek és kötelezettségvállalásainak összhangját,

- a pénztár működését. 
Megállapításait évente a közgyűlés elé terjeszti. Ha az ellenőrzés során tapasztaltak szükségessé teszik, kérheti az igazgatótanács vagy a közgyülés soron kívüli összehívását. Köteles megvizsgálni a közgyülés elé terjesztett valamennyi jelentést és a pénztár éves beszámolóját. Az ellenőrző bizottság jelentése nélkül a közgyülés érvényesen nem határozhat.

Az ellenőrző bizottság évente ellenőrzési tervet készít és gondoskodik annak végrehajtásáról. Az ellenőrző bizottság beszámolójának tartalmaznia kell az előző beszámoló óta lefolytatott ellenőrzéseket, azok megállapításait.

\subsubsection{Az ügyvezető feladata és hatásköre}

A pénztár ügyvezetője a pénztárral munkaviszonyban álló személy lehet. Ügyvezető (helyettes ügyvezető) lehet, aki büntetlen előéletü, felsőfokú végzettséggel rendelkezik és legalább 3 éves, a pénztári tevékenységben hasznosítható szakmai gyakorlattal rendelkezik. A pénztár köteles ügyvezetőjének alkalmazását 30 napon belül az MNB-nek bejelenteni. Az ügyvezető felelős a határozatok végrehajtásáért, a pénztár eredményes működéséért, folyamatos ügyviteléért, gyakorolja a pénztár alkalmazottai felett a munkáltatói jogokat. Az igazgatótanács jogsértő határozata, illetve utasítása esetén az ügyvezető az ellenőrző bizottsághoz fordulhat, és kezdeményezheti a közgyűlés összehívását is.

\subsection{A pénztárak gazdálkodása}

Az önkéntes pénztárak szolgáltatásaik szervezéséhez, finanszírozásához és teljesítéséhez kapcsolódó pénzügyi feltételek megteremtése érdekében jogosultak gazdálkodási tevékenységet folytatni.

A pénztárak gazdálkodása kiterjedhet:

- nyugdíjszolgáltatásra (nyugdíjpénztár);

- szociális kötelezettségek alapján biztosított kiegészítő ellátásra, valamint a gyógyszer és gyógyászati segédeszköz árának támogatására (önsegélyező pénztár);

- az egészség védelmét szolgáló programok szervezésére és finanszírozására, egészségügyi szolgáltatások megvásárlására (egészség- és önsegélyező pénztár);

- a pénztárvagyon befektetésére és kezelésére, valamint

- kiegészítő vállalkozási tevékenységre (csak az MNB engedélyével). 
A pénztári vagyon kizárólag a pénztári tagság érdekében fektethető be. A pénztár a gazdálkodása során elért bevételeit kizárólag a szolgáltatások fedezetének biztosítására, a szolgáltatások szinten tartására, illetve fejlesztésére, valamint a gazdálkodás költségeinek fedezetére fordíthatja.

A pénztár köteles pénzforgalmát pénzintézetnél vezetett számlán bonyolítani. A pénztárnak egy számlája lehet. Az önsegélyező, illetve az egészségpénztárak pénztári kártyát bocsáthatnak ki, és szolgáltatásaik elszámolását kártyás elszámoló rendszeren keresztül bonyolíthatják.

A pénztár három évre vonatkozó pénzügyi tervét minden évben a közgyülés elé kell terjeszteni és elfogadni. A pénzügyi tervnek kellő részletezettséggel tartalmaznia kell a pénztár bevételeit és kiadásait meghatározó adatokat (várható taglétszámot, tagdíjbevételeket, adományokat, működési és szolgáltatási kiadásokat, a befektetéseken elérendő hozamot). Az MNB megvizsgálja a pénztár pénzügyi tervét és annak átdolgozására kötelezheti a pénztárat, ha az nem tölti be a célját, hiányos a tartalma, illetve nem felel meg a pénztár alapszabályában foglaltaknak.

A pénztárak bevételeikből kötelesek fedezeti, müködési és likviditási alapot létrehozni. A fedezeti alap (az egyéni és szolgáltatási számlák összessége) a szolgáltatások finanszírozására; a müködési alap, a müködési költségek fedezésére; a likviditási alap az időlegesen fel nem használt pénzeszközök gyüjtésére és - a másik két alap általános tartalékaként - a pénztár fizetőképességének biztosítására szolgál.

A bevételeket az alábbiak szerint kell a tartalékokba elhelyezni:

- a tagok által fizetett tagdíjat, a munkáltatói tag által fizetett hozzájárulást, a vagyon értékesítéséből származó összeget és a tagok egyéb befizetéseit a pénztár működési szükségleteinek megfelelően a fedezeti, működési és likviditási tartalékba;

- a befektetések hozamát abba a tartalékba, amelynek befektetéséből származik, azonban a pénztár igazgatótanácsa dönthet úgy, hogy a fedezeti tartalék javára más tartalék befektetési hozamát jóváírja;

- a rendszeres támogatóktól befolyó összeget, valamint az adományokat a támogató rendelkezése szerinti tartalékba, ennek hiányában a likviditási tartalékba; 
- a kiegészítő vállalkozási tevékenységből származó bevételt, valamint az egyéb bevételeket a működési tartalékba;

- a belépő tagok által hozott egyéni fedezetet, valamint a pénztári befizetések kedvezményét a fedezeti tartalékba kell helyezni.

A kiadások a következők szerint teljesíthetők:

- a szolgáltatási kiadásokat a fedezeti alapból;

- a működési kiadásokat és a beruházásokat a müködési alapból;

- a tagoknak visszatérített összeget a fedezeti alapból kell fedezni;

- a befektetések vagyonarányos költségeit annak az alapnak a terhére kell elszámolni, amellyel kapcsolatban felmerült. A befektetések további költségeit a működési alap terhére kell elszámolni.

A pénztár váltót, hitelviszonyt megtestesíto értékpapírt nem bocsáthat ki; hitelt vagy kölcsönt a fedezeti alap terhére nem vehet fel. A pénztár - kivéve nyugdíjpénztár - hitelt nem nyújthat, váltót nem fogadhat el, pénzügyi garanciát és kezességet nem vállalhat. A nyugdíjpénztár a jogszabályok és a pénztár alapszabálya alapján tagjai részére kölcsönt nyújthat, a tulajdonában lévő értékpapírt kölcsön adhatja. A pénztárak a kockázatok mérséklése és az egyoldalú függőség megelőzése érdekében befektetéseiket kötelesek befektetési formák és befektetési közvetítők szerint is megosztani.

A pénztár sem a pénztárvagyon befektetése, sem adományok révén nem szerezhet egy vállalkozásban egy évnél hosszabb időtartamot meghaladóan olyan arányú közvetlen tulajdoni részesedést, amely nagyobb, mint a vállalkozás jegyzett, illetve törzstőkéjének 10 százaléka. Ilyen részesedés átmeneti megszerzéséről a Felügyeletet 15 napon belül tájékoztatni kell.

A pénztár befektetési üzletmenetét saját maga végezheti vagy kihelyezheti.

\subsection{Az önkéntes pénztárak átalakulása, megszünése}

Pénztár átalakulásának minősül a pénztárak egyesülése (összeolvadás, beolvadás) és szétválása (különválás, kiválás). Nem alakulhat át az a pénztár, amely felszámolás alatt áll. A pénztár közgyülése az átalakulásáról a jelenlévők kétharmados szavazattöbbségével határoz. Az átalakulás napja a jogutód pénztár alapszabálya hatálybalépésének időpontja. 
Az átalakulás esetei:

- Egyesülés: egyesülhetnek, ha azt az érintett pénztárak közgyülései elhatározták, de nyugdíjpénztár csak nyugdíjpénztárral egyesülhet.

Ez két módon történhet:

a) Beolvadás: a beolvadó pénztár jogai és kötelezettségei a másik pénztárra (átvevő pénztárra), mint jogutódra szállnak át.

b) Összeolvadás: az egyesülő pénztárak megszűnnek, jogaik és kötelezettségeik a létrejövő új pénztárra, mint jogutódra szállnak át az új pénztár alapszabályának elfogadásával.

- Szétválás: a közgyülés döntése alapján a pénztár több pénztárrá válhat, és a szétválás során új pénztárak jönnek létre saját alapszabállyal. Ekkor rendelkezni kell a jogutódlásról és a pénztári vagyon megosztásáról. A pénztártagok írásban nyilatkoznak, hogy melyik pénztárban kívánják tagsági jogviszonyukat folytatni.

Ez két módon történhet:

a) Különválás: ekkor a különváló pénztár megszünik és legalább két új pénztár jön létre.

b) Kiválás: ekkor az a pénztár, amelyből a kiválás történik, fennmarad és legalább egy új pénztár jön létre.

A pénztár végelszámolás vagy felszámolás következtében jogutód nélkül szünhet meg. A pénztár végelszámolásáról a közgyülésnek kell határoznia. A pénztár megszüntetésére irányuló szándékot az illetékes bíróságnak és az MNB-nek is jelenteni kell, ekkor a Felügyelet végelszámolót nevezhet ki.

Jogutód nélküli megszűnés esetén a pénztártag a rá jutó vagyonrészt:

- átlépés esetén a másik pénztárba átviheti, ekkor a pénzösszeget a tag másik pénztárban meglévő egyéni számláján kell jóváírni, vagy

- egy összegben veheti fel. Felhalmozási időszakban lévő pénztártag esetében ez a kifizetés nem minősül pénztári szolgáltatásnak.

A Felügyelet a bíróságnál kezdeményezheti a pénztár elleni felszámolási eljárás megindítását, ha

- a pénztár fizetésképtelen, azaz esedékes kötelezettségeinek pénzügyi fedezet hiánya miatt 60 , illetve a tagok javára vállalt szolgáltatási kötelezettségeinek az esedékességtől számított 90 napon belül nem tesz eleget; 
- a szükséghelyzetben hozott intézkedések hatástalanok voltak, és ez a megtakarítások vagy a szolgáltatások biztonságát fenyegeti;

- a pénztár müködésének súlyos szabálytalansága másképp nem orvosolható;

- a Felügyelet a pénztár tevékenységi engedélyét visszavonta vagy a tevékenységi engedély iránti kérelmét elutasította;

- a Felügyelet által kitűzött határidőig a pénztár a végelszámolási eljárást nem fejezi be;

- a pénztár a bíróságon bejelentett székhelyén nem lelhető fel.

A pénztári tartalékok csak a fedezeti tartalékkal szemben fennálló tagi, hozzátartozói, illetve kedvezményezetti követelések kielégítése után használhatók fel egyéb kötelezettségek kielégítésére. A tagsági viszonyból származó kötelezettségeket a felszámolási költségeket követően kell kielégíteni.

\subsection{Az önkéntes nyugdíjpénztárak}

Az önkéntes kölcsönös biztosító pénztárak meghonosítása Magyarországon a társadalombiztosítás reformjának szerves része volt. Az állami nyugdíjellátást kiegészítve az önkéntes nyugdíjpénztárak lehetővé teszik tagjaik számára, hogy aktív kereső időszakukban megalapozzák nyugdíjas éveik anyagi biztonságát. Az önkéntes nyugdíjpénztár célja, hogy kiegészítse a munkavállaló társadalombiztosítási nyugdíjellátását.

$\mathrm{Az}$ önkéntes nyugdíjpénztárak sajátosságainak ismertetése előtt fontos tisztáznunk az alábbi fogalmakat:

- Várakozási idő: a tagsági viszonynak a belépéstől számított alapszabály szerinti azon időszaka, amelynek elteltével az egyéni számlaköveteléshez, illetve a szolgáltatáshoz a pénztártag hozzájuthat. Nyugdíjpénztárak esetén ez legalább 10 év.

- Felhalmozási időszak: a tagsági viszony kezdetétől a nyugdíjszolgáltatás megállapításáig terjedő időszak.

A pénztártag az egyéni nyugdíjszámláján nyilvántartott összeghez a várakozási idő letelte, a nyugdíjszolgáltatáshoz a nyugdíjkorhatár elérése után juthat hozzá. A tagsági viszony a várakozási idő letelte előtt csak más pénztárba való átlépés vagy a pénztár megszünése esetén szüntethető meg. 
A kötelező várakozási idő letelte után, de még a felhalmozási időszakban, a tag az egyéni számláján lévő összeghez való hozzáférés tekintetében választhat, hogy:

- a pénztárban változatlan feltételek mellett tag marad;

- a pénztártagságát folytatja, és - legfeljebb háromévente egy alkalommal - az egyéni számláján nyilvántartott összeg egészét vagy egy részét a nyugdíjkorhatár elérése előtt felveszi;

- a pénztárból kilép;

- tagdíj fizetése nélkül az egyéni számláján lévő összeget a pénztárban hagyja. A nyugdíjszolgáltatáshoz a pénztártag a nyugdíjkorhatár elérése után juthat hozzá. A nyugdíjkorhatárt elérő tag írásbeli nyilatkozattal az alábbi lehetőségek közül választhat:

- egy összegben vagy járadék formájában veszi igénybe a nyugdíjszolgáltatást és a tagdíjat tovább nem fizeti;

- az egyéni számláján lévő összeg meghatározott részét egy összegben, a fennmaradó részt pedig járadék formájában veszi igénybe és a tagdíjat tovább nem fizeti;

- az egyéni nyugdíj számláján lévő összeg meghatározott részét egy összegben vagy járadék formájában igénybe veszi és a tagdíjat tovább nem fizeti;

- az egyéni nyugdíj számláján lévő összeg meghatározott részét egy összegben vagy járadék formájában igénybe veszi és a tagdíjat tovább fizeti;

- a nyugdíjszolgáltatást nem vesz igénybe és a tagdíjat fizeti;

- a felhalmozott összeget a pénztárban hagyja és a tagdíjat tovább nem fizeti.

A pénztár köteles tagjai részére az összes lehetőséget biztosítani. A tagsági viszony akkor szűnik meg, ha a pénztár a taggal maradéktalanul elszámolt.

A pénztártag - a várakozási idő letelte, illetve a nyugdíjkorhatár elérése után - egyéni számlakövetelésének legfeljebb 50\%-át a Hpt. hatálya alá tartozó hitelintézettel kötött szerződésben fedezetként felajánlhatja, amennyiben rendelkezik arról, hogy a pénztár az egyéni nyugdíjszámlájára tagi lekötést vezessen fel. A nyugdíjpénztár a pénztárak befektetéseiről rendelkező jogszabály és a pénztár alapszabályának keretei között tagjai részére kölcsönt is nyújthat.

Amennyiben a nyugdíjpénztár a magánnyugdíjról és a magánnyugdíjpénztárakról szóló törvényben meghatározott feladatokat is ellát, a pénztár a két tevékenység ellátásához egy-egy pénzforgalmi számlával rendelkezik. 
A nyugdíjpénztár választható befektetési portfóliót biztosító rendszert müködtethet, melyben a pénztár felhalmozási időszakban lévő tagjai az egyéni nyugdíjszámlájukon lévő összeget döntésük alapján, a pénztár által kialakított portfóliók valamelyikébe fektethetik. A választható portfóliós rendszerrel kapcsolatos döntések a közgyülés kizárólagos hatáskörébe tartoznak. Szabályzatban rögzítik a portfóliók számát, megnevezését, továbbá, hogy milyen életkorú és kockázatvállalási hajlandóságú tagok részére javasoltak. A tagoknak lehetőségük van portfólióváltásra is, sőt a két portfólió közötti megosztás lehetőségét is biztosíthatja a pénztár. A választható portfóliós rendszer müködtetése a Felügyelet erre vonatkozó engedélye birtokában kezdhető meg, folytatható, illetve módosítható.

\subsection{Az önkéntes önsegélyező pénztárak}

A pénztár célja a tagok szociális helyzetének javítása, az öngondoskodás támogatása olyan élethelyzetekben, amelyek többletkiadást igényelnek.

Az önsegélyező pénztár egyéni szolgáltatásokat és közösségi szolgáltatásokat nyújthat. A pénztár az egyéni szolgáltatásokat a tag egyéni számlájának megterhelésével, az egyes közösségi szolgáltatásokat pedig a fedezeti tartalékon belül létrehozott szolgáltatási tartalék terhére teljesíti. A tagi befizetés, munkáltatói hozzájárulás, támogatás, adomány - néhány kivétellel - a befizetést követő 180 napon belül nem használható fel egyéni szolgáltatás finanszírozására.

Az önsegélyező pénztár kiegészítő önsegélyező pénztári szolgáltatásokat, valamint életmódjavító önsegélyező pénztári szolgáltatásokat nyújthat a pénztártagok, illetve rendelkezésük alapján a közeli hozzátartozók részére.

A kiegészítő önsegélyező szolgáltatások köre a következő:

- gyermek születéséhez kapcsolódó ellátások;

- munkanélküliségi ellátások;

- tüz- és elemi károkhoz kapcsolódó segélyek;

- betegséghez, egészségi állapothoz kapcsolódó segélyek;

- hátramaradottak segélyezése halál esetén;

- nevelési, évkezdési, tanévkezdési (beiskolázási) támogatás;

- gyógyszer és gyógyászati segédeszköz árának támogatása;

- közüzemi díjak finanszírozásának támogatása; 
- lakáscélú jelzáloghitel törlesztésének támogatása;

- otthoni gondozás;

- idősgondozás támogatása;

- látássérült személyek életvitelét elősegítő szolgáltatás;

- életvitelt elősegítő szolgáltatások.

Az önsegélyező pénztárak életmódjavító önsegélyező pénztári szolgáltatások körében gyógyteák, fog- és szájápolók megvásárlásának támogatására is igénybe vehetők.

A pénztár szolgáltatást kizárólag a jogosult személy írásbeli igénylése alapján, az egyes szolgáltatások alapjául szolgáló esemény bekövetkezése után, vagy állapot fennállása idején nyújthat. Az igény bejelentésének minősül a pénztári kártya használata is.

\subsection{Az önkéntes egészségpénztárak}

Szolgáltatásaikat saját maguk vagy szolgáltatásszervező intézmény igénybe vételével is szervezhetik. Kiegészítő vállalkozási tevékenység keretében szolgáltatásszervezési tevékenységet más pénztárak tagjai, valamint más magánszemélyek, intézmények részére is végezhetnek.

Természetbeni szolgáltatásokat egészségpénztári szolgáltatón keresztül nyújthatnak. Az alapszabálynak megfelelően az egyes szolgáltatások kiadásainak kiegyenlítése a szolgáltatásra jogosult tag egyéni egészségszámlájának megterhelésével történik.

$\mathrm{Az}$ önkéntes egészségpénztárakon keresztül igénybe vehető szolgáltatások köre széles palettát alkot. Az egészségpénztár kiegészítő egészségbiztosítási szolgáltatásokat, valamint életmódjavító egészségpénztári szolgáltatásokat nyújthat a pénztártagoknak, továbbá rendelkezésük alapján a közeli hozzátartozóik részére egyaránt.

A kiegészítő egészségbiztosítási szolgáltatások köre a következő:

- egészségügyi szolgáltatás;

- otthoni gondozás;

- gyógytorna, gyógymasszázs és fizioterápiás kezelés igénybevételének támogatása; 
- látássérült személyek életvitelét elősegítő szolgáltatás;

- életvitelt elősegítő szolgáltatás;

- a szenvedélybetegségről való leszoktatásra irányuló kezelések támogatása;

- a gyógyszer és gyógyászati segédeszköz árának támogatása;

- pénzbeli kiegészítő egészségbiztosítási szolgáltatások;

- hátramaradottak segélyezése;

- az egészségügyi államigazgatási szerv által nyilvántartásba vett, gluténmentes speciális élelmiszerek vásárlásának támogatása;

- szolgáltatást finanszírozó egészségbiztosítások (betegségbiztosítások) díjának fizetése.

Az életmódjavító egészségpénztári szolgáltatások köre a következő:

- természetgyógyászati szolgáltatás;

- sporteszköz vásárlásának támogatása;

- gyógyteák, fog- és szájápolók megvásárlásának támogatása.

Az egészségpénztári szolgáltatások finanszírozása történhet azonnali fizetéssel, telefonos engedélyeztetéssel, valamint pénztári kártya (egészségkártya) használatával POS terminálon keresztül vagy online.

Azonnali fizetés esetén a tag előfinanszírozza az igénybe vett szolgáltatást, majd a számlát beküldi az egészségpénztárba. A pénztár megvizsgálja, hogy a tag a finanszírozható szolgáltatások körébe tartozó szolgáltatást vett-e igénybe, majd jogos igény esetén - szabályzatának megfelelöen - 3-15 banki napon belül kiutalja a számla szerinti összeget a pénztártagnak.

A további fizetési módoknál a szolgáltató finanszírozza elő az igénybe vett szolgáltatást. A telefonos engedélyeztetés „,virtuális terminálon” keresztül zajlik. A szolgáltató felhívja telefonon a pénztár kártyaközpontját, majd a szolgáltató és a pénztártag azonosítását, valamint a szolgáltatás ellenértékének megadását követően a tranzakció kap egy engedélyszámot. Az igényelt összeggel megterhelik a pénztártag egészségszámláját. A szolgáltatás pénzügyi rendezése a szolgáltató számlájának megküldését követően történik, amelyen szerepel a kártyaközponttól kapott engedélyszám. A pénztár - szabályzatának megfelelően - 3-15 banki napon belül kiutalja a számla szerinti összeget a szolgáltatónak.

Az egészségkártya segítségével a bankkártyához hasonló módon fizethet a pénztártag egyéni egészségszámlája terhére. Az ellenértéket ekkor a pénz- 
tár egyenlíti ki, ezzel párhuzamosan terhelve a pénztártag egyéni számláját. Ezen fizetési módozat jogi előfeltétele a pénztár és a szolgáltató közötti szolgáltatói szerződés megléte, valamint technikai előfeltétele, hogy a szolgáltatónál POS terminál müködjön (Polyák, 2011).

A pénztári kártya online fizetésre is használható azokon az internetes portálokon, melynek üzemeltetőjével a pénztár erre vonatkozóan szolgáltatói szerződést kötött. A kártyaadatok alapján történt sikeres azonosítást követően elöször ellenőrzésre kerül a megfelelő fedezet megléte, majd az összeggel megterhelik a pénztártag egyéni számláját.

Egészségkártyával történő fizetéseknél a szolgáltatás pénzügyi rendezése a szolgáltató számlájának megküldését követően történik. A pénztár 3-15 banki napon belül kiutalja a számla szerinti összeget a szolgáltatónak.

\subsection{A pénztári szektor helyzete és tendenciái}

Az MNB, mint a pénztári szektor felügyeleti szerve, 2015-től évente kiadja a hitelintézeteken kívüli pénzügyi piacokról szóló kockázati jelentését, mely részletesen tárgyalja a biztosítók, a pénztárak, a nem bankcsoporthoz tartozó pénzügyi vállalkozások és közvetítők, valamint a tőkepiac kockázatait. Az MNB célja, hogy az adatok nyilvánossá tétele által is növelje a felügyelt piacokon tevékenykedők kockázati tudatosságát, és erősítse a szektorokba vetett bizalmat. 2017-től ez a kiadvány „Biztosítási, pénztári és tőkepiaci kockázati jelentés” néven kerül közzétételre.

Jelen könyv megjelenésekor a 2018. évi „Biztosítási, pénztári és tőkepiaci kockázati jelentés" állt rendelkezésre, így jelen fejezetben e kiadvány legfontosabb megállapításai, azaz a 2017-ig terjedő időszakra vonatkozó adatok és tendenciák kerülnek ismertetésre.

A pénztári szektort régóta a felszámolások, az egybeolvadások és a koncentráció jellemzi. Az önkéntes nyugdíjpénztárak esetén a koncentráció foka a 2016os évre csúcsosodott ki, amikor is a tagdíjbefizetések alapján az öt legnagyobb pénztár részesedése elérte a 65\%-ot. Ez az érték 2017-re kis mértékben csökkent. Az egészség- és önsegélyező pénztári szektorban az öt legnagyobb pénztár részesedése már 2015-ben elérte a 65\%-ot, és azóta is töretlenül növekszik. A tagdíjbefizetések alapján mért Herfindahl-Hirschman index (HHI) a nyugdíjpénztá- 
rak esetén a mérsékelt koncentráció, míg az egészség- és önsegélyező pénztárak kapcsán már a magas koncentráció határát súrolja.

2017 januárjától a cafeteria rendszer keretében igénybe vehető önkéntes pénztári munkáltatói tagdíj hozzájárulások közterhei megnövekedtek, ezért fennállt a veszélye, hogy a 2017-es évben jelentősebb mértékben csökkennek majd a pénztári tagdíjbefizetések. A várakozások ellenére azonban nem csökkentek a tagdíjbevételek az önkéntes pénztári szektorban, ugyanis az egyéni befizetések növekedése kompenzálni tudta a munkáltatói tagdíj hozzájárulások visszaesését.

Habár összességében a pénztári szektor tagdíjbevételei nem csökkentek, ez a változás eltérően érintette az önkéntes nyugdíjpénztárakat és az egészség- és önsegélyező pénztári szektort. Míg a 2017-es év a tagdíjbevételek történelmi csúcsának számított a nyugdíjpénztárak esetén (105,6 milliárd forint), addig az egészség- és önsegélyező pénztárak összes tagdíj bevétele a 2016-os 55,4 milliárd forintos szintről 47,6 milliárd forintra esett vissza.

A 2017-es évben a pénztári szektorban megközelítőleg 60-40\%-os arányban az egyéni tagdíjfizetések domináltak a munkáltatói tagdíj hozzájárulásokkal szemben. A cafeteria rendszer megváltoztatása az egészség- és önsegélyező pénztári szektort érintette mélyebben, ahol a 2016-os évben ez az arány még éppen ennek fordítottja volt. A munkáltatói hozzájárulások mértéke 2017-re közel 42\%-kal esett vissza a 2016-os szinthez képest, ez okozta a szektorban tapasztalt jelentős tagdíj bevétel kiesést.

2017 végén az önkéntes nyugdíjpénztárak fedezeti tartaléka 1 373,3 milliárd forintot tett ki. A közel 126 milliárd forintos gyarapodás több mint 10\%-os növekedésnek felel meg az előző évhez képest. Ez nem csak a rekord nagyságú tagdíjbevételeknek köszönhetö, hanem a fedezeti hozamnak is. Az önkéntes nyugdíjpénztári szektor ugyanis 2017-ben a záró vagyonnal súlyozva átlagosan 6,91\%-os nettó hozamot ért el. Az egészség- és önsegélyező pénztárak fedezeti tartaléka 57,2 milliárd forint volt 2017 végén. Ez 2016-hoz képest 1,4 milliárd forintos visszaesés, ami elenyészőnek mondható, figyelembe véve a tagdijfizetések jelentős visszaesését.

Ahogy az 1. ábra szemlélteti, az önkéntes nyugdíjpénztári befektetések között a magyar állampapírok dominálnak, 2017 végén 56,5\%-os arányt képviseltek. A második legjellemzőbb befektetési formák, a befektetési alapok, több mint 
negyedét tették ki a nyugdíjpénztári befektetéseknek. A befektetési alapok állampapír-állományát is figyelembe véve, a nyugdíjpénztári portfóliókban, a tényleges állampapír kitettség $60 \%$ körüli, ami éppen duplája az Európai Gazdasági Térség (EGT) átlagának.
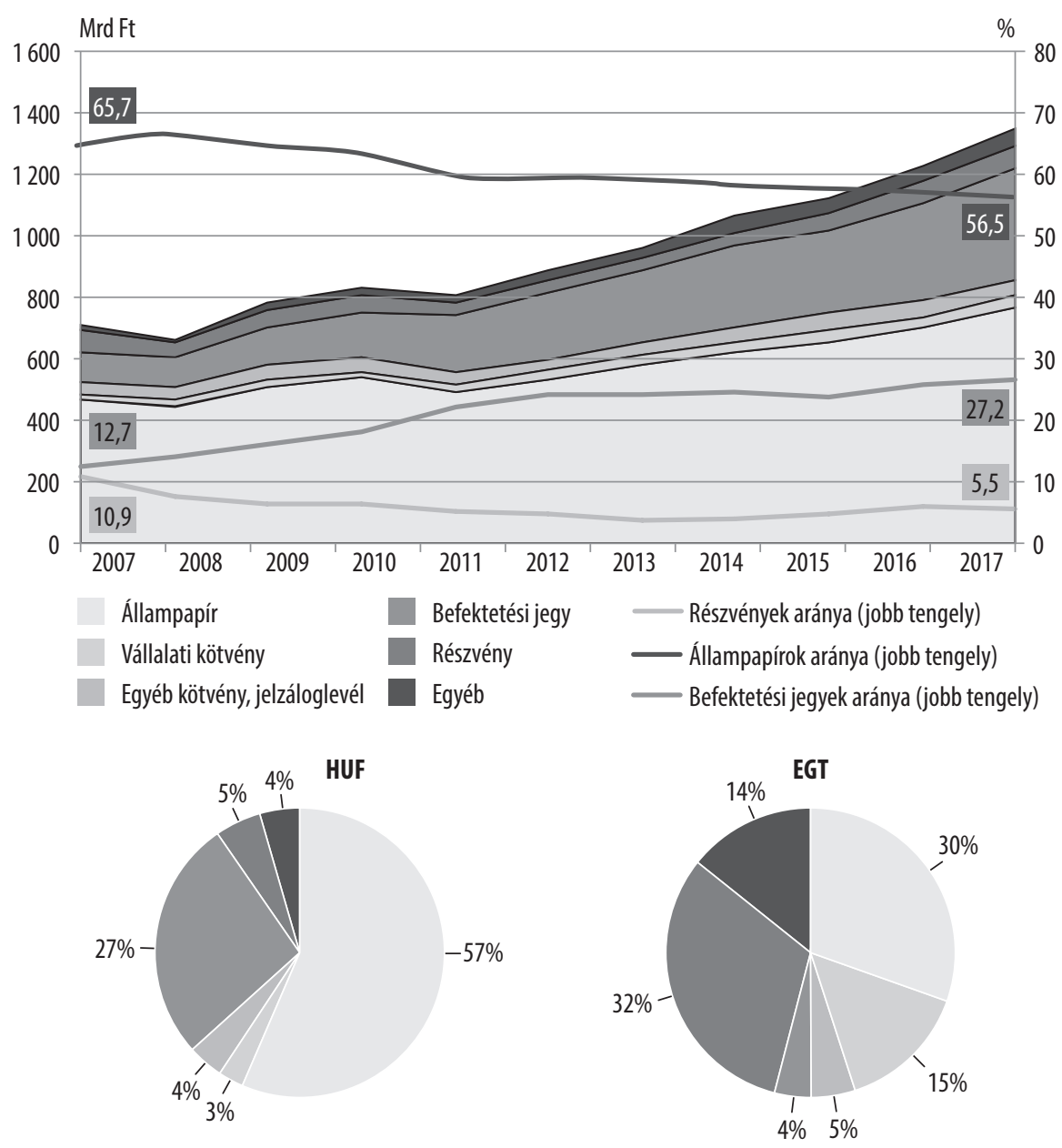

\section{1. ábra: Az önkéntes nyugdíjpénztári befektetések eszközcsoportok szerint}

Forrás: MNB (2018, p. 49.)

A befektetési alapok mögöttes eszköz-összetételéről elmondható, hogy több mint felét részvények teszik ki, közel ötödét állampapírok, kevesebb mint 10\%át vállalati kötvények, jelzáloglevelek és egyéb kötvények alkotják. A befektetési jegyek, azon belül is a külföldi befektetési jegyek, egyre nagyobb arányt képviselnek a pénztári portfóliókban. Összességében megállapítható, hogy az 1. ábrán 
szemléltetett 10 év leforgása alatt a befektetési jegyek, azaz a közvetett befektetések aránya megduplázódott, míg a közvetlen részvényállomány a felére esett viszsza. A részvények nyugdíjpénztári befektetésekben képviselt aránya jelentősen elmarad az EGT pénztárainak átlagos gyakorlatától.

A hazai állampapírok dominálnak az egészség- és önsegélyező pénztári befektetésekben is. 2017 végén arányuk 78\%-ot tett ki. A második legjellemzőbb befektetési formák, a pénzforgalmi számla és lekötött betét, 6-6\%-os arányt képviseltek. 2017-ben számos esetben a pénztárak csak negatív kamattal tudták elhelyezni a megtakarításokat a bankokban. A jogszabály 2016-os szigorítása megköveteli a lekötések fokozottabb diverzifikálását, így több hitelintézetnél kell számlát vezetniük, ami tovább csökkenti a befektetések hozamát.

Az önkéntes nyugdíjpénztárak fedezeti tartalékát érintő kifizetések 2017-ben 64,2 milliárd forintot tettek ki, ami közel 1 milliárd forintos csökkenés 2016-hoz képest. Ennek oka, hogy a kifizetésre jogosult tagok jelentős része még nem kívánta nyugdíjpénztári megtakarításait felhasználni, hanem - a 2016-tól hatályos jogszabály módosításnak köszönhetően - élt azon lehetőségével, hogy továbbra is a pénztári rendszerben gyarapítsa vagyonát.

2016. január 1-jétől van lehetőség az új pénztártípus, az egészség- és önsegélyező pénztár létrehozására. E rendelkezés hatására a nagyobb, országos lefedettséggel rendelkező pénztárak szinte mindegyike vegyes pénztárrá alakult. Az egészség- és önsegélyező pénztári szolgáltatások igénybevételének felét a gyógyszerek vételárának támogatása teszi ki, ezt követi $24 \%$-kal az egészségügyi szolgáltatás, majd 18\%-kal a gyógyászati segédeszközök vásárlása. Az egészségpénztárak tevékenységi körének bővülésével megfigyelhető az önsegélyező pénztári jellegü szolgáltatások igénybevételének növekedése. Az életmódjavító szolgáltatások igénybevétele adóköteles, ezért kevésbé népszerűek.

Új szolgáltatási struktúra kezd elterjedni a legnagyobb egészség- és önsegélyezö pénztárak körében, amelynek keretében a pénztárak és az egészségügyi szolgáltatók között stratégiai együttmüködések kerülnek kiépítésére. A pénztártagot a pénztárral leszerződött egészségügyi szolgáltató intézménybe irányítják, ahol a pénztári tagsága alapján kedvezményes szolgáltatások és ellátások igénybevételére jogosult. Ez a rendszer már egy új magánegészségügyi rendszer kiépítésének a kezdete. (MNB, 2018) 


\subsection{Irodalomjegyzék}

1993. évi XCVI. törvény az Önkéntes Kölcsönös Biztosító Pénztárakról. Letöltve: 2019. február 24-én a https://net.jogtar.hu/jogszabaly?docid=99300096. TV linkről.

KSH (2019): 2.1.2. Eltartottsági ráták, öregedési index, január 1. (2003-2018) Letöltve: 2019. február 24-én a http://www.ksh.hu/thm/2/indi2_1_2.html linkről.

MNB (2018): Biztosítási, pénztári és tőkepiaci kockázati jelentés 2018. Letöltve: 2019. május 5-én a https://www.mnb.hu/letoltes/kockazati-jelentes-2018-0613-vegleges.PDF linkröl.

MNB (2019): A Magyar Nemzeti Bank által felügyelt szektorok adatainak idősorai: Pénztári szektor. Letöltve: 2019. február 18-án a https://www.mnb.hu/ letoltes/idosor-penztar-2018q3.xls linkről.

Polyák Imre (2011): Az önkéntes pénztári rendszer. In: Tatay, T. - Vágyi, F. R. Varga, J. (szerk.): A pénzügyi intézményrendszer Magyarországon. Sopron: A Soproni Felsőoktatásért Alapítvány, pp. 274-297. 


\section{Magánnyugdíjpénztárak és foglalkoztatói nyugdíjszolgáltató intézmények}

A XIX. század végére, a XX. század elejére sok országban jöttek létre olyan nyugdíjrendszerek, amelyek a társadalmak egyre szélesebb körének kínáltak megélhetést idős korukra, illetve rokkanttá válásuk esetére. Ezek a rendszerek a modern gazdasági szerkezet kialakulásához köthetők. A hagyományos létforma felbomlásával megszünt az idősek családon belüli ellátása. A modern nyugdíjrendszerek ennek a problémának a kezelésére jöttek létre. Magyarországon az 1990-es évek elején az állami társadalombiztosítás keretén belül működött a nyugellátás biztosítása. A rendszer felosztó-kirovó elven működött. A felosztó-kirovó rendszer lényege, hogy az aktív munkavállalók befizetései biztosítják a nyugdíjra jogosultaknak járó kifizetések pénzügyi alapját. A munkavállalók részére a járulékfizetés kötelező volt. Az állami nyugdíjrendszer napjainkba is ezen az elven müködik.

A felosztó-kirovó rendszer egyensúlya akkor bomlik meg, amikor a befizetések nem jelentenek elégséges fedezetet a nyugdíjakra. Ez a helyzet akkor adódik, amikor a járulékfizetök aránya csökken a nyugdíjjogosultakhoz képest. Sok országban, és ezek közt Magyarországon is, ilyen egyensúlytalanságok jelentek meg. A társadalombiztosítási nyugdíjkasszák hiányát pótolni lehet az államháztartás egyéb forrásainak terhére, ami azonban az állami költségvetés fenntarthatóságát befolyásolja kedvezőtlenül. Sok országban emelni kellett és kell a nyugdijkorhatárt. Emellett a munkajövedelmekhez képest csökkenhet a nyugdíjak értéke. Az utóbbi megoldás a nyugdíjba vonulók korábbi életszínvonalának akár jelentős visszaeséséhez is vezethet, a nyugdíjasok más rétegekhez viszonyított életszínvonala jóval alacsonyabbá válhat. Ezeknek a problémáknak a kezelésére többféle megoldást is kidolgoztak. A kötelező, illetve önkéntes alternatív megoldásnak több szervezeti formáját is megtaláljuk. Ezek közül a fejezetben a magánnyugdíjpénztárakkal és a foglalkoztatói nyugdíjpénztárakkal ismerkedünk meg.

\subsection{A magánnyugdíjpénztárak}

A magánnyugdíjpénztárak Magyarországon 1998-tól váltak a kötelező nyugdíjrendszer részévé. A kötelező rendszer állami pillére mellett a második pillérként 
említett rendszert alkották. (A rendszer harmadik lábaként a könyv más fejezetében tárgyalt önkéntes nyugdíjpénztárakat nevezték.) A pénztártag munkavállalók kötelező járulékfizetésének egy részét tagdijként a magánnyugdíjpénztárakba irányították. A rendszer indulásakor a már munkavállalók (45 év alattiak) önkéntesen léphettek be a pénztárakba, míg a pályakezdőknek már kötelező volt egy pénztár választása és a taggá válás.

A rendszer müködési alapja a tökefedezeti elv. A tagok befizetéseiböl egy pénzalapot halmoznak fel. Ez a felhalmozás és ennek hozamai biztosítják a tagok számára a későbbi nyugdíjkifizetések pénzügyi alapját. (Varga, 2006; Bakáné et al., 2008) Mivel a kötelező járulékfizetés megoszlott az állami társadalombiztosítás és a magánnyugdíjpénztárak között, ezért a pénztártagok várható nyugdíjának egy része az állami rendszerből, másik része a magánnyugdíjpénztárból származna. Az eredeti tervek szerint a nyugdíj hozzávetőleg 75\%-a az állami, 25\%-a (léteznek olyan koncepciók is, miszerint ez az arány 2/3-1/3) a magánnyugdíjpénztárból származott volna.

Az intenzív tagszervezésnek is köszönhetően a pénztártagok száma 2000-ben meghaladta a 2 millió főt, 2011-ben a tagok száma több mint 3 millióra növekedett. A társadalombiztosítási rendszerből átlépők aránya jóval meghaladta a korábban tervezett mértéket. A tagszervezés miatt sokan úgy léptek át a magánnyugdíjpénztári rendszerbe, hogy az előre számítások szerint ez számukra egyáltalán nem volt előnyös. Az állami rendszerben a vártnál jóval nagyobb hiány keletkezett. Ezt a hiányt az állami költségvetésnek kellett kipótolnia, ami növelte az államháztartás deficitjét, ezen keresztül az államadósságot. 2010-ben az államháztartás deficitje 3,8\% volt, ami a magánnyugdíjpénztárakba való befizetésekkel korrigálva csak 2,4\% lett volna. Magyarország több másik országgal kezdeményezte az EU hiányszámítási módszerének megváltoztatását, hiszen a 3\% feletti államháztartási hiány az EU-n belüli túlzott deficit eljárást vonja maga után. Emiatt a korábban nemzetközi nyomásra végrehajtott nyugdíjreform következménye nemcsak a hiány finanszírozásának problémáját jelentette, hanem az EU részéről további szankciókat is maga után vonhatott. Az EU a statisztikai módszertan változásához nem járult hozzá, ezért a magyar kormányzatnak egyéb szabályozási eszközökhöz kellett nyúlnia. A kormányzati lépések a kétpilléres kötelező rendszer megszűnéséhez vezettek 2010 és 2012 között. (Barta, 2012) 
A magánnyugdíjpénztárak az intézményesített önkéntes nyugdíj előtakarékossági rendszer részeivé váltak. Szabad választás alapján a magánnyugdíjpénztáraknak maradtak tagjai. Az MNB (2019) adatai szerint 2018 második negyedév végén a pénztárak összesített taglétszáma 56331 fő volt. Amennyiben gazdálkodásuk lehetővé teszi, a jelenlegi szabályozás szerint a magánnyugdíjpénztárak még akár évtizedekig is működhetnek. Ezért áttekintjük a rájuk vonatkozó fontosabb tudnivalókat.

A magánnyugdíjpénztárak müködését az 1997. évi LXXXII. törvény a magánnyugdíjról és a magánnyugdíjpénztárakról szabályozza. A magánnyugdíjpénztár jogi személy, amely magánnyugdíjpénztári tevékenységet végez. A pénztárra vonatkozó alapvető döntéseket a tagok hozhatják meg az önkormányzatiság elve alapján. A tagok a döntéshozatali jogot vagy közvetlenül gyakorolják a közgyülésen, vagy közvetetten küldötteik útján a küldöttközgyülésen. Alapvető döntéseknek számítanak példaként az éves beszámoló elfogadása, a vezető tisztségviselők választása, a megszűnésre irányuló döntés.

A pénztártag az a természetes személy, aki a pénztárba belépett, oda tagdíjat fizet, illetve a későbbiekben a pénztártól nyugdíjszolgáltatásban részesül. A pénztártagokat azonos jogok illetik és kötelezettségek terhelik. A pénztártag részt vehet a pénztár tisztségviselőinek választásában, maga is választható. Jogosult a pénztár gazdálkodására vonatkozó adatok megismerésére. Igénybe veheti a pénztár szolgáltatását a jogosultsági feltételek szerint. A pénztártag köteles a müködési szabályok szerint tagdíjat fizetni, a pénztár részére adatokat szolgáltatni.

A pénztártag addig, amíg nem válik a nyugdíjszolgáltatásra jogosulttá, köteles tagdíjat fizetni. Ez az időszak a felhalmozási időszak. A tagdíj összegének döntő része a fedezeti tartalékon kerül jóváírásra. A felhalmozási időszakban megtakarított összeg nyilvántartását az egyéni számla szolgálja. Az egyéni számla a tag mindenkori követelésének és nyugdíjszolgáltatás megállapításának az alapja.

A pénztár a felhalmozott vagyont befekteti. A felhalmozási időszakban levő pénztártagok egyéni nyugdíjszámláján összegyülő megtakarítások befektetésére a pénztár választható portfóliós rendszert alakít ki. A pénztártag választhat, hogy a megtakarítása melyik portfólióban kerüljön elhelyezésre. Ha a pénztártag nem választ, akkor a nyugdíjszolgáltatásra való jogosultságig hátralevő idő alapján a pénztár rendeli hozzá a megtakarítást valamelyik portfólióhoz. A választ- 
ható portfóliós rendszer elemei a növekedési, a kiegyensúlyozott és a klasszikus portfólió. Amennyiben a pénztártag nem választ a portfóliók között, akkor a pénztár a megtakarítását a növekedési portfólióba sorolja, ha a nyugdíjjogosultságig több mint 15 év van hátra. Amennyiben a hátralevő idő 5-15 év közé esik, akkor a megtakarítást a kiegyensúlyozott portfólióba, ha a hátralevő idő kevesebb mint 5 év, akkor a klasszikus portfólióba sorolják. A növekedési portfóliót a pénztártag a nyugdíjjogosulttá válása előtti 5 éven belül már nem választhatja. Az egyes portfóliók várható hosszú távú hozama eltérő. Legmagasabb a növekedési portfólióé, és legkisebb a klasszikus portfólióé. Ugyanakkor a legmagasabb kockázatot is a növekedési portfólió hordozza, míg a legalacsonyabb kockázatú a klasszikus portfólió. A portfóliók egymástól eltérő várható hozama és kockázata a bennük levő eszközöktől függ. A növekedési portfólióban a legmagasabb, a tapasztalatok szerint kockázatosabb, de általában hosszabb időtávon nagyobb hozamú eszközök, mint például a részvények aránya. A klasszikus portfólióban az alacsony kockázatú eszközök vannak túlsúlyban, mint például az állampapírok vagy a bankbetétek. A kiegyensúlyozott portfólió eszközösszetétele a növekedési és a klasszikus portfólió között helyezkedik el a kockázatosabb és alacsonyabb kockázatú eszközök arányát tekintve.

A pénztárnak portfóliókra vonatkoztatva ki kell mutatnia az elért hozamokat, hogy azok más pénztárak hozamaival összehasonlíthatóvá váljanak.

Amennyiben a pénztártag elhalálozik a felhalmozási időszak alatt, úgy az egyéni számláján levő összeget a korábban megjelölt kedvezményezett vagy a törvényes örökös kapja meg.

A felhalmozási időszak akkor ér véget, amikor a pénztártag eléri a társadalombiztosítási nyugdíjjogosultságot. A pénztártag ezzel egyidőben, vagy ezt követően kérheti a magánnyugdíjpénztár szolgáltatását. A nyugdíjpénztár a nyugdíjszolgáltatást járadék formájában biztosítja, vagy biztosítótól vagy nyugdíjszolgáltató intézménytől vásárolt formában folyósítja.

A járadékszolgáltatást úgy számítják ki, hogy a pénztártag egyéni számláján felhalmozott összeget elosztják a tag várható élettartama és a tag járadék megállapítás kori korának hónapokban megállapított különbségével. Amennyiben a számított összeg a folyósítási költségek levonása után havi szinten nem éri el a társadalombiztosítási minimum öregségi nyugdíj (az öregségi teljes nyugdíj leg- 
kisebb összege) felét, akkor a járadékot egy összegben évente fizeti a pénztár. Ha a számított összeg meghaladja ezt a küszöbértéket, akkor a járadékot havonta fizetik. A járadékot évente újra kell kalkulálni, mivel a még ki nem fizetett megtakarítás továbbra is hozamot termel. A tag halála esetén, ha még van számláján megtakarítás, akkor ezt az összeget a kedvezményezett, vagy a törvényes örökösök részére fizetik ki.

\subsection{A foglalkoztatói nyugdíjszolgáltató intézmények}

Az angolszász országokban és Nyugat-Európában sokhelyütt müködnek munkáltatói nyugdíjprogramok. Ezek célja a munkavállalói elkötelezettség növelése, a munkavállalók béren kívüli javadalmazása. Az ilyen programoknak adhatnak intézményi keretet a foglalkoztatói nyugdíjszolgáltató intézmények. Az Európai Unión belüli szabad munkaerőáramlás, a több uniós országban is működő cégek juttatási lehetőségének harmonizálása végett igény jelentkezett a foglalkoztatói nyugdíjpénztárakra vonatkozó szabályok egységesítésére. Magyarországon az európai uniós jogharmonizációval 2007-től jöhetnek létre ilyen intézmények. (Lentner, 2015) Az intézmények létrehozásának és müködésének jogi kereteit a 2007. évi CXVII. törvény a foglalkoztatói nyugdíjról és intézményeiről adja.

A foglalkoztatói nyugdíjszolgáltató intézmény az a szervezet, amelynek célja munkaviszonyhoz kapcsolódó nyugellátás biztosítása a munkáltatók és munkavállalóik között kötött megállapodás alapján. A foglalkoztatói nyugdíjszolgáltatás a munkavállalók nyugdíjának fedezésére, vagy más forrásból kapott nyugdíjának kiegészítésére szolgál. A foglalkoztatói nyugdíjszolgáltatás kiegészítő nyugdíjnak minősül. A nyugdíjszolgáltatás megkezdése kötődhet a munkavállaló öregségi nyugdíjkorhatárának eléréséhez, rokkanttá válásához vagy halálához.

Foglalkoztatói nyugdíjszolgáltató intézményt zártkörüen müködő részvénytársasági formában alapíthat bank, biztosító részvénytársaság, befektetési társaság, vagy olyan foglalkoztatók, akik vállalják, hogy munkavállalóik részére foglalkoztatói hozzájárulást fizetnek. A foglalkoztatói nyugdíjszolgáltató intézmény kizárólag foglalkoztatói nyugdíjszolgáltatási tevékenységet végezhet. Ebbe a tevékenységi körbe tartozik a foglalkoztatói nyugdíjkonstrukcióhoz kapcsolódó tartalékok képzése, a vagyon befektetése és kezelése, a foglalkoztatói hozzájárulások, a tagi kiegészítések, az egyéb bevételek beszedése. Ide tartozó tevékenység 
továbbá a nyugdíjkonstrukcióhoz kapcsolódó nyilvántartások vezetése, az intézmény müködésének biztosítása, és a foglalkoztatói nyugdíjszolgáltatás teljesítése.

Amelyik foglalkoztató a foglalkoztatói nyugdíjszolgáltató intézményen keresztül kívánja munkavállalói számára a nyugdíj-előtakarékosságot biztosítani, csatlakozhat az intézményhez. A csatlakozó foglalkoztató, amely szerződésben vállalja, hogy munkavállalói részére hozzájárulást fizet, szerződést köt a foglalkoztatói nyugdíjszolgáltató intézménnyel. Taggá az a munkavállaló válik, akivel a foglalkoztatói nyugdíjszolgáltató intézményt alapító, vagy ahhoz csatlakozó foglalkoztató olyan munkaszerződést köt, amelyben vállalja a munkavállaló részére történő hozzájárulás fizetését. A szerződésekben kiköthető egy feltételes jogszerzési idő. Ez az időtartam azt a legrövidebb munkaviszonyban eltöltött időt jelenti, amely eltelte után illetik meg csak a munkavállalót a foglalkoztató által teljesített hozzájárulások és ezek hozamai, illetve illetik az addig keletkezett jogosultságok. A jogosultságok a nyugdíjkonstrukciótól függenek, amit szintén a foglalkoztató és a nyugdíjszolgáltató intézmény közti szerződésben rögzítenek, illetve bekerül a munkavállaló munkaszerződésébe. Például a munkáltató kikötheti, hogy a munkavállalónak legalább tíz évig nála kell dolgoznia, hogy a foglalkoztatói nyugdíjra jogosulttá váljon. Ha ennyi időt eltölt nála, akkor élethossziglan, a nyugdíjkorhatár elérése után, havi 50000 forint nyugdíjat kap a munkavállalója.

A befizetéssel meghatározott nyugdíjkonstrukció esetén a hozzájárulás mértékéről, szolgáltatással meghatározott nyugdíjkonstrukció esetén az ígért nyugdíjszolgáltatásról, a munkaszerződés vagy a kollektív szerződés rendelkezik. A munkáltató kikötheti azt, hogy a munkavállalónak kiegészítést kelljen fizetnie a nyugdíjszolgáltató intézménybe.

A foglalkoztatói nyugdíjszolgáltató intézmény nyugdíjszolgáltatást nyújt, ha a tag eléri a társadalombiztosítási nyugdíjkorhatárt, illetve amennyiben a nyugdíjkonstrukcióban meghatározott rokkanttá válik. Amennyiben az adott konstrukció azt rögzíti, a kedvezményezett vagy örökös válhat jogosulttá nyugdíjszolgáltatásra a tag halálával. A foglalkoztatói nyugdíjszolgáltatás lehet egyösszegü nyugdíjszolgáltatás, határozott idejü járadékszolgáltatás, életjáradék szolgáltatás és ezek kombinációja. A tagi számlán jóváírt összeg a tag tulajdona.

A befizetéssel meghatározott nyugdíjkonstrukciónál a foglalkoztatói hozzájárulások befizetését és az esetleges tagi kiegészítések ütemezését, összegeit elö- 
re meghatározzák. A befizetések és ezek hozamainak összege alapján számítják majd ki a nyugdíjszolgáltatást.

A befizetéssel meghatározott nyugdíjkonstrukciónál a foglalkoztatói nyugdíjszolgáltató intézmény választható portfóliós rendszert működtethet. Ebben a foglalkoztatói nyugdíjszolgáltató intézmény a felhalmozási időszakban levő tagja tagi számláján összegyült megtakarítást a tag döntése alapján, vagy a nyugdíjkorhatár betöltéséig hátralevő idő alapján a különböző eszközökbe fektető portfóliók egyikébe helyezi el.

A szolgáltatással meghatározott nyugdíjkonstrukció egy előre meghatározott összegü nyugellátást tartalmaz.

A tag halála esetén a kedvezményezettként megjelölt személy vagy a törvényes örökös válhat szolgáltatásra jogosulttá.

A foglalkoztatói nyugdíjszolgáltatásokról szóló törvény több mint tíz évvel ezelőtti hatálybalépése óta a foglalkoztatói nyugdíjszolgáltatás nem vált vonzó megtakarítási formává. (2013-ban egy piaci szereplő múködött: a Quaestor Foglalkoztatói Nyugdíjszolgáltató Zrt. 2011-es alapítással.) A népszerútlenség oka lehetett a rossz időzítés, és a tőkefedezeti nyugdíjpillérek iránti bizalmatlanság is: tőkepiaci szempontból a válság, illetve magyarországi ok a nyugdíjpénztári átalakítás, jóllehet az öngondoskodás napjainkban egyre nagyobb szerepet kap életünkben. Az alternatív nyugdíj elötakarékossági formákban felhalmozódó összegekhez képest jelentéktelen szerepet játszott mindeddig a foglalkoztatói nyugdíjszolgáltatói rendszerben felhalmozott megtakarítás. 2019-ben is csak egy foglalkoztatói nyugdíjszolgáltató, a 2015-ben alapított Allianz Foglalkoztatói Nyugdíjszolgáltató müködik Magyarországon. 


\subsection{Irodalomjegyzék}

Baka Istvánné; Balogh László; Bánfi Tamás; Kürthy Gábor; Ligeti Sándor; Polgár Éva Katalin; Sulyok-Pap Márta; Száz János; Varga József; et al. (2008): Pénzügytan: Egyetemi tankönyv. Budapest, Magyarország: Tanszék Kft., 191 p.

Barta Judit (2012): Az intézményesített kötelező, avagy „kötetlen” előgondoskodás szerepe és formái Magyarországon. In: Stipta, István (szerk.) Collegium Doctorum Konferencia [elektronikus dok.] Miskolc, Magyarország: Bíbor Kiadó, (2012) p. cd

Lentner Csaba (szerk.)(2015): Adózási pénzügytan és államháztartási gazdálkodás: Közpénzügyek és Államháztartástan II Budapest, Magyarország: NKE Szolgáltató Kft.

MNB (2019): A Magyar Nemzeti Bank által felügyelt szektorok adatainak idősorai - Pénztári szektor.

Varga József (2006): Társadalombiztosítási ismeretek. In: Kövér, Ágnes (szerk.) A számvitel adózási alapjai: Számviteli alapismeretek III. Miskolc, Magyarország : Vasas-Pesti Kft, (2006) pp. 204-220. , 17 p.

1997. évi LXXXII. törvény a magánnyugdíjról és a magánnyugdíjpénztárakról 2007. évi CXVII. törvény a foglalkoztatói nyugdíjról és intézményeiről 



\section{V. rész \\ A pénzügyi \\ intézményrendszer \\ müködésének egyes \\ speciális területei}




\section{A pénzügyi szervezetek szanálása ${ }^{1}$}

\subsection{A szanálási keretrendszer kialakulása és magyarországi bevezetése}

A 2008-as globális pénzügyi válság rámutatott a korabeli válságkezelési keretrendszer számos hiányosságára. A fizetésképtelenné váló pénzügyi szervezetek válsághelyzetének kezelésére nem voltak optimális megoldások, a felügyeleti engedély visszavonását követő rendes fizetésképtelenségi eljárás (pl. felszámolás) egyetlen alternatívája az állami, és így közvetett módon adófizetői pénzek felhasználásával megvalósuló bankmentés (ún. bailout) volt.

A pénzügyi szervezetek sajátos szerepet töltenek be a gazdaságban (megtakarítások és hitelek közötti lejárati transzformáció, beruházások finanszírozása, pénzforgalom), így egy rendszerszinten jelentős pénzügyi szolgáltató kiesése nem csupán pénzügyi stabilitási, hanem nemzetgazdasági problémákhoz is vezethet. Nem véletlen tehát, hogy a több éven át tartó, többnyire jelentős értékrombolással járó felszámolási eljárás helyett a nemzetállamok számos esetben a közpénzből megvalósított bankmentés útját választották.

Az állami bankmentésekhez szükséges források mértéke gyakran külső állami forrásbevonást tett szükségessé, ami több esetben az államháztartási egyensúly megbomlásához vezetett, melynek következtében egyes országok nemzetközi segítségre szorultak (pl. Írország, Spanyolország). A bank válsághelyzet tehát több esetben az államháztartás válsághelyzetévé transzformálódott, a banki fizetésképtelenség kezelésének költségei pedig az államon keresztül végső soron az adófizetőknek, mint az államadósság visszafizetésének végső teherviselőinek vállát nyomták.

A fejlett nyugati országok vezetői felismerték, hogy a válságkezelés állami bankmentésen keresztül megvalósuló módja nem fenntartható. Keresni kellett tehát egy olyan válságkezelési technikát, amely a felszámolás alternatívájaként lehetővé teszi, hogy a rendszerszinten jelentős pénzügyi szervezet (pl. hitelintézet, befektetési vállalkozás) válsághelyzetét gyorsan és hatékonyan kezeljék, mindezt

1 Jelen írás a szerző nézeteit tartalmazza, és nem feltétlenül tükrözi az Országos Betétbiztosítási Alap vagy a Szanálási Alap hivatalos álláspontját. 
ráadásul úgy, hogy a válságkezelés anyagi terheit elsődlegesen a tulajdonosok és a pénzügyi szektor viseljék, ne pedig az adófizetők.

A megoldás egy szanálási keretrendszer kialakítása, melynek keretében erős beavatkozási jogosítványokkal ruházzák fel a szanálási hatóságokat a pénzügyi stabilitási célok érvényre juttatása érdekében és a válságkezelés költségeit elsődlegesen a tulajdonosok és a pénzügyi szektor viseli. A szanálás globális sztenderdjeit a Financial Stability Board (FSB) dolgozta ki és publikálta először 2011-ben (FSB, 2011), majd vizsgálta felül őket 2014-ben (FSB, 2014). E sztenderdek meghatározták a szanálási célokat, javaslatot tettek a szanálási hatósági jogosultságokra, a szanálási eszközökre és a szanálás finanszírozására. Az FSB sztenderdek nem minősülnek jogszabálynak, így azok lényegi elemei némi módosítással az Európai Unió (EU) jogalkotása útján, 2014-ben elfogadott irányelvi jogharmonizációs elvárások (Bank Recovery and Resolution Directive - BRRD)² közvetítésével kerültek bevezetésre az EU tagállamokban, így Magyarországon is.

A BRRD elvárásait a tagállamoknak legkésőbb 2014. december 31-ig kellett a nemzeti jogba átültetni. Magyarország az irányelv elfogadását és publikálását követően nem sokkal, az Európai Unióban elsők között, már 2014 nyarán elfogadta és hatályba léptette a pénzügyi közvetítőrendszer egyes szereplőinek biztonságát erősítő intézményrendszer továbbfejlesztéséröl szóló 2014. évi XXXVII. törvényt (szanálási törvény, röviden: Szantv.), mely tartalmazza a hazai szanálási keretrendszerre vonatkozó legfontosabb szabályokat.

\subsection{A hazai szanálási keretrendszer föbb elemei}

\section{a) Az intézményi hatály}

A szanálási keretrendszer intézményi hatálya határozza meg, hogy a szanálási keretrendszert mely intézménytípusok válsághelyzeteinek kezelésére kell alkalmazni. A szanálási jogosultságok és eszközök a pénzügyi szervezetek közül jelenleg csak egyes intézménytípusokra alkalmazhatóak. A Szantv. az Európai Uniós irányelv intézményi hatályát követve a következő szervezetekre alkalmazandó:

2 Az Európai Parlament és a Tanács 2014/59/EU irányelve (2014. május 15.) a hitelintézetek és befektetési vállalkozások helyreállitását és szanálását célzó keretrendszer létrehozásáról és a 82/891/EGK tanácsi irányelv, a 2001/24/EK, 2002/47/EK, 2004/25/EK, 2005/56/EK, 2007/36/EK, 2011/35/EU, 2012/30/EU és 2013/36/EU irányelv, valamint az 1093/2010/EU és a 648/2012/EU európai parlamenti és tanácsi rendelet módositásáról (Bank Recovery and Resolution Directive - BRRD), 
- magyarországi székhelyü hitelintézet és befektetési vállalkozás (a továbbiakban együtt: intézmény);

- magyarországi székhelyü pénzügyi holding társaság, vegyes pénzügyi holding társaság, vegyes tevékenységü holding társaság;

- olyan magyarországi székhelyű pénzügyi vállalkozás, amelyre az összevont alapú felügyelet kiterjed, amennyiben intézmény vagy a korábbi pont szerinti holding társaság leányvállalata; valamint

- harmadik országban székhellyel rendelkező intézmény magyarországi fióktelepe.

A Szantv. hatálya nem terjed ki a Magyar Fejlesztési Bank Zrt.-re és a Magyar Export-Import Bank Zrt.-re³. Az intézményi hatály alkalmazásának hazai sajátossága, hogy a Szantv. szempontjából egy hitelintézetként kell kezelni a szövetkezeti hitelintézetek hazai integrációjába tartozó szövetkezeti hitelintézeteket az Integrációs Szervezettel együtt, ha azok jogszabály alapján egyetemleges felelősségi körbe tartoznak.

A szanálási keretrendszer intézményi hatályának kiterjesztése más intézménytípusra napirenden van a globális sztenderdek és az Európai Unió szintjén is (részletesen lásd később).

\section{b) A szanálási célok}

A szanálási hatóságnak a szanálási intézkedések alkalmazásakor és a szanálási jogosultságok gyakorlásakor figyelembe kell vennie a következő szanálási célokat:

- a bármilyen formában nyújtható rendkívüli állami pénzügyi támogatás szükségességének és felhasználásának minimalizálása révén a közpénzek védelme;

- a kritikus funkciók ellátásbeli folytonosságának biztosítása;

- a pénzügyi közvetítőrendszer stabilitását veszélyeztető hatások kialakulásának kiküszöbölése vagy a kialakult hatások megszüntetése;

- a betétbiztosítási rendszer - ideértve az OBA - által biztosított betétek és a befektetésvédelmi rendszer - ideértve Befektető-védelmi Alap (a továbbiakban: Beva) - által biztosított befektetések védelme;

3 Ennek háttere, hogy a BRRD intézményi hatálya a hitelintézetek és a befektetési vállalkozások tőkemegfelelésének EU-s szabályozásának hatályához igazodik. Az utóbbi jogszabályban e két intézmény - tevékenységük speciális jellegére tekintettel - már az intézményi hatály alól kivett körbe tartozott, amit átvett a BRRD is, és a BRRD implementációja során a Szantv. is. 
- az ügyfelek pénzeszközeinek és vagyonának védelme; valamint

- a betétesek és befektetők bizalmának fenntartása a pénzügyi közvetítőrendszer stabilitása érdekében.

Fontos rögzíteni, hogy a szanálás nem az érintett intézmény megmentésére irányul, hanem az adott intézmény által ellátott kritikus funkciók fenntartásában, ami megvalósulhat ugyan az adott intézmény müködésének fenntartásával is, de akár a kritikus funkciók más intézményhez telepítésével is. Egy szanálási eljárás tehát nem garantálja, hogy a szanálás alá vont intézmény a folyamat végén tovább tudja folytatni működését.

A szanálási célok között nincs hierarchia, a lehetőségekhez képest az összes szanálási cél egyidejű megvalósítására kell törekedni.

Ezen felül a szanálási hatóságnak törekednie kell a szanálás költségeinek minimalizálására, valamint arra, hogy a szanálás következtében ne csökkenjen a szanálás alatt álló intézmény vagyoni értéke, kivéve, ha a szanálás céljának elérése miatt ez elkerülhetetlen.

\section{c) A szanálási hatóság}

A BRRD elvárása alapján minden tagállamnak ki kellett jelölnie egy vagy több nemzeti szanálási hatóságot, mely(ek) jogosult(ak) a szanálási jogosultságok gyakorlására. A hazai jogalkotó több opció alapos áttekintését követően a Magyar Nemzeti Bankot ruházta fel a szanálási jogosultságok gyakorlására, így a hazai szanálási hatóság a szanálási feladatkörében eljáró MNB lett. Vannak olyan EU tagállamok is, melyek a szanálási hatósági jogosultságok gyakorlását megosztották több intézmény között.

\section{d) A szanálási tervezés}

A sikeres válságkezelés alapja a megfelelő felkészülés a hatóságok oldaláról. E célt szolgálja a szanálási tervezés, melynek keretében a szanálási hatóság az egyedi intézményre és a csoportra még a „békeidőben” szanálási tervet készít.

Az egyedi és a csoportszintủ szanálási tervek minimális tartalmi elemeit jogszabály rögzíti, így azoknak - egyebek mellett - ki kell térnie az intézmény, illetve a csoport bemutatására, a kritikus funkciók és a fö üzletágak jogi és gazdasági elkülöníthetőségére egy fizetésképtelenségi helyzetben, az alkalmazni kívánt szanálási eszközökre, alternatív válságkezelési forgatókönyvekre, a sza- 
nálhatóság értékelésére és a szanálhatósági akadályok elhárításának módjaira, a fizetésképtelenség és a szanálási intézkedések pénzügyi piacokra és más tagállam gazdaságára gyakorolt hatásainak bemutatására, valamint a szanálási intézkedések finanszírozására.

Fontos tervezési alapelv, hogy a szanálási terv készítése során figyelmen kívül kell hagyni a bármilyen formában nyújtható rendkívüli állami pénzügyi támogatást, és az MNB vagy más központi bank rendkívüli likviditási hitelét.

A szanálási terveket rendszeresen felül kell vizsgálni. A szanálási hatóság a szanálási tervezésbe és a szanálási tervek felülvizsgálatába köteles bevonni a pénzügyi felügyeletet ellátó hatóságot.

\section{e) A szanálás alá vonás feltételei}

A szanálási hatóság elrendeli és megindítja az intézményre vonatkozóan a szanálási eljárást, ha együttesen teljesülnek a következő feltételek:

- a pénzügyi felügyelet megállapítja, hogy az intézmény fizetésképtelen vagy várhatóan fizetésképtelenné válik ${ }^{4}$ (nem szükséges tehát, hogy a fizetésképtelenség bekövetkezzen, a szanálási beavatkozáshoz elégséges a várható fizetésképtelenség megállapítása is),

- a szanálási hatóság megítélése szerint a körülményekre tekintettel nem valószínűsíthető, hogy a szanálási intézkedéseken kívül bármilyen más intézkedés - ideértve a Felügyelet, az intézmény, az önkéntes intézményvédelmi alap, a kötelező intézményvédelmi szervezet, vagy más piaci szereplö intézkedéseit, a szanálási hatóság által végrehajtható tőkeelemek leírására vagy átalakítására vonatkozó intézkedési lehetőséget is - megakadályozná az intézmény fizetésképtelenné válását,

- a szanálási hatóság megítélése szerint a szanálást közérdek indokolja.

Ha a fenti három feltétel bármelyike nem teljesül, akkor a szanálási eljárás nem rendelhető el, így ilyen esetben a fizetésképtelen intézmény felszámolási eljárásba engedhetö.

4 Fontos hangsúlyozni, hogy a „fizetésképtelenség vagy várható fizetésképtelenség” alatt a BRRD és a Szantv. nem csak a nyelvtani értelemben vett fizetésképtelenséget érti, hanem önálló fogalmat definiál rá, mely magában foglalja a felügyeleti engedély visszavonására okot adó bármely körülményt. Az angol kifejezés (",failing or likely to fail”) jobban visszaadja a jelentéstartalmat. 


\section{f) A szanálási keretrendszer garanciális elemei}

A szanálás speciális válságkezelési eljárás, mely nem minden fizetésképtelenségi helyzetben alkalmazható.

A szanálás során veszteséget viselők (pl. tulajdonosok, hitelezők) számára garanciális szabály, hogy veszteségük egyetlen esetben sem haladhatja meg annak a veszteségnek az összegét, amelyet abban az esetben kellett volna viselniük, ha az érintett intézményt szanálás helyett felszámolás alá vonják. Ez az NCWO (No Creditors Worse Off) alapelv, amely a tulajdonosok, a hitelezők és a betétbiztosító számára is garantálja, hogy a szanálás nem okozhat számukra nagyobb veszteséget ahhoz képest, mintha az érintettek a hitelintézet felszámolása során a felszámolási rangsorban hitelezőként kaptak volna követelésük után térülést. Ha az érintett szanálási eljárás lezárását követően a jogszabály által előírt független, külső értékelés mégis megállapítja, hogy valamely érintett nagyobb veszteséget viselt a szanálás finanszírozásából fakadóan, mint amennyit egy felszámolási eljárás esetén viselt volna, akkor a negatív különbözetet a Szanálási Alap köteles kompenzációként megtéríteni számára. Itt tehát anyagi kompenzációról van szó, az eredeti állapot visszaállítása nem valósítható meg.

\subsection{A szanálási eszköztár}

A BRRD négy szanálási eszköz bevezetését várta el minden tagállamtól, de ezen felül nemzeti szinten további szanálási eszközök is bevezethetők. Az EU-s szinten harmonizált szanálási eszköztár előnye, hogy egy több EU tagállamban aktív bankcsoport összehangolt szanálási válságkezelése során hagyatkozni lehet az érintett tagállamok mindegyikében bevezetett és használható szanálási eszközökre. A nemzeti szinten bevezetett addicionális szanálási eszközök alkalmazhatósága föként az érintett tagállamban tisztán belföldi tevékenységet végző intézmények esetén jöhet számításba, felhasználhatósága tehát szükségszerüen korlátozottabb.

Magyarországon eddig csak a BRRD-ben nevesített szanálási eszközök bevezetésére került sor, melyek a következők:

- vagyonértékesítés: a szanálás alá vont intézmény részének vagy egészének hatósági értékesítése piaci szereplő részére (ez a preferált eszköz az áthidaló intézmény alkalmazásával szemben, tehát ha van piaci vevő, elsődlegesen az ő részére kell értékesíteni); 
- áthidaló intézmény alkalmazása: a szanálás alá vont intézmény részének vagy egészének hatósági értékesítése ideiglenes jellegü, jellemzően csak néhány évig működő, áthidaló intézmény részére (az „áthidaló” jelző is az ideiglenes jellegre utal, hiszen ez az eszköz a tartós piaci megoldás kialakításáig tartó időszakot hidalja át);

- eszközelkülönítés: a válságkezelés során egyes vagyonelemek átruházása speciális, e célra létrehozott szanálási vagyonkezelőre;

- hitelezői feltőkésítés: ezen eszköz alkalmazása esetén a szanálási hatóság a hitelezőket hatósági kényszerrel, akár az érintett hitelezők akarata ellenére is bevonja a veszteségviselésbe és a válsághelyzetbe került intézmény feltőkésítésébe.

A szanálási eszközök alkalmazhatóak önállóan vagy egymással kombinálva is, de az eszközelkülönítés mindig csak egy másik szanálási eszközzel egyidejűleg alkalmazható.

\subsection{Szanálási kollégiumok}

Az Európai Unió egységes belső piacán számos pénzügyi szolgáltató jellemzően több tagállamban is aktív, ami a szanálási és az egyéb érintett hatóságok összehangolt tevékenységét igényli az érintett pénzügyi szolgáltatók normál működése és válsághelyzete esetén egyaránt. Erre tekintettel a nemzetközileg aktív, több EU tagállamban letelepedett, ott tevékenységet végző csoportokra a szanálási hatóságoknak szanálási kollégiumot kell létrehozniuk. A szanálási kollégium vezetője a csoport székhelye szerinti szanálási hatóság (csoportszintű szanálási hatóság).

A szanálási kollégium munkájában nem csak a szanálási hatóságok vesznek részt, hanem egy csoportszintű válsághelyzet kezelésében érintett egyéb nemzeti hatóságok és szervezetek is. Erre tekintettel a szanálási kollégiumban a csoportszintủ és a leányvállalati szanálási hatóságokon kívül tagként részt vesznek az illetékes pénzügyi felügyeletek, az illetékes minisztériumok ${ }^{5}$, a betétbiztosítási szervezetek képviselői és az Európai Bankhatóság is (utóbbi szavazati jog nélkül).

5 Jellemzöen a költségvetési kérdésekben illetékes minisztériumok, mivel egy nemzeti szinten jelentős hitelintézet válsághelyzete nem csak az adott ország pénzügyi stabilitására, hanem gazdasági helyzetére, államháztartási egyensúlyára is kihatással lehet, valamint egy szanálási válságkezelés eredménytelensége esetén szükség lehet állami beavatkozásra, melynek végrehajtása a nemzeti költségvetésre is kihatással lehet. 
Az Európai Bankhatóság minden szanálási kollégiumban részt vesz, így a legjobb gyakorlatok beazonosítása és a terjesztése révén javaslataival nagyban hozzá tud járulni a szanálási kollégiumok hatékony és eredményes múködéséhez, és az Európai Uniós keretrendszer elvárásainak egységes és következetes érvényre juttatásához. Ha az érintett csoport harmadik országban leányvállalattal vagy jelentős fiókteleppel rendelkezik, akkor megfigyelői státuszban, tanácskozási joggal az érintett ország szanálási hatósága is meghívást kaphat a szanálási kollégium ülésére.

A szanálási kollégiumok fö célja, hogy a tagok rendszeresen egyeztessenek és együttes döntéseket hozzanak - egyebek mellett - a csoportszintű szanálási tervről, a csoportszintű szanálhatóság értékeléséről, gondoskodjanak az esetleges szanálhatósági akadályok elhárításáról, valamint hangolják össze lépéseiket egy határon átnyúló válsághelyzet kezelése során. A kollégiumok működése nem szorítkozik az évente legalább egy alkalommal tartott ülésekre, számos témakörben az ülések között is rendszeres írásos és telefonos egyeztetések zajlanak.

A szanálási feladatkörében eljáró MNB csoportszintű szanálási hatóságként felel a hazai székhelyü OTP csoportra létrehozott szanálási kollégium müködtetéséért és tagként vesz részt más európai bankcsoportokra (pl. Erste, Raiffeisen, UniCredit) létrehozott szanálási kollégiumok munkájában.

A szanálási kollégiumok speciális formája az európai szanálási kollégium, melyet akkor kell létrehozni, ha harmadik országbeli intézménynek vagy harmadik országbeli anyavállalatnak (pl. a kínai székhelyủ Bank of China csoportnak) legalább két EGT tagállamban van leányvállalata vagy jelentős fióktelepe. Az európai szanálási kollégiumnak a hivatkozott EGT-beli intézmények vonatkozásában kell a szanálási kollégium feladatait ellátnia, egyéb vonatkozásokban az európai szanálási kollégium a szanálási kollégium szabályai szerint működik.

\subsection{A szanálás finanszírozása}

A szanálási keretrendszer egyik jellemzője, hogy a szanálási válságkezelés költségeit az állami, és így közvetetten az adófizetői tehervállalás elkerülése érdekében, a pénzügyi szektor tagjaira hárítja. Ennek megvalósítására szanálásfinanszírozási keretrendszer jött létre, melynek központi eleme Magyarországon a Szanálási Alap, illetve kisebb mértékben az Országos Betétbiztosítási Alap szanálási szerepvállalása. 


\subsubsection{A Szanálási Alap}

A szanálási irányelv minden EU tagállamtól elvárja, hogy hozzon létre nemzeti szinten szanálásfinanszírozási rendszert, melyet a hitelintézetek és a befektetési vállalkozások rendszeres befizetéseiből töltenek fel. Magyarországon jogszabály hozta létre budapesti székhelyü jogi személyként a Szanálási Alapot 2014-ben, melyhez köteles volt csatlakozni és befizetést teljesíteni minden hazai hitelintézet $^{6}$ és befektetési vállalkozás. A Szanálási Alapot négytagú igazgatótanács irányítja, önálló munkaszervezete nincs, az operatív feladatokat az Országos Betétbiztosítási Alap munkaszervezete látja el. A Szanálási Alap a rá vonatkozó speciális szabályok alapján készíti el és teszi közzé honlapján éves beszámolóját minden év május 30-ig7.

\subsubsection{A Szanálási Alap forrásai}

A Szanálási Alap forrásai a következők:

- a tagok befizetései (egyszeri csatlakozási díj, rendszeres éves díj, illetve szükség esetén rendkívüli befizetés),

- külső forrás bevonása (hitelfelvétel vagy hitelviszonyt megtestesítő értékpapír kibocsátása),

- egyéb bevétel (pl. szanálásfinanszírozásból származó pozitív eredmény).

A Szanálási Alap számára a jogszabály minimális feltöltöttségi célszintet határoz meg. Ennek alapján a Szanálási Alap vagyonának egy 10 éves feltöltési időszak alatt, legkésőbb 2024. december 31-ig el kell érnie a Magyarországon engedélyezett hitelintézetek biztosított betétállománya kártalanítási összeghatárának legalább 1\%-át. Ez a jogszabály által elvárt minimum célszint, melynél a Szanálási Alap igazgatótanácsa magasabb célszintet is kitűzhet.

Az állam a Szanálási Alap - a Kormány által jóváhagyott összegü - külső forrásbevonásának visszafizetéséért készfizető kezesként felel. A készfizető kezességért a Szanálási Alap kezességvállalási díjat fizet. A Magyar Nemzeti Bank semmilyen formában nem finanszírozhatja az Alapot, tehát még áthidaló kölcsönt sem nyújthat a Szanálási Alap részére.

6 A Szantv. hatálya nem terjed ki a Magyar Fejlesztési Bank Zrt.-re és a Magyar Export-Import Bank Zrt.-re, így ezen hitelintézetekre nem vonatkozott a csatlakozási kötelezettség.

7 A Szanálási Alap éves beszámolóinak elérhetősége: https://www.szanalasialap.hu/szanalasialap/eves-jelentes/ 


\subsubsection{A Szanálási Alap vagyonának felhasználási lehetőségei}

A Szanálási Alap vagyona a szanálási intézkedések megvalósítását szolgálja, így felhasználása is ezekhez kötődik. Néhány kiemelt cél, melyre a vagyon felhasználható, akár egymással is kombinálva a felhasználási célokat:

- a szanálás alatt álló intézmény, annak leányvállalatai, áthidaló intézmény vagy szanálási vagyonkezelő eszközeinek és kötelezettségeinek garantálása;

- a szanálás alatt álló intézmény, annak leányvállalatai, áthidaló intézmény vagy szanálási vagyonkezelő részére történő hitelnyújtás;

- a szanálás alatt álló intézmény eszközeinek megvásárlása;

- áthidaló intézménynek vagy szanálási vagyonkezelőnek nyújtott tőkehozzájárulás;

- kártalanítás az OBA, a tulajdonosok és a hitelezők részére, ha a szanálás során kedvezőtlenebb helyzetbe kerülnek, mint amibe felszámolás esetén kerültek volna.

\subsubsection{Az Országos Betétbiztosítási Alap szanálásfinanszírozási szerepe}

A több mint 25 éve létező, a hitelintézetek befizetéseiből működő Országos Betétbiztosítási Alap elsődleges szerepe a betétesek kártalanítása, de a betétbiztosításra vonatkozó EU irányelv elöírja, hogy az EU tagállamok betétbiztosítási rendszerei kötelesek hozzájárulni a szanálás finanszírozásához, ha a szanálás révén a betétesek betétekhez való folyamatos hozzáférése biztosított és a betétbiztosító általi kártalanítási kifizetés így elkerülhetővé válik.

Az OBA szanálásfinanszírozási szerepvállalása nem haladhatja meg a célszint $50 \%$-át, azaz a biztosított betétek kártalanítási értékhatárt meg nem haladó részének $0,4 \%$-át ${ }^{8}$.

Magyarországon még nem került sor az OBA szanálásfinanszírozási szerepvállalására.

\subsection{Az MKB Bank Zrt. szanálása}

A hazai szanálási keretrendszeren alapuló első és eddigi egyetlen szanálás az MKB Bank Zrt. (MKB Bank) szanálási eljárása volt 2014 és 2016 között. Az MKB

8 Az OBA szanálásfinanszírozási szerepe kapcsán lásd részletesebben Kómár-Sulyok (2018). 
Bank esetében a szanálási feladatkörében eljáró Magyar Nemzeti Bank 2014 decemberében rendelte el a szanálást, mivel a bank vonatkozásában mindhárom szanálási feltétel egyidejűleg teljesült és hatósági beavatkozás nélkül az MKB Bank 12 hónapon belül várhatóan fizetésképtelenné vált volna.

A szanálási hatóság két szanálási eszközt alkalmazott: a vagyonértékesítést és az eszközelkülönítést. Elsődlegesen egyes banki portfóliók piaci értékesítését kísérelte meg a szanálási hatóság, majd eszközelkülönítés keretében leválasztásra jelölt ki bizonyos eszközöket. Az eszközelkülönítés megvalósíthatósága érdekében a Szanálási Alapnak új intézményként létre kellett hozni egy szanálási vagyonkezelőt, az MSZVK Magyar Szanálási Vagyonkezelő Zrt.-t, mely átvette az MKB Banktól a szanálási hatóság által leválasztásra kijelölt eszközöket (technikailag két céget vásárolt meg az MKB Banktól, melyekbe előzetesen elhelyezésre kerültek a leválasztandó banki eszközök, föként követelések és ingatlanok). A szanálási vagyonkezelőt ugyan 100\%-os részesedéssel a Szanálási Alap hozta létre, és gondoskodott a finanszírozásáról, de a szanálási vagyonkezelő fölött a tulajdonosi jogokat jogszabályi előírások alapján mindig a szanálási hatóság gyakorolja. A szanálási akcióterv kapcsán részletesen lásd az 1. ábrát.

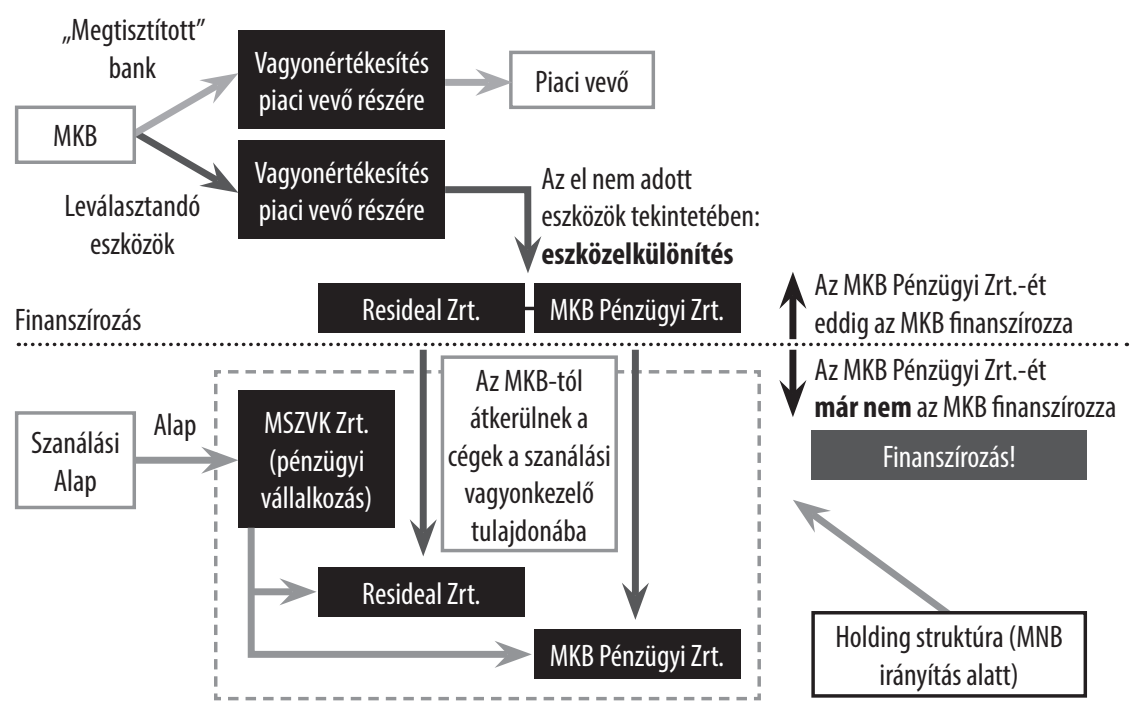

Megjegyzés: Az MKB Pénzügyi Zrt. cégneve az eszközátruházást követöen, az MKB-tól való intézményi elkülönülés hangsúlyozása érdekében Szanálási Követeléskezelö Zrt.-re (SZKK Zrt.) módosult.

1. ábra: Az MKB Bank Zrt. szanálásának akcióterve Forrás: Földényi et al. (2016, p. 12.) 
A szanálás 2016-ban sikeresen lezárult, az MKB Bank értékesítésre került szakmai befektetők részére és a szanálási eljárás lezárását követően visszatért a normál müködésbe. Az MKB Bank szanálásáról részletesebben lásd Földényi et al. (2016).

\subsection{A szanálási keretrendszer jövője}

A szanálási keretrendszer fejlődésének és elterjedésének globális és Európai Uniós trendjei nagy valószínűséggel már rövid- és középtávon is kihatnak a hazai keretrendszerre, ezért zárásként érdemes ezek közül néhányat röviden kiemelni:

a) A szanálási keretrendszer megjelenése globálisan egyre több országban

A szanálási keretrendszerek kezdetben a 2008-as pénzügyi válság által leginkább érintett fejlett országokban (pl. USA, EU) jelentek meg, de időközben más régiók (pl. Ázsia, Dél-Amerika) országaiban is bevezetésre kerültek, még ha kezdetben csak részlegesen, szűkebb szanálási eszköztárral is. Ez a pénzügyi piacok globalizációja és egy-egy pénzügyi szolgáltatást nyújtó több kontinensre kiterjedő tevékenysége miatt is egyre fontosabb szerepet játszik, hiszen pl. egy globális bankcsoport válsághelyzetének kezelése a nemzeti intézkedések összehangolását igényli, melyhez nagy segítséget jelent a globális sztenderdekre épülő nemzeti szanálási keretrendszerek léte az érintett országokban.

b) A szanálási keretrendszer intézményi hatályának fokozatos kiterjesztése A szanálási keretrendszerek intézményi hatálya kezdetben a hitelintézetekre és a befektetési vállalkozásokra terjedt ki (Magyarországon jelenleg is ez a helyzet), de már régóta vizsgálat tárgyát képezi az intézményi hatály kiterjesztése más intézménytípusokra (pl. biztosítók, befektetési alapok, központi szerződő felek). E mögött az a felismerés áll, hogy a pénzügyi stabilitásra többféle pénzügyi szervezet irányából is leselkedhet veszély, melynek állami és adófizetői források kíméletével végrehajtott kezeléséhez a jelenlegi keretrendszer intézményi hatályának kiszélesítése szükséges. A pénzügyi szervezetek eltérő sajátosságaira tekintettel egy ilyen bővítés nem automatikusan a jelenlegi szanálási szabályokat rendelné alkalmazni további intézménytípusokra. A szektorálisan jelentkező egyedi intézményi sajátosságok megjelenhetnek akár eltérő szanálási intézkedések képében is. 


\section{c) A szanálási eszköztár bővülése}

Az Európai Unióban a szanálási eszköztár minimum harmonizáció tárgya, tehát nemzeti szinten az EU-s szinten meghatározott négy szanálási eszközön kívül továbbiak is bevezethetők. Ráadásul a szanálási keretrendszer intézményi hatályának bővítése bizonyos intézményeknél (pl. központi szerződő felek) szükségszerűen vezet új típusú szanálási eszközök megjelenéséhez.

d) A szanálásfinanszírozási rendszerek közötti kapcsolat intenzívebbé válása és a mögöttes garanciarendszerek bövülése

A pénzügyi szervezetek globalizálódó tevékenysége szükségessé teszi a nemzeti szanálásfinanszírozó rendszerek közötti fokozott együttműködést, mivel azok formája és teherviselő képessége, így finanszírozási mozgástere, földrészenként és régiónként jelentős eltéréseket mutathat. Figyelemmel arra, hogy önmagában egy előzetesen (ex ante) feltöltött pénzalap is kevésnek bizonyulhat több pénzügyi szervezet egyidejű válsághelyzete kezelésének finanszírozásához, szükségesek olyan mögöttes garanciamechanizmusok (backstop mechanism), melyek garantálják, hogy a szanálás terheit végső soron mindenképpen a pénzügyi szektor intézményei és nem az adófizetők viselik.

A fentiek alapján elmondható, hogy a viszonylag új szanálási keretrendszer - részben az eddigi gyakorlati tapasztalatok alapján, részben pedig a szabályozói célkitűzésekhez igazodóan - folyamatos fejlődésben van, hogy a pénzügyi stabilitás minél erősebb pillére lehessen.

\subsection{Irodalomjegyzék}

Financial Stability Board [FSB] (2011): Key Attributes of Effective Resolution Regimes for Financial Institutions, 2011. október, letöltve 2019. március 18án a http://www.fsb.org/wp-content/uploads/r_111104cc.pdf linkről.

Financial Stability Board [FSB] (2014): Key Attributes of Effective Resolution Regimes for Financial Institutions (revised version), 2014. október 15., letöltve 2019. március 18-án a http://www.fsb.org/wp-content/uploads/r_141015. pdf linkről 
Gyura Gábor (2014): Szanálás: bankmentés másként, MNB szakmai cikk, letöltve 2019. március 13-án a https://www.mnb.hu/letoltes/gyura-gabor-szanalas-bankmentes-maskent.pdf linkről

Huertas, Thomas F. (2014): A szanálás reformja, Hitelintézeti Szemle, 2014, 13. évfolyam, 4. szám, 86-101.old., letöltve 2019. március 13-án a http://www. hitelintezetiszemle.hu/letoltes/4-huertas-2.pdf linkről

Kómár András (2014): Létrejön a Szanálási Alap! - Ezentúl nem az adófizetők finanszírozzák a bankmentéseket, MNB szakmai cikk, letöltve 2019. március 13-án a https://www.mnb.hu/letoltes/szakmai-cikk-komar-andras-a-szanalas-finanszirozasa.pdf linkről

Földényiné Láhm Krisztina - Kómár András - Stréda Antal - Szegedi Róbert (2016): Bankszanálás mint új MNB-funkció - az MKB Bank szanálása, Hitelintézeti Szemle, 2016. szeptember, 15. évfolyam 3. szám, 5-26.o., letöltve 2019. március 13-án a http://www.hitelintezetiszemle.hu/letoltes/foldenyine-lahm-krisztina-komar-andras-streda-antal-szegedi-robert.pdf linkről

Kómár András - Sulyok András (2018): A betétbiztosítók alternatív szerepkörei, különös tekintettel a szanálási szerepvállalásra, Gazdaság és Pénzügy, OBA különszám, letöltve 2019. március 16-án a http://www.bankszovetseg.hu/Public/gep/2018/2018\%20K\%C3\%BCl\%C3\%B6nsz\%C3\%A1m\%20 \%28HUN\%29/GP_39-54\%20komar-sulyok.pdf linkről

\section{Felhasznált jogszabályok}

Az Európai Parlament és a Tanács 2014/49/EU irányelve (2014. április 16.) a betétbiztosítási rendszerekről (Deposit Guarantee Schemes Directive - DGSD)

Az Európai Parlament és a Tanács 2014/59/EU irányelve (2014. május 15.) a hitelintézetek és befektetési vállalkozások helyreállítását és szanálását célzó keretrendszer létrehozásáról és a 82/891/EGK tanácsi irányelv, a 2001/24/EK, 2002/47/EK, 2004/25/EK, 2005/56/EK, 2007/36/EK, 2011/35/EU, 2012/30/ EU és 2013/36/EU irányelv, valamint az 1093/2010/EU és a 648/2012/EU európai parlamenti és tanácsi rendelet módosításáról (Bank Recovery and Resolution Directive - BRRD),

A pénzügyi közvetítőrendszer egyes szereplőinek biztonságát erősítő intézményrendszer továbbfejlesztéséről szóló 2014. évi XXXVII. törvény

A betétbiztosítási alapok és intézményvédelmi alapok, valamint a befektető-védelmi alap éves beszámoló készítési és könyvvezetési kötelezettségének sajátosságairól szóló 214/2000. (XII. 11.) Korm. rendelet 


\section{Honlapok}

A Szanálási Alap honlapja: https://www.szanalasialap.hu/

A Magyar Nemzeti Bank honlapjának szanálási aloldala: https://www.mnb.hu/ szanalas

Az Európai Bizottság honlapjának szanálási szabályozásra vonatkozó aloldala: https://ec.europa.eu/info/business-economy-euro/banking-and-finance/ financial-supervision-and-risk-management/managing-risks-banks-and-financial-institutions/bank-recovery-and-resolution_en 


\section{Az OBA, a BEVA és a Szövetkezeti Hitelintézetek Tökefedezeti Közös Alapja müködésének jellemzői}

\subsection{Nemzetközi kitekintés}

A betétesek bankcsőd esetén pánikhelyzetet idézhetnek elö, amely az egész ország bankrendszerét és gazdaságát recesszióba taszíthatja (Baranyi - Széles, 2010).

Erre volt példa az Egyesült Államokból kiinduló nagy gazdasági válság, így nem véletlen, hogy a világ első betétbiztosítási rendszerét itt hozták létre 1933-ban. A Federal Deposit Insurance Company (FDIC) volt az, amely lefektette a betétbiztosítási rendszer alapvető szabályait (Kenesey et al., 2017).

1994 óta létezik az Európai Uniós irányelv, amely előírja a tagállamoknak, hogy - ha addig nem lett volna - hozzanak létre betétbiztosítási alapot. Az akkor megalkotott direktíva harmonizálta a tagállamok betétbiztosítási szabályait, meghatározta a betétesek védelmére vonatkozó legfontosabb irányelveket, de a közelmúltig nem tartalmazott ezen felül túl sok konkrétumot az EU-s szabályozás.

$\mathrm{Az}$ is mindegy volt, hogy az alap vagyonát elöre gyüjtik össze a hitelintézetek (ex ante), vagy utólag, amikor már kiderült, hogy baj van (ex post rendszer). Ez utóbbi rendszert alkalmazta például Németország, Ausztria és az Egyesült Királyság is (Bakó, 2016).

Az Európai Bizottság 2015-ben azt a javaslatot tette, hogy 2024-ig hozzanak létre egy európai szintű betétbiztosítási rendszert, vagyis egy olyan közös alapot (EDIS), amely összekapcsolná a nemzeti betétbiztosítási rendszereket. Az alapot a bankok finanszíroznák több éven át, egészen addig, amíg az alap rendelkezésére álló összeg el nem éri az 55 milliárd eurót. Ez a közös rendszer Európa-szerte számlánként 100000 euró összegig biztosítaná a bankbetéteket, de csak akkor, ha az adott nemzeti alap forrásai már kimerültek. Az európai betétbiztosítás lenne az utolsó pillére az úgynevezett bankuniónak, amelynek az a célja, hogy biztonságosabbá tegye a bankszektort (Széles - Baranyi, 2016). 
Az EDIS csak az eurózóna tagállamai részére lenne kötelező, a saját pénznemet használó EU-tagállamok önkéntesen csatlakozhatnának. ${ }^{1}$

Az Európai Parlament és a Tanács még nem döntöttek a tervekről.

Az Európai Parlament és az Európa Tanács betétbiztosítási rendszerekre vonatkozó irányelve szerint minden tagállamban müködnie kell legalább egy betétbiztosítási rendszernek (Tóth, 2015).

Megjegyezzük, hogy az Európai Unión belül a betétbiztositás kötelező szolgáltatási minimumát Uniós elöírás rögzíti.

Mind globálisan, mind pedig Európában a betétbiztosítás sikerességét fémjelzi, hogy az utóbbi időben, Görögország és Ciprus kivételével, a bankokból való pénzkimenekítések még a gyakoribbá vált bankcsődök ellenére sem váltak általánossá. Ez jelentős részben annak köszönhető, hogy a betétbiztosítás intézményrendszere a kritikus helyeken és időben helyt tudott állni, avagy a betétesek elhitték, hogy szükség esetén képes hatékonyan ellátni a feladatát, így a betétbiztosítás ismereti szintje és társadalmi elfogadottsága elegendő volt ahhoz, hogy a pánikhatások elmaradjanak. Ez jelentős bizalmi tőkére utal (Kovács, 2018).

\subsection{A hazai betétbiztosítási rendszer jellemzői}

A kétszintű bankrendszer 1987. évi létrejöttét közvetlenül követően hazánkban nem jött még létre azonnal a betétvédelem intézményesített formája.

1993-ig a lakossági betéteket és a devizabetéteket az állam garantálta.

Hazánkban az Országos Betétbiztosítási Alapot (OBA) 1993-ban betétgyüjtésre felhatalmazott pénzügyi intézmények hozták létre, s a továbbiakban is ők teremtik elő az Alap vagyonát. Az Alap létrehozásáról az 1993. évi XXIV. törvény rendelkezett, az OBA működésével kapcsolatos elöírásokat jelenleg a 2013. évi CCXXXVII. törvény (Törvény a hitelintézetekről és a pénzügyi vállalkozásokról, a továbbiakban Hpt.) X. fejezete tartalmazza.

A betétbiztosítás összességében hasonlóan müködik a hagyományos biztosítási tevékenységhez, hiszen mindkét esetben az adott kockázatközösség befizetéseket teljesít a biztosítás tárgya kapcsán, a biztosító pedig a felhalmozott va-

1 www.consilium.europa.eu 
gyonból fizeti ki a károsultakat. A kettő közti különbség, hogy míg a biztosító profitot realizál, addig a betétbiztosító közérdeket szolgál non-profit szervezetként (Kenesey, 2015).

Betétet csak hitelintézet fogadhat el, a magyarországi székhelyü hitelintézetek kötelesek csatlakozni a magyar betétbiztosítás rendszeréhez (OBA tagok). A hitelintézetek közé tartoznak a bankok, takarékszövetkezetek, hitelszövetkezetek, lakás-takarékpénztárak. Az OBA betétbiztosítási szolgáltatása tehát csak a tagintézeteire, valamint ezek külföldi fiókjaira terjed ki, de ez utóbbiakra csak akkor, ha az adott ország szabályai ezt lehetővé teszik.

A hitelintézetek számára az OBA-hoz való csatlakozás tehát kötelező, ez alól kivételt csak harmadik országnak hazánkban létesített fióktelepe képez, amennyiben rendelkezik az Európai Parlament, illetve az Európa Tanács 2014/49/EU számú irányelvének megfelelő egyenértékű betétbiztosítással. (Önkéntes alapon még ez esetben is csatlakozhat az OBA-hoz.)

Az OBA önálló jogi személynek minősül, amely nonprofit módon gazdálkodik. Jogállásának specialitásai közé tartozik, hogy nem minősül társaságnak, ugyanakkor költségvetési intézménynek sem. Ellenőrzését az Állami Számvevőszék végzi, adófizetésre nem kötelezett. Rendelkezésre álló pénzeszközeit csak a betétesek kártalanítására használhatja fel, illetve a szabad pénzeszközeiből állampapírokat vásárolhat. Az Állami Számvevőszék az ellenőrzési tapasztalatairól az Országgyülésnek köteles beszámolni.

Az Országos Betétbiztosítási Alap létrehozásának alapvető célja az volt, hogy a pénzügyi intézmények esetlegesen felmerülő megoldhatatlan likviditási problémái esetén elsődlegesen a pénzügyekben kevésbé járatos kis betétesek pénze - legalábbis bizonyos összeghatárig - biztosított legyen, esetleges bankválság esetén a tovagyürüző hatások („dominó effektus”) mérsékelhetővé váljanak, s ezen keresztül a pénzügyi rendszer stabilitása biztosítható legyen.

Az OBA legfontosabb feladata napjainkban is az, hogy bankcsőd esetén a felhalmozott vagyonából kártalanítsa a betéteseket, s ezáltal megakadályozza, hogy a bankrendszerrel szembeni bizalmatlanság bankcsődök sorozatához vezessen.

Az Országos Betétbiztosítási Alapot egy hét tagú független igazgatótanács irányítja, amelyben képviselői útján a hazai pénzügyi világ szinte valamennyi szereplője képviselteti magát. 
Az OBA tagintézményeinek a csatlakozásukkor egyszeri csatlakozási díjat kell fizetniük, s e mellett az OBA tagjai évi rendszerességgel befizetéseket kötelesek teljesíteni az Alapba („éves tagdíj”). A csatlakozási díj a csatlakozni kívánó pénzintézet jegyzett tőkéjének fél százaléka. Az éves rendszeres tagdíj két komponensből áll össze: alapdíjból, valamint kockázat alapú változó díjból. A kockázat alapú díj megállapítása során a következőkre kell figyelemmel lenni: a hitelintézet tőkehelyzete, likviditási és finanszírozási helyzete; a hitelintézet eszközeinek a minősége; a hitelintézet egyéb kockázati mutatói, stratégiai terve és üzleti modellje.

Amennyiben egy hitelintézet olyan kockázatos tevékenységet folytat, amely indokolja az emelést, akkor az OBA növelheti a hitelintézet által a tárgyév során fizetendő díjat. Ennek megtörténte előtt azonban véleményt kell kérnie jegybanki feladatkörében az MNB-től és a Felügyelettől, valamint biztosítania kell a hitelintézet számára az észrevételezés jogát.

Amennyiben az OBA a kártalanítási kötelezettségének teljesítése érdekében kölcsönfelvételre, illetve kötvény kibocsátásra kényszerül, akkor ezek visszafizetésének (törlesztésének) érdekében rendkívüli fizetési kötelezettséget is elöírhat a tagintézetek felé. A rendkívüli fizetési kötelezettség éves mértéke azonban nem haladhatja meg a díjfizetési alap fél százalékát. Ez alól egyetlen esetben lehet kivételt tenni, mégpedig akkor, ha az OBA által felvett kölcsön vagy az általa kibocsátott kötvény összege meghaladja a kártalanítási kötelezettségének hatálya alá tartozó betétállomány (biztosított betétállomány) 0,8 százalékát. Ez esetben a Felügyelet jóváhagyásával magasabb összegű befizetéseket is elő lehet írni (Hpt.).

Természetesen nem elvárható - és nem is lenne racionális -, hogy az egyes országok betétbiztosítóinak vagyona elérje, vagy akár csak megközelítse az általuk biztosított betétek összértékét. A betétbiztosítási rendszerekről szóló Európai Uniós irányelv (az Európai Parlament és a Tanács 2014/49/EU irányelve) 2024-re várja el, hogy a betétbiztosítók vagyona elérje a biztosított betétállomány 0,8 százalékát.

Az Alap az összegyưlt vagyonból és annak hozamából látja el a feladatait. Az Alap a rendszeres befizetéseken túl - a betétesek kártalanítása céljából, mint ahogy az előzőekben tárgyaltuk - rendkívüli befizetési kötelezettséget is előírhat a tagjai számára, s ezen túlmenően kormánygaranciával biztosított hitelt 
is felvehet, illetve kötvényt bocsáthat ki. Ebből adódóan a jogosult ügyfelek kártalanításának nem lehet anyagi akadálya.

Az OBA müködésének lényege a következőképpen foglalható össze:

A hitelintézetek fizetésképtelensége esetén kártalanítást fizet a névre szóló betétek után. (Névre szólónak azok a betétek tekinthetők, amelyek tartalmazzák a betétes adatait. A pénzmosás elleni küzdelem egyik eszközeként hazánkban 2001. december 19. óta csak névre szóló betéteket lehet elhelyezni, de találhatók az intézményrendszerben - természetesen nem jelentős mennyiségben még 2001 előtt elhelyezett, s nem nevesített betétek is.) Fontos azonban tudni, hogy nem minden névre szóló befektetésre vonatkozik az OBA garanciája. Például a részvények is lehetnek névre szólók, még sincs rájuk garancia, mivel nem minősülnek betétjellegü terméknek.

A törvény a kifizetés (kártalanítás) felső határát jelenleg 100000 euróban határozza meg az EU-s irányelvnek megfelelően. Mivel a kifizetés Magyarországon forintban történik, így az átszámítást a kártalanítás kezdő időpontját megelöző napon érvényes devizaárfolyamon kell elvégezni. A devizabetétesek kártalanítása is hazai fizetőeszközben történik az előzőekben ismertetett árfolyamon. A kifizetés maximált összege a banknál elhelyezett betétekre és azok kamataira együttesen vonatkozik. Ha tehát például a betétesnek az adott hitelintézetnél elhelyezett folyószámlájának, lekötött betéteinek, illetve bank által kibocsátott forrásgyüjtési célú értékpapírjainak együttes összege eléri, vagy meghaladja a 100000 eurót (illetve annak forintra átszámított értékét), akkor már az időarányos kamat nem kerülhet kifizetése. (Természetesen a 100000 euró forint értékét meghaladó betéti összeg sem.) A betétbiztosításnál jelenleg önrészt nem kötnek ki. A betétesek ugyanazon hitelintézetnél elhelyezett forint és devizabetétei összevonásra kerülnek s együttesen vonatkozik rájuk a kifizetési összeghatár.

Nézzünk a fentiekre egy példát:

Egy magánszemélynek egy adott hitelintézetben van 15500000 forintnyi lekötött forintbetéte, valamint 50000 eurónyi devizabetéte. A lekötés időtartama alatt a hitelintézet fizetésképtelenné válik. A fizetésképtelenné válásig megszolgált idöarányos kamat a forintbetét esetében 500000 forint, a devizabetét esetében pedig 600 euró volt. A kártalanitás kezdő időpontját megelöző napon érvényes devizaárfolyam 320 HUF/EUR. Mekkora kártalanitásra számithat a betétes? 
Az 50000 euró forintra átszámitott értéke: 16000000 forint. A 100000 eurós kártalanitási összeghatár 32000000 forintnak felel meg ebben az esetben. Ez azt jelenti, hogy a befektetett tőkét (15 500000 forint +16000000 forint), valamint a forintbetéten realizálódott kamatot kártalanitásként megkapja az ügyfél, de ezzel kimerítette a kártalanitás összeghatárát, s így a devizabetéten realizált kamattól már elesik.

A kártalanítási összeghatár egyébként az OBA létrehozását követően hosszú időn keresztül csak 1 millió forint volt, amelyet később 3 millió forintra emeltek. Az Európai Uniós csatlakozással egy időben, tehát 2004. május 1-jétől ez a kártalanítási összeghatár 6 millió forintra emelkedett. Ugyanettől az időponttól kezdődően került bevezetésre a betétesi önrész intézménye. Egy esetleges betétbefagyás esetében végbemenő kártalanítás során ez a következőt jelentette: 1 millió forintos összeghatárig a befagyott betét összegének 100 százalékát, afölött viszont csak 90 százalékát fizette volna ki az OBA, de maximum betétesenként és hitelintézetenként 6 millió forintot.

2008 októberében - a pénzügyi-gazdasági válság hatására - a kártalanítási összeghatárt 13 millió forintra emelték, s ezzel párhuzamosan megszüntették a betétesi önrészt is. A bankokba vetett bizalom erősítése érdekében a 13 millió forint fölötti betéti összegekre az állam vállalt garanciát. 2009-ben a kártalanítási összeg-határt - mint korábban említettük - 50000 eurónak megfelelő forint öszszegre módosították. A 100000 eurónak megfelelö összeghatárt 2011. január elsejétől vezették be.

Fontos megemlíteni, hogy törvényben meghatározott speciális esetekben ezt az értékhatárt meghaladóan további, legfeljebb 50000 euró összeghatárig is fizethető kártalanítás.

Ilyen, a kártalanítás általános értékhatárát meghaladó kifizetésre jogosultak azok a természetes személyek, akiknek betétje:

- lakáseladás vételárából,

- lakásbérleti jog vagy lakáshasználati jog eladásából származó vételárból,

- munkaviszony megszűnéséhez vagy nyugdíjhoz kapcsolódó juttatásból,

- biztosítási összegből vagy

- bűncselekmény áldozatainak vagy tévesen elítélteknek járó kártérítésből áll.

Ennek a magasabb összegű biztosítottságnak azonban feltétele, hogy az összeget a hitelintézetnél a kártalanítás kezdő időpontját megelőző 3 hónapban elkülöní- 
tett számlán helyezték el, s az eredetét igazolni kell (pl. 30 napnál nem régebbi ingatlan adásvételi szerződéssel, 30 napnál nem régebbi munkáltatói igazolással, a biztosító 30 napnál nem régebbi igazolásával).

A biztosítás minden hitelintézetre külön-külön érvényes. Ha tehát egy betétes több hitelintézetnél helyez el betéteket, akkor mindenhol biztosítottá válik az előzőekben említett összeghatárig.

A következőkben tekintsük át, hogy kikre vonatkozik az OBA garanciája. Néhány kivételtől eltekintve az OBA által nyújtott védettség mindenkire vonatkozik, aki Magyarországon hitelintézetben, névre szólóan betétet helyez el, illetve 2003. január elsejét követően bank által kibocsátott kötvényt, vagy letéti jegyet vásárol. Ez a lehetőség csak a 2015. július 2-ig kibocsátott banki értékpapírokra vonatkozik. (Felhívjuk a figyelmet arra, hogy a nem banki kibocsátású kötvényekre az OBA garanciája nem vonatkozik.) A garancia kiterjed például a magánszemélyekre, a vállalkozásokra, az egyesületekre, az alapítványokra és az ügyvédi letéti számlákra is. Természetesen az OBA garanciája kiterjed a magyarországi székhelyű hitelintézetek külföldi fiókjaiban elhelyezett betétjellegű termékekre is. Ezzel kapcsolatban érdemes megemlíteni, hogy ilyen esetben a kártalanítás nem forintban, hanem a fióktelep országának devizanemében történik.

Hasznos tudni, hogy az egyéni vállalkozó elkülönül a magánszemélytől, tehát a magánszemélyként elhelyezett betéteire és az egyéni vállalkozásának számláira és betéteire külön-külön érvényes a 100000 eurónak megfelelő értékhatár.

Ugyanakkor nem vonatkozik OBA védettség például a 150000 eurónál nagyobb éves költségvetésü önkormányzatok, a biztosító társaságok, illetve a befektetési alapok által elhelyezett betétekre.

Hasonlóképpen nem terjed ki az OBA garanciája a költségvetési szervek, a pénzügyi intézmények, a befektetési szolgáltatók és a magánnyugdíjpénztárak betéteire sem.

Az OBA által nyújtott védettség mindig a betét tulajdonosára vonatkozik, tehát a meghatalmazott nem élhet vele.

A bankok rendszeresen kínálnak olyan megtakarítási formákat is, amelyekre nem vonatkozik az OBA általi védettség. Ebbe a körbe sorolhatók például a zártvégü és a nyílt végü befektetési alapok befektetési jegyei, vagy az önkéntes 
nyugdíjpénztári megtakarítások, esetleg a szövetkezeti részjegyek. A megtakarítások elhelyezése előtt a megtakarítóknak éppen ezért tájékozódniuk szükséges a megtakarítás védettségével kapcsolatban.

E tekintetben 2012-ig segítséget jelentett az ún. Betétregiszter felhasználása. A Betétregiszter tartalmazta az OBA tagintézetek által forgalmazott (vagy korábban forgalmazott, de még visszaváltható), az Alap általi biztosítási védelemben részesülő valamennyi betéti konstrukciót. 2012 óta az ügyfelek az adott termék biztosítottságának tényét a banki tájékoztató anyagon elhelyezett fogyasztóvédelmi embléma segítségével ellenőrizhetik.

2011-ben került bevezetésre az ún. Konszolidált Biztosított Betét (KBB) mutató fogalma. Ha egy betétes tudni szeretné, hogy az egyes hitelintézeteknél elhelyezett megtakarításának összege belül esik-e a 100000 eurós összeghatáron, akkor tájé-koztatást kérhet erre vonatkozóan a szolgáltatójától.

A KBB adat azt mutatja meg, hogy az OBA egy ügyfél egy hitelintézetben tartott összesen mennyi megtakarítását biztosítja (bankbezárás esetén ennyit fizet az OBA az ügyfélnek). Amennyiben e mutató értéke 100 százalék, akkor a teljes megtakarítás állomány élvezi az OBA védettséget, amennyiben kevesebb, mint 100 százalék, akkor van a megtakarítás állományon belül nem biztosított hányad is. A KBB adatra vonatkozó információ - a betétes kérésének megfelelően - rendelkezésre bocsátható postai, vagy elektronikus úton, illetve a hitelintézeti fiókban személyes átadással. A hitelintézetek ezt az információt évente egy alkalommal ingyenesen kötelesek az ügyfél rendelkezésére bocsátani, amennyiben igényt tart rá. (OBA Iránytü a betétbiztosításhoz)

Ha egy betétes kevesellné a 100000 eurónak megfelelő védettséget, akkor a következő megoldások közül választhat:

- Betéteit nem egy hitelintézetnél helyezi el, hanem több hitelintézetnél, így hitelintézetenként külön-külön érvényesíthető a 100000 eurós kifizetési határ.

- A másik lehetőség, hogy egy hitelintézetnél, helyeznek el betétet, nyitnak számlát, de több tulajdonos nevén (Ezt nevezik közös betétnek). Ilyen esetben tulajdonosonként érvényesíthető a garancia felső összege. Mint korábban már említettük, a garanciát csak a betét tulajdonosa élvezheti, a számla felett csak rendelkezési jogosultsággal bíró személy nem. 
Ha egy magánszemély egy hitelintézetnél saját nevében s egy gazdasági társaság nevében is elhelyez betéteket, ezekre - tulajdonosonként - külön-külön érvényes az OBA garanciája.

Meg kell jegyezni ugyanakkor, hogy 2015-től megszünt az ún. közösségi betétek (pl. társasházi betét, lakásszövetkezetek betétje) esetében az a lehetőség, hogy a közösséget alkotó betétesek száma szerint többszöröződött a kártalanítási összeg. Azóta tehát - a közösség tagjainak számától függetlenül - például egy társasház esetében is csak 100000 euróig terjed a garancia.

Az OBA a Felügyeletnek az adott bank tevékenységi engedélyét visszavonó határozatának közlését, vagy a bank felszámolásának közzétételét követően azonnal megkezdi a kártalanítást. A kártalanítási összeg kifizetésére 2019-től - a korábbi 20 munkanap helyett - alapesetben 15 munkanap áll rendelkezésre. Ettől hosszabb időtartam is előfordulhat néhány rendkívüli esetben (pl. ha a betét jogvita tárgyát képezi, vagy a magasabb kártalanítási összeghatár alá tartozik a betét). A már korábbiakban említett Európai Uniós irányelv szerint a kártalanításra rendelkezésre álló időnek 2024-ig fokozatosan 7 napra kell rövidülnie. Amennyiben a 2023. december 31-én záruló átmeneti időszakban a betétbiztosítási rendszer nem képes a 7 napos határidőn belüli kártalanításra, a betétes kérésére előzetesen kifizethető egy sürgősségi összeg. Ez az elvárás a hazai joganyagba már beépítésre is került. A „Hitelintézeti törvény” értelmében ugyanis, ha az OBA nem bocsátja rendelkezésre a kártalanítást a betétesek részére hét munkanapon belül, akkor a természetes személy betétes írásban kérelmet nyújthat be az OBA-hoz a betét sürgős kifizetése érdekében. Az OBA a hitelintézet által rendelkezésre bocsátott betétnyilvántartásban szereplö betétes részére a betétnyilvántartásban szereplö betét alapján a sürgős kifizetésre vonatkozó kérelem benyújtásától számított öt munkanapon belül részkifizetést teljesít, amely azonban nem haladhatja meg a mindenkori öregségi nyugdíjminimum négyszeresét. Természetesen a sürgős kártalanítás keretében kifizetett összeg a teljes kártalanítás összegét csökkenti (Hpt.).

Egyéb esetekben a kártalanítás kifizetéséhez a betétesnek nem kell kérelmet benyújtania.

A kártalanítás feltételeit, illetve a kártalanítás lebonyolításával kapcsolatos információkat az OBA legalább két országos napilapban, illetve a saját honlapján, valamint a kártalanítással érintett hitelintézet honlapján is közzéteszi. 
A kártalanítási eljárásban minden kártalanításra jogosult betétes személyre szóló „Elszámolási bizonylatot” kap, amelyen betétenként részletezve vannak feltüntetve a kártalanítás összegei. A kártalanítási összeget a betétes többféle módon kaphatja meg: banki úton (átutalással, banki készpénzfelvétellel, OBA betétbiztosítási kártyával), vagy postai átutalással.

Kisebb összegek esetén (jellemzően 100000 forint alatt) készpénzben, postai kézbesítő útján történik a kártalanítás, e fölött postai kifizetési utalvánnyal, illetve ún. OBA kártyával történik a kártalanítás. A kártya kizárólag a kártalanítás összegének felvételére alkalmas, vásárlásra nem. A betétes postai úton kapja meg előbb a kártya használatához szükséges PIN-kódot, majd a kártyát tartalmazó levelet, végül tértivevényes levélben a kifizetési elszámolást. A kártyával fel lehet venni az összeget az OTP Bank bankjegykiadó automatáinál (a napi limit figyelembevételével), vagy egyösszegben az OTP fiókjaiban és a postahivatalokban.

Nagyobb (jellemzően 5 millió forint feletti) kártérítési összeg esetén az OBA által küldött levélben megnevezett hitelintézeti fiókban rendelkezhetnek az ügyfelek kártalanítási összegről - ez lehet betétlekötés, átutalás vagy készpénzfelvétel. Az OBA a kártalanítás összegéről és módjáról a lakcímükre küldendő személyre szóló levélben tájékoztatja az ügyfeleket. A kifizetési módokról az OBA minden esetben „Hirdetményben” tájékoztatja az ügyfeleket (OBA Iránytű a betétbiztosításhoz).

Az Alappal szembeni követelés mindaddig igényelhetö, amíg az eredeti követelés a hitelintézettel szemben érvényesíthető lett volna.

\subsection{A BEVA működésének jellemzői}

Mint korábban említettük, részvényekre, befektetési jegyekre, vállalati kötvényekre nem terjed ki az OBA garanciája. Azokat az OBA-hoz hasonlóan működő - 1997-ben életre hívott - Befektető-védelmi Alap (BEVA) garantálja.

A Befektető-védelmi Alapnak jelenleg tagja valamennyi befektetési vállalkozás és befektetési szolgáltatási tevékenységet végző hitelintézet, valamint portfóliókezelést végző befektetési-alapkezelő. A Befektető-védelmi Alapot 9 tagú igazgatóság irányítja. Önálló munkaszervezettel nem rendelkezik, az operatív feladatokat az OBA elkülönült munkaszervezete látja el az OBA ügyvezető igazgatóhelyettesének irányítása mellett. 
A Befektető-védelmi Alap tagjai - az OBA tagjaihoz hasonlóan - a csatlakozáskor csatlakozási díjat, majd naptári évente éves díjat fizetnek az Alapnak. Meghatározott esetekben a BEVA igazgatósága rendkívüli befizetést is elrendelhet.

Az éves díj alapja a tárgyévet megelőző naptári évben az Alap kártalanítási kötelezettsége alá tartozó befektetők tulajdonát képező, az Alap tagjának kezelésében lévő pénz és értékpapír átlagos állománya.

Az Alap a vagyonát a vagyonkezelöjén - az Államadósság Kezelő Központon - keresztül fektetheti be, kizárólag állampapírokba. Ha az Alap vagyona nem lenne elegendő a kártalanítási kötelezettségének teljesítéséhez, úgy - szintén az OBA-hoz hasonlóan - hitelt vehet fel, illetve kötvényeket bocsáthat ki általános állami kezességvállalás mellett.

Fontos hangsúlyozni, hogy a befektető védelem által nyújtott biztosítás nem terjed ki a befektetés esetleges értékvesztésére. A BEVA tehát olyan károk után, mint például a részvények árfolyamvesztesége, kötvénykibocsátók csődje, nem fizet kártalanítást.

Ez az intézmény azokat a károkat hivatott mérsékelni, amelyek a befektetőket amiatt érhetik, hogy a BEVA tagjánál értékpapírt vagy pénzt helyeztek el, s az nem képes kiadni (kifizetni) jogos követelésüket.

A két biztosítás (OBA és BEVA) közötti egyik legfontosabb különbség, hogy amíg a betétbiztosítás a hitelintézetnél elhelyezett összeget védi, addig a befektető védelem nem a befektetett pénzre vonatkozik. A BEVA a szolgáltató jogellenes eljárása ellen nyújt védelmet a letétben lévő vagyon (értékpapír, pénz) biztosításán keresztül.

A BEVA kártalanítási kötelezettségét a tőkepiacról szóló 2001. évi CXX. törvény szabályozza.

Az Alap kártalanítási kötelezettsége akkor következik be, ha a Felügyelet (MNB) az Alap tagjával szemben felszámolási eljárást kezdeményez, vagy a bíróság az Alap tagjának a felszámolását rendeli el.

A BEVA kártalanítására azok a befektetők számíthatnak, akik a BEVA tagjával a biztosított befektetési szolgáltatási tevékenységek, illetve kiegészítő szolgáltatások valamelyikére érvényes szerződést kötöttek, és a szerződés alapján 
a befektetési szolgáltató birtokába került, és a nevükön nyilvántartott vagyont (értékpapír, pénz) a befektetési szolgáltató nem tudja kiadni számukra.

A Tartós Befektetési Számlán (TBSZ) és a Nyugdíj-előtakarékossági Számlán (NYESZ) elhelyezett letétekre szintén vonatkozik a BEVA kártalanítása.

A BEVA biztosítás hatálya alól a jogszabály kizárja a jogi személyek bizonyos körét (pl. az állam, a költségvetési szerv, az elkülönített állami pénzalap, az MNB, befektetési vállalkozás, tőzsdetag, a Hpt.-ben meghatározott pénzügyi intézmények, a helyi önkormányzatok és a magánszemélyek közül az érintett tag vezetö állású munkavállalói és ezek közeli hozzátartozói, valamint az Alap könyvvizsgálója (2001. évi CXX. törvény).

A kártalanítási összeget a BEVA a felszámolás alatt lévő tag nyilvántartásának adatai, illetve a befektető szerződéssel alátámasztott követelése alapján állapítja meg. A BEVA tagjánál fennálló, befektetési szolgáltatási tevékenységből származó valamennyi követelést össze kell adni.

A kártalanítást a befektetőnek kell igényelnie a BEVA-tól az erre szolgáló nyomtatványon. (Az OBA esetében nincs szükség a kártalanítás igénylésére.) A kérelmet a BEVA által rendszeresített formanyomtatványon kell benyújtani, és ehhez mellékelni kell a követelés alapjául szolgáló szerződést. A nyomtatvány beszerzési helyéről a BEVA által kibocsátott kártalanítási hirdetményből lehet tájékozódni. A kérelem előterjesztésére a befektetőnek a BEVA közleményében meghatározott naptól számított egy év áll rendelkezésére².

$A$ befektető védelem esetén is 100 ezer euró a kártalanítás értékhatára, azonban a BEVA kártalanítási önrészt is alkalmaz (1 millió forintig 100 százalékos, a fölött pedig 90 százalékos a kifizetés). A BEVA - ha rendelkezésre áll a BEVA-tag által vezetett nyilvántartás - a kártalanítási kérelem benyújtásától számított kilencven napon belül köteles elbírálni azt, és az elbírálástól számított kilencven napon belül fizeti ki a kártalanítási összeget.

A BEVA a kártalanítást forintban nyújtja. Amennyiben a kártalanítás hiányzó értékpapír után jár, a kártalanítás összegének kiszámítása a felszámolás kezdő időpontját megelőző 180 nap átlagárfolyama alapján történik. Tőzsdei, vagy tőzsdén kívüli árfolyam hiányában a kártalanítás alapjául szolgáló árat a BEVA igazgatósága állapítja meg, s ehhez a tevékenységhez akár szakértőt is igénybe vehet.

2 www.bva.hu 
Devizában fennálló követelés esetén a BEVA a kártalanítás forint összegét az érintett tag felszámolásának kezdő napján érvényes MNB devizaárfolyam alapján számolja ki. A 100 ezer euró összeghatár meghatározása szintén a felszámolás kezdő napján érvényes MNB devizaárfolyam alapján történik.

A kártalanítás során esetlegesen meg nem térült követeléseket, a felszámolási eljárás során lehet érvényesíteni. A felszámolási vagyonból az ügyfelek a többi hitelezőt megelőzően részesednek.

A BEVA bizonyos esetekben nem fizet kártalanítást. Ezek közé tartozik például - ahogy korábban már említettük - amikor a követelés alapja a befektetés értékvesztése, vagy ha a befektető nem rendelkezik biztosított szerződéssel.

A BEVA által nyújtott biztosítás nem terjed ki az olyan ügyletből eredő követelésre sem, amely esetében a bíróság jogerős határozata megállapította, hogy a befektetés forrása büncselekményből származott, és az olyan ügyletekből eredő pénzkövetelésre sem, amely nem euróban, vagy az Európai Unió, illetve az OECD tagállamának törvényes fizetőeszközében áll fenn.

Kizárólag méltányossági alapon sem fizethet a BEVA kártalanítást.

\section{A BEVA gazdálkodását is az Állami Számvevőszék ellenőrzi.}

2016 februárjától lehetőség van arra, hogy a befektetési szolgáltatók által nyilvántartott értékpapírokat és összegeket az MNB nyilvántartásából is le lehessen kérdezni. Ez azért fontos, mert a befektetési szolgáltatónak az ügyfelei számára megküldött, vagy online felületen elérhető nyilvántartásában és az MNB-nél nyilvántartott - személyes adatokat nem tartalmazó - ügyfélszámla-egyenlegében szereplő összegeknek és értékpapírkészleteknek meg kell egyezniük.

\subsection{Szövetkezeti Hitelintézetek Tökefedezeti Közös Alapja}

A szövetkezeti hitelintézetek integrációjáról szóló, 2013-ban elfogadott törvény (2013. évi CXXXV. törvény) értelmében létrejövő takarékszövetkezeti integráció két központi szerve a központi banki funkciókat ellátó Takarékbank, a másik az újonnan létrejövő integrációs szervezet (Szövetkezeti Hitelintézetek Integrációs Szervezete - SZHISZ). Utóbbi - többek között - közös intézményvédelmi szervezetként müködik (magába integrálja a korábban müködő intézményvédelmi alapokat: OTIVA, TAKIVA, REPIVA, HBA). 
Az integráció eredményeképpen létrejött a Szövetkezeti Hitelintézetek Tőkefedezeti Közös Alapja. Az Alap tagjai Garanciaközösséget alkotnak abból a célból, hogy ügyfeleik, betéteseik számára még nagyobb biztonságot tudjanak nyújtani.

A Garanciaközösség tagjai a Magyarországon müködő szövetkezeti hitelintézetek (takarékszövetkezetek, részvénytársasági formában - bankként - müködő szövetkezeti hitelintézetek, hitelszövetkezetek), a takarékszövetkezetek intézményvédelmi szerve, a Szövetkezeti Hitelintézetek Integrációs Szervezete, valamint a Takarékbank Zrt. ${ }^{3}$

Az Alap feltöltése 2014-ben kezdődött, a tagok minden évben meghatározott összeget fizetnek be az Alapba. Meghatározott esetekben rendkívüli befizetés is elrendelhető. Az önálló jogi személynek minősülő Alap pénzeszközei nem vonhatók el, az Alap adófizetésre nem kötelezett.

A Garanciaközösség lényege úgy foglalható össze, hogy a közösség tagjai kölcsönösen (egyetemlegesen) felelnek egymás kötelezettségeiért, azaz bármely takarékban elhelyezett betét, vagy egyéb kötelezettség visszafizetéséért.

Az Alapban összegyült pénzösszeg kizárólag az egyetemlegesség alapján érvényesített követelések kiegyenlítésére használható fel. A Garanciaközösség létrejötte a takarékokban betétet elhelyező ügyfelek számára kivételes betétvédelmet biztosít.

Ez abban nyilvánul meg, hogy a szövetkezeti hitelintézeteknél betétet elhelyező ügyfeleket az OBA védelmén kívül, azon túlmenően a takarékok Tőkefedezeti Alapja is védi.

Ennek alapján a védelem kiterjed az OBA által már nem védett (100 000 eurós összeghatár feletti) betétösszegekre, valamint azon befektetők (önkormányzatok, az állam) betéteire is, amelyek kívül esnek az OBA betétvédelmi hatókörén. Ez a gyakorlatban azt jelenti, hogy a szövetkezeti hitelintézetek ügyfeleinek betétei - összeghatártól függetlenül - teljes mértékü védelmet élveznek a Tőkefedezeti Alap jóvoltából. ${ }^{4}$

Ezen túlmenően a szövetkezeti hitelintézeti integráció tagjai által vezetett értékpapírokért (állampapír, befektetési jegy stb.) a Garanciaközösség tagjai szintén teljes vagyonukkal állnak helyt. A garancia kiterjed a BEVA által fedezett

3 www.szhisz.hu

4 www.szhisz.hu 
100000 eurós összeghatár feletti értékpapír állományokra is. Az egyetemleges kötelezettségvállalás kiterjed a szövetkezeti hitelintézetek által kibocsátott, hitelviszonyt megtestesítő értékpapírok (kötvények, jelzáloglevelek) tőkéjének és kamatának visszafizetésére is, szintén összeghatár nélkül. Természetesen a védelem nem vonatkozik az értékpapír árfolyamára, valamint a kibocsájtójára.

A betét- és befektető védelemre a Garanciaközösség tagjainak teljes tőkéje és likviditása felhasználható.

\section{5. Önkéntes Betétbiztosítási Alapok}

A hitelintézetekről szóló 2013. évi CCXXXVII. törvény lehetővé teszi, hogy a hitelintézetek önkéntes betétbiztosítási, illetve intézményvédő alapot (önkéntes alapok) hozzanak létre. Az önkéntes alapok önálló jogi személyiségnek minősülnek, legfőbb döntéshozó szervük a közgyűlés, amely a tagok összességéből tevődik össze. Az önkéntes alap pénzeszközei nem vonhatók el, és a létesítő okiratban meghatározott céltól eltérő célra nem használhatók fel. Az önkéntes alapból kilépés esetén kifizetés nem teljesíthető.

Az önkéntes alapnak - a házipénztárt, a pénzforgalmi számlán tartott likviditási tartalékot, valamint a kifizetések lebonyolítására vagy más, az önkéntes alap működéséhez szükséges célra hitelintézethez átutalt összeget kivéve - a pénzeszközeit állampapírban kell tartania.

Az intézményvédelmi alap a létesítő okiratában megfogalmazott feladatai ellátása érdekében jogosult - tagintézettel, illetve annak tulajdonosával kötött támogatási szerződés keretében - a tagintézet részére a következő szolgáltatásokat nyújtani:

- kezességvállalás,

- tökejuttatás nyújtása,

- kölcsön folyósítása.

Az önkéntes betétbiztosítási alap forrásait felhasználó hitelintézetek a pénzeszközök visszafizetéséig kamatként legalább a jegybanki alapkamatot kötelesek téríteni. Ha esetleg közben kilépnének a betétbiztosítási alapból, ez természetesen az alappal szembeni visszafizetési kötelezettségüket nem érinti. Az önkéntes alap a kifizetés elkerülése érdekében tervezett intézkedéseiről mindig köteles tájékoztatni a Felügyeletet. 


\subsection{Irodalomjegyzék}

2001. évi CXX. törvény a tőkepiacról.

2013. évi CCXXXVII. törvény a Hitelintézetekről és a pénzügyi vállalkozásokról. 2013. évi CXXXV. törvény a szövetkezeti hitelintézetek integrációjáról és egyes gazdasági tárgyú jogszabályok módosításáról.

Az Európai Parlament és a Tanács 2014/49/EU irányelve (2014. április 16.) a betétbiztosítási rendszerekről.

Bakó Beáta (2016): Az EU megvédené a bankbetéteinket, a németek nem kérnek belőle. Interjú Tóth Istvánnal az OBA kommunikációs vezetőjével. Mandiner, 2016. január 15. https://mandiner.hu/cikk/20160115_az_eu_megvedene_a_ bankbeteteinket_a_nemetek_nem_kernek_belole

Baranyi Aranka - Széles Zsuzsanna (2010): Egy hitelintézet kockázatvállalása és a bázeli szabályozás korlátai. Pénzügyi Szemle 55. évf. 1. szám pp. 168-179.

Kovács Levente (2018): A betétbiztosítás szerepe a bizalmi kapcsolatok fejlődésében. Gazdaság és Pénzügy OBA különszám pp. 8-15.

Kenesey Zsófia (2015): A rendszerkockázati szinten fontos bankok térnyerése a bankszektorban. In: Székely Cs. - Kulcsár L. (szerk.: Strukturális kihívások reálgazdasági ciklusok: Innovatív lehetőségek a valós és virtuális világokban. nemzetközi Tudományos Konferencia, tanulmánykötet. Nyugat-magyarországi Egyetem Kiadó, Sopron. pp. 131-140.

Kenesey Zsófia - Pataki László - Belovecz Mária - Halmosi Tímea (2017): Az Országos Betétbiztosítási Alap kártalanítási tevékenységének értékelő elemzése. In: Lehota J. (szerk.): Életem a felsőoktatásban: Dr. Molnár József 70 éves. Szent István egyetem Kiadó, Gödöllő, pp. 186-197.

Széles Zsuzsanna - Baranyi Aranka (2016): A bázeli tőkeszabályozás változása az Európai Unióban. In: Kulcsár L. - Resperger R. (szerk.) Európa: gazdaság és Kultúra. Nemzetközi Tudományos Konferencia tanulmánykötet. Nyugat-magyarországi Egyetem Kiadó, Sopron. pp.1026-1045.

Tóth József (2015): Az európai betétbiztosítási és bankszanálási rendszerek jellemzői és azok finanszírozása. Közgazdasági Szemle, LXII. évf., 2015. júliusaugusztus pp. 767-785.

https://bva.hu/hu/befekteto-vedelem/altalanos-informaciok/ www.consilium.europa.eu/hu/policies/banking-union/single-rulebook/deposit-guarantee-schemes/ 
https://ec.europa.eu/hungary/eu60/23_hu

https://www.oba.hu/images/stories/downloads/iranytu/oba_iranytu_ hu_20181219.pdf (OBA Iránytü a betétbiztosításhoz)

www.szhisz.hu

https://szhisz.hu/tokefedezeti-kozos-alap/az-alaprol/ 


\section{A pénzmosás és a terrorizmus finanszírozása, valamint a leküzdésükre irányuló szabályozás}

\subsection{A pénzmosás fogalma}

A pénzmosás az illegális úton szerzett jövedelmek legális vagyonná alakítását jelenti. A pénzmosás célja a pénzeszközök illegális eredetének felismerhetetlenné tétele, ami többnyire veszteséget eredményez, akár hosszú távon is. A pénzmosók ezzel eleve számolnak, s így nem céljuk a profit elérése, csak az, hogy a folyamat végén legális jövedelmet generáljanak. A pénzmosás fogalmából következik az is, hogy mivel az illegálisan szerzett jövedelem eredetének elrejtésére irányul, feltételezi, hogy korábban megvalósult egy vagy több olyan büncselekmény (vagy akár büncselekmények sorozata), amely az elkövetőjének hasznot, profitot eredményezett, ezeket előcselekménynek vagy alapbüncselekménynek nevezik. Fontos ismérve a pénzmosásnak továbbá, hogy a folyamat egyes műveletei önmagukban szinte mindig törvényesek, de az eredetleplezési célzat miatt az egész cselekménysorozat minősül illegálisnak, vagyis büncselekménynek számít (ma már a világon szinte mindenhol).

A pénzmosás legjellemzőbb alapbüncselekményei a kábítószer-kereskedelem, az illegális fegyverkereskedelem, az embercsempészet, a prostitúció, a korrupció, a csalás, az adócsalás. Egyes országok büntetőjogi szabályozása tételesen felsorolja, mely büncselekmények minősülhetnek alapbüncselekménynek a pénzmosás tényállásának megvalósulásához, a legelterjedtebb büntetőjogi kodifikációs megoldás azonban az, amely minden büncselekményt potenciális alapbüncselekménynek tekint. (A magyar büntetőjogi szabályozás a szabadságvesztéssel büntetendő bűncselekményeket tekinti alapbüncselekménynek.)

A pénzmosás illegális gazdasági szolgáltatásnak is tekinthető, amely arra irányul, hogy a büncselekménnyel szerzett vagyon eredete igazolhatóvá váljék, megszabadulva annak felismerhetően jogellenes mivoltától. 


\subsubsection{A pénzmosás folyamata}

A pénzmosás jellemzően egy összetett, többlépcsős folyamat, amelynek során a bűncselekményből származó pénzösszegek valódi eredete elleplezésre kerül. Az elleplezési technikák számos formát ölthetnek, az elkövetők mindig újabb és újabb módszereket alakítanak ki, illetve az alkalmazott megoldásaikat nagyban meghatározza egy adott ország jogi szabályozása, pénzügyi infrastruktúrája is.

A pénzmosási folyamat során az elkövetők arra törekszenek, hogy a büncselekményből szerzett pénz - a különböző tranzakciókat követően - ne legyen visszavezethető az elkövetőhöz, illetve ne legyen összeköthető a büncselekménynyel, hanem az „tiszta” pénzként az elkövető rendelkezésére álljon úgy, hogy azt már biztonságosan felhasználhassa.

A pénzmosás folyamatát az elméleti szakemberek többféleképpen is modellezték, azonban a legelterjedtebb koncepció az Egyesült Államokból származó „három fázis modell” (Szendrei, 2010, p. 24., Zéman et al., 2015), miszerint a pénzmosás folyamatában három szakasz különböztethető meg:

- elhelyezési szakasz: ahol a büncselekményből származó készpénz (pl. a kábítószer ellenértéke) befizetésre kerül egy pénzügyi intézményhez, vagy egy másik (legális eredetü) vagyontárgy (pl. gépjármű, ingatlan) vételáraként szolgál;

- rétegezési (bújtatási) szakasz: az a - jellemzően több tranzakcióval megvalósuló - folyamat, amelynek eredményeként a pénzeszközök valódi eredetét és tulajdonosát elfedik;

- integrációs szakasz: ebben a szakaszban a pénz visszaáramlik a legális gazdasági és pénzügyi vérkeringésbe.

Nagyon sok esetben a fenti szakaszok elkülönülten is tisztán megfigyelhetők, azonban más esetekben nem válnak el ennyire egymástól a stádiumok: két lépés akár egymással párhuzamosan is végbemegy, vagy még gyakrabban ezek egymást időben átfedik.

\subsubsection{Pénzmosási technikák}

A bűnözők számtalan különféle módszert alkalmaznak arra, hogy illegális vagyonukat, pénzeszközeiket tisztára mossák. 
A módszerek komplexitásukban eltérhetnek, azonban alapvetően három közös ismérvük van:

- a pénzmosóknak el kell leplezniük a vagyon valódi (tényleges) tulajdonosát és eredetét,

- a folyamat során a pénzeszközök feletti rendelkezést (irányítást) fenn kell tartaniuk,

- meg kell változtatniuk a bűncselekményből szerzett pénz megjelenési formáját.

\section{Pénzmosás banki betételhelyezéssel}

Figyelemmel arra, hogy az alapbüncselekmények eredménye, illetve bevétele túlnyomórészt jellemzően készpénzben keletkezik, a pénzmosási folyamatban azon belül is az elhelyezési szakaszban - az elkövetők számára kiemelkedö jelentőséggel bírnak a készpénztranzakciók. Ha ugyanis különösebb feltűnés nélkül, sikeresen el tudják helyezni a pénzüket egy bankszámlán - akár anonim módon, akár a háttérben maradva, ún. strómanok bevonásával -, a pénzmosási folyamat további lépéseit már könnyebben megtehetik. Nem véletlen tehát, hogy a kezdetekben a pénzmosás elleni szabályozás is az elhelyezésre koncentrált. Elsőként az Egyesült Államokban írták elő a bankok számára az ügyfelek azonosításának kötelezettségét, adataik és tranzakcióik nyilvántartását, valamint a bizonyos értékhatár feletti készpénztranzakciók kötelező jelentését a hatóságnak ${ }^{1}$. Ezeknek a szabályoknak a bevezetése kétségtelenül megnehezítette a bűnözők számára a készpénzbefizetéseket, hiszen nem lehetett már anonim módon (pl. jeligére) betétet elhelyezni vagy értékpapírt vásárolni, ugyanakkor például az USA-ban olyan megoldásokat szült, amelyek a készpénzbefizetésekkel járó kockázatok minimalizálását célozták. Az egyik ilyen technika a jellemzően drogügyletek során felhalmozódó kis címletű (pl. 5 vagy 10 dolláros) bankjegyek fizikai mennyiségének csökkentésére alakult ki, és az angol „refining” kifejezés alapján finomítási technikának is nevezhető. Lényege, hogy a bünözök sok szereplö bevonásával a kisebb címletű bankjegyeket az elérhető legnagyobb címletekre váltják. Ez a

1 A Richard Nixon amerikai elnök által aláirt 1970. évi banktitok törvény (Bank Secrecy Act, $B S A)$, tekinthetö az elsö olyan jogszabálynak, amelyet kifejezetten a pénzmosás leküzdése céljából alkottak. Az amerikai pénzintézeteket a BSA arra kötelezte, hogy a készpénzügyletekröl nyilvántartást vezessenek, jelentést küldjenek a hatóságnak, ha valamely ügyfél összes készpénztranzakciója egy napon belül a 10 ezer dollárt eléri, továbbá jelentsenek minden pénzmosásra, adóelkerülésre vagy egyéb büncselekményre utaló gyanús körülményt.

(A 10 ezer dolláros kötelező jelentési értékhatár mind a mai napig érvényben van az USA-ban.) 
technika lehetőséget ad a készpénzmennyiség jelentős csökkentésére még az elhelyezési szakasz elött, és amellett, hogy a kisebb mennyiségü pénzt könnyebben lehet mozgatni, az elkövetők amiatt is alkalmazzák, hogy a nagy címletekben később végrehajtott pénztári befizetések (vagyis az elhelyezés) során - az esetleg koszos, gyürött, kis címletü bankjegyek - a banktisztviselőkben ne keltsenek gyanút $^{2}$. A finomítás történhet azonban az elhelyezéssel együtt is, aminek tipikus megvalósítása egy másik technika egyidejű alkalmazása: a készpénz bevételt az elkövetők fedövállalkozásaik (tipikusan például vendéglátóhelyek, éttermek, bárok, vagy egyéb nagy készpénzforgalmú vállalkozások) legális készpénzbevétele közé keverik (majd később ennek a vállalkozásnak a bevételeként helyezik el pl. egy bankszámlán).

A kötelező jelentési értékhatár megkerülésére alakult ki az ún. törpítés (angolul: „smurfing”), vagy strukturálás technikája, ami abból áll, hogy az elkövetők az elhelyezni kívánt pénzösszeget kisebb, a kötelező jelentési értékhatár alatti összegekre osztják, és több, jellemzően ártatlan kinézetű személlyel (pl. pénzfutárokkal) fizettetik be a bankpénztárakban. A módszer kiválóan alkalmas arra, hogy rövid idő alatt jelentős összegek kerüljenek elhelyezésre bankbetétben a gyanú felkeltése nélkül, ezért széles körben elterjedt szerte a világon. Az ilyen befizetésekhez alkalmazott személyeket „törpéknek”, illetve „strómanoknak” is nevezik.

A banki befizetések lebonyolításakor a pénzmosóknak nyilvánvalóan könynyebb a helyzetük, ha őket korrupt banki alkalmazottak segítik. Azzal együtt, hogy egy banktisztviselö megkörnyékezésével óriási kockázatot vállalnak - és egyébként a vesztegetés büntetőjogi tényállását is megvalósítják -, nem ritka, hogy a bünözök ehhez a technikához folyamodnak³

2 A finomítás elleni szabályozói eszköz lehet a nagy címletek kivonása a pénzforgalomból. Az USA-ban 1969. július 14. óta a 100 dolláros bankjegy a legnagyobb címletü forgalomban lévö hivatalos fizetöeszköz (miután a nagyobb címletü bankjegyeket kivonták a forgalomból). Az eurózóna központi bankjai 2019. április 26. után már nem bocsátanak ki 500 eurós bankjegyeket, de a korábban kibocsátott, forgalomban lévö bankjegyek továbbra is törvényes fizetöeszköznek minösülnek.

3 Talán az egyik leghíresebb banki korrupciós botrány a Bank of Credit and Commerce International (BCCI) esete 1988-ból, amelyben amerikai fedett kábítószerügyi nyomozók lepleztek le a kolumbiai drogkartellek illegális bevételeinek tisztára mosásában részt vevő korrupt banki ügyintézőket. A bankra kirótt bírságok és az ügyintézők büntetöjogi felelösségre vonása eredményeként, az üggyel járó reputációs veszteség, az ügyfelek bizalmának elvesztése hatására a BCCI késöbb (1991-ben) megszünt. (Ld. Steven Mufson és Jim McGee: BCCI Scandal: Behind the „Bank of Crooks and Criminals”, Washington Post, 1991. július 28.)

Az egyik magyar hírportál napjainkban megjelent beszámolója szerint az Ausztriában folytatott 
A bankokra a legtöbb fejlett gazdasággal rendelkező országban szigorú pénzmosás elleni szabályok vonatkoznak, így a pénzmosók jellemzően szabálykövető alkalmazottakkal találják magukat szemben, akiket nem tudnak korrumpálni. Elkerülési technikaként az illegális pénz országhatárokon való átcsempészésével (currency smuggling) olyan országokban, régiókban tudják azt elhelyezni, ahol nincsenek szigorú azonosítási, jelentési előírások. A pénzek fizikai szállítására készpénzfutárokat alkalmaznak, akik pénzváltók igénybevételével, jellemzően előbb a nagy címletekre váltással (pl. 500 eurós bankjegyek), csökkentik a pénzeszközök fizikai méretét, s miután sikeresen átcsempészték a határátkelőhelyeken a pénzt, azt a célországban működő pénzváltóknál a helyi valutára konvertálják, vagy akár átváltás nélkül is, külföldön szerzett készpénzjövedelemként, külföldi pénznemben helyezik el a bankszámlákon. A készpénzcsempészet visszaszorítására három alapvető szabályozási megoldás alakult ki világszerte:

1) Bejelentési kötelezettség elöírása egy meghatározott értékhatár feletti készpénzmennyiség határon történő átvitelekor (pl. Ausztrália, USA, Európai Unió), és emellett természetesen szigorú vámvizsgálat, valamint szabálysértés esetén szigorú bírság alkalmazása.

2) A hatóságok feljogosítása a teljes pénzmennyiség elkobzására, ha gyanú merül fel, hogy az büncselekményből származik, és nem kerül igazolásra törvényes eredete (pl. Egyesült Királyság).

3) A valutaváltás szigorú szabályozása és ellenőrzése (pl. Oroszország, Ukrajna).

Az országhatárokon átnyúló, fizikai szállítással megvalósuló pénztranszfer kockázatainak kikerülésére az elektronikus banki átutalásokkal kiváló lehetöség kínálkozik a bünözők számára. Ma már nagyon rövid idő alatt, vagy akár azonnal, valós időben, a megjelölt kedvezményezett számlájára juttathatók az összegek, ami az elhelyezési és a rétegezési szakaszban egyaránt hasznos számukra. A pénzmosók gyakran alkalmaznak olyan személyeket különböző országokban, akik a már meglévő bankszámlájukon fogadják és továbbítják az összegeket, jellemzően úgy, hogy nem tudnak a pénz illegális eredetéről. Ezeket a személyeket angol kifejezéssel „money mule”-nak („pénzügyi szamár”) nevezik, ami egyaránt utal arra, hogy egyfajta „szállítóeszköz” szerepét töltik be, másrészt, hogy

illegális szerencsejáték bevételek tisztára mosásában egy magyar banki ügyintéző is segédkezett azzal, hogy több banknál is számlát nyitott az összegek elhelyezésére. (Szalma Baksi Ferenc: Osztrák-magyar pénzmosó bandát lepleztek le. Index.hu, 2019. május 24.) 
tudatlanok is, mert nincsenek tisztában azzal, mit „szállítanak”, miben vesznek részt. Az anyagilag kiszolgáltatott helyzetben lévők a könnyü pénzkereset reményében elvállalják a gyakran álláshirdetésekben kínált lehetőséget, hogy jutalék fejében ismeretlenektől fogadjanak és ismeretleneknek utaljanak pénzt. Ezzel a tevékenységgel pénzmosást valósítanak meg, amivel gyakran csak akkor szembesülnek, amikor a teljes pénzmosó hálózat lelepleződik a hatóságok előtt.

\section{Pénzmosás „nem banki pénzügyi szolgáltatók” igénybevételével}

A bankokra vonatkozó ügyfélazonosítási és kötelező jelentési szabályok bevezetése kétségtelenül megnehezítette az elkövetők helyzetét, ugyanakkor a kikerülési technikák (pl. a törpítés) alkalmazása mellett arra is ösztönözte a bünözőket, hogy a bankszektor mellett más gazdasági szereplőket is igénybe vegyenek tevékenységükhöz. Az ún. „nem banki pénzügyi szolgáltatók” a bankokhoz hasonló szolgáltatásokat kínálnak, de jellemzően kevésbé szigorú jogszabályi előírások és felügyeleti elvárások mellett működnek, vagy ezek velük szemben egyáltalán nem érvényesülnek. Hagyományosan ilyen szolgáltatóknak tekinthetők például a pénzváltó irodák, az életbiztosítási szolgáltatást kínáló biztosítótársaságok, az érték- és árutőzsdei brókerek, illetve az ún. alternatív vagy párhuzamos pénzátutalási rendszerek működtetői.

Az e körbe tartozó egyes szolgáltatóknak, mint például a pénzváltó irodáknak egyedül az elhelyezési szakaszban van jelentősége, más szolgáltatók azonban, mint például az életbiztosítást kínáló biztosító társaságok igénybevétele az elhelyezés mellett kifejezetten a rétegezés és az integrálás szakaszához is köthető. A biztosítási szerződés példáján bemutatva: a készpénzt egy nagy összegü prémium (rendszerint befektetéssel vegyes) életbiztosítási kötvény megvásárlására fordítva az elhelyezés viszonylag könnyedén megvalósítható. A későbbiekben a biztosítási kötvényt részben vissza lehet vásárolni vagy a futamidő alatt meg lehet változtatni a kötvény mögötti befektetési formákat is, ami már a folyamat rétegezési szakaszát jelenti. Az integrációs lépés a kötvény lejárat előtti visszavásárlásával valósul meg. Az életbiztosítási kötvények készpénzes vásárlása azonban a legtöbb országban nem bevethető módszer, mivel szokatlansága miatt gyanút kelt.

A biztosítások mellett számos esetben használták és használják napjainkban is a pénzmosók a részvény-és kötvénypiacokon elérhető pénzügyi termékeket és szolgáltatásokat. A vonzerőt a számos befektetési termék, és az elektronikus 
kereskedési rendszerek révén megvalósuló gyors ügyletkötés jelenti, ugyanakkor az illegális pénzek elhelyezése korántsem olyan egyszerü, mint a bankbetétek esetében: a befektetési termékek igénybevétele bizonyos szakmai hozzáértést igényel, az ügyletkötéshez jellemzően szükséges egy bróker igénybevétele, továbbá a pénzügyi instrumentumok ellenértékét jellemzően nem lehet készpénzben kiegyenlíteni. Az elkövetőknek tehát vagy a brókert kell beavatniuk és korrumpálniuk, ha közvetlenül készpénzben akarják elhelyezni az illegális pénzeszközöket - ami rájuk nézve óriási kockázatot hordoz, de ezzel együtt előfordul -, vagy a befektetés előtt más módon kell a készpénzt számlapénzzé alakítaniuk (pl. bankszámlanyitással és bankbetétben elhelyezéssel). Ha már sikerrel helyezték el az illegális pénzt valamely befektetési termékben, a különböző - akár országhatárokon átívelő - ügyletkötésekkel, lejárat előtti visszaváltásokkal, értékpapírtranszferrel, nagyon könnyen elfedhetik a pénz valós eredetét, a pénz útjának nyomon követese szinte lehetetlen.

Számos országban müködnek olyan pénzkïldő szolgáltatók (Money or Value Transfer Systems, MVTS), amelyek lehetővé teszik, hogy valaki a készpénzben befizetett összeget az ilyen szolgáltató ügynöke útján elküldje a kedvezményezett részére, akár távoli országokba is. A pénzmosók előszeretettel használják ezeket a szolgáltatókat kisebb összegek elhelyezésére és strukturálására, mivel a kis összegű tranzakcióknál kevésbé szigorúak az ügyfél-azonosítási szabályok. A pénzküldő szolgáltatókat nem csak pénzmosási célból veszik igénybe a bűnözői körök, hanem akár a büncselekmények elkövetésével megbízott személyek kifizetésére, vagy a büncselekmények megvalósításához szükséges anyagi források biztosítására (ideértve a terrorizmus finanszírozását) is.

A pénzküldő szolgáltatók mellett jónéhány alternatív vagy illegális pénzküldési szolgáltatás is elérhető a pénzmosók számára. Ezek a szolgáltatók ugyanúgy ügynökeik révén bonyolítják megbízóik tranzakcióit, ugyanakkor semmilyen jogi szabályozás, felügyeleti követelmény nem érvényesül velük szemben: nem vezetnek nyilvántartást az ügyfeleikről és a tranzakciókról, a pénzmozgások így utólag ellenőrizhetetlenek. A szolgáltatás a megbízó és a közvetítő közötti bizalomra épül. A legismertebb ilyen fizetési rendszerek a hawala (Közel-Kelet, Afganisztán, India), a fei ch’ien, (a szó jelentése: „repülő pénz”, Kína), a phoe kuan (Thaiföld) és a pesó fekete piaca (Dél-Amerika). Müködésük elve szinte 
megegyezik a pénzküldő szolgáltatókkal: a megbízó fél pénzt ad a szolgáltató ügynökének, és a címzett országában lévő ügynök (akit telefonon vagy faxon értesít a megbízás részleteiről: kinek, mennyit kell fizetni) az összeget helyben kifizeti néhány órán belül a nála jelentkező személynek. Régebben az üzenetet futárokkal vagy akár galambokkal is el lehetett juttatni a célba.

\section{Pénzmosás a pénzügyi szektoron kívüli eszközökkel}

A pénzügyi intézmények mellett más gazdasági szektoroknak is szembe kell nézniük a pénzmosási kockázatokkal, mivel az általuk nyújtott szolgáltatások vonzóak az illegális vagyonokat legalizálni kívánó elkövetők számára. A pénzmosók számára a legnagyobb vonzóerő kétségtelenül a cégstruktúrák kihasználásában rejlik. A különféle vállalkozások alapítása, finanszírozása és tevékenysége ugyanis megfelel a pénzmosás három fő célkitűzésének: lehetővé teszi, hogy az elkövetők a készpénzt más eszközökké alakítsák, megteremti a bevételi források törvényes alapját, és mindeközben a pénz valódi, tényleges tulajdonosa (a bünöző vagy a bünszervezet) a háttérben maradhat. Fedővállalkozásként a pénzmosók leginkább olyan tevékenységet végeznek, amelyeknél jellemző a nagy készpénzforgalom (pl. éttermek, szállodák, élelmiszerüzletek stb.), így lehetőségük van az illegális készpénzt a legális bevételekhez keverve lekönyvelni, és adózás után már mint tiszta, adózott nyereséget tudják felhasználni.

A cégjogi lehetőségek kihasználásának másik bevett módja olyan fiktív vállalkozások létrehozása, amelyek nem végeznek valós gazdasági tevékenységet. Leginkább az ún. offshore pénzügyi központok kínálnak cégalapítást kedvezőbb adózási szabályok mellett olyan módon, hogy a legtöbb esetben a tulajdonjogot a bejegyzett cég bemutatóra szóló részvényeinek birtokosa gyakorolhatja, amely ideális a bünözőknek a valódi tulajdonos kilétének eltitkolásához. Az offshore cégalapítással foglalkozó szolgáltatók gyakran kínálnak már előre bejegyzett, „készre gyártott” cégeket (angol kifejezéssel: „off-the-shelf” corporations), müködő bankszámlával, amelyekben a szükséges iratok aláírásával, tulajdonátruházással átvehető az irányítás. Az offshore cégek alapítása és igénybevétele a pénzmosási folyamat elhelyezési és rétegezési (bújtatási) szakaszában bír különös jelentőséggel: ha ilyen társaságokat a világ egymástól távol eső régióiban hoznak létre, és a részvételükkel bonyolítják a pénzügyi tranzakciókat, szinte lehetetlenné válik a pénzmozgások követése. Az elkövetők számára az offshore cégek 
előnye mellett megvan az a hátrány is, hogy a vagyon külföldön van, pedig azt ök rendszerint a saját hazájukban szeretnék felhasználni, így különböző további technikákat kell alkalmazniuk a folyamat utolsó lépéseként, vagyis az integrációs fázisban. Ezeknek a repatriálási technikáknak a legegyszerübb formája rendszerint valamilyen fiktív szolgáltatás (pl. üzleti tanácsadás) ellentételezéseként, fiktív számla alapján, az offshore cégektől érkező átutalások külföldről szerzett legális bevételként való elkönyvelése a hazai fedővállalkozásban. A közvetlen tökebefektetések (pl. a vállalati részesedésszerzés) szintén alkalmazhatók az illegális úton szerzett vagyonok repatriálására ${ }^{4}$.

A pénzügyi szektoron kívüli, előzőekben ismertetett megoldások közös jellemzője, hogy az elkövetők mindvégig fenntartják az irányítást és a rendelkezési jogot a pénzösszegek, illetve a vagyon felett. A jelentős készpénzbevételt generáló bűncselekmények elkövetôi azonban akár ennek a kontrollnak az ideiglenes megszűnését is vállalják, kockáztatják a pénzösszeg feletti rendelkezés elvesztését. A kaszinók és az egyéb szerencsejátékot kínáló szolgáltatók igénybevételével a készpénzből, kisebb-nagyobb veszteség árán, könnyen lehet dokumentummal igazolt nyereményt képezni szintén készpénz formában, amit már, mint igazolt jövedelmet lehet elhelyezni egy bankszámlán. Az elkövetőknek kedvez az is, hogy a világon a legtöbb kaszinó bankokhoz hasonló szolgáltatásokat is kínál: fizetési csekket állítanak ki vagy váltanak be, valutát váltanak, széfszolgáltatást kínálnak, vagy akár a nyeremény egy megadott számlára történő banki átutalását is teljesítik. Emellett pedig, mivel a szerencsejáték rendkívül készpénzintenzív tevékenység, akaratlanul is nagyfokú anonimitást biztosítanak a játékban résztvevőknek.

A nagy értékủ luxuscikkek, ingóságok készpénzzel történő vásárlása egy másik olyan megoldás, amellyel az illegális készpénz elhelyezésre kerülhet, majd később ezeknek a vagyontárgyaknak az értékesítésével legális jövedelmet lehet szerezni. A nemesfémkereskedők, a müalkotások kereskedelmével, árverezésével

4 A repatriálást sokszor az állam maga is elösegiti az adóamnesztia intézményével. Általában kivételes szabályként és csak bizonyos időbeli korlátozással, fóként az adott ország fizetőképességének javitása vagy helyreállitása céljából hirdetnek a kormányok adó- és büntetöjogi mentességet, ha a külföldön szerzett, tartott vagyonokat vagy jövedelmeket állampolgáraik hazautalják és tartósan befektetik pl. állampapírba. Az FATF (Financial Action Task Force, ld. később) külön iránymutatást dolgozott ki az egyes országok adóamnesztiaprogramjainak a pénzmosás és terrorizmusfinanszírozás elleni FATF standardokkal való összeegyeztethetösége érdekében. (Ld. FATF: Best Practices Paper - Managing the anti-money laundering and counter-terrorist financing policy implications of voluntary tax compliance programmes, 2012. október.) 
foglalkozó aukciósházak, az egyéb árukereskedők, akik nagy értékben fogadnak el készpénzfizetést, szolgáltatásaikkal a pénzmosási folyamat elhelyezéséhez járulhatnak hozzá, ha rájuk nem vonatkoznak olyan azonosítási és jelentési kötelezettségek, mint a pénzügyi szolgáltatókra.

A különböző nonprofit szervezetek tevékenysége szintén alkalmas a pénzmosási folyamat lebonyolítására, noha a rendelkezési jog itt is megszakad egy időre: az anonim adományok jelenthetik az elhelyezés megvalósítását, a szervezet célja szerinti pénzügyi támogatás folyósítása az elkövetők által megjelölt bankszámlára pedig a rétegezéssel együtt az integrálást is, mivel a kapott támogatás álcájával az elkövetők elfedhetik a pénz valós eredetét.

\section{A kapuörök}

Az 1990-es évektől kezdődően a Pénzügyi Akciócsoport (Financial Action Task Force, FATF) tipológiai jelentéseiben már beszámolt arról, hogy a pénzügyi szektor mellett más hivatások és szakmai szolgáltatók is - akarva vagy akaratlanul közremüködnek a pénzmosási folyamatokban. Az 1996-97. évi FATF tipológiai jelentés szerint: „Mivel a pénzmosás elleni szabályozás sok országban erösödött, a bünözök egyre nagyobb mértékben támaszkodnak a pénzmosás professzionális elösegitöire. Az FATF szakértöi jelentős számú ügyröl számolnak be, ahol ügyvédek, könyvelök, pénzügyi tanácsadók, közjegyzök, cégbejegyzö szolgáltatók és más ïgynökök szolgáltatásait vették igénybe a büncselekményböl származó profit elhelyezéséhez. A leggyakrabban megfigyelt taktikák között szerepelt az ügyvédi letéti számlák használata az illegális pénzek elhelyezésére és rétegezésére, amely révén a pénzmosó névtelensége garantálásában reménykedhetett az ügyvédi titoktartás szabályai miatt."

A különböző FATF jelentésekben és egyéb dokumentumokban gyakran a „kapuörök” (angolul: „gatekeepers”) kifejezés utal az ilyen professzionális szakmai szolgáltatókra, mivel ők védik a pénzügyi rendszerhez való hozzáférést: az elkövetőknek legtöbbször előbb az ő szolgáltatásaikat kell igénybe venniük (pl. egy cégalapítás esetében), hogy hozzáférhessenek a pénzügyi közvetítő rendszerhez. A FATF jelentések feltárták az elkövetők számára legvonzóbb jellemzőket is a kapuőrök által nyújtott szolgáltatásokban:

- cégek alapítása és egyéb komplex szervezeti struktúrák létrehozása (pl.

5 Financial Action Task Force on Money Laundering: Annual Report 1996-1997, Párizs, FATF, A melléklet, 34. o. 
trösztök) alkalmasak az illegális vagyonelemek és az elkövetők közötti kapcsolódás elfedésére;

- ingatlanok adásvétele egyaránt alkalmazható az illegális pénzeszközök elhelyezésére (pl. a vételár készpénzben történő kifizetésével), és az integrációs szakasz végső befektetésére (pl. a vételár átutalással történő kiegyenlítésével, miután az összeg a különböző előzetes tranzakciókkal a rétegezés folyamatán már keresztülment);

- egyes szolgáltatók az ügyfél nevében különböző pénzügyi megbizásokat is teljesítenek (például készpénzt fizetnek be vagy vesznek fel a bankpénztárban, pénzt váltanak, rendelkeznek az ügyfél bankszámlája felett stb.);

- az elkövetők a pénzügyi és adóïgyi tanácsadók igénybevétele által olyan pénzügyi befektetők látszatát kelthetik, akik csupán az adóterheiket kívánják minimalizálni a jogszabályok engedte keretek között.

\subsection{A terrorizmus finanszírozása}

A nemzetközi és hazai szabályozásban a pénzmosással együtt a terrorizmus jelensége és a terrorizmus finanszírozásának megakadályozása is kulcsfontosságúvá vált az utóbbi két évtizedben. A terrorizmusfinanszírozási tevékenység a pénzmosási folyamattal éppen ellenkező irányú vagyontranszformációt jelent: törvényes eredetű jövedelmek válhatnak törvénytelenné a súlyosan jogellenes büncselekményekhez való felhasználásukkal, ezért a folyamat „pénzbepiszkitásnak" (money dirtying) is nevezhetö.

Büntetőjogi értelemben a terrorizmus finanszírozása a terrorcselekmény elkövetéséhez szükséges személyi feltételek, anyagi javak biztosítását jelenti, vagyis a tárgyi bűnsegély megvalósítását, amelyet a legtöbb ország büntetőjogi szabályozása önálló büncselekményként is büntetni rendel.

A terrorizmusfinanszírozásra utaló jelek a pénzintézetek számára korántsem egyszerüen felismerhetőek, gyakran a hatóságok is csak egy-egy már megtörtént terrorcselekmény kapcsán indult nyomozás során tárják fel az elkövetés eszközeit, köztük a finanszírozási forrásokat. A hatóságok tapasztalatai alapján az egyik leggyakoribb módszer a civil és nonprofit szervezetek álcájával megvalósított terrorizmusfinanszírozás. Karitatív célú adománygyüjtéssel például akár legális, akár illegális források is felhasználhatók, ha a támogatást nem ellenőrzött, nem transz- 
parens módon, a későbbi terrorcselekményeket elkövető személyekhez, szervezetekhez juttatják. A terrorizmusfinanszírozás elleni fellépés a 2001. szeptember 11-i események hatására kiemelten a szabályozás fókuszába került, az egyes terrorszervezetek és terrorista személyek szankciós listákra helyezése mellett a másik szabályozási eszköz a pénzmosás elleni szabály- és intézményrendszer kiterjesztése lett: a pénzintézeteknek és az egyéb kötelezett szolgáltatóknak a terrorizmusfinanszírozásra utaló körülmények esetén bejelentési kötelezettségük van a hatóságok részére.

\subsection{Nemzetközi fellépés a pénzmosás és a terrorizmus finanszírozása ellen}

Tekintettel arra, hogy napjainkra a pénzmosás már olyan méreteket öltött, amely világgazdasági szinten is érezteti hatását ${ }^{6}$, továbbá, hogy a szervezett bűnözés és ezzel együtt a pénzmosás is olyan jelenség, amely átlépi az országhatárokat, egyértelmü, hogy csak globális fellépéssel lehet eredményes ellenintézkedéseket alkalmazni. A 2001. szeptember 11-i terrortámadások még inkább rávilágítottak arra, hogy a terrorizmus leküzdéséhez hatékony nemzetközi szabályozásra és együttmüködésre van szükség.

\subsubsection{ENSZ Egyezmények}

Az Egyesült Nemzetek Szervezete 1988. évi Bécsi Egyezménye a kábítószerek és a pszichotrop anyagok tiltott forgalmazása ellen az első olyan nemzetközi jogi eszköz, amely a pénzmosás elleni új, globális stratégiát tükrözi, és a pénzmosást büncselekménynek tekinti. 2003-ban lépett hatályba $\boldsymbol{a} \mathbf{P a}$ lermói Egyezmény a nemzetközi szervezett bünözés ellen, majd 2005-ben az ENSZ korrupció elleni egyezménye, amelyek értelmében már nem csak a kábítószer-kereskedelmet, hanem az összes súlyos, vagyont generáló bűncselekményt is a pénzmosás alapbüncselekményeként kell meghatározni a fogalom értelmezésekor. Emellett mindkét egyezmény felhívja az államokat, hogy átfogó felügyeleti és szabályozási rendszert hozzanak létre a bankok és a nem banki pénzügyi intézmények tevékenységének ellenőrzésére, továbbá, hogy állítsanak

6 Az ENSZ Kábitószer és Bünözés Elleni Hivatala (United Nations Office on Drugs and Crime) becslése szerint a pénzmosás a Föld összes országa egyesitett GDP-jének 2-5\%-át teszi ki, s összege mintegy 800-2 000 milliárd amerikai dollárra becsülhető (https://www.unodc.org/unodc/ en/money-laundering/globalization.html). 
fel olyan pénzügyi hírszerző egységeket (Financial Intelligence Unit - FIU), amelyek a pénzmosás gyanús bejelentéseket fogadják, elemzik és a szükséges hatósági intézkedéseket megteszik. A terrorizmus finanszírozásának tilalmáról szóló 1999. évi New York-i Egyezmény általános tilalmat fogalmaz meg a terrorista szervezetek és cselekmények pénzügyi támogatására vonatkozóan, illetve a részes államok kötelezettségévé teszi a nemzeti büntetőjogi szabályok szigorítását és a közvetlen összehangolt fellépést.

\subsubsection{A Pénzügyi Akciócsoport (FATF)}

A Pénzügyi Akciócsoportot 1989. július 16-án alapították a gazdaságilag legfejlettebb országok a párizsi G-7 csúcstalálkozón. Az FATF fö feladata a pénzmosás és terrorizmusfinanszírozás elleni fellépés nemzetközi standardjainak kialakítása, az egyes országok erre vonatkozó jogszabályainak, intézményrendszerének rendszeres értékelése, a szabályozás harmonizálásának elősegítése és a nemzetközi együttmüködés erősítése.

Az FATF a pénzmosás és a terrorizmusfinanszírozás elleni küzdelem kapcsán ajánlásokat fogalmazott meg és tett közzé, ezek tekinthetők a nemzetközi szabályozás alapszabályainak. Az FATF kormányközi szervezetként, az alapító országok felhatalmazása, mandátuma alapján végzi tevékenységét. Az FATF eredeti mandátuma szerint eleinte a pénzmosás elleni fellépés jegyében tette közzé 40 ajánlását, amelyet - miután mandátuma kibővítésre került - további 9 , a terrorizmusfinanszírozás elleni speciális ajánlással egészített ki. Az FATF az ajánlásokat 2012-ben felülvizsgálta, számuk azóta újból negyven, miután több ajánlás szabályait összevonták, illetve a pénzmosás és terrorizmusfinanszírozás elleni ajánlásokat immár egységesen kezelik

Az FATF-nek jelenleg 38 ország és 2 nemzetközi szervezet a tagja ${ }^{8}$, székhelye Párizsban van.

A FATF az ajánlások és az ezek követésének vizsgálatára szolgáló módszertan alapján minden tagállamról meghatározott rendszerességgel jelentést készít. Az országvizsgálatot a plenáris ülésen vitatják meg a tagállamok képviselői, amely

7 Az FATF ajánlásai a honlapján nyilvánosan elérhetöek: http://www.fatf-gafi.org/publications/ fatfrecommendations/documents/fatf-recommendations.html

8 A két nemzetközi szervezet: az Európai Unió Bizottsága és az Öböl-menti Együttmüködési Tanács (GCC). Ld: http://www.fatf-gafi.org/about/membersandobservers/ 
így a politikai-diplomáciai nyomásgyakorlás eszközéül is szolgál. Korábbi gyakorlata szerint az FATF rendszeresen közzétette az ún. „Nem Együttmüködő Országok és Területek" (Non-Cooperating Countries and Territories, NCCT) listáját, amellyel felhívta az FATF tagállamokat, hogy pénzügyi intézményeiktől követeljék meg, hogy különös körültekintéssel kezeljék a listán szereplő országok állampolgárai és vállalatai (köztük a pénzügyi intézmények) tevékenységét és tranzakcióit9

Ajánlásai mellett az FATF a gyanús, szokatlan és bizonyítottan pénzmosás elkövetésére alkalmas eseteket ún. tipológiákban összegzi és teszi közzé, továbbá iránymutatások és tematikus tanulmányok publikálásával segíti a tagországok és a piaci szereplők legjobb gyakorlatának kialakítását.

Az FATF globális hálózatát alkotják regionális szervezetei, amelyek minden kontinenst átfednek ${ }^{10}$, és az FATF-tagsággal nem rendelkező országok esetében az FATF módszertan szerint elvégzik az országértékeléseket. Az egyes országok pénzmosás és terrorizmusfinanszírozás elleni szabályainak, intézményrendszerének hiányosságaira, az azonosított kockázatokra az FATF nyilvános közleményekben hívja fel a tagországok és a piaci szereplők figyelmét, illetve - súlyos szabályozási, intézményi hiányok esetén - célzott intézkedések alkalmazására szólít fel. A magas pénzmosási és terrorizmusfinanszírozási kockázatot hordozó, és a hiányosságok miatt megfigyelt státuszban lévő országok listáját az FATF a honlapján teszi közzé.

\subsubsection{Az Egmont Csoport}

A világ 158 pénzügyi információs hatóságát (Financial Intelligence Unit, FIU) tömörítő szakmai szervezet 1985-ben jött létre, és legfőbb feladata a biztonságos, védett platformon történő információtovábbítás biztosítása az egyes hatóságok között a pénzmosással és a terrorizmusfinanszírozással összefüggő ügyekben. Az egyes tagállami FIU-szakértők részvételével emellett rendszeres fórumot teremt a tapasztalatcserére és a nemzetközi együttmüködésre.

9 2001-ben Magyarország is felkerült az FATF listájára, mivel akkor még lehetöség volt anonim betétkönyveket nyitni a hazai pénzintézeteknél (lásd: http://www.oecd.org/hungary/financiala ctiontaskforceonmoneylaundering2000-2001reportreleased.htm). Az NCCT listákat az FATF gyakorlatában felváltotta az egyes országokkal kapcsolatos hiányosságokat feltáró ún. „nyilvános közlemények” („Public Statement”) közzététele.

10 Az FATF regionális szervezetei: MONEYVAL (Európa), EAG (Eurázsiai térség), Asian Pacific Group (Észak-Amerika, Ausztrália, és Dél-Kelet Ázsia), CFATF (Karib-térség országai), ESAAMLG (Kelet-és Dél-Afrika), GABAC (Közép-Afrika), GAFILAT (Közép-és Dél-Amerika), GIABA (Nyugat-Afrika), MENAFATF (Észak-Afrika és Közel-Kelet). 


\subsubsection{Az Európa Tanács egyezményei és a Moneyval}

Az 1949-es londoni egyezmény aláírásával 10 állam létrehozta a strasbourgi székhelyü Európa Tanácsot (röviden ET, angolul: Council of Europe) ${ }^{11}$, amelynek jelenleg 47 európai ország a tagja. Az Európa Tanácshoz Magyarország 1990-ben csatlakozott, és ezzel egyben részesévé vált az Európa Tanács égisze alatt született nemzetközi egyezményeknek is, így például az Emberi Jogok Európai Egyezményének (1950), valamint a pénzmosás és terrorizmusfinanszírozás megelőzése és megakadályozása szempontjából kiemelkedő jelentőségű egyezményeknek is:

- az Európa Tanács Egyezménye a pénzmosásról, valamint a büncselekményekből származó jövedelmek felkutatásáról, lefoglalásáról és elkobzásáról (Strasbourgi Egyezmény, 1990),

- az Európa Tanács Egyezménye a pénzmosásról, a bűncselekményekből származó jövedelmek felkutatásáról, lefoglalásáról és elkobzásáról, valamint a terrorizmus finanszírozásáról (Varsói Egyezmény, 2005).

A Moneyval az Európa Tanács szakosított szerveként müködik, és fö feladata a tagállamok pénzmosás és terrorizmusfinanszírozás elleni jogalkotásának, gyakorlatának, intézményrendszerének vizsgálata és értékelése. A Moneyval az FATF regionális szervezete, amelynek Magyarország is a tagja. A Moneyval által végzett országvizsgálatok célja az FATF ajánlásoknak való megfelelés felmérése, a vizsgálat az FATF által meghatározott módszertan szerint történik, és azt ún. kölcsönösségi alapon folytatja a Moneyval, amely azt jelenti, hogy meghatározott sorrend szerint valamennyi ET tagállamban megvizsgálja a pénzmosás és terrorizmusfinanszírozás elleni jogszabályokat, gyakorlatot és intézményeket, a vizsgálókat pedig az egyes ET tagállamok szakértői közül jelöli ki, rotációs alapon.

\subsubsection{Az Európai Unió szabályozása}

Az Európai Unióban a tőkemozgás szabadsága, az egységesített gazdasági, pénzügyi térség kialakulása a pénzmosás és a terrorizmusfinanszírozás kockázatait nagymértékben növeli, ami ellen csak közösségi szintü jogszabályokkal lehet hatékonyan fellépni. Az Európai Unióban a közösségi jogi szabályozás főként irányelvekben jelenik meg, amelyeket a tagállamoknak implementálniuk kell,

11 Az alapitó államok: Benelux államok, Nagy-Britannia, Franciaország, Dánia, Norvégia, Svédország, Irország, Olaszország. Az Európa Tanács laza, kormányközi együttmüködés keretében jött létre, és szemben az Európai Tanáccsal és az Európai Unió Tanácsával, nem az Európai Unió intézménye. 
vagyis nemzeti jogalkotással az irányelvnek megfelelő szabályozást kell bevezetniük. A pénzmosás és a terrorizmusfinanszírozás elleni tárgyban az irányelvek mellett közvetlenül hatályos közösségi rendeletek írnak elö további kötelezettségeket, amelyeknek szabályait tagállami norma nélkül is alkalmazni kell ${ }^{12}$.

Az irányelvi szabályozás fejlődése az alábbiak szerint alakult:

- Már a legelső, 1991. évi irányel ${ }^{13}$ is előírta a tagállamoknak, hogy tiltsák meg a pénzmosást, és kötelezzék a hitelintézeteket és az egyéb pénzügyi szolgáltatók széles körét magában foglaló pénzügyi szektort, hogy ügyfeleiket azonosítsák, vezessenek megfelelő nyilvántartást, hozzanak létre belső eljárásokat a személyzet képzése és a pénzmosás elleni védelem céljából, valamint jelentsenek be az illetékes hatóságoknak bármilyen pénzmosásra utaló körülményt.

- 2001-ben a második irányelv az FATF ajánlásoknak megfelelő rendelkezésekkel egészült ki, és a hatálya már kiterjedt a pénzváltókra, a pénzátutalást végző és befektetési szolgáltatókra.

- A harmadik irányelv (2005/60/EK) már a terrorizmusfinanszírozás elleni intézkedéseket is elöírta, hatálya további szolgáltatói körre terjedt ki (ügyvédek, közjegyzők, könyvelők, ingatlanközvetítők, kaszinók, bizalmi vagyonkezelők), bevezette a kockázatalapú megközelítést, valamint a kiemelt közszereplőkre alkalmazandó fokozott átvilágítási szabályokat.

- A 2015-ben hatályba lépett negyedik irányel ${ }^{14}$, amely a kiemelt közszereplők fogalmát kiterjesztette a külföldi és hazai személyekre egyaránt, elöírta a tényleges tulajdonosi adatok központi nyilvántartását, hatálya alá vonta a szerencsejáték-szervező szolgáltatókat, és az ún. stratégiai hi-

12 A pénzátutalásokat kísérő megbizói adatokról szóló 1781/2006/EK rendelet (az ún. „Funds Transfer" rendelet) elöirja, hogy minden EU-n kivüllröl érkezö vagy oda irányuló átutalási megbizásnak tartalmaznia kell a megbizói adatok teljes körét. A Közösség területére belépő, illetve a Közösség területét elhagyó készpénz ellenörzéséről szóló 1889/2005/EK rendelet (az ún. „Cash Control" rendelet) értelmében határátlépéskor minden 10.000 euró feletti készpénzösszeget be kell jelenteni a vám-, illetve határrendészeti hatóságnak. A két tanácsi rendelet mellett az Európai Bizottság felhatalmazáson alapuló rendeletei alkotják a közvetlenül hatályos uniós jogszabályok körét (ld. következö bekezdéseket).

13 A pénzügyi rendszer pénzmosás céljára való felhasználásának megelözéséről szóló 1991. június 10-i 91/308/EGK tanácsi irányelv.

14 Az Európai Parlament és a Tanács (EU) 2015/849 irányelve (2015. május 20.) a pénzügyi rendszerek pénzmosás vagy terrorizmus-finanszírozás céljára való felhasználásának megelözéséröl, a 648/2012/EU európai parlamenti és tanácsi rendelet módosításáról, valamint a 2005/60/EK európai parlamenti és tanácsi irányelv és a 2006/70/EK bizottsági irányelv hatályon kívül helyezéséröl. 
ányossággal küzdő harmadik országokhoz kapcsolódó személyekkel és szervezetekkel szemben fokozott átvilágítási szabályok alkalmazását követelte meg.

- Az ötödik pénzmosás elleni irányelv ${ }^{15}$ 2018. június 19-én lépett hatályba, szabályait a tagállamoknak 2020. január 10-ig kell implementálniuk. Az új irányelv hatálya alá vonja a virtuális és törvényes fizetőeszközök közötti átváltást biztosító szolgáltatókat, valamint a letétkezelő pénztárca-szolgáltatókat. A kiemelt közszereplők vonatkozásában a fontos közfeladatok konkrét funkcióinak meghatározását írja elő a tagállamoknak, bevezeti a központi bankszámla-, fizetési számla- és széfnyilvántartást, és előírja a tényleges tulajdonosi nyilvántartások uniós szintű összekapcsolását.

Az irányelvekben megjelenő általános szabályok mellett, az Európai Bizottság külön rendeletekben megjelenő, speciális tárgykört szabályozó egyes rendeletei is a pénzmosás és a terrorizmusfinanszírozás elleni egységes uniós szintű fellépést szolgálják:

- a 2016/1675 bizottsági rendelet egészíti ki a 4. irányelvnek a stratégiai hiányosságokkal rendelkező, kiemelt kockázatot jelentő harmadik országokra vonatkozó szabályait azzal, hogy a konkrét országokat egy listán teszi közzé,

- a 2018/1108 (EU) bizottsági rendelet az elektronikuspénz-kibocsátók és a pénzforgalmi szolgáltatók központi kapcsolattartó pontjainak kijelölésével kapcsolatos szabályokat határozza meg,

- a 2019/758 (EU) bizottsági rendelet a harmadik országokban a pénzmosás és a terrorizmusfinanszírozási kockázat csökkentése érdekében hozandó minimális és kiegészítő intézkedéseket határozza meg.

15 Az Európai Parlament és a Tanács (EU) 2018/843 irányelve (2018. május 30.) a pénzügyi rendszerek pénzmosás vagy terrorizmus-finanszírozás céljára való felhasználásának megelözéséröl szóló (EU) 2015/849 irányelv, valamint a 2009/138/EK és a 2013/36/EU irányelv módositásáról. 


\subsubsection{Az Európai Felügyeleti Hatóságok ajánlásai és iránymutatásai}

Az Európai Felügyeleti Hatóságok (az EBA, EIOPA, ESMA) ${ }^{16}$ a pénzmosás és terrorizmusfinanszírozás elleni fellépés területén egy közös bizottságban (Joint Comittee, JC) működnek együtt, de közülük az Európai Bankhatóság (EBA) látja el a vezető szerepet, és tölti be a titkársági funkciót. Az EBA feladata - a másik két európai felügyeleti hatósághoz hasonlóan - a jogszabályok EU szintű egységes értelmezésének elősegítése, a felügyeletek közötti együttműködés erősítése, az EU irányelvben rá delegált feladatok (pl. kockázati fenyegetésekről szóló jelentés készítése) elvégzése, párbeszéd folytatása az érdekeltekkel és a nemzetközi szabályozó szervezetekkel. Ezeket a feladatokat többféle formában valósítja meg (konzultációk, nyilvános meghallgatások, szakbizottság működtetése, tervezetek véleményezése), de a leglátványosabb és leginkább kézzelfogható eredményei azok az írásos anyagok, amelyek jogi szempontból különböző erősségűek, de valamennyit figyelembe kell venni, és a nemzeti hatóságokkal (Magyarországon az MNB-vel) szemben elvárás azok átvétele és alkalmazása. A legfontosabb EBA dokumentumok az alábbiak:

- Közös bizottsági iránymutatás a pénzmosás és terrorizmusfinanszírozás megelőzése céljából történő felügyeleti együttműködésről és információcseréröl;

- Szabályozói technikai standard a harmadik országokban alkalmazandó csoportszintű pénzmosás és terrorizmusfinanszírozás elleni politikákról;

- Iránymutatás a pénzátutalások pénzmosásra és terrorizmusfinanszírozásra való felhasználásának megakadályozásáról;

- Iránymutatás a kockázatalapú felügyeletről;

- Iránymutatás a kockázati tényezőkről, valamint az egyszerűsített és a fokozott ügyfél-átvilágítási követelményekről.

\subsubsection{A Bázeli Bankfelügyeleti Bizottság ajánlásai}

A Nemzetközi Fizetések Bankja (Bank for International Settlements, BIS) a világ legrégebbi, jelenleg is működő nemzetközi pénzügyi szervezete, amelyet 1930-ban eredetileg az I. világháború utáni német jóvátétel elszámolása céljából hoztak létre, azonban miután a gazdasági világválság miatt a jóvátétel fizetések megakadtak, a szervezet a nemzetközi bankok közötti monetáris együttmüködés

16 EBA - European Banking Auhtority (Európai Bankhatóság), EIOPA - European Insurance and Occupational Pensions Authority (Európai Biztositás- és Foglalkoztatóinyugdij-hatóság), ESMA

- European Securities and Markets Authority (Európai Értékpapir-piaci Felügyelet). 
legfőbb szervezőjévé, a „központi bankok központi bankjává” vált, ajánlásaiban határozza meg az egységes normákat a hitelintézetek nemzetközi felügyeleti gyakorlatának közelítése céljából. A Bázeli Bankfelügyeleti Bizottság a Nemzetiközi Fizetések Bankján belül müködő, 1974-ben létrejött szabályalkotó testület, amely tematikus ajánlásai mellett számos iránymutatást adott ki a pénzmosás és a terrorizmusfinanszírozás elleni küzdelem jegyében ${ }^{17}$ :

- a bankrendszer pénzmosásra való bűnözői felhasználásának megakadályozása (1988),

- ügyfél-átvilágítás bankok számára (2001),

- általános útmutató a számlanyitáshoz és az ügyfélazonosításhoz (2003),

- egységes „Know Your Customer” kockázatkezelés (2003),

- nemzetközi átutalásokhoz kapcsolódó fedett fizetési műveletek átláthatósága és szürése (2009),

- pénzmosás és terrorizmusfinanszírozási kockázatok (2014),

- számlanyitások általános útmutatója (2016).

Ezek a szabályok kötelező erővel nem bírnak, a pénzügyi felügyeleti szerepkört ellátó nemzeti központi bankok azonban az ajánlásokban foglaltakat ellenőrzési módszereikbe beépítették és alkalmazzák.

\subsubsection{Wolfsberg Csoport}

A 2000-ben alakult Wolfsberg Csoport (Wolfsberg Group) tizenhárom globális bank szakmai szövetsége ${ }^{18}$. Célja a bankszektor gyakorlatának támogatása a pénzmosás elleni küzdelemben, az „Ismerd meg ügyfeled!” („Know Your Customer") és a terrorizmusfinanszírozás elleni szakmai alapelvek kidolgozása. A Wolfsberg-alapelvek a csoport eddig kiadott 19 ajánlásában ${ }^{19}$ fogalmazódnak meg, amelyek alkalmazását, mint egyfajta iparági standardokat, a pénzintézetek elvárják egymástól a bankközi kapcsolatokban.

17 A Bázeli Bankfelügyeleti Hatóság által kiadott ajánlások a BIS honlapján elérhetőek: https:// www.bis.org/bcbs/publications.htm

18 A Wolfsberg Csoport alapitó tagjai: Banco Santander, Bank of Tokyo-Mitsubishi UFJ, Barclays, Citigroup, Credit Suisse, Deutsche Bank, Goldman Sachs, HSBC, J.P. Morgan Chase, Société Générale, UBS. Később csatlakoztak: Bank of America, Standard Chartered Bank.

19 Ilyen ajánlást adott ki a Wolfsberg Csoport többek között a terrorizmusfinanszírozás visszaszorításáról (2002), a kockázatalapú megközelités alkalmazásáról (2006), a privátbanki tevékenység kockázatairól (2012), a levelezőbanki kapcsolatokról (2014), a mobil és internetes fizetési szolgáltatókkal kapcsolatban (2014), továbbá legújabban a nemzetközi pénzügyi és vagyoni szankciók szerinti szürésekröl (2019). A Wolfsberg-alapelvek elérhetöek a szervezet honlapján: https://www.wolfsberg-principles.com/publications/wolfsberg-standards 


\subsection{A pénzmosás és a terrorizmus finanszírozása elleni hazai szabályozás és intézményrendszer}

\subsubsection{Elözmények}

A rendszerváltás előtti Magyarországon - tekintve a szocialista tervgazdálkodásra jellemző viszonyokat, az állami monopóliumban lévő bankrendszert, a szigorú devizakorlátozásokat - gyakorlatilag nem létezett pénzmosás. A demokratikus rendszerváltással kialakult a kettős bankrendszer, megszűntek a devizakorlátozások, az országhatárok megnyíltak, megkezdődött a piacgazdaságra átállás, amivel a kezdeti években még nem járt együtt a megfelelő pénzügyi, jogi szabályozás, így a szervezett bűnözés is felismerte hazánkban a pénzmosási lehetőségeket. (Ekkoriban pl. még anonim takarékbetétet is lehetett nyitni a bankoknál, hiányoztak a pénzügyi szektor védelmét biztositó jogszabályok, nem volt azonositási kötelezettség, nem volt bejelentési kötelezettség, a banktitok érvényesült a rendőrségi adatkérések során). Magyarország végül az Európai Közösséggel kötött, és 1994-ben hatályba lépett Társulási Szerződésben vállalt kötelezettséget arra, hogy jogszabályalkotással és minden egyéb lehetséges eszközzel fellép a bűncselekményekből származó pénzek tisztára mosása ellen, így a pénzmosás 1994-ben már büncselekménynek minősült.

\subsubsection{Hatályos szabályok}

Hazánkban jelenleg a Büntetö Törvénykönyvröl szóló 2012. évi C. törvény (Btk.) rendeli büntetni a pénzmosást (399. §), a pénzmosással kapcsolatos bejelentési kötelezettség elmulasztását (401. §), valamint önálló törvényi tényállásként a terrorizmus finanszírozását (318. § és 318/A. \$).

A hatályos magyar büntetöjogi szabályozás értelmében pénzmosást követ el, aki a más által elkövetett büntetendő cselekményből származó

a) dolgot átalakítja, átruházza, vagy a dologgal összefüggésben bármilyen pénzügyi tevékenységet végez, vagy pénzügyi szolgáltatást vesz igénybe abból a célból, hogy az ilyen dolog eredetét eltitkolja, elleplezze, vagy a büntetőeljárást meghiúsítsa;

b) dolog eredetét, az ilyen dolgon fennálló jogot, vagy az e jogban bekövetkezett változásokat, az ilyen dolog helyének változását, vagy azt a helyet, ahol az ilyen dolog található, eltitkolja, vagy elleplezi. 
A Büntető Törvénykönyv a fenti alaptényálláson kívül büntetni rendeli:

- azt a cselekményt, amikor valaki a más által elkövetett büncselekményből származó dolgot magának vagy harmadik személynek megszerzi, megőrzi, kezeli, használja vagy felhasználja, és azon, vagy az ellenértékén más anyagi javakat szerez (ha a dolog eredetét az elkövetés időpontjában ismerte),

- ha valaki a saját maga által elkövetett büncselekményből származó dolgot ezen eredetének leplezése, titkolása céljából gazdasági tevékenység gyakorlása során felhasználja, vagy a dologgal összefüggésben bármilyen pénzügyi tevékenységet végez, vagy pénzügyi szolgáltatást vesz igénybe,

- a pénzmosás üzletszerüen, különösen nagy vagy azt meghaladó értékre, az egyes professzionális szolgáltatók ${ }^{20}$ tisztségviselőjeként vagy alkalmazottjaként, hivatalos személyként vagy ügyvédként történő elkövetését (súlyosabban minősülő esetek),

- önálló tényállásként a pénzmosás előkészületét,

- a pénzmosás gondatlan elkövetését (vagyis amikor valaki gondatlanságból nem tud a dolog büncselekményből való származásáról), valamint

- a pénzmosás és a terrorizmus finanszírozásának megelőzésével és megakadályozásával kapcsolatos, törvényben elöírt bejelentési kötelezettség elmulasztását.

A büntetőjogi szabályozás mellett a pénzügyi és egyéb szolgáltatást nyújtókra vonatkozó részletes kötelezettségeket további jogszabályok határozzák meg.

A pénzmosás és a terrorizmus finanszírozása megelözéséröl és megakadályozásáról szóló 2017. évi LIII. törvény (Pmt.) 2017. június 26-án lépett hatályba és rendelkezései az Európai Unió negyedik pénzmosás elleni irányelvének szabályait ültetik át a hazai jogba. A Pmt. hatálya az alábbi szolgáltatói körre terjed ki:

- hitelintézet,

- pénzügyi szolgáltató,

- foglalkoztatói nyugdíjszolgáltató intézmény,

- önkéntes kölcsönös biztosítópénztár,

- nemzetközi postautalvány-felvételt és -kézbesítést végző szolgáltató,

20 Ilyen szolgáltatóként határozza meg a Btk. a következöket: pénzügyi intézmény, befektetési vállalkozás, árutözsdei szolgáltató, befektetési alapkezelő, kockázati tỏkealap-kezelö, tőzsdei, központi értéktári vagy központi szerzödö fél tevékenységet végzö szervezet, biztositó, viszontbiztositó vagy független biztositásközvetítö, illetve önkéntes kölcsönös biztositó pénztár, magánnyugdíjpénztár vagy foglalkoztatói nyugdijszolgáltató intézmény, szerencsejáték szervezésével foglalkozó szervezet, szabályozott ingatlanbefektetési társaság. 
- ingatlanügylettel kapcsolatos tevékenységet végző szolgáltató,

- könyvvizsgáló,

- könyvviteli (könyvelöi), adószakértői, okleveles adószakértői, adótanácsadói tevékenységet megbízási, illetve vállalkozási jogviszony alapján végző szolgáltató,

- játékkaszinót, kártyatermet működtető vagy távszerencsejátéknak nem minősülő fogadást, távszerencsejátékot, online kaszinójátékot szervező szolgáltató,

- nemesfémmel vagy az ezekből készült tárgyakkal kereskedő szolgáltató,

- árukereskedő, amennyiben tevékenysége folytatása során kétmillió-ötszázezer forintot elérő vagy meghaladó összegü készpénzfizetést fogad el,

- ügyvéd (ideértve az ügyvédi irodát, európai közösségi jogászt, európai közösségi jogászi irodát), kamarai jogtanácsos, közjegyző és

- bizalmi vagyonkezelő.

A Pmt. ügyfél-átvilágítási intézkedések alkalmazását írja elő minden szolgáltató részére, amely az alábbiakat foglalja magában:

1. az ügyfelek, azok meghatalmazottjai, képviselői, rendelkezésre jogosultjai és tényleges tulajdonosai azonosítása,

2. az azonosítási adatok igazoló ellenőrzése a bemutatott azonosító okmányok alapján,

3. az ügyfelekkel létesített üzleti kapcsolatok folyamatos figyelemmel kísérése (az ügyletek, fizetési számlák forgalmának figyelése),

4. az ügyfél-átvilágítási adatok naprakészen tartása.

Az elöző törvényi szabályozásához képest ${ }^{21}$ a Pmt. új kötelezettségként írta elő a szolgáltatók részére a belső kockázatértékelés készítését, amelyben azonosítaniuk és értékelniük kell az üzleti kapcsolat vagy ügyleti megbízás jellegével és összegével, az ügyféllel, termékkel, szolgáltatással, földrajzi területtel és alkalmazott eszközzel kapcsolatos pénzmosási és terrorizmusfinanszírozási kockázati tényezőket, az azonosított kockázatok csökkentésére megfelelő kockázatcsökkentő intézkedéseket kell meghatározniuk. A belső kockázatértékelés elkészítéséhez, továbbá a kockázatok csökkentése és kezelése érdekében a szolgáltatók kötelesek figyelembe venni a nemzeti kockázatértékelés eredményét, amelyet a pénzmosás és a terrorizmusfinanszírozás elleni küzdelemben érintett valamennyi állami hatóság és fel-

21 2007. évi CXXXVI. törvény a pénzmosás és a terrorizmus finanszírozása megelözéséröl és megakadályozásáról. 
ügyeleti, szabályozói testület munkájaként először 2015-ben fogadtak el és adtak közre, majd a Moneyval ajánlásainak figyelembevételével 2017-ben aktualizáltak ${ }^{22}$.

A Pmt. - a korábbi törvényi szabályozással megegyező módon - rendelkezik arról, hogy pénzmosásra vagy terrorizmusfinanszírozásra utaló tény, adat, körülmény felmerülése esetén bejelentést kell tenni a pénzügyi információs hatóság részére, amely egy külön jogszabály kijelölése alapján a Nemzeti Adó- és Vámhivatal Központi Irányítás Pénzmosás és Terrorizmusfinanszírozás Elleni Iroda (a továbbiakban: NAV PTEI).

A Pmt. 11. címe (38-52. §) részletes szabályokat állapít meg a NAV PTEI működésére vonatkozóan. A NAV PTEI a bejelentések fogadása és feldolgozása (értékelése, elemzése, illetve nyomozószervekhez történő továbbítása), illetve a társhatóságokkal folytatott információcsere mellett operatív elemzéseket végez a bejelentések adatai alapján, stratégiai elemzések keretében vizsgálja a pénzmosás és a terrorizmus finanszírozásával kapcsolatos folyamatokat és jellemzőket. A bejelentésekben előforduló legjellemzőbb, leggyakoribb eseteket (tipológiákat), tendenciákat, illetve a statisztikákat féléves és éves jelentéseiben teszi közzé. Az aktuálisan elérhető legutolsó éves jelentésben (a 2017. évről szóló éves jelentés ${ }^{23}$ a NAV PTEI kiemelten is foglalkozik az ún. „social engineering” típusú csalás ${ }^{24}$ és a kapcsolódó pénzmosás, a virtuális fizetöeszközök (pl. bitcoin) ${ }^{25}$, valamint a készpénzfutárok, jelentös összegü készpénzes tranzakciók ${ }^{26}$ pénzmosás

22 Ld. a Nemzeti Kockázatértékelésröl készült, a Nemzeti Adó- és Vámhivatal honlapján elérhetö publikus összefoglalót: https://www.nav.gov.hu/data/cms448464/Osszefoglalo_dokumentum_a_ Nemzeti_Kockazatertekeles_felulvizsgalatarol.pdf

23 NAV PTEI (2018).

24 „Social engineering”, más néven pszichológiai manipulációs csalás, vagy számlaeltéritéses csalás, amelynek során az elkövetök a sértett fél megtévesztésével (pl. e-mailfiókja feltörésével a kiismert üzleti kapcsolatok közül választva egy hasonló írásképü e-mailröl) küldenek számára olyan kérést, hogy a megrendelt áru, termék, szolgáltatás ellenértékét étékét - bankváltás miatt - már az ott megjelölt, az elkövetők által ellenörzött számlára kérik átutalással teljesiteni. A pénz számlára való megérkezését követöen annak készpénzben való felvétele vagy másik bankszámlára történő tovább utalása már pénzmosást valósít meg.

25 A virtuális fizetöeszközökkel kapcsolatos gyanús bejelentések száma jelentősen emelkedett, ezek kétharmadában jellemzöen megjelenik a három ismert virtuális fizetöeszköz váltó platform (Kraken, Bitstamp, Coinbase) valamelyike. A pénzmosási kockázatot a virtuális fizetőeszköz váltó platformok felé, illetve onnan érkező jelentős összegü átutalások jelentik, mivel a virtuális fizetöeszközökkel az anonim pénzügyi tranzakciókat teszik lehetövé, vagyis nem ellenörizhetö a forrás és a kedvezményezett sem egy-egy fizetés esetében, ami fokozott pénzmosás és terrorizmusfinanszírozási kockázatot hordoz.

26 A készpénzzel kapcsolatos kockázatokat a NAV PTEI 2017. évi jelentése a következöképpen írja le: „Az elmúlt évben megfigyelhetö jelenség, hogy elsősorban dél-európai országokból jelentős összegek átutalása valósul meg magyarországi bejegyzésü hitelintézet által vezetett fizetési 
és terrorizmusfinanszírozási kockázataival. A NAV PTEI a Pmt. alapján továbbá felügyeleti tevékenységet lát el az ingatlanügylettel kapcsolatos tevékenységet végző szolgáltatók, a könyvvizsgálók, a könyvviteli (könyvelői), adószakértői, okleveles adószakértői, adótanácsadói tevékenységet megbízási, illetve vállalkozási jogviszony alapján végző szolgáltatók tekintetében.

\begin{tabular}{|l|r|r|r|r|r|r|r|r|}
\hline Bejelentést küldő szolgáltatók & $\mathbf{2 0 1 0}$ & $\mathbf{2 0 1 1}$ & $\mathbf{2 0 1 2}$ & $\mathbf{2 0 1 3}$ & $\mathbf{2 0 1 4}$ & $\mathbf{2 0 1 5}$ & $\mathbf{2 0 1 6}$ & $\mathbf{2 0 1 7}$ \\
\hline Bank & 6315 & 5401 & 6753 & 11443 & 8055 & 6967 & 6969 & 6119 \\
\hline Biztosítási szolgáltató & 155 & 223 & 194 & 539 & 543 & 357 & 275 & 375 \\
\hline Befektetési szolgáltató & 72 & 32 & 57 & 53 & 136 & 109 & 103 & 124 \\
\hline Pénzváltó & 352 & 225 & 257 & 119 & 148 & 173 & 352 & 771 \\
\hline Takarékszövetkezet & 210 & 213 & 252 & 350 & 241 & 170 & 261 & 215 \\
\hline Egyéb hitelintézet & 26 & 26 & 34 & 57 & 72 & 23 & 31 & 18 \\
\hline Egyéb pénzügyi szolgáltató* & 42 & 38 & 108 & 253 & 384 & 498 & 680 & 918 \\
\hline Önkéntes kölcsönös biztosító pénztár & 0 & 1 & 2 & 5 & 3 & 19 & 37 & 0 \\
\hline Átutőzsdei szolgáltató & 0 & 0 & 0 & 0 & 0 & 0 & 0 & 0 \\
\hline Postai szolgáltató & 0 & 1 & 0 & 10 & 3 & 15 & 44 & 9 \\
\hline Kaszinó & 0 & 0 & 0 & 0 & 0 & 1 & 4 & 7 \\
\hline Ingatlanügyleti tevékenységet folytató szolgáltató & 1 & 4 & 3 & 3 & 5 & 4 & 1 & 0 \\
\hline Nemesfém kereskedó & 0 & 0 & 2 & 0 & 0 & 0 & 3 & 4 \\
\hline Ügyvéd & 7 & 7 & 3 & 3 & 6 & 2 & 3 & 4 \\
\hline Közjegyző & 1 & 1 & 3 & 4 & 4 & 8 & 4 & 3 \\
\hline Könyveló & 1 & 3 & 10 & 16 & 13 & 23 & 18 & 10 \\
\hline Könyvvizsgáló & 1 & 2 & 2 & 0 & 3 & 0 & 1 & 1 \\
\hline Bizalmi vagyonkezelő & & & & & 0 & 0 & 0 & 0 \\
\hline Adószakértő & 0 & 0 & 0 & 0 & 1 & 0 & 0 & 0 \\
\hline Árukereskedó & 2 & 7 & 3 & 0 & 1 & 0 & 0 & 0 \\
\hline Államkincstár & 7185 & 6184 & 7683 & 12855 & 9618 & 8369 & 8786 & 8585 \\
\hline ÖsszESEN & & & & & & 7 \\
\hline
\end{tabular}

* Az egyéb pénzügyi szolgáltatók adatai között a Magyar Államkincstár által tett bejelentések is szerepelnek

\section{1. táblázat: A NAV PTEI-hez érkezett pénzmosás és terrorizmusfinanszírozás gyanús bejelentések}

Forrás: NAV PTEI (2018)

számlákra, ahonnan e pénzek továbbutalásra kerülnek távol-keleti országokban vezetett fizetési számlákra. Számos esetben ugyanezekre a fizetési számlákra jelentös, rövid idö alatt akár több tíz millió euró összegü ún. zsákos készpénzbefizetés történik. A befizetök jellemzően távolkeleti származású személyek, azonban elterjedt a stróman személyek alkalmazása is. A befizetett összegek szintén továbbutalásra kerülnek távolkeleti országokban vezetett fizetési számlákra." 
Az Európai Unió és az ENSZ Biztonsági Tanácsa által elrendelt pénzügyi és vagyoni korlátozó intézkedések végrehajtásáról szóló 2017. évi LII. törvény (Kit.) szintén 2017. június 26-án lépett hatályba, és elrendeli, hogy a pénzügyi és vagyoni korlátozó intézkedésekkel, azaz szankciókkal érintett személyek és szervezetek részére tilos pénzeszközöket és gazdasági erőforrásokat rendelkezésre bocsátani, illetve azokat be kell fagyasztani, továbbá részükre pénzátutalási megbízások nem teljesíthetők. A pénzintézeteknek bejelentési kötelezettségük mellett fel kell függeszteni az ügyleti megbízást, illetve zárolniuk kell azt a számlát, amellyel kapcsolatban felmerül, hogy az ügyfél szankcionált személy, illetve szervezet részére kezdeményez pénzátutalást, vagy ilyen személytől, szervezettől érkezik a számlájára pénzátutalás.

A Pmt.-ben és a Kit.-ben kapott felhatalmazás alapján a pénzügyminiszter (korábban nemzetgazdasági miniszter) és a Magyar Nemzeti Bank elnöke kapott felhatalmazást további részletszabályok rendeletben történő előírására, így jelent meg a 21/2017. (VIII. 3.) NGM rendelet, amely a Pmt. és a Kit. alapján a szolgáltatók által készítendő belső eljárásrend kötelező tartalmi elemeit határozza meg, valamint a jelenleg hatályos 45/2018. (XII. 17.) MNB rendelet, amely a Pmt. és a Kit. részletszabályait állapítja meg. Az MNB rendelete új szabályozási elemként a megfelelő informatikai felkészültséggel és biztonsági megoldással rendelkező szolgáltatók számára lehetővé teszi, hogy a személyes ügyfélkiszolgálás helyett, azzal egyenértékű módon, videókapcsolat útján végezzék el az ügyfél-átvilágítást és kössenek szerződést vagy nyissanak bankszámlát egy ügyfélnek.

A jogszabályi keretek mellett a Magyar Nemzeti Bank ajánlásai segítik elő a pénzügyi szolgáltatók egységes gyakorlatát, ezeknek az ajánlásoknak az érvényesülését az MNB a felügyeleti vizsgálatai során ellenőrzi és értékeli. 


\subsection{Irodalomjegyzék}

Gál István László (2007): A pénzmosás hatályos büntetőjogi szabályozása Magyarországon. Pécs. https://www.mnb.hu/letoltes/pszafhu-rtfkonf-gali.pdf

Gilmore, William C. (2004): Dirty money - The evolution of international measures to counter money laundering and the financing of terrrorism. Third Edition. Strasbourg: Council of Europe Publishing.

Mufson, Steven - McGee, Jim (1991): BCCI Scandal: Behind the „Bank of Crooks and Criminals". Washington Post, 1991. július 28. https://www.washingtonpost.com/archive/politics/1991/07/28/bcci-scandal-behind-thebank-of-crooks-and-criminals/563f2216-1180-4094-a13d-fd4955d59435/?noredirect $=$ on\&utm_term $=.2250 \mathrm{f} 2 \mathrm{aa} 4 \mathrm{~d} 71$

Szalma Baksi Ferenc (2019): „Osztrák-magyar pénzmosó bandát lepleztek le.” Index.hu: https://index.hu/belfold/2019/05/24/ausztria_ szerencsejatek_ penzmosas_rendorseg_nni/

Szendrei Ferenc (2010): A pénzmosás. PhD értekezés, Pécs. https://ajk.pte.hu/ files/file/doktori-iskola/szendrei-ferenc/szendrei-ferenc-vedes-ertekezes.pdf Zéman Zoltán - Lukács János - Túróczi Imre (2015): A pénzmosás megjelenése a gazdaságban. Polgári Szemle, 11. évfolyam, 4-6. szám. https://polgariszemle.hu/archivum/101-2015-december-11-evfolyam-4-6-szam/gazdasagpolitika-jegybankpolitika-allami-ellenorzes/715-a-penzmosas-megjelenese-a-gazdasagban\#note2

Financial Action Task Force (2012): Best Practices Paper - Managing the anti-money laundering and counter-terrorist financing policy implications of voluntary tax compliance programmes, 2012. október, Párizs. https://www. fatf-gafi.org/media/fatf/documents/reports/BPP\%20VTC.pdf

Financial Action Task Force on Money Laundering (1997): Annual Report 19961997, Párizs: FATF, A melléklet, 34. o. https://www.fatf-gafi.org/media/fatf/ documents/reports/1996\%201997\%20ENG.pdf

Financial Action Task Force (2012): International Standards on Combating Money Laundering and the Financing of Terrorism - The FATF Recommendations. http://www.fatf-gafi.org/publications/fatfrecommendations/documents/fatf-recommendations.html 
Financial Action Task Force on Money Laundering (2001): 2000-2001 Report Released http://www.oecd.org/hungary/financialactiontaskforceonmoneylaundering2000-2001 reportreleased.htm

NAV PTEI (2018): Éves jelentés - 2017. Nemzeti Adó- és Vámhivatal Központi Irányítása Pénzmosás és Terrorizmusfinanszírozás Elleni Iroda. https://www. nav.gov.hu/data/cms479978/Eves_jelentes__2017.pdf

United Nations Office on Drugs and Crime: „Money Laundering and Globalisation". Letöltve: 2019. május 31-én, https://www.unodc.org/unodc/en/money-laundering/globalization.html

Wolfsberg Csoport: Wolfsberg alapelvek. https://www.wolfsberg-principles. com/publications/wolfsberg-standards 


\section{A hitelintézetek könyvvizsgálata}

\subsection{Bevezető}

A piacgazdaság szereplőinek gazdasági döntéseik meghozatalához számos olyan hiteles és megbízható információra van szüksége, amelyet valamely külső ellenőrző szervezet (többnyire független könyvvizsgáló) véleményezett.

A pénzügyi intézmények (hitelintézetek és pénzügyi vállalkozások) alapvető sajátossága, hogy nem termelö, hanem szolgáltatási tevékenységet folytatnak speciális területeken, feladatuk, hogy azokat minél magasabb színvonalon nyújtsák ügyfeleik részére. (Fridrich-Mitró, 2009)

A pénzügyi intézmények beszámolóinak hitelessége és megbízhatósága a társadalom és a gazdaság főbb szereplői számára különösen érzékeny terület, ezért az ellenőrzés is kiemelt, többszereplős felülvizsgálatot foglal magában.

A hitelintézetek szabályozott környezetben müködnek, a müködésük kihat az ország, illetve az egyes települések gazdasági életére is.

A könyvvizsgálat szempontjából kockázati tényezö, hogy a hitelintézetek többnyire nagyszámú, nagy értékű ügyletet dolgoznak fel, jelentős a származékos pénzügyi instrumentumokkal és strukturált termékekkel történő kereskedelem, illetve jelentős azon mérlegen kívüli tételek állománya is, amelyek befolyásolják a beszámolóról alkotott vélemény megítélését.

A hitelintézetek esetében folyamatosan új termékek és szolgáltatások jelennek meg, amelyek nem szükségszerűen vannak összhangban a hatályos számviteli elvekkel és a könyvvizsgálói standardok fejlődésével. (Rakó et al., 2010)

A könyvvizsgálat szempontjából további kockázati tényező, hogy a hitelintézetek fiókhálózatai többnyire földrajzilag szétszórtan helyezkednek el, számos esetben külföldi leányvállalattal is rendelkeznek a hitelintézetek, illetve jellemző a döntési jogosultságok decentralizációja, a számviteli és ellenőrzési funkciók szétosztása, az összetett számviteli és belső ellenőrzési rendszer kiépítése, az elektronikus adatfeldolgozás széles körü alkalmazása. 
A kockázatok értékelése, a könyvvizsgálati eljárások tervezése, végrehajtása speciális felkészülést, tudást követel meg a könyvvizsgálótól.

E fejezet a hitelintézetek müködésének könyvvizsgálói vizsgálatával foglalkozik, általános betekintést nyújt a könyvvizsgálati elöírásokba és az alkalmazott módszertanba. A terjedelmi korlátok miatt a fejezet megírása során nem törekedtünk a teljeskörüségre, egyes módszertani kérdéseket kiemelünk, más kérdéseket felsorolás jelleggel mutatunk be.

\subsection{A hitelintézeti könyvvizsgálat környezete}

\subsubsection{A könyvvizsgálat célja és a könyvvizsgálati kötelezettség}

„A könyvvizsgálat egy olyan speciális, komplex ellenőrzési folyamat, amikor egy független szakértő (vagy szervezet) a tulajdonosok megbízásából elvégzi egy vállalkozás számviteli rendszerének felülvizsgálatát, ellenőrzi a közzétett adatok valódiságát, és ezek alapján objektív ítéletet alkot, véleményt nyilvánít a vállalkozás egészének vagyoni, pénzügyi és jövedelmi helyzetéröl.” (Lukács, 2017, p. 18.)

A számvitelről szóló 2000. évi C. törvény (továbbiakban Számviteli törvény, illetve Szt.) 155. \$ (1) bekezdése határozza meg a könyvvizsgálat célját. A könyvvizsgálat célja annak megállapítása, hogy a vállalkozó által az üzleti évről készített éves beszámoló, egyszerűsített éves beszámoló, továbbá az összevont (konszolidált) éves beszámoló a Számviteli törvény előírásai szerint készült, és ennek megfelelően megbízható és valós képet ad a vállalkozó (a konszolidálásba bevont vállalkozások együttes) vagyoni és pénzügyi helyzetéről, a müködés eredményéről. A könyvvizsgálat során ellenőrizni kell az éves beszámoló, az öszszevont (konszolidált) éves beszámoló és a kapcsolódó üzleti jelentés adatainak összhangját, kapcsolatát is.

A számviteli törvény 155. \$(3) bekezdése szerint a következő két feltétel együttes teljesülése esetén nem kötelező a könyvvizsgálat:

a) az üzleti évet megelőző két üzleti év átlagában a vállalkozó éves (éves szintre átszámított) nettó árbevétele nem haladta meg a 300 millió forintot, és

b) az üzleti évet megelőző két üzleti év átlagában a vállalkozó által átlagosan foglalkoztatottak száma nem haladta meg az 50 föt. 
A számviteli törvény a 155. $\$(5)$ bekezdésében részletezi azokat az eseteket, amikor a gazdálkodó szervezet a 155. \$ (3) bekezdésben foglaltakat nem alkalmazhatja:

a) az a kettős könyvvitelt vezető vállalkozó, ahol a könyvvizsgálatot jogszabály írja elö;

b) a takarékszövetkezet;

c) a konszolidálásba bevont vállalkozás;

d) a külföldi székhelyü vállalkozás magyarországi fióktelepe;

e) az a vállalkozó, amelyik - a megbízható és valós kép érdekében - a kivételes esetben eltér a törvény előírásaitól;

f) a közérdeklődésre számot tartó gazdálkodó.

A Magyar Könyvvizsgálói Kamaráról, a könyvvizsgálói tevékenységről, valamint a könyvvizsgálói közfelügyeletről (továbbiakban Kkt.) szóló 2007. évi LXXV. törvény 2. \$19. pontja bekezdésében meghatározza a közérdeklödésre számot tartó gazdálkodó szervezet fogalmát, amely szerint ebbe a kategóriába tartozik:

a) az a gazdálkodó, amelynek átruházható értékpapírjait az Európai Gazdasági Térség valamely államának szabályozott piacán kereskedésre befogadták;

b) minden olyan, az a) pont hatálya alá nem tartozó gazdálkodó, amelyet jogszabály közérdeklődésre számot tartónak minősít.

2015-től közérdeklődésre számot tartó gazdálkodó szervezetek a tőzsdei cégek mellett értékhatártól függetlenül a hitelintézetek (a Magyar Nemzeti Bank, az MFB Magyar Fejlesztési Bank Zártkörűen Működő Részvénytársaság és a Magyar Export-Import Bank Zrt. kivételével), a befektetési vállalkozások, valamint (a kisbiztosítók és a kölcsönös biztosítóegyesületek kivételével) a biztosítók.

A fenti törvényi rendelkezések alapján a hitelintézetek közérdeklödésre számot tartó gazdálkodó szervezetnek minősülnek, könyvvizsgálatra kötelezettek, amely audit alapján a könyvvizsgálat véleményt nyilvánít a hitelintézetek pénzügyi kimutatásairól a vonatkozó Magyar Nemzeti Könyvvizsgálati Standard (MNKS) alapján.

\section{A hitelintézetek könyvvizsgálóinak feladata:}

- a magyar számviteli törvény elöírásai (legtöbb esetben az IFRS-ek alapján készített) éves (egyedi vagy konszolidált) pénzügyi kimutatások könyvvizsgálata, és arról független könyvvizsgálói jelentés kibocsátása;

- a Kapcsolódó Szolgáltatásra Vonatkozó Standard a Könyvvizsgálói Külön- 
jelentés összeállításáról szóló 6100. témaszámú magyar nemzeti standard alapján történő jelentéskészítés.

\subsubsection{A könyvvizsgálóval szemben támasztott szakmai és függetlenségi követelmények}

A hitelintézetekről és a pénzügyi vállalkozásokról szóló 2013. évi CCXXXVII. törvény (továbbiakban Hpt.) 260. $\$$ (1) bekezdése szerint a pénzügyi intézmény esetén könyvvizsgálói feladatok ellátására csak akkor adható az érvényes könyvvizsgálói engedéllyel rendelkező, bejegyzett könyvvizsgáló (könyvvizsgálói társaság) részére megbízás, ha

a) a könyvvizsgáló (könyvvizsgálói társaság) pénzügyi intézményi minősítéssel rendelkezik;

b) a könyvvizsgáló nem rendelkezik a hitelintézetben közvetlen vagy közvetett tulajdonnal;

c) a könyvvizsgálónak nincs a hitelintézettel szemben fennálló kölcsöntartozása, valamint

d) a befolyásoló részesedéssel rendelkező tag a könyvvizsgáló cégben közvetlen vagy közvetett tulajdonnal nem rendelkezik.

A Hpt. külön kiemeli, hogy a fentebb felsorolt korlátozásokat a könyvvizsgáló közeli hozzátartozójára is alkalmazni kell.

A Hpt. számos további követelményt ír elő a hitelintézeti természetes személy könyvvizsgálóval szemben, amely szerint:

a) egyidejűleg legfeljebb öt hitelintézetnél láthat el könyvvizsgálói feladatot, ide nem értve a szövetkezeti hitelintézeteket;

b) egyidejüleg legfeljebb tíz szövetkezeti hitelintézetnél láthat el könyvvizsgálói feladatot;

c) egy-egy hitelintézettől származó jövedelme (bevétele) nem haladhatja meg éves jövedelmének (bevételének) harminc százalékát;

d) az egy tulajdonosi csoporthoz tartozó pénzügyi intézményektől, befektetési szolgáltatóktól, befektetési alapkezelő társaságoktól, tőzsdétől, vagy elszámolóházi tevékenységet végző szervezettől, valamint a tulajdonosi csoporthoz tartozó befektetési alapkezelö társaság által kezelt befektetési alaptól származó jövedelme (bevétele) nem haladhatja meg éves jövedelmének (bevételének) hatvan százalékát. 
A hitelintézeti könyvvizsgáló társaságokkal szemben további követelmény, hogy

a) a könyvvizsgálói társaságon belül a természetes személy könyvvizsgáló egyidejüleg - legfeljebb öt hitelintézetnél láthat el könyvvizsgálói feladatot, ide nem értve a szövetkezeti hitelintézeteket;

b) a könyvvizsgálói társaságon belül a természetes személy könyvvizsgáló egyidejűleg - legfeljebb tíz szövetkezeti hitelintézetnél láthat el könyvvizsgálói feladatot;

c) könyvvizsgálói társaság egy-egy hitelintézettől származó bevétele nem haladhatja meg éves nettó árbevételének tíz százalékát;

c) a könyvvizsgáló társaságnak az egy tulajdonosi csoporthoz tartozó pénzügyi intézményektől, befektetési szolgáltatóktól, befektetési alapkezelő társaságoktól, tőzsdétől és elszámolóházi tevékenységet végző szervezettől, valamint a tulajdonosi csoporthoz tartozó befektetési alapkezelő társaság által kezelt befektetési alaptól származó bevétele nem haladhatja meg éves nettó árbevételének harminc százalékát.

\section{Egyéb szakmai és függetlenségi követelmények}

- A hitelintézetek 2018 óta már IFRS szerint készítik el a pénzügyi kimutatásaikat, ezért a könyvvizsgálónak, illetve a könyvvizsgáló társaságnak IFRS minősítéssel is kell rendelkeznie.

- A befektetési szolgáltatási tevékenységet végző hitelintézet jogszabályi kötelezettségen alapuló könyvvizsgálatát csak olyan kamarai tag könyvvizsgáló (könyvvizsgáló cég) végezheti, aki (amely) rendelkezik pénzügyi intézményi és befektetési vállalkozási minősítéssel is. A könyvvizsgálóknak 2017. december 31-ig a már korábban megszerzett minősítésüket új vizsgával érvényesíteni kellett.

- 2018. január 1-jétől további követelményként jelentkezik, hogy a Hpt. 8. $\$(4)$ bekezdése szerinti hitelintézetnél pénzügyi intézményi minősítéssel rendelkező kamarai tag könyvvizsgáló is csak akkor végezhet jogszabályi kötelezettségen alapuló könyvvizsgálói tevékenységet, ha rendelkezik a közfelügyeleti hatóság által elismert, banknál végzett számviteli, ellenőrzési gyakorlattal, vagy a pénzügyi intézményi minősítésü kamarai tag könyvvizsgáló mellett legalább két évig banknál végzett jogszabályi kötelezettségen alapuló könyvvizsgálói tevékenység ellátásában való közremüködéssel. 
- 2015. július 7-től kötelező rotáció került bevezetésre, mely szerint a kamarai tag könyvvizsgáló (könyvvizsgáló cég) jogszabályi kötelezettségen alapuló könyvvizsgálói tevékenység ellátására irányuló megbízása legfeljebb 5 üzleti évre szólhat, míg ugyanazon közérdeklődésre számot tartó gazdálkodó tekintetében a megbízás lejáratát követö 4 üzleti éven belül nem vállalhat jogszabályi kötelezettségen alapuló könyvvizsgálói tevékenység ellátására irányuló megbízást.

- 2016. január 1-jétől jelentősen emelkedett ebben a körben a felelősségbiztosítás biztosítási összegének minimuma (természetes személy könyvvizsgálók esetében 100 millió forintra, könyvvizsgáló cégeknél 500 millió forintra).

- A függetlenségi követelmény erősítését szolgálja, hogy 2017. január 1-jétől kezdődően a kamarai tag könyvvizsgáló, valamint a könyvvizsgáló cég nevében a könyvvizsgálói feladatokat ellátó kamarai tag könyvvizsgáló e tevékenysége mellett az érintett gazdálkodónál más tevékenységet nem láthat el az általa vizsgált időszak kezdete és a könyvvizsgálói jelentés kiadása közötti időszakban, valamint ezen időszakot közvetlenül megelöző üzleti évben.

- További függetlenségi követelmény, hogy a pénzügyi intézmény nem adhat könyvvizsgálói megbízást a Felügyelet alkalmazottjának, vagy annak közeli hozzátartozójának. 


\subsection{A könyvvizsgálati munka szakaszai}

A könyvvizsgálati munka néhány jól elkülöníthető szakaszra bontható, melyet az 1. ábra mutat be:

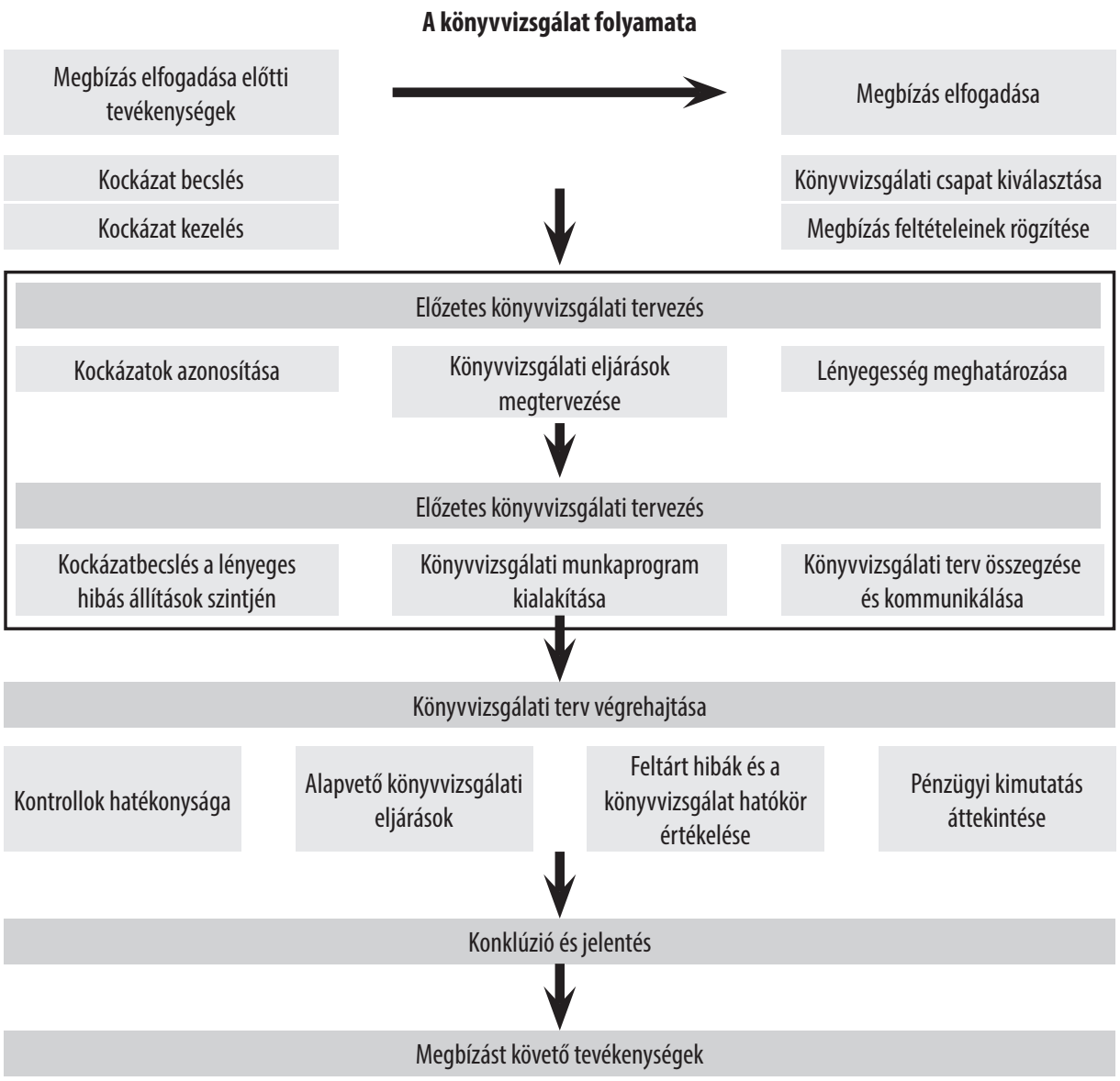

\section{1. ábra: A könyvvizsgálati munka szakaszai \\ Forrás: Deloitte Kft:: A könyvvizsgálat módszertana, 2013}

\subsubsection{A megbízás elfogadásához szülkséges alapfeltételek}

A könyvvizsgáló célja, hogy egy könyvvizsgálati megbízást csak akkor fogadjon el vagy folytasson, ha az elfogadás előtt megvizsgálja, hogy a szükséges feltételekkel rendelkezik-e, és a könyvvizsgálatot feltételeiben és annak végrehajtása tekintetében megállapodtak. 
A hitelintézetek könyvvizsgálati felkérésének elfogadásához az elfogadónak a következőket kell mérlegelnie:

- a könyvvizsgálat előfeltételei fennállnak-e, könyvvizsgáló és az irányítással megbízott személyek a megbízás feltételeit azonosan értelmezik-e;

- a könyvvizsgáló a hitelintézeti gazdálkodó egység speciális jellege miatt elegendő mértékben ismeri-e a hitelintézeti szakmát, és annak folyamatát;

- elegendő szakmai ismerete van-e a hitelintézetek által forgalmazott termékekről és szolgáltatásokról, az alkalmazott elektronikus adatfeldolgozási és pénzforgalmi rendszerekről, és azok kockázatairól;

- a megbízottnak megfelelőek-e a rendelkezésére álló erőforrások a könyvvizsgálat végrehajtásához;

- a könyvvizsgálat cégcsoportok esetében meg tudja-e szervezni a nemzetközi és hazai leányvállalatok auditját;

- a releváns etikai követelményeknek való megfelelés értékelésére is szükség van, beleértve a függetlenséget is;

- rendelkezik-e a feladatellátáshoz szükséges minősítéssel (pénzügyi intézményi, IFRS, kibocsátói, banki), könyvvizsgálói engedéllyel és megfelelő felelősségbiztosítással.

A hitelintézeti könyvvizsgálat során különösen fontos a folyamatok mélyebb ismerete, a szakmai tudás, az egyes részfolyamatok vizsgálatához szakértők bevonása (informatika, IFRS, értékelés) és a megfelelő szintű tapasztalat.

A pénzügyi intézményeket vizsgáló könyvvizsgáló társaságoknál sok esetben felállítanak egy erre szakosodott könyvvizsgálati csoportot, az egy személy által ellátott tevékenység a gyorsan változó digitalizációs világban már nem elégséges.

\subsubsection{A könyvvizsgálat tervezése}

A könyvvizsgálat megtervezése magában foglalja a megbízásra vonatkozó átfogó könyvvizsgálati stratégia kialakítását és egy könyvvizsgálati terv kidolgozását.

A könyvvizsgálónak olyan átfogó könyvvizsgálati stratégiát kell kialakítania, amely meghatározza a könyvvizsgálat hatókörét, ütemezését és irányítását, valamint iránymutatást nyújt a könyvvizsgálati terv kidolgozásához.

A könyvvizsgáló célja a könyvvizsgálat oly módon való megtervezése, hogy az hatékonyan legyen elvégezve (ISA 300). 
A könyvvizsgálat tervezése segíti a könyvvizsgálót abban, hogy

- kellö figyelmet fordítson a könyvvizsgálat fontos területeire;

- megfelelő időben azonosítsa és megoldja a lehetséges problémákat;

- megfelelően megszervezze és irányítsa a könyvvizsgálati megbízást ahhoz, hogy azt hatékonyan és eredményesen végezzék el;

- megfelelő szintü képességekkel és kompetenciával rendelkező tagokat válasszanak ki a megbízásért felelős munkacsoportba ahhoz, hogy válaszoljanak az előre jelzett kockázatokra, valamint abban, hogy a munkát megfelelően osszák fel közöttük;

- megkönnyíti a megbízásért felelős munkacsoport tagjainak irányítását és felügyeletét, valamint a munkájuk áttekintését;

- a komponensek könyvvizsgálói és a szakértők által végzett munka megfelelően legyen koordinálva.

\subsubsection{A társaság tevékenységének megismerése}

A gazdálkodó egység üzleti tevékenységének megismerése kapcsán a könyvvizsgálónak olyan mértékű ismereteket kell szereznie, amelyek révén azonosítani tudja azokat az eseményeket, ügyleteket és módszereket, amelyek megítélése szerint jelentős hatással lehetnek a pénzügyi kimutatásokra, a vizsgálatra vagy a könyvvizsgálói jelentésre.

A könyvvizsgálónak a hitelintézet tevékenységének megismeréséhez tanulmányoznia kell:

- az adott ország, régió gazdasági és szabályozási környezetét;

- a termékek, szolgáltatások, mindazon üzletágak piaci feltételeit, amelyekben a hitelintézet tevékenykedik;

- azoknak az iparágaknak a jellemzőit és aktuális piaci trendjeit, melyekkel szemben jelentős kitettsége van a hitelezés vagy egyéb pénzügyi instrumentumok következtében (Rakó et al., 2010);

- a forgalmazott termékeket és szolgáltatásokat, és azok kockázatait;

- a számviteli alapelveket és az ágazatspecifikus gyakorlatokat, beleértve a jelentős ágazatspecifikus ügyletcsoportokat, számlaegyenlegeket és a pénzügyi kimutatásokban lévő kapcsolódó közzétételeket (ISA 315);

- a társasági formát, tulajdonosi struktúrát, pénzügyi és földrajzi szervezettséget; 
- a társaság környezetét, az érdekhordozókat, a belső szabályozásokat;

- a társaság és a vezetőség céljait;

- az alkalmazott elektronikus adatfeldolgozási és pénzforgalmi rendszereket, (információ technológiai) környezetet. (Czakó-Termmel, 2013)

A hitelintézetek termékeiről és szolgáltatásiról beszerzendő információnak megbízhatónak és kellő mélységünek kell lenni. A kellő mélységű információ azt jelenti, hogy a könyvvizsgálónak tisztában kell lennie az alapvető banki tranzakciókkal (betételhelyezés, hitelnyújtás, treasury, befektetési szolgáltatások), ismernie kell ezeknek a szolgáltatásoknak a jellegét és az eredményképpen keletkező instrumentumokat, a hitelek, betétek, értékpapírok és származékos ügyletek jellemzőit, kockázatait, és számviteli kihatásait. (Rakó et al., 2010)

A fentieken túlmenően különösen fontos a könyvvizsgáló számára a 20182019. években hatályba léptetett pénzügyi instrumentumok (IFRS 9), a vevőkkel kötött szerződésekből származó árbevétel elszámolásáról (IFRS 15), valamint a lízingekről szóló (IFRS 16) IFRS-ek pontos ismerete.

\subsubsection{A kockázatok és kezelésük}

A könyvvizsgálónak meg kell ismernie, hogy a gazdálkodó egység milyen folyamatokkal rendelkezik:

a) a pénzügyi beszámolás céljai szempontjából releváns üzleti kockázatok azonosítására;

b) a kockázatok jelentőségének becslésére;

c) az előfordulásuk valószínűségének felmérésére, és

d) az ezen kockázatok kezelését célzó intézkedésekkel kapcsolatos döntéshozatalra. (ISA 315)

A hitelintézeti tevékenységben rejlő kockázatokat két fő csoportba oszthatjuk:

- üzleti és

- működési kockázatokra. (Rakó et al., 2010)

Az üzleti kockázat annak kockázata, hogy a prudens müködés feltételeit - tőkehelyzetet, tőkemegfelelést, a befektetési korlátokra vonatkozó limitet, likviditási mutató értékét, a jövedelmezőségi szintet - nem sikerül a jogszabályokban elöírt, elvárt módon teljesíteni. 
A termékek és szolgáltatások területén az egyik jelentősebb kockázat a hitelezési kockázat, amely annak a kockázata, hogy az adós vagy az ügyfél a kötelezettségét a lejáratkor vagy azt követően nem tudja teljes mértékben rendezni. A hitelezési kockázat elöfordul a hitelviszonyt megtestesítő értékpapír befektetések, a származékos ügyletekből származó követelések, sőt a mérlegen kívüli kötelezettségvállalások vizsgálata során is:

- az üzleti (termékek és szolgáltatások) kockázatai,

- piaci kockázat

- kamatlábkockázat,

- devizakockázat,

- befektetési kockázat,

- likviditási kockázat,

- vagyonkezelői kockázat.

A müködési kockázatok között a legjelentősebb az elektronikus adatfeldolgozási rendszerek alkalmazásból adódó kockázat. A könyvvizsgálónak meg kell győződnie arról, hogy a vezetés azonosította-e az IT rendszerek alkalmazásából adódó kockázatokat, ismereteket kell szereznie arról, hogy milyen preventív lépéseket tesz az adatvesztések, adatmentések, adatsérülések bekövetkezésének megelőzésére.

A müködési kockázatok területén a könyvvizsgálónak az alábbi helyzetekkel kell számolni:

- nagy mennyiségü ügylet rövid határidőn belüli pontos feldolgozásának igényével;

- az elektronikus pénzforgalmi rendszerek alkalmazásával, amellyel együtt járhat a csalás, hamisítás vagy hibák következtében történő helytelen kifizetésekkel kapcsolatos veszteség kockázattal;

- a müveleteket és adatfeldolgozások dekoncentráltságával;

- a forgalmazási napon belüli fizetési kockázatokkal (itt is megjelenik a piaci-, a kamat-, illetve a devizakockázat;

- a nagy mennyiségü monetáris instrumentumok kezelésével;

- a magas idegen tőke aránnyal;

- a bankok müködési környezetének belső bonyolultságával és változékonyságával;

- a törvények és jogszabályok betartásának elmulasztásával. (Rakó et al., 2010) 
„A könyvvizsgálónak olyan kockázatbecslési eljárásokat kell végrehajtania, amelyek alapot nyújtanak a pénzügyi kimutatások és az állitások szintjén fennálló lényeges hibás állitás kockázatainak azonositásához és felméréséhez. A kockázatbecslési eljárások önmagukban azonban nem szolgáltatnak elegendö és megfelelö könyvvizsgálati bizonyitékot, amelyre a könyvvizsgálói véleményt alapozzák." (ISA 315)

\subsection{5. Átfogó könyvvizsgálati terv kidolgozása}

A tervezési munka szakaszában olyan mértékben kell a belső audit funkciót megismernie és megértenie a könyvvizsgálónak, hogy döntése megalapozott legyen. Az átfogó könyvvizsgálati tervben a döntést minden esetben dokumentálni kell.

A helyszíni vizsgálat lefolytatásakor a belső audit munkáját értékelnie és tesztelnie kell abból a célból a könyvvizsgálónak, hogy az megfelel-e a saját vizsgálati céljaira. Az erre vonatkozó következtetéseit a munkapapírjaiban dokumentálnia kell.

Az átfogó könyvvizsgálati stratégia kialakításakor a könyvvizsgálónak:

a) azonosítania kell a megbízás azon jellemzőit, amelyek meghatározzák annak hatókörét;

b) meg kell határoznia a megbízás jelentéstételi céljait a könyvvizsgálat ütemezésének és a szükséges kommunikáció jellegének megtervezése érdekében;

c) mérlegelnie kell azokat a tényezőket, amelyek a könyvvizsgáló szakmai megítélése szerint jelentősek a megbízásért felelős munkacsoport erőfeszítéseinek irányításában;

d) mérlegelnie kell a megbízással kapcsolatos előzetes tevékenységek eredményeit és - ahol ez alkalmazható - azt, hogy a gazdálkodó egység számára a megbízásért felelős partner által végrehajtott egyéb megbízásokon szerzett ismeret releváns-e;

e) meg kell határoznia a megbízás elvégzéséhez szükséges erőforrások jellegét, ütemezését és terjedelmét. (ISA 300)

A hitelintézetek könyvvizsgálata során az átfogó terv kidolgozása számos olyan további speciális szempontot tartalmaz, amelyre a könyvvizsgálónak különös figyelmet kell fordítani. 
A hitelintézeteknél a magas idegen tőke arány miatt a mérleget érintő kisebb hibák jelentősen kihathatnak az eredménykimutatásra és a saját tőke alakulására, itt szükséges figyelembe venni a lényegesség elvét. (Rakó et al., 2010)

„A hibás állitások - beleértve a kihagyásokat is - akkor minősülnek lényegesnek, ha azok önmagukban vagy együttesen, - ésszerü várakozások szerint - befolyásolhatják a felhasználók pénzügyi kimutatások alapján hozott gazdasági döntéseit." (ISA 320)

A hitelintézetek működéséből adódóan az eredendő kockázat a legtöbb esetben meglehetősen nagy, melyre válaszul a hitelintézetek megfelelő kontrolltevékenységeket müködtetnek.

A hitelintézeti vezetés felelőssége a folyamatos belső kontroll létrehozása és fenntartása. A kontrollok vezetés általi figyelemmel kísérése magában foglalja annak mérlegelését, hogy a kontrollok a szándékoknak megfelelően müködnek-e, valamint, hogy azokat módosítják-e a körülmények változásainak megfelelően.

\section{A kontrolltevékenység}

- a teljesítmény ellenőrzések,

- az információfeldolgozás,

- a fizikai kontrollok,

- a feladatok megosztásának halmazát jelenti.

A kontrolltevékenység egyik jelentős területe a belső ellenőrzés rendszerének elvárható megbízhatósági fokának vizsgálata. A könyvvizsgálat időbeli korlátai, a hitelintézeti tevékenység kiterjedt működési és informatikai területei, rendszerei miatt nem támaszkodhat kizárólag az alapvető vizsgálati tesztek eredményeire, szükséges kellő megbízhatóságot tulajdonítani a hitelintézet belső kontrolljainak és a belső ellenőrzési rendszerének.

„A hitelintézetek létrehozták a belső audit funkciót a belső ellenörzési és vállalatirányitási struktúrája részeként. A belső audit funkció céljai és hatóköre, felelösségének jellege, valamint a szervezeti státusza, beleértve a funkció hatáskörét és elszámoltathatóságát, különféle lehet, és függ a gazdálkodó egység méretétől és felépitésétöl, valamint a vezetés és adott esetben az irányitással megbizott személyek követelményeitől." (ISA 610) 
A hitelintézetek könyvvizsgálója számára további problémát jelentő tényező a hitelintézeti számítógépes rendszerek alkalmazása által számított bevételek és ráfordítások megbízhatóságának ellenőrzése.

A hitelintézetek a legjelentősebb mérleg- és eredményelemeket (a bank eszköz- és forráspozíciói, az ügyfelek hitel- és betétegyenlegei, deviza- és értékpapír-kereskedelmi pozíciókat) számítógépes rendszerek segítségével határozzák meg, illetve számítják ki. A könyvvizsgálat támaszkodik a hitelintézetek belső auditjára, amely magában foglalja azon ügyrendi eljárások működésének ellenőrzését, amelyeket a pénzügyi és működési információk azonosítására, mérésére és jelentésére használnak, valamint az egyedi tételek pontos vizsgálatát, ideértve az ügyletek, egyenlegek és eljárások részletes tesztelését is.

A könyvvizsgáló a belső audit megfelelő működését kontrolltesztekkel ellenőrzi.

Az ellenőrzési rendszerek tesztelése útján könyvvizsgálati bizonyítékok szerezhetők:

- a számviteli és belső ellenőrzési rendszer kialakításának hatékonyságáról, tehát arról, hogy megfelelőképpen szervezték-e meg ezeket a lényeges hibás állitások megelőzése, feltárása és helyesbítése érdekében, valamint

- a belső ellenőrzési rendszernek az egész időszakon keresztül való hatékony működéséről.

Az ellenőrzési rendszerek tesztelését csak abban az esetben célszerü és/vagy szükséges tervezni és elvégezni, ha a számviteli és belső ellenőrzési rendszernek a tervezés során történő előzetes felmérése alapján a könyvvizsgáló támaszkodni kíván az ellenőrzési rendszerekben működtetett ellenőrzésekre, azaz valószínűsíti ezekben a rendszerekben a hatékony ellenőrzések létezését és azt is, hogy erről a hatékony müködésről ellenőrzési rendszerek tesztelésével meg lehet győződni.

\section{A lényegesség a könyvvizsgálat tervezése és végrehajtása során}

A lényegesség fogalma a könyvvizsgálat teljes munkafolyamatát végig kíséri, a könyvvizsgáló alkalmazza a könyvvizsgálat tervezésekor, annak végrehajtásakor, az azonosított hibás állítások és a nem helyesbített hibás állítások értékelésekor egyaránt. 
Bár a lényegesség meghatározása szakmai megítélés kérdése, a könyvvizsgálónak nem szabad elfelejteni egy fontos tényt; az általa meghatározott lényegesség és az ennek figyelembevételével elvégzett munka, kialakított vélemény, befolyásolhatja a felhasználó gazdasági döntéseit, amit a pénzügyi kimutatások alapján hoz.

A könyvvizsgálónak meg kell határoznia a lényegességet:

- a pénzügyi kimutatások egészére vonatkozóan, valamint

- az alkalmazandó lényegességi szintet azokra a sajátos ügyletcsoportokra, számlaegyenlegekre vagy közzétételekre is, amelyek esetében a pénzügyi kimutatások egészére vonatkozó lényegességnél alacsonyabb összegű hibás állítások fordulhatnak elő.

A könyvvizsgálónak meg kell határoznia a végrehajtási lényegességet is. A végrehajtási lényegesség - a gazdálkodó sajátosságát figyelembe véve - egy vagy több összeg is lehet. Nem csak egy mechanikus számítás eredménye, hanem a gazdálkodóról szerzett ismeretekkel megalapozott szakmai megítélés is.

A szabály ugyanaz, mint a lényegesség meghatározásánál:

- a pénzügyi kimutatások egészére és

- a sajátos ügyletcsoportokra, számlaegyenlegekre, valamint a közzétételekre vonatkozóan kell végrehajtási lényegességet megállapítani.

Ennek az a magyarázata, hogy az önmagukban nem lényeges hibás állítások öszszessége okozhat a pénzügyi kimutatásokban olyan lényeges hibás állítást, állításokat, amivel a lényegesség számításánál a könyvvizsgáló még nem számolt, ugyanakkor a könyvvizsgálati eljárásokra hatással lehet.

A könyvvizsgálónak a végrehajtási lényegességet figyelembe kell vennie:

a) könyvvizsgálati eljárások jellegének, ütemezésének és terjedelmének meghatározásakor, valamint

b) a hibás állítások hatásának értékelésekor.

A könyvvizsgáló:

- azonosítja a kockázatokat a gazdálkodó egység és környezete megismerési folyamata során, beleértve a kockázatokhoz kapcsolódó releváns kontrollokat is, valamint az ügyletcsoportok, számlaegyenlegek és a pénzügyi kimutatásokban szereplő közzétételek mérlegelése révén; 
- a meghatározott kockázatokat ahhoz kapcsolja, hogy milyen hiba történhet az állítás szintjén;

- mérlegeli, hogy a kockázatok olyan mértékủek-e, hogy lényeges hibás állításhoz vezethetnek a pénzügyi kimutatások szintjén, továbbá

- mérlegeli annak valószínűségét, hogy a kockázatok lényeges hibás állítást eredményezhetnek-e a pénzügyi kimutatásokban.

A könyvvizsgálónak meg kell határoznia, hogy megítélése szerint mely beazonosított kockázatok igényelnek különleges könyvvizsgálati megfontolást, és ha arra a megállapításra jut, hogy az állítás szintjén felmerülő lényeges hibás állítás becsült kockázata jelentős, akkor olyan alapvető vizsgálati eljárásokat kell végrehajtania, amelyek válaszolnak arra az adott kockázatra.

A hitelintézetek vonatkozásában, a lényegesség meghatározásánál az ügyfél sajátosságait figyelembe véve, valamint a szavatoló tőke, a befektetési korlátok, a likviditási mutató jogszabályban elvárt szintjének teljesülésével kell számolni.

A hitelintézeti könyvvizsgálat szempontjából jelentős területek egy része nem tünik ki azonnal a pénzügyi kimutatásokból. A hitelintézetek számos olyan ügyletet is végrehajtanak, amelyek egyrészt a tőkekockázat százalékában kifejezve alacsony díjbevételi vagy nyereségelemet tartalmaznak, másrészt ezek kimutatását a jogszabályok csak a mérlegen kívül követelik meg. A kezességvállalásokról, felelősségvállalási nyilatkozatokról, akkreditívekről, a származékos ügyletekről a könyvvizsgálónak azonban elfogadható szintű bizonyosságot kell szereznie.

A könyvvizsgálónak szükséges megvizsgálni az egyes ügyletek számviteli nyilvántartásba vételének teljességét, az ilyen ügyletekből származó banki kockázatok korlátozására szolgáló megfelelő ellenőrzések létezését, a veszteségek fedezetére képzett céltartalék megfelelőségét és a pénzügyi kimutatásokban szereplő bemutatás megfelelőségét. (Rakó et al., 2010)

A fentiek mellett a könyvvizsgáló azonban kizárólagosan felelős a kialakított könyvvizsgálói véleményért és ezt a felelösséget nem csökkenti az, ha a könyvvizsgáló felhasználja a belső audit funkció munkáját vagy igénybe veszi a belső auditorok közvetlen segítségnyújtását a megbízáshoz. 


\subsubsection{Az alapvető vizsgálati eljárások, tesztek jellegének, ütemezésének és terjedelmének meghatározása}

Az alapvető vizsgálati eljárások (substantive procedures) olyan tesztek, amelyek elvégzése útján könyvvizsgálati bizonyítékokat lehet szerezni a pénzügyi kimutatásokban található lényeges hibás állítások feltárása céljából, ilyenek:

- a gazdasági események és az egyenlegek részleteinek tesztelése;

- az elemző eljárások.

Alapvető vizsgálati eljárások:

- elemző felülvizsgálat;

- szemrevételezés;

- információk beszerzése és visszaigazolások.

A hitelintézeti könyvvizsgálat folyamatában - a belső ellenőrzési rendszerek tesztelésének és értékelésének eredményeként - szükséges meghatározni azon alapvető vizsgálati tesztek jellegét, terjedelmét, ütemezését, amelyeket az egyes számlaegyenlegeknél, illetve a pénzügyi kimutatásban szereplő egyéb információk kapcsán szükséges elvégezni. (Rakó et al., 2010)

A könyvvizsgáló a mintavételezéssel dolgozik, amelyek elemenkénti vizsgálati eredményei alapján következtetéseket von le a teljes könyvelési anyagra és a számviteli információkat tartalmazó pénzügyi kimutatásokra vonatkozóan. (Madarasiné et al., 2010)

A könyvvizsgáló az adatok tesztelésének tervezésekor figyelembe veszi a hitelintézeti termékekkel és szolgáltatásokkal összefüggő kockázatokat és mindazon tényezőket, amelyek a hitelintézet belső ellenőrzési rendszerének kialakításában szerepet játszottak.

A termékekkel és szolgáltatásokkal összefüggő kockázatok mérlegelésekor a könyvvizsgálónak az alábbi feladatokat kell átgondolnia:

- a forgatható eszközöket fizikailag meg kell vizsgálni;

- a kiemelt nagyságú egyenlegek esetében szükséges a külső fél általi megerősítés (más hitelintézeti, vevői, szállítói, letétkezelői KELER, nostro és loro számlák);

- szükséges a mérleg fordulónapja utáni ügyletek és gazdasági események vizsgálata; 
- megbizonyosodás a vállalkozás folytatásának elvéről, a bank működőképességéről;

- a törvényi és felügyeleti elöŕrások betartásának ellenőrzése.

A működési kockázattal összefüggő könyvvizsgálói mérlegelések a következők:

- egyes tesztek végrehajtása a mérlegfordulónap előtt (interim vizsgálat);

- a könyvvizsgálói munkát támogató szoftverek alkalmazása a tesztelésekre;

- statisztikai mintavételi technikák alkalmazása;

- elemző felülvizsgálati technikák alkalmazása.

\subsubsection{Az általános kontrollkörnyezet vizsgálata}

A hitelintézetekben múködő kontrollok fontos szerepet töltenek be a szervezet müködésében, azok hatékonysága jelentős befolyással bír az egyes könyvvizsgálati megközelítésekre.

A könyvvizsgálati eljárások tervezett összetételét könyvvizsgálati megközelítésnek nevezzük. A könyvvizsgálati megközelítést a könyvvizsgáló az üzleti tevékenység ismerete, ezen belül a belső ellenőrzési és számviteli rendszer felmérése és a kockázatbecslés alapján határozza meg.

A könyvvizsgálati megközelítést úgy kell meghatározni, hogy a könyvvizsgálati bizonyosságot a leghatékonyabban szerezze meg a könyvvizsgáló. Önmagában az, hogy egy eljárás elvégzése nehézkes, nem lehet indoka az eljárás elhagyásának.

A könyvvizsgálónak figyelembe kell vennie a könyvvizsgálati bizonyíték megszerzésének költsége és a kapott információk felhasználhatósága közötti öszszefüggést. A velejáró nehézség és költség ténye azonban önmagában véve még nem lehet jogalapja a szükséges eljárás elhagyásának.

A hitelintézetnél kialakított megfelelően müködő kontrollkörnyezet képes az esetleges hibák megelözésére, kiszűrésére. 
A hitelintézeti kontrollok vizsgálata az alábbi főbb területekre terjed ki Rakó et al. (2010) alapján:

- kontrollkörnyezet megismerése

- a szervezeti felépítés, döntési felelősségi körök

- a tisztesség és az etikai értékrend kommunikálása

- az irányítással megbízott menedzsment filozófiája, elhivatottsága, müködési stílusa

- az irányítással megbízott személyek részvétele

- emberi erőforrás-menedzsment, HR politika

- a bank egészére kiterjedő kockázat felmérési folyamata

- a pénzügyi beszámoló készítés szempontjából releváns informatikai rendszerek feletti kontrollok

- ellenőrzési és monitoring tevékenység

- előző évek feltárt gyengeségeire tett intézkedések

- IT kontrollok vizsgálata

- informatikai rendszerek vizsgálata

- lakossági és vállalati betétek és hitelek

- treasury és értékpapír tranzakciók

- pénzeszköz bankközi átutalási rendszere

- főkönyvi rendszer

- informatikai rendszerek használatával kapcsolatos kockázatok felmérése

- hibák az információban vagy annak feldolgozásában

- a csalás lehetőségének vizsgálata

- az adatfeldolgozás megszakadása

- figyelmeztető jelzések az egyes kockázattípusok esetében

- informatikai rendszerekhez kapcsolódó általános ellenőrzési környezet

- adatokhoz és programokhoz való hozzáférés (jogosultságok)

- programváltozások, programfejlesztés

- IT üzemeltetés

- alkalmazás szintü kontrollok

- részletes tesztelések a CAATs alkalmazásával

- IT-vizsgálat eredményeinek figyelembevétele a könyvvizsgálat során 


\subsubsection{A csalás kockázatának vizsgálata a hitelintézeti könyvvizsgálat részeként}

A pénzügyi intézményrendszerben 2015-ben bekövetkezett negatív események rámutattak arra, hogy a belső kontrollok nem müködtek megfelelően, a működési környezet szabályozottsága ellenére, annak gyakorlati megvalósítása nem működött megfelelően sem nemzetközi, sem a hazai környezetben, számos csalássorozatot a számviteli információk meghamisítását az irányítással megbízottak hajtották végre. A pénz- és tőkepiacokon bekövetkező nemzetközi eseményeket vizsgálva levonható az a következtetés, hogy az informatikával támogatott kontrollrendszerek ellenére a tökéletes ellenőrzési rendszer lényegében nem megvalósítható. Az egyes csalások vizsgálata arra mutat rá, hogy a belső ellenőrző rendszer működésében meglévő hiányosságok elősegítették az események bekövetkezését, ezért követelmény az ellenőrző, kontrollrendszerek megerösítése. (Hegedűs, 2016)

"A hibás állitások a pénzügyi kimutatásokban származhatnak csalásból vagy hibából. A csalás és a hiba közötti megkülönböztető tényezö az, hogy a kérdéses cselekedet, amelynek eredményeképpen hibás állitás kerül a pénzügyi kimutatásokba, szándékos vagy nem szándékos" (ISA 240)

A könyvvizsgáló azokkal a csalásokkal foglalkozik, amelyek lényeges hibás állításhoz vezetnek a pénzügyi kimutatásokban.

Az ISA 240 szerint a csalás megelőzése és feltárása elsődlegesen a gazdálkodó egység irányításával megbízott személyek felelőssége. A vezetés nagy hangsúlyt kell, hogy helyezzen a csalás megelözésére, valamint az elrettentésre, ami megygyőzheti az egyéneket, hogy ne kövessenek el csalást tekintettel a feltárás és büntetés valószínűségére. Ez magában foglalja a becsületesség és etikus viselkedés kultúrájának létrehozása iránti elkötelezettséget, amelyet megerősíthet az irányítással megbízott személyek által gyakorolt aktív felügyelet.

A könyvvizsgálatot végző könyvvizsgáló felelős azért, hogy kellő bizonyosságot szerezzen arra vonatkozóan, hogy egészében véve a pénzügyi kimutatások nem tartalmaznak akár csalásból, akár hibából eredő lényeges hibás állítást. A könyvvizsgálat eredendő korlátai miatt fennáll annak az elkerülhetetlen kockázata, hogy lehet, hogy a pénzügyi kimutatásokban szereplő néhány lényeges hibás állítást nem tárnak fel, még akkor sem, ha a könyvvizsgálatot megfelelően 
tervezték meg és hajtották végre a nemzetközi könyvvizsgálati standardokkal összhangban.

A szándékos hibás állítások két típusa releváns a könyvvizsgáló szempontjából:

a) a beszámolókészítés során elkövetett csalásból eredő hibás állítások és

b) az eszközök elsikkasztásából származó hibás állítások.

A Btk. 373. \$ (1) megfogalmazása szerint csalást követ el az „aki jogtalan haszonszerzés végett mást tévedésbe ejt, vagy tévedésben tart, és ezzel kárt okoz."

Az ISA 240 szerint a csalás a vezetésen, az irányítással megbízott személyeken, a munkavállalókon vagy harmadik feleken belüli egy vagy több személy által szándékosan elkövetett cselekedet, amely együtt jár a méltánytalan vagy illegális előny szerzése céljából alkalmazott megtévesztéssel.

A Btk. 372. \$ (1) bekezdésének megfogalmazása szerint a sikkasztás bünét követi el, aki a rábízott idegen dolgot jogtalanul eltulajdonítja, vagy azzal sajátjaként rendelkezik. Az eszközök sikkasztása a gazdálkodó eszközeinek ellopását jelenti, amelyet félrevezető nyilvántartásokkal vagy dokumentumokkal kíván leplezni.

Csalási szándékú beszámoló készítés témakörébe sorolandó:

- megtévesztés, számviteli nyilvántartások és bizonylatok manipulációja;

- események, tranzakciók vagy egyéb jelentős információk elferdítése;

- számviteli alapelvek szándékos helytelen alkalmazása.

A csalás többnyire ösztönzés vagy nyomás hatására következik be.

A hitelintézetnél előforduló nyomás az az esemény, amikor pénzügyi stabilitást vagy nyereségességet olyan gazdasági, ágazati, vagy a gazdálkodó egység müködésével kapcsolatos események fenyegetik, mint

- magas fokú verseny vagy piaci telítettség, amelyet csökkenő árrések kísérnek;

- magas fokú sebezhetőség a gyors változásokkal szemben, mint például a technológiában, a termékek elavulásában, vagy kamatlábakban történő változások;

- ismétlődő negatív működési cash flow-k vagy a működésből történő cash flow-termelésre való képtelenség, miközben a beszámolóban eredmény és eredménynövekedés szerepel; 
- gyors növekedés vagy szokatlan nyereségesség, különösen az ugyanabban az ágazatban müködő más társaságokhoz képest;

- a vevői kereslet jelentős hanyatlásai és növekvő számú üzleti bukás akár az ágazatban, akár az egész gazdaságban;

- olyan müködési veszteségek, amelyek csőddel, végrehajtással vagy ellenséges felvásárlással fenyegetnek;

- befektetői elvárások (hozamelvárások);

- nem kontrollált, vagy hirtelen jelentkező árfolyamváltozások, spekulációk;

- hitelfelvevők tömeges fizetésképtelensége;

- irreális célkitűzések, vezetői nyereségérdekeltség.

A könyvvizsgáló célja, hogy:

a) azonosítsa és felmérje a pénzügyi kimutatások csalásból eredő lényeges hibás állításainak kockázatait;

b) elegendő és megfelelő könyvvizsgálati bizonyítékot szerezzen a csalásból eredő lényeges hibás állítás becsült kockázatairól a megfelelő válaszok megtervezésén és megvalósításán keresztül, továbbá

c) megfelelően válaszoljon a könyvvizsgálat során azonosított csalásra vagy gyanított csalásra.

\section{Reagálás a kockázatokra}

Általános megfontolások:

- szakmai szkepticizmus;

- könyvvizsgálói munkacsoport összetételének megváltoztatása (tapasztaltabb kollégák bevonása);

- számviteli alapelvek és politikák felülvizsgálata;

- kontrollok, ellenőrzési kockázat besorolásának megváltoztatása.

Számlaegyenlegek, ügyletcsoportok, állítások szintjén:

- a helyszínek meglátogatása, vagy bizonyos tesztek meglepetésszerủ elvégzése;

- további információkérések külső felektől;

- részletesebb vizsgálatok elvégzése az adott területen;

- interjúk készítése az olyan területen dolgozó munkatársakkal, ahol a csalás kockázata felmerül;

- számítógép által támogatott technikák alkalmazása, adatbányászat, po- 
puláció anomáliáinak tesztelése, azonosított kulcsfontosságú kontrollok hatékony működésének terjedelmesebb mintán történő tesztelése;

- külső megerősítések kérése;

- értékvesztés és céltartalék képzési folyamat áttekintése;

- hitelbizottsági ülések jegyzőkönyveinek áttekintése, értékelése;

- a vezetés számára készített jelentések áttekintése, azok értékelése.

A csalás megelőzése és feltárása elsődlegesen egyaránt a gazdálkodó egység irányításával megbízott személyek és a vezetés felelőssége, de mint az érzékelhető, a könyvvizsgálói sokat tehet azért, hogy azok ne valósuljanak meg.

\subsection{A beszámoló vizsgálata egyéb szempontjai}

\section{A hitelezési kockázat és annak kezelése}

A pénzügyi intézmények által nyújtott szolgáltatások közül a kereskedelmi bankok hitelezési tevékenységből származó kamatbevételei teszik ki az összes bevétel 70-80\%-át.

A bankok hitelezési tevékenysége során kiemelt kockázati tényező, hogy

- a hitelfelvevő nem tesz eleget a hitelszerződésben vállalat hitel-visszafizetési, valamint kamat- és jutalékfizetési kötelezettségének (potenciális veszteség);

- az elhatárolások megfelelősége;

- a számviteli becslések (követelések és mérlegen kívüli kötelezettségvállalások) minősítései nem megfelelő körültekintéssel valósulnak meg;

- a hiteltermékek nyereségtartalma (kamat spread) a hitelek iránti alacsony kereslet következtében csökken.

A hitelezési kockázatok alapvető feladatait

- a hitelportfólió szintjén,

- ügyfélszinten kell meghatározni.

\section{A könyvvizsgálati kockázatok meghatározása}

A hitelekhez kapcsolódó könyvvizsgálati kockázatokat állítások szintjén kell meghatározni az alábbi területeken:

- ügyfelekkel szembeni követelések,

- ügyfelekkel szembeni követelések értékvesztése, 
- ügyfelekkel szembeni hitelekből származó kamat- és jutalékbevétel, valamint ezek elhatárolásai,

- függő és jövőbeli kötelezettségek, valamint kapcsolódó céltartalékképzés.

\section{Könyvvizsgálói állítások}

A könyvvizsgálói standardok legfontosabb üzenetei a könyvvizsgálati bizonyítékokkal kapcsolatban a következők:

- A könyvvizsgálónak elegendő és megfelelő bizonyítékot kell szereznie ahhoz, hogy olyan elfogadható következtetéseket tudjon levonni, amelyre könyvvizsgálói záradékát (véleményét) alapozni tudja.

- Ha a könyvvizsgáló nem képes elegendő és megfelelő könyvvizsgálati bizonyítékhoz jutni, akkor korlátozott záradékot (véleményt) vagy záradék megadásának elutasítását (a véleménynyilvánítás visszautasítását) kell adnia.

- A könyvvizsgálónak fel kell mérni a lényeges hibás állítások kockázatát az egyes állítások szintjén, és mérlegelnie kell, hogy milyen hiba történhetett egy adott állítás szintjén, illetve azok milyen lényeges hibás állításokat eredményezhetnek a pénzügyi kimutatásokban.

A pénzügyi kimutatásokban szereplő állítások olyan vezetői kijelentések, amelyek direkt vagy egyéb módon kifejezve a pénzügyi kimutatásokban öltenek testet:

a) létezés (existence): valamely eszköz vagy forrás létezik az adott időpontban - csak valós ügylet került-e be a rendszerbe,

- csak a fennálló hitelkövetelésekre számoltak-e el kamatot és jutalékot;

b) jogok és kötelezettségek (rights and obligations): egy eszköz vagy egy forrás a gazdálkodó szervezeté az adott időpontban;

c) előfordulás (occurrence): gazdasági esemény előfordulása az adott időszakban a gazdálkodó szervezetet illetően;

d) teljesség (completeness): minden eszközt, forrást és gazdasági tranzakciót vagy eseményt rögzítettek, és nincsenek közzé nem tett tételek

- minden ügylet bekerült-e az analitikus és fökönyvi nyilvántartásokba,

- minden hitelre elszámoltak-e kamat- és jutalékbevételt;

e) értékelés (valuation): az eszközt vagy a forrást megfelelő értéken mutatják ki

- a bank minden hitelére a várható veszteség összegének megfelelö értékvesztést mutatott-e ki a pénzügyi kimutatásaiban; 
f) mérés (measurement): a tranzakció vagy az esemény értékelése abból a szempontból, hogy helyes összeggel rögzítik-e, illetve bevételként vagy ráfordításként a megfelelő időszakra számolják-e el (allokálják-e);

g) be(ki)mutatás és közzététel (presentation and disclosure): egy tétel közzététele, besorolása és bemutatása megfelel az alkalmazott beszámoló készítési elveknek.

\section{Az eredendő kockázatok szintjének meghatározása}

Mint azt korábban bemutattuk, a könyvvizsgálat kockázata a nem megfelelő jelentés kiadása. A könyvvizsgálói kockázat annak függvénye, hogy

- mekkora annak kockázata, hogy a pénzügyi kimutatások lényeges hibás állítást tartalmaznak (eredendő kockázat);

- mekkora annak kockázata, hogy a számviteli nyilvántartások nem felelnek meg a törvényes elöírásoknak, illetve a belső ellenőrzés elég erős-e ahhoz, hogy az elöírások betartása biztosított legyen (ellenőrzési kockázat);

- mekkora annak valószínűsége, hogy a könyvvizsgáló az elvégzett eljárások során nem tárja fel az előforduló hibát/hibákat (feltárási kockázat).

\section{Az eredendő kockázat}

- A gazdálkodó megismerése során rögzíteni kell a külső, belső kockázatokat (pl. a vezetés tisztességessége, kényszerítő körülmények, ágazati, szabályozási, üzleti jellemzők).

- A kockázatbecslés alapján értékelni kell a beszámoló egészére és egyes állításaira vonatkozó kockázatot.

- A kockázattal érintett területeken intenzívebb ellenőrzés szükséges.

- Foglalkozni kell a csalás és hamisítás kockázatával. Az utóbbi évek gyakorlata bizonyítja, hogy a könyvvizsgálói munka magas kockázattal jár.

- A magas kockázat csak következetes kockázatelemzés és magas szintű minőségellenőrzés útján mérsékelhető.

A vállalati hitelek tekintetében alacsony eredendő kockázatúnak számítanak a nagyszámú, de kis összegü hitelek, melyeket fedezettel biztosítanak. Ezzel szemben magas eredendő kockázattal bírnak a fedezetlen, kisszámú és nagy összegü hitelek.

A lakossági hitelek esetében a lassú, konstans növekedés, és az ehhez párosult konzisztensen alkalmazott hitelbírálati követelmények alacsony kockázatot 
jelentenek, míg a gyors, hirtelen növekedés és a rugalmas követelmények magasabb kockázattal bírnak.

Az értékvesztés és céltartalék vizsgálat témakörében, ha a menedzsment legfőbb célja csak a profit, a beszámoló alacsony prioritású, az magas kockázatot eredményez. Az ügyfelek diverzifikációja alacsonyabb eredendő kockázattal jár, mint az erősen koncentrált ügyfélkör. A menedzsment állandóságának jelentős mértékű fluktuációja magas kockázattal jár. Az adott területen dolgozók tapasztaltsága jelentősen hozzájárul az eredendő kockázatok szintjéhez, a kevésbé képzett és tapasztalt dolgozók jóval nagyobb kockázatot jelentenek, mint a tapasztalt, kompetens munkaerő. A menedzsment jelentések gyakori, magas minőségű elkészítése csökkent eredendő kockázatot eredményez, míg a rendszertelen és alacsony minőségü jelentések jelentősen megnövelhetik az eredendő kockázatokat.

A kamat és jutalék vonatkozásában az informatikai rendszer használata, amely magába foglalja az automatikus kamat és jutalék elszámolást, automatizált terheléseket, csökkenti az eredendő kockázatokat, míg a manuális kalkulációk, feladások, terhelések magas eredendő kockázattal járnak.

\section{A könyvvizsgálati megközelítések}

Mint azt már a tervezés során említettük, a könyvvizsgálati megközelítés megválasztása szakmai döntésen alapul.

A hitelintézetek könyvvizsgálata során a könyvvizsgáló rendszerint nagyszámú tranzakcióval találkozik, ezért az alapvető könyvvizsgálati eljárásokkal nem tud megfelelő audit bizonyítékot szerezni, szükséges a kontrollalapú megközelítés.

A kontrollalapú megközelítéssel egyrészt az alapvető eljárások száma és terjedelme csökkenthető, másrészt a banki kontrollok jelentős része (az értékvesztés és a céltartalék kivételével) tranzakcióhoz és azok végrehajtásához kötött. Az IT általános kontrollok azonosításával és tesztelésével a kontrollfolyamatok egy része elvégezhető.

A kontrollok és az elsődleges ellenőrzési tevékenység megismerése minden könyvvizsgáló számára elsődleges feladat, az egyes megközelítések kombinációjával feltárhatóak az egyes ügyletcsoportokban, számlaegyenlegekben vagy közzétételekben szereplő hibás állítások. 


\section{Jelentéskészítés}

A jelentéskészítéshez kapcsolódó standardok:

700 A pénzügyi kimutatásokra vonatkozó vélemény kialakítása és jelentéskészítés

701 Kulcsfontosságú könyvvizsgálati kérdések kommunikálása a független könyvvizsgálói jelentésben

705 A független könyvvizsgálói jelentésben szereplő vélemény minősítései

706 Figyelemfelhívó bekezdések és egyéb kérdések bekezdések a független könyvvizsgálói jelentésben

\section{Független könyvvizsgálói jelentés az éves beszámolóról}

A nemzetközi kereskedelmi bankok könyvvizsgálatáról szóló 1006. témaszámú állásfoglalás nem tesz említést érdemlő kiegészítést a 700., 705., 706. témaszámú, a könyvvizsgálói jelentésről szóló standardokhoz.

A hitelintézetek kizárólag éves beszámolót készítenek, ennek megfelelően kell elkészíteni a könyvvizsgálói jelentést is. A hitelintézetek éves beszámolójához készített könyvvizsgálói jelentésben a számviteli törvényen túl a sajátos beszámoló készítési és könyvvezetési kötelezettségről szóló 250/2000. (XII.24.) Korm. rendeletre, valamint a Hpt-re is hivatkozni lehet. (Brehoszkiné, 2013)

\section{A különjelentés}

A különjelentés a könyvvizsgáló által összeállított jelentés, amelyet az éves beszámoló könyvvizsgálatán felül, járulékos szolgáltatásként készít.

A könyvvizsgálói különjelentés készítésének kötelezettségét az alábbi jogszabályok határozzák meg:

a) A hitelintézetekről és a pénzügyi vállalkozásokról szóló 2013. évi CCXXXVII. törvény (Hpt.)

b) a befektetési vállalkozásokról és az árutőzsdei szolgáltatókról, valamint az általuk végezhető tevékenységek szabályairól szóló 2007. évi CXXXVIII. törvény (Bszt.)

c) a biztosítási tevékenységről szóló 2014. évi LXXXVIII. törvény (Bit.)

d) a szövetkezeti hitelintézetek integrációjáról és egyes gazdasági tárgyú jogszabályok módosításáról szóló 2013. évi CXXXV. törvény 
A különjelentésbe foglalandó kérdések vonatkozásában olyan könyvvizsgálati bizonyítékok szerezhetők, amelyek képessé teszik a könyvvizsgálót arra, hogy az adott kérdésekben véleményt nyilvánítson, illetve a „leíró jellegü” tényeket a jelentésébe belefoglalja.

A könyvvizsgáló a hitelintézet éves beszámolójának könyvvizsgálata során különjelentésben köteles rögzíteni a következőkben felsorolt témákra vonatkozó megállapításait, és azt legkésőbb a tárgyévet követő év május 31-ig meg kell küldenie a hitelintézet igazgatóságának, az ügyvezetőjének, a felügyelő bizottsága elnökének és a Felügyeletnek.

A könyvvizsgálónak az éves beszámoló könyvvizsgálata mellett a következő témákat is meg kell vizsgálnia:

a) az értékelés szakmai helyességét,

b) az elöírt és szükséges értékhelyesbítések és leírások elvégzését,

c) az előírt és szükséges tartalékok képzésének megtörténtét,

d) a szavatoló tőkére, a tőkemegfelelésre, folyamatos fizetőképességre, valamint az egyes pénzügyi, kiegészítő pénzügyi szolgáltatásokra vonatkozó szabályok betartását,

e) az eredményes, megbízható és független tulajdonlásra, vagy a prudens müködésre vonatkozó jogszabályok, valamint az MNB tv., a tevékenységére vonatkozó egyéb jogszabályok, az MNB hatósági határozata betartását, valamint

f) az ellenőrzési rendszerek működését.

A hitelintézet éves beszámolójának könyvvizsgálata során a könyvvizsgálónak ellenőriznie kell a nyilvánosságra hozott információk és adatok tartalmát és értékbeli helyességét is.

\section{A vezetői levél}

A könyvvizsgáló a könyvvizsgálói jelentés mellett, vagy még a fordulónapot megelőző vizsgálatok, tapasztalatok összegzéseként, vezetői levelet is készíthet. A vezetői levélben a belső ellenőrzési és számviteli rendszerben észlelt gyengeségeket, hiányosságokat tárja fel, és megoldási javaslatokat tesz. A vezetői levél nem tartalmazhat olyan megállapításokat, amelyek a könyvvizsgáló vélemény minősítését eredményeznék. 


\subsection{Irodalomjegyzék}

Czakó László - Tremmel Zoltán (2013): A könyvvizsgálati munka szakaszai. Könyvvizsgálók kötelezö továbbképzése. MKVK OK Kft., Budapest.

Brehószkiné Mile Adrien (2013): Módszertani útmutató a közepes- és kishitelintézetek könyvvizsgálóinak. Magyar Könyvvizsgálói Kamara.

Fridrich Péter - Mitro Magdolna (2009): Hitelintézeti számvitel. Saldó Zrt., Budapest. ISBN 978-963-638-293

Lukács János (2017): Könyvvizsgálat rendszere. MKVK OK Kft., Budapest. ISBN 978-963-9878-46-4

Madarasné Szirmai Andrea - Csendes Béláné - Wessely Vilmos (2010): Kézikönyv a kis és középvállalkozások könyvvizsgálatához a Nemzeti Könyvvizsgálati Standard alapján. Magyar Könyvvizsgálói Kamara, Budapest.

https://www.mkvk.hu/letolthetoanyagok/dokumentumok/kkv/_Kezikonyv_a_ KKV-k_konyvvizsgalatahoz_2010-06-30.doc $+\& c d=1 \&$ hl=hu\&ct $=$ clnk\&g$\mathrm{l}=\mathrm{hu}$

Hegedűs Mihály (2016): Korrupció és csalás a pénzügyi szektorban. In: Fata Ildikó - Kissné Budai Rita (szerk.) Tudományos Mozaik, 12. kötet. Tomori Pál Főiskola, 2016. ISBN-978-963-89679-9-2

Rakó Ágnes - Nagy Zsuzsanna - Gálos Gréta Diana - Csikosova Sabina - Gulyás Éva - Veres Judit (2010): Hitelintézetek könyvvizsgálata és ellenőrzése. Alinea Kiadó, Budapest. ISBN 978-963-9659-51-3

Deloitte Kft. (2013): A könyvvizsgálat módszertana. Előadás anyag.

Könyvvizsgálói asszisztens képzés előadás anyaga. MKVK OK Kft., 2014.

\section{Hivatkozott jogszabályok és alkalmazott rövidítéseik}

A számvitelről szóló 2000. évi C törvény (Szt.)

A hitelintézetekről és a pénzügyi vállalkozásokról szóló 2013. évi CCXXXVII. törvény (Htp.)

A Magyar Könyvvizsgálói Kamaráról, a könyvvizsgálói tevékenységről, valamint a könyvvizsgálói közfelügyeletről szóló 2007. évi LXXV. törvény (Kkt.)

Büntető Törvénykönyvről szóló 2012. évi C. törvény (Btk.) 


\section{Hivatkozott standardok}

240 A könyvvizsgáló csalással összefüggő felelőssége a pénzügyi kimutatások könyvvizsgálatánál

300 A pénzügyi kimutatások könyvvizsgálatának tervezése

315 A lényeges hibás állítás kockázatának azonosítása és felmérése a gazdálkodó egység és környezetének megismerésén keresztül

320 Lényegesség a könyvvizsgálat tervezésében és végrehajtásában

610 A belső auditorok munkájának felhasználása

6100 Könyvvizsgálói különjelentés összeállítására vonatkozó standard IFRS 9 Pénzügyi instrumentumok

IFRS 15 Vevői szerződésekből származó bevétel

IFRS 16 Lízing 



\section{VI. rész \\ A szerzőkről röviden}




\section{Dr. Baranyi Aranka egyetemi docens}

\section{Az Eszterházy Károly Egyetem Károly Róbert \\ Campus Üzleti Tudományok Intézetének oktatója. Az MTA köztestületi tagja, valamint az MTA \\ Miskolci Területi Bizottság, Közgazdaságtudományi Szakbizottság Gazdálkodásfejlesztési kutatások Munkabizottságban bizottsági tag.}

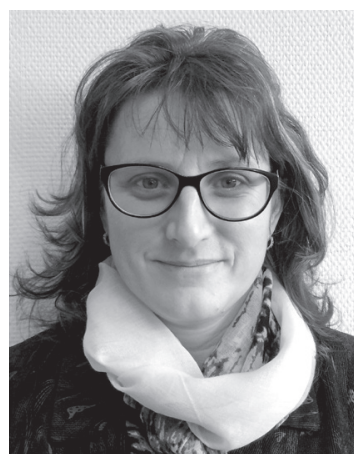

Jászberényben született, középiskolai tanulmányait Szolnokon végezte. Egyetemi éveit a gödöllői Szent István Egyetemen töltötte, a Gazdaság és Társadalom Tudományi Karon végzett, mint gazdasági agrármérnök, pénzügyi és számviteli szakirányon.

1999-ben felsőfokú logisztikusi végzettséget, 2000-ben mérlegképes köny-velői végzettséget szerzett.

1999-től dolgozik a Gyöngyösi felsőoktatásban. Doktori munkáját 1999-ben kezdte el, melyet 2003-ban fejezett be. A kutatási témája a családi gazdaságok pénzügyi helyzetének elemzése volt. A föbb oktatott tárgyak a pénzügytan, vállalkozások pénzügyei, vállalkozások finanszírozása, valamint banki ismeretek témák köré csoportosulnak. 2011-től a Pénzügy és Számvitel alapszak és felsőoktatási szakképzés szakfelelöse.

2015-ben mérnök közgazdász végzettséget szerzett a Soproni Egyetemen. 2016tól az EKE GYKRC Üzleti Tudományok Intézetének igazgatója. 2004-ben az MTA Miskolci Területi Bizottsága tudományos díjban részesítette.

2011-ben munkáját Fleischmann Rudolf Tudományos Díjjal ismerték el. 2013ban Károly Róbert Arany Plakett kitüntetést kapott.

2016-ban a legjobb oktatónak járó elismerésben részesítették az egyetem hallgatói, Aranykréta Díj tulajdonosa. 


\section{Bartók János \\ címzetes egyetemi docens}

Tagja a Common Purpose Egyesületnek, a Társ a Bajban Egyesületnek, Elnökségi tagja a Menedzserek Országos Szövetségének és tagja a Magyar Biztosítók Szövetsége ESZE Irányító Testuiletének. A Soproni Egyetem Lámfalussy Sándor Közgazdaságtudományi Karának címzetes egyetemi docense.

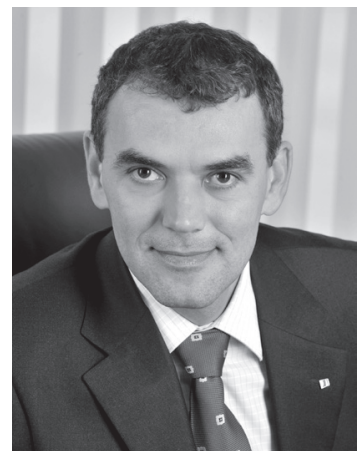

Hatvanban született és ott is folytatta tanulmányait egészen az egyetemig. Eredeti diplomáját a Gödöllői Egyetem Mezőgazdaságtudományi Karán szerezte 1992-ben, amely első munkahelye is volt.

Az AEGON-csoport vezető utánpótlást képző programjához 1993-ban csatlakozott. Végigjárva a vállalati ranglétrát dolgozott képviselőként, fiók-vezetőként, divízióvezetőként, értékesítési és marketing-, életbiztosítási- és nem-életbiztosítási vezérigazgató-helyettesként.

Vezérigazgatóként irányított AEGON leányvállalatokat és közreműködött kelet-európai felvásárlásokban és zöldmezős beruházásokban.

Az AVIVA biztosítóhoz 2007-ben csatlakozott magyarországi vezérigaz-gatóként. Később a cseh, román, szlovák és magyar vállalatok munkáját irányította a Danube régió vezérigazgatójaként.

Tagja volt az AVIVA Executive Leadership Teamjének ahol az új európai működési modell kialakítása is felelösségei közé tartozott.

A MetLife felvásárlása után az AHICO, AVIVA/MetLife biztosítók egyesülését, majd átszervezését irányította 2015-ig.

2016-tól az ERGO biztosítók igazgatósági tagja volt és felelt a vállalatok értékesítési és marketing stratégiájáért.

2018. júniusától a Duna Medical Center csoport vezérigazgatója.

Rendszeresen ad elő pénzügyi-, biztosítási-, egészségügyi szakmai konferenciákon és publikál ezen szakterületeken. 


\section{Dr. Fóriánné Horváth Margit mesteroktató}

\section{A Soproni Egyetem Lámfalussy Sándor}

Közgazdaságtudományi Kar mesteroktatója, felnőttképzési és szakmai gyakorlati koordinátor.

Felsőfokú tanulmányait a Marx Károly Közgazdaságtudományi Egyetemen végezte. Ezt követően Budapesten, az akkori ipar egyik nagyvállalatánál kezdett dolgozni,

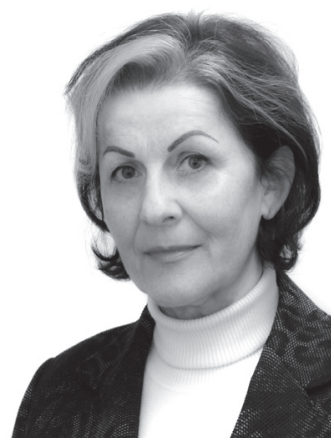
mint pénzügyi elemző-tervező.

Két év után a Magyar Nemzeti Bank gépipari, majd elektronikai ipari hitelezési területén folytatta tevékenységét, ahol döntően fejlesztésfinanszírozással foglalkozott 3 évig.

A Magyar Hitel Bankban projektfinanszírozás és nagyvállalati finanszírozás területen 10 évet töltött el.

Sopronba költözését követően a Magyar Külkereskedelmi Bank soproni fiókjában dolgozott 4 évig, ahol szakterülete a pénzügyi elemzés és tervezés, valamint a vállalatfinanszírozás volt.

2000-től lett a CIB Közép-európai Nemzetközi Bank soproni fiókjának igazgatója, és ez évben kezdte meg az oktatási tevékenységet is a Nyugat-magyarországi Egyetem Közgazdaságtudományi Kar Pénzügyi Intézetében.

Az oktatás 2012 óta fö tevékenysége, oktatási területe a vállalati pénzügy, azon belül pénzügyi tervezés, pénzügyi elemzés, vállalatfinanszírozás valamint banktan, bankismeret, pénzügyi szolgáltatások. 


\section{Dr. Für István}

Jogász, Európa jogi szakjogász

manager, vezető tanácsadó (OTP Bank Nyrt.).

Tanulmányait a Pázmány Péter Katolikus Egyetem Jogés Államtudományi Karán végezte, 2001-ben jogász, majd 2003-ban posztgraduális képzés keretében Európa jogi szakjogász diplomát szerzett.

2003-tól a Pénzügyminisztériumon belül működő Tá-

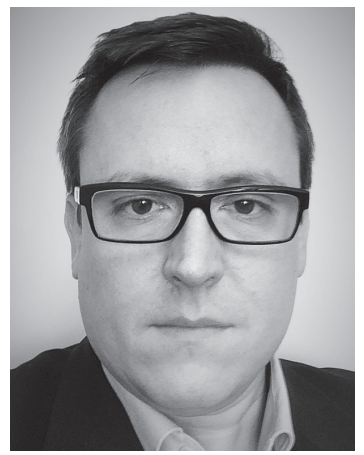
mogatásokat Vizsgáló Iroda munkatársaként az állami támogatások uniós versenyjogi szempontú ellenőrzésével foglalkozott, később a Jogi és Koordinációs Főosztály munkatársaként közreműködött több jelentős pénzügyi tárgyú jogszabály előkészítésében, köztük a 2007. évi pénzmosás elleni törvény kodifikációjában is.

2008-tól a Pénzügyminisztérium Nemzetközi Kapcsolatok Főosztályán a pénzmosás és terrorizmus-finanszírozás elleni szabályozáshoz kapcsolódó feladatokat látott el, állásfoglalásokat készített, részt vett a hazai intézmények és felügyeleti szervek feladatainak koordinációjában, a különböző európai és nemzetközi szakmai testületek ülésein (Európa Tanács - MONEYVAL, Európai Bizottság CPMLTF, OECD - FATF) képviselte a hazai kormányzati szempontokat.

2011-től a Raiffeisen Bank Zrt. Compliance Főosztályán a pénzmosás és terrorizmus-finanszírozási elleni jogszabályoknak való megfelelés biztosítása mellett felelős volt az adatvédelmi és nemzetközi adóügyi szabályoknak való megfelelésért.

2014-től az OTP Bank Nyrt. jogi szakértőjeként vett részt a pénzmosás és terrorizmus-finanszírozás elleni feladatokban, 2015-től vezetőként irányítja ezt a tevékenységet.

2011-től aktív tagja a Magyar Bankszövetség Pénzmosás Elleni Munkacsoportjának, hazai és nemzetközi szakmai konferenciákon rendszeresen tart előadásokat pénzmosás és terrorizmus-finanszírozás elleni tárgykörben. 


\section{Dr. Gál Veronika Alexandra egyetemi adjunktus}

Kaposvári Egyetem Gazdaságtudományi Kar

Pénzügy és Számvitel Intézetének oktatója

Magyar Közgazdasági Társaság (MKT) tagja.

Dombóváron született, középfokú tanulmányait a tamási Béri Balogh Ádám Gimnázium nyolcosztályos tagozatán végezte, ahol 2003-ban tett gimnáziumi érettségi

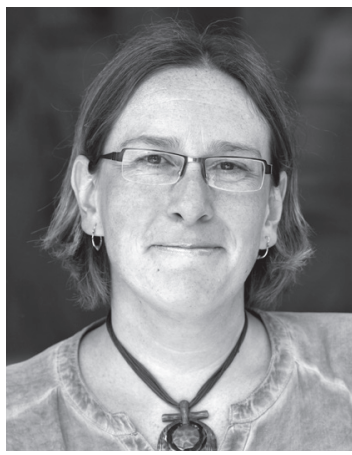
vizsgát. Azután felvételt nyert a Kaposvári Egyetem Gazdaságtudományi Karára, közgazdász-gazdálkodási szakra, ahol akkor indult ez a képzés első alkalommal. Egyetemi évei alatt többször részesült köztársasági ösztöndíjban és tanulmányai utolsó éveiben már demonstrátorként is részt vett a Gazdaságtudományi Kar Pénzügy- és Közgazdaságtan Tanszékének munkájában. 2008-ban kapott okleveles közgazdász diplomát, pénzügy szakirányon, majd később a mérlegképes könyvelői végzettséget is megszerezte.

Ezt követően a Kaposvári Egyetem Gazdálkodás- és Szervezéstudományok Doktori Iskolájában, nappali tagozaton folytatta tanulmányait. Már PhD hallgatóként tevékenyen részt vett a tanszék oktatási és kutatási tevékenységében. 2014ben védte meg doktori értekezését, summa cum laude minősítéssel, melyben a magyar kis- és középvállalkozások tőkeszerkezetének sajátosságait vizsgálta.

2010-től először tanársegédként, majd 2014 óta adjunktusként dolgozik a Kaposvári Egyetem Gazdaságtudományi Karán. Tevékeny részt vállal a tehetséggondozásban, 2015 óta kari TDT titkári feladatokat is ellát.

Főbb oktatott tárgyai: pénzügyi számítások, vállalati pénzügyek, vállalati pénzügyi döntések, vállalkozásfinanszírozás, befektetések, haladó vállalati pénzügyek, pénzügyi intézményrendszer.

Főbb kutatási területei: vállalatfinanszírozás, alternatív finanszírozási mo-dellek (helyi pénz, Grameen-modell), társadalmi vállalkozások.

2016-ban és 2018-ban a Kaposvári Egyetem Gazdaságtudományi Kar hallgatóinak szavazata alapján ő kapta a Balogh László díjat. 2017-ben pedig a Kaposvári Egyetem Kiváló Dolgozója elismerésben részesült. 


\section{Dr. Gulyás Éva egyetemi adjunktus}

\section{Budapesti Corvinus Egyetem Vezetöi}

Számvitel tanszékének oktatója, okleveles könyvvizsgáló.

A Budapesti Corvinus Egyetem Vezetői tanszékének adjunktusa, emellett IFRS szakértőként támogatja a treasury ügyletek támogatására szakosodott FX Soft-

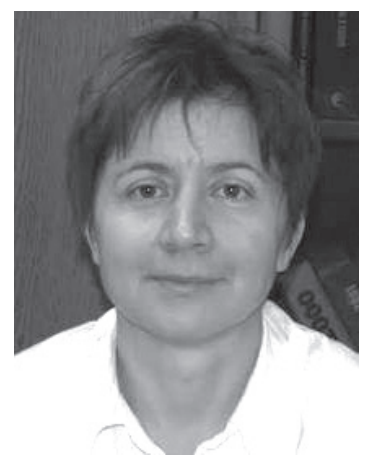
ware Zrt munkáját.

Munkája során szerteágazó tapasztalatot szerzett a lízingügyletek területén, valamint a magyar számvitel és adózás, az US-GAAP és az IFRS területén.

A Citibank valamint az ABN AMRO Eszközlízing Zrt.-nél a lízing üzletág számviteli vezetője volt, majd fökönyvelőként dolgozott a CIB lízing csoportjában. Tanácsadóként részt vett a Lombard lízingcsoport IFRS jelentéseinek, devizapozíciós nyilvántartásainak, valamint az IAS-konform értékvesztés-számításának kialakításában, valamint kisebb hazai bankok IFRS-ekre történő áttérésében.

1996 óta a Budapesti Corvinus Egyetem számvitel oktatásának fejlesztésén dolgozik. A Vezetői Számvitel tantárgyak területe mellett részt vett a Számvitel alapjai, Számviteli beszámolók, Pénzügyi számvitel, Pénzügyi számviteli informatika tantárgyak oktatásában is. Jelenleg a Hitelintézeti számvitel, a Hitelintézetek könyvvizsgálata és ellenőrzése, valamint angol nyelven a Financial Statements and analysis tárgyak oktatásáért felel. A témában való szakértelmét is jelzi, hogy munkássága során számos publikáció, könyv, folyóirat és cikk köthető a nevéhez. 1995-től okleveles könyvvizsgáló, szakterületén pedig 2014-ben PhD fokozatot, 2016-ban pedig az ACCA DIPIFR diplomáját szerezte meg. 


\section{Dr. Hegedüs Mihály föiskolai tanár}

\section{A Tomori Pál Főiskola valamint a Soproni Egyetem Lámfalussy Sándor Közgazdaságtudományi Kar Pénzügyi és Számviteli Intézetének oktatója, a Magyar Könyvvizsgálói Kamara alelnöke, az MKT, a MISZK, az Adótanácsadók Egyesületének valamint az MTA köztestületi tagja.}

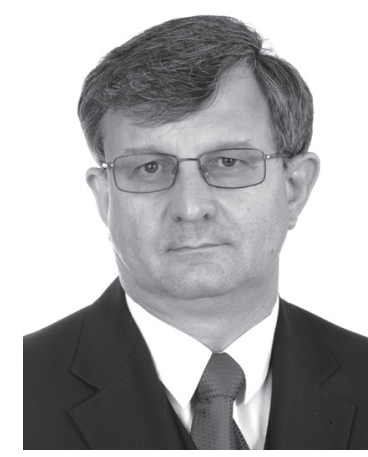

Kutatási tevékenysége szerteágazó, jelenlegi kutatási területe a negyedik ipari forradalom, az információs technológia, az automatizálás, a digitali-záció hatásainak vizsgálata a számviteli, adózási rendszerekre, könyvelés, könyvvizsgálat és ellenőrzési módszertanokra.

Több évtizede vizsgálja a rejtett gazdaság alakulását, amelyekről számos hazai és nemzetközi publikációt is megjelentetett.

Rendszeresen tart előadásokat pénzügyi, számviteli témájú konferenciákon, számos publikációja jelent meg hazai és nemzetközi tanulmánykötetekben és folyóiratokban, magyar és angol nyelven. Doktori fokozatát a Nyugat-magyarországi Egyetem Közgazdaságtudományi Karának Széchenyi István Doktori Iskolájában szerezte meg az egészségügyi folyamatok elemzése témakörben. 2007. óta vesz az egészségügy gazdasági folyamatainak elemzésében keresve a választ arra, hogyan lehet hatékony és finanszírozható egészségügyet építeni, hol húzódhatnak a határvonalak az ingyenes és a fizetős egészségügy között.

Számos felsőoktatási intézményben tart hazai és a nemzetközi számvitelhez, adózáshoz, könyvvizsgálathoz kapcsolódó kurzusokat. Gyakorló könyvvizsgáló, a Magyar Könyvvizsgálói Kamara tagja, alelnöke, igazságügyi adó-, járulék és könyvszakérö. Speciális szakterülete a befektetési alapok, alapkezelők, pénzügyi vállalkozások, az átalakulások könyvvizsgálata, valamint az egészségügyi intézményi beszámolók elemzése. IFRS oktatói, IFRS mérlegképes vizsgával és könyvvizsgálói minősítéssel rendelkezik, számos közérdeklődésnek kitett társaság IFRS szerint elkészített éves beszámolóját, átalakulását vizsgálta az elmúlt időszakban. Szakmai tevékenységét a Kecskeméti Főiskola címzetes főiskolai, a Soproni Egyetem címzetes egyetemi tanár címmel ismerte el. 


\section{Kómár András}

\section{Az Országos Betétbiztosítási Alap}

\section{ügyvezető igazgatója}

Kómár András a Pázmány Péter Katolikus Egyetem Jog- és Államtudományi Karán szerzett jogi diplomát 2004-ben, majd a Budapesti Corvinus Egyetemen végzett közgazdászként 2008-ban, tőkepiaci specializációval. 2011-ben mérlegképes könyvelö, majd 2017-ben

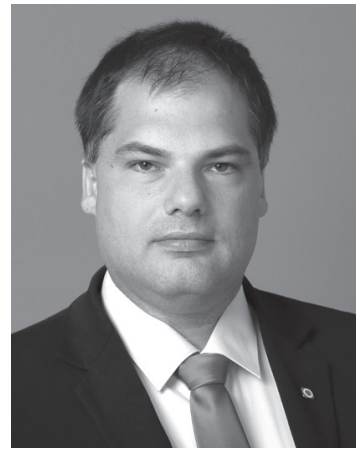
tőkepiaci és bank szakjogász képesítést szerzett. Jelenleg PhD képzésben vesz részt a Pázmány Péter Katolikus Egyetem Jog- és Államtudományi Karán.

Pályafutását a Pénzügyminisztériumban kezdte 2004-ben, ahol a pénzügyi szektor szabályozásával foglalkozott. 2006-2007-ben több hónapos szakmai programok keretében munkatapasztalatot szerezhetett a londoni City-ben, egy nemzetközi ügyvédi irodában és egy globális befektetési bankban. 2007-ben a Pénzügyi Szervezetek Állami Felügyeletén folytatta pályafutását pénz- és tőkepiaci területen. 2013-tól a Magyar Nemzeti Bankban dolgozott pénzügyi stabilitási, szanálási területen. 2018. január 1-jétől az Országos Betétbiztosítási Alap (OBA) ügyvezető igazgatója, az OBA és a Szanálási Alap igazgatótanácsának tagja.

Több szakmai szervezet testületeinek munkájában is részt vesz, egyebek mellett tagja a Magyar Közgazdasági Társaság Pénzügyi Szakosztálya elnökségének, valamint a Magyar Pénzügyi-Gazdasági Ellenőrök Egyesülete Etikai és Fegyelmi Bizottságának.

Egyetemi oktató, konferenciák rendszeres előadója és több szakmai publikáció szerzője. Főbb kutatási területei: a pénzügyi szektor hazai és EU-s szabályozása, a pénzügyi szervezetek felügyelése és felügyeleti válságkezelése, a szanálás, a pénzügyi szervezetek felszámolása, az állami stabilizációs intézkedések, a betétbiztosítás, a befektetővédelem, a pénzügyi szektor egyéb garanciarendszerei. 


\section{Dr. Kovács Róbert egyetemi adjunktus}

\section{Soproni Egyetem Lámfalussy Sándor}

Közgazdaságtudományi Kar Pénzügyi és

Számviteli Intézetének oktatója.

2003-ban szerzett közgazdász oklevelet a Nyugat-magyarországi Egyetem Közgazdaságtudományi Karának gazdálkodási szakán, pénzügy föszakirányon és Euró-

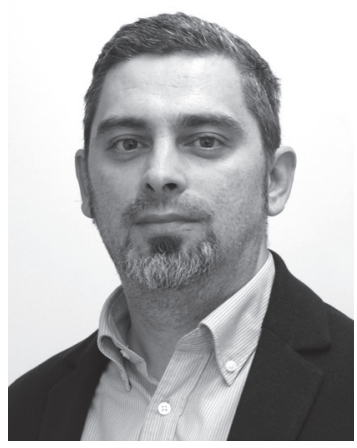
pai Uniós pénzügyek mellékszakirányon.

Ettől az évtől kezdve posztgraduális képzésen vett részt, 2006-tól biztosítási szakközgazdász másoddiplomával is rendelkezik.

Doktori fokozatát a Nyugat-magyarországi Egyetem Közgazdaságtudományi Karának Széchenyi István Gazdasági folyamatok elmélete és gyakorlat Doktori Iskolájában szerezte meg 2012-ben, témája: „Az adóssággeneráló tőkeáramlások hatása az árfolyamrendszerre" volt.

Főbb oktatott tárgyai: Nemzetközi pénzügyek, Banktan, Biztosítástan. 


\section{Dr. Kovács Tamás egyetemi docens}

\section{Soproni Egyetem Lámfalussy Sándor \\ Közgazdaságtudományi Kar Pénzügyi és \\ Számviteli Intézetének oktatója.}

Körmenden született 1981-ben. A város Kölcsey Ferenc Gimnáziumában megszerzett érettségi bizonyítványa után felsőfokú tanulmányait 2000-ben kezdte meg Sop-

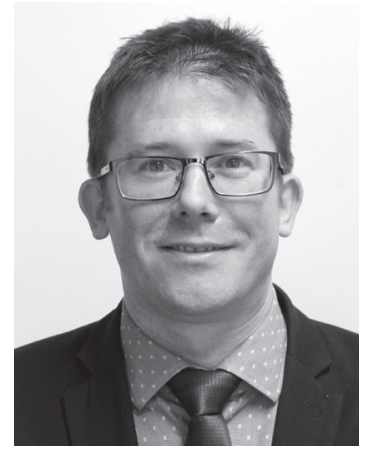
ronban a Nyugat-magyarországi Egyetem Közgazdaságtudományi Karán gazdálkodási szakon. 2002-től az Egyetemi Hallgatói Önkormányzat tagja, 2004ben Köztársasági ösztöndíjas.

Egyetemi diplomáját 2005-ben szerezte meg Alma Mater kitüntetéssel pénzügy föszakirányon. 2006-ban nemzetközi kontroller, 2008-ban adótanácsadó képesítést szerzett.

Kutatási tevékenységét a Közgazdaságtudományi Kar Széchenyi István Doktori Iskola pénzügyi alprogramjában kezdte el, A kockázatitőke-befektetések hatása a gazdaságra című értekezését 2014 januárjában védte meg. Kutatási területéhez szorosan kapcsolódva 2007 februárjában „A kockázati tőkebefektetés szerepe és lehetőségei a regionális gazdaságfejlesztésben" címmel Győrben szervezett konferenciát másodmagával, nyáron pedig az INNOSTART Nemzeti Üzleti és Innovációs Központnál bővítette szakmai ismereteit, s segítette az intézmény munkáját.

2006 óta oktat az egyetemen. Fő tárgyai: vállalati pénzügyek, ellenőrzés, pénz- és tőkepiacok, gazdasági elemzés, pénzügytan.

A Soproni Pénzügyi Napok szakmai és tudományos konferencia szervezőbizottságának tagja már több mint tíz éve. 2018 őszétől a Pénzügyi és Számviteli Intézet vezetője.

Gyakorlati tapasztalata van uniós pályázatok és üzleti projektek pénzügyi tervezésében, 2010 és 2016 között a Medicina Egészségpénztár belső ellenőre. 


\section{Dr. Moizs Attila egyetemi adjunktus}

\section{Kaposvári Egyetem Gazdálkodástudományi Karának oktatója.}

Dr. Moizs Attila Pécsett született 1969-ben, a JPTE-n szerzett közgazdász diplomát 1993-ban, jogi szakoklevelet 1995-ben, a „monetáris szabályozás és intézmények" szakirányán 1996-ban államvizsgázott, okleveles

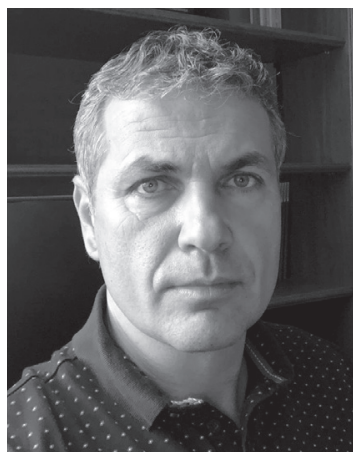
közgazda (MSc) diplomáját 2005-ben vette át.

A PTE Állam- és Jogtudományi Karának Doktori Iskolájában 2013-ban doktori szigorlatot tett alkotmányjogból és pénzügyi jogból „summa cum laude” minősítéssel, ugyanilyen eredménnyel védte meg „A szövetkezeti hitelintézetek szerepe és jogi helyzete" címü doktori értekezését és szerzett $\mathrm{PhD}$ fokozatot 2015-ben. Fő kutatási területe a szövetkezeti hitelintézetek jogi szabályozása, mely tárgyban számos publikációja jelent meg, társzerzője a Springer kiadó kezelésében és a Szövetkezetek Nemzetközi Szövetsége (ICA) Európai Kutató Bizottsága szerkesztésében kiadott „Credit Cooperative Institutions in European Countries” című szakkönyvnek.

A Kaposvári Egyetem Gazdálkodástudományi Karának adjunktusa, kutatója, gazdasági jogot, pénzügyi jogot tanít.

A bankszektorban 1994. óta több bankban is dolgozott, a szövetkezeti hitelintézeti szektorba ezt követően került. A MECSEK TAKARÉK Szövetkezetnél 1998. óta dolgozott, mint vezető, 2001. óta ügyvezető, majd 2006-tól 2017-ig elnöke is volt egyben, jelenleg a Dél Takarék Szövetkezet igazgatóságának tagja. A Takarékbank Zrt. Igazgatóságának tagja volt 2017. január 13. napjától, mely tagságáról lemondott.

A Takarékszövetkezetek Országos Intézményvédelmi Alapja, illetve a Takarék-szövetkezetek Országos Érdekképviseleti Szövetsége Felügyelő Bizottságainak elnöke volt 2011-2013-ig, 2013.-2018-ig a Szövetség elnökének választották. A Takarékszövetkezeti Érdemérem Arany fokozatával tüntették ki 2013-ban. 


\section{Dr. Parádi-Dolgos Anett egyetemi docens}

Kaposvári Egyetem Gazdaságtudományi Kar

Pénzügy és Számvitel Intézet igazgatója, az MKT Somogy megyei elnöke.

Kaposváron született 1979-ben. Egyetemi tanulmányait a Kaposvári Egyetemen folytatta ahol gazdasági agrármérnök oklevelét 2003-ban vette át. 2007-ben Ph.D. fokozatot szerzett a Kaposvári Egyetem Gazdálkodás és Szervezéstudományok Doktori Iskolában, értekezésének témája „A gazdasági versenyképesség és az adózás összefüggései az Európai Unióban”.

2006-tól a Kaposvári Egyetemen dolgozik, jelenleg a pénzügy és számvitel alapszak szakfelelősi feladatait látja el, mellette több tantárgy felelőse. Oktatott tantárgyai: Mikro- és Makroökonómia, Pénzügytan, Költségvetési pénzügyek, Közösségi gazdaságtan, Adózási ismeretek.

Meghívott oktatóként több hazai egyetemen is tart előadásokat, 2014-től vendégoktatóként dolgozik a Sapientia Erdélyi Magyar Tudományegyetemen.

Kutatómunkáját elsősorban az alternatív gazdasági és pénzügyi modellek köré építi. Kiemelt feladatának tekinti a tudományos utánpótlásnevelést és tehetséggondozást, több doktori munka témavezetője.

2013 és 2017 között a KE Gazdaságtudományi Karán dékáni feladatokat látott el, melyben a legfontosabb küldetésének a kar stabilitásának megteremtését, hazai és nemzetközi ismertségének megerősítését tartotta.

Számos hazai és nemzetközi konferencián tart előadást, tudományos eredményeit magyar és angol nyelven rendszeresen publikálja. 


\section{Dr. Pataki László egyetemi docens}

A Szent István Egyetem Gazdaság- és Társadalomtudományi Kar Üzleti Tudományok Intézetének, valamint a Soproni Egyetem Lámfalussy Sándor Közgazdaságtudományi Kar Pénzügyi és Számviteli Intézetének oktatója. Az MTA köztestületi tagja.

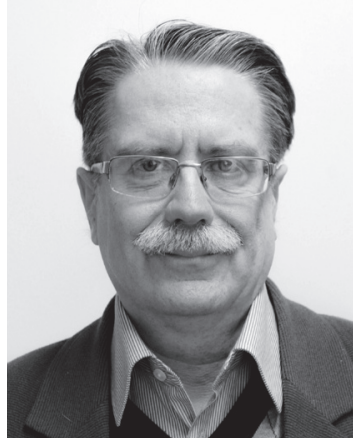

Sopronban született, ott folytatta általános és középiskolai tanulmányait. Egyetemi tanulmányait 1987-ben a Gödöllői Agrártudományi Egyetemen üzemszervező agrármérnökként végezte. 1990-ben okleveles mezőgazdasági vállalatgazdasági gazdaságelemző szakmérnöki végzettséget szerzett.

Sikeres mérlegképes könyvelői vizsgákat tett mezőgazdasági és pénzintézeti szakon. 1987 és 1997 között a Gödöllői Agrártudományi Egyetem Számviteli és pénzügyi tanszékén dolgozott tanársegédként, majd adjunktusként. 1997 és 2007 között a Károly Róbert Főiskolán dolgozott docensként, majd 2008-tól a Nyugat-magyarországi Egyetem (ma Soproni Egyetem) docense. 2013-tól fóállásban a Szent István Egyetemen oktat, ahol az Üzleti Tudományok intézetének igazgató helyettese. 2004 szeptemberétől 2007 végéig a Pénzügy-számvitel BA szak szakfelelöse volt a Károly Róbert Főiskolán.

1993-ban egyetemi doktori, majd 2003-ban PhD fokozatot szerzett. Ez utóbbit a Szent István Egyetem Gazdálkodás- és Szervezéstudományi Doktori Iskolájában. 1993 és 1996 között egy könyvelö és pénzügyi tanácsadó Kft. ügyvezető igazgatója volt. Több kisvállalkozásnak volt évekig gazdasági vezetője.

Publikációinak száma meghaladja a 140-et. Témavezetésével eddig 4-en szereztek $\mathrm{PhD}$ fokozatot, s jelenleg is több doktorandusz hallgatója van.

Főbb oktatott tárgyai: Pénzügytan, vállalati pénzügyek, befektetések, nemzetközi pénzügyek. Rendszeres résztvevője hazai és nemzetközi tudományos konferenciáknak, PhD nyilvános viták és záróvizsgák bizottságainak. Nős, két gyermek édesapja. 


\section{Dr. Sipiczki Zoltán \\ egyetemi tanársegéd}

\section{Kaposvári Egyetem Gazdaságtudományi Kar}

Pénzügyi és Számviteli Intézetének oktatója.

A Kaposvári Egyetem, Gazdálkodás- és Szervezéstudományok Doktori Iskolájában fokozatot szerzett. Mérlegképes könyvelői végzettséggel rendelkezik.

2011-2014 között a Videoton cégcsoportál kontroller

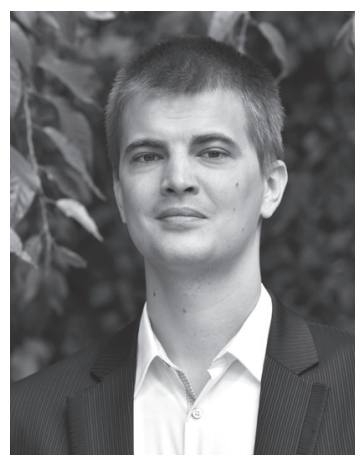
beosztásban dolgozott.

2015-tól tanársegédként oktat a Pénzügy és Közgazdaságtan Tanszéken, főként pénzügy, kontrolling, pénzügyi elemzés és bankelméleti témájú tárgyakért felel. Rendszeresen tart előadásokat pénzügyi témájú konferenciákon, számos publikációja jelent meg pénzügyi, kontrolling valamint agrárpénzügy témákban hazai és nemzetközi folyóiratokban, magyar és angol nyelven.

2017-2018-ban kontrollerként segítette a Kaposvári Egyetem Költségvetési és Kontrolling Osztály munkáját többek között új vállalatirányítási rendszer bevezetésében.

2015-2017 között a Magyar Közgazdaság Társaság Somogy megyei Ifjúsági Bizottságának elnöke volt.

Doktori tanulmányai mellett megszerezte a Bloomberg Essentials Finance and Economics Certification-t és a Magyar Nemzet Bank makroökonómia és pénzügy módszertani képzését is teljesítette. 


\section{Szarka Gábor}

\section{A Budapesti Értéktőzsde vezérigazgatójának szakmai titkára.}

\section{A Magyar Közgazdasági Társaság Felelös Vállalatirányítás Szakosztály titkára.}

Egyetemi tanulmányait a Budapesti Közgazdaságtudományi Egyetemen végezte, ahol Gazdaságpolitika föszakirányon szerzett diplomát.

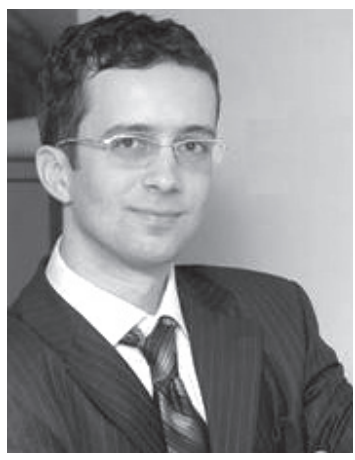

Több Tudományos Diákköri Konferencián szerepelt eredményesen, egy első és két harmadik helyezést ért el.

Angol és német nyelvből szakmai középfokú nyelvvizsgával rendelkezik.

2016 január óta a Budapesti Értéktőzsde (BÉT) vezérigazgatójának szakmai titkára, valamint a Magyar Közgazdasági Társaság Felelős Vállalatirányítás szakosztályának titkára.

Szakmai titkárként részt vett a BÉT 2016-2020 stratégiájának kialakításában, amely stratégia kiemelt jelentőséget tulajdonít a hazai KKV-k fejlesztésének a tőkepiacon keresztül.

Ezen felül szakmai munkával segíti a BÉT megjelenését és a tőzsdefejlesztés, tőzsdestratégia céljainak kommunikálását hazai és nemzetközi konferenciákon, tanulmánykötetekben. 


\section{Dr. Szóka Károly \\ egyetemi docens}

Soproni Egyetem Lámfalussy Sándor

Közgazdaságtudományi Kar Pénzügyi és Számviteli

Intézetének oktatója.

MTA VEAB Soproni Tudós Társaság tagja, a

Közgazdaságtudományi Szakbizottság elnöke, az MKT tagja és az MTA köztestületi tagja.

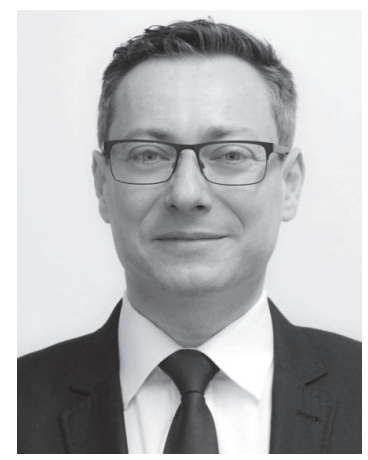

Sopronban született, ott folytatta tanulmányait. Egyetemi éveit 2001-ben Pro Patria és Alma Mater kitüntetéssel végezte a Nyugat-magyarországi Egyetem Közgazdaságtudományi Karán, pénzügyi és számviteli főszakirányon. Tanulmányai alatt öt alkalommal vett részt Tudományos Diákköri versenyen, regionális versenyen első helyezést ért el.

Okleveles adótanácsadói, nemzetközi controller, értékelemzői team-tag végzettséget szerzett.

2003-2012 között szervezte a Közgazdaságtudományi Karon folyó Felsőfokú Szakképzéseket, részt vett a 2009-ben beinduló Pénzügyi BSC képzés kidolgozásában, 2016 februárja és 2018 szeptembere között a Pénzügyi és Számviteli Intézet intézetigazgatója, 2013 óta kari alumni koordinátor és 2019 márciusától egyetemi DPR koordinátor.

Doktori fokozatát a Nyugat-magyarországi Egyetem Közgazdaságtudományi Karának Széchenyi István Gazdasági folyamatok elmélete és gyakorlata Doktori Iskolájában szerezte meg 2007-ben, témája a pénzügyi-számviteli tervezés és a controlling összefüggései és gyakorlata volt.

Főbb oktatott tárgyai: gazdasági elemzés, pénzügyi elemzés, értékelemzés, kontrolling, pénzügyi kontrolling, vezetői számvitel és kontrolling.

Főbb kutatási területei: Ipar 4.0 és a controlling, értékelemzés, pénzügyi kontrolling, költségmenedzsment, folyamatmenedzsment és controlling, pénzügyi tervezés.

Rendszeresen tart előadásokat pénzügyi témájú konferenciákon, számos publikációja jelent már meg hazai és nemzetközi tanulmánykötetekben és folyóiratokban, magyar és angol nyelven. 


\section{Dr. habil. Tatay Tibor egyetemi docens}

\section{A Széchenyi István Egyetem Kautz Gyula Gazdaságtudományi Kar Gazdasági Elemzések Tanszékének oktatója.}

Az MTA köztestületi tagja.

Egyetemi tanulmányait a Janus Pannonius Tudományegyetemen végezte Pécsett, ahol 1988-ban szerzett ok-

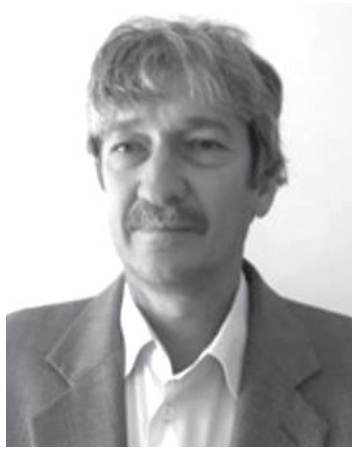
leveles közgazdász diplomát.

1988-tól a Veszprémi Egyetem oktatójaként dolgozott 2000-ig. 1994-ben Veszprémben egyetemi doktori (dr. univ.) címet szerzett.

2001-től a Nyugat-Magyarországi Egyetem egyetemi adjunktusa lett.

PhD doktori fokozatát 2009-ben kapta meg Sopronban.

2011-től Győrben a Széchenyi István Egyetemen egyetemi docens.

2015-ben habilitált a Kaposvári Egyetemen.

Oktatási tevékenysége kiterjed a pénzügyi intézményrendszer müködésére, a pénzügyi befektetések, a vállalati pénzügyek területére.

1998-tól pénzügyi tanácsadási tevékenységet végez.

A 2000-es években a pénztári szektorban is szerepet vállalt választott vezető tisztviselőként. 


\section{Dr. Tóth Gergely \\ föiskolai tanár}

Okleveles közgazdász. 2013-tól a Wekerle Sándor

Üzleti Főiskolán a Pénzügy- Számvitel szak vezetője. 2017-től a Milton Friedman Egyetem óraadó tanára.

A Gazdálkodási és Tudományos Társaságok

Szövetsége Gazdasági és Külgazdasági Tagozatának elnöke. Az Országos Statisztikai Tanács tagja.

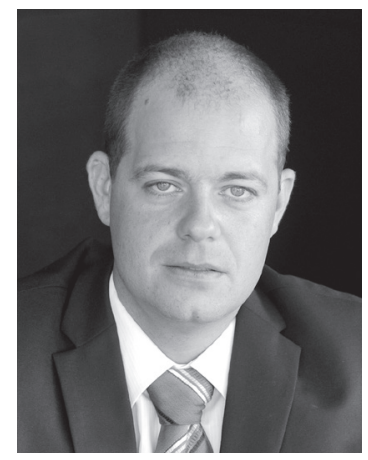

Budapesten született. Közgazdász diplomáját 2004-ben a Nyugat-magyarországi Egyetem Közgazdaságtudományi Karán szerezte, pénzügyi és számviteli főszakirányon. Doktori fokozatát ugyancsak a Nyugat-magyarországi Egyetem Közgazdaságtudományi Karán, a Széchenyi István Gazdasági folyamatok elmélete és gyakorlata Doktori Iskolájában szerezte meg 2009-ben. Témája a pénz-és tőkepiacok prudenciális szabályozásának változásai. 2016-ban kapta meg föiskolai tanári kinevezését.

Szakmai tapasztalatait az üzleti szférában szerezte, ahol 10 évig makrogazdasági elemző volt. Jelenleg a Munkástanácsok Országos Szövetségének gazdasági fötanácsadója.

Tudományos-szakmai rendezvények aktív résztvevője, rendszeresen tart előadásokat, moderál közgazdasági tartalmú konferenciákat.

Főbb oktatott tárgyai: pénzügytan, vállalati pénzügyek, államháztartástan, költségvetési gazdálkodás, nemzetközi pénzügyek.

Kutatási területei: fiskális és monetáris politika hazai és nemzetközi szinten, jellemzően makrogazdasági kontextusban; közpénzügyek; bérfejlesztések, életpályamodellek költségvetési, gazdasági aspektusai; versenyképesség. 


\section{Dr. habil. Varga József egyetemi docens}

\section{A Kaposvári Egyetem és \\ a Budapesti Corvinus Egyetem \\ oktatója.}

Varga József tanulmányait a Marx Károly Közgazdaságtudományi Egyetem pénzügy szakán végezte 1983 és 1987 között.

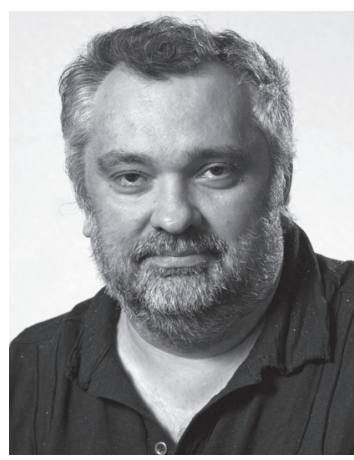

1992-ig ugyanitt tudományos aspiráns. 1992-ben egyetemi doktori fokozatot, 2003-ban Ph.D.-fokozatot szerzett. Habilitációját 2014-ben szerezte meg. 2005-től a Budapesti Corvinus Egyetem fóállású egyetemi docense, jelenleg a Kaposvári Egyetemen fóállású, a Corvinuson félállású egyetemi docens.

Megalapítása óta tanít az EMTE Erdélyi Magyar Tudományegyetem csíkszeredai karán.

2013-ban a Kaposvári Egyetem Baka József Szakkollégium alapító igazgatója, 2013 és 2016 között vezető tanára, 2013-tól az Iszlám Tudományok Kutatóintézet alapító intézetigazgatója.

2013-2017 között a Kaposvári Egyetem Gazdaságtudományi Karának tudományos dékánhelyettese.

A Magyar Közgazdasági Társaság Somogy megyei szervezetének fötitkára.

Számos szakkönyv és szakcikk szerzője, illetve társszerzője. Publikációi a pénzügyi, banki és agrárfinanszírozási területen jelentek meg. Kutatási területei a helyi pénzrendszerek, a hagyományos és iszlám bankrendszer működése. 


\section{Végh Richárd}

\section{A Budapesti Értéktőzsde vezérigazgatója.}

Végh Richárd a Budapesti Corvinus Egyetem (korábban BKE) Befektetéselemző és kockázatkezelő szakirányának elvégzése után a Budapesti Értéktőzsdén helyezkedett el. Kisebb megszakítással 2004 óta dolgozik a BÉT-en: közel kilenc évig az Üzletpolitikai Igazgatóság munkatársa volt különböző pozíciókban.

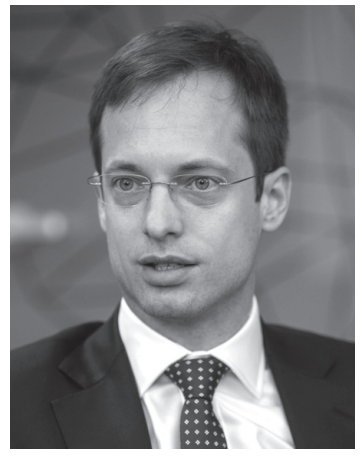
2013-ban kereskedési és üzletfejlesztési igazgatói pozícióból került a Magyar Nemzeti Bankhoz, ahol tőkepiaci felügyeleti igazgatóként a hazai tőkepiaci intézmények felügyeletéért, bennfentes kereskedelemmel, piacmanipulációval kapcsolatos piacfelügyeleti vizsgálatok lefolytatásáért, továbbá a tőkepiaci kibocsátói engedélyek kiadásáért felelt.

A BÉT 2015-ös többségi magyar tulajdonba kerülését követően visszatért a tőzsdére, ahol 2015 decembere óta az Igazgatóság tagja. 2016 január óta a BÉT vezérigazgatója, 2017 március és 2019 május között elnöke.

A BÉT az ő irányítása alatt dolgozta ki 2020-ig szóló stratégiáját, melynek fő célja a magyar tőkepiac fejlesztése, a kínálati és keresleti oldal élénkítése, a pénzügyi kultúra fejlesztése.

2013 óta a Befektető-védelmi Alap, 2016 óta pedig a Központi Elszámolóház és Értéktár igazgatósági tagja. 2018 decemberében a FESE (Európai Tőzsdeszövetség) Közgyülése az Igazgatóság tagjává választotta. 
